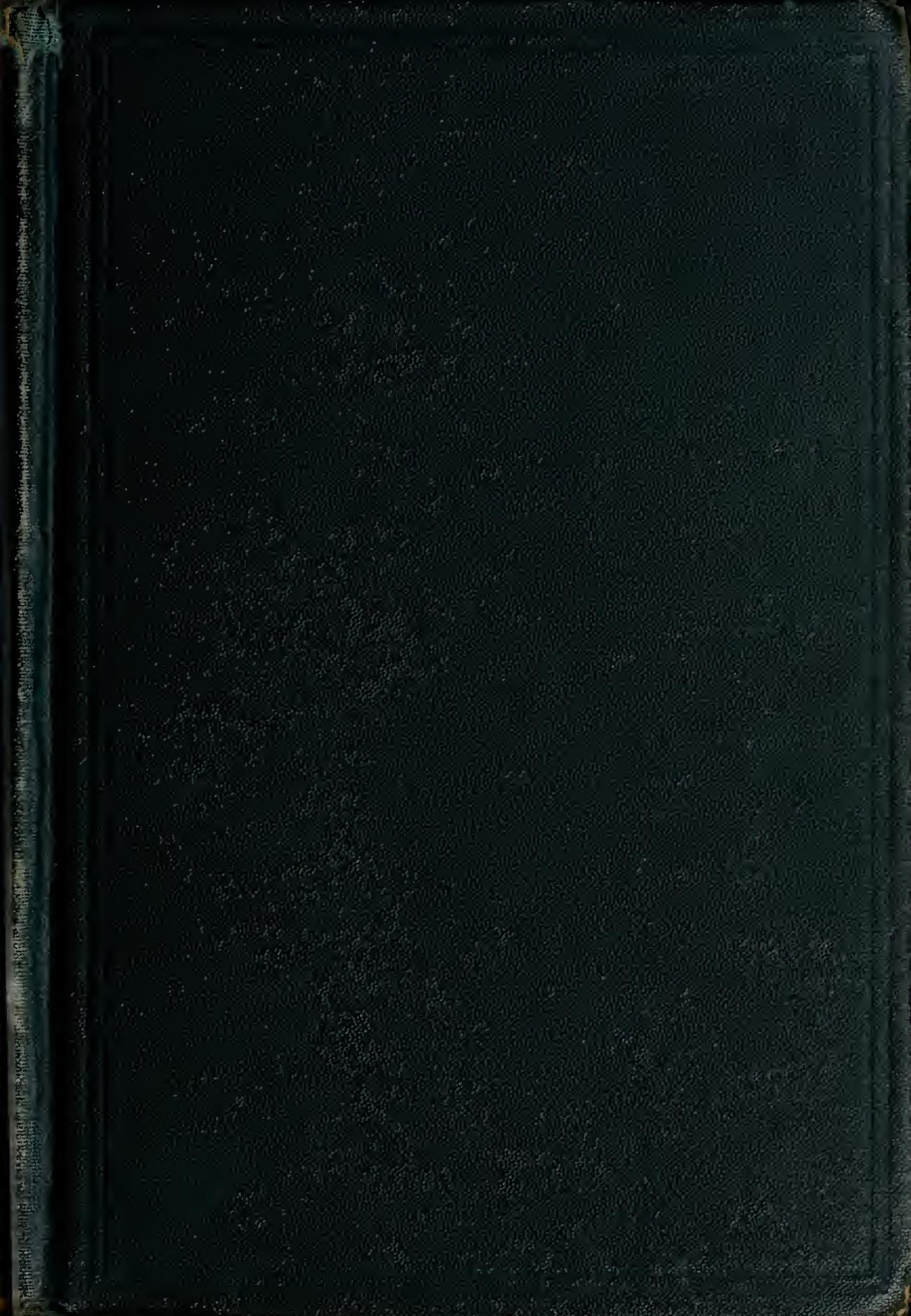




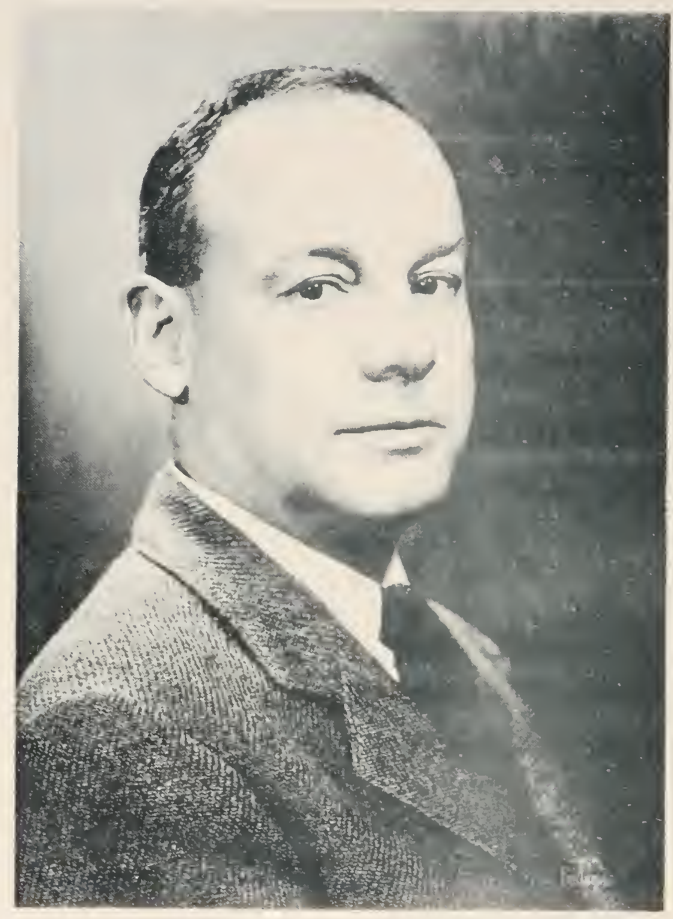

\author{
HENRY C. STETSON \\ GEOLOGICAL LIBRARY \\ WOODS HOLE, MASSACHUSETTS
}




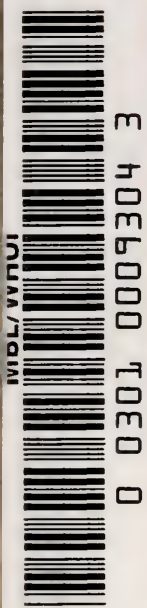

V. $C, \sqrt{\frac{1}{1, x}}$

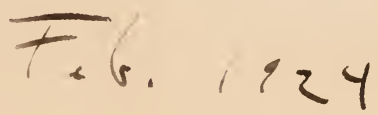

Marine Biological Laboratory Library Woods Hole, Massachusetts

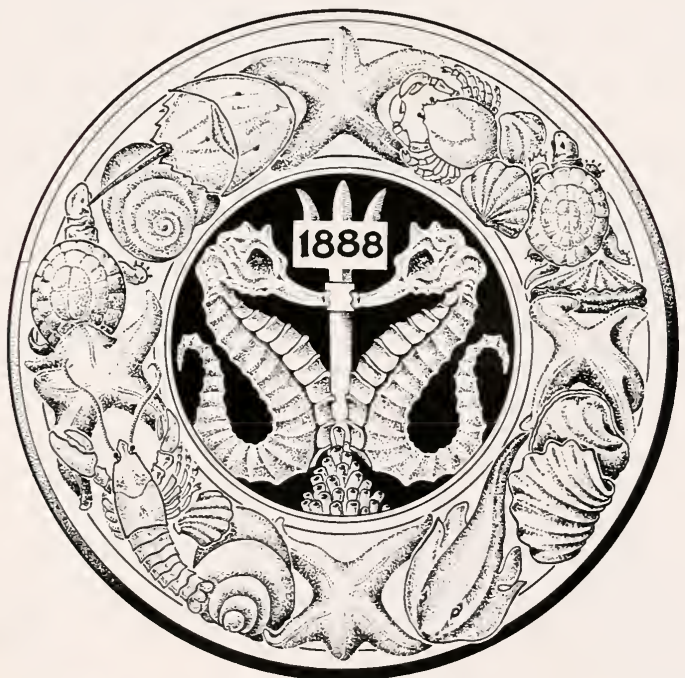

Gift of Thomas R. Stetson - 1979 

AN INTRODUCTION TO THE STUDY OF FOSSILS 


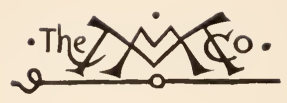

THE MACMILLAN COMPANY

NEW YORK - BOSTON - CHICAGO - DALI.AS ATLANTA - SAN FRANCISCO
MACMILLAN \& CO., Limited
LONDON - BOMBAY - CALCUTTA MELBOURNE

THE MACMILLAN CO. OF CANADA, LTD. TORONTO 


\section{AN INTRODUCTION TO THE STUDY OF FOSSILS}

\section{(PLANTS AND ANIMALS)}

BY

Hervey WoOdburn Shimer, A.M., Ph.D.

ASSOCIATE PROFESSOR OF PALEONTOLOGY IN THE MASSACHUSETTS INSTITUTE OF TECHNOLOGY

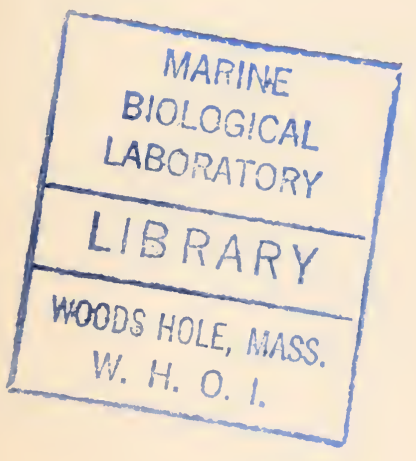

Xriw Hork

THE MACMILLAN COMPANY

I92 I

All rights reserved 
COPYRIGHT, 1914,

By THE MACMILLAN COMPANY.

Set up and electrotyped. Published November, 1914

Norwood 据ress

J. S. Cushing Co. - Berwick \& Smith Co.

Norwood, Mass., U.S.A. 
$\tau_{0}$

MY WIFE

COMRADE AND COLLABORATOR

THIS BOOK

IS DEDICATED 



\section{PREFACE}

THIs little volume has grown out of a need experienced by the author during fifteen years of teaching paleontology. He has found that students come to the subject either with very little previous training in biology, or at best with a training which has not been along the lines that would definitely aid them in understanding fossils. Too often fossils are looked upon merely as bits of stone, differing only in form from the rocks in which they are embedded. Hence to awaken interest in them as once living animals and plants, connected by the wonderful chain of evolution with the animals and plants now living, has been the chief aim of the author's lectures and laboratory work upon introductory paleontology which he here presents.

To this end certain living forms have first been discussed as types of their phyla or classes with especial reference to those features which will help the student to understand the related fossil forms considered later. The response which these living forms make to their environment is considered, where they live, how their life is maintained and how they perpetuate their kind. The relation of the soft body to the hard skeleton or shell is especially emphasized, since it is largely through this very intimate relationship that our interpretation of extinct life is made possible. The student may thus reconstruct from the hard parts preserved in the rocks the appearance of the once living animal. The discussion has been kept as free as possible from unnecessary technical terms.

Beyond this work of showing how past life may be interpreted by the life of the present, and beyond this first comprehensive view of the animal and plant world, such a book as this need 
not go. For further and more detailed study of the fossils themselves other books furnish ample material.

The author is indebted to many persons for aid in the preparation of this volume, and in particular wishes to express his gratitude to the following for criticism of various portions of the manuscript and for the loan of illustrations :

R. S. Bassler of the United States National Museum, Louis Hussakof of the American Museum of Natural History, Gary N. Calkins and Amadeus IV. Grabau of Columbia University, John M. Clarke and Rudolph Ruedemann of the New York State Geologic Survey, Charles Schuchert and Richard S. Lull of Yale University, Percy E. Raymond and William F. Clapp of the Museum of Comparative Zoölogy, Harvard University, Francis N. Balch of Boston, Robert T. Jackson and Joseph A. Cushman of the Boston Society of Natural History, Charles H. Warren and R. P. Bigelow of the Massachusetts Institute of Technology, Edward S. Morse of the Peabody Academy of Science, Salem, and S. W. Williston of Chicago University.

To G. R. Wieland of Yale University he feels especially indebted for most valuable suggestions on, and the loan of illustrations for, the chapter on plants. The original drawings in the book owe much to the scientific knowledge and personal interest which their delineator, Mr. J. Henry Blake of Cambridge, has contributed to their execution. 


\section{CONTENTS}

INTRODUCTION :

PAGE

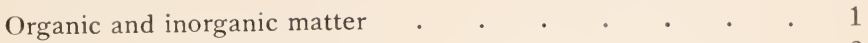

Plants and animals distinguished . . . . . . . . 2

Fossils . . . . . . . . . . 3

Conditions of preservation . . . . . . . . 3

Classification of fossils . . . . . . . . . 8

Process of fossilization . . . . . . . . . . . 9

Restoration of fossils . . . . . . . . . . 17

Color . . . . . . . . . . . 20

Fussil objects due to inorganic agencies . . . . 20

Distortion . . . . . . . . 21

Pseudo-fossils . . . . . . . . . . . 21

Collecting fossils . . . . . . . . . . 22

Index fossils . . . . . . . . . 22

Migration, etc. $\quad$. $\quad . \quad$. . . . 23

Naming of organisms . . . . . . . . . . 24

Composition of hard parts . $\quad . \quad$. $\quad . \quad$. 25

PLANTS :

Division I, Thallophyta . . . . 32

Sub-division A, Myxömycetæ . . . . . . . . 33

Sub-division B, Schizophyta . . . . . . . 33

Sub-division C, Diatomeæ . . . . . . . . 34

Sub-division D, Algæ . • . . . . . . . . 35

Sub-division E, Fungi . . . . . . . . . . 40

Division II, BRYOPHYTA . • • . 42

Division III, Pteridophyta . . . . 44

Order $a$, Filicales . . . . . . . . . . 46

Order $b$, Equisetales . . . . . . . . . 48

Order $c$, Lycopodiales . . . . . . . . . 51

Order $d$, Sphenophyllales . $\quad . \quad$. $\quad . \quad$. 55 
PLANTS (Continued) :

Division IV, Spermatophyta . . . 55

Sub-division A, Gymnospermæ . . . . . . . 56

Order $a$, Cycadofilicales $\quad . \quad$. $\quad . \quad . \quad . \quad . \quad . \quad 57$

Order $b$, Cycadales . . . . . . . . . . . 60

Family 1, Cycadeoideæ . . . . . . . . 60

Family 2, Cycadeæ . . . . . . . . 66

Order $c$, Cordaitales . . . . . . . . . . 67

Order $d$, Ginkgoales . . . . . . . . . . . 69

Order $e$, Coniferales . . . . . . . . . . 70

Order $f$, Gnetales . . . . . . . . . . . 75

Sub-division B, Angiospermæ . . . . . . . 75

Class 1, Monocotyledones . . . . . . . . . 78

Class 2, Dicotyledones . . . . . . . . . . 79

ANIMALS :

Phylum I, Protozoa . . . $\quad . \quad 83$

General survey of phylum . . . . . . . . . 83

Type of phylum, Amaba proterss . . . . . . . . $\quad$. 84

Class A, Sarcodina . . . . . . . . . . . $\quad .88$

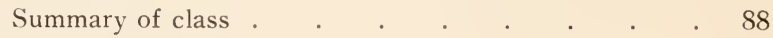

Sub-class 1, Rhizopoda . . . . . . . . . 88

Summary and classification of sub-class . . . . $\quad 88$

Living and fossil examples . . . . . . . 90

Sub-class 2, Actinopoda . . . . . . . . . $\quad$. 93

Summary and classification . . . . . . . . 93

Class B, Mastigophora . . . . . . . . . . . 94

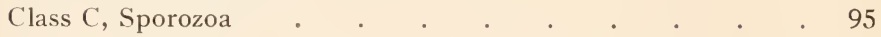

Class D, Infusoria $\quad . \quad$. $\quad . \quad$. $\quad . \quad . \quad$. $\quad . \quad$. 95

Phylum II, Porifera . . . . 96

General survey of phylum . . . . . . . . . . 96

Type of phylum, Grantia ciliata . . . . . . . . 99

Sub-class A, Calcarea . . . . . . . . 102

Sub-class B, Non-Calcarea . . . . . . . 102

Fossil examples . . . . . . . . . . . 103

Phylum III, Celenterata . . . . 108

General survey of phylum . . . . . . . 108

Class A, Hydrozoa . . . . . . . . . . 108

Type of class, Sertularia pumila . . . . . . . 108 
General survey of class. . . . . . . . 112

Order 1, Graptolithida . . . . . . . . . 113

Type of order, Diplograptus foliaceus . . . . 113

General survey of order . . . . . . . . 115

Fossil examples . . . . . . . . 117

Class B, Scyphozoa . . . . . . . . . 121

Class C, Anthozoa . . . . . . . . . 122

Type of class, Astrangia dana . . . . . . . . 122

General survey and classification of class . . . . 128

Fossil examples . . . . . . . . . 131

Class D, Ctenophora . . . . . . . . . 139

Phylum IV, Platyhelminthes . . . 140

Phylum V, Nemathelminthes . . . 140

Phylum Vi, Trochelminthes . . . 141

Phylum VII, Annulata . . . . 141

Class A, Archi-annelida . . . . . . . . . 142

Class B, Hirudines . . . . . . . . . 142

Class C, Gephyrea . . . . . . . . . 142

Class D, Chætopoda . . . . . . . . . 142

Type of class, Nereis virens . . . . . . . . . 142

Summary of Chætopoda . . . . . . . . 146

Fossil examples . . . . . . . . . 146

Phylum Vili, Echinodermata • . . 148

General survey and classification . . . . . . 148

Type of phylum, Asterias forbesi . . . . . . . . 149

Class A, Cystoidea . . . . . . . . . . 154

General survey of class . . . . . . . . . 154

Type of class, Caryocrinus . . . . . . . . 155

Fossil example . . . . . . . . . . 156

Class B, Blastoidea . . . . . . . . . 157

General survey of class. . . . . . . . . . . 157

Type of class, Pentremites . . . . . . . . 157 
ANIMALS (Continued):

Class C, Crinoidea

General survey of class .

Type of class, Pentacrinus

Fossil example

Class D, Asteroidea

General survey of class .

Fossil example

Class E, Ophiuroidea

General survey of class

Class F, Echinoidea

General survey of class .

Type of class, Strongylocentrotus

Fossil example

General survey of class

General survey and classification .

ss Aryozoa.

Type of class, Bugula azicularia . . . . . . . . 173

General survey of class . . . . . . . . . . 176

Fossil and living examples . . . . . . . . . 178

Class B, Phoronida . . . . . . . . . . 181

Class C, Brachiopoda . . . . . . . . . 181

Type of class, Terebratulina septentrionalis . . . . . 181

General survey of class . . . . . . . . 187

Fossil and living examples . . . . . . . . . . 193

Phylum $\mathrm{X}$, Mollusca . . . . 206

General survey and classification . . . . . . 206

Class A, Amphineura . . . . . . . . . 207

Class B, Pelecypoda . . . . . . . . . . . 208

Type of class, Venus mercenaria . . . . . . . 208

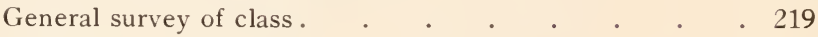

Fossil and living examples . . . . . . . . . 223

Class C, Gastropoda . . . . . . . . . . . 234

Type of class, Busycon canaliculatus . . . . . . . 234

General survey of class. . . . . . . . . . 241

Fossil and living examples . . . . . . . . . 244

Class D, Scaphopoda . . . . . . . . . . . 250 
ANIMALS (Continued) :

Class E, Cephalopoda

Type of class, Nautilus pompilius . . . . . . . 251

General survey and classification . . . . . . 259

Fossil and living examples . . . . . . . . . 262

\section{Phylum XI, Arthropoda • • • . 274}

General survey and classification . . . . . . . 274

Class A, Crustacea . . . . . . . . . . 275

Type of class, Cambanus . . . . . . . . 275

General survey and classification . . . . . . 284

Sub-class 1, Trilobita . . . . . . . . . 285

Type of sub-class, Triarthrus . . . . . . . 285

General survey of sub-class . . . . . . . 290

Fossil examples . . . . . . . . . 294

Sub-class 2, Phyllopoda . . . . . . . . . 299

Summary . . . . . . . . . . 299

Type of sub-class, Apus . . . . . . . . . . 299

Fossil examples . . . . . . . . . 301

Sub-class 3, Ostracoda . . . . . . . . . . 303

Summary . . . . . . . . . 303

Fossil and living examples . . . . . . 303

Sub-class 4, Copepoda . . . . . . . . 304

Sub-class 5, Cirripedia . . . . . . . . . 305

Summary . . . . . . . . . . . 305

Fossil examples . $\quad . \quad . \quad . \quad . \quad . \quad . \quad . \quad 305$

Sub-class 6, Malacostraca . . . . . . . . 306

Summary and classification . . . . . . . 306

Fossil and living examples . . . . . . 306

Sub-class 7, Stomatopoda . . . . . . . . 308

Class B, Onychophora . . . . . . . . . . 308

Class C, Myriopoda . . . . . . . . . . 309

Class D, Arachnida . . . . . . . . . . 309

General survey and classification . . . . . . 309

Order 1, Xiphosura . . . . . . . . . . . 311

Summary of order . . . . . . . . . . . 311

Fossil and living examples . . . . . . . 312

Order 2, Eurypterida . . . . . . . . . 312

Summary of order . . . . . . . . . 312

Fossil examples . . . . . . . . . 313

Order 3, Limulava . . . . . . . . . 314

Orders 4-16 . . . . . . . . . . . . . 314 



\section{AN INTRODUCTION TO THE STUDY OF FOSSILS}

\section{INTRODUCTION}

\section{ORGANIC AND INORGANIC MATTER}

Matter is either organic or inorganic. Organic matter is arranged in the form of a plant or animal body, and is so called because it is made up of various organs such as those for eating, breathing and reproduction. In the lowest organisms the entire body forms but a single organ. When matter is not thus organized, as in air, earth and water, it is called inorganic. Food in the shape of lifeless matter, including many inorganic substances and those organic substances in which all the organs have ceased functioning, is absorbed by functioning organisms, and in some manner, not understood, is transformed by them into living matter, that is, into protoplasm. For protoplasm is the only living matter, and through its activity is built up such supporting and protecting tissues as the cellulose of plants, the bone and shell of animals.

Protoplasm, whether plant or animal, has the following properties which distinguish it from lifeless matter. (I) Chemically it always contains proteids or albumins, - complex compounds of carbon, hydrogen, oxygen, nitrogen and sulfur. It contains, on the average, of carbon $5^{2}$ per cent, of hydrogen 7 per cent, of nitrogen 16 per cent, of oxygen 23 per cent and of sulfur $0.5^{-2.0}$ per cent. The nucleoproteids, found in the cell nuclei, contain also a small amount of phosphorus. (The 
white of an egg is almost pure proteid plus much water.) (2) Physiologically it has the power of waste and repair, of growth and of reproduction.

Living organisms waste away by oxidation, a kind of internal combustion, but continually repair this waste by additions between the existing molecules. If this addition is greater than that necessary for repair, growth occurs. (Inorganic substances, on the other hand, such as crystals, grow solely by external addition.) Living bodies likewise detach portions of themselves, which thus acquire independent existence and develop into the form of the parent.

\section{PLANTS AND ANIMALS DISTINGUISHED}

Plants and animals differ fundamentally in their food; the former usually feed upon inorganic, and the latter upon organic matter. As a result of this, plants tend to a life of immobility, deriving their food from the soil, water and air about them. They accomplish this through the agency of the sun's rays, which, working through the green coloring matter, - chlorophyl, combine the unorganized elements into the complex products, - proteids, carbohydrates and fats. Animals, on the other hand, as a result of searching for their food, tend to a life of mobility, deriving their food from plants or other animals; hence chlorophyl is absent, and as a consequence of its absence starch is not manufactured and thus cellulose is likewise wanting. (All animals have freedom. of movement at some period of their lives, even those sessile when adult, as the sponge, coral and barnacle, can move from place to place in their embryonic life.) These differences between plants and animals are, however, not absolute; some of the lower forms of each sub-kingdom have properties which in their full development characterize the opposite sub-kingdom. For example, among plants, fungi live upon organic matter, many algæ, as diatoms, spores of cryptogams and the male sexual element of 
most plants have the power of locomotion; the dodder and most bacteria have no chlorophyl. Among animals the protozoön, Euglena, has chlorophyl, while cellulose is present in some Protozoa and is abundant even in the ascidians of the Chordata.

\section{FOSSILS}

Conditions of their preservation. - I. That they soon be embedded in some protective material.

In order that a plant or an animal may leave a record of its existence, that is, become a fossil, a speedy entombment within some protective material is necessary. If an organism is left exposed after death, it quickly becomes disintegrated either through decay or through the attacks of living animals. In other words it at once becomes food to living animals and plants ranging in size from bacteria and protozoöns to beasts and birds of prey. This disintegration is aided likewise by chemical and mechanical agencies so that the dead organism passes rapidly back into its inorganic elements. The undertow of waves is the strongest mechanical agency in the disintegration of marine organic remains, such as corals, shells and bones.

The habitat of the animal controls the kind of protective material in which it may become embedded after death. As protective materials may be noted sedimentary deposits due to water or wind, ashes from volcanic explosions, bog waters, resin, ice, and incrustations from mineral solutions.

Occasionally the entire animal or plant is encased by the rapid deposition of silica or calcium carbonate. Such incrustations may occur through immersion in springs, as in the geyser area of the Yellowstone National Park. Much more common is preservation by means of water which has percolated through or over limestone beds; upon the evaporation of the water the lime which it has dissolved is again deposited. This is especially apt to occur in caves or at the margins of limestone ledges. Many remains of Pleistocene man and 
beasts occur in caves of western Europe preserved by such a stalagmite covering.

During a time of increasing cold, as at the beginning of the late Glacial Period, the bogs within the colder areas became frozen. In these natural refrigerators remains of plants and animals are well preserved.

As resin stickily exudes from trees it is apt to hold all small objects that touch it, especially seeds and insects, and these are soon completely inclosed by it. Fossil resin, known as amber, is found in various parts of the world, but is most abundant in the Oligocene beds along the Prussian shores of the Baltic Sea.

The water of peat bogs and marshes has antiseptic properties, and because of this organisms immersed in it decay very slowly. Logs long inclosed in such waters have been dug up and utilized in various regions, such as southern New Jersey.

Volcanic eruptions are at times accompanied by very much fragmental material, especially ash. This ash, falling thickly, is apt to bear down with it many insects, and if falling into a shallow lake, will bury them with such other organisms as may be there present. Such showers occurred at times during the Miocene at Florissant in Colorado, and to them we doubtless owe much of the marvelous record of insect life there preserved (Fig. I37).

Similarly, when prevailing winds blow from a dry into a moist region, or from an area without vegetation to one with it, dust will accumulate in the latter region, resulting in time in thick deposits of unconsolidated, fine, porous, siliceous silt. Such deposits, called loess, are especially abundant in North America, Europe and Asia, from Pleistocene times to the present, and are apt to contain land shells. Some loess is of aqueous origin. The coarser wind deposits, such as sand dunes, are not likely to contain fossils; such an unfossiliferous dune deposit is seen in the coarse-grained, white sandstone of Jurassic age in southern Utah.

The vast majority of organic remains preserved as fossils 
have been covered with sediment brought by water. Deposits upon the surface of the continent - lake, flood plain, alluvialfan and playa deposits - are in the zone where erosion is dominant and are hence apt to be quickly, geologically speaking, worn away with all their included organic remains. Those

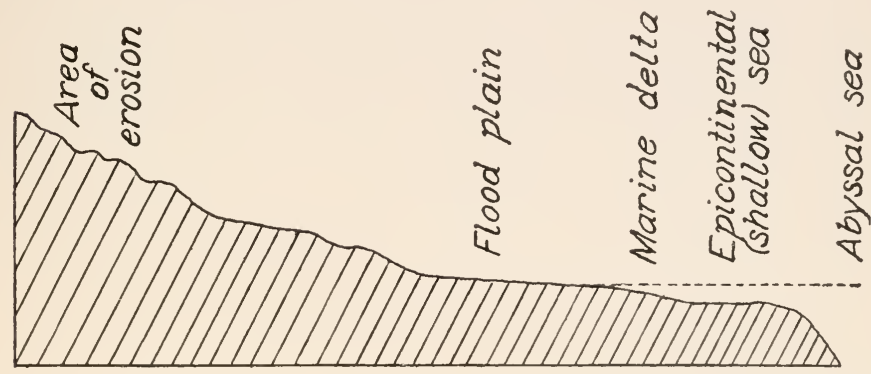

FIG. I. - Diagram to illustrate that the habitat of a plant or animal determines its chance of preservation as a fossil.

deposits are thicker and stand a much better chance of preservation, which are poured by continent-draining rivers into the sea as a delta and are spread upon its margin as a flood plain (Fig. I). The delta and flood plain of the Ganges and Indus rivers (Early Tertiary to present) and that forming the Mauch Chunk shales (Mississippian) of Pennsylvania are good examples. The seaward portion of these deposits, being more continuously under water, is best able to preserve the organic remains deposited in it ; hence we find the Greenbrier formation, interfingering the Mauch Chunk shales in southwestern Pennsylvania, full of marine fossils. The landward portion is covered with water and its accompanying layer of sediment only during times of flood when the river overflows its banks; during the rest of the year the level of the ground water sinks to a greater and greater depth, gradually dissolving all soluble objects as it moves, while the air circulates freely through the upper waterfree deposits, completing the oxidation of all organic remains there present. The decay of plants or animals is an oxidizing 
process due largely to the multiplication of bacteria. Hence in these more landward deposits an organism encounters many agencies of destruction, both chemical and organic, and stands little chance of preservation (Fig. I). Thus in the Mauch Chunk shales of Pennsylvania and in the Newark beds (an Upper Triassic alluvial fan and flood plain deposit) of Connecticut, New Jersey, etc., few fossils occur and these are principally footprints and plant impressions. In portions of the Wasatch and Bridger formations (Eocene flood plain deposits) of Utah and Wyoming more fossils occur, but they are much more abundant in the Florissant beds (a Miocene lake deposit) of Colorado.

In short, the more completely air and circulating water are kept away from organic remains the better the chance for their preservation as fossils; and, accordingly, marine, lake or marsh deposits are more favorable than those of a flood plain, alluvialfan or playa, while clay or limestone are better mediums than sandstones or coarse ash deposits.

It is thus seen that the chances for the preservation of animals or plants varies with their habitat (Fig. I). Inhabitants of mountainous regions where erosion is greater than deposition stand very poor chance for preservation in the fossil state; those living on low plains and in fresh water are more likely to be preserved; but it is the marine forms, especially those living upon the seafloor beyond the breakers but in water still comparatively shallow, that stand the best chance for preservation (Fig. I). Here at their death the organic forms are quickly covered by the sediment which, brought in by the rivers or torn by the waves from the land, is widely distributed by the drift of the waters. Hence of all organic forms, marine invertebrates stand the best chance of preservation, for they are the most numerous of all animals and they occupy those areas where oxidation is slow and where a prolonged sedimentation is apt to occur; these forms are, accordingly, the most important of all fossils for the correlation of strata. It is not strange, therefore, that many species of fossil insects are known each from but a single speci- 
men, and that such a land form as Archæopteryx - the earliest known bird - is represented by only two specimens and a separate feather, all from the lithographic limestone quarries (Upper Jurassic) of Solenhofen, Bavaria. Species of fossil marine shells, on the other hand, are known by thousands of individuals.

2. That hard parts be present in the organism.

To insure preservation it is usually necessary that the organism have some protective structure, such as the shell of a clam, the bones of a reptile, or the woody fiber of a tree, which upon the death of the animal or plant resists decay for a much longer time than do the softer portions. Usually the less fibrous plants and the softer parts of animals - epithelium, nerves, muscles, and even cartilage and horn - quickly suffer decay; and only the skeleton or the external covering, composed of chitin, silica, or of the carbonate or phosphate of calcium, are preservable. Thus multitudes of animals, such as most protozoöns, jelly-fish, sea anemones, many bryozoa and mollusks, most worms, the tunicates, most parasites, and the embryos of most animals, which lack such hard parts, are exceedingly rare or entirely wanting as fossils. Since the vast majority of the invertebrates living in the sea or fresh water are naked or provided with very fragile hard parts, it is only the bottom-living forms, which, in their heavy, protective hard parts, are usually preserved. Notwithstanding the rapid decay of all soft tissues they are occasionally preserved, as for example, by freezing in the bog-ice of Siberia, by carbonization (page 13), or even by the taking up of lime phosphate on the part of the epidermal and muscular tissues. Animals without hard parts at times also leave a record of themselves, such as trails (like those due to the tentacles of a jelly-fish), as internal molds (as the sandfillings of the lobed pouches of the jelly-fish, Fig. 45), or as impressions of the entire jelly-fish, of leaves, etc.

Only rarely are plants protected by calcium carbonate or silica (page 26); usually their preservation is due to direct 
replacement, to the formation of external molds or to the process of carbonization (page 13 ).

Classification of Fossils. - A fossil is the remains of a plant or animal, or the record of its presence, preserved in the rocks of the earth.

The word is derived from the Latin fodere, to dig, and hence has associated with it the thought of something dug up, for in most cases the preservation of a form depends upon its burial. Many geologists restrict the term fossil so as to include evidences of life to the close of the Pleistocene only. According to this definition all post-Pleistocene remains are spoken of as recent, not fossil.

Fossilization is the sum of the phenomena by which the remains of animals or plants, or the evidences of their presence are preserved in the earth's strata.

Fossils may be divided according to the above definition into,

I. Fossilized remains of organisms.

II. Objects indicating the former presence of organisms.

Sometimes these fossils preserve their original composition as when first buried, that is, they are unaltered. At other times they become more or less completely altered by infiltration of minerals from the surrounding rocks, or the more volatile parts are gradually given off, leaving a residue composed very largely of carbon. It is to such fossils only that the term petrifaction, i.e. " turned to stone," should be applied.

I. Fossulized Remains of Organisms

A. Unaltered (i.e. original).

I. Originally soft portions of the animal preserved. Examples: insects in amber; mammoths in frozen earth of Siberia.

2. Only hard parts preserved. Examples: many Cenozoic shells, bones, teeth, horns.

B. Altered (i.e. petrifications); these are divided into four main divisions according to the material petrifying them. Al- 
though silica, lime carbonate, and iron pyrites are the most common replacing minerals, 30 to 40 others replace more rarely.

I. Through silicification. - Varying from the merely partial filling of cavities in fossils (even if composed of silica) to entire replacement with silica. Examples: Shells, plants.

2. Through calcification. - Varying from the merely partial filling of cavities in fossils (even if composed of calcium carbonate) to entire replacement with calcium carbonate. Examples: Most fossil corals, brachiopods, echinoderms, mollusks.

3. Through pyritization. - Varying from the merely partial filling of cavities to entire replacement with pyrite or marcasite. Examples: Shells, crustacea, plants.

4. Through carbonization. - Animal or vegetable tissue decomposed under water, resulting in a giving off of comparatively more hydrogen and oxygen than carbon, with a resultant concentration of carbon. Examples: Fish, graptolites, plants.

\section{Objects Indicating the Former Presence of Organisms}

\section{A. Molds, external and internal.}

I. Imprints of shells, feathers, tree trunks, entire animal (as dog), etc.

2. Tracks of amphibians, reptiles, birds, etc.

3. Trails of worms, crustaceans, etc.

4. Burrows of worms, echinoids, mammals, etc.

B. Coprolites.

C. Artificial structures. Examples: Birds' nests, early human implements.

Fossils unaltered (original). - All organic remains last longer in a region of almost continuous dry or cold than in one which is moister and warmer. In very cold, or very dry, regions, even the softer portions may remain-unchanged for a long time, preserving to future ages the entire animal. Thus, examples of the ancient elephant - the mammoth - entombed in the ice and frozen earth of Siberia since the Pleistocene, are so well 
preserved that dogs and wolves will eat their flesh. Likewise, remains of the cliff dwellers in Arizona and New Mexico, such as clothing, food, and human bodies, have been preserved in the dry air of that plateau region for at least many hundreds of years. Many Tertiary insects have been preserved in their entirety, except for complete desiccation, without a trace of mineral infiltration, inclosed in amber; upon this ancient gum as it was exuding from the pine trees, insects settled, and being held fast by the sticky substance, were finally entirely inclosed. Such trees and their gum were buried in the sediment beneath the waters of seas or large lakes, thus preserving these ancient insects in all their perfection of form and brilliant coloring.

Usually, however, only the hard parts of organisms are preserved, and but few of these are found in an unaltered state in pre-Cretaceous rocks; it is principally in the Cenozoic rocks that they thus occur. The unaltered bone is more or less spongy in appearance, something like volcanic pumice or slag, but most of the cavities are canals, continuous and anastomosing; they do not end blindly as do those in slag. These Haversian canals, filled during the life of the animal with arteries, veins and nerves, are much larger and more numerous in the interior of the bone than in the more compact and consequently harder outer portion. Non-petrified shells of Cenozoic or older age, besides having lost much or all of their original color, are usually also somewhat chalky in appearance. This chalkiness is due to the loss of the fleshy material which penetrates the living shell, not only vertically, but also horizontally. The abundance of this spongy animal matter may be demonstrated by an experiment. If a recent shell be placed in a dilute acid which is changed frequently, in two or three days the calcium carbonate will be dissolved away but the shape of the shell will still be retained by the animal matter which formerly penetrated it. Thus shells from the Sankaty beds (Pleistocene) of Nantucket, Massachusetts, differ from the recent shells only in their porosity and in having lost much of their color. 
Fossils altered (petrifactions). - Whenever organic remains are inclosed in sediment to which the air has free access, their disintegration is rapid and complete (page 5); but if the deposits become very thick before they are raised from the water, free air will be largely excluded and destruction of the fossils will be principally due to the percolation of the water through the strata from higher to lower levels. That heat is not necessary in the solution of shells is seen in many deposits of glacial age. For example, the drumlins in and to the south of Boston Harbor, which have remained surface deposits from the time of their formation, contain no shells in the upper half, but below that level they are quite fossiliferous. Here it could only be the carbonic acid gas, caught by the rain drops while falling through the air, that caused the gradual solution of the shells.

Silicification.-- If the percolating water is a supersaturated solution of some mineral substance, such as silica or lime, the first step in the petrifaction of the fossil will be the filling of all existing cavities with this substance. In such a case the original chemical composition of the shell, bone or wood will remain, but with the many minute openings filled with the foreign mineral. This is the condition of many of the dinosaur and other vertebrate bones of the Mesozoic. Often, however, the petrifaction, or making into stone, is a process of solution and deposition taking place pari passu, and due to the waters being under-saturated with the chemical substances of which the fossil is composed, but oversaturated with some other substance. Such a replacement is at times very perfect. The probable process is that as a molecule of the original structure is removed, a molecule of the depositing substance takes its place; in this case the finer structure, such as the fiber in wood, or the pores and lamellæ in shells, is perfectly preserved. Such preservation of the finer details of structure is seen in many of the sections of the trunks of petrified trees from the fossil forests of the Yellowstone National Park (Fig. 24), from Arizona and from 
many other states. In the case of plants, the wood may act as a sponge, capillary attraction drawing up the siliceous water, while possibly the high density of this liquid would aid the solution and extrusion of the cellulose (woody fiber).

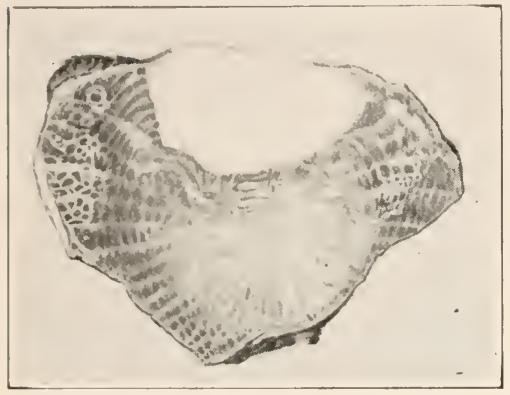

FIG. 2.- Iron replacing lime in the Devonian coral, Heliophyllum halli E \& H, from New York. Natural size. The iron forms the ramifying white lines upon each side; this largely follows the septa, but it branches from these in all directions. This molecular replacement is most common with silica, lime and iron. In iron, replacement takes place in the presence of organic substances; percolating waters rich in iron and sulfur will be precipitated upon coming into contact with these, causing the formation of marcasite or of iron pyrites ( $\mathrm{FeS}_{2}$ ) (Fig. 2).

Silica is soluble in waters containing carbonates of the alkalis $(\mathrm{Na}, \mathrm{K}$ ) or alkaline earths ( $\mathrm{Ca}, \mathrm{Mg})$, such as the ordinary water leaching through the soil. This solution (alkaline solvent of silica), coming in contact with the carbon dioxid of a decaying organism, is neutralized and the silica thrown down; or this precipitation of silica may occur through the agency of the carbon dioxid evolved by a living organism, such as the diatom, which thus manufactures its siliceous skeleton. The siliceous skeleton of organisms is composed of hydrous silica and is subject to dehydration into chalcedony, or to a later crystallization into quartz. Hence deposits of the minute diatom skeletons (about 40 million to the cubic inch), known as tripolite, are rarely older than the Tertiary, since the older deposits have probably been dissolved and redeposited as chert.

Similar replacement by silica occurs very frequently at the surface of a rock; probably the majority of silicified shells are thus formed. 
It is thus seen that the present composition of a fossil is no indication of its original composition, for there may be iron or siliceous replacements (pseudomorphs) of calcareous shells, iron pseudomorphs after chitinous skeletons and plants, and even, as in some sponges, calcareous pseudomorphs after siliceous skeletons. The determination of the original composition depends, in such cases, upon comparison of the form of the organism with the nearest living representatives.

Carbonization. - If leaves fall into water, they sooner or later sink to the bottom, where they may be noted along the tree-lined margin of any lake or quiet stream; here comparatively little free oxygen can reach them. Decay accordingly is very slow and usually but partial, leaving a residue of carbon ; this, made fine by the motion of the water, gives the black color so characteristic of such bottoms. The form of the leaves under these conditions is, accordingly, not preserved, but their presence is indicated by the black color still persisting after these ancient lake and river margins have hardened into rock. Other leaves, though suffering a similar concentration of carbon, fall in a situation that insures their more rapid burial by the mud brought in by the rivers; they are accordingly preserved as carbonized films, showing all their original veining. This same process would occur in the case of any other form of vegetation or even of animals (Hydrozoa, Crustacea, fish, etc.), if they were buried beyond the reach of those that prey upon them.

The process of carbonization is essentially the giving off of marsh gas $\left(\mathrm{CH}_{4}\right)$, water $\left(\mathrm{H}_{2} \mathrm{O}\right)$ and carbon dioxid $\left(\mathrm{CO}_{2}\right)$; the last cannot be developed to the exhaustion of the carbon, since, compared with air, little free oxygen exists in standing water. Thus wood $\left(6 \mathrm{C}_{6} \mathrm{H}_{10} \mathrm{O}_{5}\right)$ under such conditions would eventually yield an anthracite coal $\left(\mathrm{C}_{24} \mathrm{H}_{8} \mathrm{O}\right)$.

Good examples of carbonized plant fossils occur in the roof shales of coal mines. Remains of animals similarly preserved are likewise abundant; well-known examples are Hydrozoa (graptolites) in the Utica shales (Ordovician) of eastern New 
York, and fish in the Newark beds (upper Triassic) of New Jersey and Massachusetts.

Objects indicating the former presence of organisms.Molds. - When a leaf falls upon soft mud, it will impress there its form and surface markings; but the sun may quickly

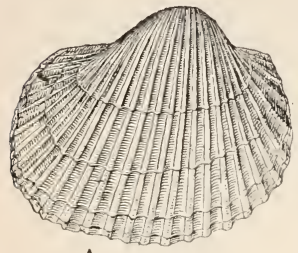

A

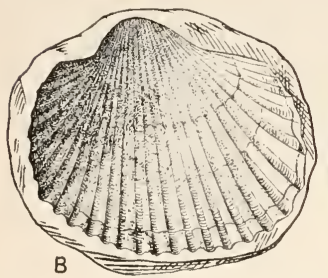

B
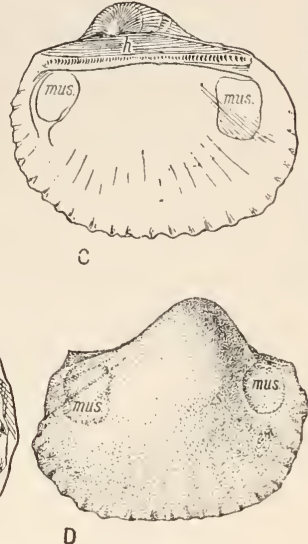
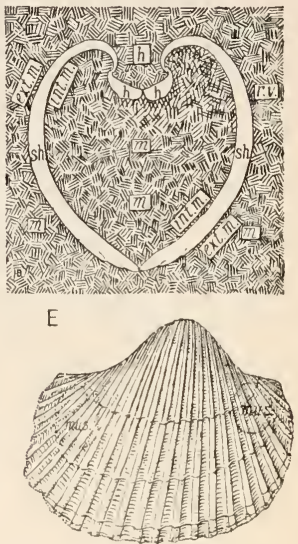

$\mathrm{F}$

FIG. 3. - Diagram to explain molds, external and internal, and casts. The shell is the common ark, Arca transversa from Long Island Sound. A, external surface of right valve; $B$, the concave external mold of same valve; $C$, interior view of right valve; $D$, internal mold of same valve; $E$, section through entire shell from hinge-line $(h)$ forward, the shell being embedded in and filled with sediment $(m) ; F$, external ornamentation impressed upon the internal ornamentation through the settling of the sediment after the chemical removal of the shell (as from Fig. E) by water percolating through the strata. ext.m., external mold; $h$., hinge-line; int. m., internal mold; m., matrix, or sediment; mus., muscle scars; $r$. v., right valve; sh., shell (or, if shell is removed and this cavity is filled by some foreign substance, this substance is termed a cast of the valve, since it is formed between molds). ( $\times \frac{1}{2}$.)

curl its edges so that it will be blown away by the wind. If this impression or mold be covered by sediment, the imprint is preserved without the leaf itself being inclosed. The mold is thus shaped into the form and surface character of the original. If a shell, such as a clam or snail, be covered with sediment, it will impress its external ornamentation upon the surrounding material (Fig. 3, B). The motion of the water aided later by the weight 
of the overlying sediment will usually completely fill the interior of the shell, and upon this filling is impressed the shell's internal ornamentation (Fig. 3, D). The external and internal molds have thus the exact form and surface characters of the exterior and interior of the shell. (Good examples of these molds may easily be made by taking a complete clam or ark shell, first dipping it in water, and then filling and surrounding it with plaster of paris moistened to a plastic state.)

If the waters percolating through the earth's strata be rich in some solvent, as carbonic acid, and poor in lime, they will dissolve the calcareous shells from between their external and internal molds, and carry them away as a solution of bicarbonate of lime, leaving hollows where were the shells. In such a case one of three things happens: (I) there remains an open cavity, as in much of the Devonian (Oriskany) sandistone of eastern New York, Pennsylvania and New Jersey ; (2) through the settling of the strata the external mold comes into contact with the internal (Fig. 3, F), and the external ornamentation thus becomes impressed upon the interior markings, as in many brachiopod and pelecypod shells from the Paleozoic; or (3) a petrifaction will be formed; i.e. through a change in the direction of flow due to a differential upheaval of the region, or some other cause, the percolating waters become supersaturated with, for example, silica, lime or iron; these hollows will then be filled and the foreign mineral will be shaped by the molds already formed into a cast (Fig. 3, E). Such a cast will bear an exact surface likeness to the original shell, but will lack entirely its internal structure. It is in such formation of a cast that the external and internal molds perform the true function of molds as usually defined, since they are thus " that in which something is molded or formed." (Casts of iron fossils must usually be covered with a thin coating of melted paraffin to prevent a rapid rusting (oxidation and hydration) upon exposure to the air.)

When the shell has been removed, leaving an open cavity, the shape and ornamentation of the original shell may be ob- 
tained by pressing into it dental wax softened by heating in hot water, forming thus an artificial cast. Soft plaster of paris may likewise be used. If, however, the cavity is partially closed, the mold must be destroyed in extracting the cast. This method of restoring the form of the organism must frequently be used, since plants and animals are often coated with stone while the organic structure is still perfectly retained. Upon the decay of the inclosed organism, which occurs rather quickly, there is left a perfect external mold. In the ancient ash-covered town of Pompeii the use of plaster of paris has enabled the workmen to preserve the external form of several men and dogs buried by the fragmental material which fell during the Mt. Vesuvius eruption of 79 A.D.

Tracks. - When birds or other animals searching for food walk over the mud flats of a river or sea, impressions of their feet are left, which when covered with sediment may be preserved as fossils. Examples of such are the reptile tracks in the Upper Triassic shaly sandstones of the Connecticut Valley (Fig. I53) and the tracks of the Mississippian amphibian, Sauropus primavus, in the Mauch Chunk red shales of Pennsylvania.

Trails. - Similar to the preservation of tracks is that of trails, though many of these are made on the soft sediment beneath the surface of the water. Trails are the irregular markings of animals, such as those due to the crawling of a worm or snail, the dragging tentacles of a jelły-fish, the impressions of the fins of fish or the markings left by the movements of crustaceans or sea urchins.

Burrows. - When a worm burrows and eats its way through rather compact earth the hole remains for some time and finer material may later be washed into it; when it burrows its way through very moist sediment, as at the seashore, the finer material is usually carried into the cavity immediately behind it by the water oozing in from the sides. In both of these cases the resultant is a tube of finer material surrounded by coarser; as, 
for example, Scolithus from the upper Cambrian sandstones of the Appalachian region. Burrows are likewise formed in rocks on exposed coasts by sea urchins, in rocks and wood by different species of pelecypods (Lithodomus, Teredo, etc.), in soft earth by mammals. All of these burrows are capable of preservation as fossils under favorable conditions.

Coprolites. - The contents of the intestine and the excrement of many ancient animals, especially of fish and reptiles, are often preserved and such fossils have received the name of coprolites. These are usually nodular or contorted in appearance and phosphatic in composition. They often contain such indigestible remnants of the animal's food as portions of scales, bones, teeth or shells. Recent deposits are known as guano and are largely due to the excrement of sea birds and of such marine mammals as seals.

Restoration of fossils. - Since fossil organisms are built on the same general plan as living ones, a reconstruction of their appearance when living, like their identification and classification, is a matter of comparison. The broader and deeper one's knowledge of living species, the nearer the truth is apt to be one's conclusions. The relation between the soft, unpreservable portions of an animal, and the hard parts capable of preservation, is very close. The shell, for example, is such an intimate part of the animal that an injury to it means a lessening of the vitality of the entire organism, while the loss of it means death (Fig. 4). It is, accordingly, incorrect to speak of the animal and its sheil as though the shell were a house which the animal could leave at will. An invertebrate animal may thus be divided, for convenience of description, into body (the soft parts) and shell; a vertebrate may be considered as flesh and skeleton.

In the restoration of a fossil the better preserved the material, the truer to life will be the result. In very fine-grained shales and limestones impressions of the soft parts are often preserved to even minute details. Thus in making a restoration of the trilobite, Triarthrus, extinct since the end of the Paleozoic, the 
Utica shale in New York State furnished not only the legs, antennæ and gills, but traces of the digestive tube as well (Fig. I26). The Lithographic limestone in Bavaria and the Oxford clays in England show by the preservation of arms, outline of body and
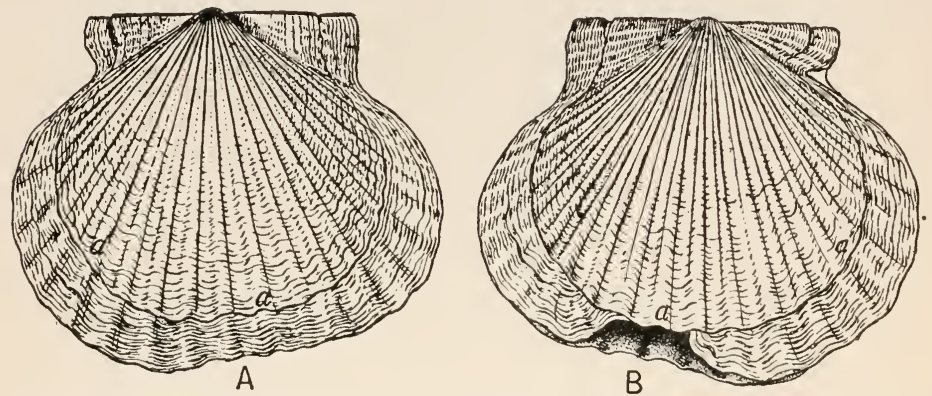

FIG. 4. - The intimate relationship which exists between the hard shell and the soft body of an animal is seen here in the scallop, Pecten gibbus borealis, from the New England coast. $A$, outer surface of left or upper valve; $B$, right valve, with the left showing slightly at the base. The mantle secreting the right valve $(B)$ received an injury when the edge of the shell was the growth line $a-a^{\prime}$; this injury lowered at once the vitality of the entire body, so that anterior growth of both mantles wholly ceased for a time, a fact recorded in the conspicuous growth line $a-a^{\prime}$. Though the animal lived for some time after this injury it never regained its former vitality, as is shown in the development of such old age characters as the obsolescence of the ribs and the irregularity of the growth lines. The mantle at (a) upon the right valve ceased growing entirely but the opening thus made was partially filled by the inbending of the opposite valve. (Slightly reduced.)

ink sac that the Mesozoic belemnoids were very similar to the living squid, while in the shale of the Stephen formation of Alberta, occur beautiful impressions of such soft-bodied animals as jelly-fish, worms and sea cucumbers. In trilobites there is usually preserved only the hard dorsal shield ; in belemnoids only the small, internal skeleton; in worms, teeth; and in sea cucumbers scattered calcareous plates.

In all vertebrate animals muscles are fastened to an internal skeleton by projections, roughened surfaces or depressions upon the latter; the larger such surface or projection, the larger the muscle attached to it. Hence from the bone alone the number and size of the muscles formerly attached to it can be estimated. 
Since muscles and bones make up the main bulk of the animal, a restoration to living proportions is possible. 'The shape of the teeth tell the character of its diet, which in turn reveals the size of the digestive organs. The superficial covering, however, is often a matter of conjecture. In fish the covering of scales is usually preserved; in amphibia mucous gland impressions often show upon the surface of the bones, thus indicating a soft, slimy skin for the animal; in reptiles the preservation of scales or bony denticles or their impressions indicate the character of the external covering (Fig. 5). When, however; as often happens, nothing of the sort

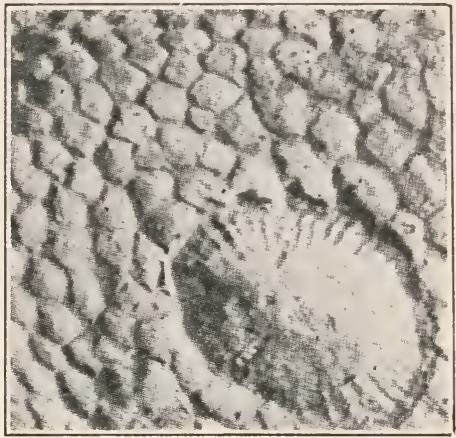

Fig. 5. - Natural mold of the surface markings of the dinosaur, Stephanosaurus marginatus Lambe, from the Cretaceous of Alberta. These markings are from the side of the body, where the yielding mud receiving the impression of the skin of the reptile upon its burial, has preserved them intact though the skin itself has long since disappeared. (From Lambe.) is preserved, the restoration must be based upon comparison with fossil and living forms; especially suggestive are the young of nearly related living species. Studies in evolution have shown that each individual in its development from the egg to maturity passes through stages which are similar in general to its successive adult ancestors from earliest geologic ages to the present. Hence a stage in the youth of a living animal would be suggestive of related extinct forms. This principle, however, must be applied with the greatest caution. The adult elephant and rhinoceros are almost hairless, while the young have much hair; that this may be reminiscent of the ancestral forms is suggested by the Pleistocene hairy mammoths preserved in the Siberian ice fields. The coloration of the young likewise is difficult of explanation unless it be taken as representing the 
coloration of its adult forbears. The young Malayan tapir is longitudinally banded, the adult loses these bands; the young wild swine are longitudinally banded, the adult are not; the young lion is spotted, the adult is of uniform coloration.

Color of fossils. - Recent organic calcium carbonate, such as occurs in shells and corals, is white, except for the occasional presence of a pigment or epidermis; Tertiary shells are darker, while those from the Paleozoic are, as a rule, darkest. Likewise, whereas many recent shells are lined with mother-ofpearl, very little is found in pre-Mesozoic shells. These changes are due to one or more of several causes. The chalky aragonite becomes changed to the darker calcite. As the pores and interstices become filled with some foreign substance light is excluded and a darker color results. If the inclosing sediment is dark in color, the fossil will be stained by it more and more deeply according to the length of time inclosed. A secondary replacement by calcium carbonate may likewise be accompanied by foreign impurities, such as carbon or iron, and thus produce a darker color. Hence the older the fossil, the greater is the probability, as a rule, of the shell being dark. This generalization holds true too for vertebrate and arthropod remains, though here the increasing dark color is mostly due to carbonization.

The process of fossilization likewise rapidly destroys the epidermis and the pigment present on many shells. Very little pigment remains in pre-Cretaceous shells. Where shells are light colored and originally had color bands, such are apt to be preserved in fossils as dark bands.

Fossil objects due to inorganic agencies. - Many objects due to inorganic agencies are often called fossils. It is in accordance with general usage, however, to reserve this name for those objects having some relation to an organism, but the word fossil may be conveniently used as an adjective before objects due to inorganic agencies, such as ripple marks, to show that they have been preserved in the earth's strata. On the marginal flats of an ocean may be formed and preserved marks of 
ripples, cracks in the mud due to drying, imprints of rain drops, flows of mud due to an excess of water, and the marks showing the upper limit of the waves. But it is especially upon the mud flats of an aggrading stream or of temporary lakes, especially in the drier regions of the country, that very many and perfect ripple marks, mud cracks, and rain-drop imprints are formed and stand best chance of preservation. Such are the very regions where organic remains stand very slight chance of preservation, for the periodic removal of the water causes the rapid oxidation of all lifeless organic matter, so that the principal fossils present in such strata are tracks, trails, and burrows.

Distortion of fossils. - In the bending, twisting, slipping and crushing of portions of strata usually consequent upon upheaval of great thicknesses of sediment from a region of deposition to a region of erosion, more or less distortion of the included fossils must occur. At times, merely the great weight of the overlying sediment causes distortion. So it is necessary to critically examine the fossil and, if possible, compare it with others of the same species to fully determine its original shape.

Pseudo-fossils. - The slipping and twisting of strata likewise produce forms that at times closely resemble organic remains. These pseudo-fossils are especially noticeable in metamorphic rocks. The slipping of one rock face against another along a fault plane produces slickensides which are often closely similar to the Carboniferous plant, Cordaites, or at times to

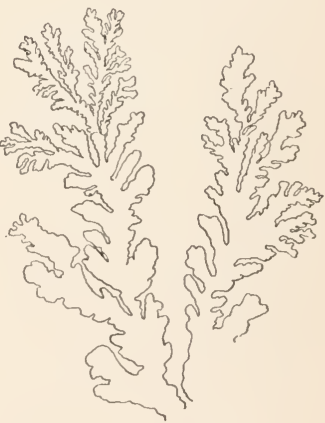

FIG. 6. - Dendrite ( $\left.X I_{5}\right)$, a branching incrustation, usually of manganese oxid. It reveals its inorganic nature in the complete irregularity of its branching. Drawn from the fractured surface of a Pleistocene shell.

Calamites; but the surface of a fossil will be parallel to the lamina, whether it is the organism itself or its external mold since it could normally have been deposited only in a position 
parallel with the bedding of the strata, whereas the slickenside will be seen usually to cross successive laminæ or even beds. Sometimes fractures, especially in dense, fine-grained rocks, resemble the external molds of pelecypods or other bivalve shells. An inorganic form very often mistaken for true organic remains is the dendrite (Fig. 6); this branching incrustation, formed usually of manganese oxid, is common, either inclosed, as in the moss agate, or merely as surface markings. It looks much like a piece of moss or fern, but there is no regularity in its method of branching, whereas an organism always exhibits a regularity, a symmetry.

Collecting fossils. - In compact, semicrystalline rocks the fossils upon an exposed surface, especiaily under a residual clay, are apt to become silicified, and hence when entirely weathered out of the rock they form ideal specimens. This weathering out of the entire compact fossil is especially characteristic of shales, shaly limestones, and of marls, consolidated or unconsolidated. Hence excellent places for collecting fossils are along weathered rock surfaces, water courses leading from such rocks, or even in plowed fields, especially immediately after a rain.

Index fossils. - Every fossil is more or less an index to the age of the rock in which it occurs, for it is a relic of the life which inhabited the earth when that sediment which now forms the inclosing rock was being deposited. It was early observed that succeeding rocks contain different fossils, that as they were followed from the lower to the higher beds, the inclosed fossils changed. At present the succession of life in general upon the earth is known, though more and more of its details are being discovered each year. It is known that these successive faunas and floras follow each other in the rocks the world over in approximately the same order.

It has been observed that each fossil is not of equal importance as an index to the age of a rock; some species, such as the brachiopod, Atrypa reticularis, occur in the strata of two 
periods, while others are confined to a very small portion of one; that is, some have a great and others a limited vertical distribution or time endurance. Some are confined to the strata of a single locality, while others, such as the brachiopod, Productus semireticulatus, occur in strata of similar age over the world; that is, some have a wide and others a limited horizontal distribution or geographic range. The best index fossils are those which combine a wide horizontal with a limited vertical distribution.

The study of Index Fossils is thus of great importance in determining the age of strata, for the making of geological maps and sections, working out faults, etc.

Migration, etc. - Fossils tell us of the body of water in which the rocks inclosing them were laid down, - whether shallow or deep, near to or far from land, open sea or inclosed basin. They tell us of changes in climate. They tell us of the presence of land barriers where now are none, of land bridges that formerly united lands now long separated. This knowledge of ancient geography that they give us is based upon the observed fact that species migrate. The larvæ of beachdwelling creatures are carried by tide and waves along the edge of the sea and thus colonize new areas. Large bodies of water, however, few animals can cross, and hence, when the same species of the trilobite Trinucleus, for example, is found in Ordovician deposits of both Europe and America, we must assume a continuous beach line, a land bridge between the two continents at that time. Mammals migrate by walking and swimming, but they, too, are limited in range by broad areas of water, high mountain ranges, etc. Thus the same species of elephant in the Pleistocene strata of both Europe and America indicates a land bridge at that time.

An example of the rate of speed at which a species may migrate is found in the record of Littorina littorea, the common periwinkle. It is very abundant on the rocky shores of England. Since it does not occur in the fossil state, or in any of 
the prehistoric shell heaps in America, it is evident that it was introduced from Europe about the middle of the nineteenth century, for it was recorded from the Gulf of St. Lawrence in I850. Thence it slowly spread southward along the coast, probably by the transport of its larvæ by the southward-flowing Greenland current. In i870 a few were noted on the Maine coast; in 1872 it was found at Salem, in 1880 at New Haven, and in r89 I as far south as Delaware Bay. In each locality where observed it had become the most abundant gastropod within two or three years after its first appearance. On the New England coast it covers the rocks and seaweed between tide limits.

Naming of organisms. - In early times, only variable common names or a single technical name was applied to a species of animal or plant; more often the name was long and descriptive. This procedure was first changed by the great Swedish naturalist, Linnæus (or Linné), who introduced the binomial, or two-name, method. His great work ("Systema Naturæ') was published in $\mathrm{I} 735$; this was in Latin, the scientific language of Europe at that time, hence all his technical names have Latin or Greek endings. This use of Latin and Greek was found so satisfactory, since the same names could be used by all nationalities and languages, that it now governs the naming of fossils the world over. The generic name is usually taken from the Greek and the specific name from the Latin language. As a result the technical name of an organism, fossil or living, is the same whether used in English, German, Russian, or Japanese works.

Before Linnæus, the single technical name was often modified by a descriptive phrase ; for example, one of the lady bugs was called the Coccinella with the seven black spots; this Linnæus called Coccinella septem-punctata. The first of the two names is that of the genus and represents the broader relationship, the second is that of the species and includes all individuals which are almost exactly similar; this likewise 
follows the Latin order of names, the family name being placed first and the individual name last. The ancient Romans would not have said John Jones, but Jones John.

Composition of the hard parts of organisms. - The composition of the hard parts varies considerably in different organisms and consequently causes a variation in the preservation of the different forms as fossils. For example, percolating waters dissolve aragonite with great ease, but have little effect upon chitin.

The following list contains the mineral composition of the hard parts of the more important animal and plant classes:

Animals. - I. Lime carbonate: Foraminifera (most); sponges (some); Hydrozoa (some); corals (most); Molluscoidea (most); mollusks (most); Echinodermata (all).

a. Calcite $\left(\mathrm{CaCO}_{3}\right)$ : Foraminifera (vitreo-calcareous forms, such as Globigerina); corals (many); sponges (Calcarea); Bryozoa (most) ; brachiopods (all except the phosphatic ones); worms (Serpula, etc.) ; Crustacea (calcareous part of skeleton); Pelecypoda (many entirely of calcite, as Pecten, Ostrea ; many with only outer layer of calcite and inner of aragonite, as Mytilus, Unio) ; Gastropoda (few; as Scalaria ; some, as Patella and Littorina, have only outer layer of calcite); Cephalopoda (few, as Argonauta and Belemnites); Echinodermata (all); hens' eggs.

b. Aragonite $\left(\mathrm{CaCO}_{3}\right)$ : Foraminifera (probably most porcellanous forms, as Peneroplis); corals (Madreporaria); most scaphopods, pelecypods, gastropods, and cephalopods.

Calcite and aragonite have the same composition $\left(\mathrm{CaCO}_{3}\right)$ but crystallize in different systems. Aragonite crystallizes in the orthorhombic system; in shells it usually has a chalky, opaque appearance and is compact throughout. Calcite crystallizes in the hexagonal system; in shells it is usually translucent, with a compact surface but porous interior. In carbonic acid it dissolves more slowly than aragonite and hence when subject to percolating waters persists longer. In Mytilus edulis, the outer layer of the shell is of calcite, the inner of aragonite; 
many of these shells from the Pleistocene have the calcite preserved but the aragonite dissolved away. Hence it is seen why shells of brachiopods are better preserved fossils than those of mollusks.

Calcite may be distinguished from aragonite by the following simple method: powder the substance and boil one minute in dilute cobalt nitrate; if it is aragonite the precipitate will be of a pink or lilac color; calcite, even with longer boiling, will remain white (or at times somewhat yellowish from the presence of some organic substance).

2. Silica. - Radiolaria (most); sponges (Silicispongiæ; this order contains most of the fossil and many of the recent sponges).

(Silica $\left(\mathrm{SiO}_{2}\right)$, in the form of quartz, is one of the most stable of minerals, but when secreted by an organism it contains some water, is glassy and isotropic, i.e. is penetrated by light and heat equally in every direction; in this condition it is dissolved with comparative ease by percolating waters containing alkali.)

3. Chitin $\left(\mathrm{C}_{15} \mathrm{H}_{26} \mathrm{~N}_{2} \mathrm{O}_{10}\right)$. - Foraminifera (few); sponges (Ceratospongiæ); Hydrozoa (most, Leptolinæ and Graptolithida); corals (axis of sea-fan, etc.); arthropods. (The word chitin is here used in a general sense and does not imply a chemical and structural identity with the true chitin of the Arthropoda.)

4. Lime phosphate. - Brachiopods (a few, as Lingula, etc.); vertebrates (about 40 per cent of the ash of bones is phosphoric acid).

5. Cellulose $\left(\mathrm{C}_{6} \mathrm{H}_{10} \mathrm{O}_{5}\right)$. - Protozoa (a few); ascidians.

Plants. - I. Cellulose $\left(\mathrm{C}_{6} \mathrm{H}_{10} \mathrm{O}_{5}\right)$. - All plants from the thallophytes up, with a few exceptions.

2. Silica $\left(\mathrm{SiO}_{2}\right)$. - More or less silica is present in the cell walls of diatoms, equisetes (horsetails), Carex, margins of grass blades, etc. It is especially abundant in the diatoms, the form of the plant being retained by it after the burning away of the organic matter. 
3. Lime carbonate $\left(\mathrm{CaCO}_{3}\right)$. - Many alg:e, as Corallina officinalis (a red alga) which it thickly coats with the white deposit, Lithothamnion (a red alga) and Halimeda (a green alga) both of which are most important in the building up of coral reefs; also the fresh-water alga, Chara, the principal agent in the formation of marl.

I. Distinguish between organic and inorganic matter.

2. What is protoplasm?

3. Give three differences between plants and animals.

4. What are the two chief conditions for the preservation of an organism in the fossil state?

5. Name three kinds of deposits in which organisms may become buried and thus preserved.

6. What is amber? loess?

7. Draw a diagram illustrating terrestrial and seashore deposits and indicate the most favorable of all localities for the preservation of fossils.

8. Mention an example of a recent flood plain deposit in the United States; of a fossil flood plain. What kinds of fossils are we most apt to find there?

9. Give an example of a fossil lake deposit and the kind of fossils for which it is noted.

ro. Define and classify fossils.

II. What are the chief minerals concerned in fossilization?

I2. How may the entire bodies of animals at times be preserved?

I3. Describe the process by which $(a)$ a leaf is preserved and fossilized; (b) a clam shell; $(c)$ a bone; $(d)$ the burrow of a worm; (e) a jelly-fish.

I4. Explain by diagram the formation of an external and an internal mold; of a cast.

I5. Why does an injury to the mantle affect the shell ?

I6. How may we judge of the shape of a vertebrate animal merely by its skeleton?

I 7. What changes in color does a shell undergo during fossilization?

I8. Mention three examples of "fossils" due to inorganic agencies; three of pseudo-fossils.

I9. What are index fossils? Describe their bearing on geologic and evolutionary problems. 
28 AN INTRODUCTION TO THE STUDY OF FOSSILS

20. How do animals migrate?

2 I. Name three groups of animals whose hard parts consist principally of lime carbonate.

22. Give an example of a siliceous skeleton; of a chitinous.

23. What is the most usual hardening substance of plants?

24. Mention two plants with silicenus hard parts, two with calcareous hard parts. 


\section{PLANTS}

THE continued existence of such life as is familiar to us depends upon the acquirement of external energy. At the surface of the earth the most available source of energy is the sun's rays. Acting through the chlorophyl, - the green coloring matter of plants, - this energy of the sun breaks up the inorganic components of earth, air and water into their separate elements and then recombines them into the potential or stored-up energy of foodstuffs. Plants expend this energy largely in reproduction, - in the development of spores and seeds. Animals, on the other hand, make use of this energy stored up by the plants, expending it in free movements as well as in reproducing their kind. In the lowest divisions of each kingdom, however, - the thallophytes of the plants and the protozoöns of the animals, still occur individuals, such, for example, as the protozoön, Euglena, which combine both methods of energy getting.

The food of plants consists principally of inorganic salts and carbon dioxid in solution in water; this is absorbed by the protoplasm of the plant. In the case of the unicellular plant, the whole plant body surrounds the food and absorbs it, while among higher plants the roots and rootlets are differentiated to perform that function. In higher plants the taking up of excess liquid, or the contraction of the intaking cells, forces this food solution up through tubes which are arranged in bundles (vascular bundles). Under the influence of the sunlight the carbon dioxid is broken up into the gases carbon and oxygen ; the former after being combined with the inorganic substances is transferred to the growing parts of the plant through other tubes in the vascular bundles, while the oxygen is thrown off. Parasitic plants, such as the fungi and bacteria, are exceptional in that 
they absorb the food directly from the host, either plant or animal, which has manufactured it.

In respiration plants take in air through small openings (stomata) which are especially abundant upon the leaves. The use made of the oxygen is shown in the rise of temperature and in the energy of growth. Since respiration is in plants as well as in animals a breaking down process, a waste product, carbon dioxid, is thrown out.

Reproduction among plants may be either sexual or asexual. Asexual plants reproduce either by simple division, as among the bacteria, or by merely detaching single cells from themselves, as among certain algæ; each of these detached cells, called in the latter case a spore, is capable of developing without fertilization into an independent plant. In sexual reproduction the plant likewise separates from itself certain single cells, but these cells lack the power of developing by themselves; before growth can occur each must unite with another cell, either from a separate plant or from different parts of the same plant. The larger of these complementary reproductive cells in the higher plants contains the egg and is the female; the other cell, which may or may not be free-swimming, contains the male element. In all except the seed-plants the presence of external fluid water is a necessity, otherwise the male cell cannot travel to the female and produce fertilization.

Plants as indicators of climate. - Plants, at least the later ones, are excellent criteria of climatic conditions; their inability to migrate under the stimulus of the annual alternation of cold and warm, wet and dry seasons makes them more valuable than animals as geologic thermometers. But that in the Mesozoic, and especially in the Paleozoic, geographic distribution was as sharply limited by climatic environment as now is unlikely. Some persistent primitive types such as the common brake (Pteris) which thrive in both temperate and tropical regions are suggestive in this connection. The worldwide distribution of the ancient floras was mainly due to their 
primitive and generalized structure; but it should not be overlooked that the ability to endure climatic variation may have been well developed, and supplied a highly important factor in that cosmopolitan distribution which is so sharply marked from the appearance of the earliest land plants down to Upper Jurassic time.

Preservation of plants. - There are of necessity many gaps in the record left by the regetation of past ages. The early plants were soft and perishable. Moreover, it is predominantly water life - the life of the sea beaches and the inland lakes and swamps - which has been preserved in the fossil state, since land conditions favor decomposition and destruction and do not furnish the conditions necessary to fossilization. It must accordingly be only a very incomplete idea of the past vegetation of the earth that fossil plants can furnish. Despite, however, the exigencies of fossilization all the great groups of plants - thallophytes (algæ, fungi), bryophytes (mosses, liverworts), pteridophytes (ferns, horsetails, club-mosses), and spermatophytes (gymnosperms, angiosperms) - have left a fossil record of the larger outlines of their past history. Plant evolution has not been uniform and there are many cases of retrogression, as in the club-mosses and horsetails, yet in general a higher group has succeeded a lower one, the latter not disappearing but falling into the background. Following the early Paleozoic, or age of seaweeds, spore-bearing plants and primitive gymnosperms dominated in the Upper Paleozoic. More modern gymnosperms and the cycadaceous or proangiospermous types made up the still cosmopolitan forest facies of early and mid-Mesozoic time, while from the Cretaceous to the present the angiosperms have been the leading type.

It must be borne in mind that the study of fossil plants is fully fifty years behind even that of fossil vertebrates. This study, however, is being aided by the discovery of new chemical methods for the examination of carbonized remains and by the application of petrography to this field. Above all, existing 
knowledge of various plant forms is being constantly supplemented by discoveries of petrified plants in all stages of growth and with their various parts, such as leaves and stems, still connected as in life. Consideration of these advances of paleobotany indicates that the plant record may soon come to have all the importance in the study of climate, former geographic relationships and evolution that the animal record has.

Plants are divided, mainly on the basis of their method of reproduction as well as the accompanying development of supporting tissue, into four large divisions:-

Division I. Thallophyta

Page

II. Bryophyta . . . . . . . 42

III. Pteridophyta . . . . . . . . . . 44

IV. Spermatophyta . . . . . . . . . 55

\section{DIVISION I, THALLOPHYTA}

The thallophytes include the most primitive plants, ranging in size from single microscopic cells to seaweeds of enormous dimensions. The forms included in this group agree in their simple structure, being plants in which there is usually little or no differentiation of organs, such as stems and leaves. Such a simple plant body is called a thallus, and the plants distinguished by possessing this undifferentiated mass of cellular tissue are called the thallophytes or thallus plants $(>$ Greek phyton, a plant).

The Thallophyta include the following five sub-divisions:-
A. Myxomycetæe
B. Schizophyta
C. Diatomeæ
D. Algæ
E. Fungi . 


\section{SUB-DIVISION A, MIXOMYCET E}

The slime-moulds are sticky masses frequently occurring on decaying logs and leaves in a forest. They so combine the characters of plants and animals as to make it doubtful with which they should be classed. They live upon decaying organic matter, have active locomotion, and possess no chlorophyl, but they are terrestrial (sub-aërial) in habit and reproduce by spores which are very much like those of certain fungi. They possess no parts capable of preservation after death, and are not known in the fossil state.

\section{SUB-DIVISION $\cdot$ B, SCHIZOPHYTA}

One-celled plants reproducing by simple division into two more or less equal parts, hence called fission-plants. They are subdivided as follows, -

I. Bacteria. - One-celled plants, $\frac{1}{10000}$ inch or less in diameter. These are of great economic importance as agents of fermentation, decay and disease; they are now the chief agents in the decomposition of organic matter and unquestionably were similarly active in disintegrating the dead vegetation of past ages, as is indicated by fossil evidence. Certain fossilized plant tissues of the Pennsylvania coal-beds show a destruction of cell walls which has been ascribed to this cause. But for their activity it is probable that ancient plant and animal remains would have been preserved in greater abundance.

2. Blue-green algæ.-Unicellular plants, occurring in slimy masses in the presence of damp, decaying organic matter. When present in enormous numbers they often produce a discoloration of the water, as in the Red Sea. Some are lime-secreting and thus are important as rock builders. To their agency, for example, is due the formation of oölite grains on the shores of the Great Salt Lake, the Red Sea, and elsewhere; these grains are blown landward into dunes and thus form continental deposits. Oscillatoria is a blue-green alga which is one of the 
forms responsible for the hot springs deposits in the Yellowstone Park. The origin of many of the oölites of the Jurassic of England, - Superior, Great oölite, etc., - has been referred to these algæ as has likewise that of the oölites of the Bunter sandstone (Triassic) of Germany.

\section{SUB-DIVISION C, DIATOMEE}

The diatoms are a group of thallophytes with possible kinship with the algæ. They are microscopic, one-celled plants, inclosed in two valves of which one overlaps the other. This cell wall is impregnated with silica and hence forms a resistant skeleton (Fig. 7). Reproduction is either asexual, through

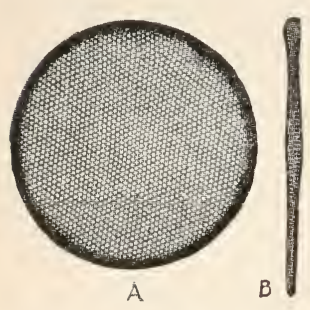

FIG. 7. - Examples of the silica-secreting algæ, diatoms, abundant in the ocean covering eastern Maryland during the Miocene (Calvert) times. $A$, Coscinodiscus lineatus Ehrenberg, a circular species. B, Sceptroneis caduceus Ehrenberg, a lanceolate species. Each X I 7 o. (From Boyer.) division of the cells, or sexual, through union of two cells to form a new individual.

Diatoms occur in both fresh and salt water as well as in damp soil. In the ocean they form a large part of the plankton, - the drifting mass of organisms at the surface of the water, and furnish the food of many marine animals. So great is their abundance that their skeletons, cast off at death or in the process of reproduction, form on the ocean bottom or on the bottom of ponds or marshes deposits of siliceous earth, - the diatomaceous ooze. Such deposits are known from the Jurassic to the present, especially in the Miocene of California and of the Atlantic coastal plain. One such deposit between the Santa Yuez and Los Alamos Valleys, California, reaches a thickness of forty-seven hundred feet. 
SUB-DIVISION D, ALGE

The seaweeds are primitive, water-dwelling plants, ranging from microscopic, one-celled forms to large and complex plants. They show an advance over some other groups of the thallophytes in the presence of the green coloring matter, - chlorophyl, which is, however, in certain of the algæ masked by brown or red pigments. There is great variety in the method of reproduction. It may be either asexual through the production of special cells, - the spores, which later develop into new plants, or sexual through union of male and female cells. Upon other structural and reproductive characters coupled with the difference in color is based the classification into green, brown, and red algæ. Algæ have been recognized from the pre-Cambrian to the present.

I. Green algæ. - Common examples are:-

a. Spirogyra, the common green alga floating on ponds where its long green threads form the frothy masses called pond scum.

$b$. Halimeda, a lime-secreting alga of modern seas. It grows on coral reefs, connecting dead coral masses. It forms extensive limestone deposits in the lagoons of coral atolls, as in the Funafuti reef. The analysis of the plant, which gives over 90 per cent of lime $\left(\mathrm{CaCO}_{3}\right)$ and only $3 \frac{8}{10}$ per cent of organic matter, shows its importance as a rock builder.

$c$. Chara (stonewort). (There is a growing tendency to remove Chara from the green algæ and to raise it into a distinct group.) This plant inhabits fresh water lakes of the temperate region. It secretes lime with which it encrusts its leaves and stems, making them white and brittle. Upon the death of the protoplasmic part of the plant, this lime deposit disintegrates and settles as a limy mud, the marl of marl ponds. Chara is responsible for many fresh water limestones of the past. Characteristic spore cases occur in the mid-Devonian at the Falls of the Ohio and in the Hamilton of Missouri, and it is well known since the Upper Jurassic. It was especially abundant in the 
Tertiary. On the Isle of Wight there are considerable deposits of Oligocene fresh water limestone which are rich in remains of Chara.

2. Brown algæ. - Examples are:-

a. Fucus, the rock weed, common on rocks exposed between tides.

b. Laminaria, the large alga, devil's apron, etc., growing in the deeper water beyond the low tide limits (Fig. I I, A). This marine genus includes the largest plants known, some having
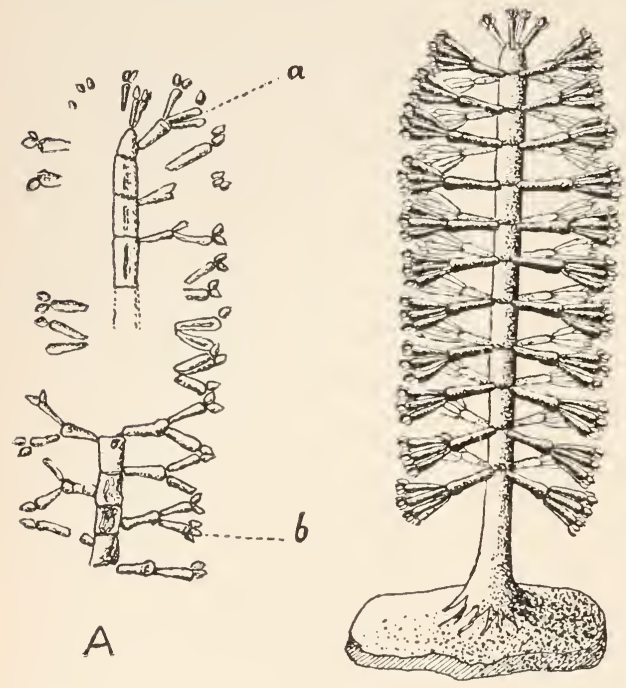

B

FIG. 8. - A marine lime-secreting alga, Primicorallina trentonensis Whitfield, from the Trenton limestone (Middle Ordovician) of New York. Much of the limestone where it occurs is made up of its remains. $A$, a specimen showing the whorled arrangement of the branchlets of the second order at $a$ and those of the third order at $b . \quad B$, restoration of the entire plant. (From Ruedemann.) huge trunk-like stalks and reaching a height of several hundred feet.

c. Sargassum of the Sargasso seas.

d. Nematophycus, a large plant whose fossilized stems have been found in the Silurian and Devonian of Europe and America. In some respects it resembles the big Laminarian seaweeds of the present, though its exact relationship cannot be determined since its microscopic structure is not preserved.

There are no important lime-secreting genera among the brown algæ. 
3. Red algæ. - The lime-secreting types of these algæ are the "nullipores" or " corallines." They include among others, $a$. Corallina. This plant grows in delicate jointed filaments which form little tufts on rocks and seaweeds in tide pools along the northern Atlantic Coast. The white incrustation of its fronds gives it a coral-like appearance. Primicorallina is a distantly related form from the Ordovician (Fig. 8).

$b$. Lithothamnion. This usually forms crusts on the surfaces of shells, corals and rocks (Fig. 9, C). On the coast of Spitzbergen, for example, it covers the bottom in deep layers for many
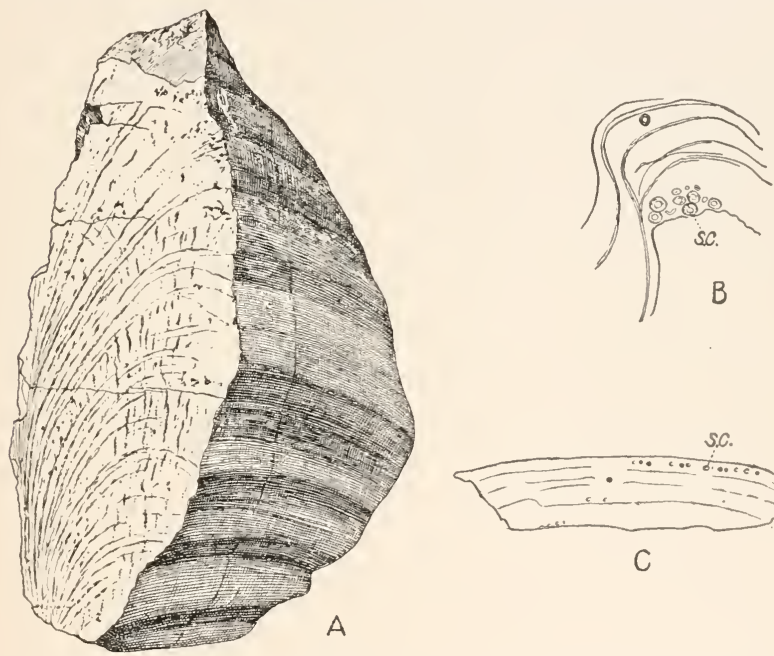

Fig. 9. - Comparison of the ancient Cryptozoun with the modern alga, Lithothamnion. A, Cryptozoön bassleri Wieland $\left(\times \frac{1}{6}\right)$, from the Cambrian of Pennsylvania. The vertical transverse section shows the successive laminæ of growth. $B$, Cryptozoön proliferum Hall, from the Beekmantown (Lower Ordovician) of Pennsylvania. The transverse section $(x 6)$ shows what may be spore cases (s.c.). C, Lithothamnion living off the coast of Eastport, Maine. The vertical transverse section $\left(X_{1}^{\frac{1}{2}}\right)$ shows the growth laminx and the spore cases. ( $A$ and $B$ after Wieland.)

miles, the material for future strata of the earth's crust. Some globular arctic species reach a diameter of six to eight inches. 
Lithothamnion has been one of the principal reef builders since the Cretaceous.

c. Here also may probably be placed such early Paleozoic calcareous masses as Cryptozoön (Fig. 9).

Lime secretion. - It is in the securing of carbon from the decomposition of $\mathrm{CO}_{2}$ for the building of their tissues that algæ secrete lime. Land plants derive the $\mathrm{CO}_{2}$ from the air. Aquatic plants must secure it from the water. An excess of $\mathrm{CO}_{2}$ in the water holds lime carbonate in solution, and when the $\mathrm{CO}_{2}$ is abstracted from the water by the plants, the lime is of necessity thrown down, and thus is deposited in or upon the tissues of the plant which caused its precipitation.

Algæ as rock-builders. - Algæ have been found to be in many cases, at least, the most important lime contributors to the upbuilding of the coral reefs, much more important than the corals themselves. A boring in the atoll of Funafuti penetrating to a depth of III4.5 feet showed that in the composition of this typical "coral-reef" the order from most to least abundant of the most common organisms is as follows: I. Lithothamnion; 2. Halimeda; 3. Foraminifera, a lime-secreting order of Protozoa; 4. Corals. All these occurred from top to bottom of the boring. Thus in the formation of this atoll nullipores were found to be the most important agent. This is true to a greater or less degree of many other " coral-reefs" of the Pacific Ocean, also of the East Indian and West Indian waters and the Mediterranean. Of these nullipores, Lithothamnion grows abundantly at a depth of two to three hundred fathoms; it also occurs in waters far from the tropics; off the coasts of Spitzbergen and Nova Zembla it covers the bottom in water of ten to twenty fathoms. The growth of nullipores may be faster than that of corals since they often cover and smother living colonies of the latter. Lime-secreting algæ are thus seen to be of vast geologic importance in the formation of limestones since they grow so rapidly and at such various depths and temperatures. But evidences as to the nature of the organisms 
which build the limestone may be destroyed. The studies of J. Walther on a Lithothamnion reef at a depth of one hundred feet in the Bay of Naples have shown that the action of percolating water may obliterate all the structure of the seaweed, leaving a structureless limestone. Many examples of such structureless limestones are known from the Mesozoic and Cenozoic rocks of southern Europe in some of which a few specimens of Lithothamnion are still preserved. Thus it may not always be possible to tell in the study of any given limestone what organisms were operative in its upbuilding. In those cases, however, where the species can be recognized, calcareous algæ are often valuable as index fossils since there are certain forms with restricted geological, but wide geographical, range. Such, for example, is Solenopora compacta, abundant during the middle Ordovician in Canada (Trenton and Black River formations), in Scotland (Llandeilo-Caradoc), and in northern Europe. It often forms entire beds of limestone; at times it weathers out as little pealike masses.

Fossil banks of calcareous algæ are believed to be responsible for certain structures in the Bighorn dolomite of Wyoming. Other fossil reefs on a gigantic scale are now represented, according to many geologists, by the dolomites of the southern Tyrol.

Certain algæ, the thermal algæ, are responsible for the beautiful siliceous and calcareous deposits of the Yellowstone Park. In some way not wholly understood they cause the deposition of the calcium, as at Mammoth Hot Springs, or of the silica, at most of the other hot springs. The beautiful colors of these deposits are hence due to plants, - plants which here live in water of a very high temperature, - between $90^{\circ}$ and I $85^{\circ} \mathrm{F}$. The kind and color vary with the temperature, there being representatives of the green algæ, the blue-green, etc. In the cooler waters these forms may be recognized as algæ, appearing in green filaments, or red or brown leathery sheets lining the springs and resembling the seaweeds of the coast. But in the 
hotter springs the masses become so densely gelatinous, or so thickly encrusted with silica, as not to be easily recognized.

Doubtful algæ. - It has been shown that many fossils which were formerly described as alga are not plants. Some are the molds of burrows or tracks of anima's and some are of inorganic agency, such as Oldhamia from the Cambrian of Ireland, formerly considered the oldest of all vegetation and now explained as merely the wrinkling of the slate due to pressure. The "Cockstail alga" (Taomurus cauda-galli) which occurs in great abundance in the "Cauda galli grits" (Esopus) of the Middle Devonian of New York, and Arthrophycus harlani, abundant in the Medina sandstone of the Silurian, are at present generally regarded as the burrows of sedentary chætopod worms.

\section{SUB-DIVISION E, FUNGI}

These plants are especially distinguished by the absence of chlorophyl. They are thus unable to manufacture starch and sugar from the soil and air and must live on that already manufactured, - that is, upon other organic matter. Accordingly they live either as saprophytes upon decaying organic matter or as parasites upon living organisms.

Instead of possessing the more complex structure of chlorophyl-bearing plants, a fungus consists essentially only of a branching mass of threads called the mycelium. These threads penetrate the cell walls of their "host," - plant or animal, - and live upon its substance. Toadstools and mushrooms, molds, mildews and yeast are common examples.

As would be expected from their structure, fungi are rarely preserved as fossils. Mycelium threads of a fungus have been detected under the bark of Sigillaria from the Pennsylvanian coal-beds, and there is evidence that even as far back as the Silurian, fungi preyed upon "shell-fish," since certain brachiopod shells are found more or less perforated by fine tubules which in some cases end in spherical swellings. These borings (Fig. Io) 
are probably the work of the mycelia of a mold-like fungus (Phycomycete).

Lichens are thallophytes of wide distribution. They are dry, gray and brown fronds spreading over tree trunks and rocks. They represent a union of algæ and fungi, since each lichen is actually made up of a fungus and an alga, living together in the mutually helpful relationship which is called symbiosis. The threads or mycelium of the fungus interweave among the cells of the alga, and while the fungus is dependent upon the foods manufactured by the alga, it aids the latter by the protection which its threads afford and by the water which it takes up and holds.

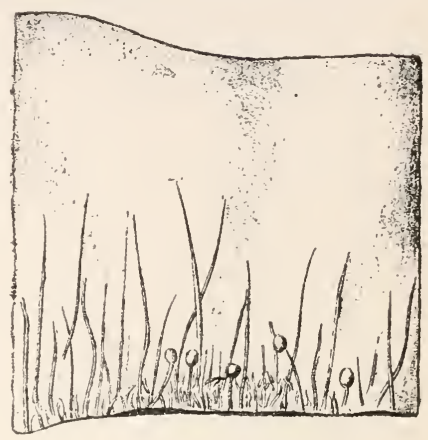

FIG. I0. - A fungus penetrating an impunctate brachiopod shell on one side only. The round swellings were probably spore sacks. This fungus from the Clinton (Silurian) of Rochester, New York, is probably a member of the Phycomycetes. $\times 250$. (After Loomis.)

Fossil lichens have been recognized only from very recent formations.

I. What is the source of the energy of plants? Of animals?

2. How do plants eat? Respire?

3. What difference between the gametophyte and sporophyte phases from algæ to seed-plants?

4. What significance has this in theories of plant evolution?

5. Compare plants and animals (I) as indicators of climate; (2) as to likelihood of preservation as fossils.

6. Give the four large divisions of plants with the geologic range and the significance of the name of each.

7. What distinguishes the thallophytes?

8. Give distinguishing characters of the five sub-divisions with known geologic range and examples of each.

9. Upon what is based the division of Algæ into green, brown and red groups? Give examples of each. 
Io. How do plants secrete lime?

II. Name the important lime-secreting groups of Algæ with two genera under each.

I 2. How important are Algæ as rock-builders?

I3. What are lichens? Their geologic age?

\section{DIVISION II, BRYOPHYTA}

The Bryophyta exhibit a distinct advance upon the Thallophyta in the greater specialization of the plant body and in the different method of reproduction. As the algæ are essentially water-dwelling plants there is little necessity for specialization of organs since any of the plant's cells can serve for absorbing the food which surrounds it on all sides. With the evolution of the bryophytes there came a change from aquatic to terrestrial conditions and there thus arose the need for specialized organs adapted to getting the food from the soil and from the air. The adaptation to terrestrial conditions being still imperfect, however, many of the bryophytes, such as some of the liverworts, still have thalloid plant bodies, without distinction of root, stem and leaves, while the group as a whole is moistureloving (Fig. I I).

The most distinct advance, however, of the bryophytes upon the thallophytes is in the method of reproduction, - in the establishment of a distinct alternation of generations. This method is illustrated by the life history of some common moss, such as the hair-cap (Polytrichum commune, Fig. I I, C). This plant, as we commonly see it, consists of a green stalk bearing many tiny leaves, and, if the plant is fruiting, it supports at its apex a slender bristle-like seta which ends in a sac (capsule) containing spores. When the spores fall on moist earth they may germinate by sending out a mass of green threads, the protonema, and from this grow the tiny moss plants. These plants bear the male and female reproductive organs and from the union of their products, - the fertilized egg cell, arises the spore-bearing part of the plant, i.e. the capsule borne at the summit of the seta. Thus there is an alternation of the asexual or sporophyte 

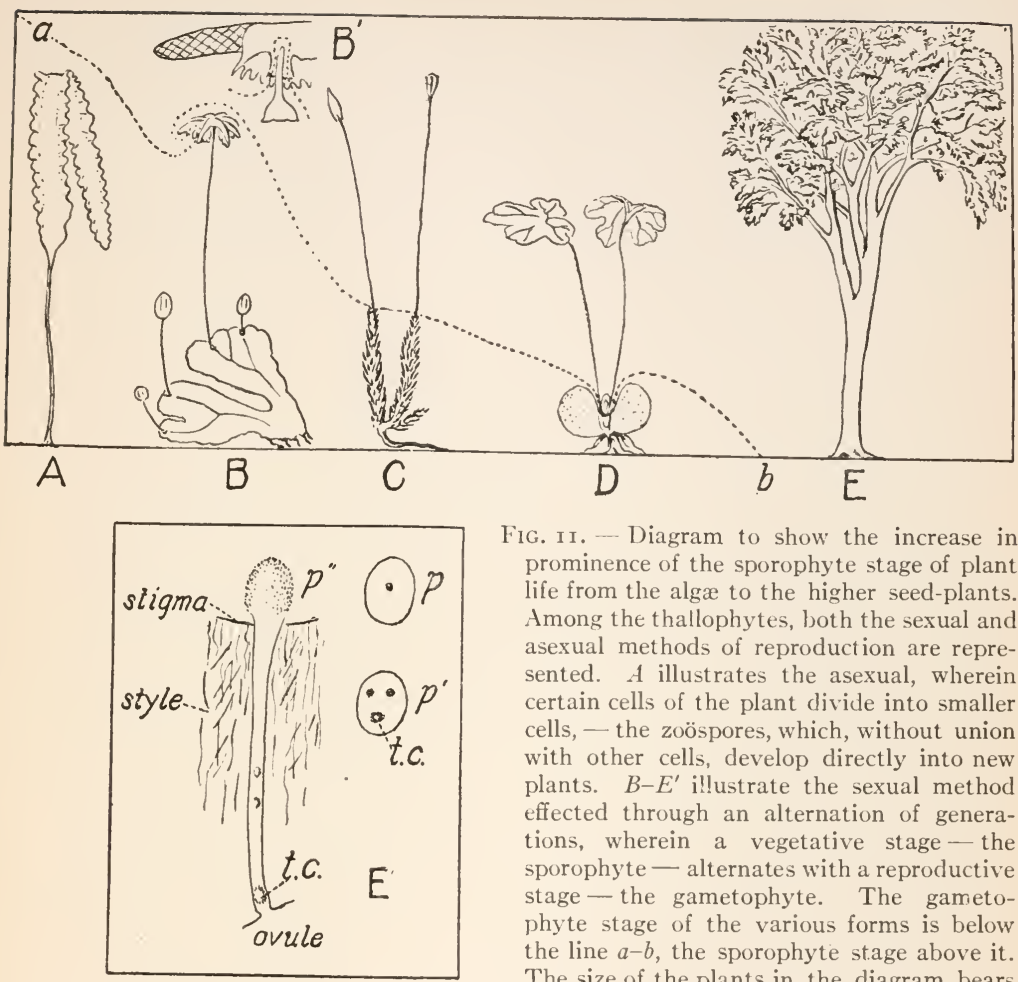

FIG. II. - Diagram to show the increase in prominence of the sporophyte stage of plant life from the algæ to the higher seed-plants. Among the thallophytes, both the sexual and asexual methods of reproduction are represented. A illustrates the asexual, wherein certain cells of the plant divide into smaller cells, - the zoöspores, which, without union with other cells, develop directly into new plants. $B-E^{\prime}$ illustrate the sexual method effected through an alternation of generations, wherein a vegetative stage - the sporophyte - alternates with a reproductive stage - the gametophyte. The gametophyte stage of the various forms is below the line $a-b$, the sporophyte stage above it. The size of the plants in the diagram bears no relation to their size in nature. This diagram need not imply that the seed-plant has been evolved from the algæ successively through the mosses, etc.; the fern may have evolved directly from the algæ. Any direct fossil evidence in favor of either line of evolution is wholly lacking. $A$, the marine alga, Laminaria saccharina, the devil's apron. $B$, the very common liverwort, Marchantia polymorpha. $B^{\prime}$, same, with the tip of one of the umbrella-like lobes magnified. C, the hair-cap moss, Polytrichum commune. D, a very young sensitive fern, Onoclea sensibilis. E, the elm tree, Llmus americanus. $E^{\prime}$, same, with the gametophyte stage enlarged (see p. 77). Among the bryophytes, $B$ and $C$, the gametophyte is the prominent stage. This is the common liverwort or moss plant which bears the sporophyte; this latter remains attached to and dependent upon the gametophyte throughout its whole existence. In the pteridophytes, $D$, the sporophyte is the prominent, common, leafy fern plant which has become independent of the gametophyte. The latter is the true two-lobed prothallus which, though independent of the sporophyte, is tiny and short-lived. In the spermatophytes, $E$, the gametophyte stage has become so reduced that its whole existence is passed invisibly dependent upon and within the sporophyte. $p$, pollen grain with its single included nucleus; $p^{\prime}$, the same at a later stage with three nuclei; $p^{\prime \prime}$, the same lodged upon the stigma, with the tube cell already within the ovule; t.c. tube cell. 
stage, - the product of the union of male and female elements, and the sexual or gametophyte stage, - the product of the germination of the spores.

The moss plant is distinguished by the predominance of the gametophyte stage over the sporophyte, since the sporophyte is only the slender stalk and its capsule, dependent on the leafy moss plant, - the gametophyte.

Derivation of name. - Greek bryon, moss, + phyton, plant, referring to its typical class, the mosses.

The Bryophyta are divided into two classes, - the liverworts (Hepaticie) and the mosses (Musci).

Liverworts include the simplest bryophytes, with many similarities to the Algae. Marchantia is a common example (Fig. II, B).

A common moss is the hair-cap, Polyrichum commune (Fig. II, C). Mosses, especially of the genus Sphagnum, have been in recent times most important agents in the formation of peat. Such mosses grow in bogs, and as they die below continue to grow above. They are mainly sub-arctic to cold temperate in habitat. The Dismal Swamp sphagnum is one of the most southerly deposits, occurring thirty-five feet thick.

There is no fossil record of mosses and liverworts earlier than the Tertiary, though probably they are not confined to such relatively modern times.

I. Describe both stages (gametophyte and sporophyte) of a common moss plant.

2. Give two differences between a thallophyte and a bryophyte.

3. How far back in geologic time are fossil mosses found?

4. Name the two classes into which the Bryophyta are divided, with an example under each.

\section{DIVISION III, PTERIDOPHYTA}

The pteridophytes are much more complex plants than the bryophytes. While the structure of the moss plant is more or less simply cellular, that of the fern plant is vascular; that is, 
like the higher flowering types, the plant possesses a series of vessels which form a conducting apparatus for the food and manufactured sap. Bryophytes and pteridophytes are sometimes called cryptogams; that is, plants without true flowers and seeds, in distinction to the phanerogams, or higher flowering plants; of these the bryophytes are the cellular cryptogams, and the pteridophytes the vascular. Like the bryophytes, the pteridophytes reproduce by a conspicuous alternation of generations, but difier from the bryophytes in the relative importance of the sexual (reproductive) and the asexual (vegetative) stages. In both, the better known and longer-lived part of the life history is r.presented by a leafy plant which alternates with a less conspicuous phase. The leafy moss plant, however, originates from the spore and produces the male and female elements, while the leafy fern plant originates from the fertilized egg and produces spores. Thus, while the moss plant is the reproductive or gametophyte stage, the fern plant is the vegetative or sporophyte (Fig. I I, D). The life history of the Pteridophyta may be illustrated in general by observing the development of some fern, such as the common Christmas fern. Some of its leaves will be found to bear shorter leaflets near their ends. Upon the under side of such leaflets are rows of small dots, the sori or heaps of spore cases. When one of the tiny spores drops to the ground under conditions where it can germinate it develops into a small, flat, disk-like body, the prothallus. This bears the male and female reproductive organs and from the union of their products, the fertilized egg, grows the leafy fern plant. Thus, in ferns, the sporophyte, which is the leafy plant, and the gametophyte, which is the prothallus, are independent of each other. It has been seen that in mosses the sporophyte is dependent on the gametophyte, and it will be seen later that in the higher, flowering plants the gametophyte is completely dependent on the sporophyte.

Derivation of name. - Greek pteris, a fern, + phyton, a plant, in reference to its best known order, the ferns. 
The Pteridophyta are sub-divided into the following orders: a. Filicales (including Ophioglossales, which is sometimes considered a distinct class), - the ferns.

$b$. Equisetales, - the horsetails.

c. Lycopodiales, - the club-mosses.

$d$. Sphenophyllales.

\section{ORDER $a$, FILICALES}

The ferns usually possess a broad frond or leaf which is often divided into pinnæ, or leaflets. The spore cases are gathered into sori, the round "fruit dots," borne on more or less modified portions of these leaves or on independent fruiting stalks. Common living examples are Polystichum, - the Christmas fern, and Onoclea, - the sensitive fern.

Ferns are known to have existed from the time of the Devonian, and must have appeared before the close of the Silurian. Nearly all the living families have existed since the Jurassic, while at least two families, the Osmundaceæ and the Marattiaceæ, have been traced back to Paleozoic ancestors. It is rare that all of the organs of any fossil plant may be described, since they are so easily separable from one another. This incompleteness of data is, for example, true in the case of fern-like forms. Hence until recently the characterization of many fossil genera rested solely on the form and venation of the leaf. One of the largest of these frond genera was Neuropteris. Fructifications later found in connection with leaves of this genus have determined that this as well as many other genera with fern-like fronds is not a true fern but a member of the great group of Cycadofilicales, - an order of Pteridophyta intermediate between the ferns and the cycads.

Fossil examples of true ferns are:

(I) Osmundites (Jurassic to Tertiary). - Fern stems with the peculiar structure of the stem of the living Osmunda, the common royal fern. This relationship is suggested by the name in which the suffix "-ites" added to the name Osmunda 
means "stony"; this suffix is used in many names of fossil plants to suggest their kinship with modern forms.

(2) Dictyopteris and Camptopteris. - Remarkably handsome forms of Upper Triassic-Cretaceous age, with lyrate fronds often three feet or more broad, and with a characteristic netted venation.
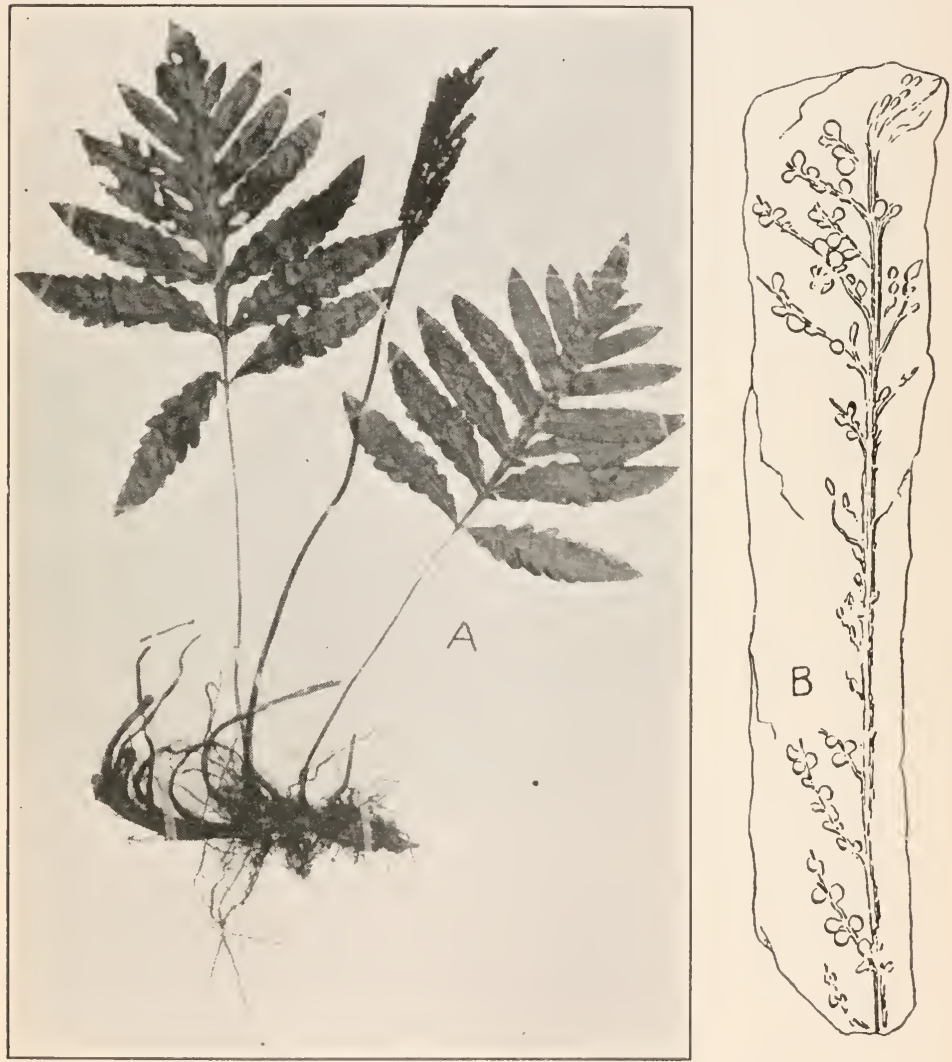

Fig. I 2. - The fern, Onoclea. A, the living sensitive fern, $O$. sensibilis $L .\left(\times \frac{1}{4}\right)$, from Maine; the fruiting stalk between two sterile leaves. $B, O$. inquirenda Hollick $\left(\times \frac{3}{4}\right)$, from the Cretaceous of Long Island, New York; the fruiting stalk. ( $B$, from Hollick.) 
(3) The sensitive fern (Onoclea sensibilis). - Now living only in eastern North America and eastern Asia, but present throughout the Northern Hemisphere during the Pliocene (Figs. II, D, I2).

I. Discuss two characteristics of pteridophytes which show them to be more highly organized plants than bryophytes.

2. Give briefly the life history of the common Christmas fern.

3. Tell how the Pteridophyta are sub-divided, giving both scientific and common names.

4. With what ferns are you familiar? Have you ever seen a fern prothallus? Which is the more commonly seen stage of the fern, - the reproductive or the vegetative?

5. When, in geological time, did ferns appear?

6. Name two fossil examples.

7. Give an example of a fern which has existed from the Tertiary to the present. Has it changed much in appearance since the Tertiary?

\section{ORDER $b$, EQUISETALES}

Living horsetails are low plants with simple or branching stems which are strongly furrowed longitudinally and are divided into sections by joints. The leaves are small papery scales, arranged around the stem in a circle at each node. In the Carboniferous, however, representatives of this order were large forest trees and bore large leaves.

These fossil remains, moreover, show that horsetails were formerly one of the most abundantly represented groups of plants, though at present the order survives in only one genus, Equisetum. The Equisetales have existed from the Devonian to the present. Apparently the last of the Calamites group,the Paleozoic horsetails, died out at the close of the Paleozoic; but in the Mesozoic the equisetes were represented by forms which were probably intermediate between the Paleozoic and the living horsetails. Equisetites was a very large horsetail of the Triassic with a stem eight inches in diameter and with over a hundred leaves in a whorl. Other fossil examples are :- 
(I) Calamites (Figs. I3, I 50). - A tree often attaining a height of one hundred feet, usually preserved in the form of casts of the interior of the hollow stem. The markings on the surface of

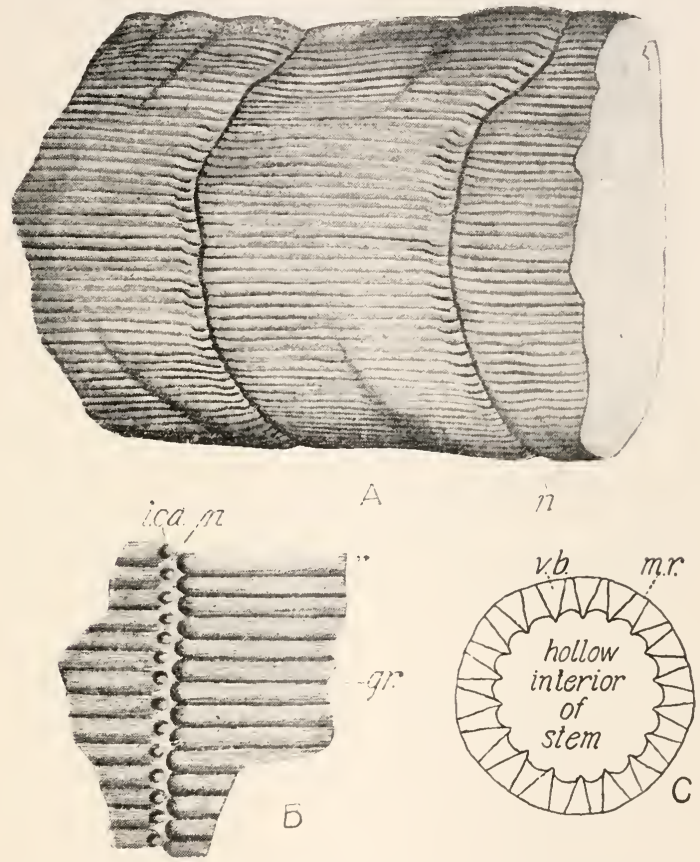

FIG. 13. - The ancient horsetail. A, B, Calamites suckowi Brongniart, from the Carboniferous coal deposits of Pennsylvania. A, a cast of the hollow interior of a small section of the stem $\left(\times \frac{3}{4}\right)$. $B$, a portion of the surface of this in detail. $C$, diagrammatic cross section of a mature calamite stem to show origin of the ribs and grooves upon the cast. $g r$., grooves (internodal furrows) formed by the inwardly projecting ends of the vascular bundles; i.ca., casts of infranodal canals opening in the medullary rays at the nodes; $m . r$. , medullary rays; $n$., nodes; $r$, ribs (internodal ridges) formed by the groove upon the inner surface of each medullary ray; v.b., vascular bundles. ( $A, B$ from Lesquereux.)

these casts are the print of the inner surface of the wood and do not correspond to the ribbing of the external surface of an Equisetum. Hence conclusions establishing the relationship of Calamites to the horsetails cannot be based on the external 
appearance of most of the fossil specimens but on comparison of the internal anatomy when preserved, and on the fructification.

These internal molds are marked with longitudinal ribs and furrows, and are jointed, as are the stems of the modern horsetails. The furrows correspond to the vascular bundles.

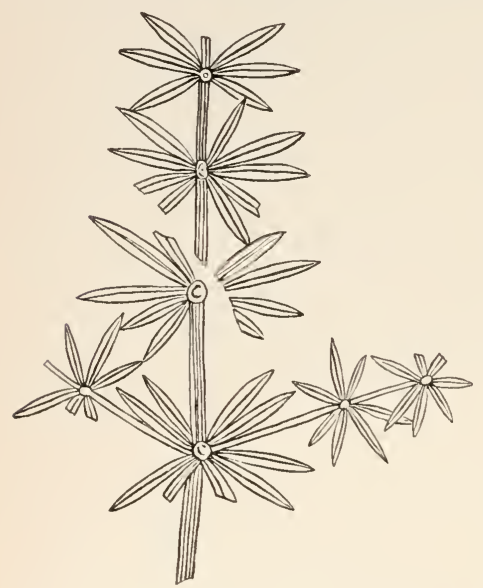

FIg. I4. - The ancient horsetail, Annularia longifolia Brongniart $\left(\times \frac{1}{2}\right)$, from Pennsylvania, showing seven whorls of leaves. This flourished in the freshwater coal swamps of eastern North America during the Pennsylvanian time. (Redrawn from Lesquereux.)

The stems branched and bore narrow, lance-shaped leaves arranged in whorls at the nodes, or joints, of the stem. A single nerve passed from end to end of the leaf. Certain cones described under various names when found separately have been found in connection with a few specimens of Calamites stems.

Calamites disappeared in the Permian; during the Pennsylvanian it was an abundant form in the coal swamps of eastern North America.

(2) Annularia (Fig. I4), a smaller plant with a stem of two or three inches diameter, and abundant in the Pennsylvanian of eastern North America, is classed with Calamites as a near relative, if it is not actually in some cases merely smaller branches of that form.

I. What is the name of the only living genus of this order? Describe its appearance.

2. When in the past did this order include large forest trees? Name an example of such a tree.

3. Sketch Calamites, (I) two joints, surface view, (2) cross section. Label joint, leaf bases, position of vascular bundles.

4. Sketch Annularia; label leaflet. What is its probable relationship to Calamites? What is its age? 


\section{ORDER $c$, LYCOPODIALES}

Living club-mosses are largely creeping, many-branched plants. Tiny moss-like leaves thickly clothe the stem while the spore-bearing leaves are arranged in club-like cones.

They embrace but four living genera, of which the two more common are Lycopodium, - the common ground pine, and Se'aginella. These are, however, the remnant of a very important group of the Paleozoic which attained their greatest size and abundance in the Carboniferous, where they included many of the largest forest trees. They have since gradually declined pari passu with the increasing importance of the more specialized seed plants. Lycopodiales are known from the Devonian to the present.

Among their fossil representatives are:-

Lepidodendron (Figs. I5, I50). - This was a lofty tree of the later Paleozoic, appearing in the Lower Devonian and dying out in the Permian; it was especially abundant throughout the world during the Carboniferous.

The trunks were straight and somewhat palm-like, attaining at times a height of one hundred feet, and bore toward the top a crown of branches. Both branches and stems always forked dichotomously. The stems were densely clothed in long, simple, pointed leaves, much like those of the pine, which sometimes reached a length of six or seven inches. When these leaves were shed, their bases remained attached to the stem, thus covering the bark of the branches and even of the larger trunks with a distinctive spirally arranged ornamentation. Each of these marks of the former attachment of the leaves is rhombic in outline and somewhat convex. It is called a "leaf-cushion." The apex of its convexity represents the scar left by the fall of the leaf, while the remainder of the rhombic area is formed by the decurrent base of the leaf which has remained on the stem. The various marks upon the leaf-cushion are the prints of various parts of the stem of the leaf. Thus the central of the 
three dots on the lower edge of the scar itself is the severed end of the vascular bundle which formerly passed out through the stem into the leaf, the other two representing strands of
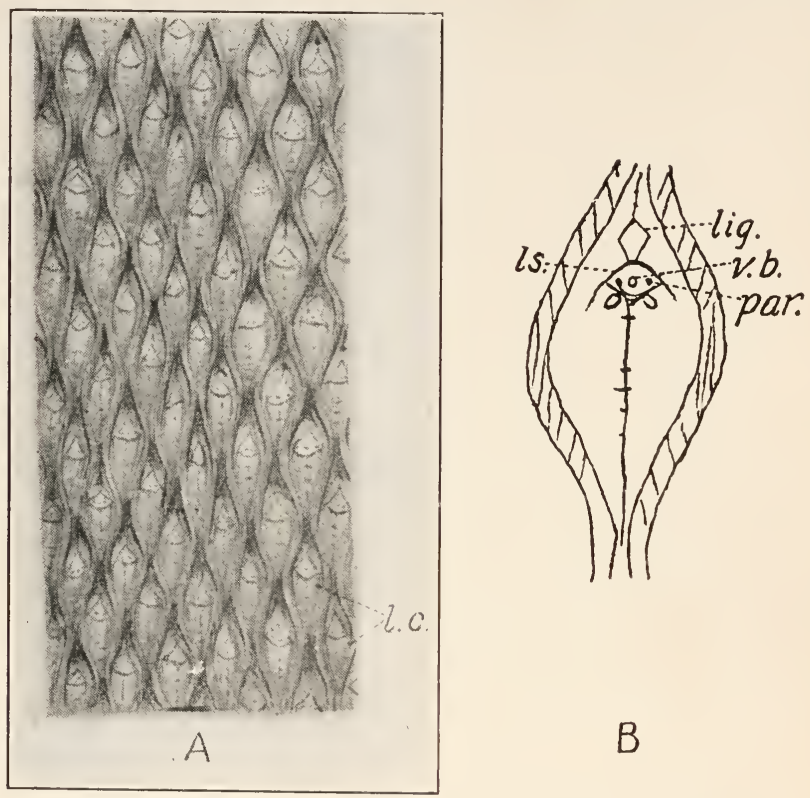

Fig. I5. - The ancient club-moss, Lepidodendron modulatum Lesquereux, from the coal horizon of Pennsylvania; Pennsylvanian in age. $A$, surface characters of a small part of a trunk $\left(\times \frac{1}{5}\right)$. B, a single leaf-cushion; natural size. l.c., leaf-cushion, - the entire rhombic area except the leaf scar $\left(l_{. s}\right.$. $)$ and the base of the ligule (lig.) ; l.s., scar left by the fall of the leaf; lig., ligule; par., lateral strands of leaf tissue (the parichnos), supposedly here respiratory in function; v. $b$., vascular bundles, the main tubes for the transfer of sap to leaf and manufactured material back to trunk. (A from Lesquereux.)

leaf tissue. The small triangular dot above the scar has been shown to mark the position of the ligule, a leaf-like organ present in Selaginella and Isoetes, living allies of Lepidodendron.

Our knowledge of Lepidodendron is based upon fossilized remains of all of its parts. The large trunks have been fcund abundantly in England in such a good state of preservaticn that 
the cellular structure is easily observed, while the peculiar ornamentation of the surface of the stem is shown by the external molds. In the great majority of specimens the leaf bases only are preserved; but attached leaves have been found in some of the calcified specimens of the English " coal balls," in which whole masses of stems, leaves, and fruits are found in a wonderfully preserved condition. These coal balls are simply concretions of the carbonates of lime and magnesia which formed around certain masses of the peaty vegetation as centers and, through inclosing and interpenetrating them, preserved them from the peculiar processes of decay which converted the rest of the vegetation into coal. In them the mineral matter slowly replaced the vegetable matter, molecule by molecule, thus preserving the cellular structure to a remarkable degree. Such balls are especially frequent in the coal of certain parts of England (Lancashire and Yorkshire).

Enormous spreading root-like underground stems occur in the rocks of the Pennsylvanian, apparently in the position in which they grew. Such root-like organs, to which the name Stigmaria has been given, were possessed by both Lepidodendron and the allied genus, Sigillaria. That they are not true roots is evidenced by their anatomical structure and their habit of branching, always into two, as has been noted in the stems of Lepidodendron. They bear many small appendages which seem to be true roots. Such root-bearing underground stems are characteristic of living lycopods. These large and spreading root-like organs were adapted for growth in wet ground where long roots were not needed for penetrating far into the soil for moisture.

It is in the fossil cones, that show its manner of fruiting, that Lepidodendron betrays its relationship to the living club-mosses. The cones of both fossil and living lycopods consist of scales arranged around an axis, each bearing on its upper side a large spore case containing many spores, all of one kind. These cones of Lepidodendron are known by the collective name 
of Lepidostrobus, and usually occur as impressions in coal; the internal structure is well known from the study of the cal-

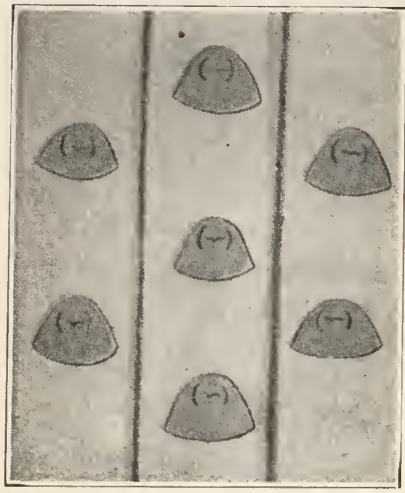

FIG. I6. - Sigillaria polita Lesquereux, from the Pennsylvanian formations of Pennsylvania, showing the leaf scars arranged in vertical rows. Natural size. (From Lesquereux.) cified specimens of the coal balls together with several silicified specimens and casts. The cones vary from an inch to one and a half feet in length.

Sigillaria (Figs. I6, I 50). - This was a tree which probably resembled Lepidodendron in general appearance as well as in geologic range. It differed in the structure of its stem and in the arrangement of leaves, as is indicated by the impressions of the bark covered with leaf-cushions. The leafcushions are hexagonal in outline and arranged in quite regular vertical rows. Its cones are known as Sigillariostrobus.

Its underground stems have been discussed under Lepidodendron.

I. Name two common living club-mosses. Where have you seen them growing?

2. What is the geologic range of this order?

3. Sketch a leaf-cushion of Lepidodendron; label, where present, scar left by fall of leaf, the decurrent base of leaf, and of vascular bundle passing into leaf.

4. Sketch (reduce in size) a foot length of Stigmaria, a small portion in detail, indicating the little "roots." What was the function of Stigmaria?

5. Sketch a small portion of Sigillaria. How does it differ from Lepidodendron?

6. What are coal balls? In what country and in what geological formation do they occur most abundantly?

7. Why are the fruit, stem and roots of Lepidodendron and Sigillaria known under separate names?

8. How do fossil lycopods resemble living ones? 
ORDER $d$, SPHENOPHYLLALES

A Paleozoic group of slender plants with jointed stems, and leaves in whorls. They were probably trailing or climbing in habit, and are known from the Devonian to the Permian.

Sphenophyllum and a related Mississippian genus, Cheirostrobus, based on one of the most beautifully preserved fossil fruits ever recovered, combine to such a degree the characters of both the lycopods and the equisetes that the Sphenophyllales are held to be the descendants of the ancient stock from which club-mosses and horsetails have diverged in the course of evolution. The group became extinct at the close of the Carboniferous.

Sphenophyllum (Fig. I 7). - A small, branching plant with slender, ribbed stems, represented by many species in the Pennsylvanian coal fields of eastern North America. Leaves usually six in a whorl and wedge shaped or cut into lobes. Thus externally it resembles a small Calamites, but the anatomy of the stem,

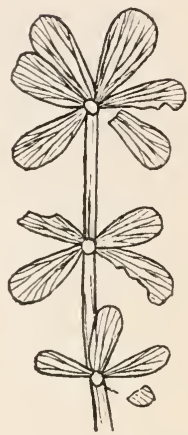

Fig. 17. - Sphenophyllum schlotheimii Brongniart, from the Pennsylvanian coal deposits of Pennsylvania. Natural size. (Redrawn from Lesquereux.) and of the cone, show it to be different. The name from the Greek sphenos, a wedge, + phyllon, a leaf, refers to the usual shape of the leaves.

I. Has this order any living representatives?

2. Describe Sphenophyllum.

3. How is this order related to the club-mosses and the horsetails?

\section{DIVISION IV, SPERMATOPHYTA}

These include the most highly organized plants and are distinguished by the production of seeds (whence the common name of seed-plants). The difference between these and the 
lower groups is not, however, so great as at first appears. There is the same alternation of the vegetative (asexual) and reproductive (sexual) generations, the sporophyte and the gametophyte, as is seen in the Pteridophyta, but the alternation is less evident. Inequality between sporophyte and gametophyte is still more pronounced than in the fern.

The "seed" is the beginning of the sporophyte stage; the embryo within it later unfolds into the mature plant. In specialized organs within the flower or cone there are developed the sporangia, either male or female. The female sporangium is called the ovule, and the male the anther sac. From these sporangia are discharged the spores, - the pollen from the anther sacs, a specially differentiated cell from the ovule; these spores develop either into the male or the female gametophyte as the case may be, and from the union of their products results the fertilized ovum, - the seed. All the process of formation of the gametophyte takes place within the flower. For discussion of this process see page 77 .

Derivation of name. - Greek sperma, seed + phyton, plant. The members of this division are distinguished by the production of seeds.

The spermatophytes are divided into:

Page

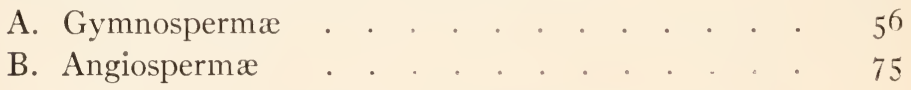

\section{SUB-DIVISION A, GYMNOSPERMIE}

In these plants the seeds are unprotected by any covering. This character is indicated by the derivation of the name from the Greek gymnos, naked + sperma, a seed.

Trees and shrubs, mostly evergreen. They include the following orders :

a. Cycadofilicales.

b. Cycadales:

I. Cycadeoideæ.

2. Cycadeæ. 
c. Cordaitales.

d. Ginkgoales.

e. Coniferales.

f. Gnetales.

\section{Order A, Cycadofilicales}

A Paleozoic group of plants with fern-like leaves (Fig. I50). They were often fern-like in habit, though including likewise vines and trees. They were formerly thought to be ferns because of the form and venation of their leaves. No sporangia, however,
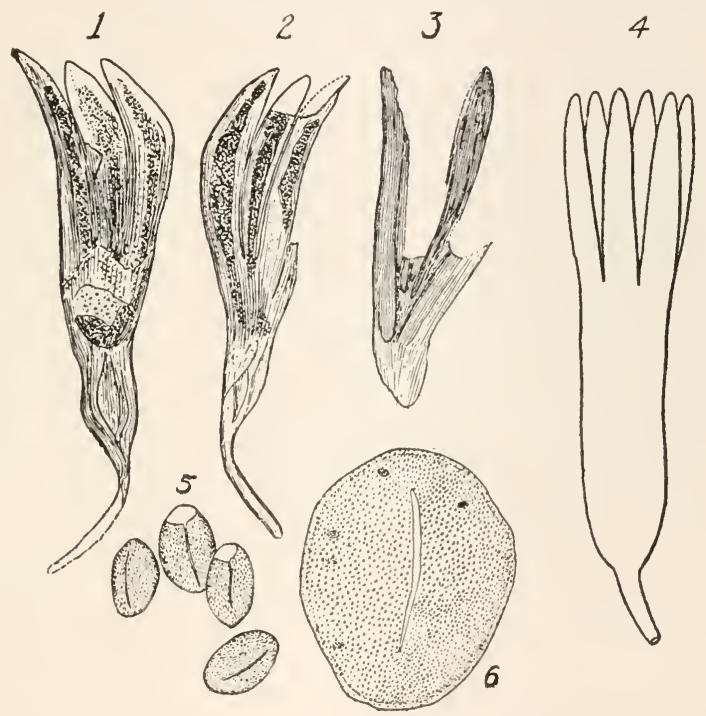

FIG. $18 a$. - Codonotheca, one of the most singular and ancient microspore-bearing fruits known. From the Pennsylvanian of Mazon Creek, Illinois. Figures I-3 show the interior faces of the lobes covered with spores just as brought to view when the nodules in which the fruits are embedded are split open. Figures $5^{-6}$ are the spores enlarged 28 and 85 times respectively, while Fiz. 4 is a restoration of the flower-like fruit, natural size. (From Sellards.)

were found on any of the leaves and hence it came to be suspected that they might not be true ferns. Stems were finally found in association with some of these leaves whose anatomy com- 
bined characters of ferns and cycads. Recently true seeds have been found attached to stalks bearing the fern-like leaflets. These plants were accordingly shown to be primitive seed-plants intermediate between the ferns and the cycads, a relationship indicated by the name applied to them. In some the cycad features predominate, in others those of the ferns.

Of those fruits which may belong to this gymnospermous line, one of the most important yet discovered is that shown in the adjoining figure $18 a$. It accompanies cycadofilicalean foliage in some abundance in the ironstone nodules of Mazon
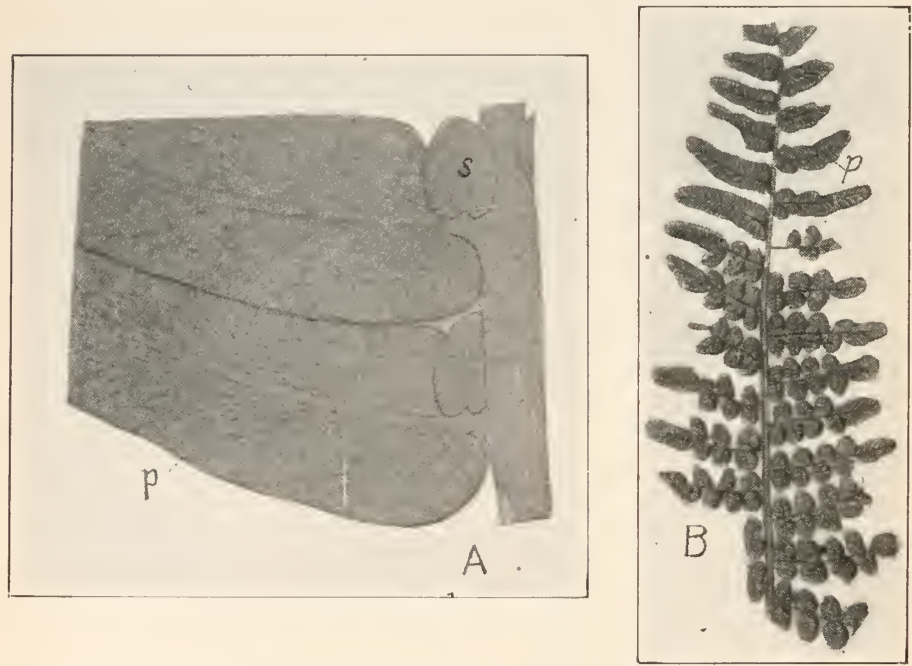

FIG. I $8 b$. - Examples of the cycadofilicales (an extinct class combining characters which to-day are separated into the distinct groups of ferns and cycads). $A$, Neuropteris hirsuta Lesquereux; a portion of two leaflets (pinnules, p.), with the small stipules (s.) at their base. $B$, an almost complete frond of $N$. smithsii Lx. Both (natural size) from the Pennsylvanian period of Pennsylvania. (From Lesquereux.)

Creek, Illinois, and in its outer features closely resembles the fruits described in England as the seeds of Neuropteris. The full meaning of this ancient type of fructification is not yet 
understood. If, as is quite possible, it is the male flower of Neuropteris there was a much stronger resemblance between the male and female flowers of some of the cycadofilicaleans than has been su sposed. Needless to say the study of such forms has a primary importance because of the direct bearing on vital prob:ems of plant evolution and morphology.

It has been estimated that the Cycadoficicales formed fully half of the known vegetation of the Carboniferous coal deposits.

Neuropteris (Fig. I $8 b$ ). - This is an example of one of the most familiar of the fern-like fronds of the Pennsylvanian coal deposits. The leaves are very large and compound, being bi-, tri-, or quadri-pinnate, with oblong leaflets which are usually attached to their common stalk by a short stem. Each bears a median nerve from which spring secondary ones. The leaves therefore are fully fern-like in superficial appearance. That Neuropteris was not, however, a true fern was suspected from the constant absence of sporangia from the leaves and this conclusion was established by the finding of leaves of the Neuropteris type in association with cycad-like stems bearing true seeds.

Pinnules of this genus are abundant in the Mazon Creek iron carbonate clay concretions. These Pennsylvanian strata in Grundy County, Illinois, have in this manner preserved without crushing and in wonderful perfection not only plant remains such as Neuropteris, Pecopteris and fruits, but also crustaceans, insects and fish-bones.

Pecopteris. - Fronds much like those of Neuropteris, and of similar age, but leaflets attached to the stalk by their whole width and touching one another. The small, flat-winged seeds are well known in $P$. plunckneti.

Lyginodendron. - Stems varying in diameter from one eighth of an inch $(3 \mathrm{~mm}$.) up to an inch and a half $(4 \mathrm{~cm}$.), not branching, but very long, bearing many leaves. Leaves very large, much divided and fern-like in appearance.

That Lyginodendron was a climbing plant is considered likely 
from the slenderness of its stem in proportion to its length and from the presence of spines on stems and leaves.

Fragments of the stems and leaves of this plant occur very abundantly and in well-preserved condition in the calcareous nodu'es or coal balls of the English Carboniferous coal deposits mentioned above.

The plant has very nearly the stem structure of a cycad, but a fern-like leaf. Highly organized seeds have been found in a definite connection with this leaf, which shows that Lyginodendron, instead of being a fern as was formerly supposed, was a seed-plant. It was still, however, a very primitive seed-plant for both seeds and pollen sacs were borne on slightly altered portions of the ordinary leaf. Lyginodendron is thus seen to be a noteworthy example of synthetic types, that is, of forms that combine characters which afterward separate and distinguish separate orders.

I. What is the chief distinguishing characteristic of the Spermatophyta? How is this indicated in the name itself?

2. Describe the formation of the sporophyte and the gametophyte stages in the spermatophytes.

3. Into what subdivisions are the spermatophytes divided?

4. What is the difference between a gymnosperm and an angiosperm? Show that this difference is indicated in the derivation of the name. Name three common living gymnosperms.

5. Into what orders are the gymnosperms divided?

6. What are the Cycadofilicales? In what respect do they resemble ferns? How are they like cycads? When were they most abundant? Name an example.

7. Sketch a Neuropteris pinnule. How is it known that this is not a fern?

8. For what is Mazon Creek famous?

9. In what respect is Lyginodendron a synthetic type?

\section{Order B, Cycadales}

Family I, Cycadeoidea. - This extinct family of trees or shrubs resembled the living cycads in general outer appearance. 
The stem in most forms was thick and short and closely covered with an armor of persistent leaf-bases (Fig. I9). Among these leaf-bases were wedged numerous small

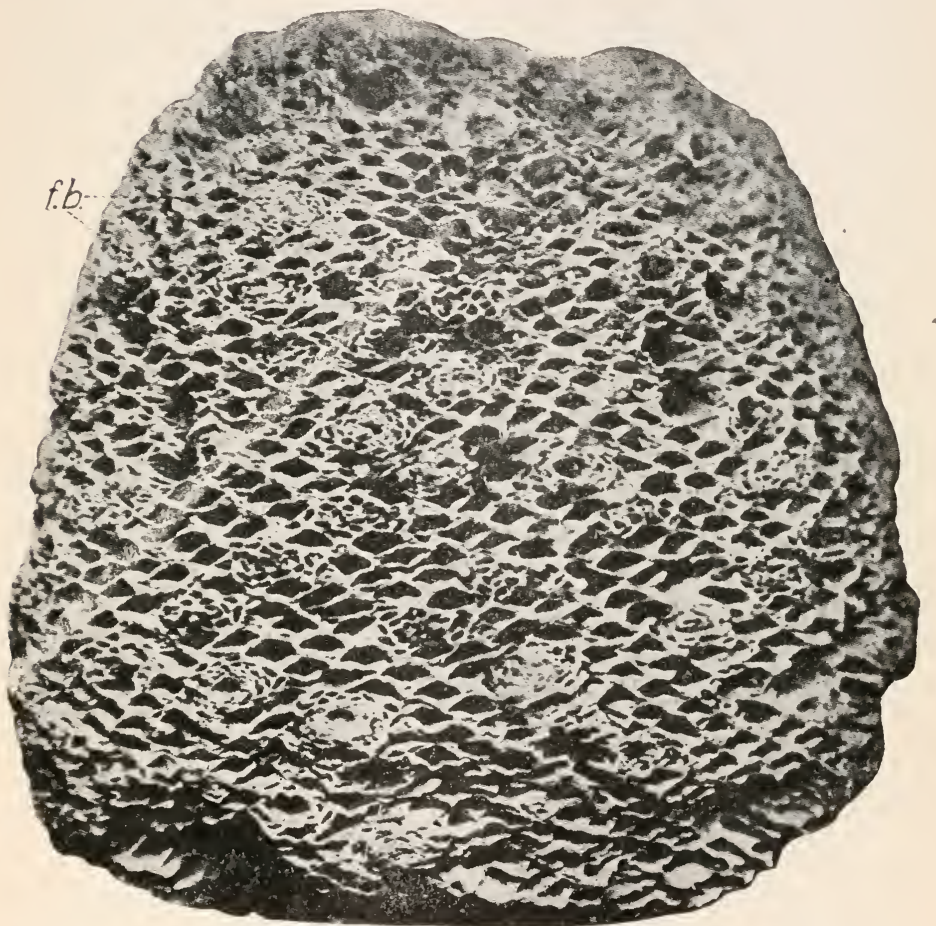

Fig. I9. - A fossil cycad, Cycadeoidea marylandica Fontaine $\left(\times \frac{1}{4}\right)$, from the Potomac formation (Comanchean) of Maryland. At the time of fossilization it was about to blossom. Nearly thirty flower buds $(f . b$. ) show here between the old leaf-bases. The wonderful preservation of some of the flower buds embedded in these ancient fossilized trunks is seen in Figs $21,22$.

branches, each terminating in a fructification. The stem usually bore at top a crown of large cycas-like leaves (Fig. 20).

As in general appearance, so likewise in the anatomy of the 
stem, there was a close similarity between these plants and the living cycads. Some of their characters, such as their lateral

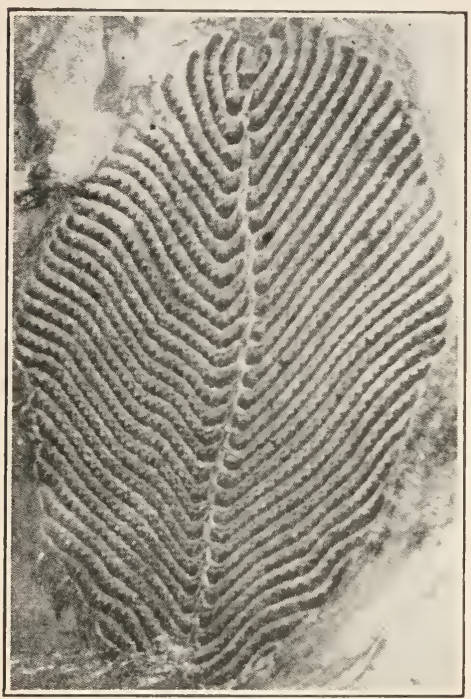

Fig. 20.-Cycadeoidea jenneyana. Photograph $(\times 3)$ of a longitudinal section through a silicified young leaf not yet emerged from the bud. (From IVieland.) branching and the hairlike and papery scales profusely covering the leaf-bases recall the cycadofilicales and the ferns. In the structure of their fruiting organs, however, the cycadeoids were peculiar to themselves, and showed an advance over the other orders. They had a true flower since both male and female organs were borne on the same axis and were arranged in the manner typical of the later flowering plants, - the angiosperms. This flower (Fig3. 21, 22) consisted of a sheath of hairy overlapping bracts inclosing a circle of leaf-like, pollenbearing organs analogous to stamens, central to which is a conical axis bearing stalked seeds, the "receptacle" of higher plants.

The seeds are often so well preserved in various species that the embryo may be distinguished; this is dicotyledonous, differing from that of other gymnosperms in occupying nearly the whole seed. This is, however, the only order of fossil plants in which an embryo has been sufficiently well preserved to be studied in detail.

In general appearance, therefore, these plants at once suggest the cycads; in the large, leaf-like stamens and certain features of their pollen sacs they indicate an affinity with the ferns, and in the possession of true flowers they distinctly approach the angiosperms. 
It has seemed evident to students of these analogies that the cycadeoids, as their name implies, are closely related to the cycads, and that both groups sprang separately from certain Paleozoic ferns, the marattiaceous type. Moreover, the structure of their

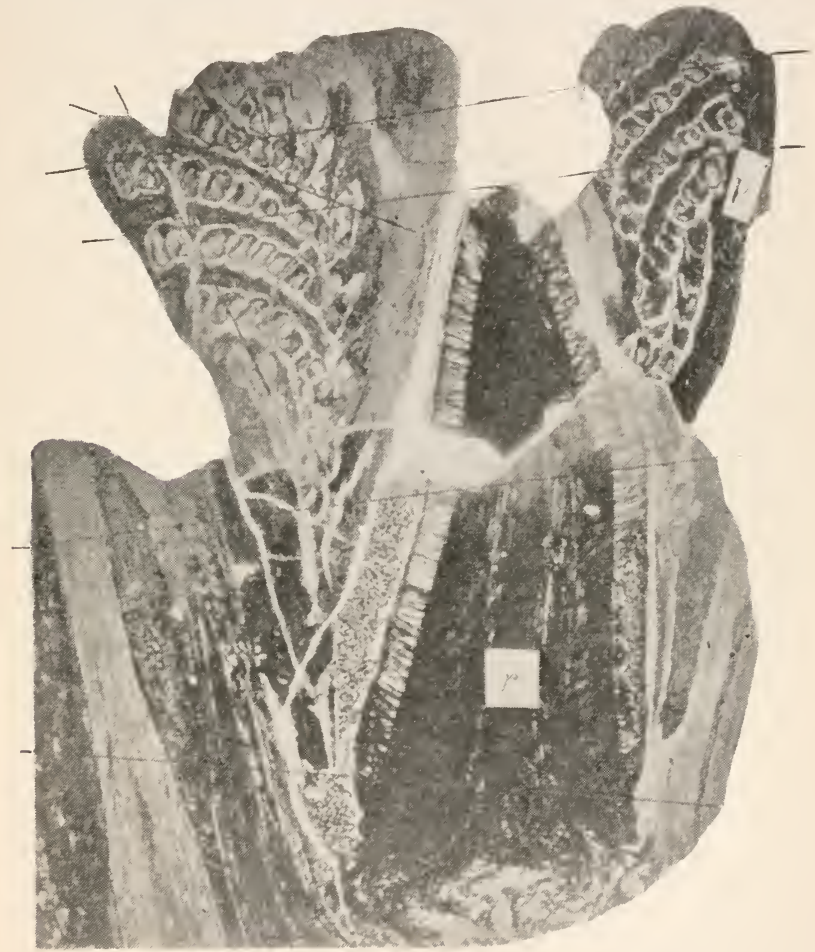

FIG. 2I $a$. - The unexpanded flower of Cycadeoidea dacotensis Macbride, from the terrestrial deposits of Upper Jurassic age in South Dakota. Photograph $(\times 2)$ of a vertical section of a silicified specimen. The lines refer to various sections through the flower published in Wieland's "Am. Fos. Cycads." p., pinnules: $r$., receptacle.

fructification, the arrangement of its parts into a "flower," suggests that the cycadeoids represent an intermediate stage in the supposed line of development of the angiosperms from their fern ancestors. 
This order formed the dominant vegetation of the Mesozoic ranging from the Triassic into the Potomac (Comanchean). It was exceedingly abundant during the Jurassic in North

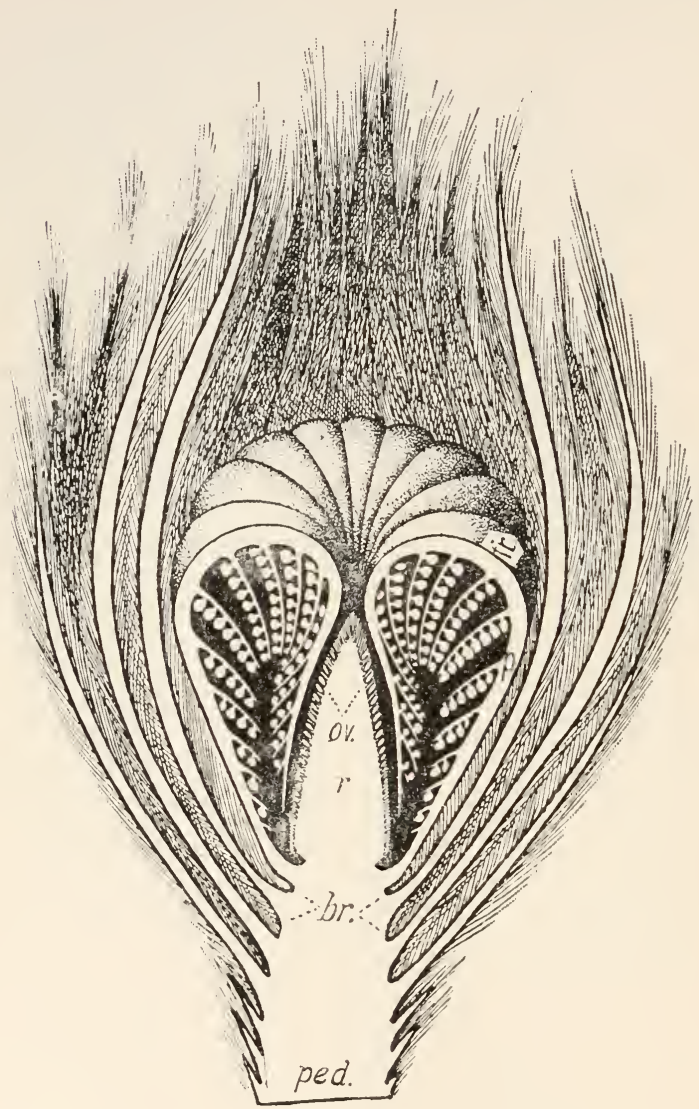

Fig. 2I $b$. - Restoration of flower bud of Fig. 2I $a$, based upon many other examples besides this figure. Nine of the eighteen staminate fronds $(f r$.$) are$ shown folded with reduced pinnules ( $p$. ) bearing densely packed oval synangia, pollen sacs (in white). At the center is the pistillate portion of the flower, the elongate conical receptacle $(r$.) covered externally with short stalked ovules (ov.) separated by scales. br., bracts; ped., pedicle, or stalk, attaching the flower to the stalk. (Both figures from Wieland.) 
America, Europe, India and the Arctic regions. Especially fine representatives of the genus Cycadeoidea (Bennettites) are found in the upper Mesozoic of Maryland, South Dakota, Wyoming and Mexico. The genus Wielandiella from the Upper Triassic (Rhætic) had slender stems branching dichotomously

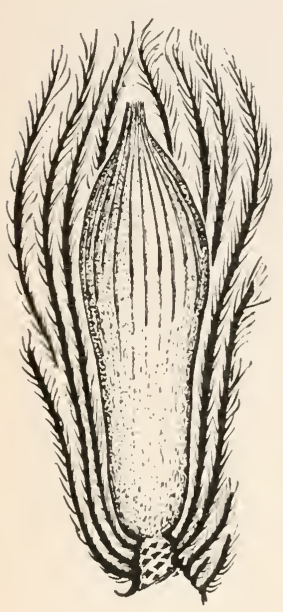

1
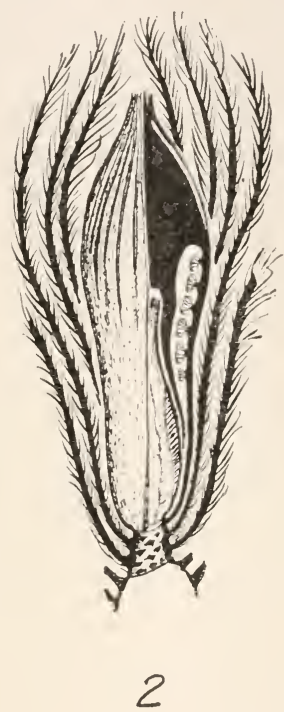
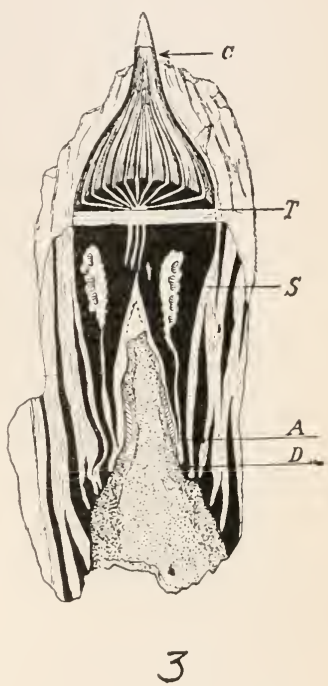

FIG. 22. - The flower-bud of Cycadeoidea colossalis removed from between the old leaf bases which form the heavy "armor" of the trunk of the plant. This is such a flower-bud as that shown at f.b. in Fig. I9. I. Outer features of the capsular disk of stamens which incloses the central cone; bract-husk mostly cut away; diagrammatic. 2. Same as preceding but with a quarter of the bud cut away so as to disclose inner seed cone and structure of the outer disk. 3. Dome of bud drawn in relief down to level of transverse section $(T)$ and then continued below by a median longitudinal section. The disk of stamens $(D)$ divides into ten fronds each of which sends up two prolongations to form the apical dome $(T-C)$ of twenty segments. The ten once decurved tips of the fronds envelop the seed cone $(A)$. At $S$ are the synangia or complex pollen sacs. Compare with Fig. 21 . Natural size. (From Wieland.)

and bore its flowers in the forks. Another genus, Williamsonia, is also of varied structure and had a cosmopolitan distribution in the Jura-Cretaceous. To the genera already mentioned 
various cosmopolitan leaf genera of the Mesozoic, as Podozamites, Zamites, etc., are hypothetically attached.

Family 2, Cycadea, the existing cycads or sago palms. Plants with thick, columnar stems, at times attaining a height of thirty to sixty feet. The trunks are covered with an armor of old leaf-bases and bear a crown of large, usually once pinnate leaves, with from one or two apical cones to as many as thirty in one Australian form. The fructifications are in nearly all genera cones, either male or female, the sexes being separate on different plants. In the female plant of the living Cycas, however, the reproductive organs are not compacted into a cone, but consist of simple, leaf-like blades on which are borne the unprotected seeds. This is the simplest arrangement of reproductive organs among living seed plants and is reminiscent of ferns.

Another primitive character of the cycads is their method of fertilization. In most of the living seed plants the male cells are carried by the pollen tube to the ovule (Fig. II, $E^{\prime}$ ). In the cycads and ginkgos alone among seed plants the male cells are ciliated and motile, swimming activaly to the ovule after the rupture of the pollen tube, as is usually the case in the cryptogams, - the ferns, mosses and many algæ. This motility of the male cell is a survival of the earlier stages of the process of plant evolution when water was an essential medium for the process of fertilization, and of a still earlier stage when the whole plant body was adapted to life in the water.

Living cycads are tropical. There are nine genera, of which Cycas, the best known eastern genus, is found in Asia and Australia, and Zamia is the most conspicuous American genus. They existed in the Mesozoic in some number, but so far definite evidence of them remains meager; it is the abundance of their kindred, the Cycadeoideæ, that marks out the Mesozoic as the "Age of Cycads," or as some name it "The Age of Proangiosperms." The genus Cycas has been found in the Lower Jurassic, though its leaf type goes back much farther. 
I. Into what two families are the cycads divided? Describe each briefly, stating one respect in which they resemble each other; one in which they differ. What is their geologic range?

2. Where are cycads living at present?

3. Why is the motility of the male cell especially interesting ?

4. Among what plants was the first flower evolved? Did it resemble any modern flowers? What testimony does it furnish upon the origin of the higher flowering plants?

5. Sketch Cycadeoidea, labeling bracts, flower buds (if present). What do the bracts represent? Make restoration of entire plant, naming stem, crown of leaves.

6. What was the age of cycads?

\section{Order C, Cordaitales}

An extinct group of tall, slender trees which had a general distribution throughout the world from the Devonian to the Permian, inclusive. It is represented by the genus Cordaites. The trunk rose to a height of thirty to one hundred feet and was surmounted by a dense crown of branches bearing narrow swordlike leaves. The leaves were distinguished by their conspicuous parallel veins, and their great size, attaining at times a length of three feet.

The general structure of the stem resembles that of the conifers except in the very large pith, which suggests rather that of the cycads. Casts of this pith cavity, called Sternbergia, are common fossils. They are cylindrical bodies, one to four inches in diameter, longitudinally ribbed and marked by transverse constrictions at short intervals. The pith in the living stem ruptured transversely at intervals, dividing into disks of solid tissue separated by empty spaces. In the casts of this cavity, where there is a later decay of the pith and wood, the position of the pith-disks would be represented by transverse constrictions. This appearance may be seen on a lesser scale in the pith of the walnut, hickory and other common trees to-day.

The fructifications of Cordaites were small male and female catkins. 
In leaf structure and in certain primitive features of the seeds, Cordaites shows relationship to the Cycadofilicales, in stem and root anatomy it inclines toward the conifers (Fig. 23), while its male catkins resemble those of the Ginkgo. From these and other characters it is evident that the Cordaitales

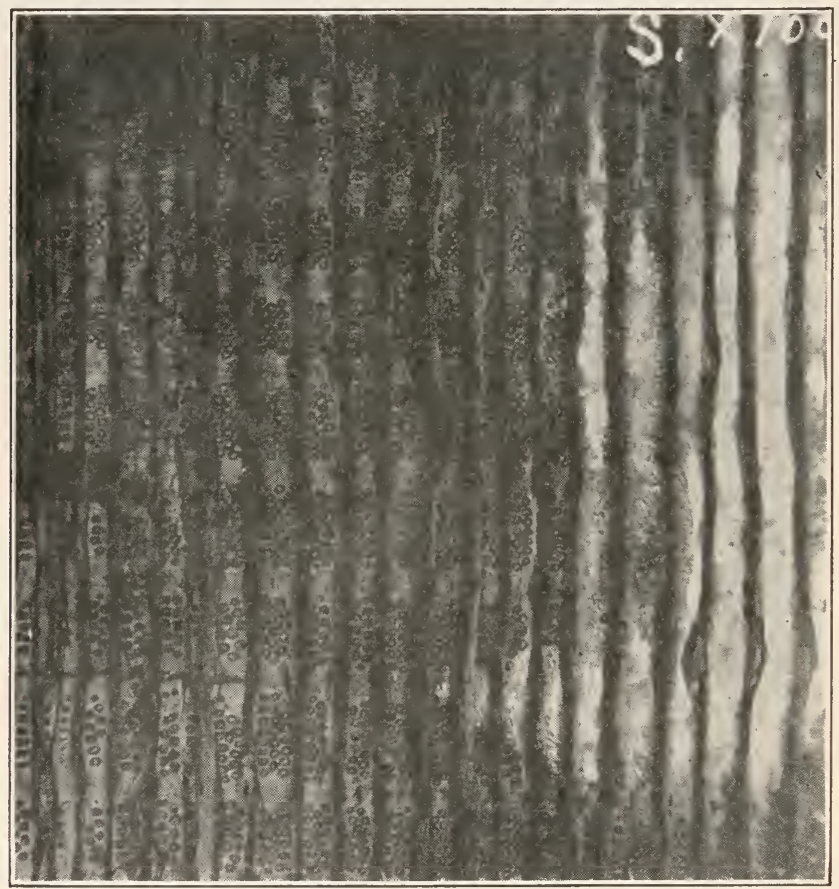

FIG. 23. - Photomicrograph of a radial section of one of the most ancient of known woods, Callixylon (Cordaites) oweni Wieland, from the Upper Devonian Black Shale of Indiana. The preservation of this wood is so perfect that the thin sections may be freely studied at 600 diameters. At the roo diameters shown here, the bordered pits of the radial surfaces of the wood cells or tracheids are seen to have a radially grouped arrangement; this radial grouping is rare in the Paleozoic. (After Wieland.)

were a highly generalized group of seed-fern affinity near the base of all the later gymnosperm lines, originating probably in 
the Silurian. Among living gymnosperms, the ginkgos are their closest kin.

The Cordaitales are confined to the Paleozoic and seem to have furnished the predominant members of the gymnosperm forests during the Devonian, and especially later during the Carboniferous.

Cordaites, named in honor of the early paleobotanist, Corda, is the best known genus. In the Upper Devonian black shale of Indiana are trunks two feet in diameter and twenty feet. long, indicating trees probably one hundred to one hundred and fifty feet high (Fig. 23). In Pennsylvanian shales in New Brunswick the leaves are packed in layers like those of modern forests.

I. Describe the appearance of Cordaites.

2. How were casts of its pith cavity formed? What are they called?

3. Discuss its relationships and probable evolution.

4. Describe a for est of Carboniferous time as you think it must have appeared.

\section{Order D, Ginkgoales}

An isolated order of gymnosperms, represented at present by only one genus and one species, Ginkgo biloba, - the maidenhair tree, but with the long and varied ancient history that such isolation in the existing flora always indicates. The ginkgo is a tree which in general appearance and in the anatomy of the stem closely resembles the conifers. The leaves, however, are fan-like in outline like the large leaflets of the maidenhair fern, and are shed each year.

A primitive character which it possesses along with the cycads, and which is reminiscent of a fern ancestry, is the motility of the male cells in fertilization, already mentioned (p. 66).

The ginkgo tree has long been cultivated by the Chinese and Japanese, especially in the temple grounds; now a common cultivated tree, it is not surely known wild in any part of the 
world, though it may possibly be native to western China. It is the last member of a race that is seen by the fossil records to have spread over all the world. This race, the Ginkgoales, was especially numerous and widespread in the Jurassic and was still abundant in Cretaceous time. Leaves and flowers of representatives of this order are found in rocks of these ages in Europe, northern Siberia, Greenland, Spitzbergen, China, Turkestan, Australia, South Africa and the Pacific Coast of America. In at least the earlier part of the Tertiary, the ginkgo flourished in Alaska, Greenland, and the northern part of Great Britain. Because of its great antiquity and isolated position it has been called a "living fossil." It is supposed to have arisen from the group of the Cordaitales.

I. Describe the ginkgo tree. What is its common name and from what derived?

2. What is the geologic range of this order?

3. Discuss the present and former geographic distribution of the ginkgo tree. Can you account for this difference?

\section{Order E, Coniferales}

This order includes the conspicuous gymnosperm vegetation of the north temperate regions, made up of trees and shrubs, mostly evergreen, usually with rigid, needle- or scale-like leaves and with male and female cones. The conifers were probably derived from the Cordaitales of the Paleozoic, retaining fewer primitive characters than the Ginkgoales, but derived from the same source. Living conifers are represented by forty genera and three hundred and fifty species. They are divided into two families:

(I) Taxacer, the yews. - With fleshy seeds and exposed ovules. Comparatively modern, with no record below the Comanchean, they already during this period formed an important element in the Potomac flora of eastern North America. 
(2) Pinacea. - With dry seeds and ovules covered by scales. These include four tribes:

(a) Arancariae. - A group that is now mainly restricted to a small region of the southern hemisphere-Norfolk Island, Brazil, southwestern Argentina and Chili, but widely distributed during the Mesozoic, being abundant in the Jurassic rocks of Great Britain, Spitzbergen, South Africa, Australia, India, the eastern United States, and in the Antarctic regions. A comparison of the former and the present distribution of such a genus is of vivid interest as indicating former geographic connections which are now severed.

From the association of fragments of petrified araucarian wood with the jet at Whitby, England, it may be supposed that

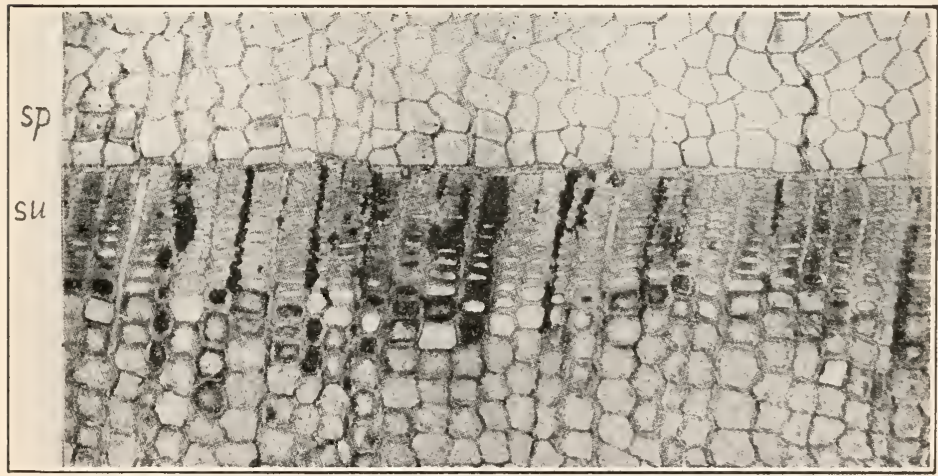

FIG. 24. - Transverse section $(\times 60)$ through an annual ring of the Tertiary conifer, Sequoia magnifica Knowlton. sp., cells added during spring or wet season when an abundance of moisture caused rapid growth, hence large cells; su., cells added during summer or dry season; the cells here are small. The change is gradual from the moist spring to the succeeding dry season, but the next spring's growth begins suddenly, hence here is a very sharp change in size of cells. These more or less sudden changes produce the annual ring, merely a contrast in size of cells, contrasting periods of slow and rapid growth. (From Knowlton.)

some of the jet, at least, consists of the fossilized remains of the wood of Araucaria.

(b) Abietc. - The group of the more common evergreens, - 


\section{AN INTRODUCTION TO THE STUDY OF FOSSILS}

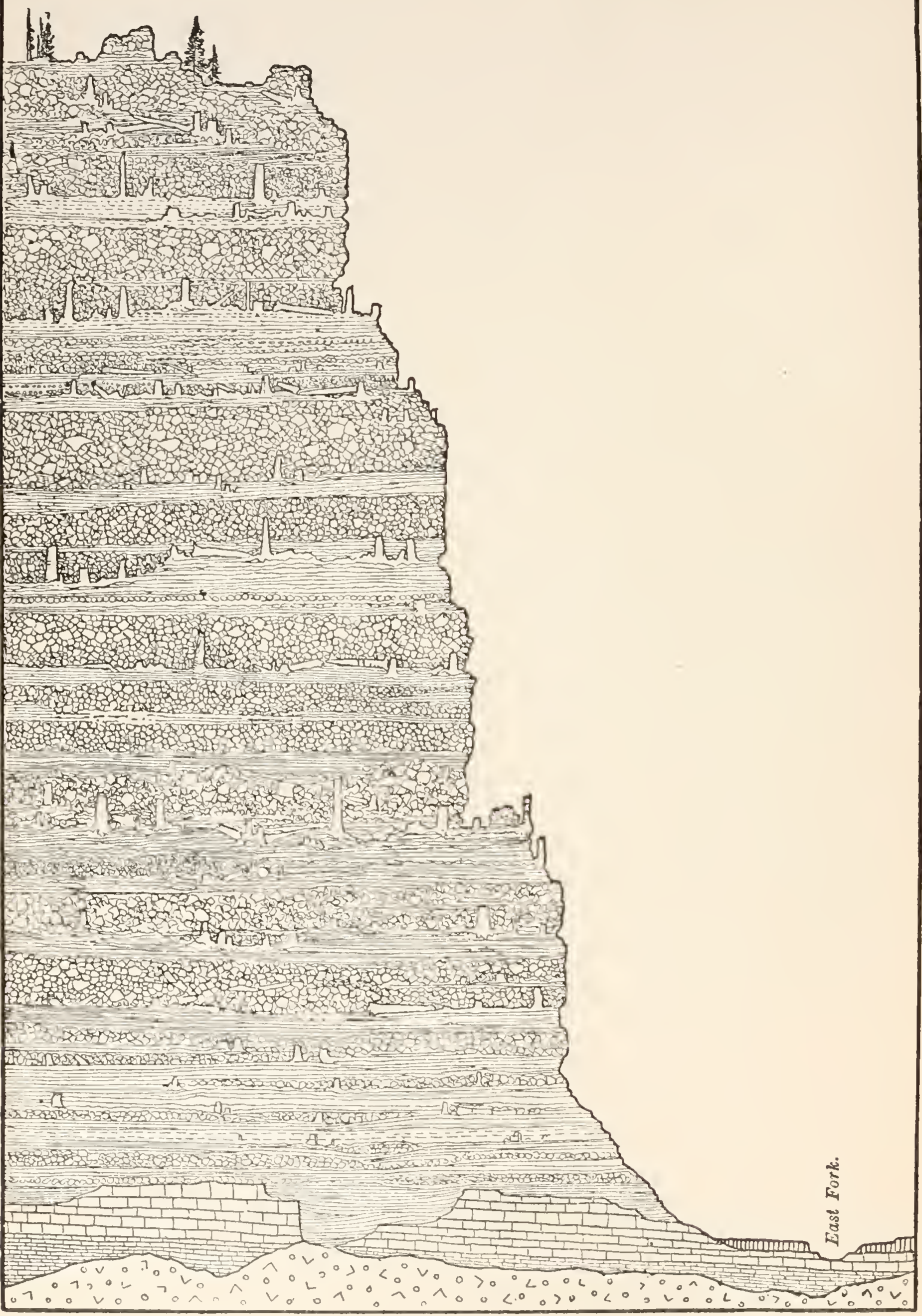

FIG. 25. - An ideal section through the fossil forests of Amethyst Mountain, in the Yellowstone National Park. There occur in this region 2000 feet of volcanic material in layers alternating with at least fifteen successive forests, indicating thus fifteen volcanic outbursts separated by at least sufficient time to allow the growth of forest trees with a diameter of two to ten feet. (From Holmes.) 
pines, cedars, hemlocks, etc. Recorded from the time of the Comanchean.

(c) Taxodice. - Includes (I) Voltzia from the Upper Permian and Triassic. To this tribe likewise belongs (2) Sequoia (Figs. 24, 25). The genus Sequoia is now represented only by two species, - S. semperivens, the redwood, and $S$. gigantea, the big tree, - living in restricted areas in California and southern Oregon. These trees are unique in the world in their

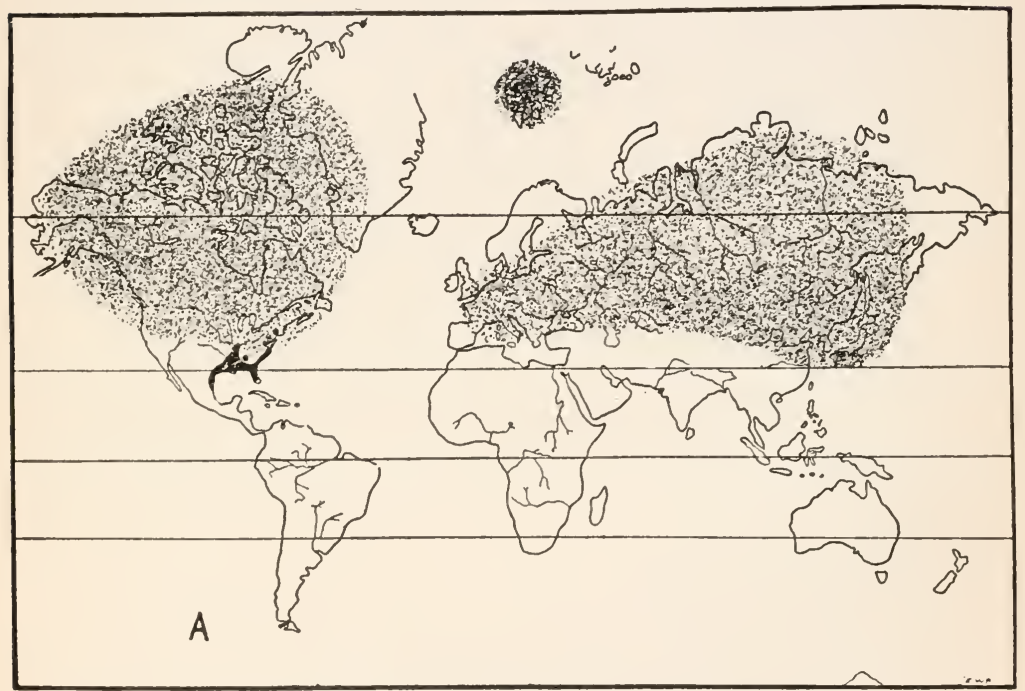

FIG. 26, A. - Sketch map showing the known distribution of the bald cypress (Taxodium). Tertiary distribution shaded; Pleistocene occurrences north of its present limits, in dots; present distribution black. (From Berry.)

size, age, and szarcity. The trunk often attains a height of over three hundred feet and a diameter of over thirty feet. Like Araucaria, Ginkgo, etc., Sequoia, as at present represented, is merely the lonely survivor of a once widely distributed group. Though not known conclusively from the Jurassic, its twigs, cones, and seeds are abundant in the Comanchean of North America from Virginia-Texas-California, north to. Greenland, 
in Spitzbergen and Europe from Russia to Portugal ; it continued in abundance and with wide distribution during the Cretaceous and Tertiary, but disappeared during the cold climate of the Pleistocene, except in the California-Oregon region. Sequoia langsdorfi, the direct ancestor of the redwood, was very wide-

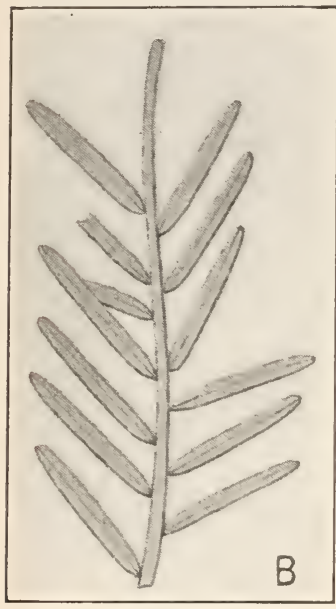

Fig. 26, B. - A twig of Taxodium distichum miocenicum Heer $\left(x_{2}\right)$, from the Tertiary of Utah. (From Lesquereux.) spread in the great circumpolar conifer forests of Upper Cretaceous time; while S. magnifica, so abundant in the Tertiary of the Yellowstone National Park, was almost identical with the living redwood. (3) The genus Taxodium (Fig. 26), consisting of the bald cypress, characteristic of hard or sandy bottom swamps, and of a Mexican species, is now confined solely to the southem Atlantic and Gulf Coastal plain; but in early Tertiary time this genus was as figure $26, A$ shows, universal north of the tropic of Cancer. Such a map indicates the tremendous changes in plant distribution brought on by the advent of glacial conditions in the north polar area, while the recent description of the fossil flora of Graham Land (Upper Jurassic) by Halle shows like changes on a gigantic scale in Antarctica.

(d) Cupressea. - Including the juniper, arbor vitæ, etc. Known doubtfully from the Jurassic.

I. Name three living conifers with which you are acquainted.

2. What is the geologic range of this order?

3. Into what two families is it divided?

4. What is jet?

5. Discuss Sequoia, noting its appearance, present habitat, and former distribution. 
6. How did the climate of the Tertiary differ from that of the Pleistocene and the present? What was the chief cause of this difference? Give examples among plants that show that this climatic change took place.

\section{Order F, Gnetales}

This group of small trees or shruls consists of three living genera, including Ejhedra of the desert regions of both hemispheres. They differ from other gymnosperms and show somewhat angiospermous tendencies in certain structural characters of the wood and in some flower-like features of the reproductive organs.

Fossil record of the order would have high interest but so far has not been forthcoming.

I. What are the Gnetales?

2. What fossil record have they?

\section{SUBDIVISION B, ANGIOSPERME}

As the mammals represent the culmination of the much branched animal line of ascent, so the angiosperms contain the plants of highest rank. This group, the latest to come upon the earth, comprises over half of all known living species of plants. It is the angiosperms which clothe most of the earth with vegetation; in every climate and at almost all altitudes they nearly always compete successfully with all other vegetal types. They not only cover much of the earth with forests and grasses, flowering herbs and shrubs, but many species (e.g. water-lily, duckweed) have invaded the fresh-water realm of the algæ with wonderful success. Though very few angiosperms, as the eel-grass (Zostera), have tried to dispute with algæ a habitat in the sea, they are the only group to have invaded the sea at all, for the gymnosperms, ferns and mosses have no representatives there.

The members of the Angiospermæ are commonly known as 
the Flowering Plants (Fig. 27). The typical flower is composed of (I) a covering, the perianth, which may consist of an outer bud-covering portion, the calyx, and an inner colored portion, the corolla. The entire perianth may be brightly colored or uncolored. Within the perianth are (2) the male

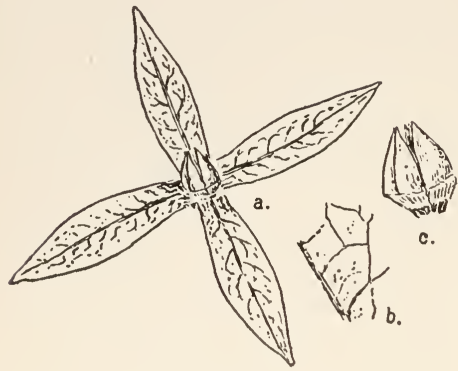

A

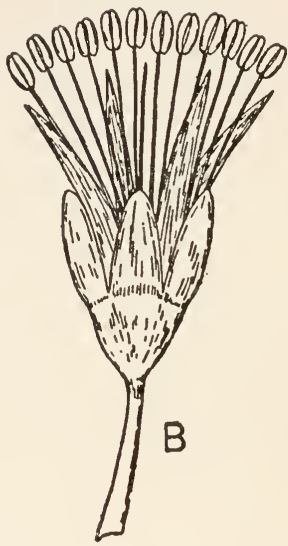

FIg. 27. - Fossil flowers, because of their delicacy, are rarely preserved. $A$, Carpolithes macrophyllus, from the Miocene shales of Florissant, Colorado. (From Cockerell.) $a$, entire flower with its four large calyx lobes; $b$, detail of venation; $c$, fruit. $B$, restoration of flower of Combretanthites eocenica, from the Eocene of Tennessee. $\times 4$. (From Berry.)

organs, - the stamens bearing the pollen, which are the male cells of fertilization. The stamens are arranged in one or more circles; at their center is (3) the female organ, the pistil, the outer portion of which, the stigma, receives the pollen while the inner portion, the closed ovary, contains the ovules which after fertilization by the pollen become seeds.

The method of fertilization is somewhat complicated. Each dust-like pollen grain is a single cell with a single nucleus at its center. When this pollen grain is lodged, through the agency of the wind or an insect, against the stigma, the usually sugary solution there holds it and causes it to grow. By this time the single nucleus will have divided into two or three, one of which, 
the tube cell, piercing the stigma, grows down its stalk and penetrates an ovule, permitting the passage thither of the other two cells (Fig. II, $\mathrm{E}^{\prime}$ ). By this time the nucleus of the ovule has also divided several times, forming several cells ; to one of these cells one of the two male cells is attracted, and there results a fusion of the two cells into one; this fusion is fertilization. Immediately this new cell, nourished by the other cells, grows rapidly into a minute embryo. This embryo consists of a stem with seedling leaves (cotyledons) at one end, and a root at the other. In this state, the seed, it ceases growing and may remain dormant for years. As animals prepare food material - the yolk - for the growing embryo, so also do plants; in the grasses and palms this nourishment lies in the seed outside the cotyledons, in the bean and walnut within the cotyledons themselves.

It is thus seen that the pollen grain and ovule always develop into distinct plants of a few cells each. These few cells form the sexual or gametophyte stage of the angiosperms, corresponding to the entire liverwort and moss plant and to the prothallus of ferns. The union of two cells, one from each of these plants, produces the embryo which under favorable conditions will develop into the adult plant, - the asexual, or sporophyte stage; it, like the fern-plant or the little capsule of the moss, produces spores calied here the pollen and ovules.

Both classes of the angiosperms made their first appearance, so far as known, in the Upper Comanchean. Here appeared such modern dicotyledonous genera as the poplar, willow, laurel and fig, as well as primitive representatives of such monocotyledonous families as the pondweed and the sedge. This early flora is best known from the Upper Potomac formation (Patapsco) of Virginia and from strata of corresponding age in Portugal. Later upon the Cretaceous lands flourished very luxuriantly many of our best known living plants, - the oak, walnut, beech, birch, holly and ivy of the dicotyledons, the lily and palm of the monocotyledons. The rapid rise of the angio- 
sperms, - the true flowering vegetation, - was probably due to the pari passu development of flower-loving insects, the bees and wasps (Hymenoptera) and the butterflies and moths (Lepidoptera); these families first appeared in the Jurassic, the period immediately preceding the one which apparently saw the beginning of the angiosperms.

Derivation of name. - Angiospermæ> Greek angeion, a vessel + sperma, seed, because the seed is inclosed in a protecting ovary, e.g. the core of an apple, the pit of a cherry, the chaff of grass. In the gymnosperms the pollen can reach the ovules directly.

The Angiospermæ are divided into the classes :-

a. Monocotyledones.

b. Dicotyledones.

\section{Class i, Monocotyledones}

These plants are usually distinguished by the following characters: the plant begins with a single leaflet or cotyldon (whence the name mono-cotyledon); the leaves are parallelveined; the stem is cylindrical with the vascular bundles scattered, a cross section accordingly not showing concentric growth lines; the roots are fibrous; the parts of the flowers in threes.

This class includes to-day members of vast economic importance to man. The grasses, especially their fruit, the grains, have become an absolute necessity to him in the temperate zones, just as the plantain, banana, and various palms (e.g. date, coco and sago palms) are now an essential to his existence within the tropics. Representatives of the class are first known from the Upper Comanchean of eastern North America and Portugal in such lowly forms as the pondweed and sedge; the lily and palm, however, soon appeared in the Cretaceous, while not until rather late in the Tertiary did true grasses make their appearance.

The paleontologic record of the palms goes back to the midCretaceous (Fig. 28). It is probable that they occurred 
rather extensively from this time on; they were apparently abundant in North America, both on the coastal plain and in the formations of the continental interior.

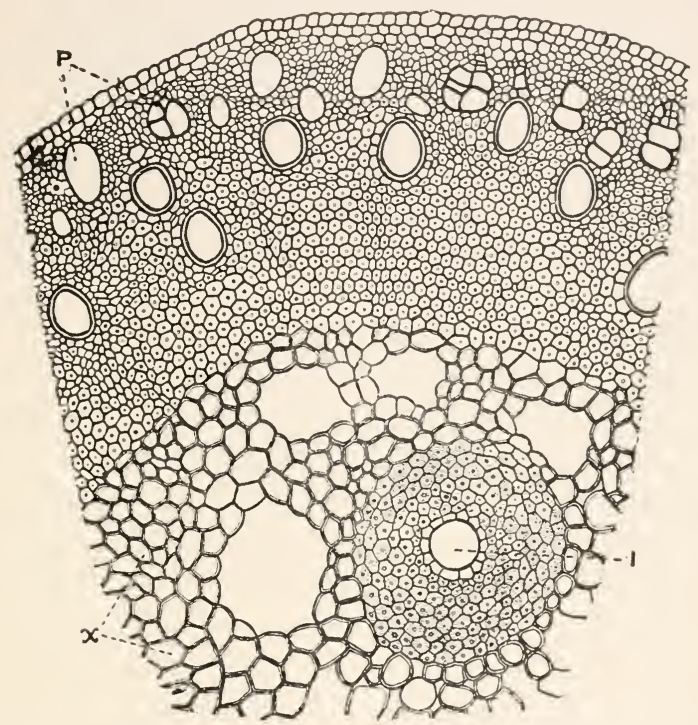

FIG. 28. - Transverse section of the New Jersey Upper Cretaceous palm, Palmoxylon anchorus Stevens. This is an example of the often marvelous perfection of preservation of cell structure in fossilized plants. Portion of a large root ( $\left.X_{130}\right)$; p., phloem, thin-walled cells, through which most of the organic substances manufactured by the leaves pass down to the roots; $x$., xylem, thick-walled woody cells through which the crude materials absorbed from the soil pass up to the stem and leaves; $i$, an internal vessel surrounded by sclerenchyma fibers, very thick-walled, strengthening cells. (After Stevens.)

\section{Class 2, Dicotyledones}

The dicotyledons usually possess the following characters, the plants begin with two seedling leaves, the cotyledons (whence the name di-cotyledons); the leaves are usually nettedveined. The stem is usually thicker below than above, with the vascular bundles arranged to form a cylinder inclosing a pith center; as growth proceeds new cylinders are formed, and 
since the vascular bundles formed in spring have thinner walls than those formed in late summer and fall the annual growth becomes visible as a concentric ring. A taproot is usually present; the parts of flowers are in fours or fives.

The dicotyledons are now generally regarded as more primitive than the monocotyledons and as their probable ancestor.

(I) One of the most primitive of the dicotyledons is the American tulip tree, Liriodendron tulipifera, a beautiful forest type, of eastern North America, reaching a diameter of four to twelve feet, and a height of sixty to one hundred and ninety feet. The closely related species, L. chinensis, occurs in eastern Asia. These are the sole survivors of the genus Liriodendron which had formerly a far wider distribution. Appearing first in the Cretaceous in great variety and number of species, it flourished during this period in North America from Wyoming to Néw Jersey and in Greenland. In Tertiary time it still extended its range over Iceland and Eurasia; but the cold climates of the Pleistocene forced the last remnants of Liriodendron southward in Europe and finally cut them off on the shores of the Mediterranean Sea, which, with the Alps, acted as a transverse barrier to the farther retreat of this and many other types. Thus is explained the paucity of dicotyledons in Europe as compared with North America and eastern Asia, where retreat southward during the ice age was not thus cut off by high mountains or transverse shores. This late restriction of distribution is also seen in Engelhardtia (Fig. 29).

(2) Sassafras, like Liriodendron, is also a ditypic genus now restricted to $S$. officinalis, confined to eastern North America, and a closely related Chinese form. Like Liriodendron, it is the last representative of a large group which flourished at least throughout North America and Europe since the Comanchean, but could survive the cold Pleistocene climate only in North America and eastern Asia. It is known first from the Comanchean of Virginia, Greenland and Portugal, later from the 
Cretaceous of North America (occurring from the Rockies to New Jersey), Greenland and Europe, and it continued to have a cosmopolitan range throughout the Tertiary; a late Pleisto-

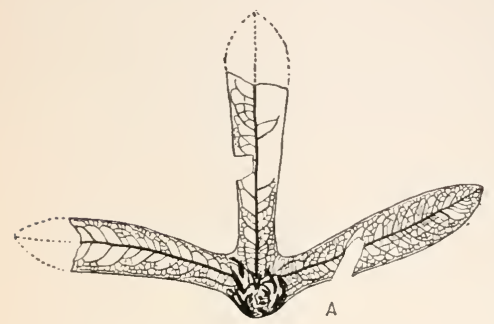

cene species from France and Italy is almost identical with the living form.

(3) The poplar (Populus) is known to have lived during Comanchean time in Virginia and Greenland, throughout North America and Greenland

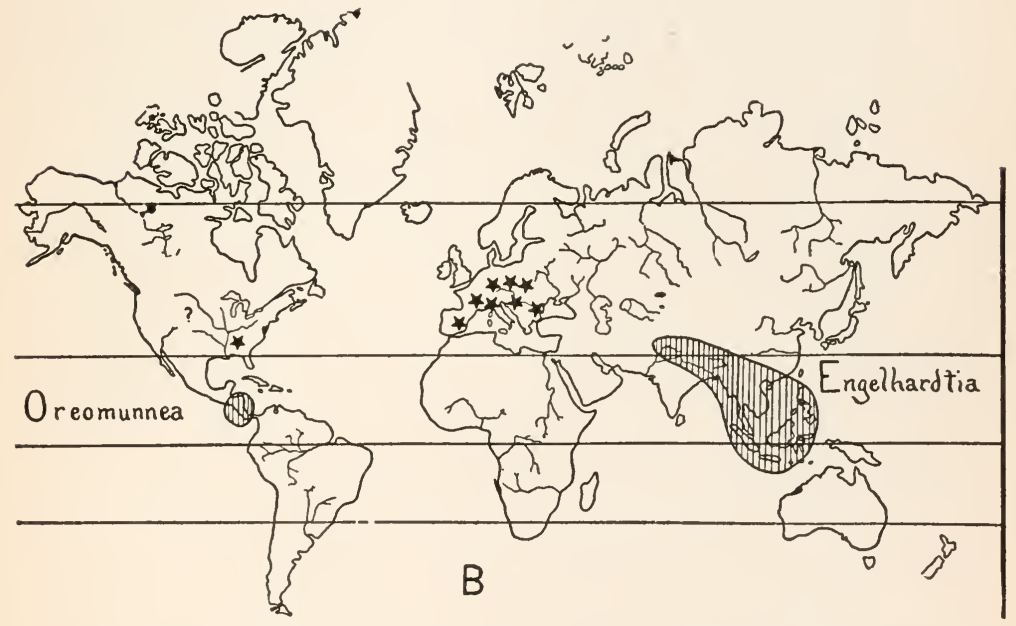

FIG. 29. - $A$, a fossil relative of the walnut family, Engelhardtia (Oreomunnea) mississippiensis Berry, from the Eocene of Mississippi $\left(\times \frac{1}{2}\right)$. B, sketch map showing the existing distribution of Engelhardtia (vertical lining) and fossil occurrences (stars). There is here an indication of movement southward as the northern regions became colder, and of the obliteration of this tropical genus from Europe, where southward migration during the glacial period was prevented by the transverse shores of the Mediterranean Sea. (From Berry.)

during the Cretaceous, and in Europe, North America and Arctic lands in the Tertiary. 
I. What is the especial feature that characterizes the angiosperms? What is the difference, indicated by the derivation of the words, between angiosperms and gymnosperms?

2. Describe a typical flower.

3. Outline the method of fertilization.

4. What is the sporophyte stage of an angiosperm? What the gametophyte? How does their relative importance among angiosperms compare with it among the mosses? Among the ferns?

5. In what geologic age did angiosperms appear?

6. How are angiosperms divided?

7. Name three features which distinguish a monocotyledon from a dicotyledon.

8. Discuss one example of the former class, giving its geographic and geologic range.

9. Discuss one example of the dicotyledons, giving geographic and geologic range.

I. Name the divisions into which plants are classified, giving the basis of this classification. How does the increase in complexity of organization correspond to the order of appearance in geologic time?

2. Outline the changes in the relation of sporophyte to gametophyte stages from the thallophytes to the spermatophytes.

3. In what mineralogical state do the majority of fossil plants occur? Outline the process which changes the living tissue of the plant to this condition. 


\section{ANIMALS}

THE lines into which life branches do not possess the same power to evolve; along the animal pathway the three main branches are those of the mollusks, arthropods and vertebrates. In very ancient times each of these phyla had partly at least followed the example of the plants in encasing themselves in a hard external skeleton through which stimuli could with greater difficulty penetrate, and because of which freedom of movement was greatly curtailed. Before this condition had become universal, however, branches developed from each, which, anticipating historic warfare in this respect, gradually eliminated this protecting but cumbersome armor and developed instead a higher type of nervous system and more responsive muscles. These more progressive branches terminate at present in the squids and devil-fish (Dibranchiata) of the mollusks, the insects of the arthropods and the mammals of the vertebrates. These three phyla pursued the same pathway through the Protozoa, Cœlenterata and possibly also through the worms.

From the protozoöns to the chordates, as in the human social life, the advance of life is measured by sub-division of labor. In the Protozoa the single cell composing the entire animal performs all the functions which in the Chordata are accomplished by the millions of cells working through hundreds of organs. Naturally the work is better done by the latter than by the former. Upon this division of labor as well as upon the varying form of the organs through which the work is performed, the Animal Kingdom is divided into twelve great groups or phyla.

\section{PHYLUM I, PROTOZOA}

The Protozoa are simple, one-celled, aquatic animals consisting of protoplasm, usually microscopic in size, with or without 
hard parts, and without differentiated tissue or organs. The hard parts, secreted within or upon the surface of the protoplasm, consist of chitin in some of the Sarcodina, of cellulose in the Dinoflagellata, of calcium carbonate in the Foraminifera, and of silica in the Radiolaria. Protozoa are the most abundant aquatic animals.

Two extremes in size among living Protozoa are the organism causing yellow fever, supposed to be a protozoön but so minute that it has never been seen, and Porospora gigantea, a parasite on the intestine of lobsters, which is two-thirds of an inch in length. The same species may vary much in size " due solely to the lack of food in the one case." A living species of Dileptus varied from a proportional length of 80 when normal to ro when starved $\left(\mathrm{I}_{3}\right)$.

Derivation of name. - Protozoa $>$ Greek protos, first, + zoon, animal; in this phylum occur the first or lowest animals.

The Protozoa are divided into the following four classes, of which only the Sarcodina and possibly the Mastigophora have fossil representatives :-
A. Sarcodina
B. Mastigophora
C. Sporozoa
D. Infusoria

Type of phylum, Amceba proteus (living) (Fig. 30).

This is a microscopic mass of jelly-like protoplasm, about $.2 \mathrm{~mm}$. in diameter with a clear, usually thin, outer layer and a granular inner portion, the granules being mostly proteid and fat particles. Within this granular portion is a darker, rounded body, the nucleus, and a rounded, pulsating, clear space, the contractile vacuole.

It secretes no skeleton, and is free-moving and abundant at the bottom of fresh water pools and ponds among decaying vegetation. It is irregular and variable in outline, continually altering its shape by slowly pushing out and withdrawing 
various parts of its body; these temporary finger-like processes are called pseudopodia. Movement takes place by the gradual streaming of the entire substance of the amœba into the projections from one side, and is thus practically a flowing process, " the upper surface" (in Amcba verrucosa) "continually passing forward and rolling under at the anterior end so as to form the lower surface" (I5).

Its food consists of those entire minute animals or plants, or those organic particles with which the pseudopods, or main body portion have come into contact. The amœba pursues such prey as long as it is in contact with it, rolling it ahead in its attempts to catch it, then sending out pseudopodia on each side to surround it. Finally if the prey has not escaped the amœba succeeds in surrounding it with its side pseudopodia and sends out from its upper surface a thin film of protoplasm over it, thus com-

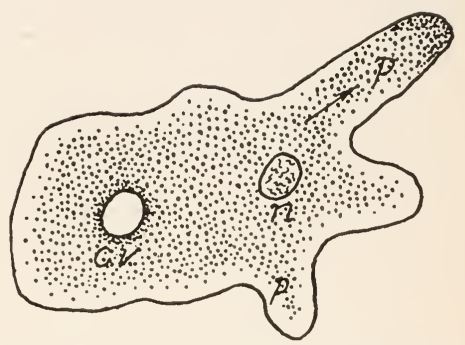

FIG. 30. - The fresh-water protozoön, A maba proteus. It is now moving in the direction of the arrow. n., nucleus; c.v., contractile vacuole; $p$., pseudopodia. Very much enlarged. pletely engulfing it. This food is pressed into the soft substance and passes gradually into the interior.

Digestion. - With the food-victim a certain amount of water is taken in by the amœba; this water with the victim forms a "gastric vacuole" or an improvised stomach, surrounded on all sides by a wall of living protoplasm. From this protoplasm there soon begins to form an acid secretion, probably hydrochloric acid, which thus gradually changes the chemical nature of the water of the gastric vacuole and kills the prey which it incloses; with the first changes in chemical nature of the surrounding water the prey begins to struggle and ceases its efforts to escape only when killed by the secretion. It is probable that the product of the digestive action of this acid is the formation 
of soluble peptones similar to the products of proteid digestion in the higher animals. This is followed by a digestive ferment like trypsin, acting in an alkaline medium.

The manufacture of the acid secretion is intimately connected with the chromatin material of the nucleus, for digestion does not take place when the nucleus is absent. "Protozoa evidently have the power of secreting different kinds of ferments in response to the stimulus of different kinds of living food particles." Some types of Protozoa can create starch-dissolving ferments or fat-emulsifying ferments, though other species throw the starch grains out of the body with other indigestible parts of the food (13).

Assimilation. - "The granules that are formed by the breaking down of the food particles through the digestive process are ultimately distributed by means of the protoplasm which streams to all parts of the protozoön" through the animal's rolling method of progression and by osmosis. "Some are probably converted directly into protoplasm by an assimilative process that is as little understood in these forms as in the Metazoa" (13).

Excretion. - The undigested food particles pass outwards into the surrounding water, and are left behind as the amœba rolls forward. Thus, whatever part of the amoeba's body touches food becomes mouth, whatever portion the food particle enters becomes digestive cavity, and the undigested material may leave from any part of the surface.

It is probable that the contractile vacuole is the chief organ of excretion, that by its means the animal rids itself of the waste products of assimilation and metabolism, such as urea and carbon dioxid.

Respiration, or the exchange of gaseous waste products for oxygen, takes place through the entire surface of the body, most of the oxygen being obtained in this way, though probably most of the carbon dioxid is thrown off by the contractile vacuole. 
There is no trace of a nervous system, though the animal displays many of the reactions to stimuli which higher forms possess. It is sensitive to chemical changes in the water surrounding it and to heat, moving away from the chemically changed area and from the source of heat. It moves away likewise from the source of strong light and toward the negative pole when the water containing it is charged with electricity. It avoids mechanical obstacles in the water by reversing the flow of its protoplasm into the opposite direction. Thus mechanical, chemical and electrical stimuli and variations in heat and light control the direction of movement (I5).

Reproduction is mainly by simple division. When more food is taken in than is required for maintaining the size unaltered, a constriction appears dividing the entire amoba, including the nucleus, into two parts, thus producing two cells or two individuals. Each individual amœba is a single cell, that is, it consists of a mass of protoplasm with an included nucleus. All animals higher than Protozoa, as well as all higher plants, consist of many such cells, usually with some more or less firm protective or strengthening substance.

I. If Amœba is available it should be examined under a compound microscope, its shape and movements noted.

2. Give size and structure of the animal. Illustrate with sketch.

3. Where does it live? What does it feed upon? off?

4. How is food procured? How digested, and waste thrown

5. How is the food assimilated?

6. How does the animal breathe? Excrete waste matter?

7. Does Amœba possess nerves? How does it respond to stimuli?

8. Describe its reproduction.

9. Where do Protozoa occur? What is meant by calling them one-celled animals?

Io. What classes of Protozoa have been found fossil? 


\section{CLASS A, SARCODINA}

Marine or fresh-water Protozoa with a body which alternately protrudes and retracts first one and then another part into fingerlike processes, - the pseudopodia. A contractile vacuole is present in some fresh water but not in marine forms. Reproduction is by binary or by multiple (spore-formation) fission. The members of this class are relatively large, many being visible to the naked eye. Some of the fossil forms especially, as Nummulites and Orbitoides, attain giant proportions for Protozoa.

Derivation of name. - Sarcodina $>$ sarcode $>$ Greek sar $x$ (sark-) flesh. Sarcode was the name applied by Dujardin to what is now called protoplasm.

The Sarcodina are divided into the two sub-classes, -

I. Rhizopoda.

2. Actinopoda.

\section{Sub-class i, Rhizopoda}

Usually creeping forms with branched pseudopodia (whence the name from Greek rhiza, a root, + pous (pod-) foot). This is subdivided into the orders, -

a. Amcebea. - Amœboid (changeable) forms, usually without shells. Unknown in the fossil state. The genus Amœba gives the name to the order.

b. Xenophyophora. - This includes some deep sea forms with a peculiar internal structure and a skeleton composed of foreign bodies, such as sand grains, sponge spicules, etc. (whence the name from Greek xenophyra, foreign bodies, + pherein, to bear). Unknown in the fossil state.

c. Foraminifera. - Skeleton (test) present, composed of calcium carbonate, more rarely of sand or of chitin, forming one or more chambers; this is perforated by one or more openings (whence the name from Latin foramen, a hole, + ferre, to bear). Pseudopodia are long and slender, uniting at intervals. These are typically creeping forms, using their net-like pseudopodia 
to capture food, but some, such as Globigerina and some twenty other modern species, have taken to a pelagic existence, that is, they have become planktonic.

Reproduction in the Foraminifera is both sexual and asexual. The sexually produced test results from the conjugation of zoöspores. It has a microspheric first chamber (proloculum). With increase in size and in number of chambers the nucleus also divides, often resulting in a greater number of nuclei than chambers. In the adult, each nucleus takes some of the protoplasm and forms a megalospheric first chamber (proloculum) larger than the microspheric; this develops into an adult test similar to the microspheric test, but smaller. In this adult form there is a single nucleus which moves forward so as to occupy the middle chamber numerically; this finally divides, each portion taking some of the protoplasm ; a further division results in zoöspores, or it may first continue for some generations reproducing asexually. The life cycle, consisting of an alternation of generation, is thus completed (I4).

Most Foraminifera are marine; a few of the simpler forms live in fresh water. They are now found everywhere in all seas (seldom below 2500 fathoms, since by the time such depths are reached the tests are dissolved). They flourish best in waters free from sediment and are hence much less abundant in estuaries and at the mouths of rivers than elsewhere.

Foraminifera did not become rock builders until the Mississippian period, Fusulina being one of the earliest to form rockmasses. The chalk of the upper Cretaceous of Europe and of North America (Niobrara, Austin and Rotten limestone formations) is largely composed of Foraminifera; accompanying these are sponge spicules, sea-urchins and shallow-water mollusks, indicating shallow seas for the growth of these ancient foraminiferal - or globigerina - oozes.

Foraminifera occur from the Ordovician to the present. Owing to the resemblance of their convoluted chambered shells to those of Nautilus, they were first classed with the Cephalopoda. 
Globigerina (Fig 3I).

Triassic to present.

This differs from Amœba in the possession of a calcareous support, the test. This test is composed of several globular chambers arranged in an irregular spiral (whence the name from

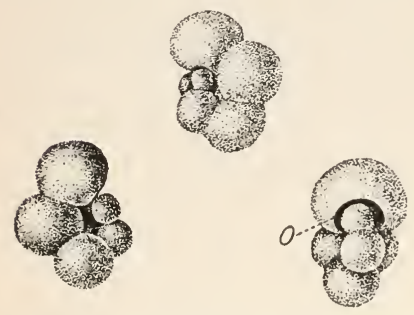

Fig. 31. - The lime-secreting protozoön, Globigerina aquilateralis Brady, from the Gulf of Mexico. This species is world-wide in its distribution, in both tropical and subtropical waters. Three views of the same specimen (much enlarged). The greatest mass of protoplasm was extended through the large opening $(O)$. Latin globus, a ball, + gerere, to carry). It also differs from Amoba in the length and delicacy of pseudopodia, which unite with each other at intervals. The chambers are somewhat glassy in appearance, and are pierced by numerous microscopic pores through which, as well as through the large opening from the largest chamber, the pseudopodia are extended. The protoplasm is perfectly continuous throughout all the chambers. The food consists mostly of microscopic plants, such as diatoms and algæ, more seldom of the minute copepod crustaceans; these are enveloped and digested by the net-like pseudopodia.

Globigerina typically lives floating at the surface of the ocean, spreading out its pseudopodia in all directions around it. At the death of the individuals, the tests fall to the sea bottom, and accumulate in vast layers, forming the globigerina oozes.

Although known from the Triassic to the present, it occurs but sparingly in the Mesozoic.

I. Examine the specimens under the compound microscope (these should include thin sections of chalk, and some globigerina ooze or sand scraped from such shells as those from the Paris Basin, from sponges or from corals).

2. Sketch ( $a$ ) Globigerina, (b) Textularia (Pennsylvanian to present), usually cone-shaped with two rows of alternating, 
communicating chambers, (c) Rotalia (Jurassic to present), chambers of test forming a flat spire. For examining the chambers use transmitted light. Label chambers, large and small openings.

3. Did the protoplasm occupy one or more chambers?

4. What is the food of Globigerina? How does its manner of capture differ from that in Amoeba?

5. Describe the reproduction.

6. What is meant by "alternation of generation"?

7. What is the significance of the name Foraminifera?

8. If Foraminifera occur in all seas, why do they form such masses as chalk and globigerina ooze when the muds and sands accumulated at the same time have so few?

9. Is chalk of shallow or deep water origin? Reasons.

Fusulina (Fig. 32). Pennsylvanian. Test spindle-shaped (whence the name from Latin fusus, spindle), bilaterally symmetrical; each chamber extending from end to end so that each whorl completely covers the preceding one; aperture in form of a fissure.

Exceedingly abundant in the Pennsylvanian limestone of North America, Russia and Asia.

I. Sketch $(a)$ entire fossil with opening upwards, $(b)$ cross section, showing method of coiling.
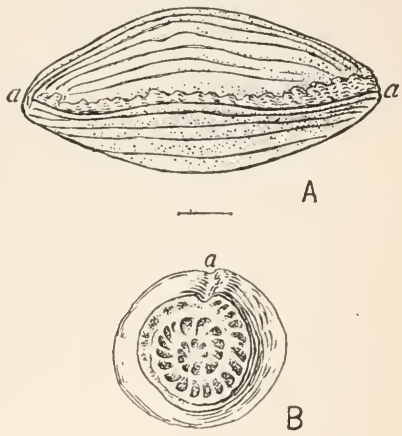

FIG. 32. - The protozoan skeleton, Fusulina secalica Say, abundant in the shallow seas covering Kansas during a part of the Pennsylvanian period. $A$, surface view showing the fissure-like aperture $(a-a)$. $B$, cross section showing the internal chambers and the aperture (a). Both enlarged; note scale of $A$.

2. Comparing with Globigerina, how did the living animal probably procure its food?

Nummulites (Fig. 33).

Pennsylvanian to present.

Test flattened, lens- or coin-shaped (whence the name from Latin mummulus, diminutive of nummus, a coin). Internally there is a spiral series of chambers. Each whorl completely 
incloses the preceding by means of a lateral prolongation of the chambers. The aperture is an inconspicuous slit at the inner margin of the last chamber. In Nummulites the increase in size is mainly on the periphery, in Fusulina it is mainly axial. A large and a small form are usually found associated in the same rock; these most probably are the large sexually produced test, and the small, asexually produced test of the same species.
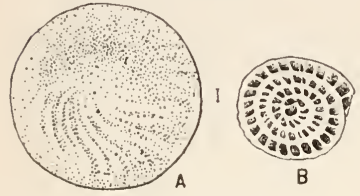

FIG. 33. - The skeleton of a marine protozoön, Nummulites, from the Eocene of Egypt. A very small specimen enlarged. $A$, surface view of the coin-like shell. $B$, section parallel to the flat surface.

Nummulites occur from the Pennsylvanian to the present, but sparsely outside the Tertiary. The one or two forms now living, as off the southeast coast of Asia, are tropical and subtropical. Nummulites attained their maximum abundance during the Eocene, making limestone masses, nummulitic limestone, up to several thousand feet in thickness, in the East Indies, Japan, South Asia, South Europe, North Africa and Central America. The largest species in these rocks attains a diameter of $60 \mathrm{~mm}$.; the smallest, $2 \mathrm{~mm}$. Associated with these Nummulites are other marine forms, such as mollusks and corals. The great pyramid of Cheops is built of this limestone.

I. Sketch $(a)$ surface view, $(b)$ longitudinal section, $(c)$ transverse section. A thin section made from nummulitic limestone will usually give the above sections.

2. How does this differ in its manner of coiling from Fusulina?

3. What is the significance of the name?

4. When and where did it occur most abundantly?

5. Account for the large and small forms usually found associated in the same rock.

Orbitoides (Fig 34).

Cretaceous to Miocene.

General shape of test very similar to that of Nummulites, but the chambers are smaller, much more numerous and complicated. 
Orbitoides is very abundant in the lower Tertiary. In the Gulf States of North America it makes up in places the entire rock, just as Nummulites does in the Mediterranean region of Eurasia and Africa. The Vicksburg or Orbitoides limestone of Oligocene age attains a considerable thickness in Alabama.

I. Sketch $(a)$ surface view, $(b)$ longitudinal section, $(c)$ transverse section.

2. How does this differ from Nummulites?

\section{Sub-Class 2, ACtinopoda}

Usually floating forms with ray-like, unbranched, rarely changeable pseudopodia provided with an axial thread (whence the name from Greek aktis (aktin-) a ray, + pous (pod) foot). This is subdivided into the orders :

a. Heliozoa, commonly called the "sunanimalcules" because of the fine ray-like pseudopodia (whence the name from Greek helios, sun, + zoon, animal). These do not possess the chitinous central capsule char-
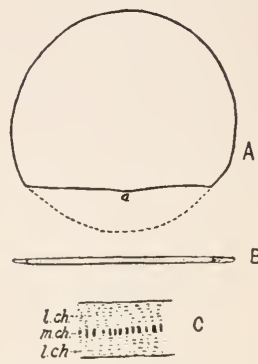

Fig. 34. - A protozoan calcareous skeleton, Orbitoides, abounding in the Oligocene sea at St. Stephens, Alabama. $A$, surface view $\left(\times \frac{1}{2}\right)$. $B$, vertical section along line $a$. $C$, section of another specimen much enlarged. m.ch., median chambers; this row is much larger than the ones (l.ch.) upon either side; l.ch., lateral chambers.

acteristic of the Radiolaria. They

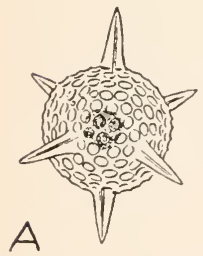

FIG. 35. - Siliceous skeletons of Radiolaria, from the Miocene of Maryland. A, Hexalonche microsphara Vinassa $(\times 130) . \quad B$, Cenosphara porosissima Vinassa ( $X$ I60). (From Martin.) are almost confined to fresh water. Unknown in the fossil state. Example, Actinophrys.

b. Radiolaria (Fig. 35). The body is composed of a central mass of protoplasm inclosed in a perforated, chitinous membrane, the central capsule, and is continuous through this with a layer of protoplasm outside the membrane; this layer gives off ray-like pseu- 
dopodia (whence the name from Latin radiolus, a little ray). There is usually present, in addition to the central capsule, another skeleton, beautiful and delicate; this is secreted by the protoplasm, usually without, sometimes extending or originating within the central capsule; it consists of isolated spicules, bars or latticework made of silica (Fig. 35), or rarely of acanthin, a substance allied to chitin. When the silica is secreted it is thrown down in the protoplasm all at once, apparently at the supersaturation of the protoplasm with silica.

The Radiolaria are marine organisms, floating at the surface of the ocean, or even at abyssal depths, and present in all climates. In some deep parts of the Pacific and Indian oceans these shells, falling after the death of the animal, accumulate on the sea-bottom, forming a siliceous deposit, known as " radiolarian ooze." The Radiolaria did not become important rock builders until the Tertiary; before this they occur only in scattered siliceous cherts but from nearly all periods. The Barbados earth, Miocene in age and covering large areas in the Barbados Islands, resembles very closely the modern radiolarian ooze and is probably a deep-sea deposit. Heliodiscus and Astromma are two genera found here.

In the "Barbados earth" the siliceous skeletons of radiolarians still retain their originally amorphous condition. Usually these skeletons are dissolved soon after burial in the rocks by percolating waters containing alkaii and may be redeposited as chert. The chert nodules of the upper Cretaceous chalk are probably largely due to these skeletons.

Radiolaria occur from the pre-Cambrian to the present.

\section{CLASS B, MASTIGOPHORA}

Protozoa with a definite body outline, the body protected in some species by a skeleton of cellulose or chitin, but usually naked. Organs of locomotion and of food-capture in adults are the flagella, - slender threads capable of whip-like lashing movements (whence the name from Greek mastix, a whip, + pherein, to bear). Euglena is an example. 
Fossil representatives of the order Dinoflagellata with a cellulose skeleton are reported from the flint in the European Cretaceous (Bütschli).

\section{CLASS C, SPOROZOA}

Parasitic Protozoa. There are no definite organs of locomotion or of food-getting in the adult. Reproduction is typically by the formation of seed-like bodies, - spores (whence the name from Greek spora, seed, +zoon, animal). Each spore contains one or more minute germs, - sporozoites. Unknown in the fossil state. Gregarina and Plasmodium are two of the common genera. Three different species of the latter may cause human malaria.

\section{CLASS D, INFUSORIA}

Protozoa with a definite body outline. The organs of locomotion and food-capture during all or a part of their active life are cilia, - small vibratile threads, smaller and more numerous than flagella. There is a vegetative large macronucleus and a smaller generative micronucleus. (The name was originally applied to all those minute plants and animals that make their appearance in infusions of decaying organic substance, but is now restricted to Protozoa as defined above.) Unknown in the fossil state. Examples are Vorticella, Paramocium and Stentor. 


\section{PHYLUM II，PORIFERA (SPONGES)}

SPONGES are organisms consisting of many cells, plant-like in appearance and extremely variable in shape. Sponges growing side by side will frequently fuse into one mass, and almost any fragment of a sponge will grow into a perfect individual. They are fixed, aquatic, and usually colonial animals. Nearly all sponges are marine and are most abundant in the shallow parts of the ocean (Euspongia, Cliona); but some with a siliceous skeleton (Euplectella) occur in the abyssal portions. The only sponges inhabiting fresh water are the green sponges (Spongilla, etc.) ; the natural color of these is a light gray, but they are usually colored green through the presence of algæ.

Typically a simple sponge looks like a hollow, attached vase; it consists of a cylindric body pierced by many canals which conduct water through the wall into a large central or paragastric cavity; this opens to the exterior by a large opening, the osculum. Water is drawn in through these many small canals and forced out through the large osculum. These canals are of three kinds, $(a)$ the incurrent, leading from the outside into the wall of the sponge, $(b)$ the flagellate or gastral, and $(c)$ the excurrent, leading into the central cavity.

The flagellate canals, - the gastral layer, consist in all sponges of collar-cells; they are the principal organs for the capture and digestion of food.

The paragastric or central cavity may be very deep, often is very shallow, at times it may disappear so that the excurrent canals are upon the surface. Forms with one central cavity and one osculum are regarded as individuals, those with more than one as colonies, but as it is difficult to distinguish between 
small oscula and large excurrent canals, the distinction of individuals from colonies is likewise difficult.

The sponge is not a colony of protozoöns, but an individual, for not until an osculum is formed can it feed and reproduce.

The skeleton consists of calcareous or siliceous spicules or of horny fibers, all developed in the mesoglœa. In the develop- . ment of either calcareous or siliceous spicules there is first formed an organic thread at the center of the cell; around this axial thread the mineral matter is deposited. The calcareous spicules, of almost pure calcium carbonate, are deposited in a crystalline condition, each spicule behaving optically like a single crystal. The siliceous spicules are composed of colloidal silica which is deposited in concentric lamellæ alternating with organic lamellæ. The spicules of the Hexactinellida, when united, are joined by a secondary deposit of silica, but those of the Tetractinellida and Monactinellida are at times united by spongin, at others the spicules are enveloped in spongin, as in Chalina; finally in the Ceratospongida the spicules disappear and spongin alone remains, as is seen in the common bath sponge. Sponges are classified according to this skeleton.

The Myxospongida, with no skeletal elements, and the Ceratospongida, with skeleton of perishable fibers of spongin, can seldom be preserved as fossils. Practically all fossil sponges, therefore, belong to the orders secreting siliceous or calcareous spicules. In these orders fossils may be preserved in two states. If the skeletal framework is sufficiently firm to hold together after the death of the animal, and consequent disappearance of the soft parts, it may be preserved in its entirety, as for example in Prismodictya and Astylospongia. If, however, this framework is composed of spicules so loosely bound together as to fall apart upon the disappearance of the soft parts, the scattered spicules alone will be preserved, as in Lyssacina, Cliona and Renieria.

During fossilization the composition of a sponge skeleton may be greatly modified. In those forms with siliceous spicules 
the silica is in a colloidal condition; during fossilization this becomes crystalline, or is dissolved and carried off by percolating waters or is replaced by calcium carbonate or some other substance. Likewise the calcareous spicules are often replaced by silica. Thus originally siliceous spicules may be converted into calcite and calcareous spicules may become silicified. Hence the distinction between siliceous and calcareous sponges in the fossil state depends upon form and not upon chemical composition.

When the siliceous spicules are so loosely bound together as to fall apart upon the decomposition of the soft parts of the animal, they will collect in the depositing sediment and where abundant form porous siliceous beds. Usually the spicules have undergone partial solution in sea-water; this dissolved silica being redeposited as siliceous cement binds the remaining spicules together. Since the spicules are so very small their presence is detected only by an examination of thin sections of the chert under a high power microscope. The silica from such dissolved spicules and from other siliceous organisms is frequently redeposited as nodules of flint. The flint nodules in the Cretaceous chalk beds of England and France are notable examples.

Sponges are known from the pre-Cambrian to the present.

Derivation of name. - Porifera > Latin porus, a pore, + ferre, to bear; referring to the many minute incurrent canals penetrating the wall of the sponge.

The Porifera may be divided into the following sub-classes:

A. Calcarea .

PAGE

B. Non-Calcarea

The old sub-class Silicispongiæ include the Hexactinellida, Tetractinellida and Monactinellida; while the apparently more genetic sub-class Desmospongiæ includes the Tetractinellida, Monactinellida, Ceratospongida and Myxospongida. According to this latter classification all sponges would be divided into Calcarea, Hexactinellida and Desmospongiæ. 
Type of phylum, Grantia ciliata (living) (Fig. 36).

This is a hollow cylinder, somewhat spindle-shaped, about half an inch high by a quarter of an inch wide, attached at base to some solid object. It is dull yellow to gray in color, with a large opening edged with spicules at its summit. It is found
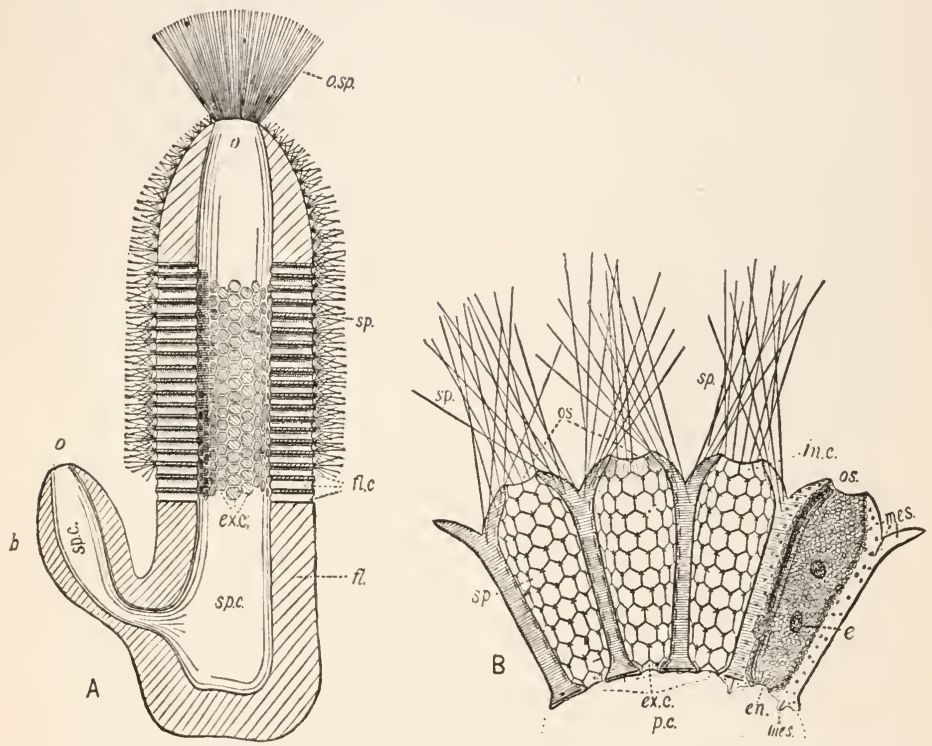

Fig. 36. - The common sponge, Grantia ciliata. The protecting and supporting spicules are calcareous. $A$, longitudinal section $(\times 10) . \quad B$, transverse section $(\times 250)$. b., bud; $e$., eggs; $e n$., endoderm lining the flagellate canals, each armed with a single long cilium; ex.c., excurrent canals; $f$., "flesh" of sponge; fl.c., flagellate canals; in.c., incurrent canals; mes., mesoglœa, with scattered nuclei; $o$. , osculum; os., ostia, the outer openings of the incurrent canals; o.sp., the very long spicules surrounding the osculum; p.c., paragastric cavity; $s p$., the long spicules surrounding the ostia; $s p^{\prime}$, the three-rayed spicules surrounding the flagellate canals; sp.c., paragastric cavity shown in longitudinal section. (After Brooks, relettered.)

growing in tide pools from Rhode Island to Greenland and on the northern coasts of Europe.

The body wall consists primarily of three cell-layers, ectoderm, endoderm and mesoglœa. It is protected and a firmness given 
to the walls by a network of interlacing calcareous spicules. These are microscopic, spike-like calcareous bodies, with one to four rays. Each spicule is secreted by a single mesoglœal cell, the remains of the cell being at times still distinguishable as a thin investment upon the surface of the full-grown spicule.

Food and Digestion. - The entire surface of the sponge is perforated by numerous, minute holes (ostia), through which a current of water enters the incurrent canals (lined with flattened ectodermal cells); from here it enters the elongate flagellate canals and passes out into the large central, or paragastric cavity by the short excurrent canals; these elongate flagellate or gastral canals are lined with endodermal cells, each of which is furnished with a protoplasmic collar from within which projects a thread-like lash, the flagellum; these cells are very similar to certain Protozoa, - the Choanoflagellata, of the class Mastigophora. These flagella, having a stronger and swifter movement in one direction, moving in some forms ten times a second, cause the currents of water to pass from the outside through the incurrent, flagellate, and excurrent canals into the large central or paragastric cavity and thence out through the large opening, - the osculum, at the summit of the sponge. The excurrent canal is in Grantia very short, a mere opening; in all the higher sponges, as in Spongilla, it is very long. This current of water carries with it many microscopic animals and plants, and food particles, which the collar-cells capture and ingest by means of the flagella and collars; each cell acts thus as a single protozoön. Wandering amœba-form cells take part in digestion; these can move from one part of the sponge to another. Thus digestion usually takes place within individual cells as in the Protozoa.

Circulation. - The transference of the digested particles of food from the digestive cells to the rest of the body is largely a process of simple osmosis, - the cells having recently digested food being denser than the others; it is aided also by the very free wandering of the amœba-form cells and to a less extent by 
the mesoglœa, into which some cells cast fluid or solid substances which are taken up by other cells.

All waste, such as undigested material, etc., is carried out through the osculum. Exchange of waste gases for oxygen is also effected by this current of water.

Around the outer edges of the incurrent and excurrent canals and the osculum are elongate cells (ectodermal and endodermal) which are contractile and thus represent muscles. These muscle cells effect the closing of these openings.

There is probably in all sponges a total absence of special nerve cells, and hence a great lack of coördination in cell movements, "thus the flagella of the collar-cells do not beat in unison like the cilia of the epithelia in higher animals, but each works independently of the others" (I 7 ).

Reproduction takes place through the development of the sexual reproductive cells, - spermatozoa and ova ; these develop from the amoboid wandering cells of the mesoglœa, which for this take up their position directly below the flagellate cells. Both ova and spermatozoa are developed in the same sponge individual, though rarely at the same time. The amœboid cell, to form spermatozoa, divides into many small cells, each of which develops a long tapering tail. The amœboid cell, to become an ovum, simply becomes round and enlarges, and after a sperm has penetrated it, thus effecting impregnation, the ovum becomes inclosed in a brood-pouch made by the neighboring cells. In its development the ovum, after its impregnation, divides into two cells; these divide again and again, resulting in a hollow sphere, the blastula. In this shape, the embryo escapes to the exterior and moves about by means of flagella. Later the layer of cells from one side bends in against the layer of the opposite side, forming a double-walled cup, the gastrula. The opening of this gastrula cup, the blastopore, gradually closes, and at this stage of its development the young sponge becomes fixed by the side on which was situated the blastopore; an opening, the osculum, breaks through at the opposite end and the 
incurrent, flagellate, and excurrent canals develop. The osculum thus does not correspond to the gastrula opening, as it does in the Colenterata, but is a later development opposite it.

I. Examine (a) an entire Grantia, (b) longitudinal and transverse sections under the compound microscope.

2. Show by diagram how the animal eats. What does it eat

3. How is the food digested? assimilated?

4. How is respiration effected? excretion?

5. How are the soft parts of the body supported and the animal protected?

6. Are muscles present?

7. What is the nervous system like?

8. Describe the reproduction and the development of an animal from the egg to maturity.

9. If the genus Grantia were to become extinct, what record of its former existence and of its appearance would the rocks preserve?

\section{SUB-CLASS A， CALCAREA}

Skeleton of calcarous spicules (whence the name from Latin calx, lime). Spongin not present. At present these sponges occur in the shallower portions of the sea bordering the coasts; the fossil representatives (Middle Paleozoic to the present) lived under similar conditions, judging from the marly or sandy nature of the strata inclosing them.

Living examples are Grantia (described on page 99), and Sycon.

\section{SUB-CLASS B，NON-CALCAREA}

Skeleton of siliceous spicules, of spongin fibers, or absent. This sub-class is divided into five orders.

Order I, Hexactinellida. - Skeleton of six-rayed siliceous spicules (whence the name from Greek hex, six, + aktis, a ray + Latin diminutive ella). When these spicules are united with each other, it is through the addition of secondary silica, never of spongin. To this order belong most of the fossil sponges. At present they are characteristic of deep water, but the ancient 
forms, as the character of sediment and associated life forms indicate, lived mostly in comparatively shallow water. They are known as fossils, at least from the Cambrian to the present. Euplectella aspergillum (Venus' flower basket) (Fig. 37, B).

Living.

A tubular cornucopia-shaped sponge with a transverse, terminal sieve-like cap at its summit and an anchoring root-tuft at its base. The skeleton consists of siliceous threads, each of which is probably the greatly elongated ray of one axis of a three- to six-rayed spicule (the other rays being suppressed), cemented in adult life end to end to others by the addition of secondary silica. This process results in the formation of long, vertical, spiral and circular threads which form a polygonal network around the central cavity. There is usually one ostium in each quadrangular interval. The vertical threads terminate in the conical root-tuft which forms the base. Upon the outside there are ornamental spiral ridges (whence probably the name from Greek $e u$, well, + plektos, twisted). It grows at considerable depths in the ocean fastened by the penetration of the stiff threads of the root-tuft into the mud or ooze. This species was dredged by the Challenger Expedition from a depth of 95 fathoms, and E.crassistellata from a depth of $275^{\circ}$ fathoms.

I. Sketch side view of entire specimen, labeling cap, roottuft, ostia.

2. What is the composition of the skeleton? function of the root-tuft?

3. Give the probable origin of the long threads.

4. Describe the process by which Venus' flower basket could leave a record of itself in the inclosing sediments.

Prismodictya (Fig. 37, A).

Devonian-Mississippian.

An elongate, slender, gradually expanding, eight-sided prism; each prism-face reticulated by the spicular threads, which are arranged regularly in larger and smaller quadrate meshes situated one within another. Found as internal molds (I6).

This sponge was very similar to Venus' flower basket, though 

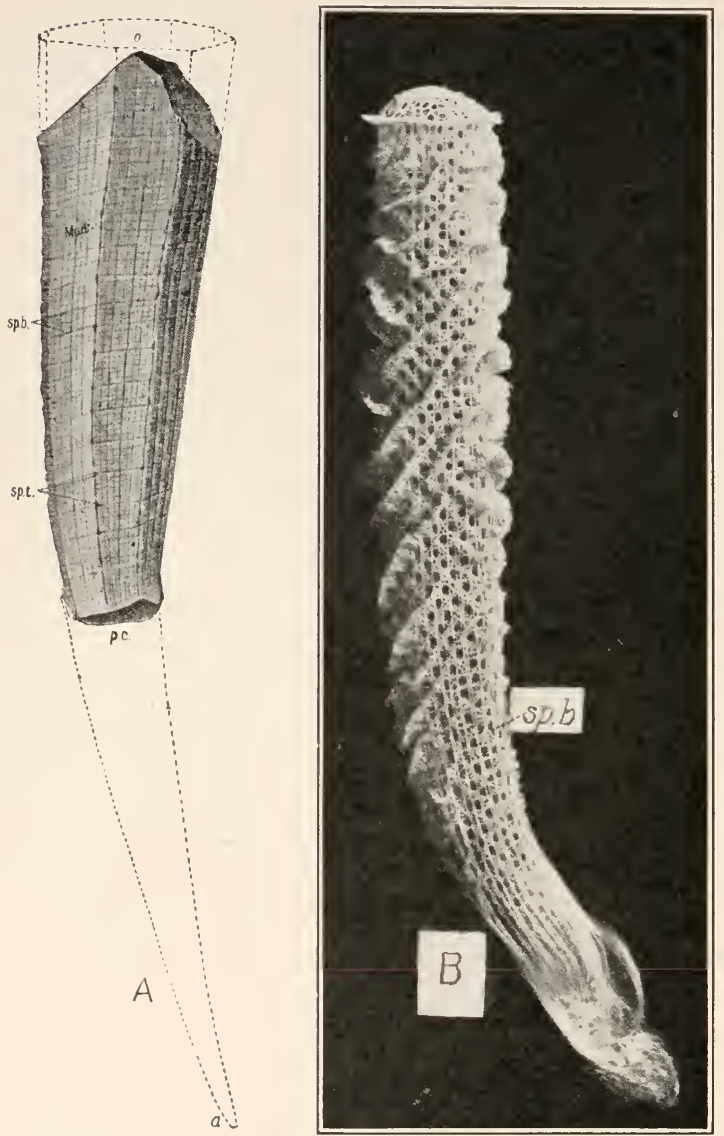

Fig. 37. - Comparison of a fossil and a modern glass sponge. $A$, internal mold of Prismodictya prismatica Hall; very abundant in the ocean covering New York state during the Upper Devonian time. Natural size. $B$, the siliceous skeleton of Vemus' flower basket, Euplectella, about a foot high, living in the East Indian seas. o., osculum, the opening of the large central cavity ( $p . c$.$) now partially filled$ with mud. At the junction of the principal bands of spicules $(s p . b$.) were probably tufts of spicules, the bases of which have left their impressions (sp.t.) upon the internal mud mold. Prismodictya was probably attached to some foreign object by a flattened area at $a$. A modified from Hall and Clarke. 
without its siliceous cap or anchoring root-tuft. After the decomposition of its soft parts, sediment very readily oozed through the meshes of the skeleton, completely filling it. Upon this sediment were impressed the form of the skeleton and the shape of its quadrate meshes. With the disappearance of the hydro-siliceous skeleton through the destructive agency of alkali-bearing percolating waters, the shape of the mass of sediment within the skeleton remained.

Prismodictya belongs to the family Dictyospongidx (SilurianMississippian). These, unlike their modern representatives, - Venus' flower basket, lived in comparatively shallow water. Most of the Devonian forms, as Hydnoceras, were anchored in sand or sandy muds by their root-tufts, while in the Mississippian the majority were apparently fastened to a solid object, stone or dead shell, by a more or less broadened base; this last was probably also the case with Prismodictya. Ornamental ridges may also occur (e.g. Clathrospongia and Thysanodictyon), upon the outer surface as in the modern Euplectella.

Prismodictya prismatica is very abundant in the upper Deronian (Chemung) sandstones of the Appalachian region.

I. Sketch side view of entire specimen with a small portion in detail, noting the quadrate meshes.

2. Describe the steps in the formation of this fossil from the death of the animal to its present appearance.

3. How did the living Prismodictya differ from Venus' flower basket?

Order 2, Tetractinellida. - Skeleton of four-rayed siliceous spicules (whence the name from Greek tetra, four, + aktis, ray, + Latin dim. ella). When these spicules are united with each other, it is through the addition of spongin. These are known in the fossil state from the Cambrian to the present.

Astylospongia (Fig. 38).

Ordovician-Silurian.

Spherical, with a shallow depression (osculum) at the summit, and with many pores (incurrent canals) over the entire 
outer surface. The rigid skeleton is probably due to the irregular mesh-like union of the spicules.

I. Sketch entire specimen, labeling osculum, incurrent canals.

2. How would you know this to be a sponge?

Order 3, Monactinellida. - Skeleton of one-rayed siliceous spicules (whence the name from Greek monos, one, + aktis,

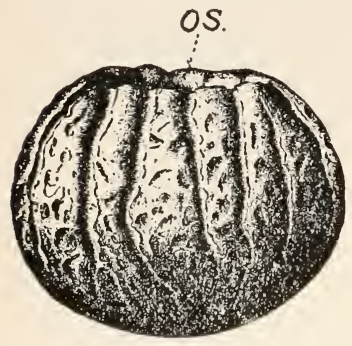

Fig. 38. - The sponge, Astylospongia premorsa Goldfuss, from the Middle Silurian of Indiana. $\times 2$. Side view showing the osculum (os.) above. (After Hall.) ray, + Latin dim. ella). When these spicules are united with one another it is through the addition of spongin. This order includes the few freshwater sponges (Spongilla, etc.) and the majority of existing marine sponges; they inhabit the more moderate depths. They are known from the lower Paleozoic to the present.

The boring-sponges (Cliona) are compound forms with many oscula. They secrete pin-shaped siliceous spicules encased in spongin, with which, aided by a power of absorption, they bore passages in dead or living shells for protection, not for food. These sponges and boring worms help to perform the same function in the economy of nature in the sea as fungi and insects do upon land, namely the disintegration of dead organisms.

Order 4, Ceratospongida. - Skeleton of horny, spongin fibers (whence the name from Greek ceras, horn, + spongia, sponge). Not definitely known in the fossil state. The common bath sponge (Euspongia) is an abundant living form.

The common commercial sponges grow in warm seas, as those of the West Indies and the Mediterranean, from tide level to a depth of 200 feet. When prepared for commerce they are torn from the sea-bottom, exposed on the hot beach to decompose, then washed in water to remove all fleshy parts, leaving the tough, 
fibrous, chitinous skeleton. The separate individuals of these usually compound sponges are distinguished only by the oscula ; the rest of the body is intimately united with its neighbors.

Order 5, Myxospongida. - Skeleton absent (whence the name from Greek myxa, mucus, + spongia, sponge). Unknown in the fossil state.

I. Since a protozoön consists of a single cell and a sponge of many cells, why cannot the latter be considered a colony of the former?

2. What is the principal advance of the Porifera upon the Protozoa?

3. What is the characteristic skeletal element in sponges? Give variations in its chemical composition and in its structure, with examples of each.

4. Amongst the different sponges, give stages of the gradual replacement of spicules with spongin.

5. Give the habitat of commercial or bath sponges. How are they prepared for market? Are they simple or compound?

6. What function did the various holes in the common bath sponge have when the animal was living?

7. Why do the boring sponges penetrate shells?

8. From the rocks of what period is the earliest record of sponges? 


\section{PHYLUM III, CEELENTERATA}

The Cœlenterata are aquatic, usually marine animals, with a radial (instead of a bilateral) symmetry and with the mouth opening into the digestive cavity (colenteron); this latter usually forms the entire body cavity. The mouth is nearly always surrounded by tentacles, - hollow or solid outgrowths of the body wall. A cross section of the body wall or of a tentacle shows it to be composed of three layers, an outer layer of cells (ectoderm), an inner layer of cells (endoderm) and between these two a layer of a rather stiff structureless substance (mesoglœa) inclosing few or no cells. These animals are provided with special offensive weapons, the nettle-cells (nematocysts).

Derivation of name. - Coelenterata $>$ Greek koilos, hollow, + enteron, intestine. The entire cavity within the body walls acts as a digestive cavity (like the stomach and intestine of higher animals).

The Colenterata are divided into the following classes:-

A. Hydrozoa

B. Scyphozoa

C. Anthozoa .

D. Ctenophora

\section{CLASS A, HYDROZOA (HYDROIDS AND MEDUSÆ)}

Type of class, Sertularia pumila (living) (Figs. 39, 40, C).

This is a colonial form with the individuals, - the polyps, in sessile cone-shaped cups (hydrothecæ) arranged in two opposite rows along a stem. The polyp consists essentially of a hollow, sac-like digestive cavity, surrounded at the top by a single circle of tentacles, and in the midst of the tentacles an 
opening, - the mouth. The stems, an inch to an inch and a half long, simple or branched, spring at intervals, usually in clusters, from a creeping and much branching root-stock (hydrorhiza). This species is very abundant off the northeast coasts of North America from New Jersey to the Arctic, also on the northwest coasts of Europe. It occurs in especial profusion between tides attached to the rock weed, Fucus.

Each polyp is continuous at its base with the central canal; its entire surface secretes a protective layer of chitin composed of superposed lamellæ. When mature it largely draws away from this protective covering. There is thus formed a cup out of which the animal can expand to get food, and into which it can withdraw for protection.

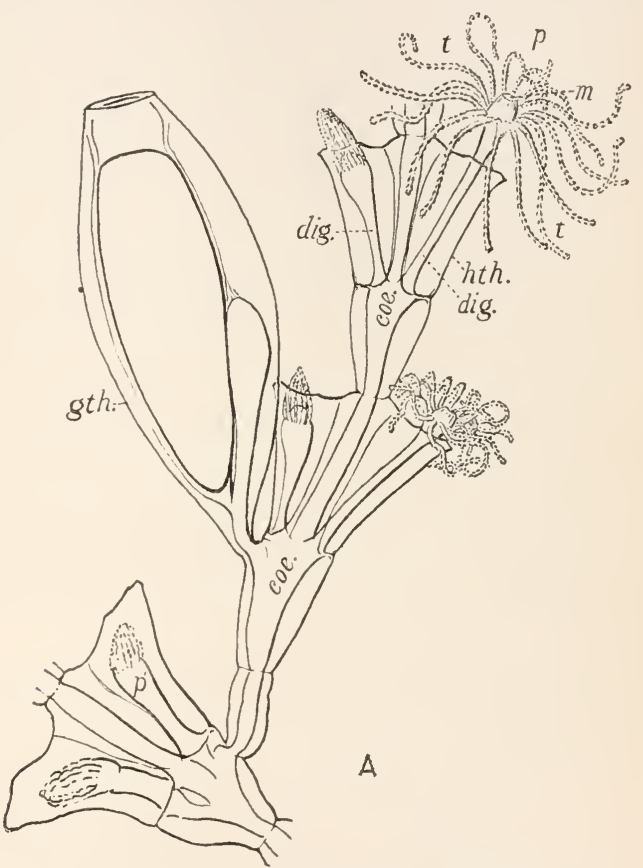

FIG. 39. - A portion of a colony of the hydroid, Sertularia pumila, from the coast of Massachusetts. co., cœenosarc, - the common flesh uniting the various individuals of the colony, - through which passes the central canal; dig., digestive cavity; gth., gonotheca, or cup lodging a reproductive polyp; $h$ th., hydrotheca, or cup lodging a feeding polyp; $m$., mouth; $p$., a polyp expanded, in feeding position; $p^{\prime}$., a polyp contracted, in protected position; $t$., tentacles. $\times 60$.

Its food consists of small, usually microscopic animals and plants, as well as of organic fragments. These it catches with 
its sixteen tentacles and by their aid pushes into its mouth. The tentacles are covered with numerous nettle-cells (nematocysts) by means of which any living prey is paralyzed and thus rendered harmless. Through the mouth, the food enters the large, central or digestive cavity, into which is poured a digestive fluid secreted by some of the smaller endoderm cells lining this cavity. The undigested waste is thrown out again through the mouth, while the digested food is taken up by the bordering cells through osmosis, and thus passed to all the cells, each taking what it needs for repair or growth.

Respiration is performed by the entire surface of the body, for the covering of the cells of the ectoderm (the surface layer of cells) is so thin that osmotic interchange of the excess carbon dioxid of the animal for the oxygen of the water easily takes place.

There are many muscular fibers, especially along the inner edge of the ectoderm, the contraction of which enables the animal to shorten its entire body and thus withdraw into its protective cup. Accompanying these muscles are large, muchbranched nerve cells in contact with one another for the regulation of their action.

Reproduction is both sexual, through the development of spermatozoa and ova, and asexual, by budding. Some of the digested food passes through the base of the polyp into the central canal, and up this to the growing tip, where new buds for the formation of new polyps occur; some passes into polyps which are completely inclosed in urn-shaped cups (gonothecæ) ; these latter, - the reproductive polyps, cannot procure their own food, but give rise to spermatozoa or ova, the union of two of which produce a new colony. Reproductive polyps are present only during the breeding season, from May to September.

Within the gonotheca develop (by budding) usually only minute jelly-fish, - the medusæ; these breaking loose from the parent swim about freely and develop spermatozoa and ova, the 
union of which gives rise to the sessile colony, - the hydroid. This alternation of generation may be represented thus :-

ist GENERATION

2D Generation

3D Generation

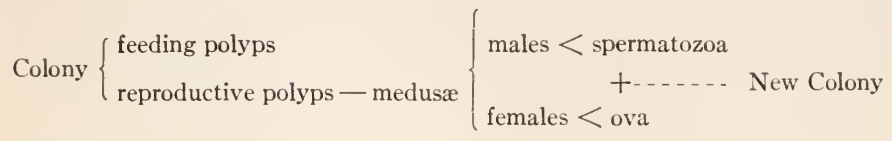

There is evidence in the order Leptolinæ, that this alternation of the fixed nutritive colony with the free-swimming sexual medusa is being gradually abandoned. The medusa generation, whose special function it is to develop spermatozoa and ova, gradually becomes reduced to a few cells which, remaining attached within the gonotheca, produce the sexual products. In Tubularia the medusæ are almost fully developed, but never break loose from the parent. In Sertuiaria pumila the medusa form is entirely lost.

Sense organs. - The medusæ often have eye-spots (ocelli) at the bases of the tentacles; these are often only a few pigmented cells, but at times (as in Lizzia) a cuticular lens is present. Otocysts, too, are present upon, or near, the tentacles; these are partially open or closed pits inclosing one or more otoliths, organic or calcareous in nature, and are probably mainly balancing organs. Both ocelli and otocysts are ectodermal in origin.

Development. - The fertilized egg is a single cell ; this splits into two cells, which in their turn divide again, and so on, until they give rise to the blastula (a single layer of cells surrounding a central cavity), and this develops by true invagination as in the sponge into the gastrula. The gastrula is vase-like in shape, with two layers of cells; between the outer (ectoderm) and the inner (endoderm) layer, and deposited by them, is a stiff gelatinous, non-cellular secretion, the mesogloea. The ectoderm becomes ciliated, enabling the minute embryo to swim freely about. When it comes to rest, it affixes itself by root-like processes (hydrorhizæ). The opening (blastopore) of the vase-like gastrula becomes the mouth of the polyp, and a circle of outpushings around it gives rise to the tentacles. The adult is thus practically in the gastrula stage with the body wall consist- 
ing of three layers: the ectoderm, the mesoglœea and the endoderm, the latter lining the digestive cavity. It is of special interest that this adult animal should persist in the shape of the gastrula, since all higher animals pass through this gastrula stage very early in their development from egg to maturity. This fact is taken to mean that all higher animals have diverged from a coelenterate ancestor in remote geological ages.

I. Examine the specimens mounted in alcohol, noting the size of a colony, its attachment, the individuals, each with its circle of arms surrounding the mouth.

2. Sketch, from the slide under the compound microscope, one individual animal and its connection with the central canal of the colony. Label tentacles, mouth, cup, central canal.

3. Indicate the portion of an animal capable of being preserved in the fossil state.

4. How does the animal capture its food?

5. What prevents a large, active animal swallowed by the polyp from struggling and thus tearing the soft body walls to shreds?

6. How is the food digested? How assimilated?

7. How does the polyp breathe?

8. What kind of a muscular and nervous system does it possess?

9. How does it multiply?

Io. Trace the development of an individual from the fertilized egg to adulthood.

II. What are medusæ?

I2. Why is a colony of Sertularia, which has a plant-like attachment to foreign objects, placed with the animals?

\section{General Survey of Class Hydrozoa}

Aquatic animals with the body consisting of a large, centrally placed, digestive cavity with but one opening (the mouth); this mouth is usually surrounded by many arms (tentacles).

These are lowly forms of animal life with the cells making up the body arranged in two layers, the ectoderm and endoderm, separated by a non-cellular layer, the mesoglœe. The endoderm lines the large, undivided digestive cavity. 
Hydrozoöns, including the Graptolithida, are abundant from the Cambrian to the present.

Derivation. - Hydrozoa > Greek hydor, water, + zoon, animal.

The Hydrozoa are subdivided into the following orders:-

I. Graptolithida

2. Leptolinæ .

3. Trachylinæ

4. Hydrocorallinæ .

5. Siphonophora

There is a growing tendency to make the Graptolithida a sub-class of the Hydrozoa, or even to make them a distinct class of the Cœlenterata. They differ from the Hydrozoa in the presence of (I) the sicula and (2) the virgula; also in (3) the bilateral symmetry of the thecæ, seen even in the sicula. Since the apex of the sicula, i.e. the embryo-sheath, lacks growth lines it probably possessed the radial symmetry characteristic of the typical Hydrozoa. This embryo-sheath is quite similar, except in composition, to the primary cup of Tabulate corals, as is likewise the alternate budding of new cups (thecæ). On the other hand very many graptolites, like Diplograptus, were similar to the existing hydrozoan order Siphonophora in the presence of a float (pneumatocyst), and especially like the living Sertularia of the hydrozoan order Leptolinæ in arrangement of thecæ, presence of generative cysts (gonangia) and composition of protective covering.

\section{Order i, Graptolithida (Graptolites)}

\section{Type of order, Diplograptus foliaceus (fossil) (Fig. 40).}

This species is like the true hydrozoön, Sertularia, in being colonial. It consists of two crowded rows of cups (hydrothecæ) like saw teeth, arranged in opposite series along a stalk to which they are broadly but obliquely fastened. Each cup, a subprismatic tube longer than wide, represents as in Sertularia one individual polyp; in it were lodged the soft parts and into it the entire polyp could withdraw for protection. At its base 
it was connected by means of a tube with the central canal running the length of the stalk. Unlike Sertularia, however, it was not attached to the sea-bottom in shallow water, but floated freely at its surface suspended from a float-like disk (Fig. 40, fl.), somewhat like forms included with the hydrozoan order Siphonophora.

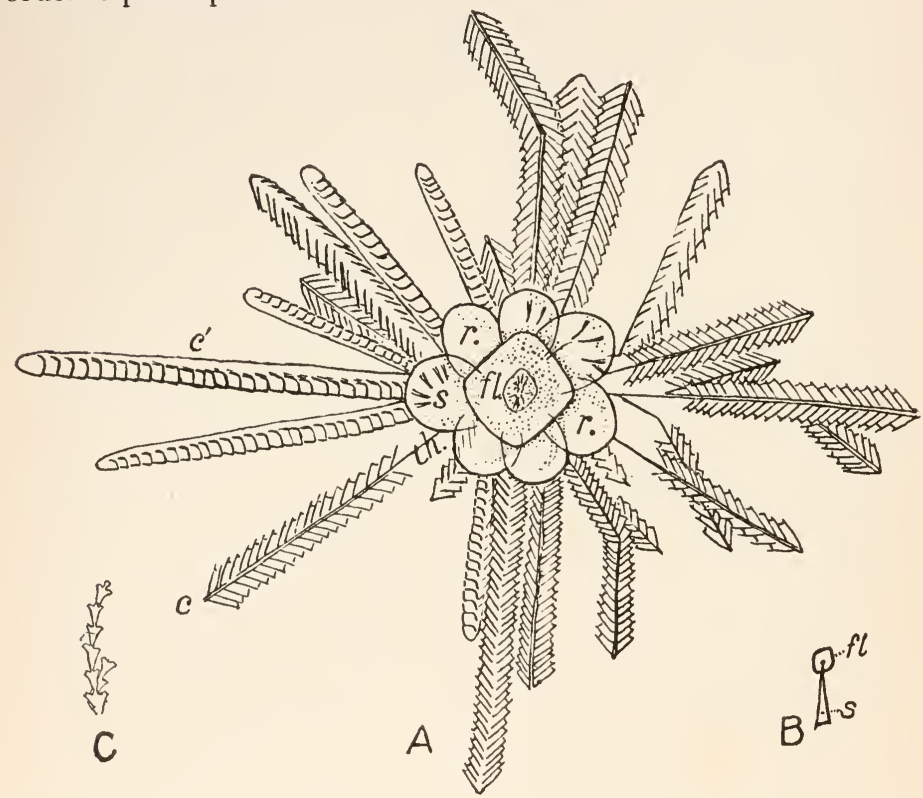

FIG. 40. - Diplograptus foliaceus Murchison, from the Utica (Ordovician) shale of New York. A, a compound colony of graptolites. Natural size. B, a young graptolite just emerged from the reproductive bladder $(r$.$) . Natural size.$ $C$, the living hydrozoön, Sertularia pumila $(\times 2)$, for comparison of external forms. $f l$., the supporting float-like disk; $r$., reproductive bladders in three of which are young graptolites (siculæ, s.); th., thread supporting the colonies $\left(c ., c^{\prime}.\right) ; c$., side view of colony showing the two rows of cups; $c^{\prime}$., front view showing the width of the cups. $A, B$, slightly modified from Ruedemann.

As in Sertularia, the protective covering was of chitin, but its partial decomposition, due to its great age, aided probably by the heat engendered by pressure of the overlying sediments, 
has resulted in driving off most of the hydrogen, oxygen, and nitrogen, thus leaving as fossil only a film composed mostly of carbon.

It was very probably similar to Sertularia in the character of its food, its digestive, excretory and nervous systems, and in its assimilation and respiration.

Its reproduction was likewise both sexual and asexual, and it seems to have lacked the jelly-fish stage. The union of a spermatozoön and ovum gave rise to the first polyp which secreted the earlier protective cup, called the sicula. From this by budding developed the colony (rhabdosome).

In the genus Diplograptus (Ordovician-Silurian) the cups (hydrothec $x$ ) are arranged in two rows along the stem (whence the name from Greek diploos, double). In a side view, the virgula shows as a raised ridge running through the middle of the colony, while each cup has a thick outer edge owing to the compression of its entire width.

D. foliaceus is abundant in the Utica (Ordovician) shales of eastern North America and in the Ordovician of Europe.

I. Sketch a portion of the colony, enlarging it three times. Label cup, virgula, sicula (if present).

2. In life what part of the animal was probably visible outside the cup when feeding?

3. Give in tabular form resemblances to and differences from Sertularia.

4. What is the chemical composition of the fossil? What produced this change from its composition when living?

\section{General Survey of Order Graptolithida}

Extinct, colonial Hydrozoa, fixed to some object upon the seabottom, or floating upon the surface attached to drifting seaweed or to a pneumatocyst of their own manufacture. They secreted a protecting and supporting skeleton of chitin, with the separate individuals lodged in pits upon, or cups along the margin of, the chitinous stalks. 
These extinct Hydrozoa are known only from their colonial phase, the presence of the jelly-fish phase not yet having been demonstrated. Some forms, at least, as Diplograptus, developed direct, without the alternate generation; here generative cysts formed on the colony, in which developed the siculæ (embryonic graptolites); the rupture of these cysts scattered the siculæ; each surviving sicula grew into a new colony.

Habitat. - Graptolites, with the exception of some of those belonging to the sub-order Dendroidea, lived suspended. That they did not live fastened to the sea-bottom is shown by the fact that their remains are always confined to one bedding plane, never passing vertically from one bed to another. They are always spread flat as though they had fallen with the entombing sediment. While they are found in all kinds of sediment, including limestones, they are most numerous in very fine-grained, carbonaceous shales. The carbon of the shales was probably derived from floating marine plants, not from the abundant graptolite remains, for seldom, if ever, do decomposed rhabdosomes pass into the surrounding shales. Since few land plants were probably in existence during Ordovician times, - the climax of graptolite development, - it is likely that the carbon is due to the partial decay of marine plants. Many fragments of seaweed occur in such typical graptolite beds as the Utica shale of the Ordovician of the Appalachian region. Suspended from these plants were representatives of the Axonolipa division of the Graptoloidea, while floating among them were Axonophora colonies supported by their pneumatocysts. The latter probably sank during periods of roughened seas, as some of them had developed ridges which might have subserved such a directive function. A roughening of the water surface would cause a rain of the broken, fragile colonies upon the sediment beneath. This method of growth accounts likewise for the wide distribution of so very many of the species. That even the Graptoloidea sub-order was derived from forms which grew upright upon the sea-bottom as did many of the Dendroidea 
is suggested by the reversion of direction of the cups in a colony, the embryonic cup or sicula growing in a direction opposite to the rest of the cups (20).

Graptolites were abundant during the upper Cambrian, the Ordovician and the Silurian, while a few stragglers continued to exist into the Mississippian.

Derivation. - Graptolithida > Greek graptos, written, + lithos, stone. The resemblance of these fossils, especially those of the sub-order Graptoloidea, to the ancient writings on stone suggested not only the name of the order but also the latter part (graptus) of most of the generic names of graptolites.

The graptolites (Order Graptolithida) are sub-divided as follows:

Sub-order a, Dendroidea. - Colony (rhabdosome) branching irregularly in a funnel or fan-like manner. Cups (hydrothecæ) usually pits upon the branches.

Probably most of the Dendroidea, especially the heavier and more shrub-like forms, were sessile in an upright position, attached to some object at the sea-bottom; this would likewise account for their local distribution. Some have adhesive threads (hydrorhizæ), like Sertularia and other modern sessile hydroids. Many of the species of Dictyonema, on the other hand, have a very wide distribution, and, at least in their younger stages, floated about attached to a supporting disk.

The name is from the tree-like (Greek dendron, a tree) method of growth of the colony.

Dictyonema (Fig. 4I).

Cambrian-Mississippian.

Colony (rhabdosome), a rapidly expanding fan or cone with cups upon the inside. The slender branches are united at short intervals, producing a net-like appearance (whence the name from the Greek dictyon, net, + nema, thread). When young, the rhabdosome was suspended from a long, thin thread attached to a chitinous disk; later (at least at times), it was sessile by rootlets. D. flabelliforme is common in the earliest Ordovician rocks of eastern North America and western Europe. 
I. Sketch the fossil; if the entire colony is not preserved, dot in its probable shape and size.

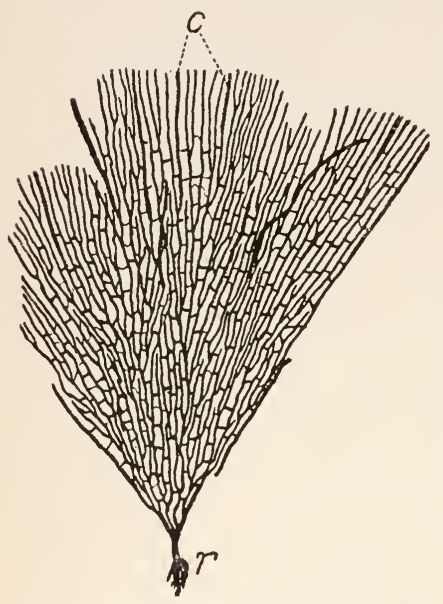

FIG. 4I. - Dictyonema flabelliforme

Eichwald, from the lowest Ordo. vician of New Brunswick, showing cups $(c$.$) and roots (r$.$) . Natural$ size. (After Matthew.)

2. Where upon the colony did the individual animals live?

3. What probable difference between the habitat of the young and of the adult? Reasons.

Sub-order b, Graptoloidea. Colony (rhabdosome) simple, or if branched it is not tree-like. Cups (hydrothecæ) usually distinctly marked and projecting. The Graptoloidea lived suspended, floating.

This sub-order embraces two divisions :-

(I) Axonolipa. Virgula absent. Representatives of this division were suspended from seaweeds. Named from the Greek axon, axis, + lipein, to lack, referring to the absence of the virgula.

Phyllograptus (Fig. 42).

Ordovician.

Colony consisting of four short, broad, leaf-like (whence the name from Greel- phyllon, leaf) branches grown together, each pair back to back, in such a way as to form a cross in section. Hydrothecæ upon the outer edge of each branch.

I. Sketch entire colony, labeling the cups.

2. Make an ideal cross section through the colony.

(2) Axonophora. Colony with a median axis, or strengthening rod of chitin, called the virgula, running its entire length.

The division Axonolipa is replaced from the mid-Ordovician onward by the Axonophora, i.e. those with an axis (virgula). This axis of chitin is brittle, which probably accounts for the 
fragmentary condition of most of these species. The virgula extends through the entire colony (rhabdosome), even penetrating the sicula. Probably all of the Axonophora were attached to a float of their own secretion. Examples are Diplograptus (p. I I3), Climacograptus and Monograptus.

Named from the presence of the virgula, from the Greek axon, axis, + pherein, to bear.

Climacograptus (Fig. 43). OrdovicianSilurian.

Hydrothecæ sharply curved below, the upper edge or aperture more or less horizontal; hence they are widely separated. The colony thus presents a ladder-like appearance (whence the name from the Greek climax, a lad-

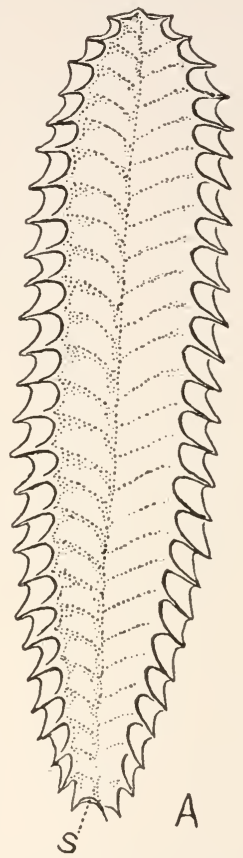

FIG. 42. - Phyllograptus angustifolius Hall, from the Ordovician of New York. $A$, entire colony $\left(\times_{4}\right)$, showing the earliest cup, the sicula (s.); the opening of the latter is between the two spines. $B$, transverse section through the colony $(\times 6) ; c a$., common canal with its four longitudinal septa; th., the individual cups (thecæ). $C, P$. ilicifolius Hall $(\times 8)$, showing the openings of five cups, in each of which was lodged the soft body of a single individual. (All from Ruedemann; $A$ and $B$ after Holm.)

der). The straight outer margins of the hydrothecæ are parallel to the axis of the colony. C. typicalis is very abundant in the Utica (Ordovician) shales of New York State. 


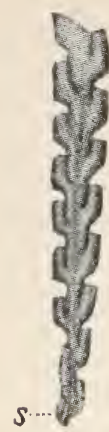

FIG. 43. - The graptolite, Climacograptus typicalis. Hall $(\times 7)$, from the Utica shale of New York. Only the end of the colony bearing the sicula (s.) is here shown. (From Ruedemann.)

I. Sketch a portion of a colony, indicating a hydrotheca and its aperture.

2. What is the chemical composition of the fossil at present? When living?

3. How do you account for the great abundance and the fragmentary condition of these colonies, as for example in the Utica shale?

Monograptus (Fig. 44).

Silurian.

Cups (hydrothecæ) arranged in one row along the straight or curved stem (whence the name from the Greek monos, one). The virgula can be seen as a ridge extending the length of the colony opposite the cups. M. clintonensis is an abundant and well-preserved species in the Silurian (Clinton) shales of New York State.

I. Sketch portion of a colony, enlarging it three times. Label a hydrotheca and its aperture, the virgula, the position of the central canal.

2. Sketch the probable appearance of the soft body of a polyp with tentacles expanded.

3. Briefly describe the probable digestive system of Monograptus.

4. How was the hydrotheca formed?

5. What use did this cup subserve?

6. What is the significance of the name Monograptus?

7. Give reasons for placing this under the Coelenterata rather than under the Porifera.

Order 2, Leptolina. - Hydrozoa which during one generation are fixed to some foreign object, as seaweed, and grow by budding, very much like a plant. These bud off por-

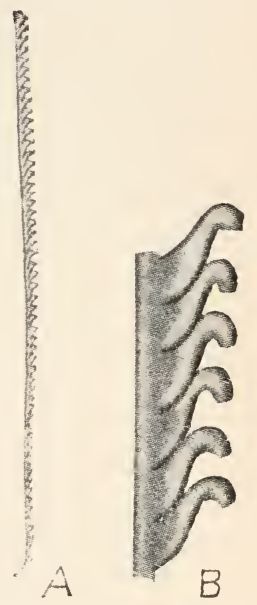

FIG. 44. - The graptolite, Monograptus clintonensis Hall, from the Clinton formation (Middle Silurian) of New York. Side views. $A$, natural size (from Hall); $B$, an enlargement of six cups. (From Ruedemann.) 
tions of themselves, which usually become free-swimming jelly-fish (medusæ) ; these in turn produce eggs and sperm, the union of which gives rise again to a fixed generation. Known from the Mesozoic to the present. Living examples are Obelia and Sertularia (see p. I08).

Order 3, Trachylinæ. - No fixed generation discovered; all are free-swimming medusæ. No fossils known.

Order 4, Hydrocorallina. - Colonial Hydrozoa, the common base of the colony secreting a massive calcareous support. Known from the pre-Cambrian to the present. Millepora is a living genus, while the species of Stromatopora were very abundant and important limestone builders in the Paleozoic.

Order 5, Siphonophora. - Colonial, pelagic Hydrozoa, with remarkable diversity of form among the various individuals in a colony. They are often supported by a float of their own manufacture. Not known in the fossil state. Example, Portuguese man-of-war (Physalia).

\section{CLASS B, SCYPHOZOA (JELLY-FISH)}

Large, free-swimming, umbrella-shaped jelly-fish (medusæ). The margin of the umbrella is usually lobed, bearing tentacles, while the mouth occupies the position of the umbrella's handle. They develop directly from the egg or by the alternation of a sessile stage; in the latter case they multiply by transverse fission. They swim by rhythmically opening and closing their umbrella-like bodies. Their food consists of small fish, crustaceans, and even of each other. None live longer than a year.

The Scyphozoa are known to have existed from the Cambrian (Fig. 45) to the present. They are entirely without hard parts and consist of about 99 per cent water, so that only under exceptional conditions have they left a record of their presence. At times in very fine-grained muds, as in the lithographic slates of Bavaria (of Jurassic age) impressions of their soft bodies are preserved, or even imprints of their tentacles trailing over the yielding mud. At other times the lobed digestive cavity has 
become filled with fine sand or mud; this mud or sand filling becoming covered by other mud before the soft jelly-fish body

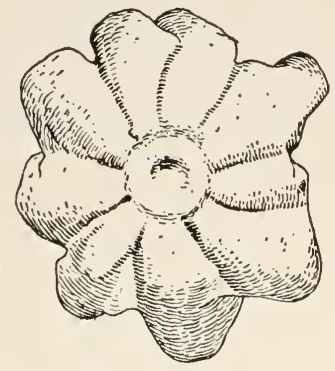

A

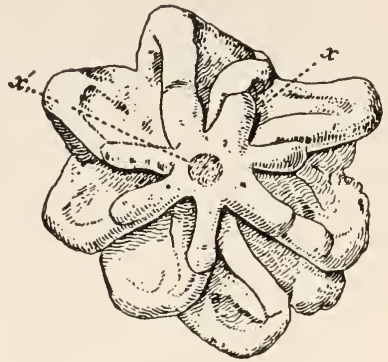

B

Fig. 45. - A fossil jelly-fish, Brooksella alternata Walcott, from the Middle Cambrian of Coosa Valley, Alabama. $A$, top view showing the nine lobes and a trace of the furrow in the ring about the central disk; $B$, under view of same specimen. The lobes are shown, as also are what appear to be oval arms $(x)$ for carrying food to the central stomach. A central depression $\left(x^{\prime}\right)$ may represent the position of the mouth. Natural size. (After Walcott.)

has become disintegrated preserves the outline of its containing cavity (Fig. 45).

Derivation. - Scyphozoa > Greek scyphos, cup, + zoon, animal, referring probably to the inverted cup-like appearance of the swimming jelly-fish.

\section{CLASS C, ANTHOZOA (CORALS)}

Type of class, Astrangia dance (living) (Fig. 46).

This is a colonial form, with the individuals, - the polpys, in sessile, star-like cups encrusting stones, dead shells, etc. Living and active it looks much like a tuft of white, translucent moss ; after death and the decomposition of the flesh nothing is seen but a calcium carbonate mass (one-half to three inches in diameter) of star-like cups (corallites), each with a diameter of three to five millimeters.

It lives in shallow seas off the coast of North America from 
Florida to Cape Cod; it does not occur in the colder water north of the Cape.

Each polyp, glassy white and translucent in appearance, consists of a barrel-shaped body, averaging $3 \mathrm{~mm}$. wide by $9 \mathrm{~mm}$.

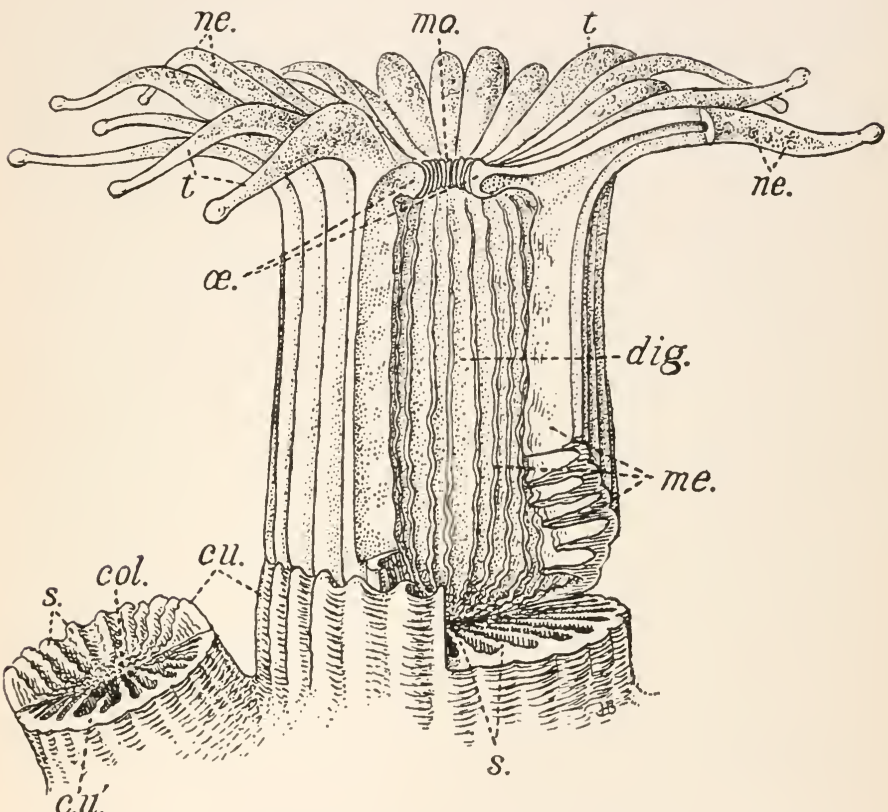

FIG. 46. - The common coral, Astrangia dance ( $\left.X_{12}\right)$, from Long Island Sound, showing a polyp in feeding position upon the calcareous, cuplike base (cu.), also (at left) the coral portion of a bud without its secreting polyp. col., the spongy pseudo-columella; $c u$., the cuplike calcareous base secreted by the polyp; $c u^{\prime}$., part of the cup sectioned transversely ; dig., digestive cavity, - the entire interior of the barrel-shaped body; me., mesenteries; mo., mouth; ne., clusters of nettlecells, by means of the poison in which the prey is paralyzed; $\alpha$., œsophagus; $s$. , septa (which alternate with the mesenteries) ; $t$., tentacles (one is partly dissected to show that its hollow interior is continuous with the large digestive cavity of the polyp).

high when fully expanded, with a circle of 18 to 24 long, tapering tentacles surrounding the top. At the center of the top and slightly raised is the oval mouth; this leads through a short 
œsophagus into the large digestive cavity. The digestive cavity constitutes the entire interior of the body, but is partly divided into compartments by radial partitions (mesenteries, Fig. 46, me.); each intermesenteric compartment is continuous with a hollow tentacle.

The polyp preys upon marine animals, - small crustaceans, worms, etc. These it catches with its tentacles. Each tentacle ends in a white knob and is speckled all over with white warts, each one of which is a cluster of nettle-cells (nematocysts). When one of these cells is touched it sends out a long barbed, thread-like tube, through which poison is forced. This multitude of nettle-cells, piercing the prey, paralyze it. The tentacles then push this food into the mouth, through which it enters the digestive cavity. The white cords (mesenteric filaments) edging the mesenteries are crowded with nettle-cells; these cords, wrapping themselves about the prey, complete the killing, while the many gland cells covering the cords pour out a digestive fluid.

After the digestion of the food, the waste is thrown out through the mouth; the digested portion mingled with the sea water is forced by the contractions of the body through the radial compartments and into the tentacles, the various cells taking what they need for growth and repair. The entire body acts thus as a huge blood-vessel, and since the digestive cavity connects freely through the mouth with the water of the ocean, the "blood" consists of sea water mingled with nutritive portions of food.

Respiration is performed mainly by the tentacles; these being thin and containing the body fluid or blood, permit a free interchange of the excess waste carbon dioxid, etc., of the body for the free oxygen in the sea water.

Well-developed muscles are present. There is a sphincter muscle surrounding the body at the top which draws in the tentacles and closes the mouth much as a string may close a bag by gathering it together. Muscular layers line the mesenteries on 
each side, and it is through their expansion and contraction, thus admitting and expelling water, that the animal is able to expand and contract. When the animal is disturbed these muscles contract, the tentacles are rolled inward and the entire body becomes a small dome-like mass.

There are no sense organs present, excepting specialized tactile cells. There are many nerves present in both ectoderm and endoderm which regulate the complexity of the animal's movements.

Astrangia reproduces by development of spermatozoa and ova. The sexes are distinct. The reproductive elenents form by the division of some of the endoderm cells of the mesenteries near the lower end of the body. The product of the union of an ovum and spermatozoön develops rapidly into an ovoid, hollow body, the planula (blastula stage). This elongate body has two layers of cells, an inner (endoderm) and an outer ciliated layer (ectoderm). After swimming about for a time by means of its cilia, the planula settles down to the bottom of the water and becomes attached. At the free end an inbending of the wall occurs, forming mouth and œsophagus and finally piercing the inner cavity (gastric cavity).

Secretion of lime. - After the larva sinks down from its free-swimming condition and rests upon some object, certain ectoderm cells (calicoblasts) of the base of the animal begin to secrete a calcareous liquid directly exterior to themselves, and from this is inorganically crystallized the calcium carbonate (I8) (Fig. 47). According to some students the "calcareous deposit is laid down within the individual calicoblasts of the ectoderm. At the same time new ectodermal cells are formed next the mesoglœa, and these which are undergoing calcification become loose external layers of partly calcareous, partly organic tissue." Ogilvie.

This deposit, developed between the base of the animal and the rock or other foreign object to which it is attached, gradually forms a calcium carbonate base (called the basal plate) 
outlining the size and shape of the base of the soft parts of the animal. At the same time the soft basal portion between the mesenteries bends upward, permitting a greater deposit of lime

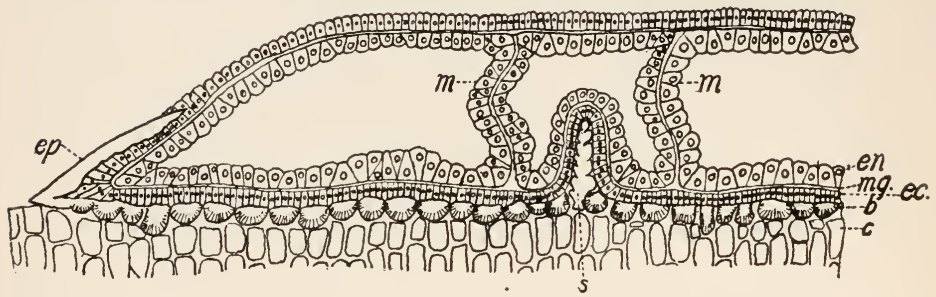

Fig. 47. - Vertical section through the edge of a very young stage of the coral, Astroides calicularis, which has fixed itself to a piece of cork (c.). Very much enlarged. The deposits of lime $(b ., e p$.) are apparently thrown down outside the ectoderm (ec.) but through the agency of these cells. b., basal plate; ec., ectoderm ; $e n$. , endoderm; ep., epitheca ; $m g$. , mesogloea; $m$. ., mesentery; s., septum, developed by upward bending of wall of animal between the mesenteries $(m .-m$.) upon the basal plate (b.). (Redrawn from Lankester's Zoölogy, after Von Koch.)

here; since the mesenteries radiate from the center to the edge of the soft body portion so these ridges (septa) of calcium carbonate radiate likewise. These septal ridges grow higher and higher, resulting finally in the thin septa, over each of which are folded the three layers - ectoderm, mesogloea and endoderm. The upper edges of the septa are conspicuously toothed, giving them a saw-like appearance. The septa are seen to alternate with the mesenteries but are external to the polyp, i.e. each septum corresponds to a radial inpushing of the base and lower sides of the polyp. The outer portion of the barrel-shaped body of the animal early bends upward faster than the inner portion; it thus results that the non-porous deposit of lime thrown down by the ectoderm takes on a cup-like appearance, called the calyx, with the septa extending from the edge of the cup down to its center. Later the longest septa, expanding, unite with one another to form a spongy, central mass, the pseudo-columella.

As the animal grows in circumference and adds new mesen- 
teries, and new tentacles, so the coral base enlarges in circumference and new septa develop between the older ones, - six in the first set, six in the second, twelve in the third. The animal thus impresses its growth stages from youth to maturity upon its coral secretion, and accordingly we would look towards the narrower end of the coral for the record of its youth.

The basal portion of the polyp grows a very short distance from the edge of the cup out over the shell or stone upon which it is fastened; from this basal expansion bud up new polyps, while from their basal expansions or from that uniting them with their parent or each other, arise other buds. All these finally develop into polyps capable of catching and digesting their own food; but until then, they grow through the nourishment contributed by all the other polyps, for the digestive cavities of all the colony are continuous with one another through these basal expansions, - the common flesh, or cœnosarc.

I. Examine Astrangia, noting the tentacles, mouth, œsophagus, mesenteries and their relation to the septa, digestive cavity, nettle-cells.

2. Examine the sea anemone: (a) an entire specimen; (b) an individual sectioned vertically through the mouth. Note tentacles, mouth, œsophagus, mesenteries.

3. What is the habitat of Astrangia?

4. Of what does its food consist? How does it procure it?

5. What keeps the prey from struggling after being swallowed, and thus injuring the soft body of its captor?

6 . Briefly describe the digestion of the food, excretion of the waste and the method by which the nourishment reaches all parts of the body.

7. How does Astrangia breathe?

8. What muscles are present? Their use?

9. What is the function of the nerves?

Io. What sense organs does it possess?

II. Describe the development of Astrangia from the egg to adulthood, noting quite fully the development of the hard parts.

I2. What record of this development is present in the coral secretion of an adult?

I3. How does a single polyp become a colony? 


\section{General Survey of Class Anthozoa}

Usually sessile polyps differing from Hydrozoa in the possession of a short œesophagus, differentiated from the digestive cavity, and in the division of the body chamber into radiating compartments by means of the mesenteries.

Some Anthozoa, as the sea anemone, are without hard parts, but in most forms a skeleton of lime or chitin is secreted by the ectoderm, more rarely by the mesoglœa. The simplest form of coral skeleton is that composed of microscopic spicules of lime carbonate of different shapes, developed in great quantities in the mesoglœea and remaining detached, as in Alcyonium (" dead men's fingers"). In some forms the spicules are firmly cemented together, thus forming tubes (" organ-pipe coral," Tubipora) or a branching axis ("precious red coral," Corallium). In most corals there are no spicules present but a calcareous skeleton is secreted by the outer surface of the ectoderm of the lower part of the polyp. This entire skeleton is called the corallum; when consisting of one individual it is called simple; when of many, it is termed compound. In the latter case each individual is termed a corallite. In a simple coral, or a corallite, the outer wall (theca) bounds the radiating vertical plates (septa). The depression in the broad end of the coral, called the calyx, was occupied by the base of the polyp and into this it could partly withdraw for protection. In many corals the theca is surrounded by another calcareous layer with ring-like wrinkles, the epitheca; this was secreted by the external surface of the ectoderm at the base of the polyp. In some forms the partial or complete absence of one of the principal septa caused the formation of a groove or fossula; it has been suggested that the mesenteries bounding this produced most of the reproductive elements. For the formation of the septa and basal plate see page I 26. Projecting upward from the base at the center of the coral is often a little column, the columella; this is secreted by the center of the base of the polyp; the ecto- 
derm bends upward just as in the formation of septa, except that it is domed up instead of being ridged up. In the interior of a coral there are usually present besides the septa, tabulæ and dissepiments. Tabulce are the transverse partitions extending across the entire space within a coral from wall to wall, secreted by the ectoderm of the base of the polyp like successive basal plates. As the sides of the theca in some species grow higher the polyp cannot occupy the entire interior and hence draws itself upwards, and wherever it rests for a time a tabula is built beneath it. These periods of quiescence may follow the expenditure of energy at times of reproduction, either sexual or asexual. Dissepiments are the horizontal or oblique plates connecting adjoining septa, formed in a mainner similar to tabulæ, except that the base of the polyp is withdrawn in sections, not as a distinct whole, nor at such regular intervals.

The nettle-cells (nematocysts) contain barbed threads (some about one-fortieth of an inch long) which can pierce by their sudden unrolling a man's calloused foot; millions occur on the tentacles. Each one is used but once, but new ones are continually being formed. The polyp can reproduce lost parts and a small piece of the base can reproduce the whole animal.

Reproduction is sexual or asexual. In sexual reproduction the reproductive elements are formed in the endoderm of the mesenteries; there is no medusa stage. The new animal resulting from this method of reproduction is a single individual.

In asexual reproduction the process of budding or of division forms from this single individual a colony of various shapes and often of great size. In the Alcyonaria buds are always formed on tubular outgrowths of the polyps, the solenia, never directly from the polyps (e.g. Tubipora, Syringopora). In the Zoantharia buds arise directly from the polyp or from the cœnosarc. Except for a few forms, this sub-class (Zoantharia) is divided into the perforate and the imperforate orders. In the perforate corals (as Madrepora) the spongy tissue (cœnenchyme) is perforated by many canals 
permanently connecting the digestive cavities of all the polyps of the colony; the cœnenchyme is deposited both around these canals and by the superficial conosarc. In the imperforate corals (as Astrangia) there are a few canals between the surface of the cœenenchyme and the cœnosarc, not penetrating the cœnenchyme; these connect the polyps over the edge of the calices, not directly through the cups. The conosarc is nourished by these canals and secretes the cœnenchyme.

In the Zoantharia, asexual reproduction takes place also by equal or unequal division, that is, the polyp divides into two or more individuals, each taking a portion of the mouth and some of the tentacles, mesenteries, etc. This division usually takes place by the sides of the mouth growing inward, thus gradually constricting the original mouth. There thus result two mouths in place of one, each surrounded by its own circle of tentacles. Usually the digestive cavity also divides completely so that in each separate polyp the mesenteries and consequently the septa radiate in all directions from a separate center. The incomplete division is illustrated by the "brain-coral" (Meandrina); here the mouth divides completely but not the digestive cavity and consequently not the calyx; a repetition of such division gives rise to the long, calcareous furrows, characteristic of Meandrina, each surmounted by many polyp mouths.

Distribution takes place mainly in the larval stage when the animal is free-swimming. All forms are marine. They occur from sea-level to a depth of three and a fourth miles, and therefore at all temperatures. The deep-sea corals are solitary forms. Compound corals are very abundant on coral-reefs. The condition for the reef-building corals is that the temperature be not lower than $68^{\circ} \mathrm{F}$., the water usually not deeper than I 50 feet, and that there be but little sediment in the water.

In the formation of coral-reefs corals enter to a much less degree than was formerly supposed; in at least many reefs limesecreting plants are the chief agent. (See p. 38.)

Anthozoa are known from the Cambrian to the present. 
Derivation of name. - Anthozoa $>$ Greek anthos, flower, + zoon, animal ; in reference to the flower-like appearance of the expanded polyp, especially of the more brilliantly colored tropical species, the tentacles corresponding to the petals, and the region about the mouth to the disk.

The Anthozoa are subdivided into the following sub-classes and super-orders :-

I. Zoantharia .

PAGE

a. Tetracoralla (Tetraseptata)

b. Hexacoralla (Hexaseptata)

2. Alcyonaria .

a. Octocoralla (Octoseptata)

b. Tabulata (Aseptata) .

\section{Sub-Class i, Zoantharia}

Tentacles usually hollow and simple, never pinnate; they are four to six, or more than eight in number, with a usually equal number of mesenteries and septa.

Skeleton present or absent; when present it is developed by the ectoderm and may be horny or calcareous, but is never in the form of scattered spicules.

\section{Super-order a, Tetracoralla}

Simple or composite corals with septa in quadrants (whence the name from Greek tetra-, four). Corallum calcareous. Entirely extinct, known from the Ordovician to the Permian.

Microcyclas (Fig. 48).

Devonian.

Simple, disk-shaped (whence the name from Greek mikros, small, + cyclos, circle). It consists merely of a calcareous plate with ridge-like septa and a fossula.

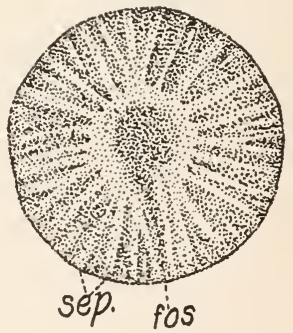

Fig. 48. - A simple coral, Microcyclas discus Meek and Worthen, from the Hamilton (Middle Devonian) of Illinois. fos., fossula; sep., septum. Natural size. (Redrawn from Meek and Worthen.) 
I. Sketch specimen, top view, noting septa, fossula.

2. How was the calcareous plate secreted? the septa?

3. What is possibly the origin of the fossula?

Heliophyllum (Figs. 49, 2).

Devonian.

Coral usually a single cup, not compound; septa numerous, slightly twisted near center of coral and thickened on their sides

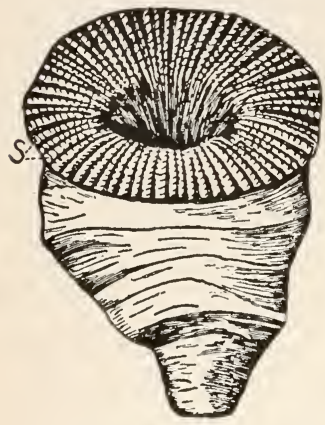

FIG. 49. - The coral Heliophyllum halli $\mathrm{E}$. and $\mathrm{H}$. from the Hamilton (Middle Devonian) formation of New York. This limestone mass was deposited by a single individual, as can be told by the septa (s.) radiating from a center. The flesh of the animal rested upon this mass and within the central, cuplike cavity ; it covered only the upper portion. Natural size. (From Hall.) by conspicuous vertical ridges (carinæ). (Name from Greek helios, sun, + phyllon, leaf (coral) because of the septa radiating conspicuously like the rays of the sun.)

$H$. halli from the Hamilton formation of eastern North America is one of the most abundant American species; in this as in all true Heliophyllums, carinæ are lacking for some distance from the apex of the cup, and then appear only gradually. It thus in its individual development passes through a stage in which in this respect it is similar to Streptelasma, a Tetracorolla coral ranging from the Ordovician to the Devonian.

I. Sketch $(a)$ view of entire specimen, showing both side and top, $(b)$ horizontal section near top, $(c)$ horizontal section near tip. Note septa, carinæ, dissepiments.

2. How were the septa formed? the carinæ? the dissepiments?

3. What does the section I $c$ suggest as to the ancestry of Heliophyllum?

Columnaria (Fig. 50).

Ordovician to Devonian.

This is a closely compound coral with prism-shaped corallites (whence the name from Latin columnarius, formed of columns). 
The corallites are thick-walled with well-developed tabulæ. The polyp occupied only the space above the last-formed tabula.

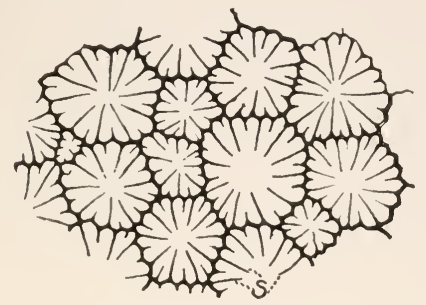

A

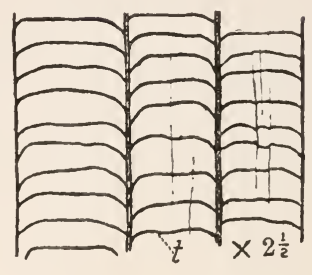

B

FIG. 5o. - Columnaria alveolata Goldfuss, an abundant coral in the Ordovician seas which covered most of the present area of the North American continent. $A$, transverse section $\left(\times 2 \frac{1}{2}\right)$ through eleven entire individuals; $B$, longitudinal section of three of the individuals. $s$., septa ; $t$., tabulæ. (From Lambe.)

It is much like Favosites, but without mural pores and with septa well developed or present as vertical ridges.

I. Sketch a group of three or four corallites, showing both sides and top; grind one corallite down until it shows the tabulæ. Label corallites, septa, tabulæ.

2. Did a single or several polyps secrete the corallites sketched? Reasons.

3. How did the polyp form the septa? the tabulæ?

4. Outline a polyp upon your above sketch.

\section{Super-order b, Hexacoralla}

Simple or composite corals with septa in cycles of six or multiples of six (whence the name from Greek hex, six). Corallum calcareous, horny or fleshy. Here are included the reef-building and deep-sea corals of to-day. The Hexacoralla are abundant from the Triassic to the present. The few Paleozoic (Silurian-Permian) forms referred to the Hexacoralla may belong to the Tetracoralla.

The living sea anemones belong here likewise. These pos- 
sess no hard skeleton, either in adult state or at any time during their development. They are not known in the fossil state. The brown sea anemone (Metridium marginatum) extends from New Jersey to Labrador; a large specimen measures 3 inches wide by 4 inches high. The orange-streaked anemone (Sagartia lucia), especially abundant from New Jersey to Massachusetts, is marked by twelve longitudinal orange streaks. It is about onequarter inch wide by three-eighths inch high.

Madrepora (Fig. 5I) Tertiary to present.

Coral compound, branching, with small,

FIG. 5I. - The terminal portion of a branch of a madrepore coral. The individual polyp at the tip was the largest. cor., corallites, each occupied during the life of the colony by a separate individual polyp. $\left(X+\frac{1}{2}.\right)$ tube-shaped corallites embedded in abundant vesicular cœenenchyme. Each corallite has from six to twelve septa, which are sometimes imperfectly developed. The corallites terminating each branch are the largest. (Name from Latin mater, mother, + porus, a pore, -i.e. a light, friable stone.)

I. Sketch five or six corallites at the tip of a branch, enlarging two times. Label corallites, septa, cœnenchyme.

2. How was the cœenenchyme produced?

3. Account for the branching of Madrepora.

4. Outline a single polyp in place upon the above sketch.

5. How does Madrepora aid in the formation of coral reefs? 


\section{Sub-Class 2. Alcyonaria}

Tentacles hollow, pinnate, always eight in number as are likewise the mesenteries.

A calcareous skeleton is apparently present in all ; it is usually composed of separate spicules which develop in the ectoderm but often pass into the mesoglœa. These forms may have in addition a horny skeleton. They occur from the Ordovician to the present.

\section{Super-order a, Octocoralla}

Usually composite corals; skeleton calcareous, or horny, or apparently absent (name from Greek octo, eight, in allusion to the eight tentacles). Ordovician to present.

Tubipora.

Living.

This red coral is composed of parallel tubes, - the corallites (whence the name from Latin tubus, a tube, + porus, a pore). During the life of the colony each corallite lodges a polyp. The polyps are connected with one another by horizontal platforms which branch out from the level of the tabulæ and from which new polyps arise by budding. The skeleton is formed by the union of the spicules scattered throughout the mesogloea.

I. Sketch (a) top view, (b) side view. Label corallites, platform, solenia tubes.

2. How do new corallites arise in the colony?

3. What are the solenia?

Gorgonia.

Living.

Compound coral, tree-like, but branching in one plane, and all branches united to their tips by cross branches. The upbending of the ectoderm of the base forms a branched horny axis extending throughout the colony. The calcareous spicules present in the mesoglœa form a coating upon this axis in the dried specimen (whence the name from Latin Gorgonia, Gorgon-like, in allusion to its hardening in the air, just as the Gorgon, or 
Medusa, turned all beholders to stone). During the life of the colony a polyp occupied the position of each minute prominence.

I. Sketch $(a)$ entire colony in outline, (b) a small portion enlarged four times. Note position occupied during life by an individual polyp. ing ?

2. How was the horny axis produced? the calcareous coat-

3. What in general is the food of Gorgonia?

\section{Super-order b, Tabulata}

Composite corals; walls of corallites, thick, separate. Septa poorly developed or absent. No dissepiments present. Tabulæ

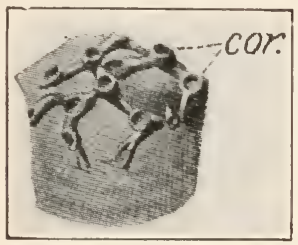

FIG. 52.- 1 ulopora repens Knorr and Walch. Natural size. A branching coral growing upon a brachiopod shell, from the Jennings formation (Upper Devonian) of Maryland. cor., corallites. (From Clarke and Swartz.)

2. Outline a polyp in place upon sketch.

3. How did the colony increase in size?

Favosites (Fig. 53).

Ordovician to Mississippian.

Coral closely compound, with the corallites in contact but with separate walls. Corallites prism-shaped (whence the common name "honey-comb coral" from Latin farus, honeycomb). Walls perforated by equidistant pores believed to represent 
attempts at budding. Septa usually wanting; tabulæ numerous and conspicuous.

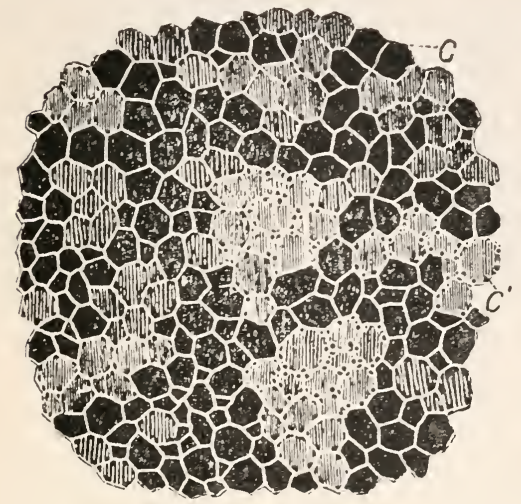

A

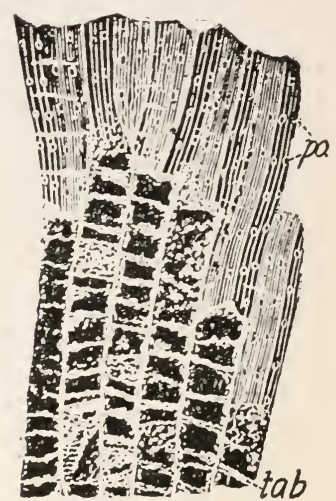

B

Fig. 53. - The compound "Honey-comb coral," Favosites favosus Goldfuss, abundant in the seas covering the eastern portion of North America during the Niagara (Middle Silurian) time. $A$, top view of colony ; $B$, side view of a colony ; upper portion, showing the exterior with the pores and the vertical striations; the lower portion is a section showing the granular tabulæ. c., corallite, - the space occupied by a single individual polyp; $c^{\prime}$., corallite with a convex tabula at the surface, margined by the characteristic pits; po., pores (probably unsuccessful attempts of the individuals to bud new individuals); tab., tabulæ. Natural size. (From Hall.)

I. Sketch a group of five or six corallites, (a) top view, (b) side view of two. Label corallites, tabulæ, mural pores

2. How did the colony increase in size?

3. What may the mural pores indicate?

4. How were the tabulæ formed?

5. What is the significance of the name?

6. Was the living animal able to move?

Halysites (Fig. 54).

Ordovician to Silurian.

Coral compound, composed of long, laterally compressed corallites, and covered by a peritheca. Septa absent or represented by spines; tabulæ numerous. Between each pair of 
corallites is a small tube. Budding occurs only from one side, and the young corallites remain in contact with the parent by

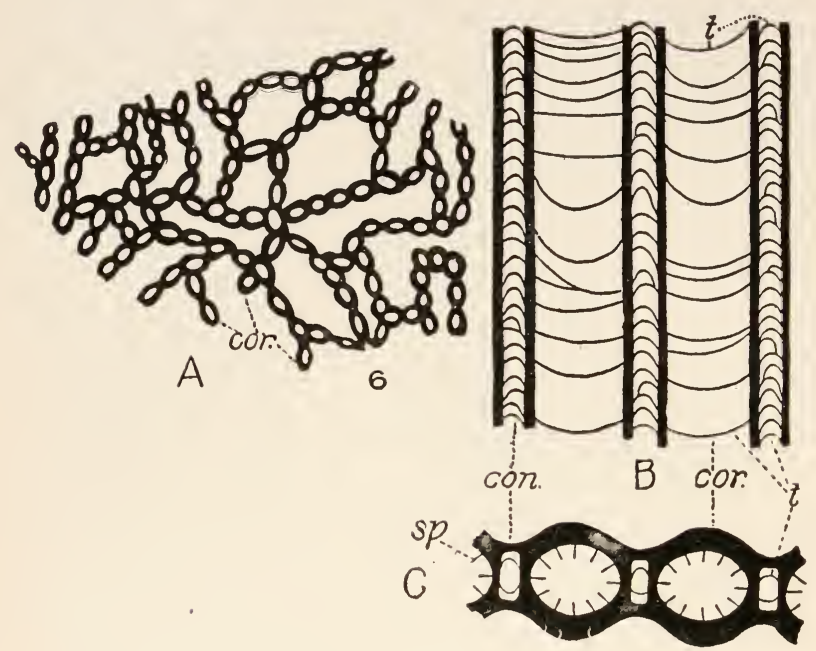

FIG. 54. - The chain-coral, Halysites catenularia (Linnè) from the Niagara (Middle Silurian) of New Jersey. $A$, top view of a portion of a colony, natural size; $B$, longitudinal section $(\times 5)$ showing two individuals (cor.) with their slightly concave tabulæ $(t)$, and the small connecting tubes (con.) with their very convex tabulæ. $C$, transverse section through the same showing the septa-like spines $(s p$.$) and$ within the small connecting tubes a section of the highly arched tabulæ $(t$.). (After Weller.)

a constricted edge, thus forming chains, in which each corallite is a link (whence the common name, "chain-coral," from Greek halysis, chain).

I. Sketch an inch square portion of colony, $(a)$ top view, (b) side view. For side view polish corallites to show tabulæ. Label corallites, tabulæ.

2. How did the colony increase in size?

3. Account for the chain formation.

4. What is the significance of the name?

5. Did each individual animal possess a separate digestive system or did it share a common one with others? 


\section{CLASS D, CTENOPHORA (COMB-JELLIES)}

Pelagic individuals with no sessile or colonial stage. Tentacles when present are usually two in number. Movement is by the large cilia which are fused into comb-like structures; these are arranged in 8 meridian-like rows or swimming plates. Not known in the fossil state. Example: Cestus (Venus' girdle).

Derivation of name. - Ctenophora > Greek kteis, a comb, + phoros, bearing, from the fusion of the large cilia to form comb-like swimming structures.

I. In what respects are the Coelenterates an advance upon the sponges?

2. Define the four classes into which the Cœlenterata are divided, with a living and a fossil (where possible) example of each.

3. Since the large jelly-fish, the Scyphozoa, consist of about 99 per cent water, how have fossil records of them been made?

4. Distinguish Hydrozoa from Anthozoa, in $(a)$ the soft body, (b) the hard skeleton. 


\section{PHYLUM IV, PLATYHELMINTHES (FLAT-WORMS)}

THE old phylum Vermes (Latin vermis, a worm) was a comprehensive group of no exact classificatory value, including soft, invertebrate animals, many bearing a general appearance to the common earthworm. This is divided into four phyla, Platyhelminthes (flat-worms), Nemathelminthes (round-worms), Trochelminthes (wheel-worms) and Annulata (ring-worms).

Body unsegmented, usually flattened from above downward. Digestive canal without an anus, the waste being carried off by the excretory system. No blood vascular system is present. The sexes are united in the same individual. Many forms are parasitic. This is the lowest phylum to assume a pronounced bilateral symmetry. The Nemertinea differ from the other orders of this phylum as described above in the possession of an anus, a blood vascular system and a protrusible œsophagus. The nemertines are covered by a very slimy secretion. Fossil flat-worms are extremely rare; they are known from the Pennsylvanian to the present day.

Derivation of name. - Greek platys, flat, + helmins, worm, referring to the flattened appearance of the body.

Living examples are the Planaria (fresh water flat-worm), Distomum hepaticum (liver-fluke, parasitic in sheep), and Tania solium (common tape-worm, parasitic in man and the pig).

\section{PHYLUM V, NEMATHELMINTHES (THREAD-WORMS)}

Body unsegmented, long and cylindrical, with mouth and anus at opposite ends. Sexes usually separate. Mostly parasitic. Fossils extremely rare. A few examples of this and the preceding phylum have been found fossil as parasites upon insects from the upper Paleozoic coal measures and the Tertiary amber. 
A fossil looking much like the living round-worm Sagitta has been found in the Middle Cambrian shales of British Columbia.

Derivation of name. - Greek nema, thread, + helmins, a worm, referring to the round thread-like body.

Living examples are Ascaris lumbricoides (the round-worm from the small intestine of man), Oxyuris vermicularis (the pin-worm infesting the rectum of man), Trichina spiralis (parasitic in man and the pig) and Gordius (the hair-worm ; parasitic in asexual generation, free in sexual; in the latter it is often I $5 \mathrm{~cm}$. long by $5 \mathrm{~mm}$. in diameter and popularly is supposed to be derived from horsehairs which have fallen into the water).

\section{PHYLUM VI, TROCHELMINTHES (WHEEL-WORMS)}

All Trochelminthes, except the few belonging to the slightly related orders Gastrotricha and Dinophilea, belong to the wheelworms (order Rotifera). These are microscopic in size, being the smallest of all animals except the Protozoa. The anterior end is surrounded by many variously arranged cilia, often in a circle, by means of which the animal moves. Body unsegmented. The œsophagus has a chitinous masticating apparatus. Anus present. Sexes separate. Few species are parasitic. Unknown in the fossil state.

Derivation of name. - Greek trochos, wheel, + helmins, worm, referring to the successive movement of the cilia at the anterior end of the body which gives an appearance of rotation.

Living examples are Branchionus (abundant in ponds and ditches) and Rotifer.

\section{PHYLUM VII, ANNULATA (RING-WORMS)}

All, except the class Gephyrea, have a ciliate, elongate body, with mouth at one end and anus at the opposite; the bilaterally symmetrical body is divided by ring-like constrictions into a series of segments representing a like segmentation within, where each segment contains a portion of the digestive canal, a pair of 
nephridia, a pair of nerve ganglia from the ventral chain and blood vessels. The nervous system consists of a dorsal brain connected around the mouth with the anterior end of the double ventral nerve cord. Paired excretory organs (nephridia) conduct the nitrogenous waste matter from the general body cavity (cœlome) to the exterior.

Derivation of name. - Latin anmulus, a ring, referring to the ring-like constrictions of the body.

The annulata are divided into the four following classes:

\section{A. Archi-annelida}

Living.

A primitive class of annulata. Unknown in the fossil state.

B. Hirudines

Living.

Including the genus Hirudo, the leech. Unknown fossil.

\section{Gephyrea}

Living.

With larva similar to that of the Chætopoda. Unknown fossil.

D. Chætopoda

Cambrian to present.

\section{CLASS D， CHÆTOPODA}

Type of the class, Nereis virens (Fig. 55).

This form lives in sandy or muddy beaches, usually between tide levels, under rocks or among seaweeds; at times it reaches a length of over eighteen inches. It inhabits a-burrow which it makes firm by cementing the sand particles of the wall together with a mucilaginous secretion. This common form ranges from Long Island to Labrador, to Great Britain and Norway.

Its body, rounded above and flattened below, is divided by ring-like constrictions into a series of segments. Each segment, except the most anterior (head segment) and most posterior (tail segment), bears externally at the sides of the body, a pair of outgrowths, - the flapper-like gill-feet or parapodia, which aid in creeping or act as oars in swimming. The parapodia are strengthened by chitinous rods extending outwards from the body and are bordered by several bundles of chitinous bristles. 
The head segment consists of two distinct portions, - the anterior of which bears dorsally four simple eyes and anteriorly a pair of slender tentacles or feelers and a pair of thick palps;

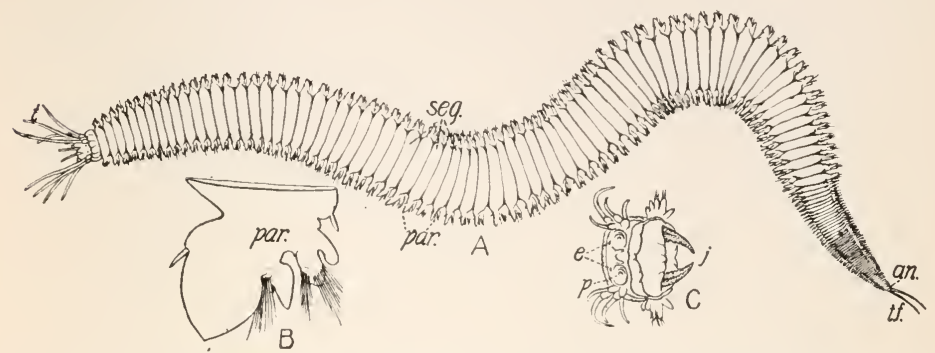

FIG. 55. - The common carnivorous worm, Nereis virens from Massachusetts Bay. $A$, entire worm. $B$, a paddle (or parapodium, - much enlarged) from the fiftyfifth segment. $C$, the head of another specimen, showing the toothed jaws extended. an., anus; $e$., eyes; $j$., jaws; $p$. ., palp; par., parapodium; seg., segments or divisions of body; $t$., tentacles; $t$.f., terminal feelers. (A and $\mathrm{C} \times \frac{3}{5}$.)

the posterior portion bears antero-laterally four pairs of tentacles. The tail segment bears merely a pair of long terminal feelers. The body is inclosed in a very thin layer of chitin secreted by the epidermis beneath it.

Beneath the epidermis are circular muscles by which the worm can diminish its diameter, while beneath these are four longitudinal muscles which can diminish its length; the latter are arranged in two pairs, a dorso-lateral and a ventro-lateral pair. Besides these there are muscles to move the parapodia.

Its food consists of both plants and animals, but especially the latter. It is active and voracious, eating especially crustaceans and other worms. At night it leaves its burrow, swimming actively about in search of food, at which time many of these worms are eaten by fishes. The mouth is situated at the end of the head upon the under side; through this Nereis can thrust out the anterior portion of its œesophagus, by a process of rolling inside out as with the finger of a glove. This thrustout portion, the proboscis, is provided with two laterally placed, 
strong, notched, black chitinous jaws. After seizing its prey with these jaws, the proboscis is rolled in again and the jaws then tear the food into pieces. The food next passes through the narrow œsophagus, into the long, straight intestine; the anus is at the posterior end of the tail segment. The intestine is regularly narrowed, corresponding to the surface constrictions. Into the œesophagus, from the glands at its sides, is poured a fluid, probably digestive in function. From within outward the walls of the intestine consist of (I) a layer of epithelial cells, (2) a layer of circular muscles, (3) a layer of longitudinal muscles and (4) a surface membrane. The muscles aid the forward movement of the food, while the innermost layer probably aids in absorbing the digested portions of the food. Since both the anterior portion of the digestive canal to the beginning of the œsophagus, and the posterior portion within the tail segment are developmentally invaginations of the external surface they are similarly lined with chitin.

The blood, of a bright red color, is carried in two main blood vessels, a dorsal tube carrying it forward and a ventral tube moving it backward; connecting these two are loops in each segment and from these loops branches are given off to the digestive canal and to the parapodia. There is no distinct heart, but in the walls of most of the blood vessels are rings of muscles which, contracting in succession, move the blood forward; the walls themselves are likewise contractile. These wave-like contractions move the blood from behind forwards in the dorsal vessel and from before backwards in the ventral vessel.

Respiration takes place through the entire body surface but especially through the leaf-shaped gill-lobe attached to the upper side of each parapodium; these lobes are green at the head end of the body but bright red at the middle and posterior parts.

While the excretion of $\mathrm{CO}_{2}$, etc., takes place largely through the gill-lobes of the parapodia, the nitrogenous waste (uric acid, etc.) is carried off by a pair of curved tubes (nephridia) in each segment. 
The nervous system consists of a bilobed dorsal ganglion, or brain, situated in the anterior part of the head, connected around the mouth with the anterior end of the ventral nerve cord which extends to the posterior end of the body. This cord is in reality double, each part with a separate swelling or ganglion in each segment, but both united into one by a common covering.

The sense organs include the tentacles and cirri as probable organs of touch, the palps used in testing food, and the four simple eyes. Each eye consists of (I) the outer cuticle, the continuation of the body chitin, (2) the cornea, the flattened cells of the epidermis, (3) the large gelatinous lens, (4) the retina, composed of many radially arranged cells, one end of each of which is continuous with the optic nerve and the other projects towards the lens as a clear, glass-like rod. The body of each retinal cell is densely pigmented for the absorption of excess light rays.

The sexes are separate. At certain times during the summer they swim near the surface and cast the ova and spermatozoa into the water, where union between them later occurs. The fertilized egg develops into the adult through a series of radically different forms, one of which, the trochosphere stage, it possesses in common with mollusks as well as with other worms.

Preservable as fossils are the chitinous jaws, trails, excrement and burrows.

I. Examine Nereis, noting the black jaws at the end of the protrusible pharynx, the eyes, body segments, parapodia, bristles.

2. What is the habitat of the animal ?

3. Its food and how procured?

4. How is the food digested and the waste moved through the digestive canal?

5. How is the digested food absorbed and carried throughout the body?
6. Describe briefly
(a) respiration;
(b) excretion;
(c) the nervous system; (d) sense organs.

7. What are the principal muscles and their uses?

8. What fossil record can Nereis leave of itself? 


\section{Summary of Chatopoda}

Annulata with few or many bristles attached to the sides of the body (whence the name from Greek chaite, bristle, + pous (pod), foot). This class includes (a) the earthworms and their allies, unknown as fossils, (b) Nereis, Prioniodus, and other carnivorous allies and $(c)$ the vegetable-feeding tube builders.

The tube-building worms inhabit a tube of their own manufacture; these tubes may be formed of lime carbonate, of agglutinated particles of sand, etc., or they may be membranous or leathery. These animals have short parapodia which are never used for swimming, and they are devoid of jaws. They include Serpula and Spirorbis. The Chætopoda are known from the Cambrian to the present.

Prioniodus (Fig. 56).

Ordovician-Devonian.

A jaw of this form, the only portion found fossil, consists of a narrow basal part which supports many, usually five to twenty,

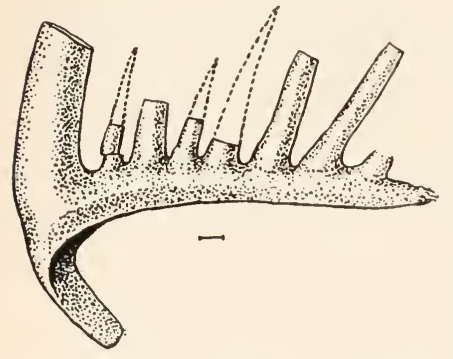

FIG. 56. - A conodont, an imperfect jaw probably of an annelid worm, Prioniodus, from the Genesee (Devonian) of New York. The projections were pointed; three of these have been restored. Enlarged; true size indicated by line below. small teeth, besides a long tooth situated anywhere from the middle to the end of the basal portion. This long tooth is always continued below the basal part. These jaws probably corresponded in position and function to the jaws of Nereis. The name, from Greek prion, a saw, + odous, a tooth, refers to the saw-like arrangement of the teeth.

Very many such cone-shaped teeth, found in the Paleozoic from the Cambrian to the

Pennsylvanian inclusive, have received the general name of conodonts. Some of them may be fish teeth. 
I. Sketch specimen, enlarging it three times.

2. What is the significance of the name?

3. What general name is applied to all such teeth?

4. In what part of the living animal were these? their function?

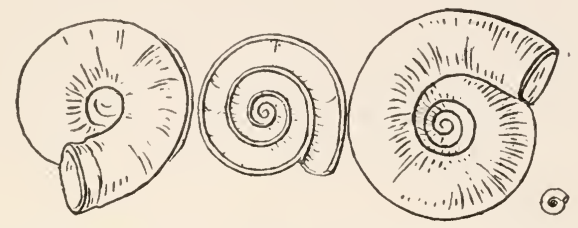

FIG. 57. - A tube-building worm, Spirorbis borealis Daudin, belonging to the class Chætopoda, abundant upon seaweed, etc., off the New England coast. The small one to the right is natural size. The middle of the enlarged three is a section of the shell.

Spirorbis (Fig. 57).

Ordovician to present.

Minute, calcareous, spiral tubes (whence the name from Latin spira, spire, + orbis, circle). These tubes are cemented by their flat underside to some foreign object.

I. Sketch a tube.

2. How could the body of the animal within cement this to some foreign object?

3. Could the animal leave its tube and later return to it? 


\section{PHYLUM VIII, ECHINODERMATA}

TyPICALLy radially symmetrical marine animals with a skeleton of calcareous plates or spicules embedded in the skin. The arrangement of the skeletal plates and of the internal organs is usually pentamerous, the numeral five being thus the governing number of the echinoderms. They are likewise characterized by the presence of a water vascular system which functions in respiration and movement.

They represent an advance upon the Cœlenterata in the presence of a digestive tube distinct from the body cavity (cœlome), in their more highly developed nervous system, in the possession of a blood vascular system and in an almost exclusively sexual mode of reproduction.

The seven classes of the Echinodermata form a more or less closely related group. If the comparison is made with considerable latitude, the arms of the starfish and crinoid are homologous to the ambulacra of the cystoid, blastoid and echinoid; moreover, if the starfish be placed with mouth uppermost, the lower side of the central disk corresponds to the base of the cystoid, blastoid, and crinoid, while the upper side with its central mouth and radiating ambulacra is similar to the upper side of these classes, and internally the position of the ambulacral, blood vascular, and nervous systems is then similar; in echinoids, a like orientation with the starfish may be made by bending the arms of the latter until they almost meet dorsally.

The three classes, - cystoids, blastoids, and crinoids, - the individuals of which are usually fixed to some foreign object, are of all the Echinodermata the most intimately related. The blastoids are nearest to the cystoids, the hydrospire probably corresponding to the pore-rhombs, while the position of 
mouth and anus is approximately the same in both. The hydrospires of blastoids are likewise correlated with the pores beneath the arm bases of certain crinoids, such as Batocrinus.

The Blastoidea and Crinoidea have probably descended from the Cystoidea, while if a common ancestor for all the Echinodermata, both fixed and free, be sought, it would possibly be found in the primitive cystoids, the Edrioasteroidea (see p. I 57).

Derivation of name. - Greek echinos, hedge-hog, + derma, skin, in allusion to the spines possessed by many of the members of this phylum.

The Echinodermata are divided into the following seven classes :-

A. Cystoidea

B. Blastoidea

C. Crinoidea .

D. Asteroidea

E. Ophiuroidea

F. Echinoidea

G. Holothurioidea

PAGE

I 54

I 57

I 59

I65

I 7 I

Type of the phylum Echinodermata, Asterias forbesi, the starfish (Fig. 58).

Asterias forbesi ranges from Maine to the Gulf of Mexico, but is very common only south of Cape Cod, living from high tide line to a depth of one hundred feet. In summer and autumn it lives in rocky places in shallow water, but seeks greater depths in winter.

The starfish is a free-moving animal, consisting of five rays or arms united broadly to a central portion, the disk. The mouth is situated in the center of the under or ventral side of this disk and from it radiate five grooves, one in the middle of each arm. These grooves are called the ambulacral grooves, or ambulacra.

Into each of the ambulacral grooves project four rows of soft tubular bodies with sucker-like extremities. These are the tubefeet, the locomotive organs of the animal, and they form a part 
of the water vascular system which is especially characteristic of the echinoderms. This system consists of a series of tubelike passages filled with sea water. The water is admitted through a finely perforated plate, the madreporite, situated on the dorsal side near the junction of two of the arms. From the

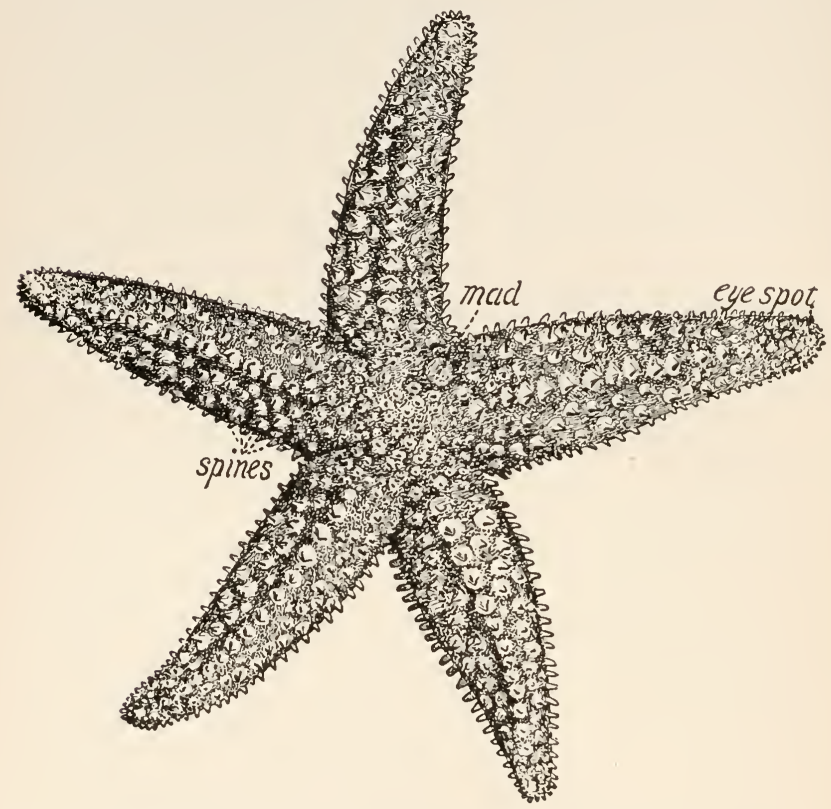

FIG. 58. - A four-months-old starfish, Asterias forbesi, from Narragansett Bay, Mass. Natural size. mad., madreporite. (From Mead.)

madreporite an S-shaped tube, the madreporic or stone canal, descends to the ventral side of the animal and connects with a five-sided ring-like canal surrounding the mouth. From this ring-vessel radiate the five straight ambulacral vessels to the extremities of the five arms. Along each of these radial tubes are given off the four rows of tube-feet. Each of these tube-feet is a small muscular tube, closed at one end and expanded at the other into a bladder-like ampulla. The ampullæ are inside the 
arm, protected by the dermal plates, while the small closed end extends between the plates, protruding out into the arm furrow and ending in a disk-like expansion. The sea water is admitted from the radial ambulacral vessel of the arm into the ampulla; by the contraction of this it is forced into the corresponding tube-foot, which thus becomes greatly lengthened. When the foot is thus extended and comes into contact with a stone or other solid object the water is withdrawn from it, the middle of its tip is drawn inward, forming under it a vacuum, and thus the disk-like end of the foot is converted into a sucker which clings to the rock. When water is again forced into the foot by the ampulla, the hold of the sucker is relaxed. Thus the many tube-feet acting independently reach forward in the general direction of locomotion, attach themselves to some foreign object, and through contraction pull forward the entire body with a slow gliding motion, while the other feet already contracted loose their hold and then reach forward. A fair speed is six inches a minute. Although a starfish can move in any direction, it usually proceeds with the arm lying immediately to the left of the madreporic plate in advance.

The skeleton or test consists of many calcareous plates embedded in the sub-epidermis (mesoderm), which, except at the mouth, completely surrounds the body. Since bands of muscular fibers extend between all contiguous plates, the arms and disk are movable. The protective spines are covered only by the epidermis.

The chief food of the starfish is mollusks (especially mussels, clams and oysters), barnacles, worms, and small crustaceans. In securing its food, such as a clam, it folds its arms about its prey, attaching its hundreds of tube-feet to the valves of the shell, and through the steady pull thus exerted tires the large adductor muscles of the mollusk. Experiment has shown that a large starfish can exert a steady pull of over two and a half pounds. Between the valves thus opened the starfish rolls its very distensible stomach in the form of a thin sheet spread over the 
soft tissues of its prey. Then the great digestive glands in the upper part of the stomach and in the arms pour out their secretion through the tubular passage remaining in the center of the sheet, and the food is rendered fluid and absorbed. The stomach then contracts and is rolled back through the mouth into the body. The starfish may live for months practically without food, but when opportunity offers it will eat many mollusks, one immediately after another. It opens gastropods (periwinkle or conch) in a similar manner by attaching the tube-feet to the operculum and shell.

The upper, narrow portion of the stomach has long divisions, one extending to the end of each arm. These divisions secrete a digestive fluid which converts starch into sugar, proteids into peptones, and emulsifies fat; the resultant, chyle, is taken by osmosis into the veins. A vein runs along the digestive tube from the mouth to the arms and forms a circle around each end of the tube; branches from these traverse the body and each arm. The rings around the mouth open at one side into the general body cavity, the colome; hence the "blood" of the colome and of the blood vessel is the same, a thin fluid consisting of sea water, chyle, and some amoboid corpuscles. From the upper portion of the stomach, the waste products are conducted out through the anus, which is situated nearly in the center of the dorsal surface of the disk.

Respiration takes place (I) through the short, hollow, threadlike processes (dermal branchiæ) which extend out through microscopic pores between the plates over the whole body and open directly into the coelome, and (2) by the ambulacral system, the oxygen entering through the tube-feet and madreporite.

The nervous system has three divisions, (I) the epidermal, - a pentagonal nerve ring around the mouth, from each of the five angles of which one radial nerve fiber extends below the radial ambulacral vessel to each eye-spot; (2) the deep portion, a double pentagon around the mouth, of which each angle sends 
a nerve to each arm; and (3) the cœlomic, the nerves extending along the top of each arm.

The sense organs include that of smell and the so-called eye. At the tip of each arm is a bright red speck, the eye-spot. This is practically nothing but a collection of pigment granules upon the expansion of nerve cord; since there is no lens there can be no image, and hence the animal can probably distinguish light and color, but not form. The perception of light is probably merely the sensation of warmth due to the absorption of the light rays by the pigment and their consequent conversion into heat.

Over the eye is a tentacle similar to a tube-foot, but smaller and without the sucker. Experiments have determined its function to be that of smell, and that the animal is guided to its food more by this sense than by sight.

Reproduction is exclusively sexual. The eggs and spermatozoa are discharged into the water in great abundance during the last three weeks of June, although they are also found during the summer and occasionally even during the winter. The eggs after fertilization develop into little transparent larvæ covered with waving cilia. At this time their greatest enemy is the menhaden. They swim about slowly near the surface and feed on minute organisms until they attain a length of an eighth of an inch. Then the star shape begins to develop and in a few hours a very small star lies at the bottom of the ocean. These settle on seaweeds and eel grass and begin at once to devour the young clams which have likewise begun life here. It has been found that one of these little starfishes devoured over fifty young clams somewhat smaller than itself in six days. Their growth depends upon the amount of food eaten, and hence the age at which a female begins to produce eggs is said to vary from one to six years. A starfish can regenerate lost arms.

I. Sketch $(a)$ ventral view, (b) dorsal view. Label disk, arms, ambulacra, tube-feet openings, mouth, eye spots, madreporite, anal plate, spines. 
2. Give the habitat of Asterias.

3. How does it move?

4. What is its food? Describe how it eats.

5. How is the food digested? assimilated? waste expelled?

6. What protection against enemies has Asterias?

7. Is the skeleton (test) external or internal? Explain.

8. How does the animal respire?

9. Of what does the nervous system consist? Its use?

Io. Describe the sense organs.

II. Give very briefly its development from the egg to the adult.

I2. How long does it take to mature?

I3. What makes the starfish such an enemy to oyster and clam culture?

I4. In what respects are the echinoderms more highly evolved than the colenterates?

\section{CLASS A, CYSTOIDEA (CYSTOIDS)}

Calyx usually stemmed. Mouth nearly or quite central upon the upper (ventral) surface. From the mouth radiate two to five or more simple or branching ambulacra, along which passed food particles to the mouth, probably driven by numerous cilia. These food grooves may be upon the outer surface of the calyx plates, between them, or upon their inner surface, and are rarely extended into free branches, the arms. Anal opening excentric, often closed by a valvular pyramid.

Calyx plates usually irregularly arranged, varying in number from thirteen to several hundred; as a rule a few, or all of the plates, are pierced by pores which are either irregular or arranged in rhombic figures, with half of the rhomb on one plate and half on an adjoining one; the pores from opposite plates are united by closed straight ducts which may have functioned in respiration.

Cystoids are the oldest and least specialized group of the Pelmatozoa (which include cystoids, blastoids, and crinoids), and probably represent most nearly the ancestral type of the three classes. 
They are extinct, being confined entirely to the Paleozoic. They extend from the Cambrian to the Permian, inclusive, with maximum development in the Ordovician and Silurian.

Derivation of name. - Greek, cystis, bladder, + eidos (oid), form, in allusion to the globular shape of most of the species.

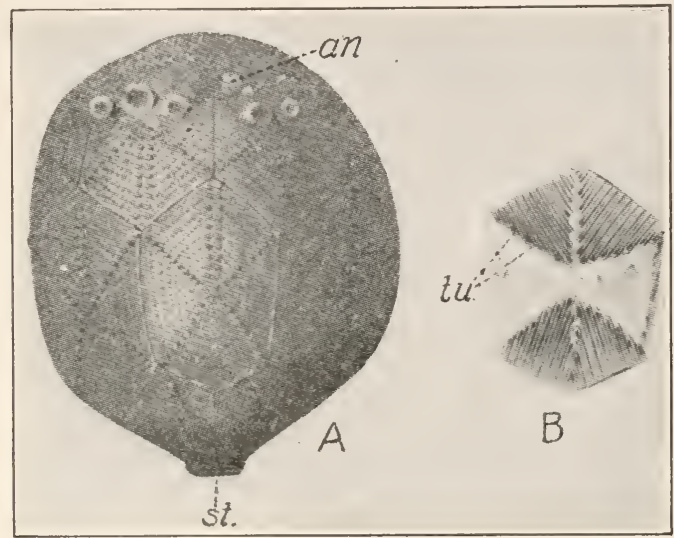

Fig. 59. - Caryocrinus ornatus Say, from the Niagara shales (Middle Silurian) of western New York. A, calyx of a large specimen (natural size) with stem and arms missing. $B$, inside of one of the plates (slightly enlarged), showing the water tubes, with an opening at their inner ends. an., anus, protected by a valvular pyramid; st., position of stem; tu., tubes. (After Hall.)

Caryocrinus (Fig. 59).

Ordovician to Silurian.

The principal portion of the body, a sub-globular hollow ball, called the calyx, contained the digestive and blood vascular systems. This calyx was anchored to the ground by a long, jointed stem. The food grooves (ambulacra) radiating from the mouth terminate in six to thirteen feeble arms. Both mouth and food grooves are within the upper part of the calyx. Upon the outer surface of each calyx plate, except the summit one, are five or six single or double rows of pores radiating from its center. Each of these pores is prolonged upon the inner surface of the plate into a straight calcareous tube (Fig. 59, tu) which in turn opens by a pore upon a bordering plate. All the tubes 
thus uniting across the straight suture of two contiguous plates form in outline a rhomb, from which these have received the name of pore-rhombs. The function of the pore-rhombs is supposed to have been respiratory.

Caryocrinus is thus somewhat similar to a starfish turned mouth side uppermost, with an anchoring stalk attached to the dorsal side, the mouth and much of the ambulacra concealed by calcareous plates, and with the ends of the ambulacra branching into free arms. With the mouth concealed, food was of necessity urged into it through the ambulacral grooves by the cilia lining them. Since the ambulacra were often concealed by calcareous plates, tube-feet were in all probability absent.

I. Sketch $(a)$ side view, $(b)$ enlarge a plate twice. Label calyx, place for attachment of stem and of arms, plates forming the ventral surface of calyx, pores.

2. What was probably the function of the pores?

3. Of what did the animal's food probably consist? How did it procure it?

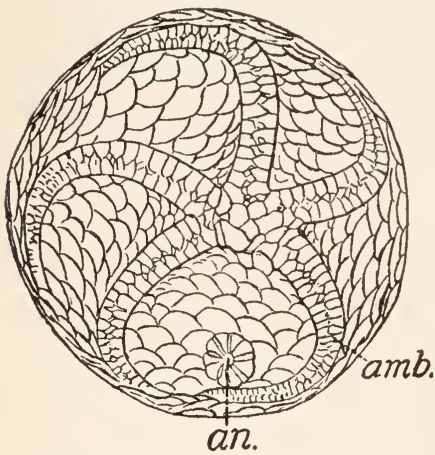

FIG. 6o. - A cystoid, Agelacrinus cincinnatiensis Rœmer, from the Ordovician of Cincinnati, Ohio. Top view $(\times 2)$ showing the curved ambulacra $(a m b$.$) within which are the covered$ food grooves. Anus (an.) nearly marginal. (Redrawn from Meek.)

4. Compare Caryocrinus to a starfish.

5. What was its habitat? Reasons.

6. What part of the living animal does the fossil represent?

7. What animals living off our coast are likewise fastened to the ground?

8. What characters show the cystoids to be primitive unspecialized types?

9. Give the geologic range of the cystoids.

Agelacrinus (Fig. 60).

Ordovician to Mississippian.

The animal is circular, flat, stemless, cemented by the entire lower (dorsal) surface to a foreign object, usually a brachiopod 
shell. The hard protecting calyx is composed of many thin, flexible and more or less overlapping plates ; these are perforated by pores, which probably had a respiratory function. From the centrally placed mouth, which is covered by four plates, radiate five curved, unbranched, covered food grooves. The anus occurs between two of the food grooves roofed over by a low pyramid of plates.

This genus and the many other forms similar to it are often placed together in a distinct class, the Edrioasteroidea, extending from the Cambrian to the Mississippian.

I. Sketch surface view, noting calyx, mouth, anus, ambulacra.

2. How, probably, did the animal procure its food?

\section{CLASS B, BLASTOIDEA (SEA-BUDS)}

Calyx ovate, short-stemmed or stemless; distinct arms absent; these exist only as pinnules. Around the central mouth are five or ten spiracles which are connected internally with the hydrospires, - canals probably respiratory in function. Some forms have a distinct anal opening; in others this opening is fused with one of the spiracles. From the mouth radiate five ambulacral areas.

The class is entirely extinct and confined to the Paleozoic, ranging from the Ordovician to the Permian.

Derivation of name. - Greek blastos, bud, + eidos (oid), form, in allusion to the bud-shaped calyx of most species.

Pentremites (Fig. 6I).

Mississippian.

This differs in general from the starfish in its bud-shaped body $(\operatorname{cal} y x)$, which was anchored to the ground by a short, jointed stem attached to its dorsal surface; the mouth, or ventral side, was thus uppermost. The calyx inclosed the digestive and blood vascular systems. In the center of the upper surface is a five-angled opening, the mouth, surrounded by five round openings, the spiracles. From each angle of the mouth radiates 
a food, or ambulacral groove, and from this groove branch off smaller side grooves almost at right angles, the whole forming a $\mathrm{V}$-shaped ambulacral area.

At the upper end of each side groove is a small pore (marginal pore) ; these pores open upon the inside of the calyx into a cal-
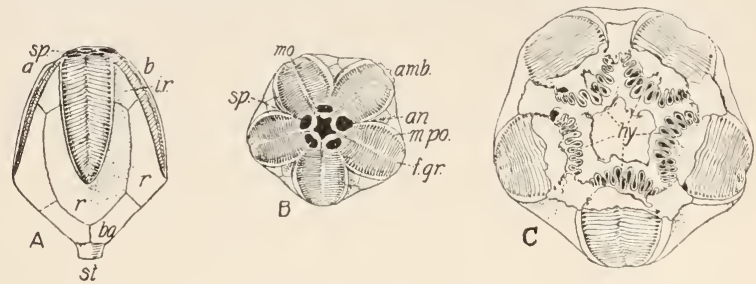

FIG. 6I. - This blastoid, Pentremites pyriformis Say, was very prolific in the clearer portions of the sea (i.e. Kentucky, Alabama, and Mississippi), which covered much of North America during Kaskaskia (Upper Mississippian) time. A, side view (natural size) with stem missing, as is nearly always the case. $B$, top view. $C$, cross section $\left(\times_{2}\right)$ at $a-b$ in Fig. $A$. $a m b$., ambulacrum; $a n$., anal opening fused with a spiracle; $b a$., basal plate; $f . g r$. , food groove; $h y$., hydrospires (to conduct water from the marginal pores out through the spiracles); i.r., interradial plates; m.po., marginal pores; mo., mouth; sp., spiracles; r., radial plates; st., place of attachment of stem.

careous canal looking like a much-folded bag, - the hydrospire, probably respiratory in function. Each of the five pairs of hydrospires from adjoining ambulacra end in one of the spiracles. During life, it is probable that a current of water passed in at the marginal pores, through the hydrospires, and out at the spiracles. Around the marginal pores were long, jointed pinnules which functioned in straining out the food particles; this food, probably similar to that of crinoids, was urged down the side grooves by the cilia lining them, and thus down the central groove to the mouth. In exceptionally well-preserved specimens the central and side food grooves to the base of the pinnules are roofed over by very minute plates. The position of the pinnules is indicated by minute pits and knobs.

Little is known concerning the digestive, blood vascular, and nervous systems; there is some evidence of radial nerve cords connected with an oral ring, ard of radial blood vessels likewise 
connected with an oral ring. The anal opening is fused with the largest spiracle.

The calyx has thirteen definitely arranged calcareous plates, - three basals, five large incised radials, and five interradials or deltoids. The plates are firmly united. The structure of the stem is similar to that of the crinoids.

Pentremites was exceedingly abundant in the sea which covered most of North America during Mississippian time.

I. Sketch (a) side view, (b) ventral view. Label calyx, mouth, spiracles, ambulacra, marginal pores, anal opening, place for attachment of stalk.

2. Explain the process by which the animal ate.

3. How did it probably respire?

4. Compare it to a starfish.

5. Give the geologic range of Pentremites.

6. What was its habitat?

7. What part of the living animal does the fossil represent?

8. Could the animal move? Reasons.

\section{CLASS C, CRINOIDEA (SEA-LILIES)}

Body, the calyx, more or less globular, fastened, temporarily or permanently, to some foreign object by means of a stalk arising from its dorsal (lower) surface. The ventral (upper) surface bears the mouth, which is usually central, the anus, which is excentric, and the ambulacral grooves. These grooves extend into the more or less complexly branched arms, which are usually bordered with pinnules. Some forms, as Eucalyptocrinus, were attached by roots, some, as Pentacrinus and Ancyrocrinus, anchored themselves to seaweeds and other objects by processes from the lower end of the stalk, and some probably used their stems for coiling around a support.

Crinoids range from the Ordovician to the present time, though they were most abundant in the upper Paleozoic. Owing to their gregarious habits, their skeletons form the chief part of great masses of limestone (hence called crinoidal limestone), especially in the Devonian and Mississippian periods. 
Fossil remains of these animals consist mainly of detached portions of stems or scattered calyx plates. Complete forms,
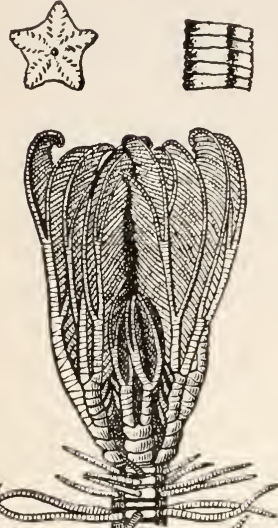

自管 am

\section{है}

Fig. 62.-Above, stem joints of the crinoid, Pentacrinus asteriscus $\mathrm{M}$. \& H., from the Jurassic of Montana. To the left the surface view of a joint (natural size); to the right five joints, side view. Below, a modern crinoid, Pentacrinus caput-medusa (much reduced), from the Gulf of Mexico. This shows the arms (concealing the calyx) and the upper portion of the stem. The last is reproduced from Lucas' "Animals before man in North America." Copyright, I902, by D. Appleton and Co. preserving calyx, stem, and root, are rare.

Derivation of name. - Greek crinon, lily, + eidos (oid), form. The stalked forms resemble lilies, as is noted also in the common name of the class, "sealilies."

\section{Pentacrinus (Fig. 62).}

Triassic to present.

This form, unlike the starfish, has the mouth, or ventral side, uppermost, while the opposite, or dorsal, sicle is fixed to the ground by a long flexible stalk.

The animal is composed of a globular body ( $\operatorname{calyx}$ ), from the upper surface of which branched arms, and from the lower surface is given off the stalk. Embedded within the skin of all parts are many calcareous plates forming a strong protective skeleton. The stalk is made up of grooved disks, resting one upon the other like a pile of coins, and pierced at the center by a canal containing a prolongation of the nervous and blood vascular systems. Small branches, the cirri, whose function is doubtful, are given off from the stem and have an internal and external structure similar to that of the stem. In some cases, probably, the stalk was attached to the ground by a branching root; more generally it was free, being merely anchored to seaweeds, eic., by the entwining of the cirri 
at its lower end. The stalks are very long, attaining at times a length of at least twenty feet.

The calyx is made up dorsally of calcareous plates definitely arranged; the plates upon the ventral surface are without definite order. All the plates are firmly united, forming a rigid skeleton. The mouth occupies the center of the upper surface and from it radiate five open ambulacral or food grooves to the tips of the arms. These arms, unlike the usually simple ones of the starfish, branch repeatedly, each branch in turn giving off many short side branches or pinmules. The ambulacral grooves branch correspondingly. These grooves are lined with cilia by the aid of which the food, chiefly diatoms, protozoöns, and microscopic crustaceans, is urged into the mouth. The ambulacral system here, as in the starfish, forms a ring around the mouth and sends a ray to each pinnule ; connected with this ring are several ciliated, branched water-tubes opening into the coelome. Into this cœlome, the body cavity, water enters from the exterior by means of minute water-pores through plates on the ventral surface. Small, distensible tube-feet, the tentacles, are present ; they, however, lack suckers, and are not locomotor but merely tactile and respiratory in function. The water-pores and water-tubes represent the madreporite and its canal of the starfish.

The mouth opens through an œesophagus into a wide stomach, thence into the intestine, which coils inside the body wall, but does not have extensions into the arms. It opens by the anus through a tube eccentrically placed upon the upper (ventral) surface. The blood vascular system consists of a ring around the oral end of the digestive canal, giving off radial vessels to the arms and the stalk.

The nervous system consists of (I) the ambulacral portion, a ring around the mouth from which pass series of nerves to arms and pinnules through the base of the ambulacral grooves; and (2) the axial portion, - a five-angled organ beneath the basal plates at the junction of calyx and stalk, from which radiate 
nerves through the center of the arm and pinnule plates and to the stalk. A transverse section through an arm would thus show a blood tube, a water tube and a nerve cord directly beneath the food groove, while deep within the calcareous plate is lodged a second nerve cord.

The sexes are separate. The dilated pinnule bases lodge the ovaries and testes.

The stalk is five-sided throughout in ancient fossil species (e.g. P. asteriscus) but in living forms only near the calyx. New plates are added directly beneath the calyx; these are in living Pentacrinus at first five-sided like the entire stalk of lower Mesozoic species; but later they become round. These changes, in which the animal recapitulates its ancestry, may be noted in a single individual from the small plates directly beneath the calyx to the large ones at the lower end of the stalk. The young stem joints are more porous than older ones, and therefore not so apt to be preserved fossil.

The range of the genus is from the Jurassic to the present. The symmetrically pentagonal stem joints of Pentacrinus asteriscus are very abundant in the Jurassic of the western part of North America. Living forms occur chiefly in the Caribbean Sea and the Pacific Ocean.

I. Sketch side view, noting calyx, arms, pinnules, stalk.

2. Compare it to the starfish.

3. How and what does Pentacrinus eat? How breathe?

4. Of what does the nervous system consist?

5. Could the animal move? Reasons.

6. Is the skeleton external or internal? Illustrate by means of a plate of the stalk.

7. What is the significance of the name crinoid?

8. What is the evolutionary significance of the fact that the plates of the stalk immediately below the calyx are five-pointed, but later become rounded?

Eucalyptocrinus (Fig. 63).

Silurian, rarely Devonian.

Calyx with a deep concavity at the stem end. Attached to the elongate ventral portion of the calyx and extending its full 
length are ten vertical partition plates; in each of the ten compartments thus formed are lodged two arms, which unlike Pentacrinus never extend upward beyond the calyx.

I. Sketch side view, noting calyx, vertical partitions, arms if preserved.

2. In what conspicuous feature does this genus differ from most other crinoids?

\section{CLASS D, ASTEROIDEA (STARFISHES)}

Body free, star-shaped, with a central disk and hollow arms (usually five in number), each containing a prolongation of the organs of the body. Movement is by means of the tube-feet which project between the plates from the five ambulacral grooves radiating from the mouth.

Asteroidea range from the Cambrian to the present. Living examples include Asterias vulgaris and Asterias forbesi (p. 149), the common starfishes of the Atlantic coast, the former north and the latter south of Cape Cod. There are many tropical species.

Derivation of name. - Greek aster, star, + eidos (oid), form, in allusion to the star-shaped body.

\section{Paleaster (Fig. 64).}

Ordovician to Mississippian.

Differs from Asterias in having the two rows of ambulacral plates

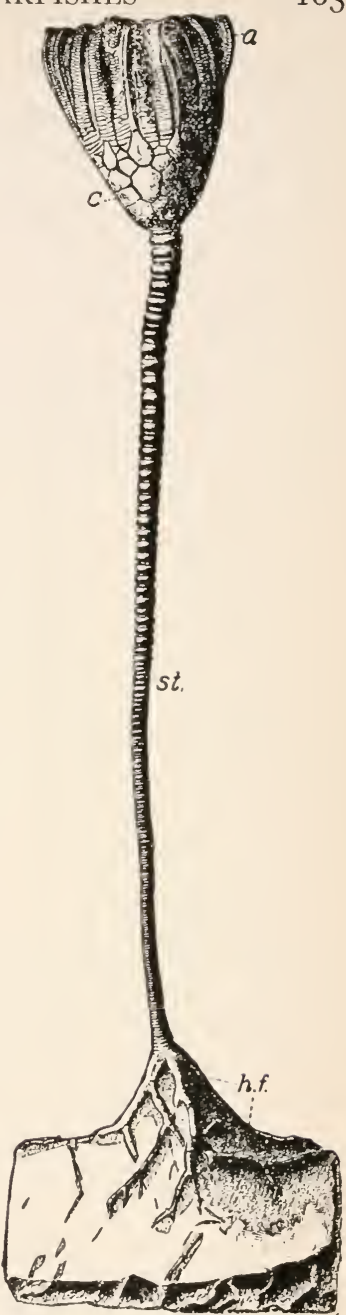

FIG. 63.-Eucalyptocrinuscrassus Hall, from the Middle Silurian of Indiana. a., arms ; c., calyx or cup; h.f., hold fasts, the rootlike basal part for attachment to the ground ; st., stalk. Slightly reduced. (From Hall.) 


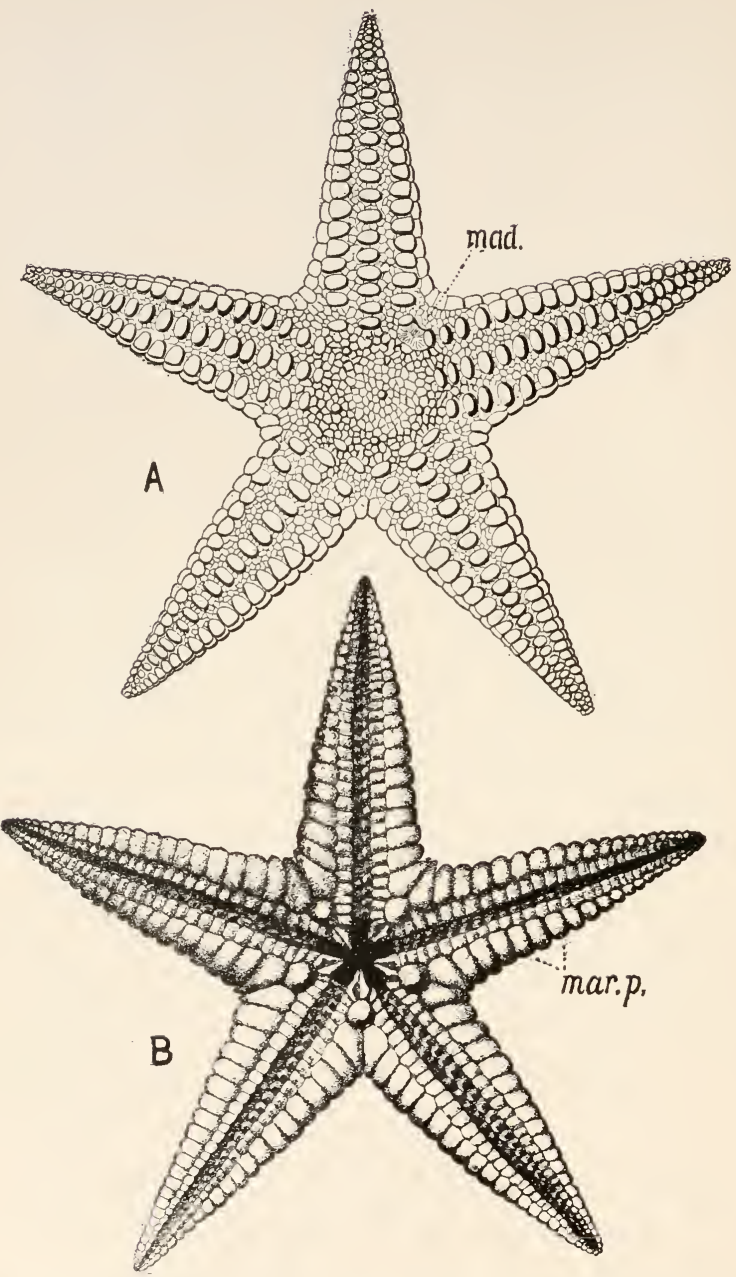

Fig. 64. - Paleaster eucharis Hall, from the Devonian of New York. A, dorsal side, showing the madreporite (mud.). $B$, ventral side, showing the centrally placed mouth and the large marginal plates (mar. p.). (After Hall.) 
but slightly inclined to each other, the plates from the opposite sides alternating, in the very large marginal plates and in having two, instead of four, rows of tube-feet.

I. Sketch specimen.

2. Is it a dorsal or ventral view ?

3. How does it differ from Asterias?

\section{CLASS E, OPHIUROIDEA (BRITTLE STARS)}

Ambulacral and digestive systems confined to the central disk; otherwise in external appearance much like the Asteroidea. Movement by means of the slender, rounded arms which are quite sharply marked off from the central disk. No anal opening present. Madreporite ventral.

The range of the class is from the Ordovician to the present. Living forms are more commonly inhabitants of deep than of shallow waters. Ophiopholis aculeata (Fig. 65), the "brittle starfish," is abundant at a depth of one to one hundred
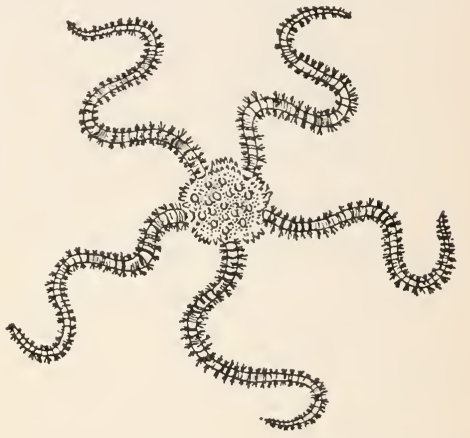

FIG. 65.- Ophiopholis aculeata Gray, from the coast of New England. The brittle starfish. Dorsal view $\left(\times \frac{1}{2}\right)$. (From Verrill and Smith.)

feet in rocky crevices from the coast of New Jersey to the Arctic Ocean and is likewise common on the Pacific coast and in northern Europe.

\section{CLASS F, ECHINOIDEA (SEA URCHINS)}

Free-moving animals, usually with a globular, or disk-shaped, body. Skeleton (test) rigid, formed of firmly united calcareous plates, or more or less flexible with imbricating plates, covered with movable spines. Mouth ventral and central, or anteriorly eccentric, with (except in the adult spatangoids) a complicated 
masticating apparatus, the Aristotle's lantern. Madreporite dorsal, in the right anterior genital plate; this plate orients the sea urchin, the antero-posterior axis passing through the ambulacrum on its left and through the opposite interambulacrum. The anal opening is dorsal, in the posterior interambulacrum.

Straight or variously arranged ambulacral areas run from the dorsal to the ventral surface.

Movement is by means of the elongated tube-feet which pass through, not between, the plates. Many forms in addition move by means of their spines, often quite rapidly.

Sea urchins are gregarious, frequently occurring in such abundance as to pave the surface of the rock and the bottom of tide pools in sheltered places. On exposed coasts, many forms bore cavities by their teeth or by absorption into calcareous and noncalcareous rocks. Common examples are Strongylocentrotus, on the Atlantic coast north of Cape Cod; Arbacia, on the Atlantic coast south to Florida; Echinarachnius, the "sand dollar," on sand beaches from New Jersey northward and on the Pacific coast.

Echinoids are known from the Ordovician to the present.

Derivation of name. - Greek echinos, a hedge-hog, + eidos (oid), form, referring to the spines so characteristic of all members of this class.

Strongylocentrotus (Figs. 66, 67). Upper Tertiary to present.

This differs from the starfish in its globular form, which is slightly compressed dorso-ventrally. The calcareous plates are firmly fitted together like a mosaic, forming a rigid shell. The entire surface, except the region around the mouth, is thickly studded with many rounded tubercles, to which are attached solid spines which are movable by muscles on ball and socket joints (Fig. $67, B$ ). Corresponding to the five ambulacral grooves of the starfish are five slightly expanding ambulacral areas (ambulacra) extending radially from near the center of the dorsal to the ventral side. Each ambulacrum consists of two narrow 

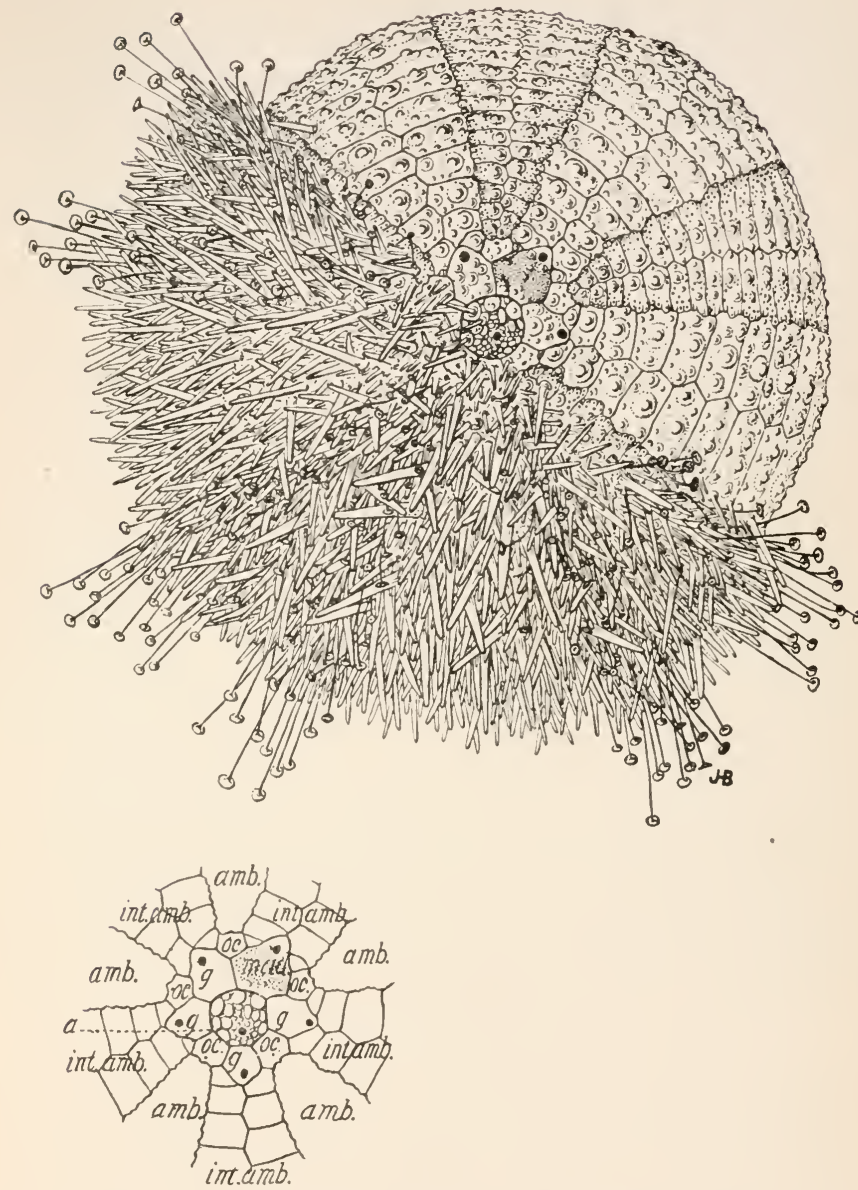

FIG. 66. - The common sea urchin, Strongylocentrotus dröbachiensis Say, from the coast of Maine. Entire individual, dorsal view (with spines, etc., removed from half of the shell (test)). Below is the central dorsal area with ornamentation omitted. $a$., anus, the large black spot within the periproct (the area within the circle of genital plates and protected by many small plates); $a m b$., ambulacrum; $g$., genital plate at tip of each interambulacrum, perforated by the genital opening, - the large black spot; int. amb., interambulacrum; mad., madreporite; oc., ocular plate at tip of each ambulacrum. 
columns of plates through which the long, sucker-bearing tubefeet protrude (Fig. $67, A t . f$.) ; the middle of the area is without pores for tube-feet and bears numerous spines. The tube-feet number about I 800 , and can be protruded beyond the longest

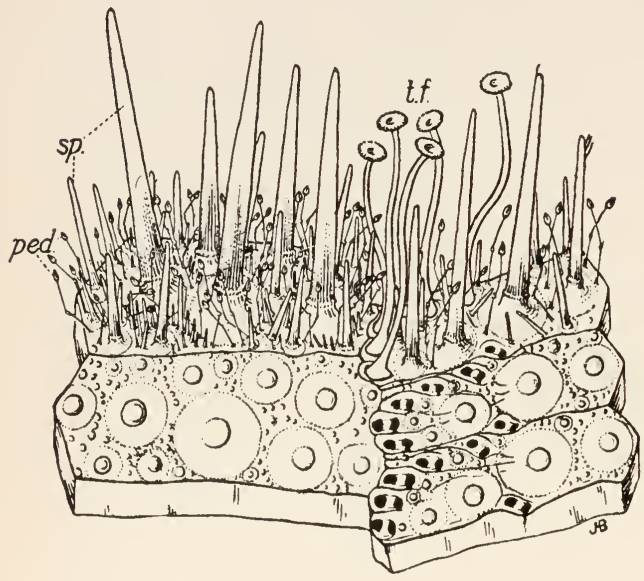

A

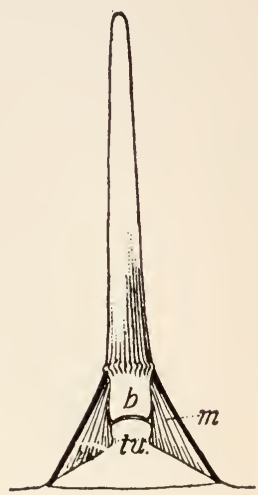

B

Fig. 67. - An enlargement of a small portion from Fig. 66. $A$, an enlargement of the seventh and eighth interambulacral plates, and the adjoining ambulacral ones, counting from the first ocular to the right of the madrepore. $B$, a single spine $(\times 5)$, showing its ball-and-socket joint and the attachment of the muscles to move it. $b$., base of spine; $m$., muscles to move the spine; ped., the small grasping pediceilariæ with the minute pincer-like heads; $s p$., large and small spines; t.f., tubefeet ending in suckers and capable of expansion to double the length shown here, or of contraction to far within the spines; $t u$., tubercle.

spines. Between each set of two ambulacra are the interambulacra, - broad, spine-bearing areas composed of two columns of plates. The water-vascular system is similar to that of the starfish, except that the radial canals giving off the tube-feet lie within, not without, the test.

Growth takes place by the increase in size of the plates and by the addition of new plates dorsally at the ends of the ambulacra and the interambulacra.

A complicated apparatus, called Aristotle's lanter $n$, is connected 
with the digestive system. It consists principally of five enameled teeth meeting in a point; they project slightly out of the mouth, and are moved by a complicated set of muscles. The teeth and muscles are supported by five pyramidal plates which with their connections (epiphyses, bases and compasses) form the skeletal part of Aristotle's lantern. These teeth are used to grind the food into bits. A wide digestive tube extends from the mouth in the center of the ventral (lower) surface to the anus in the center of the dorsal (upper) surface, winding around the inside of the test. There is no such differentiated stomach, nor radial divisions of the digestive system, as occur in the starfish.

The five double rows of long, slender tube-feet enable the animal to cling to the rocks over which it slowly glides in search of the algæ and small organisms on which it lives. Sea urchins are usually vegetable feeders.

The blood vascular circulation is very similar to that of the starfish, having in addition two large intestinal veins parallel to the intestine. The blood has about the same composition as that of the starfish.

Respiration is effected mainly by the upper end of the digestive canal and by the shrub-like gills at the ventral margin of the test.

The nervous system is similar to that of the starfish, and there are present, likewise, five eye spots at the tips of the ambulacra in the ocular plates.

At the tip of each interambulacrum is a genital or basal plate in which are openings for the extrusion of the reproductive elements. Through these pores the eggs and spermatozoa are cast out into the water during summer, where after union they rapidly develop into tiny translucent bilateral larvæ. These larvæ swim about and feed on smaller creatures for several weeks, finally developing a minute, globular, radial sea urchin at the posterior end. In a few hours the larval portion becomes absorbed and leaves the minute sea urchin to drop to the sea bottom. 
Strongylocentrotus dröbachiensis is found in the deep waters of Long Island Sound, in shallow tide pools north of Cape Cod, and covering the rocks upon the Maine coast. It extends into the Arctic Ocean and occurs also on the north Pacific coast.

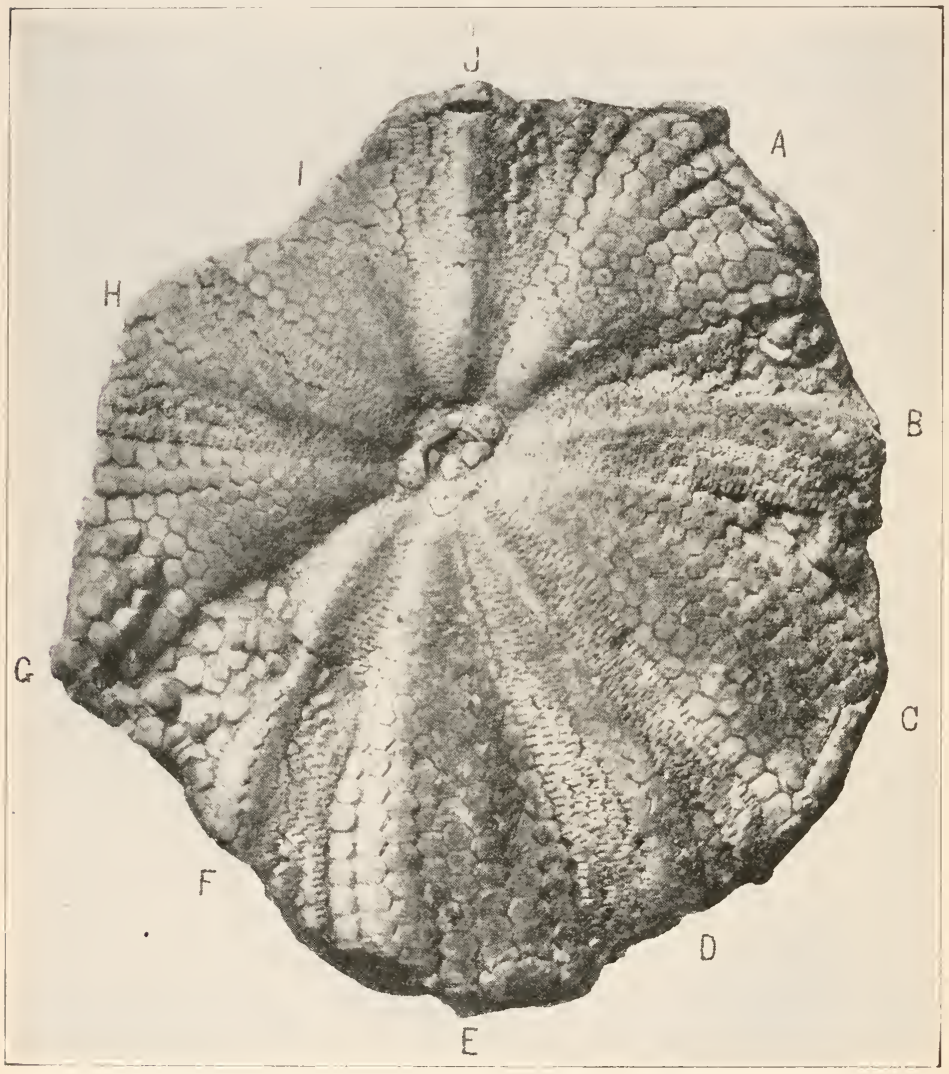

FIG. 68. - The Paleozoic sea urchin, Melonechinus multiporus (Norwood and Owen) which was very abundant in the shallow seas covering much of Missouri during the St. Louis (Upper Mississippian) time. Dorsal view; slightly reduced in size. $A, C, E, G$, and $I$ are the interambulacra; $B, D, F, H$, and $J$ the ambulacra. At the tips of the interambulacra are the genital plates, each with three pores; the ocular plates at the tips of the ambulacra are much smaller than the genitals. (From Jackson.) 
I. Sketch (a) side view, $(b)$ ventral view, $(c)$ dorsal view. Label ambulacra, interambulacra, mouth, anus, teeth if present, openings for tube-feet, madreporite, ocular and genital plates.

2. Compare it with a starfish.

3. How and what does Strongylocentrotus eat?

4. Describe its respiration.

5. How does the animal move?

6. How does it increase in size?

7. Of what use are the spines? Make a sketch illustrating how they are moved.

8. In what directions may a spine be moved?

9. Can Strongylocentrotus climb?

ı. Give the geologic range of Echinoidea.

Melonechinus multiporus (Fig. 68).

Mississippian.

Test very large, spheroidal, marked vertically by elevated, melon-like ribs, which are due to the thickening of the plates and are hence hardly recognizable in internal molds. Ambulacra broad with ten columns of plates at widest part; interambulacral areas with eight or nine columns of plates. Tubercles small, numerous; spines minute, needle-like. This species was very abundant in the St. Louis (Mississippian) seas of Missouri.

The earliest species of Melonechinus had fewer columns of plates than the later ones. (This genus was formerly called Melonites.)

I. Sketch side view, noting ambulacra, interambulacra.

2. Was the living animal attached or free?

\section{CLASS G, HOLOTHURIOIDEA (SEA CUCUMBERS)}

Free, with elongated, more or less cylindrical body. Mouth and anal opening at opposite ends. The body differs from that of the starfish in being greatly drawn out in the direction of the line joining mouth and anus; this line is likewise the direction of movement. The ventral surface is parallel with the axis joining mouth and anus, not at right angles to it as in the 
starfish, and is furnished with rows of well-developed, functional tube-feet. The place of tube-feet on the dorsal side is taken by papillæ lacking suckers. Ten large, branched, contractile tentacles, which are probably enlarged tube-feet, surround the mouth. After the manner of some worms, holothurians devour sand and mud, deriving their nourishment from the organic particles contained in them.

The leathery body is usually supported only by scattered calcareous spicules of various shapes, and possesses no true skeleton. Usually the spicules alone are capable of preservation as fossils; these are known from the upper Paleozoic to the present, but representatives showing the impression of the entire body have been described likewise from the Middle Cambrian of British Columbia.

Holothurians are widely distributed at present through all seas, with a habitat extending from shallow to deep water, in tide pools, on rocks, or in the sand or mud.

Derivation of name. - Greek holothourion, a water-polyp, + eidos (oid), form.

I. Name the seven classes of Echinodermata, giving very briefly the distinguishing characteristics of each; likewise a living and fossil example of each when possible.

2. What do these classes possess in common that they should be placed in the same phylum?

3. How do the Echinodermata differ from the Colenterata in the following characters: $(a)$ habitat, $(b)$ protecting and supporting skeleton, $(c)$ locomotion, $(d)$ food, $(e)$ its capture, $(f)$ its intake, $(g)$ digestion, $(h)$ blood circulation, $(i)$ excretion of waste, $(j)$ respiration, $(k)$ nervous system, $(l)$ sense-organs, $(m)$ reproduction, $(n)$ geologic range?

4. Compare the arms of a starfish to corresponding structures in the other classes.

5. In what class would you look for the ancestor of the stalked forms? For the ancestor of all Echinodermata?

6. In what respects do the Echinodermata show advance over the Coelenterata? 


\section{PHYLUM IX, MOLLUSCOIDEA}

THE Molluscoidea are aquatic, usually marine animals with a well-developed digestive canal. There is a tentacle-bearing ridge (lophophore) surrounding the mouth. This ridge is partly respiratory in function. A nerve ganglion is present dorsal to the osophagus. The soft parts of the body are supported and protected by a calcareous, corneous or membranous covering.

Derivation of name. - Molluscoidea $>$ English Mollusca + Greek eidos (oid), form. The external, bivalve shell of the class Brachiopoda bears some resemblance to the molluscan shell of the class Pelecypoda.

The Molluscoidea are divided into the following classes:

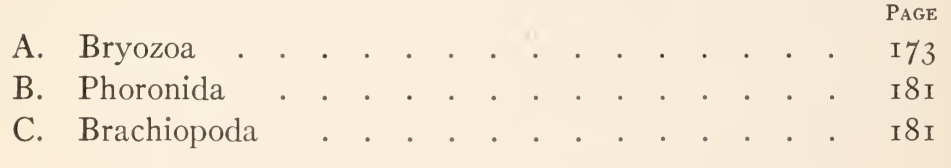

CLASS A, BRYOZOA

Type of class, - Bugula avicularia (living) (Fig. 69).

The most common species on the Atlantic coast, from North Carolina to Maine is Bugula turrita. This may be used in the laboratory in place of $B$. avicularia.

This is a colonial form, growing in tufts two or three inches long on piles or rocks on the seashore in all parts of the world. The colony (zoarium) is made up of erect stems, attached by root-like fibers to the rock or other support. Each stem consists of four parallel rows of closely arranged zoccia, - the individual cups. On nearly all zoøcia is an appendage, the avicularium, with very much the appearance of a bird's head, 


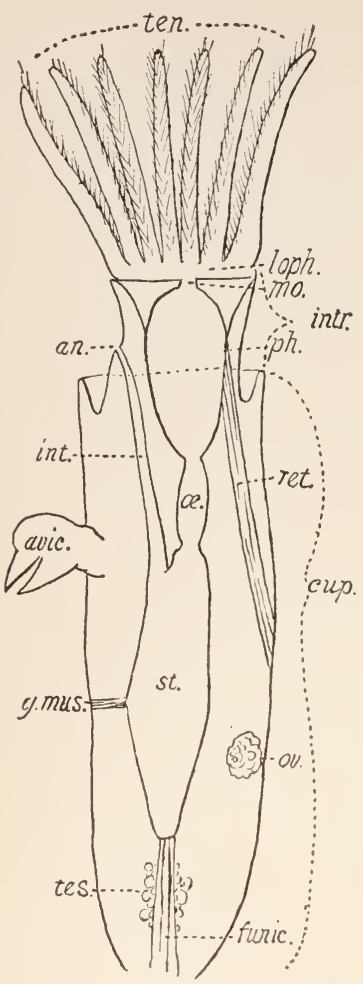

FIG. 69. - Bugula avicularia. Diagrammatic longitudinal section through a single individual, expanded from its protective cup of chitin, in the position of feeding. an., anus; avic., avicularium; funic., funiculus ; $g$. mus., one of the muscles attaching the stomach to the walls of the cup; int., intestine; intr., introvert; loph., lophophore; mo., mouth; a., œsophagus; ov., ovary; ph., pharynx; ret., one of the muscles to retract the introvert within the cup; st., stomach; ten., tentacles; tes., testis. Much enlarged. which is in almost constant movement and whose function is rather problematical, though it is doubtless somewhat protective.

Protection. - Each individual consists externally of a chitinous cup, with the broad opening extending outward from the colonial stem. (The material is closely akin to the true chitin of the Arthropoda.) This cup of chitin is the hardened and thickened cuticle of the entire animal except the anterior portion, or introvert (Fig. 69). Into this hard-walled cup muscles can withdraw the soft-walled anterior body portion, while the contraction of the sphincter muscle at the orifice completely closes the cup and protects the inclosed soft parts. By these muscles likewise the tentacles can be swayed in any direction.

The digestive system is U-shaped with mouth and anus both anterior, and is suspended within the pouchlike colome or body cavity of the animal. The whole anterior portion of the body, the introvert, has walls of thin cuticle continuous with the walls of the chitinous cup and in the contracted state of the animal it is folded back within the cup like the turned-in finger of a glove. When, however, the animal expands, the introvert is pushed out through 
the opening of the chitinous cup. In this expanded condition, the position of feeding, the mouth is seen to occupy the anterior end of the introvert; it is surrounded by a circular ridge, the lophophore, bearing about I4 tentacles. The tentacles surrounding the mouth are densely covered with cilia on their inner surfaces and the vibration of these cilia drive currents of water towards the mouth. The particles of food in these water-currents, as well as those caught by the prehensile tentacles, pass through the mouth into a wide pharynx, thence through a short œsophagus into the stomach. It is here that the digestive canal makes its $\mathrm{U}$-shaped bend, for the intestine rises from the forward end of the stomach and extends in an anterior direction, near and parallel to the oesophagus, to its termination in the anus, which is near the mouth, but outside the circle of tentacles.

There are no blood vessels and no excretory organs. The digested food passes through the digestive canal into the pouchlike body cavity (colome), which contains a fluid in which are colorless corpuscles, the leucocytes. The movement of this fluid is effected largely by the movements of the animal. The collection of the nitrogenous waste matter is probably carried on largely by these leucocytes.

The tentacles are the chief organs of respiration; they are hollow, forming narrow prolongations of the colome and probably effect a transfer of the fresh oxygen of the sea water for the effete gases of the body cavity.

No nervous system has been traced in Bugula. In some other genera it takes the form of a small, rounded ganglion between the mouth and the anus which gives off nerves to various parts of the body. Aside from the tentacles, which may be organs of touch, there are no organs of special sense in any of the Bryozoa, except possibly the epistome of the Phylactolæmata; this is a fold of the lophophore which closes the mouth and may in a manner taste what passes into the mouth.

Each zoœeium is lined internally by a cellular substance, 
the parenchyme, and through this parenchyme it is posteriorly closely united with its neighbors.

Reproduction. - Each new colony arises from a sexually produced individual. The same zoöid possesses both ovary and testis formed from specially modified cells of the parenchyme. The spermatozoa move about in the cœlome and there fertilize the ova. The fertilized ovum passes into a rounded outgrowth of the zoœcium, which forms a sort of brood pouch and there develops into the embryo. This escapes from the parent body, becomes fixed by a sucker to some object, and as the "primary zoöid" secretes the first cup (protœcium), and subsequently gives rise asexually by budding to the new adult branching colony.

I. Examine a colony, noting its attachment, method of branching, the individual cups, avicularia.

2. Examine the mounted specimen under a compound microscope, noting the $\mathrm{U}$-shaped digestive canal, tentacles surrounding mouth, chitinous cup.

3. What is the habitat of Bugula?

4. How is it protected?

5. How does an individual get its food?

6. Describe the method by which the digested food reaches all parts of the animal.

7. How does it breathe?

8. How are the individuals of a colony united?

9. Describe its method of reproduction.

\section{General Survey of Class Bryozoa}

Usually colonial and encrusting animals. A tentacle-bearing ridge, lophophore, surrounds the mouth. An introvert is usually present, and a U-shaped digestive tube. The two sexes are commonly united in the same individual. The body wall of each individual, called the zoœcium, usually becomes hard by means of horny or calcareous materials, forming an exoskeleton which persists after the death of the animal, and which forms the only portion of the animal capable of being preserved 
in the fossil state. Fossil Bryozoa are known from the Lower Ordovician to the present.

Derivation of name. - Bryozoa > Greek bryon, moss, + $z o o ̈ n$, animal. The colonies frequently look like tufts of moss.

Bryozoa are subdivided into the following sub-classes and orders : -

I. Ectoprocta

a. Gymnolæmata

b. Phylactolæmata

2. Endoprocta

Sub-Class I, Ectoprocta

Colonial Bryozoa with the mouth inside but the anus outside the tenacle-bearing lophophore (whence the name from Greek ektos, outside, + proktos, the anus). A well-developed introvert is present.

\section{Order a, Gymnolamata}

Almost exclusively marine; lophophore circular; epistome absent (whence the name from Greek gymnos, naked, + laimos, the gullet). At present the marine forms live from tide level to a depth of over I 8,000 feet. Geologically they extend from the Lower Ordovician to the present. All fossil Bryozoa known, with possibly a single exception, belong here.
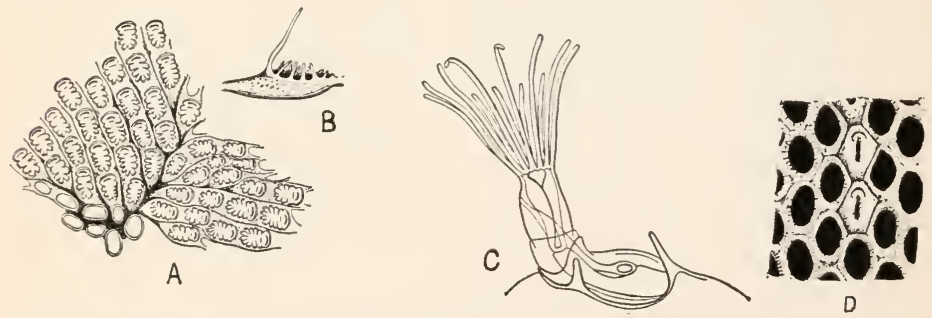

Fig. 70. - The marine bryozoön, Membranipora. $A, M$. pilosa ( $\times 15$ ) from the coast of Massachusetts. Portion of a colony seen from above. $B$, single cell of same seen in profile. $C$, same with one of the individual animals expanded as in feeding. $D$, a fossil species, $M$. rimulata Ulrich $(\times 10)$, from the Eocene of Maryland. (From Ulrich. $A-C$ from Verrill and Smith.) 
Membranipora (Fig. 70).

Jurassic to present.

This genus differs from Bugula in the arrangement of the individuals in the colony. The colony has the form of a flat expansion incrusting seaweed; thus the zoøecia, the individuals, are arranged in one plane, irregularly, or in rows. Each individual, as in Bugula, consists of a chitinous bag, but much shorter and with the rim around its aperture calcified. These individual zoœcia are united to one another by their thickened walls to form a flat, net-like framework.

I. Sketch three zoœcia of a dried specimen.

2. How many individual animals do these three represent?

3. How do the zoœcia differ from those of Bugula?

4. Of what is the skeleton composed?

5. Where at present may living Membranipora be found?

6. What conditions must exist for such a living form to be preserved as a fossil?

Monticulipora (Fig. 7I).

Ordovician to Silurian.

Colonial, occurring as a flat expansion of upright, parallel tubes of calcium carbonate. These tubes have thick, non-
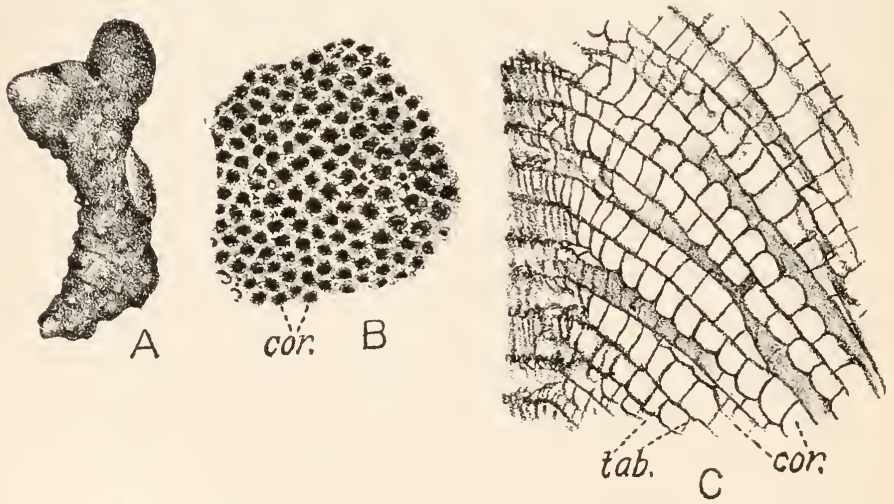

FIG. 7 r. - Monticulipora arborea Ulrich, from the Middle Ordovician of Minnesota. $A$, portion of a colony, natural size. $B$, view of surface $(\times 9)$, showing the cups (corallites, cor.) occupied by the soft bodies of the individual animals during life. $C$, longitudinal section from the periphery of branch inwards through fifteen corallites ( $X \mathrm{r} 8)$; cor., corallites; tab., tabulæ or diaphragms. (From Ulrich.) 
porous walls and are divided into compartments by numerous transverse partitions (diaphragms). The lowest portion of each tube is the narrowest, having been built by the individual in its youth; from this point the tube rapidly enlarges to its maximum, normal diameter. The diaphragms mark its withdrawal from a lower to a higher position. Unlike Bugula, each tube increases in length throughout life. Since, however, the soft parts of the animal increase in size but little, the lower (older). portions of its house-like skeleton must be vacated; this removal takes place at more or less regular intervals, probably due to a contraction of the soft parts of the body following the extrusion of the sexual elements, and wherever the base of the body comes to rest it secretes a calcareous plate, the diaphragm. The tube openings are polygonal or rounded. The surface of the colony is often made irregularly rough by the elongation of groups of individual tubes so as to form small elevations, - monticules (whence the name from Latin monticulus, a little hill, + porus, a pore).

I. Sketch $(a)$ outline of entire colony, $(b)$ a view of three zoœcia showing both the tubes and their openings, also diaphragms in one. Label zoœcia, diaphragms.

2. What may probably be the cause of the diaphragms?

3. How do the zoœcia differ in composition from those of Bugula?

4. Indicate in one zoœcium the position last occupied by the soft portions of the animal.

Fenestella (Fig. 72).

Silurian to Permian.

Colony usually funnel-shaped, composed of a calcareous net-like frame-work made up of straight radiating branches united by cross bars (whence the name from Latin fenestra, a window, + the diminutive ending ella). Upon the upper (inner) side of the radiating branches are two rows of small pits (zoœcia), separated by a median keel-like ridge ; each of these pits lodged the soft body portion of an individual bryozoön. The cross bars do not bear pits. In development the large first, 
or primary, cup (protœcium) secreted by the sexually produced zoöid budded off two cups; each of these gave rise to others. Continued budding produced the mature colony.
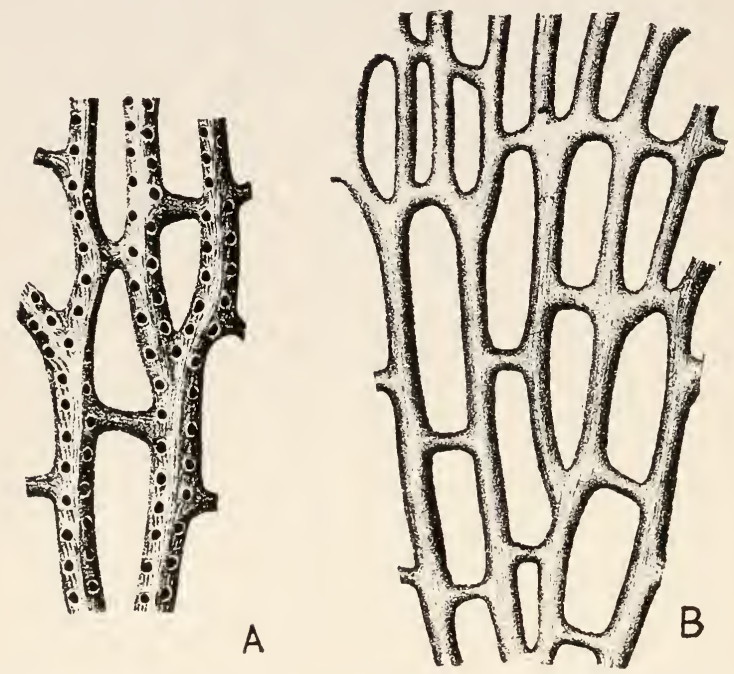

Fig. 72. - Fenestella filistriata Ulrich, from the Burlington limestone (Mississippian) of Iowa. $A$, inner surface of a colony showing the two rows of zoœcia. $B$, outer surface of a colony; note absence of zoœcia. Each $\times 6$. (After Ulrich.)

I. Sketch the upper side of a portion of a colony; indicate the zoœcia, median ridge, cross bars.

2. Sketch in outline the probable shape of the entire colony.

3. Outline its development.

4. What is the significance of the name?

\section{Order b, Phylactolcmata}

Fresh-water inhabitants; lophophore horseshoe-shaped; an epistome overhangs the mouth (whence the name from Greek phylassein, to guard, + laimos, the gullet). Unknown in the fossil state, with the possible exception of Plumatellites from the Cretaceous of Bohemia. 


\section{Sub-Class 2, Endoprocta}

Colonial or solitary Bryozoa with both mouth and anus within the tentacle-bearing lophophore (whence the name from Greek endon, within, + proktos, the anus). The introvert is but slightly developed or absent. All forms belonging to this small sub-class are marine except the American fresh-water genus Urnatella. Not known in the fossil state.

\section{CLASS B, PHORONIDA}

Marine, worm-like, inclosed in a membranous or leathery tube but unable to withdraw the soft parts of body into it; a tentacle-bearing lophophore present, very similar to some bryozoan Ectoprocta. Name from Greek Phoronis, the only living genus. Not known in the fossil state.

\section{CLASS C, BRACHIOPODA (BRACHIOPODS)}

Type of class. - Terebratulina septentrionalis (living) (Figs. $73 a, b)$.

This species is abundant off the coast of Maine, living from low tide to a depth of 300 feet. It occurs from Massachusetts to Nova Scotia inclusive. (Species of the same genus occur in the shallower waters of nearly all seas.)

The animal is protected by a calcareous shell, usually fiveeighths of an inch long and consisting of two pieces (valves). It is attached to a rock or other support by a posterior, fleshy prolongation of the body, called the pedicle.

Skeleton. - The valves are secreted by two fleshy folds of the body, the mantles. The pedicle passes out through a hole (the pedicle opening or delthyrium) in the beak of the larger or ventral valve; hence this valve is at times called the pedicle valve. Fastened to the inside of the smaller or dorsal valve is a calcareous ribbon-like loop, the brachidium, forming an internal support for the hollow, arm-like branches 
(brachia) of the lophophore; because this valve supports the brachia it is often called the brachial valve.

Externally the shell is marked by concentric lines (growth
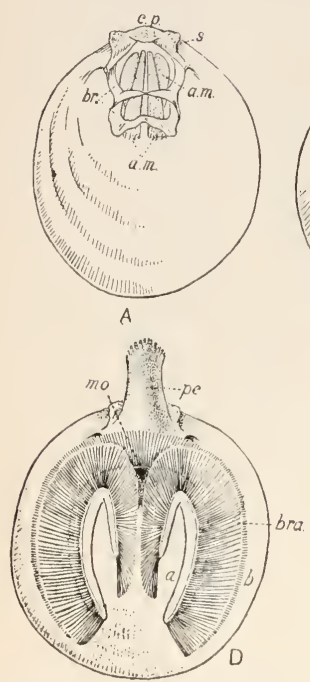
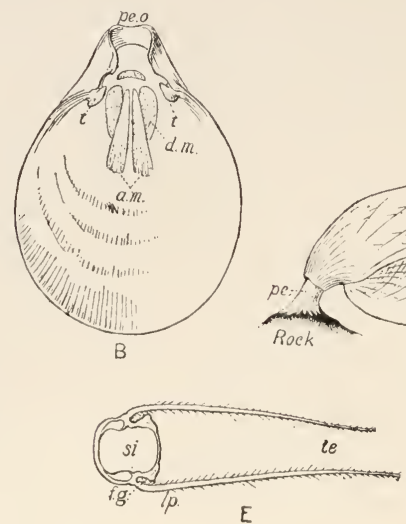

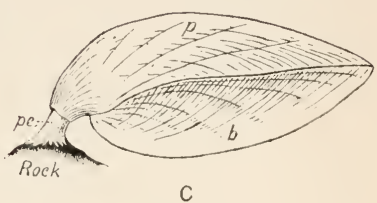

E

FIG. 73 a. - Terebratulina septentrionalis Couthoy, from the coast of Maine. $A$, inside of the brachial valve. $B$, inside of pedicle valve. $C$, side view of the animal fastened to a rock by the fleshy pedicle. $D$, soft body of animal in brachial valve with pedicle valve removed. $E$, an enlarged section of the brachium along line $a-b$ in figure $D$, showing the ciliated tentacles (te.) which urge the food into the ciliated food grooves (f.g.); $a-b$, line of section, Fig. $E ; a . m$. , adductor muscle scar; $b$., brachial valve; $b r$., brachidium; bra., the horseshoe-shaped lophophore with its branches or arms, - the brachia ; c.p., cardinal process, place for the attachment of the diductor muscles; d.m., diductor muscle scar; f.g., food groove ; $l p$., lip; mo., mouth; p., pedicle valve; pe., pedicle; pe.o., pedicle opening for passage of pedicle; s., socket into which fits the tooth $(t.) ; s i$., sinus; $t$., tooth ; te., tentacles. All natural size, except $E$.

lines) which represent the successive stages of growth; as the shell grew new layers were added to the inside, projecting beyond the preceding layers and forming thus a series of shell extensions. (See also pp. 215, 216.) Since the pedicle is present in the youngest shell-secreting stage of the brachiopod, and the animal when young must have had a minute pedicle, growth must 
have begun at the small end or beak of the shell. That this was the initial point of growth is seen likewise by the curving of the growth lines around it. The beak, then, is the oldest portion, while the latest built portion is the edge of the shell away from the beak.

The pedicle is further inclosed, as it passes out of the valve, by two triangular plates, the deltidial plates, which, therefore, more or less close the delthyrium. A pair of teeth on the posterior portion of the pedicle valve fit into corresponding sockets in the brachial valve; these sockets are also the bases of the calcareous skeleton that supports the arms. Projecting between the teeth of the pedicle valve is a short prolongation, the cardinal process (c.p., Figs. $73 a, 80,85$ ) of the posterior portion of the brachial valve.

Since during the growth of the shell the teeth enlarge externally and anteriorly, while probably both resorption and wear take place internally and posteriorly, the hinge line becomes continually broader; i.e. the teeth move farther apart and, pari passu, calcium carbonate is added to the inside of the sockets, thus causing the hinge line of this valve likewise to become broader. Thus the brachial valve as a whole moves anteriorly.

Muscles. - The valves are opened and closed by muscular action. The pedicle valve may be said to be stationary because to it is firmly attached the pedicle. Two pairs of muscles, the diductors, extend from the posterior portion of the pedicle valves back to the tip of the cardinal process. Being thus situated, their contraction tends to cause the valves to fly open. The valves close by the contraction of two other muscles, the adductors, which pass transversly from valve to valve. These are elongate and narrow on the pedicle valve, and in passing over to the brachial valve divide, leaving here four more or less circular scars. A pair of muscles extending from the brachial valve and another pair from the pedicle valve with insertion on the pedicle enable the animal as a whole to move in many different directions. 
The soft body of the animal, lying at the posterior portion of the shell, occupies only about a third of the interior. The body wall gives off two folds or mantles, one fitting closely to and secreting the pedicle valve, the other secreting the brachial valve. Prolongations of this mantle, the cæca, fitting into minute pores (tubules) in the valves, probably supply nourishment to and take waste from the non-calcareous part of the shell. Any marked injury to a mantle is necessarily reflected in the shell. If something injures a mantle edge, the first process in healing is a puckering up of the mantle around the injured place (as in the healing of an injury to a man's skin) which causes a like puckered appearance in the shell at that place; as the mantle becomes healed the growth lines of the shell become more and more regularly spaced. But since an injury to one mantle causes a lessened vitality, even if very slight, of the entire animal, the opposite mantle likewise displays a crowding and general interruption of regularity in the growth lines. It thus follows that the life history of the individual can be read from the beak forward, not only in relation to the shape and size of the shell, but to its injuries, social crowdings and general health. (See also Fig. 4.)

Most of the inner space between the mantles is filled with the tentacle-bearing lophophore; this is supported by the calcareous ribbon or skeleton, the brachidium. Those portions of the lophophore which diverge arm-like from the two sides of the mouth are called the brachia.

The food consists of diatoms, infusorians, etc., as well as of microscopic organic fragments. Upon each branch of the brachia there is a groove bounded on each side by lines of ciliated tentacles, and which extend from the tip of each arm to the mouth, - a slit-like opening in the middle of the lophophore.

The motion of the cilia upon these tentacles and within the food grooves (Fig. $73 a, E$ ) causes a current of water, and with it any near-by food particles, to sweep into the grooves and along these grooves to the mouth. 
From the mouth the food passes through an œesophagus into the stomach, into which from each side opens a large stomachal gland which probably performs the functions of both liver and
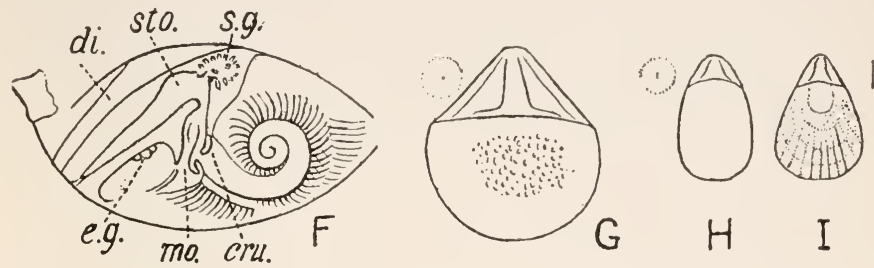

FIG. 73 b. - Terebratulina septentrionalis. $F$, longitudinal vertical section through entire animal ; $G, H, I$, young stages of the shell, looking upon the brachial valve and the pedicle opening of the pedicle valve. $G$, earliest attached stage in the growth of the shell, showing the large open delthyrium. $H$, a later stage. $I$, stage showing the introduction of the radiating striæ and an approach to the adult in outline. cru., crura (the bases of the brachidium); di., diductor muscle; e.g., external glands; mo., mouth; s.g., stomachal glands; sto., stomach. The size of $G$ and $H$ are indicated by the mark within the circle, of $I$ by the line to the right. (From Morse.)

pancreas of higher forms, thence into the intestine which terminates in a closed point, no anal opening being present (Fig. $73 b, F)$. The digestive waste, in the shape of minute pear-shaped bodies, is carried out of the stomach through the œesophagus by the cilia lining it, and is ejected through the mouth. The digested food absorbed by the surface of the digestive tract, aided very largely by the stomachal glands, passes into the body cavity surrounding it. The fluid filling this body cavity is moved by the cilia lining it and performs the function of the blood; thus the digested food entering it is urged into all parts of the body. This body cavity, or coelome, is continued into the lophophore and its branches; it also extends into each of the mantle lobes in the form of branched canals, - pallial simuses; the impression of these upon the shell is often seen in fossil forms (Fig. 85, D, E). The colomic fluid or blood is colorless and contains corpuscles. A small contractile sac posterior to the stomach has been considered as possibly a heart, and radiating from this are a number of vessels; since the main blood circula- 
tion, however, is independent of it, its function may be lymphatic or more probably genital.

The excretory organs consist of two large funnel-shaped nephridia, one on each side of the intestine. They have a wide inner opening into the coelome and a narrower outer opening near the mouth ; their function is to get rid of the nitrogenous waste gathered from the colomic fluid.

Respiration is effected mainly through the mantles, for the blood sinuses branch broadly within them; it is largely aided also by the lophophore and its tentacles.

There is a nerve ring around the osophagus enlarged into a dorsal and a ventral ganglion which give off nerves to the lophophore, mantle, etc. No sense organs are known, but the animal is sensitive to touch.

The sexes are probably separate; at least the same individual does not produce both ova and spermatozoa at the same time.

After the fertilization of an ovum by a spermatozoön the single cell divides into two cells. Repeated division results in the formation of a many-celled but hollow sphere, - the blastula ; one side of this sinks in against the other, producing a twowalled cup, the gastrula. After the cup-like opening of the gastrula closes, the embryo becomes ciliated and is capable of moving freely about. It now becomes gradually constricted into three regions, - the head, thoracic and pedicle areas, with a total length of about a third of a millimeter. From the middle, or thoracic, segment grows a ring-like fold extending back towards the pedicle segment. Soon, however, this circular fold or mantle divides into two, the dorsal and ventral mantle lobes, which develop bundles of chitinous bristles upon their free edges. After three or four days of this early embryonic life, the animal settles down, attaching itself to some foreign object by the end of the mucus-coated, sucker-like pedicle; later the mantle lobes turning inside out, bend forward so as to inclose the head segment and what is now the outer surfaces 
secrete the dorsal and the ventral valves of the horn-like, embryonic shell (protegulum, Fig. $73 b, G, H, I$ ). About the same time a crescentic fold, the future lophophore, grows out from the inner side of the brachial mantle lobe, developing gradually into the two arms which diverge from the mouth; simultaneously the muscles develop, the additions to the shell become calcareous and in all ways the animal approaches the adult.

I. Examine specimens, noting pedicle, mantle, adductor and diductor muscles; the relation of mouth to food grooves on lophophore.

2. Sketch transverse section of one of the brachia, labeling food groove and tentacles.

3. Make drawings of $(a)$ entire shell, side view, (b) interior and exterior of each valve. Label pedicle and brachial valves, pedicle opening, teeth, sockets, cardinal process, brachidia, adductor and diductor muscle scars.

4. Sketch an ideal longitudinally transverse section through the slightly gaping valves, labeling the valves, pedicle opening, cardinal process, muscles and mantle.

5. How are the valves held together? How are they opened? How closed?

6. Give the habitat of Terebratulina septentrionalis.

7. What does the animal eat? How does it procure its food?

8. Briefly describe its digestion; absorption; circulation.

9. How is the digestive waste thrown off?

I0. How does the animal breathe?

I I. What is its nervous system like?

I 2. Describe the development of an individual from the fertilized egg to adulthood.

\section{General Survey of Class Brachiopoda}

Marine animals, secreting a bivalved, equilateral, inequivalved shell, which is composed of lime carbonate, lime phosphate, or a horny substance (ceratin); the valves are dorsal and ventral in position. The animal, in its youth, is always attached to a foreign object by a posterior, fleshy stalk, called the pedicle; 
when adult the pedicle may be lost, but in all such cases the animals are held in place by social crowding, spines, or other devices (Rafinesquina, Stropheodonta demissa, Productus); at times it is cemented to some foreign object (Crania, Meekella, Richthofenia).

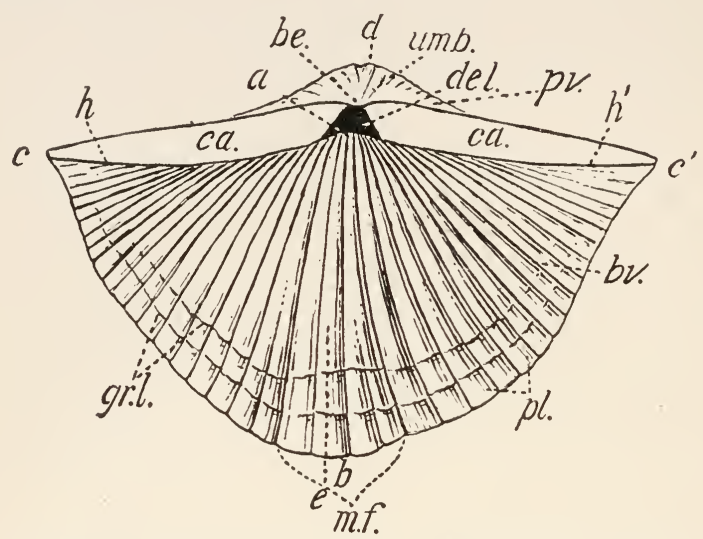

FIG. 74. - Spirifer increbescens Hall, from the Mississippian of Alberta. ( $\times 2$.) $a-b$, length of shell (from hinge line beneath the beak to front of shell); $b$, anterior margin or front of shell; be., beak, the posterior end of the shell; $b v$., brachial valve; $c-c^{\prime}$, width of shell; $c$ and $c^{\prime}$ are the cardinal extremities; ca., cardinal area of pedicle valve, the flattened area above the hinge line and between the cardinal extremities (each valve has a cardinal area) ; $d-e$, height of shell (measured between the centers of the valves and at right angles to the plane of length and breadth); del., delthyrium, or triangular pedicle opening; $g r . l$. , concentric growth lines marking the anterior margin of the shell at successive periods; $h-h^{\prime}$, hinge line (compare Fig. $78, h l$.) ; m.f., median fold (composed here of four plications in this species); $p l$., plications (folds radiating from the beak, not longitudinally striate); p.v., pedicle valve; umb., umbo of pedicle valve.

For terms describing the exterior of the shell see Fig. 74 . The valves are opened and closed by muscles, the impressions of which show upon the interior of the valves in front of the beaks (Fig. 73 a). For formation of ribs, etc., see p. 220.

The interior of the shell is lined by the mantle, - a membranous fold of the body-wall, which is often studded with minute tubes, the cæca; these fit into correspondingly minute holes (tubules) in the shell; the tubules give to the shells 
their punctate appearance; in some species, as Terebratella plicata, this is quite coarse, being almost visible to the naked eye. Within the mantle are hollow spaces, the pallial sinuses; impressions of these sinuses are often found upon the interior of the valves.

The pedicle valve is secreted by the ventral and the brachial valve by the dorsal mantle lobe. In those forms in which the brachial valve as a whole moves forward during the enlargement of the shell this would leave the dorsal surface of the pedicle unprotected were it not that this surface has developed upon it one or two special plates. In a portion of the Articulata (the Protremata) the surface of the pedicle itself secretes a shell, the deltidium, which unites with the posterior margin of the pedicle valve and continues to grow anteriorly (as in Rafinesquina). In the rest of the Articulata (Telotremata) where the deltidium is absent, the extension of the ventral mantle lobe grows out laterally for the protection of that portion of the pedicle by a secretion of two plates, - the deltidial plates (as in Atrypa).

Teeth and sockets are absent in many forms with ceratin (horn-like) shells; these are therefore known as the Inarticulata, the opening and closing of the valves being effected by a more complicated set of muscles. In the great majority of brachiopods the shells are calcareous and here there are teeth and sockets; these are the Articulata.

In the Inarticulata, where the setæ upon the mantle margins are long, acting as strainers (Fig. 75) to the ingoing water, the shells are non-plicate. In the Articulata, where the setæ are short, the shells are often plicate. In a plicate shell the valves need open but slightly to admit sufficient water and yet keep out sand, enemies and other objectionable objects.

The pedicle valve can usually be distinguished from the brachial by some one of the following characters :

I. Larger size and greater depth.

2. Presence of a pedicle opening. 
3. Higher cardinal area (vertical distance from hinge line to beak) than in the brachial valve.

4. Beak incurved over that of brachial valve.

Brachiopod shells often appear to be very similar to pelecypod shells, but may usually be readily distinguished from them by one or more of the following characters:

\section{Brachiopoda}

I. Equilateral

2. Inequivalved

3. Pedicle opening present (except in Atremata)

4. Teeth in one valve, sockets in the opposite valve (except in Inarticulata)

5. No ligament present; valves opened by muscles

6. Valves dorsal and ventral

\section{Pelecypoda}

I. Inequilateral

2. Equivalved (generally)

3. No pedicle opening present (in some a byssal notch or hole)

4. Teeth and sockets in each valve (typically)

5. Valves not opened by muscles but by ligament or resilium at hinge line

6. Valves right and left

It is suggestive of retrogression in the Articulata sub-class that while in living species the anus ends blindly, in Paleozoic forms it was probably functional. In Rensselæria, Athyris, Atrypa, Rhynchonella, etc., the beak of the brachial valve is notched or perforate (between floor of valve and union of the bases of the arm supports) for its passage to the exterior. In Strophomena and Stropheodonta it passed between the branches of the cardinal process. In living Inarticulata, as Lingula, the digestive canal ends in an open anus.

All brachiopods are in the larval stage free-swimming, sometimes for a very short time (longest among Inarticulata); it is hence during this period that their distribution in space takes place. The cause of the distribution is mainly one of ocean currents, since the microscopic larva, about a third of a millimeter long, swims about by a twirling motion for comparatively few hours and at a rate which could carry it only about a yard an hour. 
Brachiopod shells are small, averaging from a half inch in length and breadth to an inch and a half. The largest species known - Productus giganteus of the Mississippian - reaches at times a width of almost a foot, while mature forms are known which are no larger than a pinhead.

There are about 160 species of living brachiopods, which are distributed in 33 genera. Over 75 per cent of these species belong to the Articulata.

Living brachiopods are found in all seas and down to depths of I 7,000 feet, hence at all oceanic temperatures; about 20 per cent live in the shallow seas around Japan, the most prolific area for these shells. Over 70 per cent live in shallow waters, i.e. from between tides to a depth of 600 feet. The great majority ( 75 per cent) of the Inarticulata live above the 15 -fathom line, while but 20 per cent of the Articulata live here. Compared with the deep sea species, the shallow water and littoral forms are much more prolific in numbers, with much thicker and usually larger shells. Brachiopods are thus very important in the study of ancient geography. For example, the presence of fossil Inarticulata, especially those of the Lingula group, is good evidence of shallow water deposits. Of those species belonging to groups existent in the Paleozoic not one is known which at present has a wholly abyssal habitat; most of the abyssal forms date from stocks having their rise in the middle Mesozoic or later. Hence the conclusion, corroborated by other classes of animals, that abyssal seas began to form at the close of the Paleozoic with the late Paleozoic upheavals, known for North America as the Appalachian Revolution.

Though all brachiopods are strictly marine in habitat, some forms, such as Lingula, can endure a considerable amount of fresh water, living in estuaries where there are heavy spring freshets, but they never live in rivers.

The living inarticulate brachiopods possess a wonderful vitality. Lingula may be exposed between tides, covered with mud from freshets, or immersed in fetid water for months without 
apparent ill effects. Crania will also thrive under most adverse conditions. Such adaptability is probably the cause of the persistence of these two genera from Ordovician times to the present.

The persistence of genera and species in time varies greatly. Some genera, as Hipparionyx and Rensselæria (Lower Devonian), survived but a short time ; while others, as Lingula and Crania, have existed since Ordovician times. Rhynchotrema capax (Richmond formation of the Upper Ordovician), for example, was short-lived but of wide distribution; it is thus a good index fossil (see page 22), while Leptana rhomboidalis, persisting from mid-Ordovician to Mississippian, Atrypa reticularis, throughout the Silurian and Devonian, and Productus semireticulatus, throughout the Mississippian and Pennsylvanian, were the brachiopod Methuselahs of the Paleozoic; these forms are accordingly almost valueless as indicators of the age of their inclosing strata.

Brachiopods are known since the earliest Cambrian, and therefore the class must have originated in the pre-Cambrian; the class reaches its maximum of differentiation in the Silurian and Devonian, with the dying out of stocks in the late Paleozoic. Since Mesozoic times the rhynchonellids and terebratulids have dominated, and along with them a few lingulids, discinids, cranids and strophomenids have persisted. The class is tending slowly toward extinction.

Derivation of name: Brachiopoda $>$ Greek brachion, arm, + pous (pod), foot. The arms (brachia) were formerly thought to be organs of locomotion.

The Brachiopoda are subdivided into two sub-classes:

I. Inarticulata.

2. Articulata.

\section{Sub-Class i, InARTiculata}

Valves held in apposition merely by muscles, there being usually no teeth or sockets to hold the two valves firmly together 
(whence the name from Latin in, not, + articulatus, jointed). Intestine ends in an anus; this in the Lingula group opens laterally between the two valves.

Lingula (Fig. 75).

Basal Ordovician to present.

Valves thin, almost equal, elongate, tapering towards the beak (i.e. tongue-shaped, whence the name from Latin lingula,

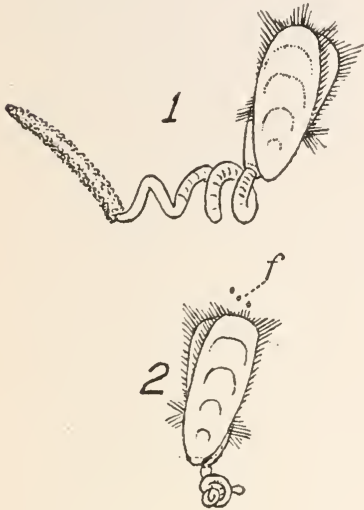

A
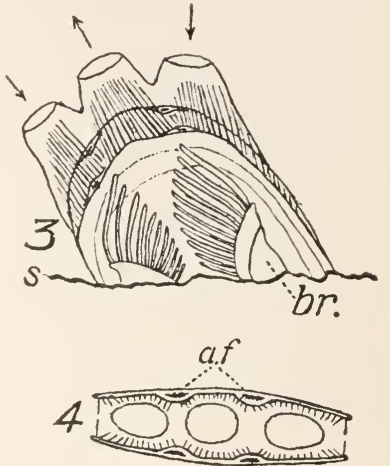

B

FIG. 75. - Brachiopod movements. A, a Lingula-like shell, Glottidia pyramidata, very abundant upon the shoals of the North Carolina coast, ixposed at low tide. Natural size. I. A characteristic attitude; the sand tube inclosing the posterior end of the pedicle is here preserved. 2. Fæces $(f$. ) being extruded from shell. $B$, Lingula lepidula, very abundant upon the coast of Japan, showing the formation of tubes by the mantle and setæ. Through these tubes the water is urged by the cilia lining the brachia, and with the water food is taken in and waste is extruded by the outgoing current. 3. Attitude in sand with setal tubes formed; the brachia show through the transparent shell. 4. Front view of above. a.f., anterior folds of mantle; $b r$., brachia; $s$, surface of the sand in which the animal lies half buried. (From Morse.)

a little tongue). Valves glistening, composed of alternate layers of phosphate of lime and a horn-like substance (ceratin), impunctate. The animal burrows in the sand by means of the long, slender pedicle which emerges from between the two valves and 
not through one of the beaks as in the majority of other brachiopods.

Lingula anatina is a large species very abundant in the Japanese seas.

Glottidia pyramidata (Fig. 75, A), belonging to the Lingula group, is very abundant off North Carolina on shoals exposed at low tide; it occurs from Chesapeake Bay to Florida. In its normal condition, it lies with its shell half buried in the sand, its anterior setæ so grouped as to form three rude channels for the entrance of water at the angles of the front of the shell and for its exit at the middle. Each mantle is at the same time raised into two folds, one upon each side of the median line of the shell, thus aiding in the formation of these water channels (see Fig. $75, B$ ). The tentacles of the brachia are directed towards these setal tubes, while the vigorous motion of the cilia covering the tentacles causes the movement of the water. At this time the two valves are separated vertically but not laterally. Anteriorly they are open, but posteriorly as nearly closed as the pedicle will allow. The sand is kept out of the buried portion of the shell by the arrangement of the lateral setæ vertical to the plane of the valves, the setæ from opposite mantles meeting tip to tip. When disturbed the shell is quickly drawn down into the sand through the contraction of its long pedicle, the lower end of which obtains greater purchase by being sheathed in a tube of sand grains cemented together by the mucus which it secretes. This species does not live beyond a year.

I. Examine specimens on the demonstration table, noting the elongate pedicle emerging from between the two valves.

2. How long geologically has Lingula existed?

3. Is either valve perforated by a pedicle opening?

4. What is the use of the long pedicle?

5. How does the animal get its food?

6. What is the composition of its shell?

7. How do fossil Lingulæ indicate the depth at which the inclosing sediment accumulated? 
Crania (Fig. 76).

Ordovician to present.

Shell small, nearly circular in outline, without pedicle opening in adult but cemented by apex or by entire surface of pedicle valve to the surface of a shell or other foreign object. Brachial (upper) valve conical, with beak almost central and directed posteriorly. In each valve there is a pair of widely separated muscle scars near the posterior margin and a pair close together near the center. Impressions of the pallial sinuses branch finger-like.

I. Sketch a valve, naming the valve and noting muscle scars if present.

\section{Sub-Class 2, Articulata}

Valves held firmly together by teeth and sockets (whence the
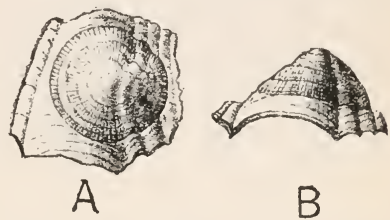

FIG. 76. - Crania bordeni Hall and Whitfield, from the Middle Devonian of Indiana. Natural size. $A$, an entire individual attached to a brachiopod shell which has vertical ribbing at the right of the figure. The conformation of the upper valve to the ornamentation of the brachiopod shell indicates the intimate relationship existing between the mantle edges of the two valves. $B$, side view of the same. (After Hall and Clarke.)

\section{name from Latin articulatus,}

jointed). In living species the intestine ends blindly, but in some Paleozoic forms it apparently opened through a foramen in the cardinal area of the brachial valve; if this opening was in life occupied by the anus, it suggests that a degeneration in structure has accompanied the retrogression in numbers for this sub-class.

Rafinesquina (Fig. $77, A, B$ ).

Almost wholly Ordovician.

Pedicle valve more or less convex, often without pedicle opening in the adult. The apex of its beak has a minute depression, - the pedicle opening of the very young shell, but with age the pedicle usually disappeared, probably through resorption. The shell rested free upon the sea-bottom, but was held in place through social crowding, while the inner end of the pedicle opening became filled with lime, secreted prob- 
ably by the extension of the ventral mantle. Brachial valve flat or concave. Hinge line straight. Surface with radiating
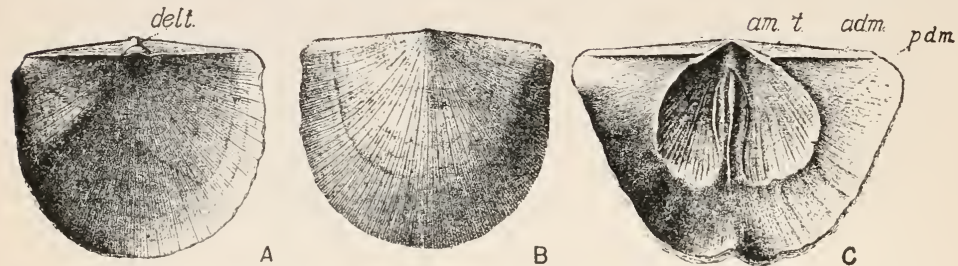

FIG. 77. - Rafinesquina alternata Conrad $\left(\times \frac{3}{5}\right)$, from the Ordovician of Cincinnati, Ohio. $A$, exterior of brachial valve. $B$, exterior of pedicle valve. $C$, interior of pedicle valve of Strophomena. a.m., adductor muscle scar; a.d.m., posterior diductor muscle scar; delt., deltidium; p.d.m., anterior diductor muscle scar; $t$., tooth. (From Hall and Clarke.)

striæ alternating in size. Shell punctate. (Name in honor of the French-American scientist, Rafinesque.)

$R$. alternata is the most widely spread and abundant species; being found almost everywhere in the Middle to Upper Ordovician of North America.

I. Sketch $(a)$ exterior of pedicle valve, $(b)$ cardinal areas of entire shell, $(c)$ the cut portion of a vertical section through entire shell from beak forward. Label in all, where present, pedicle and brachial valves, hinge line, cardinal areas, beak, deltidium, front of shell.

2. Indicate in sketch I $(a)$ the oldest portion of shell, stating your reasons.

3. How do you know the convex valve is the pedicle valve?

4. Draw in your sketch of the pedicle valve the outline of the shell when half grown, stating how you know that this was its shape.

5. State whether the animal was attached or free when adult, giving reasons.

Strophomena (Figs. 77, C, 78).

Ordovician.

A resupinate Rafinesquina, i.e. pedicle valve concave or sigmoid in section, and the brachial convex. The muscular area on the pedicle valve is sharply limited by elevated ridges. Shell punctate. 
I. Sketch the cut portion of a vertical section through the entire shell from beak forward, labeling the pedicle and brachial valves.

2. How do you distinguish this genus from Rafinesquina?

3. Was the pedicle valve concave and the brachial convex in its youth as it is in its adult state? Reasons.

Leptæna (Fig. 79).

Ordovician-Mississippian.

Pedicle valve convex, brachial concave. The flat portion of the shell is concentrically wrinkled; where these wrinkles cease the shell is abruptly deflected. Shell with closely appressed valves, thin, i.e. with very little space for the soft parts of the animal. Shell punctate.

I. Sketch $(a)$ a view of exterior of pedicle valve showing the concentric wrinkles and the deflected anterior portion, $(b)$ the cut portion of a vertical section through the entire shell from beak forward. Note pedicle and brachial valves.

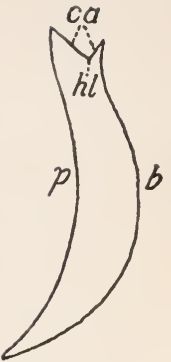

FIG. 78.- A diagrammatic longitudinal cross section of the brachiopod shell. Strophomena planumbona Hall $(\times 2)$. Section cut beside the deltidium. This is similar to Rafinesquina (Fig. 77), except that the convexity of the valves is reversed; $b$., brachial valve; c.a., cardinal areas of brachial and pedicle valves; h.l., hinge line; $p$., pedicle valve.

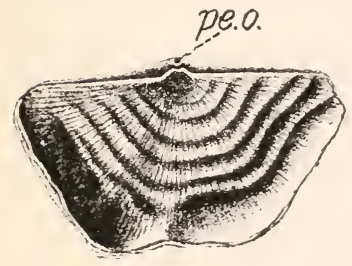

A

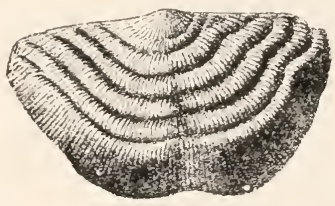

B

FIG. 79. - Leptana rhomboidalis Wilckens. A, adult brachial valve (natural size), showing the exceptional retention of the pedicle opening (pe.o.) in the opposite (pedicle) valve. $B$, adult pedicle valve. $C$, pedicle valve $(\times 10)$, a young stage in the growth of the shell showing the beginning of the radiating striæ. $C$ redrawn from Beecher. ( $A$ and $B$ after Hall and Clarke.) 
Stropheodonta (Fig. 80).

Silurian to Devonian.

Shell similar to the preceding but with the hinge margins marked by more or less long transverse ridges which terminate

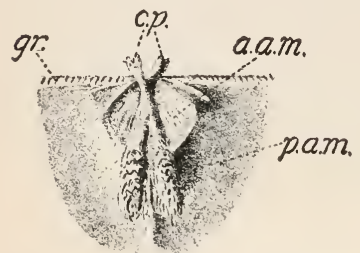

FIG. 80. - Stropheodonta concava Hall, from the Hamilton (Devonian) of New York. $\left(\times \frac{3}{4}\right.$. $)$ Muscle area of the interior of a brachial valve. a.a.m., the broad posterior adductor muscle scars; c.p., cardinal process for attachment of diductor muscle; $g r$. , vertical grooving, or ridging, of the edge of shell at hinge line, giving rise to the name; p.a.m., the elongate anterior adductor muscle scar. (From Hall and Clarke.)

times produced into ears. ribs, or elongate pustules, which are usually studded with spines. Shell punctate. (Name from Latin productus, produced; so named from the prolongation of the beak of the pedicle valve beyond that of the brachial.)

Productus semireticulatus is world-wide in distribution, in the Mississippian and Pennsylvanian.

I. Looking fully upon the hinge line of entire shell, sketch a view showing brachial valve and umbo of pedicle valve; indicate valves, spines, radiating ribs.

2. State whether the animal was attached or free when adult, giving reasons.

3. How were the spines formed?

4. Is Productus semireticulatus a good index fossil? Reasons. 

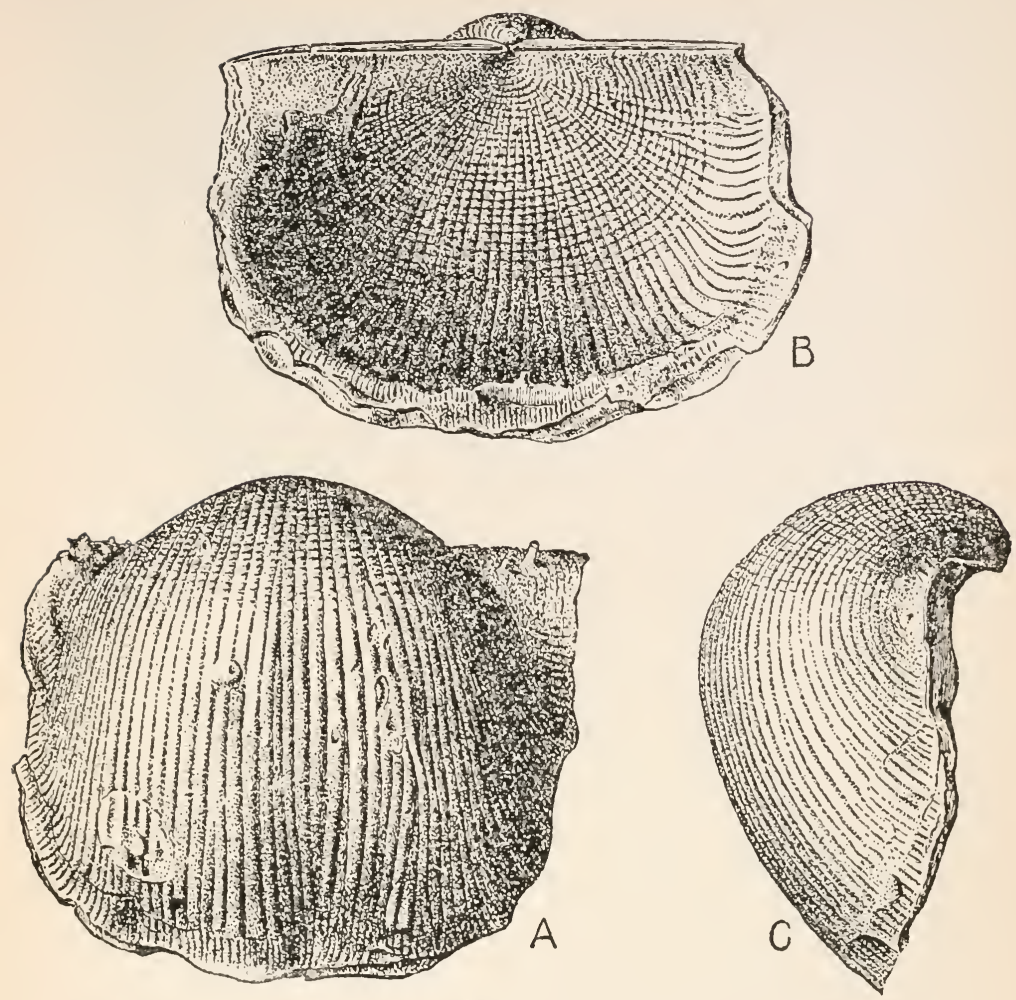

Fig. 8r. - Productus semireticulatus Martin, from the Pennsylvanian of Indiana.

Three views of one individual, natural size. $A$, pedicle valve; $B$, brachial valve with umbo of pedicle valve showing over edge of hinge line. $C$, side view. (After White.)

Platystrophia (Fig. 82).

Ordovician to Silurian.

Hinge line long. Both valves very convex, with a strong median fold in the brachial valve and a corresponding deep sinus in the pedicle valve. Entire surface covered with broad, strong, sharp plications (whence the name from Greek platys, wide, + strophos, a band). Shell impunctate but with a granulose surface. 
This has developed from Orthis lenticularis of the Upper Cambrian, a plicate species with a smooth median fold upon the pedicle valve and a smooth sinus upon the brachial. Later the median fold of the former becomes depressed between the two bounding plications forming the central plication of the median

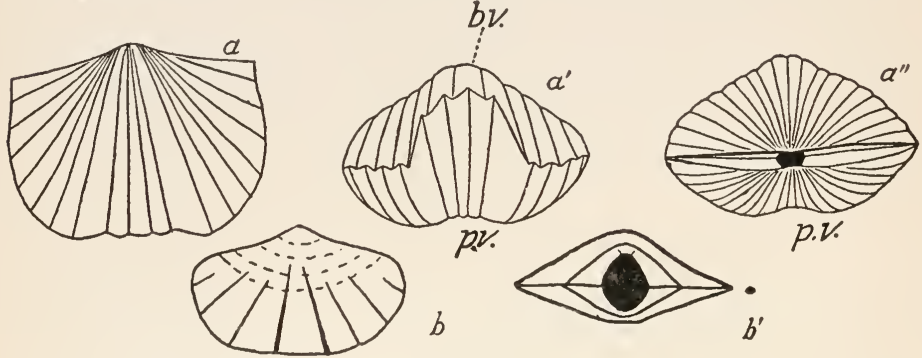

FIG. 82.- Platystrophia lynx (Eichwald), from the Upper Cincinnatian of Indiana. $a$, surface of pedicle valve, natural size; $a^{\prime}$, junction of the two valves anteriorly ; $a^{\prime \prime}$, junction of the valves posteriorly, showing the open delthyrium; $b$, exterior of pedicle valve of a very young individual, showing the introduction of plications; $b^{\prime}$, posterior view of same; $b . v$., brachial valve; $p . v$., pedicle valve. The natural size of $b^{\prime}$ is noted by the black spot to the right. (From Cumings, who has worked out the recapitulation of Platystrophia.)

sinus of the adult shell, while the two plications bounding the early median sinus upon the brachial valve become, through their enlargement, two of the plications of the strong median fold of the adult. This shifting of the median sinus from brachial to pedicle valve may be due to the enlargement of the median lobe of the brachia, thus keeping the mantle from sagging here. All species of Platystrophia, whether from the Ordovician or Silurian, pass through the same Orthis lenticularis stage (shown at the beak in well-preserved specimens). Platystrophia looks much like Spirifer, but has no calcareous supports for its brachia, and the cardinal area of the brachial valve is almost as high as that of the pedicle valve.

Platystrophia lynx is a very abundant species from the Lorraine (mid-Ordovician) of the Appalachian region and of the Ohio Valley. 
I. Sketch $(a)$ side view of entire shell, $(b)$ view looking fully upon hinge line. Label in each the valves, cardinal areas, plications.

2. Describe as much of the evolution of Platystrophia, noted above, as is preserved upon the specimens at hand.

3. What can you say as to its probable ancestry?

4. What is the significance of the name?

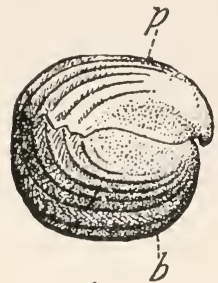

A

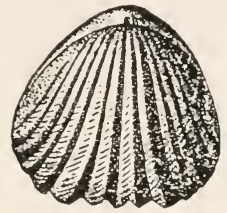

B

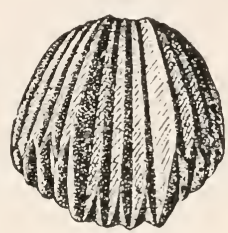

C

Fig. 83. - Rhynchotrema capax (Conrad), from the Upper Ordovician of Indiana. Natural size. $A$, side view of the joined valve; $b$., brachial valve; $p$., pedicle valve. $B$, brachial valve with beak of pedicle valve showing above. $C$, pedicle valve showing the deep median depression. (From Indiana Survey.)

Rhynchotrema (Fig. 83).

Ordovician .

Valves thick, very convex. Pedicle valve strongly incurved at umbo, with thick concave deltidial plates. Entire surface covered with strong, radiating plications crossed by many concentric growth lines. (Name from Greek rhynchos, a beak, + trema, a hole; the forms usually have the beak of the pedicle valve perforated by a pedicle opening.)

$R$. capax was widely distributed throughout the shallow ocean covering much of North America during Upper Ordovician time. In some adults a large pedicle opening is present, in others it is absent.

I. Sketch $(a)$ side view of entire shell, $(b)$ anterior view, $(c)$ cut portion of a vertical section through entire shell from beaks forward. Label valves, plications, growth lines, umbos.

2. Was this specimen attached or free when adult? Reasons.

3. By means of an ideal sketch, explain how the shell was built; what do the growth lines represent? 
4. In sketch I $(c)$ indicate by drawing in the muscles how the valves were opened and closed.

5. How do brachiopods eat? Breathe?

6. Do brachiopods live in the sea or in fresh waters?

7. At what depths do they live?

Terebratula-like forms (Fig. 84).

Devonian to present.

Shell usually biconvex, and elongate oval. Pedicle valve has generally a large circular pedicle opening (whence the

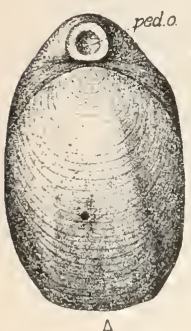

A

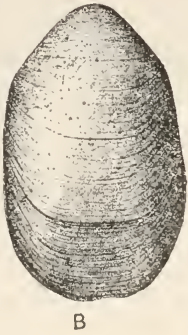

B

Fig. 84. - Terebratula harlani Morton from the Cretaceous of New Jersey. $A$, brachial valve, with pedicle opening (ped.o.) of opposite valve showing above. $B$, surface of pedicle valve. $\left(\times \frac{1}{2}\right.$. $)$ (After Whitfield.) name from the Latin diminutive of terebratus, perforated). Deltidial plates prominent. The old genus Terebratula has been subdivided into many genera.

Rensselæria is an ancient type from the lower Devonian of North America and Europe. Terebratula harlani is a large form abundant in the Cretaceous of the Atlantic coast of North America, where also is the coarsely punctate species Terebratella plicata. For Terebratulina septentrionalis see page $\mathbf{I} 8 \mathrm{I}$.

Note the large pedicle opening, deltidial plates and microscopic punctæ of $T$. harlani, the coarse punctæ of $T$. plicata.

Atrypa (Fig. 85).

Silurian to top of Devonian.

Pedicle valve slightly convex, brachial usually very convex. Entire surface radially plicate, crossed by many more or less prominent concentric lamellæ of growth. Apices of spiral brachidia directed towards middle of brachial valve, hence the strong convexity of this valve.

Atrypa reticularis is very abundant throughout the world in the Silurian and Devonian. The Silurian forms are usually smaller with brachial valves much less convex and with less extensive lamellæ than the Devonian forms. 

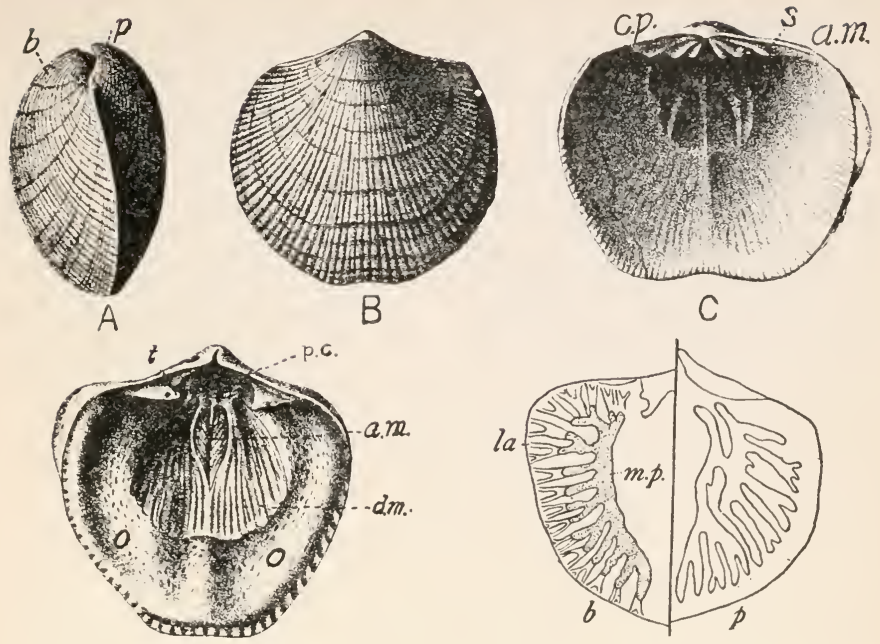

D

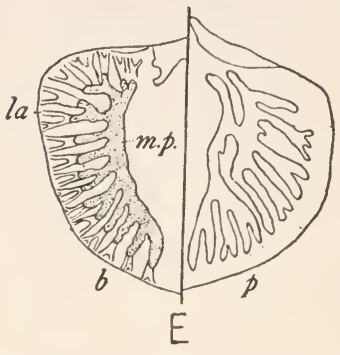

Fig. 85. - Atrypa reticularis Linnè, from the Hamilton formation (Middle Devonian) of New York. Natural size. A, side view showing both valves. $B$, brachial valve. $C$, interior of brachial valve. $D$, interior of pedicle valve. $E$, mantle of the living Terebratulina coreanica with the sinuses (spaces in the mantle cavity) filled with eggs. The eggs have not been indicated in the mantle of the pedicle valve. Beneath these sinuses roughened thickenings of the shell frequently occur, especially in the old shells as at $o$ of figure $D$. a.m., adductor muscle scar (in figure $C$ it includes all the scars within the shell); $b$., brachial valve; c.p., cardinal process; d.m., diductor muscle scar; la., lacuna; m.p., main pallial sinus; o., ovarian markings on shell; $p$., pedicle valve; p.c., cavity for attachment of pedicle; $s$. , socket ; $t$., tooth. ( $A$ to $D$ after Hall and Clarke; $E$ after Morse.)

I. Sketch $(a)$ exterior of pedicle valve, $(b)$ exterior of brachial valve with umbo of pedicle valve showing, $(c)$ interior of pedicle valve. Label valves, plications, growth lines, impressions of pallial sinuses, adductor and diductor muscle impressions.

2. What function did the pallial sinuses perform?

3. How were the growth lamellæ formed? Illustrate by sketch.

Spirifer (Figs. 74, 86).

Silurian to Permian.

Shell usually wider than long, with straight hinge line. Pedicle valve usually with high cardinal area and strong median 
sinus. Brachial valve with very low cardinal area and strong median fold. Surface of entire shell radially plicate or striate, or with the fold and sinus not plicate, crossed by more or less

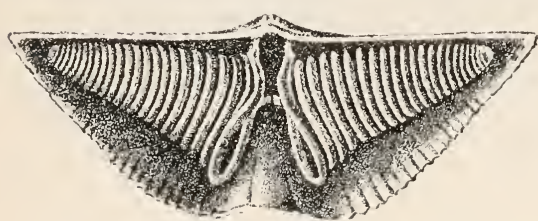

FIG. 86. - Spirifer mucronatus Conrad, from the Hamilton (mid-Devonian) of New York, showing the long, tapering spirals attached to the inside of the brachial valve for the support of the brachia. Natural size. (After Hall and Clarke.) strong growth lines. Brachidia are spirals (whence the name, from Latin spira, a spire, + ferre, to bear); the spirals are directed towards the cardinal angles (hence the great width of the shell); some Spirifers have spirals of 35 revolutions. The animal was anchored by a short pedicle which passed out through the delthyrium. The genus Spirifer of authors has been subdivided into many genera made necessary by the variations in the vast number of species found.

S. mucronatus is a characteristic Middle to Upper Devonian species of North America; $S$. disjunctus, an Upper Devonian species throughout North America and most of the world; $S$. cameratus, a widely distributed North American Pennsylvanian species.

I. Sketch $(a)$ side view of entire shell, $(b)$ exterior of pedicle valve, $(c)$ view looking directly upon the hinge line, $(d)$ interior of brachial valve showing the spirals. Indicate in sketches the valves, plications, growth lines, median sinus, median fold, hinge line, cardinal areas, delthyrium, spirals.

2. What is the relation of the mantle to the shell?

3. What was the function of the spirals?

4. How do you distinguish this genus externally from Platystrophia?

5. What is the significance of the name Spirifer?

6. What is the geologic range of the class Brachiopoda?

7. During what periods did the greatest number of brachiopods live?

8. How many species are living at present? 
I. Define each of the classes into which the Molluscoidea are divided, giving a recent and fossil example of each where possible.

2. Which class has the best-known fossil representatives?

3. What do Bryozoa and Brachiopoda possess in common that they should be placed in the same phylum?

4. Do these two classes enter into direct competition as regards food getting?

5. How do the Molluscoidea differ from the Cœlenterata in the following characters: $(a)$ habitat, $(b)$ protecting and supporting skeleton, $(c)$ locomotion, $(d)$ food, $(e)$ its capture, $(f)$ its intake, $(g)$ digestion, $(h)$ blood circulation, $(i)$ excretion of waste, $(j)$ respiration, $(k)$ nervous system, $(l)$ sense organs, $(m)$ reproduction, $(n)$ geologic range?

6. How do the Molluscoidea differ from the Annulata in the characters given under question 5 above? 


\section{PHYLUM X, MOLLUSCA (MOLLUSKS)}

The Mollusca as a group possess bilaterally symmetrical, unsegmented bodies enveloped in a sac-like fold, the mantle, which secretes a protective exoskeleton, the shell. The primitive bilateral symmetry is often obscured by a secondary torsion of the body.

They are mostly free-living, able to crawl, swim and burrow.

The general external divisions of the body are the head (absent in the Pelecypoda), - possessing mouth, various kinds of appendages, and nearly all the organs of special sense; the foot, - a ventral projection of various shapes; and a dorsal portion, - including the viscera and covered by the mantle which secretes a shell.

The digestive system consists of three divisions: $(a)$ an anterior division, consisting of the mouth, buccal cavity (absent in most pelecypods) and œsophagus; the buccal cavity contains the characteristic radula; (b) a middle division, the stomach, into which pours the secretion of the liver, an important digestive gland; $(c)$ a posterior division, - the intestine, ending in an anus.

The circulatory system consists largely of closed tubes, although there are some open sinuses. It includes a heart consisting of one ventricle and usually two auricles (in Nautilus, four).

The blood is a fluid with both nutritive and respiratory function. It varies in color among different mollusks, being colorless, bluish from the presence of hæmocyanin, or red from the presence of hæmoglobin.

Respiration is usually effected by ctenidia or gills, - specialized expansions of the ventral surface of the mantle, through 
which passes nearly all of the blood just before entering the auricles on its way back from circulation throughout the body.

The excretory system consists primarily of renal sacs or kidneys, - tubes which in most mollusks connect the body cavity with the exterior through the mantle cavity. Nearly all of the venous blood traverses the kidneys on its way to the gills and is by them purified of the nitrogenous waste products of metabolism.

The nervous system consists essentially of a nerve ring surrounding the cesophagus, giving off four nerve cords, - a pair to the dorsal region of the body and a pair to the ventral region.

The sexes are usually separate. The union of spermatozoa and ova is followed by laying of eggs, usually in a gelatinous or leathery matrix.

Most mollusks (Cephalopoda excepted) in their development pass through a larval stage, the veliger, in which the tiny, freeswimming form possesses a thickened retractile rim in front of the mouth, which bears a circlet of cilia and is called the velum. A shell gland on the dorsal surface secretes the shell, characteristic of most Mollusca.

Derivation of name. - Latin molluscum, a soft-bodied animal.

The Mollusca are divided into the following classes; the names are mainly references to the form assumed by the foot:
A. Amphineura .
B. Pelecypoda
C. Gastropoda
D. Scaphopoda .
E. Cephalopoda

PAGE

207

. 208

. 234

. 250

. $25 \mathrm{I}$

\section{CLASS A, AMPHINEURA (CHITONS)}

The Amphineura are distinguished by their bilaterally symmetrical body, with mouth and anus at opposite ends. They possess a foot adapted for creeping. The mantle surrounds 
the body either entirely (in the Aplacophora) or only dorsally (in the Polyplacophora), and secretes in the former order calcareous spicules, in the latter a dorsal armor of eight plates.

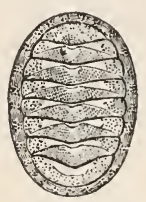

FIG. 87.-Dorsal view of a living chiton (Chatopleura apiculata Carpenter) from Massachusetts (but abundant from Cape Cod to Florida). (From Verrill and Smith.)

Amphineura are marine, in all oceans, with a wide range in depth. They have existed since Ordovician times. All fossil forms are members of the Polyplacophora, - those possessing a dorsal armor (Fig. 87).

\section{CLASS B, PELECYPODA}

Type of class, Venus mercenaria (Figs. 88-9I).

I'emus mercenaria, called variously the hard or little-neck clam or quahog, is a warm water form with range of greatest abundance along the southern Atlantic coast from the southern side of Cape Cod to Texas. North of Cape Cod it occasionally occurs up to the Gulf of St. Lawrence. It is found most abundantly on sandy and muddy flats just below low water mark, but its possible range is great, from high tide line to a depth of over 50 feet. It burrows into the mud to a depth just sufficient to cover the shell. This species has inhabited the Atlantic coast since Miocene time.

The soft body (Fig. 88, B) is inclosed in a calcareous shell which consists of two halves, the valves, joined by a hinge along the dorsal edge. From one end of the ventral or open edge of the shell protrudes a muscular, tongue-like body, the foot, by means of which the animal may slowly make its way through the sand or mud, in which it lies superficially buried. The presence of the foot indicates that end to be anterior and it is in that direction that the animal moves. From the opposite, the posterior end of the shell, project two tubes, the siphons, united almost to their ends.

When the valves are opened, each is found to be lined by a thin membrane, the mantle. 
The two lobes of the mantle are attached to the body dorsally, and extending down over the sides, come closely together along
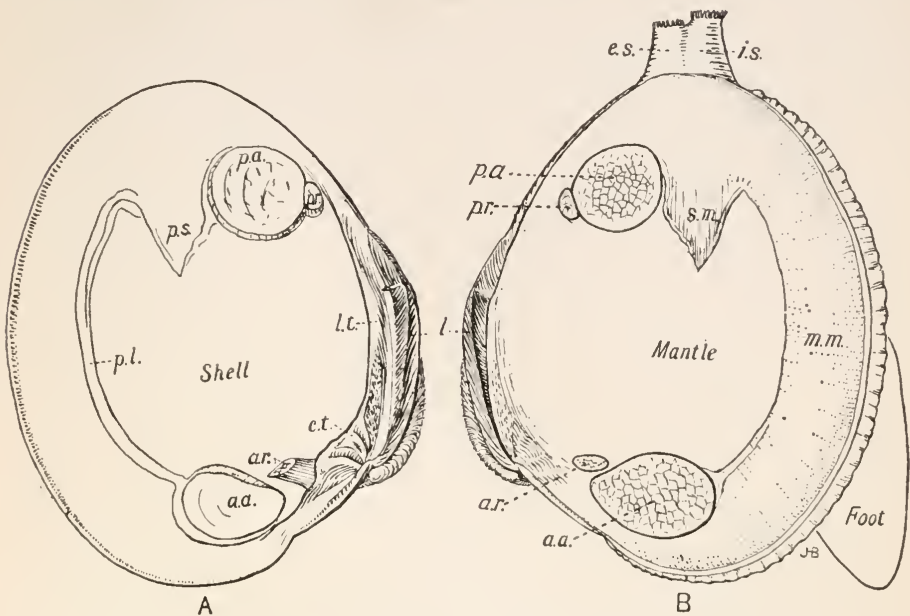

FIG. 88. - The quahog, Venus mercenaria Linné, in position of feeding. $\left(\times \frac{2}{3}\right.$. $)$ Left valve separated from its mantle and muscles which are left lying in the right valve. a.a., anterior adductor muscle and scar; a.r., anterior retractor muscle (a portion of it is attached to the left valve); c.t., cardinal teeth; e.s., excurrent siphon; i.s., incurrent siphon; l., ligament; l.t., lateral teeth; m.m., mantle muscle; p.a., posterior adductor muscle and scar; p.l., pallial line (the scar left by the mantle muscle); p.r., posterior retractor muscle and scar; p.s., pallial sinus (the scar left by the siphonal muscle); s.m., siphonal muscle.

the ventral edge, thus inclosing the body of the animal as in a sac. The siphons are merely projections of the mantle edge united into muscular tubes. The lower is the incurrent or branchial siphon; it draws in water carrying food to the mouth and oxygen to the gills. The upper is the excurrent or anal siphon; it discharges the waste products of the digestive system and the water which has passed over the gills and has hence become impure with the products of respiration.

The organs of respiration are the gills and mantle. The gills are two thin, curtain-like folds hanging free on each side of the main body mass just beneath the mantle (Fig. 89, B). Each 
of these four gills is double, being a very narrow bag open dorsally. From the union of these gills with each other and with the mantle on each side, and anteriorly with the viscero-pedal mass (the main body mass into which the foot merges), it results
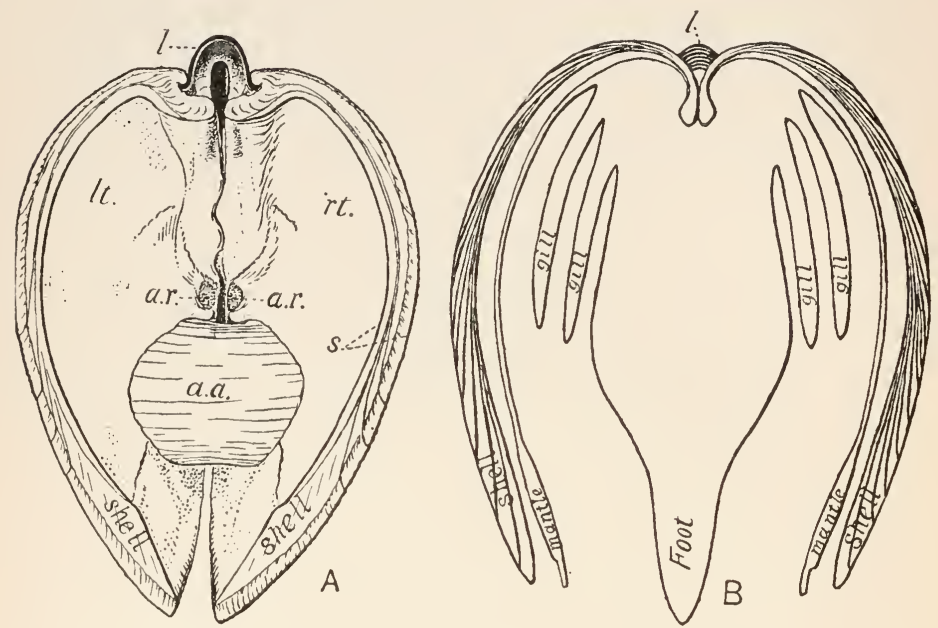

FIG. 89, - Vertical section through the quahog, -Venus mercenaria Linné. $A$, looking into the shell toward the anterior end. a.a., anterior adductor muscle; a.r., anterior retractor muscle scar; $l$., ligament showing its $\mathrm{C}$-spring shape; $l t$., left valve; $r t$., right valve; $s$, section of shell showing the increments of growth. $B$, an ideal section through a pelecypod. Such a section may be compared to a book, with binding along the dorsal (ligamental) edge and with the valves corresponding to the covers, the mantle lobes to the fly leaves, the two pairs of gills to the first two and the last two pages and the foot to the remainder of the leaves fastened together.

that the gills form a partition extending through the mantle cavity, dividing it thus into two chambers. Of these the upper is called the cloacal and from it passes the exhalant or anal siphon; the lower is called the branchial and into it opens the inhalant or branchial siphon (Fig. 90).

The gills are vertically striated. Microscopic examination shows these striæ to be parallel hollow tubes. Thus it is seen that each lamellar half of a gill is composed of a series of these 
tubes placed side by side and bound together. Through them the blood circulates and their walls are bathed on all sides by the water which pours into the gills between the tubes. As these walls consist of a single layer of cells, there is a ready interchange between them of the waste gases (which the blood brings from the body to the gills) and the oxygen of the water.

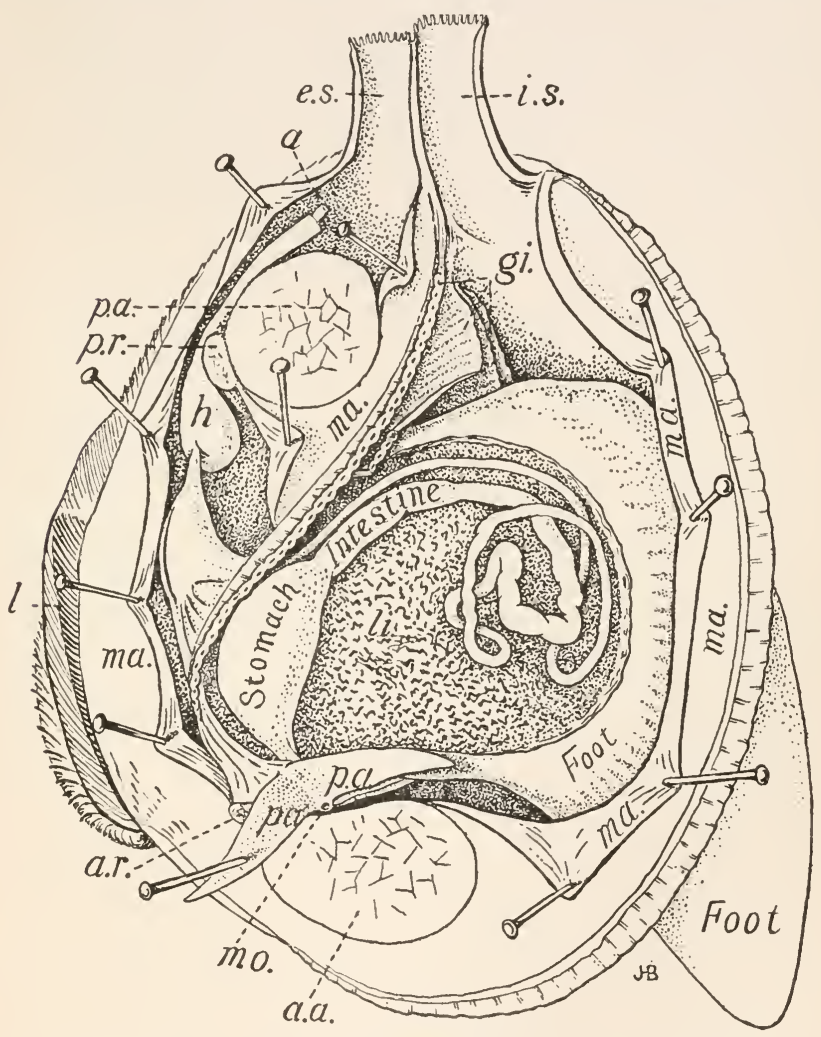

FIG. 90. - The quahog, Venus mercenaria Linné, in position for feeding (natural size), partly dissected lying in the right valve; $a$., anus; a.a., anterior adductor muscle; a.r., anterior retractor muscle; e.s., excurrent siphon ; gi., cut edges of gills; $h$., heart ; i.s., incurrent siphon; $l$., ligament; li., liver; ma., mantle cut and pinned back to show the organs within its cavity; mo., mouth; $p a$. , palps or lips at side of mouth; p.a., posterior adductor muscle; p.r., posterior retractor muscle. 
Water, admitted through the branchial siphon into the branchial chamber of the mantle cavity, is driven in a rapid continuous current into the gills by the cilia bordering them. From the gills the water passes in a strong current into the cloacal chamber and thence through the exhalant siphon to the exterior. The mantle likewise functions in respiration, being a thin-walled reservoir for blood in contact with the water.

Food as well as oxygen is brought to the animal in the water introduced by the branchial siphon into the mantle cavity. The principal food is diatoms, though according to the location and the season the clam feeds also on small crustaceans and rotifers, protozoöns and larvæ of mollusks. These small food particles are swept in with the current and become entangled in the mucus poured out by the gland cells of the gills. Movements of the cilia on the gills urge these food masses on to the mouth. This lies in the median line just below the anterior adductor muscle. Triangular flaps, the labial palps, unite above and below it to form an upper and a lower lip. The food is swept by the cilia on these palps into the mouth and thence passes through the osophagus into the stomach. Here it is digested by the fluid poured in from the digestive gland or "liver," a paired dark brown mass surrounding the stomach. The intestine leads from the stomach as a narrow tube which makes several convolutions in the visceral mass, and passing backward, opens into the exhalant siphon just over the posterior adductor muscle.

The chief organ of the circulatory system is the heart, situated saddle-like upon the intestine, dorsally near the hinge. It consists of one ventricle and two auricles, and is inclosed in a membranous chamber, the pericardium. (This is the only body cœlome possessed by the pelecypod.) The blood is a colorless liquid and forms an important part of the mass of the body. It is pumped by the ventricle into two aortæ, the anterior and the posterior, which branch into arteries and open sinuses, thus penetrating all parts of the body with its load of 
food and oxygen. From these sinuses the blood is gathered up by veins and returned to the auricles, the larger part passing through the gills on its return.

The excretory organs are the nephridia, a pair of dark, U-shaped tubes, of which one arm is glandular and spongy, the kidney, and the other is non-glandular and thin-walled, the bladder. They are situated in the postero-dorsal region. The kidney communicates with the pericardium and the bladder opens into the mantle cavity. Waste material gathered from the body by the blood is extracted from the blood by the kidneys and passed out of the body into the mantle cavity by the exterior opening of the bladder.

The nervous system consists of three pairs of large ganglia and their connectives: a ganglion on each side of the osophagus, united by a nerve cord and connected by other nerve cords with the two pedal ganglia in the base of the foot, and the two visceral ganglia near the posterior adductor muscle.

Sense organs. - All of the soft parts are sensitive to touch, but this sense is especially well developed on the edges of the mantle and of the siphons. There are no definite eyes, but there are pigmented areas in the siphonal region, which are sensitive to light, but which can distinguish no color or form. The osphradium is a small organ at the point of attachment of the gills whose function is supposed, from its situation, to be to test the water as it flows into the gills. It has been suggested that it may possess the undifferentiated chemical sense of smell and taste combined. The otocysts are spherical cavities filled with liquid in which is suspended a solid particle, the otolith. These are balancing organs, serving to keep the clam upright. They are supposed likewise to have an auditory function since pelecypods are able to sense sounds transmitted through the water.

The following are some of the principal muscles of the body (Figs. 88, 89) :

I. Mantle muscle. This extends around the edge of the man- 
ile lobe and unites it to the shell. The mark left on the shell by this attached mantle edge is called the pallial line.

2. Siphonal. This is a specialized part of the mantle muscle, originating from the siphons and serving to draw them into the shell. It spreads out fan-wise in proportion to the length of the siphons, and its insertion on the valve interrupts the evenly curved line of attachment of the mantle muscle. Hence the pallial line is indented by the pallial simus.

3. Adductor. These are two large cylindrical muscles which pass transversely across the body and are attached at each end to one of the valves; their insertion leaves on each valve an anterior and a posterior muscle impression. The contraction of these muscles pulls the valves together and closes the shell: a chitinous ligament, tough and elastic, unites the valves externally. This, like a C-spring, exerts a constant tendency to straighten and thus to cause the valves to open to a certain extent. Beyond that distance it tends to prevent the valves from opening. When the adductor muscles, therefore, relax, the valves yield to the action of the ligament and open.

4. Foot muscles. The foot is drawn into the shell by the anterior and posterior retractor muscles and is extruded by a single protractor muscle which spreads fan-like over the whole visceral mass and by the compression of which the foot is forced out. The attachment of these muscles is marked by three faint scars on each valve - that of the anterior retractor and the protractor near the anterior adductor impression, and that of the posterior retractor just dorsal to the posterior adductor. The foot itself is likewise very muscular.

That part of the mantle which is outside the pallial line is free, is somewhat thickened and contains shell-building glands. This series of glands around the edge of the mantle secretes a somewhat viscous liquid containing carbonate of lime, a shell material probably derived from the blood by the epithelial cells of the mantle margin. This hardens at once into a layer of shelly matter deposited around the edges of the shell aper- 
ture. Thus the shell grows by the continual building out of its edge through successive depositions of lime and of conchiolin. In this way are formed the two outer of the three layers of which the shell consists.

A transverse section through a valve reveals (I) an outer horn-like layer of conchiolin secreted only by the extreme edge of the mantle and hence always projecting slightly in advance of the other layers; (2) a middle prismatic layer composed of calcareous prisms placed at right angles to the shell surface; and (3) an inner pearly layer, composed of thin alternate layers of calcareous matter and of conchiolin, parallel to the shell surface. This presence of conchiolin throughout the shell furnishes it with a sort of membranous framework sufficient in amount to enable the shell to retain its shape after the removal by acids of all calcareous matter.

After the glands around the edge of the mantle have secreted these layers in the manner described, other glands covering the whole external surface of the mantle line the shell thus formed with the inner pearly layer.

When the seasons, temperature or food supply are unfavorable to rapid growth, the mantle does not increase in size. The glands which secrete the shelly matter continue active, however, and their deposit forms an extra thickness on the shell already

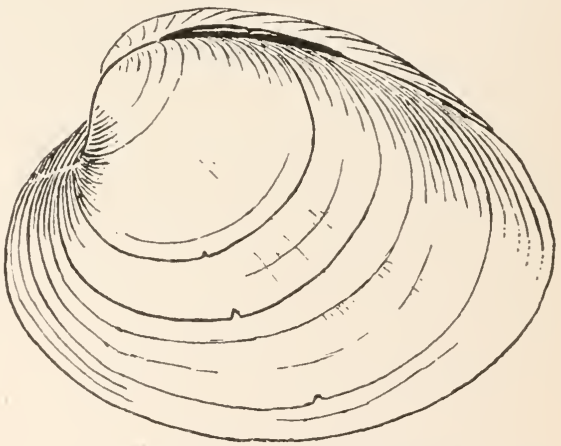

FIG. 91. - The quahog, Venus mercenaria Linné, showing how age may be reckoned by counting the more prominent growth lines. Three and a half years old; three inches long. At the same time each year a notch was filed into the edge of the shell. (Redrawn from Belding.) formed, especially around its edge. With the return of conditions favorable to the growth of the animal the mantle 
grows forward, again extending the shell and leaving behind as a thickened line the deposit of shelly material formed during the quiescent stage. The shell thus bears a succession of raised lines of growth or varices (Fig. 9I), indicating inactive periods and separated by thinner bands marking periods of active expanding growth of the mantle. There may be many such growth lines in a year, as favorable and unfavorable conditions alternate, minor oscillations in conditions as that between high and low tide, day and night, etc., being indicated by very fine growth lines.

The dorsal or cardinal margin of each valve is strengthened by a thick vertical plate, the hinge plate. Upon this are strong projections and ridges forming a system of teeth and sockets, the teeth of one valve fitting into the sockets of the other. This interlocking apparatus constitutes the hinge of the shell; by means of this an exact closure of the valves necessarily occurs. The teeth are of two kinds, the anterior or cardinal, consisting of short transverse elevations, and the posterior or lateral, longer teeth parallel with the dorsal margin of the valve.

The rounded, elevated portion of each valve is called the umbo; it ends in a point, the beak, which curves toward the anterior end of the shell. This is the oldest portion of the shell and from it growth has proceeded. Hence the beak is the initial point of the concentric growth lines. Under the beak and anterior to it is a depression called the lunule.

The sexes are distinct. The reproductive elements are extruded into the mantle chamber and out into the surrounding water through the exhalant siphon. Millions of eggs and spermatozoa are produced, most of which perish, since it is only by chance that their union is effected and fertilization thus results.

Development starts directly in the fertilized egg; this results in the formation of a blastula which soon invaginates, thus passing into the gastrula stage. Thus, about ten hours after the egg has been fertilized, the embryo has become a spherical 
gastrula $\frac{8}{100}$ of a millimeter in diameter. Up to this time it has remained inclosed in the gelatinous case which covered the egg, but in its gastrula form it is provided with hair-like cilia which start it rapidly revolving, and soon it breaks through the transparent egg case and escapes as a trochosphere larva into the water. This trochosphere stage is characterized by a topshaped body with cilia confined to the blunt anterior end, by a primitive mouth and by the appearance of a shell gland opposite the mouth.

During the next twenty-four hours a tiny valve, secreted by the shell gland, forms on each side of the animal and slowly increases in size until it completely envelops the embryo. The dorsal portion alone remains uncalcified and by additions of conchiolin it develops into the $\mathrm{C}$-spring ligament. Other changes taking place along with the formation of this shell are the development of a velum, - a peculiar kind of extensible ciliated swimming organ, the development of a foot and the increasing complication of the digestive tract. This shelled swimming form, succeeding the shell-less swimming trochosphere, is called the veliger. All these changes, from gastrula to veliger, are accompanied by but small increase in size; but at the end of the veliger period, which endures from six to twelve days, according to the temperature of the water, important changes are inaugurated which lead rapidly toward the attainment of the adult form. The animal increases in size, and with the complete disappearance of the velum and the loss of the swimming function of the foot, it leaves the free swimming life and sinks to the bottom.

A gland in the foot secretes the byssus, fine, tough threads by which the animal becomes attached to sand grains, shells, eel-grass or other objects. It is, however, an active animal at this stage and constantly travels from one place of attachment to another, breaking its byssal threads and forming new ones. The addition to the shell from this time on is coarser, whiter, and characterized by well-marked concentric growth lines. A 
sharp line separates this new shell growth from the earlier larval shell, - the prodissoconch, which had a smooth, homogeneous structure (compare Fig. Ioo, $p d$.).

During this attached stage the various organs of the body slowly take on adult characteristics. The clam remains attached until it has become large enough to make its way into the sand. When it is about $9 \mathrm{~mm}$. long the byssus disappears and the active foot burrows into the sand, pulling the shell after it in a series of jerks, the siphonal end of the animal being left projecting upward in the burrow. Hereafter it moves but little, occasionally, however, crawling short distances.

Though the young clams sustain heavy losses before they become able to burrow, the adult animal is one of the hardiest of pelecypods. It is very insensible to temperature changes and to changes in the saltness of the surrounding water, and it can endure long exposure to the air. There are few natural enemies of the adult clam. Even the starfish and oyster drill are not very destructive.

They are known to live four or five years and perhaps in some cases longer. Growth is most active in August, being nearly at a standstill from November I to May I. One individual with length of an inch when measured was found to have grown $\frac{7}{8}$ of an inch the following year. Fertilization (in New England) occurs from early June to the middle of August.

I. What is the common name of Venus mercenaria?

2. Its present range of habitat? Its geologic range?

3. Examine the specimens preserved in alcohol: (a) with valves held apart exhibiting relation of mantle to shell, the gills, muscles and foot; $(b)$ with one valve raised preserving attachment at hinge, showing upon the mantle the following muscles and upon the shell their attachment scars: (I) mantle, (2) siphonal, (3) adductor, and (4) foot.

4. Examine a dried specimen, sectioned through the two valves from ligament anteriorly, showing the ligament which opens the valves, one of the muscles which closes it, the lines marking the growth of each valve in length and thickness.

(The 
specimen should first be sectioned, then all the soft parts removed except the muscles, soaked in corrosive sublimate for a day or two, and thoroughly washed and dried.)

5. What is the mantle? Its function? What mark does it leave upon the shell?

6. What are the siphons? Their functions? What mark does their presence make upon the shell and why?

7. Compare a transverse section of this pelecypod to a book.

8. Explain in detail how respiration is effected.

9. What does the clam eat? Explain the process of getting the food, its digestion and assimilation.

IO. Describe briefly the blood circulatory system. off ?

I I. How are the different waste products of the body thrown

\section{I2. Of what does the nervous system consist?}

I3. What sense organs does the clam possess? Their function?

I4. Name four sets of muscles, explaining the function of each.

I 5. Describe in detail the growth of the shell.

I6. What is the origin of pearls?

I7. Sketch the exterior of a valve, noting the umbo, beak, growth lines, lunule.

I8. Why are the growth lines arranged concentrically?

9. Explain the occurrence of the few strong growth lines upon the shell.

20. How can the mantle secrete three layers of shell?

$2 \mathrm{I}$. Sketch interior of a valve, locating hinge margin, ligament, hinge plate, teeth (cardinal and lateral), pallial line, pallial sinus, the two adductor and three foot muscles.

22. What is the function of the teeth?

23. How is the foot protruded?

24. What is the relation of the pallial sinus to the siphons?

25. How are the valves opened? How closed? Illustrate with sketches.

26. How do you distinguish the right from the left valve?

27. Are the two sexes united in one individual ?

28. Describe the development of the clam from the union of spermatozoön and ovum to its adult state.

\section{General Survey of Class Pelecypoda}

Pelecypods are compressed, usually symmetrical, mollusks protected by a calcareous shell of two, usually equal, valves 
and possessing a ventral, often hatchet-shaped, foot capable of burrowing in sand.

There is no distinct head, nearly the whole ventral aspect of the animal consisting of the muscular mass of the foot.

The presence of a siphon in the various species of pelecypods is nearly always indicated on the valve by a pallial sinus (see page 2I4), though in a few exceptional species there is no such indication of its presence. When no pallial sinus is present, the pallial line is called simple. The portion of the mantle which is outside of the pallial line bears the pigment glands and in certain pelecypods papillæ and tentacular processes. On this edge likewise are the visual organs when such are present, as in Pecten.

Pearls are pathological products of the secreting function of the general mantle surface, not of its edge. Small foreign objects, usually some parasites such as the larvæ of certain worms, get between the mantle and the shell and set up an irritation there. The secretion of pearly deposit by the irritated glands around these offending objects results in pearls. (See also page 2I5.)

All surface irregularities of the shell, such as lines, knobs, spines, etc., are simply the result of corresponding modifications of the margin of the mantle. Thus spines indicate the existence of finger-like projections extending out from the edge of the mantle and secreting around themselves these hollow shelly processes. Ribs on the shell indicate wavy undulations of the mantle margin. The hinge teeth are probably derived from the crenulations or ribbing of the surface of the shell.

The digestive canal is much coiled, consisting of mouth œsophagus, stomach (into which open two large digestive glands) and intestine, ending in an anus. The blood of pelecypods contains nucleated amœboid corpuscles and in some forms, such as Arca pexata, - the bloody clam, some species of Tellina, etc., there are also present non-amœboid corpuscles containing hæmoglobin; in such cases the blood is red. In other forms 
(some Veneridæ, Cardiidæ, etc.) the blood is bluish, owing to the presence of hæmocyanin. In Venus, Ostrea, Pecten, etc., it is nearly colorless.

The nervous system consists typically of four pairs of ganglia, cerebral, pleural, pedal and visceral, united by nerve connectives. The usual sense organs are otocysts and osphradia. Eyes are at times present on the mantle edge; these range from simple pigmented cells to the complicated eye of Pecten.

The sexes are usually separate. The order Anatinacea is hermaphroditic, as also the Cyrenidæ and certain other isolated genera and certain species of Pecten, Ostrea, Anodonta, etc.

The valves are held together by one or two strong adductor muscles, passing transversely from valve to valve, and their opening is effected, upon relaxation of this muscular tension, by external or internal ligaments. The external ligament, acting on the principle of a C-spring, is exemplified in Venus (Fig. 89, $A$ ). The internal ligament (resilium) functions as would a piece of elastic rubber between a door and its jamb. Its triangular shape (narrower at the hinge than internally) keeps the hinge portion of the valves firm while causing the opposite side to open. It may be single, as in Mactra and Ostrea (Fig. 95,l), or multiple, lying in a series of pits, as in Inoceramus. In some forms, such as Mactra, a special spoon-shaped projection from the hinge, the resilifer, or ligament pit, lodges the internal ligament. The ligament, whether external, or internal, is, in its origin, continuous with the shell, being the part of the original embryonic shell which remained uncalcified.

The dorsal hinge of interlocking teeth necessitates an exact closure of the valves so that even at the approach of danger, when the valves are hastily closed, they will meet edge to edge and thus prevent the access of any enemy to the soft and tempting body portion.

The two valves are usually similar in size and appearance, one being the "mirror image" of the other. They are distinguished as the right and the left valve, that to the right and 
left respectively, as the shell is held with beaks uppermost and with the anterior extremity directed outward.

The following are the criteria for distinguishing the anterior and posterior ends of a valve.

I. The umbos are nearly always directed forwards.

2. The pallial sinus is posterior.

3. The external ligament is never entirely anterior, and is, usually mostly posterior to the beaks.

4. When there is but one adductor impression it is the posterior.

Both pelecypods and brachiopods have an external, bivalved, calcareous shell. That of the former differs from that of the latter as follows :-

I. Valves are right and left, not dorsal and ventral.

2. Valves are usually inequilateral and equivalved.

3. Umbos are never perforated by a pedicle opening.

4. Teeth when evident are present in both valves.

5. Ligament is present.

Shell accessories are present in some genera, such are described under Teredo.

The anterior adductor muscle may become diminished in importance or entirely absent. In such a case the posterior adductor necessarily assumes a more central position as a result of the greater demand placed on it for mechanical efficiency. The disappearance of the anterior adductor and the assumption by the posterior of a more central position are accompanied by a shortening of the antero-posterior axis of the shell and a proportional lengthening of the dorso-ventral axis. Such a transformation has been effected in the oyster (Fig. 95).

Pelecypods range from the lower Paleozoic to the present time, being, however, extremely rare in the Cambrian, where they are represented by a very few doubtful genera, such as Fordilla. Fordilla is oval, concentrically striated, and somewhat similar in appearance to Estheria of the Crustacea, with which it is at times classed. 
Derivation of name. - Greek pelekus, an ax, + pous (pod), foot. The foot of many pelecypods is shaped like an ancient battle ax.

Nucula (Fig. 92).

Ordovician to present.

Valves small, oval or triangular, with a pearly interior. Hinge line taxodont, i.e. bearing a series of small, nearly equal, transverse teeth. Beak exceptional in facing the posterior end of the shell, i.e. the beak faces away from the mouth, which is near the anterior edge of the shell. Mantle lobes free, without siphons, hence pallial line simple. Two adductor muscles present. Name from Latin nucula, a little nut.

Especially abun-

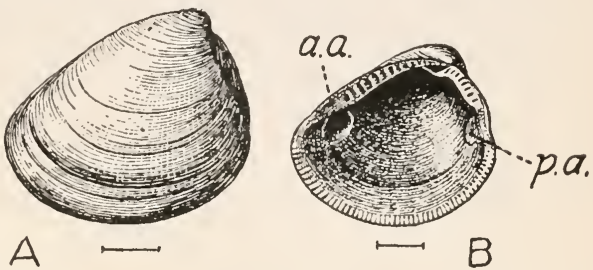

FIg. 92. - Nucula proxima Say, from the Miocene of Maryland. Natural size. A, exterior of left valve. $B$, interior of right valve showing the two muscle scars and the numerous teeth in a row (taxodont dentition). a.a., anterior adductor muscle scar; p.a., posterior adductor muscle scar. (From Glenn.)

dant in the Hamilton, Pennsylvanian and Cretaceous of North America, but widely represented by both fossil and recent forms in Europe and Asia as well.

I. How do the beaks of Nucula differ from those of most other pelecypods? How is this known?

2. Sketch an interior view of one valve, indicating anterior and posterior ends, beak, hinge line, teeth, muscle scars, pallial line.

3. What is the function of the teeth?

4. Mention three characters which determine this to be a pelecypod shell rather than a brachiopod.

5. What is the probable origin of teeth in pelecypods?

Inoceramus (Fig. 93).

Jurassic to Cretaceous.

Valves unequal. Hinge line long, straight, without teeth, but with numerous small, transverse ligament pits. Surface 
marked by coarse concentric undulations. This genus is especially characteristic of the Cretaceous.
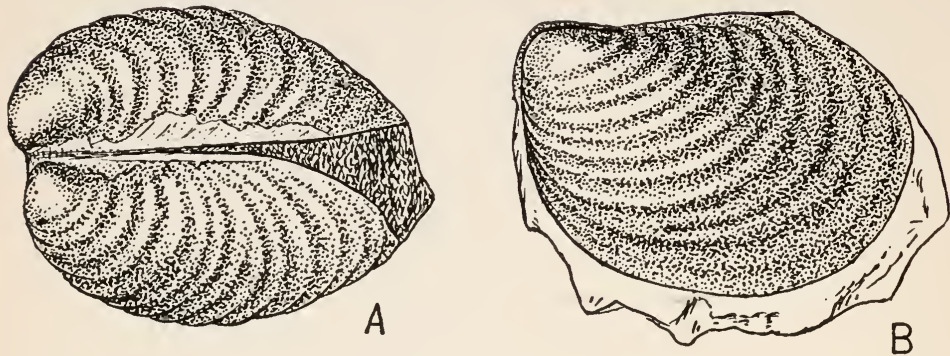

FIG. 93. - Inoceramus barabini Morton, from Montana. This pelecypod abounded in the shallow waters of the large ocean which cut North America into an eastern and a western continent during Cretaceous times. $A$, hinge view of entire shell. The valves are separated posteriorly, and the beaks have been slightly displaced; the absence of articulating teeth renders such displacement, through the weight of sediment, very easy. $B$, outer surface of left valve of same specimen. Natural size of a small individual.

I. Sketch $(a)$ hinge view of combined valves; $(b)$ outer surface of one valve. Label in sketches umbo, hinge line, growth ridges, oldest portion of shell, youngest portion, right valve, left valve.

2. Distinguish between umbo and beak.

3. What was the function of the row of pits along the hinge line?

4. Account for the slipping of one valve past the other in most specimens, so that the edges of the valves do not meet edge to edge. This slipping seldom occurs in such forms as Unio and Venus. Why?

5. How are pelecypod shells thickened?

6. Is the shell external or internal?

\section{Pteria.}

Ordovician to present.

Shell oblique, inequilateral and inequivalved, with the left valve more convex than the right. Hinge line long, bearing one or two small cardinal teeth and a long lateral tooth. Posterior ear wing-like, longer than the anterior. Sinus for the passage of the byssus present under the right anterior ear. 
Ligament in a groove, partly internal and partly external. Only posterior adductor scar present in adults.

Meleagrina (Fig. 94), a sub-genus of Pteria, is of especial interest from the fact that one of its species, $M$. margaritifera, is the chief source of the white pearls of commerce. Pearl oysters are found especially in the East Indies. For the origin of pearls see page 220 .

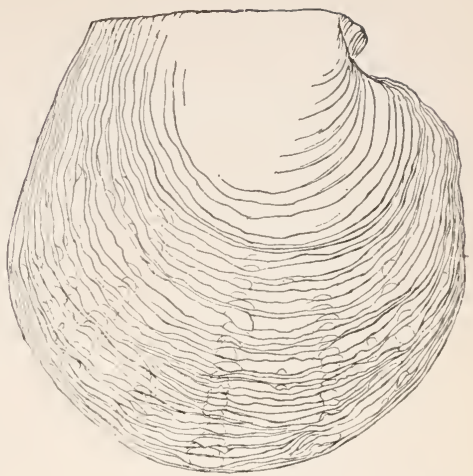

FIG. 94. - The "pearl oyster," Meleagrina margaritifera, from tropical seas. $\left(\times \frac{1}{2}\right.$.)
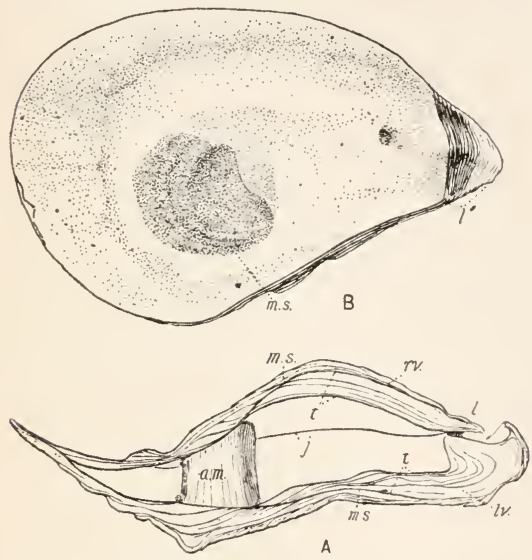

FIG. 95. - The common oyster, Ostrea virginica Gmelin, from the Atlantic coast of North America. $A$, longitudinal section through the valves showing the opening ligament $(l$.$) , the$ closing or adductor muscle (a.m.), the anterior progression of the muscle scar (m.s.), which in this species is black, and the internal thickening of the shell $(t) ;$.$j , junction of the$ two valves; $l^{\prime}$., ligament area; l.v., left valve; r.v., right valve. $B$, interior of right valve. (Both $\times \frac{1}{2}$.)
I. Sketch exterior of one valve, noting wing, ear, byssal sinus.

2. How are pearls formed?

Ostrea (Fig. 95). Pennsylvanian to present. Shell irregular, attached when young to other objects by the left or larger valve. Beaks terminal. Left valve convex, right valve flat or concave. Structure of shell lamellar. External surface more or less distinctly ribbed. Teeth generally absent but hinge line broken by a triangular cavity for the ligament. Anterior 
adductor impression absent, posterior nearly central. No siphons present.

The shell becomes attached at the close of its free-swimming stage as soon as it settles to the bottom of the water. The mantle at the front (ventral) edge of the left valve when coming in contact with some foreign object secretes a cement similar to the organic material within the shell itself.

Oyster shells are very often found to be completely riddled with small holes, the work of the boring sponge, Cliona sulphurea.

Fossil oysters are found in North America, Europe, and India. They are especially abundant in the Cretaceous of America and in the Tertiary of the coast states. A brackish water form, living in tropical and temperate seas, the oyster thrives best in clear water close to the shore where the water is fresher than in the open sea.

I. Sketch interior view of one valve, noting the characteristic $\mathrm{V}$-shaped ligament area and the muscle marking.

2. Explain the action of the ligament in opening or closing the shell.

3. How does Ostrea differ from Nucula in $(a)$ number of muscle impressions; (b) teeth?

4. Discuss the reason for the central location of the posterior adductor impression.

5. Is Ostrea attached or free during life? How can this be told from the shell?

6. In what kind of water does it usually live?

7. The oyster is a good example of adaptation to a sedentary life. How does this show in the shell?

8. Notice the difference in the shape and size of the valves. Why is this desirable?

9. Would such a heavy shell be satisfactory for the scallop (Pecten)? Why?

ro. Sketch longitudinal vertical section of a valve, showing the progression of the muscle impression and thickening of the valve.

I I. Why does Cliona bore into such shells as the oyster? 
Very characteristic of the Comanchean of Texas and of the Cretaceous of both the western and eastern states. E. arietina, at times, as in the Del Rio clay of the Texas Washita, occurs in enormous quantities, forming solid beds up to six inches thick (Fig. 97).

I. Name one similarity to Ostrea; one difference between the two forms.

2. At what time in the life of the individual Exogyra does it become attached to a foreign object? Reasons.

3. Sketch interior view of left valve, indicating muscle impression and ligament groove.

4. How is this known to be a pelecypod and not a gastropod?

Unio (Fig. 98).

Jurassic to present.

Valves of equal size, with a thick, brown, horny epidermis developed as a protection against the carbonic and humic acids in the fresh water as well as against the movement of the water itself. Shell thick, with a hinge line of heavy, indefinitely shaped teeth. External ligament present. There are no true siphons, simply openings between the mantle edges for incurrent and excurrent water. The animal grows slowly and may live fifteen or twenty years. The name is derived from the Latin unio, a pearl; the shells are occasionally pearl-bearing.

These are the "river mussels" found at the bottom of lakes, ponds, or running streams in all parts of the world, more especially in the northern hemisphere. They rest erect with valves slightly gaping, partly buried in the mud and sand ; if disturbed, the foot and mantle edge are drawn into the shell and the valves shut tightly.

The sexes are distinct. The eggs are fertilized within the body by spermatozoa introduced with the respiratory current; these fertilized eggs are passed into the cavities of the outer gills, where they are nourished by a secretion from their walls. The larvie are thrown out through the exhalent siphon. The presence of these developing young cause the shell of the female to be more arched than that of the male. 
There are more than one thousand living species. In the fossil state the genus is especially well represented in the Cretaceous of the Rocky Mountains.
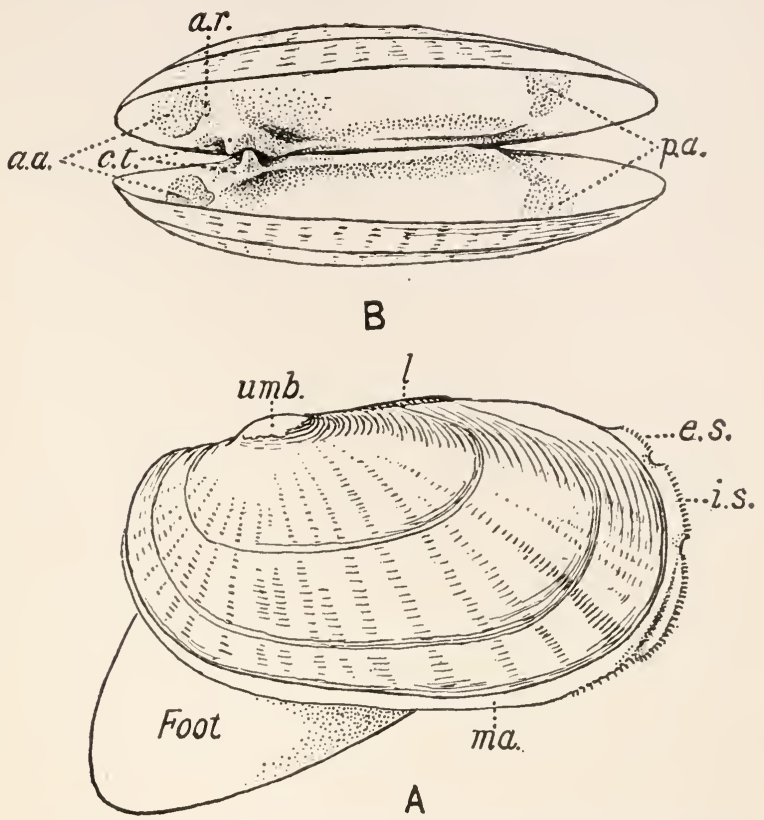

FIG. 98. - A fresh water mussel, Unio luteolus Lamarck, from Chisago Lake, Minnesota. $A$, exterior of living animal, left side. $B$, interior of the conjoined valves; a.a., anterior adductor muscle scar; a.r., scar of anterior foot retractor muscle; c.t., cardinal teeth; e.s., excurrent siphon; i.s., incurrent siphon; $l$, ligament; ma., mantle edge; p.a., posterior adductor muscle scar; $u m b$., umbo, showing here its characteristic corrosion by the acids in the water. Natural size.

I. Sketch interior view of one valve, noting teeth and sockets, pallial line, ligament and its place of insertion.

2. In the opening and closing of the valves what function was performed by $(a)$ the teeth and sockets; $(b)$ the ligaments; (c) the muscles?

3. What is the habitat of Unio? Its common name?

4. Why is the chitinous exterior of this form thicker than that of marine forms? 
5. How do you account for the roughened surface at the umbo of most individuals?

6. What is the function of the teeth?

7. How can you usually tell the shell of a female Unio from that of a male?

Pecten (Figs. 99, 100).

Pennsylvanian to present.

Shell nearly equilateral, with well-developed ears. Hinge line straight with a central pit for the insertion of the internal ligament. Only one adductor muscle present. Surface usually

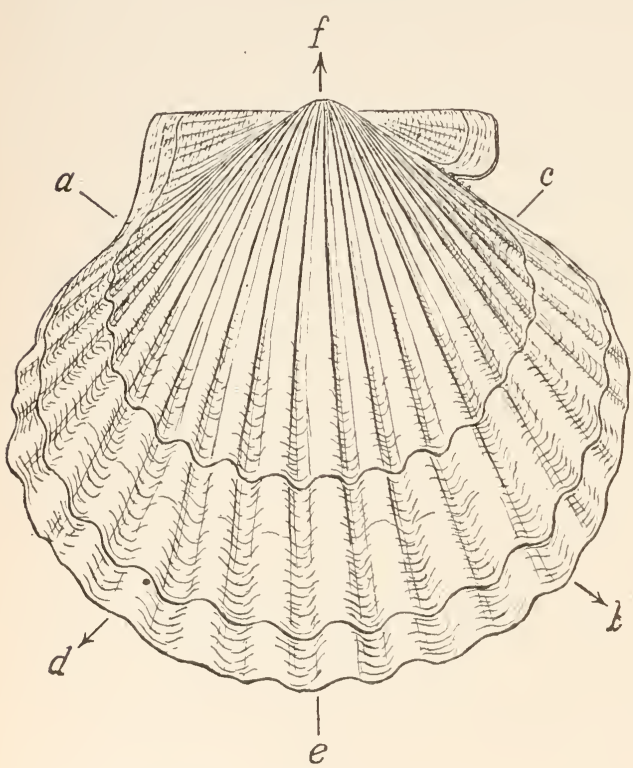

FIG. 99. - The right or lower valve of a two and a half year old scallop, Pecten gibbus borealis Say. $\left(\times \frac{3}{4}\right.$.) The arrows show how the scallop moves. When the animal forces the water out between the valves at $a$ it moves in the direction of $b$, when out at $c$ in the direction of $d$, when out at $e$ in the direction of $f$. marked with radial sculpture.

No siphons are present. Tentacles are present on the edges of the mantle. Of especial interest are the bright, bead-like eyes, arranged around the edge of the mantle. They possess cornea, crystalline lens, and retina. Experiment has shown them to be sensitive to changes in light and shade, though incapable of perceiving objects. They possibly sense the approach of an enemy by its shadow or by its movement in the water. 
The animal swims rapidly by flapping its valves together, thus ejecting water from the mantle chamber. When swimming, its hinge edge is usually directed backward and the propelling jet of water is forced from near the right and left ear alternately, thus acting like an oar in producing a zigzag coarse (Fig. 99).

It lives usually only a little over a year, spawning but once : very rarely does it reach a second spawning season. Its enemies are not many nor very destructive.

In the development of Pecten from the earliest shelled condition to that of the adult, remarkable changes occur. The very young shell (the prodissoconch), about $.2 \mathrm{~mm}$. in diameter, has a smooth surface, a very convex umbo, a curved hinge line with ten pairs of teeth fitting into corresponding sockets, with probably two adductor muscles and a non-prismatic shell structure. Immediately succeeding this stage and continuing until the shell reaches a diameter of about $\mathrm{I}$ $\mathrm{mm}$. is the dissoconch (Fig. Ioo, d.). It is characterized by a byssus, a byssal notch, formation of ears, a straight hinge line, a large active foot, prismatic structure of shell in at least the right valve, and a loss of the anterior adductor muscle. Later, at a diameter of about $1.25 \mathrm{~mm}$. (the plicated stage) the number of plications normal to the adult appear all at once. In the adult the foot has almost entirely disappeared, and the shell structure is non-prismatic. The prodissoconch has usually been completely eroded in the adult shell.

Upon comparing the above changes

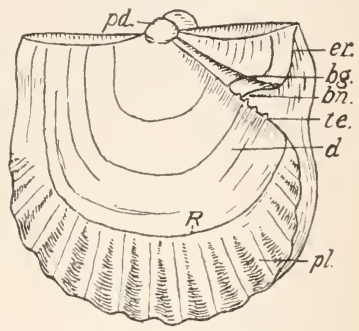

FIG. I00. - Plicated stage of a young scallop, Pecten gibbus borealis Say; outer surface of right or lower valve; the left valve shows slightly to the right. b.g., byssal groove; b.n., byssal notch; $d$, dissoconch; er., ear; $p d$., prodissoconch or earliest shell; pl., plications; $R$., Rhombopteria stage (the Aviculopecten stage is reached when the plicated stage is about five times longer than represented here); te, teeth. Size $1.4 \mathrm{~mm}$. (Redrawn from Belding.) with fossil shells it is seen that the prodissoconch is exceedingly similar to the Ordovician Nucula, the dissoconch to the Silurian Rhombopteria (Fig. Iо०, $R$ ), allied to Pteria, the plicated stage to the Silurian Aviculopecten, the adult Pecten being known 
from the Pennsylvanian. The resemblances are so numerous and so close as strongly to suggest a true descent.

The genus is of world-wide distribution. Three of the more common Atlantic coast American species used as food are, - P. magellanicus, New Brunswick to North Carolina, $P$. gibbus borealis of the New England coast, and $P$. gibbus irradians, which ranges from New Jersey to Texas. Other species are much esteemed in Europe. Only the adductor muscle of scallops is eaten. Fossil forms are especially abundant in the Comanchean of Texas and the Cretaceous of New Jersey.

I. When at rest Pecten lies upon its right valve. How does the right valve differ from the left?

2. Sketch right valve, both exterior and interior, indicating ears (anterior and posterior), umbo, ribs, growth lines, pallial line, byssal notch, muscle scar. Only one adductor muscle is present; is this the anterior or posterior?

3. Why is the byssal notch present?

4. Indicate with a heavier line upon your sketch the size of the shell at the end of one year. Why is this growth line so conspicuous?

5. Why are siphons, and hence a pallial sinus, not necessary in Pecten?

6. How can you tell which is the right valve?

7. Mention two differences between Pecten and Venus.

8. How does it move from one place to another?

9. What is the common name of recent Pectens?

ro. How does the shell usually give indication of the age of the animal ?

I I. How does the living Pecten breathe?

I2. What portion is eaten by man?

13. What need has it of so large an adductor muscle?

I4. Where are the eyes? Why? Can most pelecypods see?

I 5. Give briefly the development of the shell from the early prodissoconch stage to the adult.

I6. Parallel this development with fossil forms.

I7. How are the plications formed?

I8. Distinguish Pecten from Pteria. 
Teredo (Fig. IOI).

Jurassic to present.

Shell much reduced, globular, with valves gaping at both ends. Pedal muscles attached to a long, narrow plate beneath the umbos.

The animal lodges at the inner end of a long burrow which it has formed in wood. This burrow is lined by a shelly tube, secreted by and covering the long conjoined siphons of the animal which extend from between the valves out to the open end of the burrow. The free extremities of these siphons are protected by two small, movable, calcareous plates, the palets.

The food introduced with the water into the branchial siphon consists of Infusoria and other minute organisms. The wood eroded by the animal in the formation of its burrow is of no nutri-

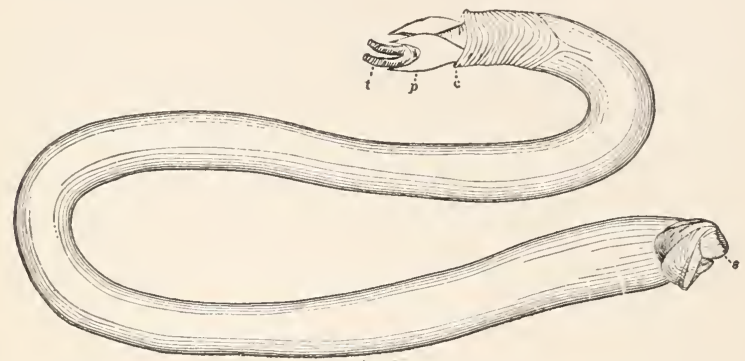

FIg. IоI.- The "ship-worm," the pelecypod, Teredo navalis I,inné, from the coast of Massachusetts. In life a tube of lime carbonate encases the animal from the shell (s.) to the collar (c.). $c_{\text {., }}$ collar; p., palets; $s$., shell; $t$., siphons. (From Verrill and Smith.)

tive value to it. It passes with no chemical alteration through the digestive canal and is expelled through the anal siphon as a mass of extremely minute particles which still retain their fibrous structure.

Teredo navalis is abundant on American and European shores, doing great damage to submerged timbers, such as piers, ships, etc. At one time it seriously injured the piles in Holland. Various methods of metal sheathing have, however, been found 
effectual in protecting such timbers. The various species of Teredo are nearly always found within some hard vegetable substance.

I. Sketch exterior of one valve.

2. What is the food of Teredo? How is this procured?

3. Does it digest the wood eroded in the formation of its burrow?

\section{CL.ISS C, G.ISTROPODA}

Type of class, Buspocon cancaliculatus (Linné) (Figs. I02-104).

This species is one of the largest gastropods on the Atlantic const, often attaining a length of six inches. It is especially abundant on sandy bottoms, at or below low tide level, where it may be found slowly plowing its way through the sand or lying with the foot partly buried. It ranges from Cape Cod southward, favoring especially the New Jersey coast and Long Island Sound. It has lived along the Atlantic coast since Miocene times.

The soft body of the animal is inclosed within a single calcareous shell, somewhat pear-shaped and consisting of six coils or whorls. At one end the shell is prolonged into a slender, half cylindrical canal. As the animal moves the canal projects forward and the apex of the whorls backward. Thus it is seen that the canal is at the anterior end of the shell and the apex of the whorls at the posterior.

Viewed in the position assumed when feeding, there is visible externally a head with two tentacles or feclers and a large foot, which forms the whole ventral aspect of the animal. When the shell is removed, the large elongated body mass, the visceral spiral, is found to extend backward from the upper side of the foot. This, like the shell in which it was lodged, is twisted into a coil. A delicate colorless mantle surrounds the visceral spiral, fitting closely both anteriorly and posteriorly but arching away in the middle, leaving a wide mantle (pallial) cavity. Marginally, the mantle is thickened and at one place is produced into 

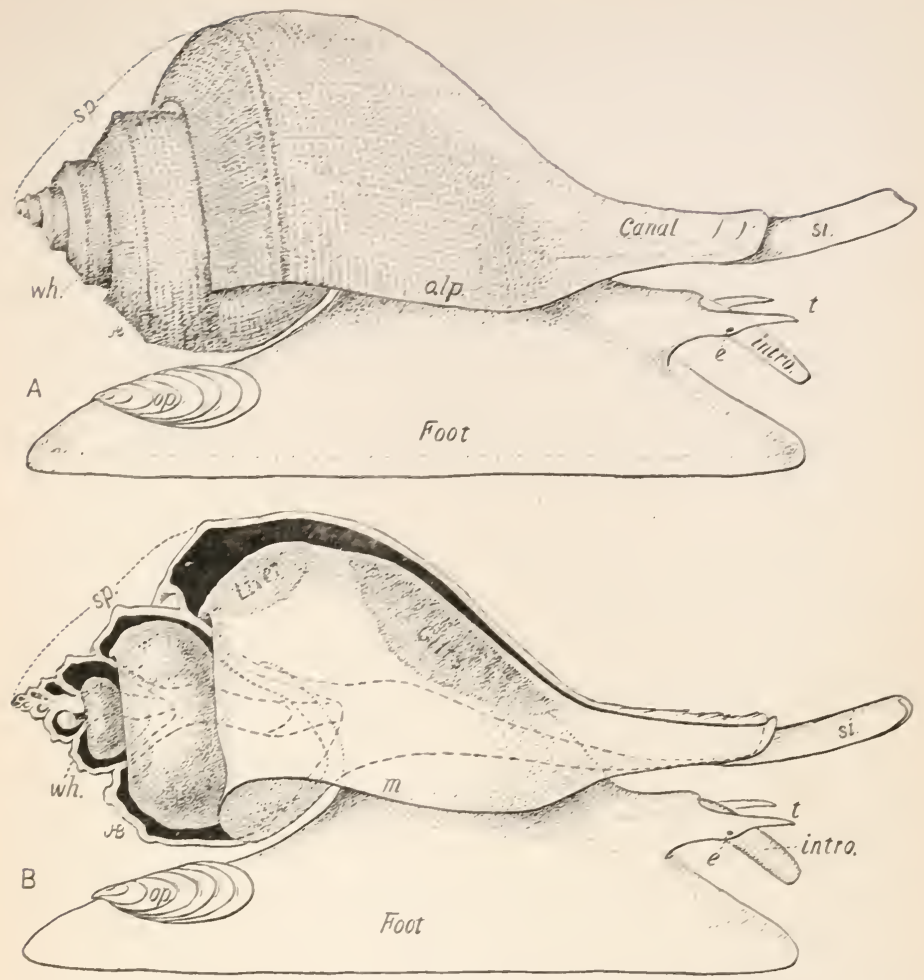

Fig. 102. - The marine snail, Busycon canaliculatus Say, from the Atlantic coast of the United States, in prosition of feerling. $A$, entire adult animal. $B$, a portion of the shell removed exposing the soft borly portion within, occupying nearly the entire snell. The dotted lines show the outline of the cut edges of the shell. (Compare with Fig. I03.) e., eye; intro., introvert, partly extended; m., mantle edge; o.l.p., outer lip of shell; op., operculum; si., siphon; sp., spire of shell; t., tentacles; wh., whorl or revolution. Fig. $A$ shows a shell of six whorls. $\left(x \frac{2}{3}.\right)$

a tube, the siphon, open along one side; this extends out through the canal of the shell.

The organ of respiration is the single gill which lies on the wall of the mantle cavity. This is a leafy expansion of the mantle, consisting of a row of flattened tubes bound together at the base 
by a common axis like the leaves of a book. A fresh supply of water is forced through the siphon into the pallial cavity, and hence the gill is constantly bathed in water abundantly supplied with oxygen. (The structure of the gills and the digestive organs is similar to that in Venus, Fig. 90.)

The impure blood from the body is brought to the gill by a large vein and is forced into these gill tubes, through the thin wall of which the carbon dioxid carried by the blood is exchanged for the oxygen carried by the water. It is probable that the function of respiration is likewise in part performed by that portion of the mantle surface which is exposed to the water, as in most mollusks this portion is crowded with thin-walled capillaries.

The digestive system begins with the mouth situated at the anterior end of the alimentary canal. Usually, however, the mouth is not visible, being pulled back into the osophagus. The peculiar mechanism which accomplishes this withdrawal of the mouth is called an introvert; it works like the pulling in of the finger of a glove by a thread from within. During its invagination the wall of the digestive canal is folded twice on itself, thus pulling inward its anterior extremity, the mouth. During evagination this fold partially straightens out and the mouth is thus pushed out to occupy an anterior position.

The mouth leads into the buccal cavity, an enlargement of the digestive canal which in turn opens into the œesophagus. The muscular walls of this cavity bear the apparatus for mastication, two small chitinous jaws or mandibles, and the radula, a thin membranous ribbon bearing transverse rows of many tiny chitinous teeth. The radula is borne on a cartilaginous support, - the odontophore, furnished with protractor and retractor muscles by whose action the radula may be sent out through the mouth and may work to and fro like a rasp upon the animal's prey. The extrusion of the mouth through the agency of the introvert carries with it likewise the buccal cavity with its included radula, thus placing the animal in position for feeding. 
Into the buccal cavity open the salivary glands which secrete a simple mucus with little or no digestive action. Food passes from the buccal cavity through the osophagus to the stomach, a simple enlargement of the digestive canal. The liver is a soft brownish mass, more or less completely surrounding the stomach and forming a large part of the coiled mass of viscera. It is the chief organ of digestion, secreting a ferment which it pours into the stomach. From the stomach the food enters the intestine through whose walls the digested food is absorbed and from whose posterior extremity the waste products are discharged into the mantle cavity, whence they are borne outside the body by the respiratory current of water as it leaves the gills. Busycon is carnivorous.

The main organ of the circulatory system is the dorsal heart inclosed in the pericardium at the base of the gill; it consists of two chambers, one auricle and one ventricle. From the heart the blood passes through arteries, open sinuses, and veins, thus distributing food and oxygen all along its course. The blood of Busycon is colorless. The chief organ of excretion is the kidney, - essentially a sac lined with secretory eipthelium, which discharges the waste products which it collects into the mantle cavity, whence it is washed out of the shell.

The nervous system consists of paired cerebral and pleural ganglia situated over the œsophagus, paired pedal ganglia situated in the foot and paired visceral and abdominal ganglia. Nerve connectives unite all these ganglia; those uniting the pleural and visceral ganglia are crossed, producing an 8-shaped loop.

Sensory cells are present over the whole surface of the mantle, but in certain areas, mostly in the anterior regions of the body, they become specialized into definite sense organs. The sense of touch is especially resident in the lower surface of the foot, which is covered by a network of fine nerves, and also in the tactile tentacles. The tentacles function also in the sense of smell. 
The osphradium, with function possibly somewhat of the nature of smell, is a ciliated region specialized by an accumulation of sensory cells, and situated at the outer edge of the gill, where the current of water supplying the gill must pass over it. Otocysts, the organs of hearing, are located at the base of the tentacles; they are hollow sacs containing a liquid and some auditory concretions and with ciliated walls possessing sensory cells. The organs of sight are two small sessile eyes upon the outer edge of the tentacles; they are provided with a protecting cornea, a light-focusing lens, and a retina with pigmented and sensory cells.

Two of the more important muscular areas are the foot and the columellar muscle. The foot is a powerful mass of muscular

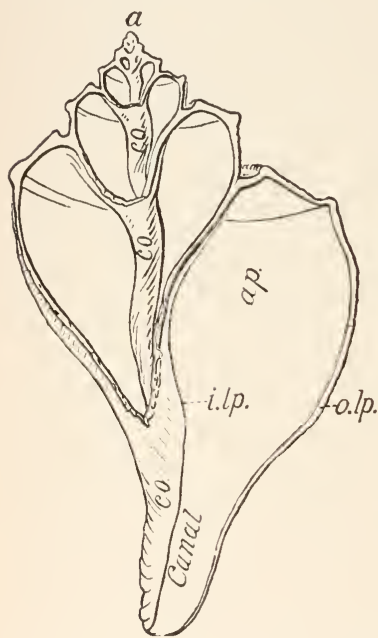

Fig. 103. - The shell of Busycon canuliculatus, with a portion broken away showing the method of coiling. a., apex of spire, the position of the protoconch when preserved; ap., aperture of shell; co., columella; i.lp., inner lip; o.lp., outer lip. (A small individual $\times \frac{3}{4}$.) tissue with a flat lower surface adapted to creeping. Successive waves of movement pass over this surface wherein successive points are raised, passed forward and again planted and thus effect the creeping movement of the whole foot, as in walking a man raises one foot, pressing the other at the same time against a resistant surface. The animal is held in its shell by the contraction of the columellar muscle which extends from the concave right side of the body to the columella to which it clings, its place of attachment moving spirally forward with the growth of the shell.

The shell is formed by the mantle as in Pelecypoda (p. 2I4); the surface irregularities of the shell merely reflect corresponding surface irregularities of the mantle. The closely 
wound whorls form an elongate cone whose base is the aperture of the shell, and whose apex, the oldest portion of the cone, corresponds to the umbo of pelecypods. The axis of union of the whorls is the columella (Fig. I03, co.). It forms the inner boundary of the aperture called the columellar or inner lip in opposition to the thin outer lip. The operculum is a small accessory shell, a flat oval plate, borne on the foot, which on the withdrawal of the head and foot into the shell closes the aperture (Fig. IO2, op.).

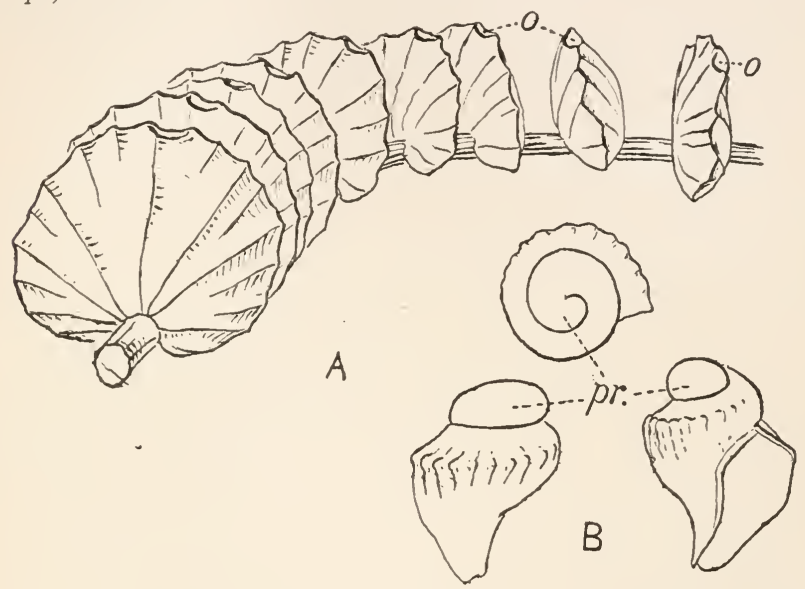

Fig. I04. - Busycon canaliculatus. A, portion of a string of egg capsules. Natural size. $B$, three views of the young shell ( $4 \mathrm{~mm}$. long) when ready to leave the capsule by the opening $v$. in Figure $A$. Top sketch shows view looking upon apex of spire. The first or smooth whorl is called the protoconch (pr.).

The sexes are distinct. The eggs are fertilized within the body of the female and are laid in great masses together with abundant nutritive material. In Busycon these masses of eggs and food are in the form of a long series of disk-shaped parchment-like capsules, like checkers on a string (Fig. I04). There are on the average 70 capsules in each string and each capsule contains about 50 embryos surrounded by much albuminous fluid which serves as nourishment during the growth from eggs to 
tiny shelled individuals. These egg cases are frequent on the beaches in spring and early summer. So small is any one individual's chance of surviving the various unfavorable conditions and the many enemies surrounding it that it has been estimated that about one in 20,000 of the tiny embryos reaches maturity. The first shell of the larval stage forms, when preserved, the extreme tip of the adult shell. It is called the protoconch and consists of a single smooth volution with no anterior canal; it suggests the shell of Natica in appearance (Fig. Io4, pr.). This naticoid stage is one that very generally occurs among gastropods and one that recalls the characters of early gastropods, such as Straparollina remota of the Lower Cambrian, which is perhaps close to the protogastropod, the earliest gastropod ancestor.

Just before the animal breaks out from the egg capsule a second whorl is added which develops tubercles on its shoulder angle and whose lip begins to extend into the anterior canal so characteristic of the adult. The growth of this canal tilts the plane of coiling of succeeding whorls at an angle to the plane of the first whorls. Hence the protoconch has an oblique appearance in the adult.

r. What is the present habitat of Busycon? Its geologic range?

2. As it moves, which way does the spire point?

3. Describe the respiration of the animal.

4. What does it eat? How is this procured and eaten? How digested?

5. Outline briefly the circulation of the blood.

6. What sense organs does Busycon possess? Where situated?

7. How does the animal move?

8. How is the body held in the shell ?

9. What does the word gastropod mean and why applied to this class?

Io. Sketch $(a)$ shell, looking into aperture and with spire pointing upwards; (b) section of shell from tip of spire to siphon. Label whorl, columella, inner and outer lips, spire, oldest portion of shell. 
II. Sketch the entire body removed from the shell. Indicate mantle, siphon, spire, columellar muscle, liver, operculum, foot.

I2. What is the function of the operculum?

I3. Did the body of the animal occupy the whole or only a portion of the shell?

I4. How was the shell built?

I5. Are the sexes separate or united in one individual ?

I6. How are the eggs laid? How many at a time? What proportion of these reach maturity?

I7. Define the protoconch. What does this indicate as to the past history of Busycon?

I8. How would an internal mold of the shell be formed?

\section{General Survey of Class Gastropoda}

Gastropoda are with few exceptions characterized by the possession of a distinct head, creeping foot and single mantle which in most forms secretes a spiral or saucer-shaped shell. The head, except in a few degenerate forms, bears tentacles and eyes.

Nearly all gastropod shells are more or less coiled, resulting from the more rapid growth of one side of the body and its mantle. It is usually the left side which grows more rapidly than the right, producing a dextral (right-handed) coil. If, when the shell is held apex up with the aperture towards the observer, the aperture is on the right, the coiling is said to be dextral; if on the left, it is sinistral.

In addition to this external asymmetry produced by the coiling of the shell, gastropods are characterized, at least at some period of their development, by an internal asymmetry resulting from a torsion of the body. In this the digestive canal, which in the very young embryo (up to the trochosphere stage) has mouth and anus at opposite ends of the body, becomes flexed upon itself and twisted upward, bringing the anus to the anterior end, above the mouth. This torsion is connected with the increasingly great development of the foot and the enlargement of the main visceral mass, the liver and reproductive organs. In the train of this torsion follow various displacements of the 
gill and nephridium on the shortened side, and typically their atrophy and disappearance. In many gastropods this twisting of the body involves likewise the nerve connectives, which thus become crossed.

In the pulmonates, - the air-breathing snails, which are mainly terrestrial or of a fresh-water habitat, there are usually no gills. The mantle cavity becomes completely closed except for a small opening, and functions as a lung.

The water for respiration passes in through a fold of the mantle lying in the anterior notch of the shell, or through the canal, where these are present, and out above, past the anus. If a posterior canal is present it passes out through this.

The heart consists usually of but two chambers, an auricle and a ventricle; rarely, as in Haliotis, are there two auricles and a ventricle. The blood is usually colorless. It is red in most species of Planorbis in which hæmoglobin is diffused in the plasma, and bluish in Polygyra albolabris owing to the presence of hæmocyanin, an albuminoid containing copper.

The heart of adult gastropods beats between 30 and 100 times a minute, but during hibernation not more than twice a minute. In young gastropods the number of beats may reach I 50.

Experiment indicates that touch and smell are the most acute senses of gastropods. It is almost exclusively by the sense of smell that food is found. This sense varies in acuteness in different gastropods. Its usual range does not exceed one inch, though some carnivorous marine forms (e.g. Nassa) can thus detect objects at a distance of more than six feet. It has been shown that Polygyra albolabris can locate food when covered from sight, even at a distance of $\mathrm{r} 8$ inches. Natica heros will go in a straight line to a dead crab.

A large percentage of the gastropods are herbivorous. Of the marine forms the vegetable feeders have as a rule the outer lip of the shell aperture entire (exceptions are Natica, the Scalariidæ, etc.), while the carnivorous forms have this lip notched or 
drawn out into a canal (as Murex, etc.). Most of the former likewise have many and small teeth upon the radula, while in the latter they are few but strong.

Experiment has shown that to aquatic gastropods the form of objects is indistinguishable. Terrestrial species can distinguish form when distant only one to two millimeters. It has been shown that Polygyra albolabris, the common land snail, for example, has so little perception of forms that it often creeps directly against an object, changing its course only when the tentacles touch it. The same animal is entirely unaffected by any noise which does not actually jar its body.

Sometimes the inner parts of the whorls coalesce into a coinmella. When they do not thus unite but leave a central tubular cavity, the opening of this cavity below is called the umbilicus. In some cases the inner edge of the mantle is reflected back over the inner edge of the aperture. This secretes a shelly growth beneath it which partially covers the umbilicus and is called the callus.

In many forms the mantle protruding from the shell aperture is reflected back over the shell to such an extent that it covers more or less of its external surface as in Cypræa, and this reflected portion may secrete a coating of enamel over the part of the shell on which it lies. The shell in these forms becomes thus more or less inclosed within the soft body portion, a process which attains such an extent in certain forms representing offshoots from various groups (e.g. Marseniidæ from the Streptoneura, the slugs from the Pulmonata, the sea-hares from the Opisthobranchia, etc.) that the animal appears to be quite naked. In these the mantle not only covers the shell but its edges are fused together over the top. The shell accordingly, having almost ceased to be of use as a protection, degenerates into a small plate, appearing entirely unlike the ordinary gastropod shell. Finally the shell disappears entirely in the nudibranchs, some of the pteropods and some of the air-breathing gastropods.

As the shell is the only part preserved in fossil forms our knowledge of the characteristics of extinct species and their relation- 
ship to one another and to living forms is based largely on considerations of shell outline and ornamentation, i.e. on the presence or absence of such shell characters as columella, umbilicus, callus, etc. The operculum is commonly of corneous nature and is hence rarely preserved in the fossil state. For a consideration of the protoconch see page 240 .

Busycon, with its twisted nerve connectives and separate sexes, is a type of one of the two sub-classes of the gastropods, the Streptoneura; while Clio, with its untwisted nerve connectives and united sexes, is an example of the Euthyneura. Under the Streptoneura belong Pleurotomaria, Bellerophon, Fissurella and Turritella, while under the Euthyneura, Clio and Teutaculites are included with the order Opisthobranchia, Helix with the second of the two orders, the Pulmonata. Gastropods are known from the Cambrian to the present, though in abundance only since the Ordovician.

Derivation of name: Greek gaster, stomach, + pous (pod), foot. The stomach is directly above the creeping foot in most gastropods.

Pleurotomariidæ (Fig. I05).

Ordovician to present.

In this family of gastropods the outer lip of the aperture is cut by a slit resulting from a corresponding notch in the mantle.

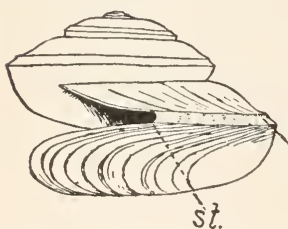

FIG. 105.-- One of the Pleurotomariidæ gastropods, $E o$ tomaria supracingulata Billings, from the Stones River formation (Lower Ordovician) of Illinois. st., slit in outer lip; st.b., slit band. (From Ulrich.)
Through this posterior notch are expelled the digestive waste and the respiratory water; the incoming water and the food are thus kept unpolluted. From the slit in the shell, a slit band, marking the progressive closing of the slip during the growth of the shell, extends backward; around this the growth lines bend obliquely. Name from Greek pleura, side, and tomarion, a cut. Though an abundant fossil form, with over I Ioo species known, there are but five living species, 
I. Sketch view showing aperture and spire; label spire, whorls, aperture, slit.

2. To what is the slit due?

3. Of what advantage is the slit to the animal?

\section{Bellerophon.}

Ordovician to Permian.

Globular, with the earlier whorls concealed by the later ones. Umbilicus present on each side. Aperture sub-circular with a deep median slit, comparable to that present in the members of the Pleurotomariidæ, which as it progressively closes up with the growth of the shell, arches into a keel.

Especially abundant and widespread in the Mississippian and Pennsylvanian of North America.

I. Sketch $(a)$ view looking directly into the aperture, $(b)$ side view showing umbilicus. Indicate aperture, umbilicus, keel, slit band.

2. How is the umbilicus formed?

3. A section through the shell shows several whorls. Why are the earlier whorls not visible in the unbroken specimen?

4. What characters indicate that this is not a coiled cephalopod shell?

5. What caused the slit band? its use?

Fissurella (Fig. I06).

Carboniferous? to present.

The mantle and shell of this keyhole limpet are pierced by an oval hole just over the summit of the visceral cone. This hole
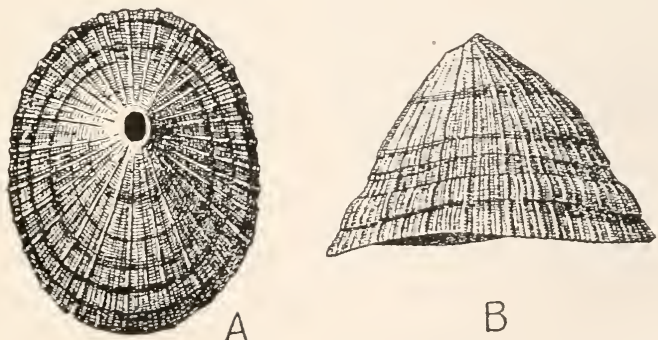

Fig. 106. - The keyhole limpet, Fissuridea alticosta Conrad, from the Miocene of Maryland. Natural size. $A$, dorsal view. $B$, side view. (From Martin.) 
in the mantle functions as an anal siphon, for it gives passage to the digestive waste and to the water from the gills, which have been poured into the mantle cavity. It thus corresponds to the slit of the Pleurotomariidæ (Fig. I05, st.), to some of the posterior holes in the Pacific coast earshell (Haliotis) and to the posterior canal of such shells as Cypræa. This hole first appears as a notch in the border of the mantle, as in Haliotis, but is surrounded by the later growth of the mantle and, consequently, also of the shell. From this aperture are derived both the Latin and common names (Latin fissurella, a little hole).

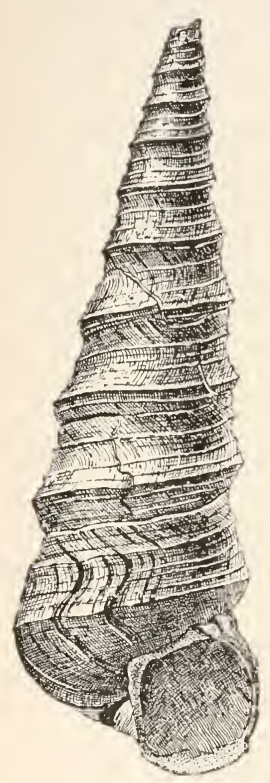

A

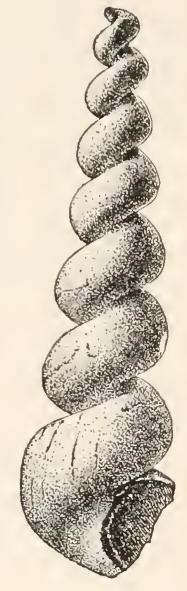

B

FIG. 107. - Turritella mortoni Conrad, from the Eocene of Maryland. $\left(\times \frac{3}{4}.\right) \quad A$, shell entire except for the missing apex of the spire. $B$, the internal mold (or mud filling) of the shell. (After Clark and Martin.)

The fossil forms are now referred to Fissuridea, ranging possibly from the Carboniferous.

I. Sketch side view, noting the anal aperture.

2. What function did the anal aperture subserve?

3. In regard to this aperture compare Fissurella with Pleurotomaria, Bellerophon and Haliotis.

\section{Turritella (Fig. I07).}

Triassic to present.

Shell shaped like a tapering tower or turret, suggesting the name (from the diminutive of the Latin, turris, a tower). No umbilicus persent. There is no siphon and hence the aperture of the shell is entire, i.e. not produced into a canal.

It is represented by many species in the Cretaceous 
and Tertiary of North America, such as T. mortoni of the Eocene of the Atlantic and Gulf coastal plain.

The terminals of various genetic lines of Turritella are found in the species of the genus Vermicularia (Tertiary to the present). In this genus, the earlier, younger, whorls are like Turritella, while the later, adult, whorls are uncoiled and somewhat twisted.

I. Sketch $(a)$ side view showing the elongate spire and the aperture; (b) side view of an internal mold. Note spire, whorls, aperture.

2. How much of the shell did the body of the animal occupy?

3. How does this compare with the portion of the shell filled by the internal mold?

4. How is an internal mold formed?

5. In what kind of rocks are the best internal molds found?

6. What information about the soft body of the animal does this form of preservation give?

7. Show that Vermicularia is descended from Turritella.

8. Given only the irregularly coiled portion of Vermicularia, show that it was secreted by a gastropod and is not $(a)$ a wormtube like Serpula nor $(b)$ a siphonal tube like that of Teredo.

9. Why is Turritella placed in the class Gastropoda?

ı. What according to derivation does the word gastropod mean? Why applied to the members of this class?

I I. How is the gastropod shell built?

I2. When the animal moves which way does the spire point?

Clio (Fig. I08).

Tertiary to present.

Clio is a tiny gastropod, often shaped like a narrow, elongate cone, about an inch long. It occurs in immense swarms in northern and southern seas, swimming in the open ocean by flapping movements of the fin-like lobes of its foot. It forms much of the food of whales.

It differs from Busycon in its symmetrical, uncoiled body and shell, and in the expansion of the foot into the two symmetrical fins used in swimming.

The shell is thin, in the form of a tapering tube, without transverse septa. From its larger and open end project the two large wing-like lobes of the foot. This open end is anterior; there 


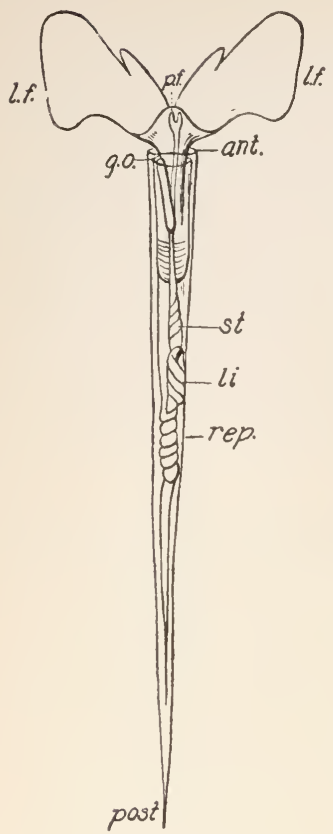

FIG. I08. - The gastropod, Clio acicula, ventral view; this has a universal distribution. Much enlarged. ant., anterior margin of shell ; g.o., genital opening ; l.f., lateral fin, - the winglike lateral lobe of the foot; li., liver; p.f., posterior fin, — the median posterior lobe of foot; post., posterior end of shell; rep., reproductive gland; st., stomach. (Redrawn from Lankester's Zoölogy after Souleyet.)

is no distinct head. A mantle surrounds the body and secretes the shell.

There is a general symmetry of the body organs resulting from a second torsion of $\mathrm{IS} \mathrm{S}^{\circ}$ in a direction opposed to that of the original torsion of other gastropods; the primitive torsion appears in the course of the animal's development. This secondary symmetry is most manifest in the nervous system. The visceral connectives are not crossed as they are in Busycon, and the nerve elements are concentrated in the anterior region, around the œsophagus.

The two sexes are united in one individual.

Clio is one of the Pteropoda, - a group formerly differentiated among the Gastropoda, but now usually broken up and scattered among various divisions of the tectibranchs, - a sub-order of the Opisthobranchia. They were formerly segregated on the basis of their common possession of a foot transformed into two wing-like fins and of their lack of a distinct head.

I. What characters do Clio and the other members of the old class Pteropoda possess in common which distinguish them from the rest of the gastropods?

Tentaculites (Fig. I09).

Ordovician-Devonian.

The shell is thick-walled, conical, and tapering posteriorly to an acute apex. The surface of the shell is banded with raised parallel rings. 
This is an extinct genus exceedingly abundant in the Silurian and Devonian.

Tentaculites, Hyolithes, Conularia, etc., are genera of problematic relationship occurring abundantly in the Paleozoic.
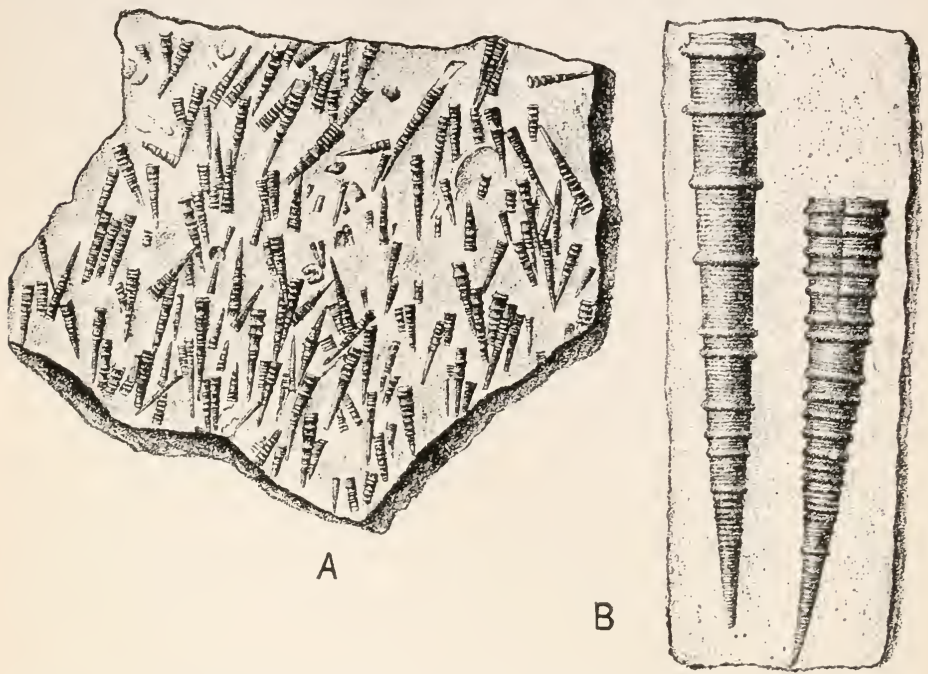

FIG. Io9. - Tentaculites gyracanthus Eaton. A straight gastropod (conularid) from the Upper Silurian of New York. A, block of limestone showing their abundance (natural size). $B$, two individual shells $\left(x_{4}\right)$, the smaller one has been slightly crushed. (After Hall.)

They are often raised into a distinct class of the phylum Mollusca, the Conularida. Though the occasional presence of transverse septa has somewhat suggested relationship with the Cephalopoda, still their shell is most similar to that of Clio, and hence they are undoubtedly most closely akin to the Gastropoda among classes of living mollusks.

I. Sketch side view, noting the long, uncoiled tube with its ring-like ornamentation.

2. Why is this shell, and others of similar structure, often raised into a distinct class? 
Helix (Fig. I IO).

Eocene to present.

This is a pulmonate gastropod. The mantle cavity contains no gill and itself functions as a lung for breathing air, since its

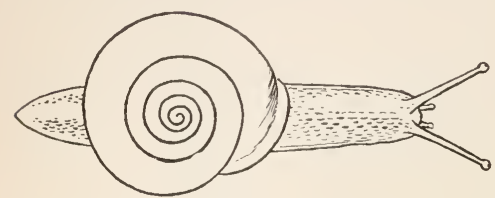

FIG. IIo. - The common land snail, Polygyra albolabris, from New York State. $\left(\times \frac{3}{4}.\right)$ This is closely allied to Helix. Dorsal view of creeping animal, showing the coiled calcareous shell and the active feelers or tentacles; each of the two longer tentacles terminates in an eye. Note that the coil of the shell is posterior (compare with Fig. II3). (Redrawn from Simpson.) walls are traversed by blood vessels. The animal is hence terrestrial in habitat.

The genus and its subgenera include more than 4000 species.

I. Sketch side view showing aperture and spire, labeling spire, aperture, whorls.

2. What modification has the animal undergone that enables it to live upon land?

\section{CLASS D, SCAPHOPODA}

The Scaphopoda are characterized by an elongate, bilaterally symmetrical body which thus looks worm-like. This body is inclosed in a tubular, calcareous shell which is curved and tapering, and open at both ends, and is secreted by the mantle lobes; the body is attached to the posterior part of the shell by muscles. The concave side is dorsal. The larger end is anterior; through it the foot can be protruded and used for burrowing in the sand and mud. In this end of the shell, likewise, is the short proboscis or "head," which bears the mouth.

The structure of the body is very simple. There are no special circulatory organs, no gills, respiration being effected by the whole mantle, and the head bears no eyes. Into the posterior aperture of the shell is drawn the water used for breathing, and through it is discharged the body waste. The food is chiefly Foraminifera.

The somewhat similar tubular shells of gastropods and cephalopods may be distinguished by the fact that they are always closed at one end. 
Scaphopods are marine and live embedded in mud and sand, usually at great depths. They range from the Ordovician to the present. Dentalium, the tooth shell, ranges from the Tertiary to the present (Fig. I I I).

\section{CLASS E, CEPHALOPODA}

Type of the class, Nautilus pompilius (Fig. II 2).

The pearly Nautilus lives in moderately shallow or deep water in the South Pacific, usually creeping about on the bottom. The body is inclosed in a coiled shell, secreted by the mantle, from which project the head and tentacles when the animal is moving and into which they may be withdrawn for protection. The appearance of Nautilus, with its expanded tentacles surrounding the head, is similar to that of the disk of a seaanemone. The shell consists of an elongate cone coiled in one plane and is divided by

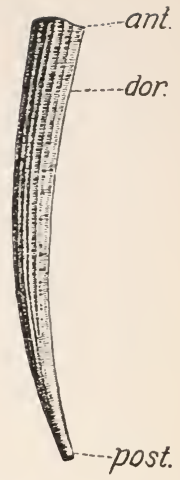

FIG. III. - A scaphopod, Dentalium attenuatum Say, which lived in the seas covering eastern Maryland during the Miocene. ant., anterior aperture; dor., dorsal side of shell ; post., posterior aperture. Length of shell 2.3 inches. (After Martin.) transverse partitions (the septa) into a series of chambers. The soft body of the animal is lodged in the wide end of the cone in front of the last formed septum; this cup-like chamber in which it lies is called the living chamber. An extension of the body, the siphon, passes backward from the living chamber, through perforations in the septa; it thus maintains connection with the earliest formed chambers in the apex of the shell.

This siphon is really just an extension of the cœlome or body cavity of the animal, a tubular extension opening from the posterior portion of the cœlome. An artery extends through its entire length, finally ending openly. Though the siphon narrows where it passes through each septum yet its cavities are not effaced. 
The function of the siphon is unknown. Some have supposed it to be a hydrostatic organ, assisting the animal to rise and sink through the water. And some have considered that what-

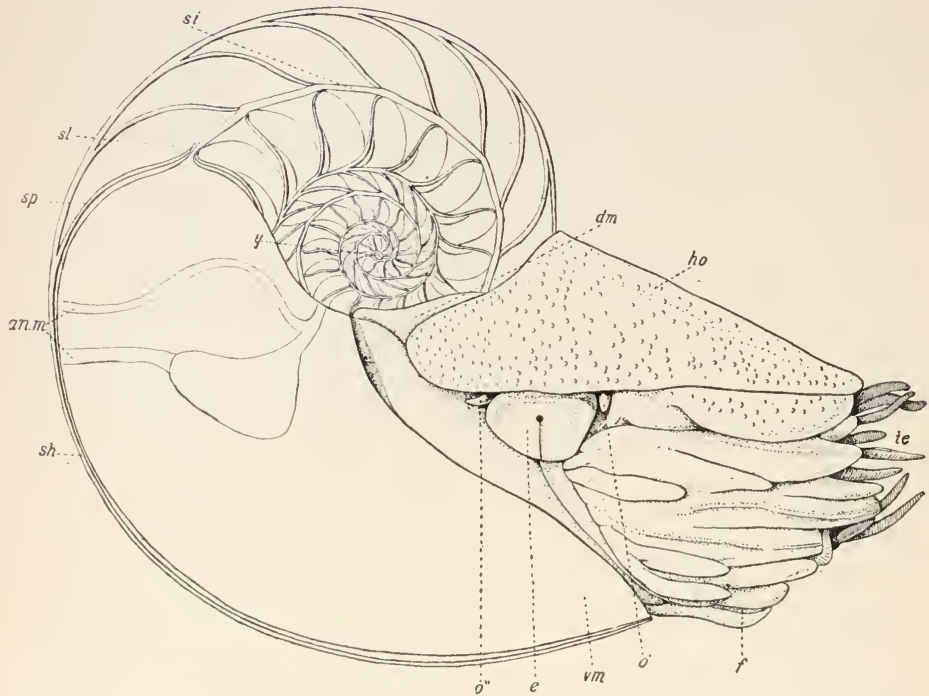

FIG. I1 2. - Nautilus pompilius, from the Philippine Islands. $\left(\times \frac{1}{2}\right.$.) The animal is seen from the right side, the right half of the shell having been cut away. an.m., annular muscle which holds the body of the animal in the shell; the posterior portion of the muscle is attached at the junction of the last septum with the shell; d.m., dorsal portion of mantle; e., eye; $f$., funnel ; ho., hood, which, like the operculum of gastropods, may be drawn in against the apęrture to close the shell; $o^{\prime} ., o^{\prime \prime}$., anterior and posterior ocular tentacles; si., siphon, the fleshy prolongation of the mantle extending backward through the empty chambers; sl., siphuncle, the shelly covering of the siphon; $s p$., septum, one of the transverse partitions of the shell ; te., tentacles; v.m., ventral portion of mantle; $y$., earliest formed portion of the calcareous shell. (Redrawn from Griffin.)

ever be its function it is in Nautilus a vestigial structure which has become progressively reduced during the course of evolution of the Nautiloidea.

When creeping on the sea bottom the tentacles surrounding the mouth are applied to the surface over which the animal is traveling and movement is effected by them (Fig. II3). 
In this natural creeping position the soft body is nearly horizontal, though curving upward posteriorly. The head is anterior, the siphuncle is posterior, the funnel is ventral and the coil of the shell is dorsal.

Shell. - The adult shell possesses about two and a half whorls; the exterior is marked with alternating bands of reddish brown and white. Internally, the shell as previously stated is made up of a series of chambers separated by septa. Pelseneer suggests that each septum shutting off a chamber "is formed during a period of quiescence, probably after the reproductive act, when the visceral mass of the Nautilus may be slightly shrunk." The thin glandular skin covering the posterior portion of the animal secretes the septum, probably first as a membrane of conchiolin,

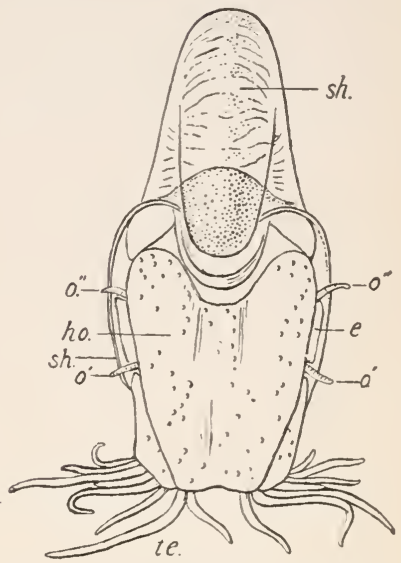

FIG. II3. - Nautilus macromphalus, creeping upon a horizontal surface. Note that the coil of the shell is anterior (compare with Fig. II0). e., eye ; ho., hood; $o^{\prime}$., $o^{\prime \prime}$., anterior and posterior ocular tentacles; sh., shell; te., tentacles. (Redrawn from Lankester's Zoölogy after Willey.)

which later becomes impregnated with lime. The lines of union of these septa with the outside walls of the shell are called sutures. These are invisible externally except where the outer surface has been worn off. (Compare with Fig. I16, su.) The sutures are slightly undulating, possessing a small ventral lobe (an undulation convex away from the aperture) and broad lateral saddles (undulations convex toward the aperture). (Compare with Fig. I 7 , l.l., l.s.)

Thus as the animal grows it moves forward, building about it an ever enlarging shell and at certain intervals shutting off by a septum the empty shell, which it thus leaves behind, and maintaining connection with the empty portion only by the siphon 
which enters the successive chambers through apertures in the septa.

The unoccupied chambers are filled by a gas which resembles air but with a somewhat larger proportion of nitrogen. These gas-filled chambers seem to support the shell in the water to a sufficient extent to relieve the animal of its weight in swimming or floating.

The tubular prolongation of the mantle, i.e. the siphon left behind in the apertures of the successive septa, secretes about itself a calcareous wall, the siphuncle (Fig. I I $2, s l$.), just as the posterior portion of the mantle elsewhere has built the septum. That portion of the siphuncle, called the siphonal collar, projecting backwards a short distance from each septum, is built by the enlarged anterior end of the siphon where it joins the mantle at the body ; it is heavier and hence more likely to be preserved fossi ${ }^{1}$ than the remainder of the siphuncle.

An external depression or opening, called the umbilicus, is visible at the center of the coils in Nautilus umbilicatus; in $N$. pompilius the outermost volution so envelops the inner ones that no opening is visible. The dark portion of the coil just inside the aperture is covered during life by a convex fold of the mantle extending upward from the umbilicus of the shell.

The body is held in the shell by strong muscles whose large crescentic areas of attachment are clearly visible on the inside of the living chamber near the umbilicus. The banded muscle scar connecting these two areas marks the place of attachment of three muscular (aponeurotic) bands which serve likewise in attaching the body to the shell and are called collectively the annular muscle or annulus (Fig. I 2 , an.m.).

The body when removed from the shell is found to be roughly oblong in outline and between six and seven inches in length. It is divided into a large, distinct head, bearing eyes and tentacles, and a rounded trunk. The ventral portion of the body is on the external or convex side of the shell, the dorsal on the inner or concave side. 
The mouth is at the free extremity of the head region and is surrounded by slender tentacles, sixty in the male, ninety in the female; these are situated on the edges of a series of fleshy lobes which represent the anterior part of the foot of other mollusks. Each tentacle consists essentially of two parts, a slender cirrus and an elongate, tubular sheath into which the cirrus can be retracted for protection.

The tentacles serve the double function of prehension and adhesion, being used for seizing food and for attachment to surfaces. They are provided with longitudinal, circular, oblique, and transverse muscles so that they are well equipped for a variety of muscular services. There are no true suckers as in the squid, but a kind of sucker-like efficiency is imparted to the tentacle by the contraction of certain of its muscles. Thus there are formed definite suctorial ridges on the lower and inner surfaces of the tentacles, and Nautilus can hold to the surface of attachment with considerable tenacity. The lower portions of the tentacles on the inner or dorsal side of the head are fused into a thick muscular lobe, the hood, which serves like the operculum of gastropods to close the aperture of the shell when the body is withdrawn into the living chamber. On the ventral side of the head region is the funnel or hyponome (Fig. II 2, f.) ; this looks like a thick, muscular leaf with free, rolled-in edges. The position of this funnel is indicated on the exterior of the shell by the hyponomic sinus, a down-bending of the lines of growth on the ventral (outside) portion of the shell.

The short, rounded body is enveloped by the mantle, which is prolonged posteriorly into the fleshy, hollow tube of the siphon, extending backward within the siphuncle of the shell through all the otherwise empty chambers. Anteriorly the mantle is produced into a free flap surrounding the head and attached to the shell near the edge. When the large mantle cavity is opened there are seen the two pairs of gills, the two pairs of osphradia, and the sac-like body wall containing the viscera. Opening from this sac into the mantle cavity are the apertures for the discharge of the waste and reproductive products. 
Water is admitted into the mantle cavity through the wide cleft between the free anterior edge of the mantle and the wall of the visceral sac. It bathes the gills and into it are thus discharged the effete products of respiration. It likewise receives the waste products discharged from the intestine and the products of the excretory and reproductive organs. After the admission of the water, the mantle cleft closes almost completely by appression of its walls, and contraction forces the water out through the funnel. The successive jets of water thus violently expelled through the funnel act as an oar in pushing the animal backward; this is its normal mode of locomotion.

Respiration is effected through the gills. These are two pairs of plume-shaped bodies attached to the wall of the mantle cavity and consist of delicate lamellæ with thin walls. The blood is carried throughout the gills in a system of minute branches and through their thin walls exchanges the waste gases it has collected from the body for the oxygen of the water which bathes the outside of the gills in the mantle cavity. It is then gathered up into vessels leading back to the auricle of the heart.

The digestive canal passes back in a straight line from the mouth, through the buccal cavity, œsophagus and crop to the stomach at the posterior extremity of the visceral mass. From the stomach the intestine bends abruptly, develops a rounded cæcum and proceeds in a nearly straight line to the anus, which opens into the mantle cavity. A very large digestive gland, the "liver," opens into the cæcum.

The food is largely small crustaceans, especially one species of decapod; the shells of these are easily crushed by the strong jaws. These and the small fishes, and mollusks which serve likewise for food, are seized by the tentacles and passed into the mouth, where they are torn by the powerful movement of the jaws. These jaws form a sort of beak situated just inside the thick-walled buccal cavity. They are mainly composed of hard black chitin but are calcified on the biting edges. So sharp are the jaws and so powerful their closing muscles that Nautilus is 
able to cut off the leg of a chicken as if with a pair of shears. The upper jaw fits closely inside the lower so that their action in biting is like that of a steel shear where two heavy blades having sharp square corners move past each other. The jaws form the main part of the buccal mass, leaving a comparatively small buccal cavity. As in the Gastropoda, Scaphopoda, and Amphineura, the floor of the buccal cavity bears a radula, set with pointed teeth, also a large fleshy projection called the tongue. The walls of the intestine are extremely thin and have an abundant supply of blood vessels which thus are in position to gather up the products of digestion from the digestive canal and carry them throughout the body.

The heart consists of a large, muscular ventricle into which open four branchial veins, one from each of the four gills. The blood passes from the ventricle in five arteries, the divisions of which penetrate all parts of the body. These arteries finally subdivide into capillaries and from these the blood passes into the sinuses, - extensive blood spaces in the various tissues.

Four nephridia or kidneys discharge their waste products into the mantle cavity. It is seen, then, that excretion of the body wastes is effected through the kidneys and gills which purify the blood, and by means of direct discharge by the anus through which passes the unused products of digestion.

The nervous system possesses no distinct ganglia, the central nervous system being represented by a very thick nerve collar surrounding the œesophagus. From this collar pass nerves to the various organs of the body.

Sense organs. - The eyes (Fig. I I $2, e$.) are very large, nearly an inch in diameter, but extremely simple, each consisting essentially of a saucer with convex bottom attached to the side of the head by a stalk and with the top covered by a disk perforated by a central aperture; this saucer is lined by the retina and possesses no lens or vitreous humor. It is filled by the sea water, which has free access through the aperture at the top. Thus the naked 
retina is bathed by sea water on one surface and receives the fibers of the optic nerve on the other.

It is considered probable from experiments in baiting Nautilus that the animal is guided in the capture of its prey largely by the sense of smell; though the eyes are doubtless likewise useful, still their simple character and the darkness of the depths where Nautilus is usually found would render them less useful guides.

The organs of hearing or of balancing are the two otocysts, - little sacs near the nerve collar, which are almost completely filled by a large number of otoliths, - tiny crystals of calcium carbonate.

Four modified tentacles, the so-called ocular tentacles, are supposed to serve an olfactory function. They differ from the other tentacles in the possession of vibratile cilia, and their sensitiveness is shown by their instant retraction when touched by a foreign body, - a sensitiveness not shared by the other tentacles, whose function is mainly adhesive. (The Dibranchiata do not possess these accessory olfactory tentacles, and it has been suggested that this difference is to be correlated with the fact that while Nautilus finds its food chiefly by the sense of smell, the Dibranchiata find it chiefly by the aid of their remarkably perfect eyes.)

The four osphradia situated in the mantle cavity near the gills are probably sense organs; they are knob-like projections containing nerve cells.

The sexes are separate, each individual possessing a single testis or ovary near the posterior end of the body. These discharge their products through ducts into the mantle cavity.

The eggs are laid singly, each egg being about an inch and a half long and surrounded by two thick shells.

The development of Nautilus is unknown.

I. What is the present habitat of Nautilus? Its geologic range?

2. Sketch the shell of a living species of Nautilus $(a)$ side view; $(b)$ view looking into aperture ; $(c)$ cut portion of section 
parallel to plane of coiling. Label aperture, living chamber, septa, siphuncle, muscle scars.

3. How are the septa secreted? Give a probable theory as to the cause of their presence and equal spacing.

4. What was the function of the muscles which caused the scars upon the inside of the shell?

5. Describe the siphon; its relation to the siphuncle.

6. How does Nautilus creep? While creeping what is the position of the funnel? the coil of the shell? How does it differ in this respect from a gastropod like Helix?

7. What are the functions of the tentacles? What is the hood? its function?

8. Describe the hyponome; its function. How is its presence indicated upon the shell?

9. What portion of the body secretes the shell? the siphuncle?

ı. What organs are located in the mantle cavity?

I I. How does the animal breathe?

I 2. Name two modes of progression of the animal.

I3. What is its food? How caught and eaten?

I4. Briefly describe the circulation of the blood.

I5. What waste products are there and how are these thrown out of the body?

I6. What are the principal differences between the nervous systems of the cephalopod Nautilus and the gastropod Busycon?

I 7. Describe the eye of Nautilus; the otocyst.

I8. Are the sexes united or separate?

I9. What are sutures? Examine them upon a fossil Nautilus.

20. What is the direct cause of the coiling during the growth of the shell?

$2 \mathrm{I}$. What part of the mantle secretes the "mother-of-pearl" of the shell? What is the cause of its brilliant luster?

22. Label on the sketch 2, (c) the dorsal and the ventral portions of the shell. How does it differ in this respect from gastropods, e.g. Busycon and Helix?

\section{General Survey of Class Cephalopoda}

Cephalopods are bilaterally symmetrical mollusks, with the foot transformed into a crown of appendages surrounding the 
mouth and a funnel-shaped swimming organ, the hyponome. The mouth is provided with jaws and a radula. The nervous system is highly developed.

A shell may be present or absent and when present may be external or internal, and modified into various forms. The general method of shell secretion in the mollusks is described under the Pelecypoda, pages 2 I4 $^{-2}$ I6, 220.

If oriented with the head and arms down, in the position assumed by Nautilus when moving over the sea bottom, the visceral mass is on top as in the normal position of gastropods, but unlike gastropods is not twisted. The shell likewise differs in being coiled dorsally, i.e. the outside of the curved shell of Nautilus is the ventral portion, of gastropods the dorsal.

(Compare Figs. II 3 and I Io.)

Cephalopods are exclusively marine. The sexes are separate.

Derivation of name. - > Greek cephale, head, + pous (pod), foot. The foot of other mollusks is here transformed into the arms and funnel about the head.

Cephalopods are divided on the basis of the number of gills, into two orders.

I. Tetrabranchiata.

2. Dibranchiata.

\section{Order I, Tetrabranchiata}

Cephalopods possessing an external shell of many chambers, only the last of which is occupied by the body of the animal. Head region bearing many appendages with suckers, and saucershaped eyes open to the exterior and without lenses. Four gills and four kidneys present, but no ink sac.

Named in reference to the number of gills from Greek tetra, four, + branchia, gills.

This order is represented by but one living genus, Nautilus, which has flourished from Tertiary to present times. There are, however, a great many fossil cephalopods found in Paleozoic and Mesozoic rocks which, though not affording much informa- 
tion as regards the anatomy of the living animal, such as the number of gills and kidneys, are classed with this order because their shells agree closely with that of Nautilus.

Cephalopods have been the strongest competitors of the vertebrates in the oceans from Silurian time to the present. Sections through the living chambers of different Paleozoic species show scales or other armor of the fish then living, indicating that such animals formed part of their food.

This order includes the two great groups Nautiloidea and Ammonoidea; the former have a non-calcareous and the latter a large calcareous initial chamber, the protoconch (Fig. i $6, p r$.). The siphuncle in the nautiloids varies in position from dorsal to ventral, being often centrally placed; in ammonoids it is, with the exception of one group, ventral in position, i.e. upon the outer edge of the coil. The curved growth lines of the hyponomic sinus almost invariably indicate the ventral side. In general the size of the siphuncle decreases from the nautiloids, through the ammonoids and belemnoids, to the sepioids, where it is a mere rudiment, distinguished with difficulty. This same relative decrease in the size of the siphuncle is seen in the development of an individual ammonoid from youth to maturity. Bactrites with its straight shell, simple sutures, ventral, but submarginal, siphuncle, peculiar collars and large calcareous protoconch may be transitional between the two groups, the Nautiloidea and the Ammonoidea.

Sub-order $a$, Nautiloidea. - Shells straight, curved, or coiled. Sutures simple, i.e. straight or undulated, never acutely angular. Living chamber usually with aperture notched by a hyponomic sinus for the passage of the funnel. Siphuncle usually central or dorsal, i.e. on inner margin of whorl, rarely ventral. Shells smooth or with simple ridges or nodes, never complexly ornamented.

Nautiloids are first known from the Cambrian rocks; they reach their maximum development in the Silurian and decline to the Triassic; since that period their retrogression has been 
slight. At present they are represented only by the genus $\mathrm{Nau}$ tilus, which has given the name to the sub-order.

Orthoceras (Fig. I I4).

Ordovician to Triassic.

Shell usually straight in the form of a long, tapering cone (whence the name from Greek orthos, straight, + ceras, a horn). Surface smooth. Living chamber long. Sutures simple,

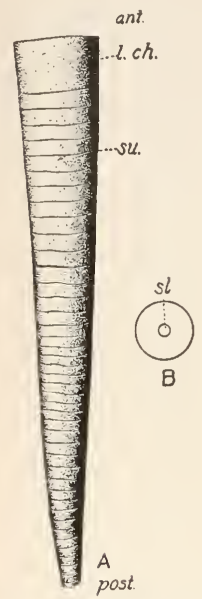

Fig. I 14. - The cephalopod, Orthoceras sociale Hall, from the marine Maquoketa formation (Upper Ordovician) of Iowa. ( $\times \frac{1}{2}$.) $A$, an almost complete internal mold of the shell showing the suture lines and probably most of the living chamber. ant., anterior end ; l.ch., living chamber; post., posterior end; su., suture. $B$, an ideal cross section showing the siphuncle (sl.). ( $A$, after Clarke.) straight or nearly so. Siphuncle usually central.

I. Sketch (a) side view; (b) top view. Label sutures, living chamber if present, siphuncle.

2. How do you account for the succession of chambers and their equal spacing?

3. What was the function of the siphuncle?

4. What part of the body secreted the shell?

5. What chamber did the body occupy at the time of the animal's death ? Was the siphuncle filled or empty during life?

Ryticeras (Fig. I I5).

Devonian.

Shell varying from slightly curved to loosely coiled. Siphuncle ventral, slightly expanded between the septa. Surface marked by coarse bands and at times by spinous processes.

I. Sketch side view, showing curve of shell.

Nautilus (Figs. I I2, I I3).

Tertiary to present.

Four living species of Nautilus are known; these are from the Indian and Pacific Oceans. N. pompilius is described on page $25 \mathrm{I}$. 
Sub-order $b$, Ammonoidea. - Shell usually closely coiled in a flat spiral. Sutures more or less complex, at times acutely angular. 'Siphuncle small, and situated near the ventral (outer) margin. Surface often highly ornamented with ridges and nodes.

In some ammonoids the aperture of the shell was closed, after the withdrawal of the animal, by a plate corresponding in function to the operculum of the gastropods, and probably secreted by such a muscular lobe as the hood of Nautilus.

Ammonites are especially important as index fossils in the Mesozoic. They are known from the Silurian to the Cretaceous inclusive.

As this sub-order is wholly extinct, we are dependent for knowledge of the animal and its habits wholly upon the information afforded by the shell and

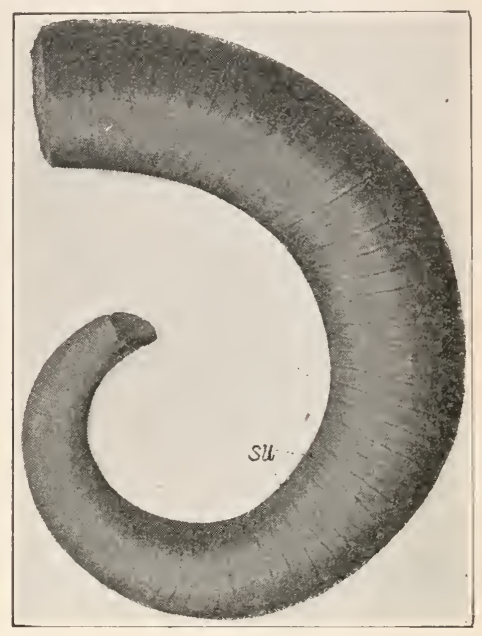

FIG. I 5. - Internal mold of the shell Ryticeras trivolve Conrad, from the Onondaga (Middle Devonian) of New York. ( $\times \frac{2}{3}$.) su., sutures. (From Hall.) the character of the rock in which it is found. It was probably closely comparable with Nautilus. A few were swimming forms as is indicated by the presence of a hyponomic sinus on the shell, the mark of the swimming organ, - the hyponome; but most ammonites were apparently able only to crawl. The apertures of these latter have in place of the hyponomic sinus a pointed prolongation of the ventral portion of the shell, the rostrum.

Bactrites (Fig. II6).

Devonian.

Shell straight, gradually tapering, round or compressed elliptical in section (whence the name, from Greek bactron, a staff, 


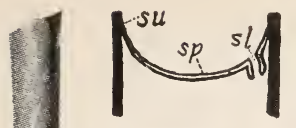

+ites, meaning stone). Sutures simple except for the small ventral lobe. Siphuncle ventral, sub-marginal.

B

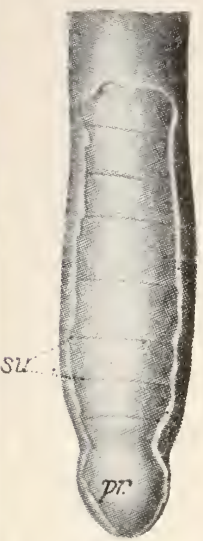

C

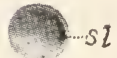

A

D

FIG. II6. - Bactrites gracilior Clarke, from the Naples beds (Upper Devonian) of New York. $A$, a nearly entire shell $\left(\times \frac{3}{4}\right)$. B, an ideal longitudinal section showing septum $(s p$.$) , suture (s u$.$) , and$ siphuncle $(s l.) . C(\times$ 2o), apex of shell showing protoconch ( $p r$.) and, where the shell is broken away, the sutures $(s u$.$) . D$, upper surface of a septum showing siphuncle $(s l$.$) .$ (After Clarke.)

after which there is an abrupt decrease. lobe, siphuncle. order Nautiloidea? saddle. the ventral side. umbilicus.

4. What is a suture? tral sides of a shell?

Placenticeras (Fig. I 18 ).

I. Sketch $(a)$ side view showing ventral lobe; (b) top view; label sutures, ventral

2. Why is this not included with the sub-

Muensteroceras (Fig. II7).

Mississippian.

Shell coiled into a thick disk. Umbilicus moderately wide, with angular margin. Sutures with angular lateral lobe and broad lateral saddle, and with a narrow lobe on the venter broken by a small notched

All shells with the above type of simply angular sutures were formerly classed as goniatites (from Greek gona, a knee).

I. Sketch view showing coils, noting sutures, lobes, saddles, umbilicus; indicate

2. How was the umbilicus formed?

3. Sketch an entire suture from venter to

5. What determines the dorsal and ven-

Cretaceous.

Shell coiled into a thin disk. Suture complex, made up of numerous serrated lobes and saddles (the ammonitic type of suture); the third lateral lobe is the deepest, 
I. Sketch $(a)$ circular view of specimen showing sutures; (b) view showing aperture.

2. What is the relation between septum and suture?

3. Under what conditions do sutures become visible?

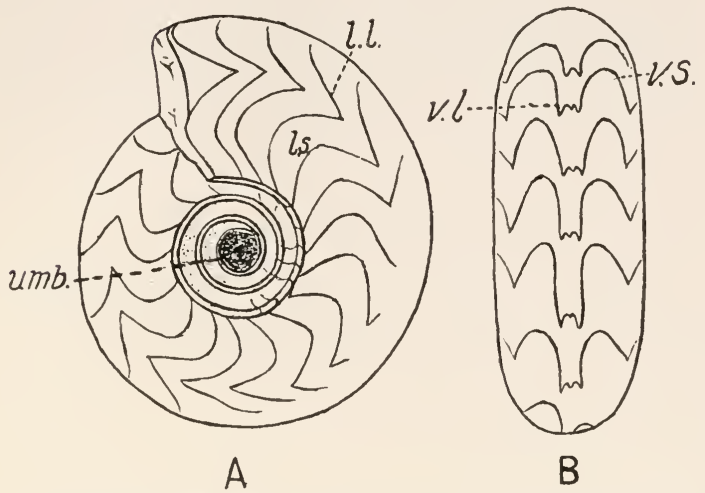

FIG. I1 7. - An ammonite, M uensteroceras oweni Hall, abounding in the ocean covering Indiana during Kinderhook (Lower Mississippian) time. Natural size. $A$, side view. $B$, ventral view. Sutures goniatitic; l.l., lateral lobe; l.s., lateral saddle; $u m b$. , umbilicus; v.l., ventral lobe ; v.s., ventral saddle. (Redrawn from Hall.)

Scaphites (Fig. I I9).

Cretaceous.

Coiled in a plane spiral with the whorls in contact and embracing, except the last, which often becomes somewhat uncoiled and detached from the spiral and recurved in the form of a hook. Surface ornamented with bifurcating ribs which often bear tubercles; ribs continuous across the venter. Sutures generally much divided with several auxiliary lobes. Name from Greek scaphe, a boat, + ites, meaning stone, in reference to the shape.

The variety $S$. nodosus brevis is exceedingly abundant in the Cretaceous of the Rocky Mountain region, also in New Jersey.

I. Sketch $(a)$ view of spiral; $(b)$ apertural view ; $(c)$ interior of section of entire shell cut parallel to the plane of coiling; note siphuncle, sutures, ribs, septa.

2. How much of the entire shell did the body of the animal occupy during life? Compare with gastropods. 
3. On shell I, $(c)$ follow a septum from its center to its outer edges, - the sutures; note it gradually changing from the simple, flat septum into the very complex lobes and saddles of the

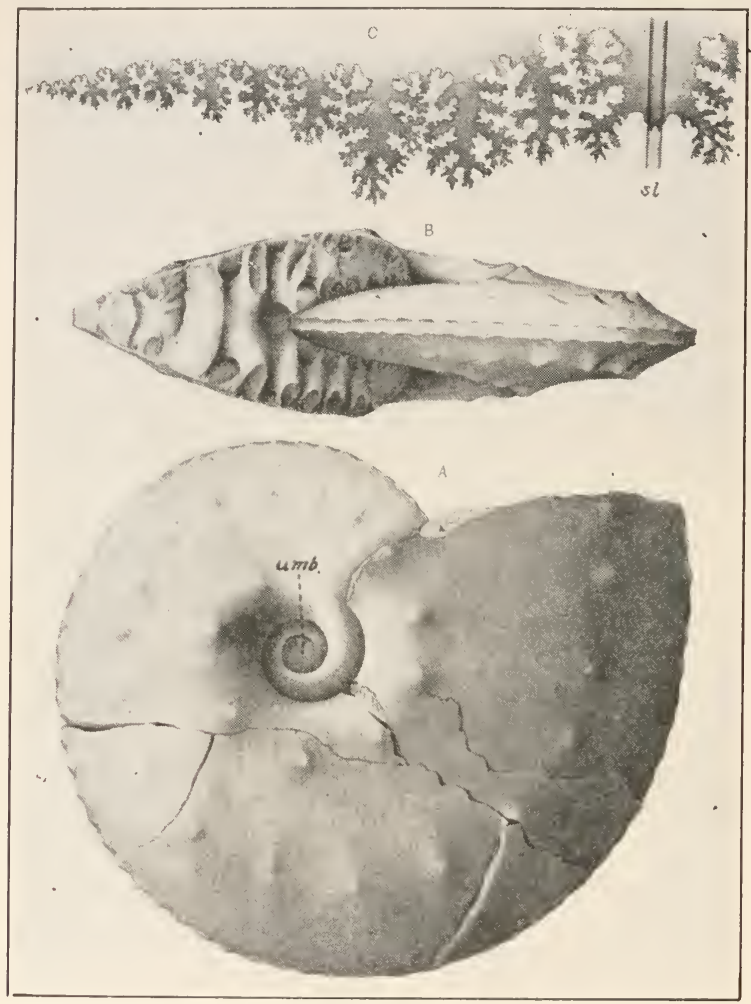

FIG. II8. - The ammonite, Placenticeras intercalare Meek, from the Pierre formation (Cretaceous) of South Dakota. A, side view of specimen $\left(\times \frac{1}{2}\right) . \quad B$, apertural view. $C$, suture of same from siphuncle (upon the outer edge of the coil) to umbilicus $(u m b$.). sl., siphuncle. (From Meek.)

sutures. (A section of any ammonoid shell will show the same change.) Compare this with a similar section through a fossil Nautilus; what difference do you note?

4. What principally distinguishes the Ammonoidea from the Nautiloidea? 
5. Distinguish the ammonitic type of suture from the goniatitic; give examples of each.

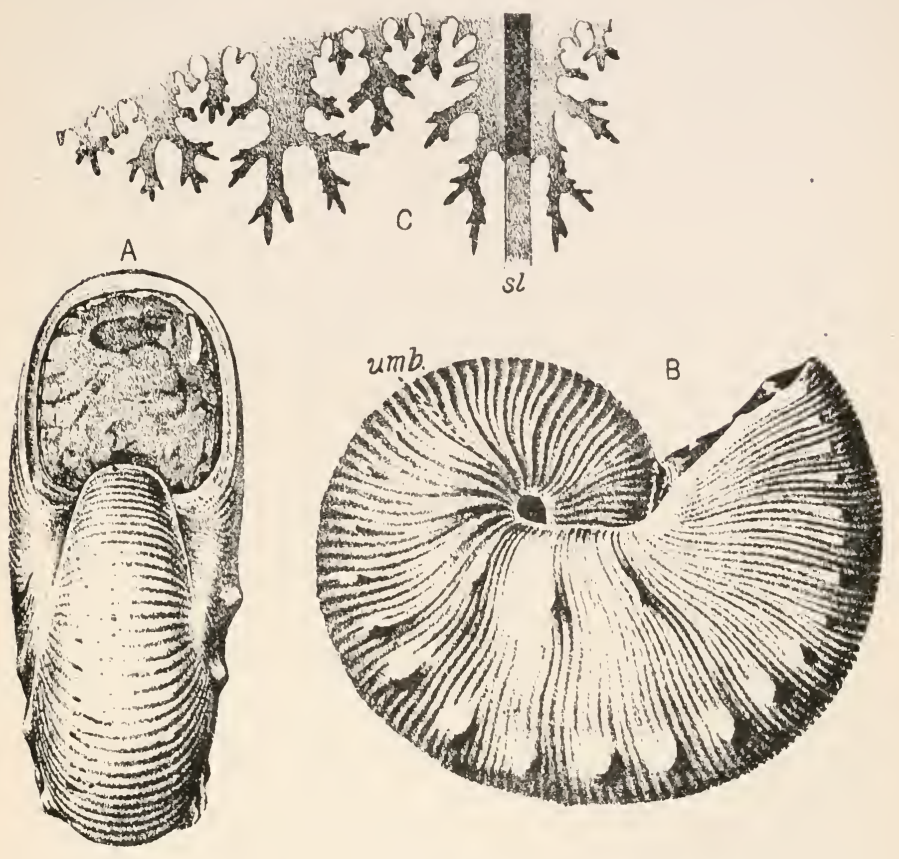

FIG. II9. - Scaphites nodosus, var. brevis Meek. An entire shell from the Pierre

(Cretaceous) of Montana. $A$, view of opening of living chamber $\left(\times \frac{3}{4}\right)$. $B$, side view. $C$, the suture $\left(X \mathrm{I}^{\frac{1}{2}}\right.$ ) extending from the position of the siphuncle (upon the outer edge of the coil) to the unbilicus $(u m b$.). sl., siphuncle. (From Meek.)

Baculites (Fig. I 20).

Cretaceous.

Straight (except the first-formed part, which is spiral), elliptical in section. Sutures with the lobes symmetrically divided. Named from its shape, from Latin baculum, a staff, + ites, meaning stone.

B. compressus is abundant, associated both east and west with the variety of Scaphites noted above and with several species of the pelecypod Inoceramus. 
I. Sketch $(a)$ the elongate flattened surface of a specimen showing the sutures; $(b)$ top view ; label sutures, lobes, saddles, umbilicus, septum, siphuncle.

2. These fossils usually occur with mud filling all the chambers. How did the mud penetrate the chambers?

3. Distinguish between septa and sutures.

4. What does a single perfect shell of Baculites suggest as to its ancestry?
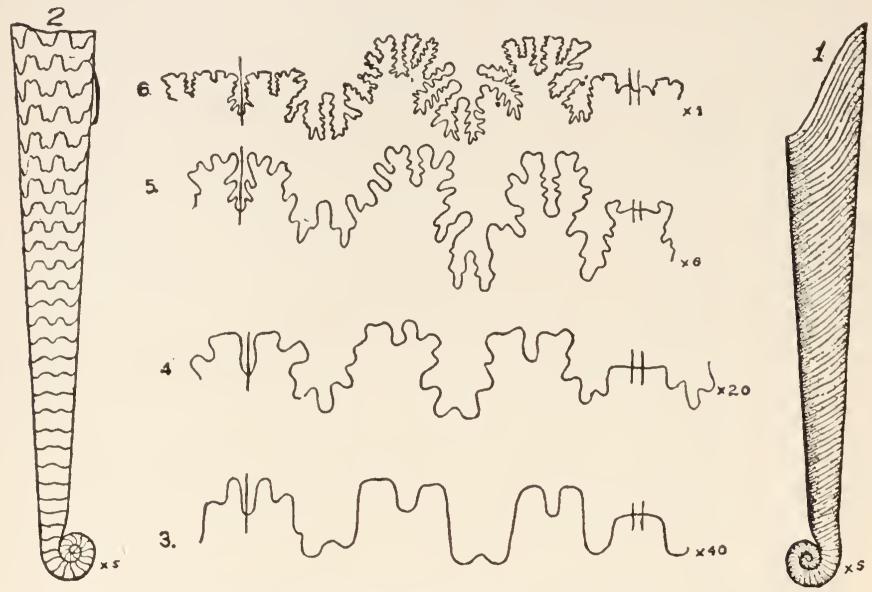

Frg. I 20. - Baculites compressus Say, from the Cretaceous of South Dakota. I. A young shell preserving the early coils. The living chamber occupied about one half the length of the shell. 2. A specimen of same size as the last but with the outer shell broken away revealing the sutures, - the outer edges of the septa. Note the variation in the sutures from the apex of shell 2 to its wide end and on through the progressively larger shells as shown in 3, 4, 5, and 6.6 represents the condition of the suture in the adult shell. (After Brown.)

\section{Order 2, Dibranchiata}

Cephalopods with shell internal or wanting, or exceptionally external but not chambered (Argonauta). Head bearing eight or ten arms around the mouth; these are furnished with suckers. The eyes are very large and of complex structure. Two gills and two kidneys are present. An ink sac discharges its contents through the funnel when the animal is startled, thus constituting 
a means of defense, since under cover of the blackened water the animal may escape. Indications of this ink bag are often present in fossil forms in the shape of an external mold of the sac, and even in carbon particles, the remains of the ink itself.

The typical internal shell is seen in Belemnites, a fossil form described below. The shell is absent in the devil-fish (Octopus).

The Dibranchiata are known from the Triassic to the present.
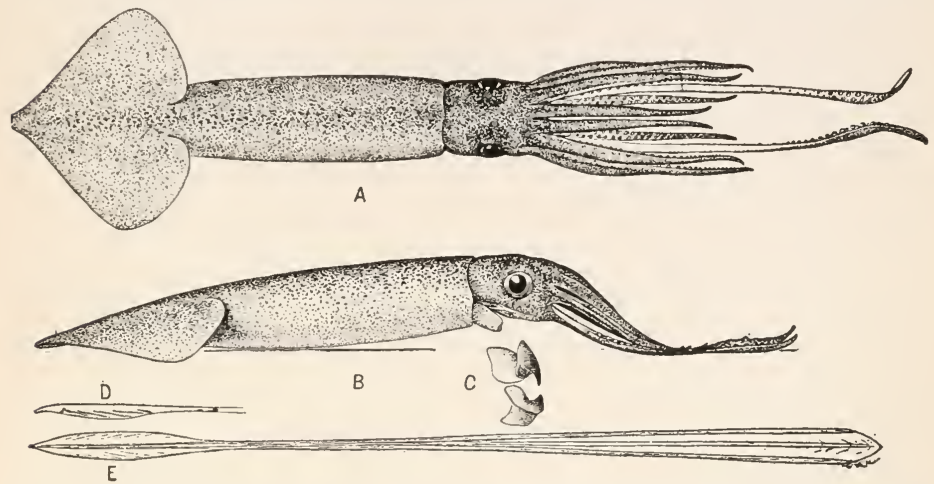

FIg. I2I. - In American squid, Ommastrephes illecebrosa Les. $\left(\times \frac{1}{4}\right)$, from the Atlantic Ocean at Provincetown, Mass. $A$, dorsal view. $B$, side view of animal asleep; note how the water for respiration is kept pure by the elevation of the anterior mantle slit above the mud. $C$, the jaws in position. $D$, side view of tip of skeleton. $E$, upper view of entire skeleton. (All drawn from life by J. Henry Blake.)

Ommastrephes (Fig. I 2I).

Living.

This marine, free-swimming animal is world-wide in its distribution. In general all forms similar to this genus are commonly called squids. It has a distinct head bearing ten long, very muscular arms and two large, highly developed eyes; two of the arms are much larger than the other eight. The head is separated from the trunk by a constricted region, the neck. The trunk is elongate, shield-shaped, bordered laterally by a fleshy fin. The entire body is surrounded by a thick muscular mantle which is free from the body except along the median dorsal line. 
The skeleton is entirely internal; it consists principally of the narrow pen of conchiolin (Fig. I I $D, E$ ) passing the entire length of the trunk and protecting the visceral organs dorsally. There are, in addition, several somewhat horny cartilages which are supporting and protective in function. The cranial cartilage protects the principal nerve centers and supports the eyes; other cartilages support the bases of the fins and the arm bases.

Another protective organ is the ink sac. This is located in the posterior part of the trunk and secretes a dark brown substance. When the squid is startled, it discharges this fluid through the duct opening within the anus, where, mixing with the water in the mantle cavity, it is discharged through the funnel as a black cloud under cover of which the animal escapes.

Locomotion. - The squid can dart with great rapidity, partly by the arms, partly by the muscular, lateral fins, but principally by the rhythmical contraction of the mantle. The expansion of the mantle draws water through the slit between the anterior edge of the mantle and the body into the mantle cavity. Muscles then close this opening and the contraction of the mantle forces the water out through the funnel, causing the animal to move in the opposite direction. It can move in any direction by simply bending the funnel in the direction opposite to that in which it wishes to move. A valve prevents the water from entering the mantle cavity through the funnel.

The animal's food consists of mollusks, crustaceans, and fishes which it catches with its arms. The arms are furnished on the inside with many suckers.

Each sucker is a shallow cup supported on a short stalk; its membranous lip is lined internally by a narrow, horny rim and in the middle of the bottom of the cup is a piston-like plug which, when drawn down by the contraction of muscles, produces, when held against a solid object, a partial vacuum and resulting adhesion. The prey stands little chance of escape when surrounded by arms lined by hundreds of such suckers.

The eyes are much more perfect than those of Nautilus, and are next in order of development to those of the vertebrate. 
Light rays passing through the protective transparent cornea are bent towards the pupil by the water filling the external chamber of the eye; this chamber is open by a small hole to the sea water. The pupil is an opening through the firm wall of the eye; the portion of this wall immediately bounding the pupil and called the iris contains muscle fibers by whose action the pupil can, to a limited extent, be enlarged or diminished. The light is then focused upon the retina by passing through the spherical, dense lens and next through the large mass of jelly-like vitreous humor.

There are two otocysts in the posterior portion of the head; these have the power of coördinating movements in maintaining equilibrium, and are possibly also functional in hearing. There may also be present a sense of smell and of taste.

The sexes are distinct. The eggs are fertilized through copulation.

Belemnites (Fig. I 22).

Jurassic to Cretaceous.

Belemnites is closely related to the squid. Impressions of the tentacles and arms are sometimes found preserved in the fossil state, showing the suckers provided with horny hooks. The mandibles and ink sac are likewise at times found with the ink preserved in the form of solid carbon particles. The shell, however, is more complete than that of the squid, consisting of three parts, - guard, phragmocone, and proöstracum. The guard is

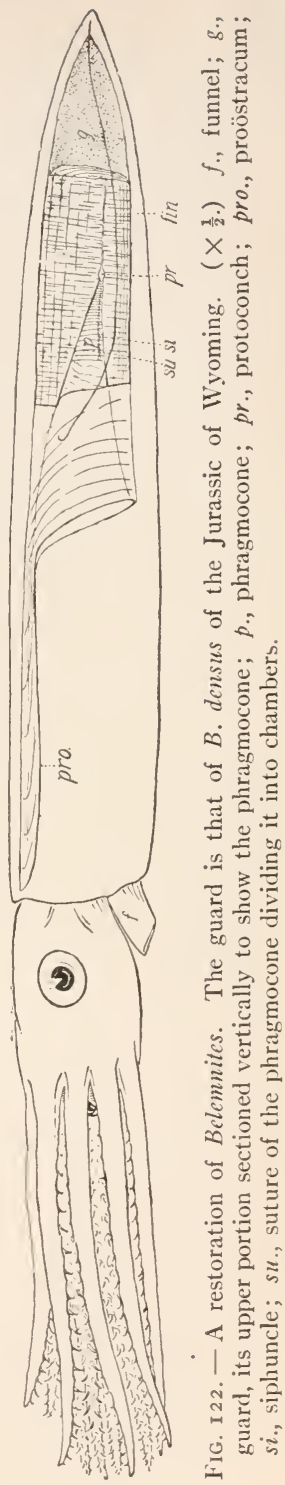


solid, and when examined in section is seen to be composed of prisms of calcite radiating from an axial line slightly nearer the ventral surface. The phragmocone fits into the hollowed end of the guard - the alveolus, and is divided into chambers by septa which are perforated by the ventrally placed siphuncle; this is followed by the calcified, blade-like proöstracum. The proöstracum corresponds to the pen of the squid and probably in life afforded dorsal protection to the viscera. The phragmocone corresponds to the entire shell of the Tetrabranchiata.

-As an index fossil of the Jurassic and Cretaceous it is scarcely less important than the ammonites. The name, from the Greek belemnos, a dart, was given by Agricola in I546. It is commonly called "arrowhead" or "finger stone" from the shape, and "thunderbolt" or "thunder stone" from its supposed origin.

I. Split the broad end of a specimen longitudinally from the ventral groove backwards (if the narrower end splits likewise, this should be glued into place again). Sketch view showing this section. Label alveolus, guard.

2. Note the calcareous, prismatic fibers of which the guard is composed, and the successive conical layers by means of which the guard increases in size. Make a cross section showing this increase.

3. The walls of the alveolus usually show faint impressions of the chambered phragmocone, the siphuncle of which was located ventrally, i.e. upon the side next the ventral groove. Indicate upon the first sketch the ventral and dorsal sides.

4. What is the significance of the name Belemnites?

In the genus Sepia (Tertiary to present) the shell is likewise internal but extends the entire length and breadth of the body. It is without differentiated phragmocone and guard, but consists essentially of proöstracum or "pen." The projecting point may represent the guard. This is the familiar cuttle bone of commerce. Sepia officinalis is very common in the Mediterranean. The coloring matter from its ink sac is insoluble in 
water and gives a beautiful brown color much used in monochrome drawing.

Other living genera of the Dibranchiata are the devil-fish (Octopus) and the Argonaut. Common American squids are Loligo and Ommastrephes. 


\section{PHYLUM XI, ARTHROPODA}

THE Arthropoda are transversely segmented animals with mouth and anus at opposite ends of an elongate body, with muscles attached to the inside of an external skeleton (the very opposite of the vertebrates), and with a nervous system composed of a dorsal brain above the œsophagus, connected by nerves around this with a double ventral chain of segmentally arranged ganglia. A few or most of the body segments bear paired appendages, the distinct segments of which latter are separated by joints and moved by special muscles. Thus, as the animal does not need the movement of the skin for locomotion (as in the annulate worms) the skin secretes a horn-like substance, chitin, to form a hard outside skeleton. Since this rigid exoskeleton prevents increase in size, growth can occur only through the shedding or molting of this chitin. Eyes are nearly always present and are simple or compound. The cavity of the body between the exoskeleton and the internal organs consists largely of spaces, the blood sinuses, which are in full communication with the blood circulatory system. The heart, usually present, is elongate and is situated in a blood sinus from which the blood enters by valvular openings (ostia).

Arthropods are probably descended from some annelid wormlike ancestor, the crustaceans continuing to live in the water, while the insects, myriopods and most of the arachnids are diverging to a life upon the land.

Derivation of name. - Greek arthron, joint, + pous (pod), foot, referring to the division of the limbs into movable segments.

The phylum is subdivided as follows:-

Sub-phylum I, Branchiata.-Mostly water breathers; breathe by gills (branchiæ). 
Class A. Crustacea

Sub-phylum 2, Tracheata (except many of Class D). - Air breathers; breathe mostly by tracheæ.

Class B. Onychophora .

Class C. Myriopoda .

Class D. Arachnida .

Class E. Insecta .

\section{CLASS A, CRUSTACEA}

Type of the class, Cambarus (Fig. I23).

The crayfish, Cambarus, lives in fresh water lakes, rivers and pools and is found in North America east of the Rockies and in eastern Asia. The only other genus of crayfish living in the northern Hemisphere is Astacus; it is found in North America west of the Rockies, in Europe and in western Asia. There are also some blind crayfish of the genus Cambarus inhabiting the caves in Carniola, southern Austria, which point to the former more extended occupation of Europe likewise by this genus.

The body is divided externally into the anterior unjointed portion, - the cephalothorax (union of head and thorax) covered with the carapace, and the posterior portion, the abdomen, made up of distinct segments and terminating in the large horizontally flattened telson. The cephalothorax bears the eyes, feelers, and the five large walking legs. This division into head, thorax and abdomen is not equivalent to the like division of the vertebrate body.

The body consists of twenty segments bearing upon their under side nineteen pairs of appendages. As can be seen by the appendages on the ventral side, the head consists of five segments bearing pairs of antennæ or feelers, the short and the long, one of mandibles or jaws, and two of maxillæ. The thorax is made up of eight segments bearing five large posterior or walking legs and three smaller anterior pairs or foot-jaws, with their 
bases toothed for passing the food obtained by them forward to the mouth. The abdomen consists of seven segments, each of which except the last, or telson, bears a pair of appendages.

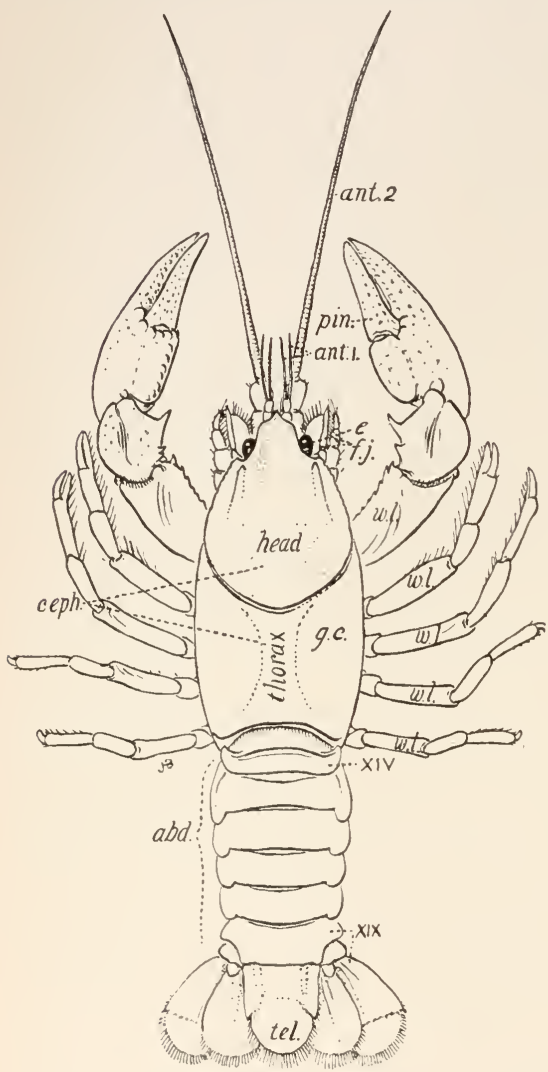

FIG. 123. - The crayfish, Cambarus bartoni Fabr. $\left(\times \frac{3}{4}\right)$, from Colchester, Vermont. Dorsal view; $a b d$., abdomen; ant. $I$, anterior antennæ; ant. 2, posterior antennæ; ceph., cephalothorax; $e$., eye; f.j., foot jaws; g.c., gillcover; pin., movable arm of pincer; tel., telson; w.l., walking legs (five pairs); $X I V$, fourteenth body segment or first abdominal segment; $X I X$, nineteenth body segment.
In the female the five anterior pairs are small swimming feet or pleopods, while the sixth pair is much enlarged, each consisting of two flattened parts which with the telson compose the five-parted tail-fin, the principal organ of locomotion. The male differs only in having the anterior two pairs of pleopods converted into incomplete tubes for transferring the spermatozoa to the body of the female.

The typical appendage consists of one or more basal joints, the protopodite, which divides into two branches: an inner and ventral, the endopodite, and the outer and dorsal, the exopodite ; this latter division is largely respiratory in function.

The skeleton is external and is both protective and supporting to the muscles and other soft parts within. It is composed of chitin secreted by the epidermis, and hardened with more 
or less lime carbonate. It is segmented because it is thickened with lime carbonate in those regions not subject to bending, but remains thin and hinge-like in the intermediate spaces.

The carapace arises as a fold of the skin from the posterior margin of the head region; dorsally it coalesces with the body segments, but at the sides it is free, forming the gill-covers (Fig. I23, g.c.). As these covers are unattached below they permit the free entrance of water to the gills within, which lie between the sides of the carapace and the walls of the thorax proper.

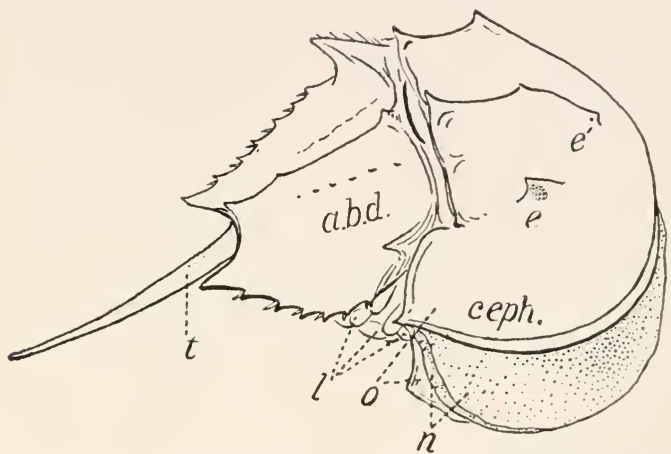

FIG. I 24. - A young horseshoe crab, Limulus polyphemus, from the Massachusetts coast, molting. abd., abdomen; ceph., cephalothorax; e., a compound eye; $e^{\prime}$., a simple eye; $l$., legs; $n$., newly molted portion; 0. , the edges of the old shell; t., telson.

Since the soft parts of the body are completely incased in resistant chitin, growth can take place only by a process of molting, - of shedding the chitinous covering periodically (see Fig. I 24). This is thrown off as a distinct whole. Not. only is every part of the exterior shed, but also the lining of the œsophagus, stomach, and all of the intestine except the middle portion, though some internally shed chitin, however, as that of the stomach, does not leave the stomach, but is redigested. This molt, an exact copy of the exterior of the living animal, is shed about once a year during adult life, but oftener during the rapid growth of youth. 
The process of molting has been described as follows, a description holding true in general for all Crustacea: "Previous to the throwing off of the old skin a new soft one is formed inside" (the epidermis secretes new layers of chitin), "the lime is absorbed from the old shell in a dorsal line along the carapace, reaching from the rostrum to its posterior margin. Absorption also takes place at the joints of the limbs. The carapace now splits along this dorsal median line of absorption, the blood leaves the limbs, which are thus made flabbier, and by involuntary muscular movements they are drawn, large claw and all, through the joints of the old shell. The anterior portion of the body is first drawn out through the dorsal vent, and lastly the tail. By means of the return of the blood to the limbs and the rapid absorption of water, the body . . . soon swells to a size far beyond that of the old shell" (2). The lime taken up by the blood by absorption previous to molting is used in hardening the new shell, doubtless aided by the lime carbonate from pieces of shells, sea urchin spines, discarded lining of the stomach, etc., which have been found in the stomachs of crayfish and other Crustacea.

Beneath the epidermis is a layer of connective tissue, - the dermis to which the muscles are attached. They are thus fastened to and supported by the external skeleton. The muscular system consists principally of two longitudinal pairs of muscles, a large and complex ventral pair and a smaller simple dorsal pair, both extending the entire length of the abdomen and into the thorax from whose walls they arise. The dorsal pair or extensor muscles straighten the abdomen, while a portion (the flexor muscles) of the ventral pair bends it downward; the quick contraction of these latter powerful muscles causes the crayfish to dart rapidly backwards. It moves forward by the action of the abdominal swimming feet.

Of the five pairs of long thoracic legs the four posterior ones are used in walking, the large anterior one with its huge terminal pincer for defense and offense. Each tube-like section of one of 


\section{ARTHROPODA - CRUSTACEA}

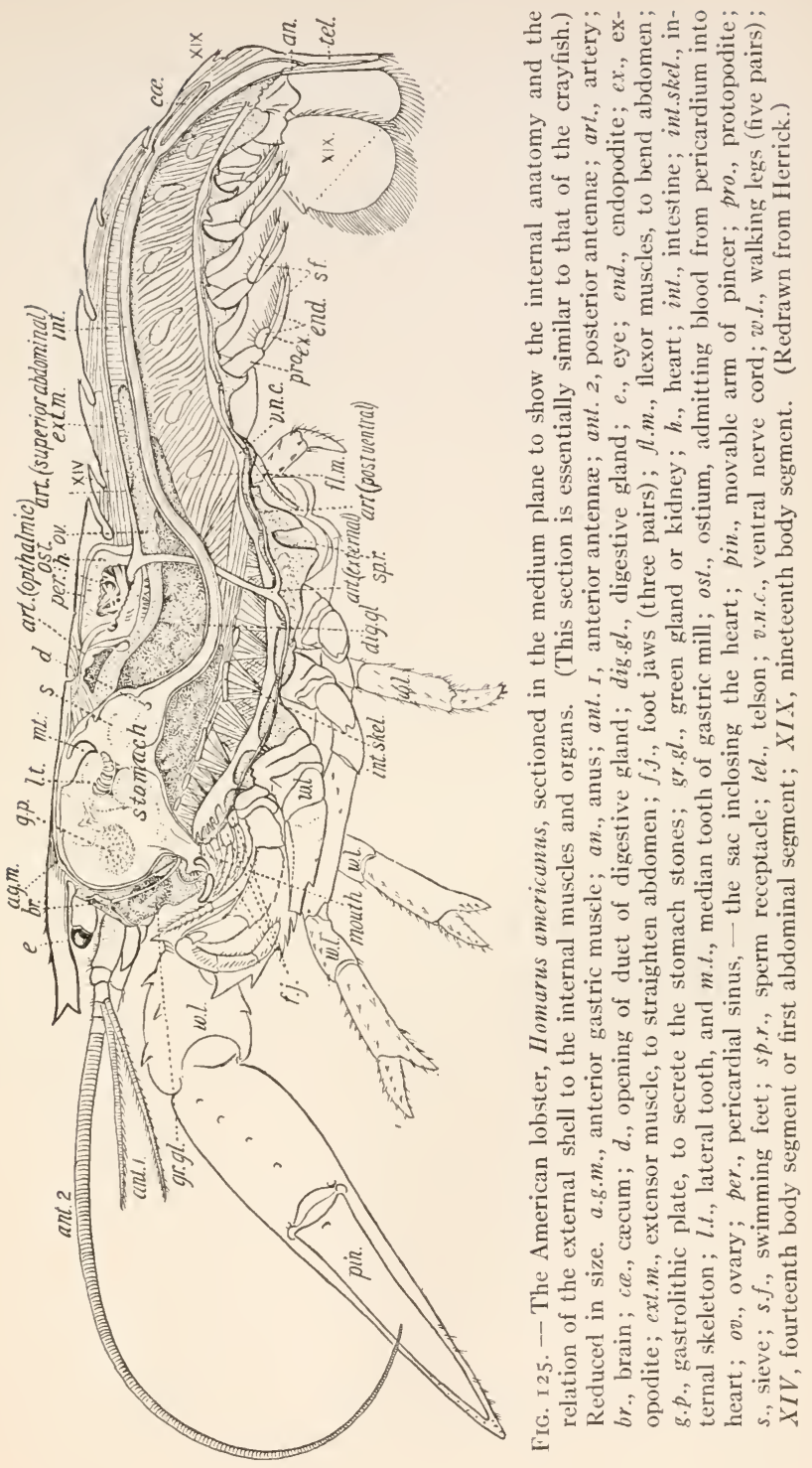


these is united to its fellow by a hinge-joint, hence movement can occur in but one plane, as at the knee and elbow in man; but since the axis of the hinge is different at successive joints, each entire leg can move in all directions. Movement is effected by an extensor and a flexor muscle fastened to the sides of each tube-like section and inserted in the sides of the proximal end of the next outer section; the movable arm of the pincer is similarly worked.

Digestive system. - The food of the crayfish is varied; it may be animal or plant, living or dead ; it is largely decaying animal matter. On account of their need of lime they are fond of stonewort (Chara). The smaller particles of food caught by the toothed bases (gnathobases) of the three anterior pairs of thoracic feet are carried forward by them to the mouth, as are the larger pieces caught by the huge claws. There the food is torn into bits by the toothed edges of the strongly calcified mandibles situated at its sides. Anteriorly the mouth is bounded by a single plate, - the upper lip (labrum or hypostome); posteriorly by a pair of delicate lobes, - the lower lip. The food passes from the mouth through the œsophagus to the gastric mill, a division of the stomach; this is lined with chitin and has projecting into it from its walls three calcified teeth (see Fig. 125). The mill is so moved by two pairs of muscles extending from it to the thoracic skeleton that the three teeth meet in the middle and thus complete the comminution of food begun by the mandibles. The food then passes to the smaller or pyloric division of the stomach; the numerous hairs which extend across this division act as a sieve to prevent all but the very fine food from passing on into the intestine. The stomach is thus merely a masticating and straining apparatus; digestion takes place in the small intestine. Into this is poured from the single pair of digestive glands a yellow fluid which digests both the proteids and fats, combining thus the function of both pancreas and liver of the vertebrates. The undigested remnant passes out through the large intestine and finally through the 
anus, which is situated on the ventral surface of the telson. With the exception of the sharp downward bending to the mouth the digestive canal is a straight tube extending the length of the body.

Since the œsophagus and stomach as well as the large intestine are formed by the inbending of the surface of the gastrula, they are formed from the ectoderm as is the surface layer (epidermis) of the mature animals ; hence they similarly secrete a lining of chitin which must be shed with each molt. Only the small intestine and its digestive glands are formed from the inner cell layer, the endoderm, of the gastrula stage.

The absorption of the digested food takes place through the walls of the small intestine and its digestive glands directly into the blood (since the intestine is surrounded by a blood sinus) and thus finally into the heart.

The blood circulatory system consists of a muscular heart in the dorsal part of the thorax, arteries, capillaries, blood sinuses (cavities without definite walls among the muscles and viscera) and veins.

The rhythmical contraction of the heart forces the blood into seven arteries, which, dividing, extend into all parts of the body and finally into microscopic capillaries which terminate by open mouths in the blood sinuses. All blood sinuses communicate with the ventral sinus which runs the entire length of the abdomen and thorax, and conducts the blood to the veins on the gills. From the gills, veins carry it to the sac-like cavity (pericardial sinus) in which the heart is located. The blood enters the heart, upon the latter's rhythmical expansion, through three pairs of apertures with inwardly opening valves. The blood is a colorless fluid and all the corpuscles are similarly colorless (i.e. leucocytes.) When combined with oxygen it is bluish gray owing to the hæmocyanin in the fluid (not in the corpuscles), which like hæmoglobin in mammals has great affinity for oxygen; it thus acts as the oxygen carrier from the gills to the tissues.

Respiration is performed by the gills, aided probably by the inner surface of the gill covers which bound them externally. 
Internally they are bounded by the wall of the thorax, since they are outpushings of the body wall. They are freely open below for the entrance of water. The renewal of fresh water is brought about by the vibratory movements of the exopodite of the maxilla, causing a current to set in over the gills from below and out in front.

The gills thus excrete carbon dioxid. Another excretory organ is situated at the base of each posterior antenna; this is the green gland which collects the uric acid, urea, etc., in a urinary sac and discharges it through a duct opening on the proximal segment of the antenna.

The nervous system consists primarily of a brain in the dorsal region of the head united by nerve cords around the œsophagus to the anterior end of a ventral nerve cord. The former supplies the eye, antennæ, etc. The latter is composed primarily of a double, ladder-like chain of ganglia united by connectives and extending to the posterior end of the body. Most segments have their own ganglia.

The sense organs include those of touch, sight and possibly also smell and hearing.

The setæ on the two pairs of antennæ are tactile as are those in many other parts of the body. These are hollow outgrowths of the epidermis and its chitinous covering and contain the end of a nerve fiber prolonged outward from the dermis. There are two compound eyes at the front of the head, and since the latter is firmly fixed to the thorax the eyes are raised on movable stalks.

Each eye is covered with the protecting, transparent cornea, the surface chitin; this is divided into very many four-sided facets. Beneath each facet is the eye proper, or ommatideum, optically separated from its neighbor by a black pigment. The outer portion of each ommatideum is the refractive vitreous body, which bends the light rays falling upon it downwards to the inner portion, the small retina. The retina is composed of very sensitive cells, the ends of the optic nerve fibers, and through these is connected with the brain. The pigment surrounding the ommatideum absorbs all light not reaching the nerve fibers, thus preventing a distortion of the imag. Each sep- 
arate division of the compound eye gives a complete image, but the resultant vision of the entire eye is not a mosaic, although each facet gives a different perspective from its neighbor. The resultant is a single image just as in man, where the two eyes, each with a different perspective, produce a single image.

Some delicate setæ upon the shorter, or anterior, pair of antennæ are supposed to function as organs of smell.

In the proximal segment of the shorter pair of antennæ occurs a sac-like inbending of the surface chitin. This sac, the otocyst or statocyst, is in free communication with the water outside through a small opening guarded by hairs. It is lined with sensory feathered setæ, similar in structure to the tactile setæ, and contains some minute sand grains. One function of this organ has been shown to be the maintenance of equilibrium, similar to that of the semicircular canals in man. Gravity acting upon these grains brings them into contact with different setæ as the body becomes tilted at different angles and through these setæ corresponding sensations are produced in the neighboring nerves which transfer them to the brain. Probably these setæ also take cognizance of the sound waves passing through the water and thus act likewise as organs of hearing. When the animal molts, the chitinous lining of this sac is also shed so that new sand grains must be gathered after each molt.

Reproduction is sexual. The eggs are of considerable size with a large amount of yolk. They are fertilized immediately after extrusion and are fastened to the swimming legs of the female by a sticky secretion from glands on those appendages.

The one-celled egg after fertilization rapidly develops into the blastula-like stage and this into the gastrula. Thickenings then develop in definite parts, forming the rudiments of the three anterior appendages of the head; this is the nauplius stage. After this the embryo rapidly passes into the form in which it is hatched, that is, it becomes adult in form but not in size.

I. What is the present habitat of Cambarus?

2. Name the principal external divisions of the body.

3. What are the divisions of a typical appendage?

4. Is the skeleton internal, i.e. covered upon the outside by a renewing fleshy layer, or external ? 
5. What is the composition of the skeleton? What difference in composition between the regions subject to bending and those not so subject?

6. Why is molting necessary to growth?

7. What parts of the body are thus renewed?

8. How often does molting occur? Describe the process.

9. Are the gills external to the body or internal? How are they protected?

Io. Where are the muscles fastened? How does this differ from the muscles of the Vertebrata?

I I. What are the principal muscles of the body? Give location and use.

I2. How does the animal move?

I3. Give three methods of progression used by the crayfish.

I4. How do the muscles effect the complicated leg movement?

I 5. What does Cambarus eat? How is food procured?

I6. Describe digestion; absorption.

I7. Briefly trace the course of the blood through the body. What are its functions?

I8. How does the crayfish breathe?

I9. Give three means by which the waste of the body is eliminated.

20. Of what does the nervous system consist?

2I. In effectiveness of response to environment, how does this system compare with that of the pelecypod? The coral?

22. What sense organs does Cambarus possess? Describe each.

23. Describe reproduction.

\section{General Survey of Class Crustacea}

Usually aquatic and carnivorous arthropods, with body divisible into head, thorax and abdomen. The body is inclosed by a protective and supporting chitinous cuticle which becomes much thickened with lime carbonate where no movement is required. The food, consisting largely of decaying animal matter, passes through the mouth usually into a large stomach, thence through a straight intestine to the exterior at the posterior end of the body. The anterior and posterior portions of the digestive canal are lined with chitin, which is continuous with 
that of the exoskeleton; only the middle portion is unlined and this alone develops outgrowths for secretion of digestive fluids and for absorption. A contractile heart forces the blood through the arteries to the surface of the body, whence it returns through the veins or open sinuses to the heart, passing on the way through the gills, where these are present. Respiration is by the general surface of the body or by gills (hollow offshoots of the thoracic walls or of the thoracic or abdominal limbs). The young usually passes through a series of larval stages, - the nauplius, zoœa and mysis stages. Through successive molts the young animal increases in length by the addition of new segments anterior to the telsonic region.

Abundant as fossils.

Derivation of name. - Latin crusta, a crust, referring to the hard, crust-like, calcareo-chitinous skeleton completely inclosing the animal.

The class Crustacea is divided into the following sub-classes:

PAGE

I. Trilobita

2. Phyllopoda

3. Ostracoda

4. Copepoda

5. Cirripedia

6. Malacostraca

7. Stomatopoda

285

299

303

304

305

305

308

\section{Sub-Class i, Trilobita}

Type of the sub-class, Triarthrus (Fig. I26).

Triarthrus is much more closely allied to Apus (see p. 299) than to the crayfish, or any other living form, but lacks the peculiar carapace and probably the long, anal processes of the former. These processes, however, are known to be present, extending backward from the ventral surface of the abdomen, in Neolemus serratus of the Burgess shale (mid-Cambrian) of British Columbia. The carapace is lacking in many species of the order Phyllopoda, to which Apus belongs; this is true of the fresh water shrimp, Branchipus, and of the brine shrimp, Artemia, but in 


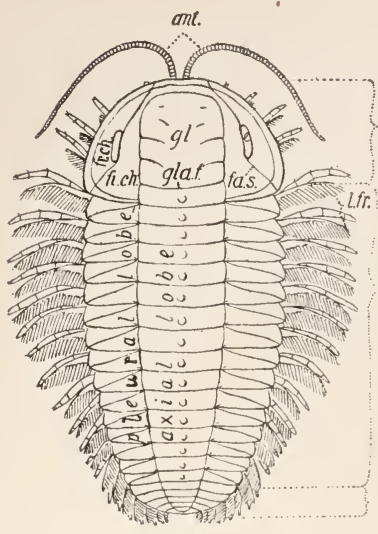

A
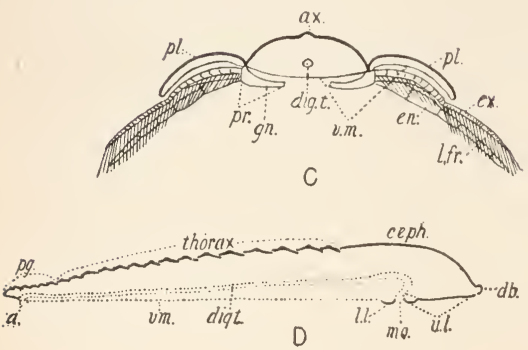

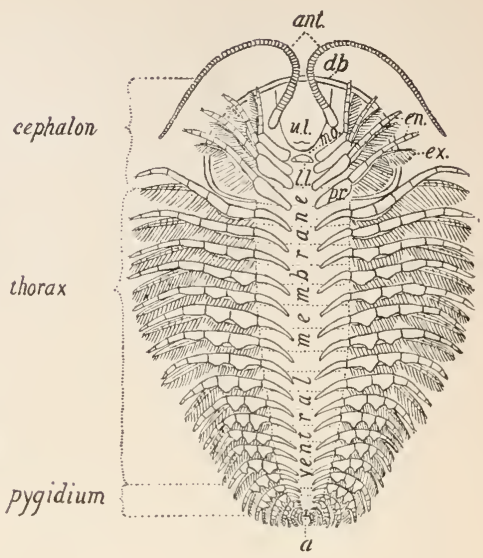

B

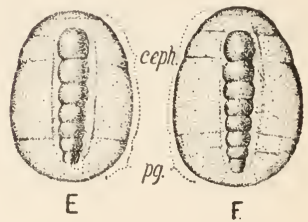

FIG. I 26. - The trilobite, Triurthrus becki Green, from the Utica shales (mid-Ordovician of eastern North America). This species flourished in the muddy portions of the ocean which then covered this region. $A$, dorsal view. $B$, ventral view. $C$, a transverse vertical section at second thoracic segment $\left(A-C \times \mathrm{r} \frac{1}{3}\right) . \quad D$, a median longitudinal vertical section. $E$ and $F(\times 45)$, two molts of the larval (protaspis) stage; the later molted one $(F)$ has added to the pygidium an additional segment ; in neither are any thoracic segments yet developed; the head has five segments with the eye-lines extending from the first segment. $a$. , anus; ant., antennules or feelers; ax., axial lobe; ceph., cephalon or head segment; $d b$., doublure; dig.t., digestive tube; e., eye lobe protecting the compound eye; en., endopodite; ex., exopodite; fa.s., facial suture; fi.ch., fixed cheeks; fr.ch., free cheeks; $g l$. , glabella ; gla.f., glabellar furrows; $g n$., gnathobase (the free, inward projecting part of the protopodite) ; $l$.fr., limb fringes, for swimming and respiration; l.l., lower lip or metastome; mo., mouth; pg., pygidium, covering the abdomen; $p l$. , pleuræ ; pr., protopodite; u.l., upper lip or hypostome ; v.m., ventral membrane. (All after Beecher, except $D$.) 
other respects these genera are more specialized and hence less like the trilobites than Apus.

Triarthrus, a trilobite crustacean, lived in the marine waters of eastern North America and northern Europe during the Ordovician period.

The body was entirely incased in a chitinous skeleton, hardened with more or less lime carbonate. Dorsally this skeleton was thickened, forming the dorsal shield; it is this which is usually preserved. It is divided into the head (or cephalon), thorax and pygidium; two furrows extend from the front of the head to the end of the pygidium, separating a higher, narrow median portion, the axial lobe, from a lower portion on each side, the two pleural lobes.

The portion of the axial lobe in the head is called the glabella; it is large, well-defined, subquadrate and marked usually by two pairs of discontinuous furrows (glabellar furrows). (Compare gla.f. in Figs. I26 and I27.) Extending from the posterior angles of the head shield obliquely toward the glabella and then anteriorly to the margin is the facial suture (compare fa.s. in Figs. I 26 and I28), dividing the sides of the head shield into free and fixed cheeks, united by uncalcified chitinous joints.

The thorax is divided by transverse furrows into fourteen to sixteen segments, united by joints of chitin.

The pygidium, which covers the abdomen, consists of a single piece, though the superficial grooves divide it into axial and pleural lobes.

The head shield is anteriorly bent under and reflexed. To this reflected border, or doublure, was attached medially a separate plate, the upper lip, or hypostome. Posterior to this was a small convex plate, the lower lip, or metastome. The animal was further protected on the under side by a thin, uncalcified, chitinous membrane (Fig. I 26, B) divided into an axial and two pleural portions corresponding to the axial and pleural lobes of the dorsal shield. This ventral membrane was attached to the upper and lower lips, to the reflected border of the head shield, 
to the pygidium, and to the ends of the pleuræ; it was further supported by transverse, calcified, chitinous processes to which the legs were attached.

Triarthrus is well called the daddy longlegs trilobite, for its appendages were unusually long for a trilobite, extending far beyond the margins of the dorsal shield. (In such forms as Trinucleus and Isotelus they did not extend to the margin of the dorsal shield.) These appendages were very uniform in character from the pair directly behind the antennules to the last pair upon the abdomen.

All except the most anterior pair of appendages, the antennules, are biramous, consisting of a basal portion : the protopodite bearing two branches, - ( I) the highly jointed endopodite adapted to crawling and (2) the less jointed exopodite, fringed along its posterior border by lamellæ-like setæ and thus adapted both to swimming and respiration. Anteriorly the endopodites are long, cylindrical, crawling legs; posteriorly they become more and more broadly flattened and leaf-like, bearing tufts of setæ; they are thus well adapted to swimming. Each protopodite has an inward projecting portion, - the jawlike base or gnathobase.

There were paired dorsal and ventral muscles beginning in the head and ending in the abdomen; the dorsal pair extended the animal, the ventral pair flexed it; but apparently it lacked the power of enrollment (p. 29r). The ventral pair of muscles were separated by a chitinous ridge; from each of these a muscle band extended obliquely outward and backward to the next thoracic segment to be there attached as is indicated by oblique chitinous ridges. The appendages were probably moved similarly to those of Apus and Cambarus.

Judging from the food of the living Crustacea, Triarthrus was carnivorous, eating both decaying and living animal matter. The food brought to the ventral median line of the body by the rhythmical movement of the appendages was seized by the gnathobases and by them carried forward to the mouth; the broader 
and stronger ones of the head may, like the mandibles of Apus, have torn the food into smaller pieces. The mouth, opening between the upper and lower lips, led into a long intestinal tube which extended backward parallel to the dorsal test, opening through the anus at the postero-ventral end of the pygidium (Fig. I 26, D). The digestion of food was very likely similar to that of Apus (p. 299), except that in the absence of a stomach the digestive fluid was probably poured into the anterior portion of the intestine.

Somewhat similar to the condition in Apus may likewise have been its blood circulation, excretion, its nervous system and sense organs. The intestinal tube, as well as the double chain of nerve ganglia, heart, etc., were located beneath the axial lobe in the median line of the body.

Respiration took place mostly through the limb setæ or fringes, aided probably by an exchange of gases through the chitinous covering of the ventral surface, which was apparently almost as thin as that covering the setæ.

The antennules were probably tactile organs. There is a pair of slightly raised, compound eyes situated at the inner edge of the free cheeks, while the neighboring border of each fixed cheek is raised into a small eyebrow-like mound, the eye lobe or palpebral lobe (see Fig. 128, e.l.).

For reproduction and development, see page 292.

I. Give the habitat of Triarthrus; its geologic range.

2. Sketch specimen; label cephalon, thorax, pygidium, glabella, axis, glabellar furrows, eye lobes, facial sutures, fixed cheeks, free cheeks, pleural lobes.

3 . Is the skeleton external or internal?

4. What is its composition now? When living?

5. How did growth take place?

6. Does each entire fossil necessarily represent the death of an animal? Why?

7. After molting or after the death of the animal separation at the uncalcified joints occurs rather quickly. Name the parts of the dorsal shield which would remain intact; your reasons. 
8. Describe the ventral protection of the animal.

9. What ventral appendages were there?

I0. Why are the ventral appendages so seldom found?

I I. What were the principal muscles of the body? Where located? Their function?

I2. What was the character of the food of Triarthrus? How procured? tion.

I3. Trace the food through the digestive canal and its diges-

I4. Give the probable character of the blood circulatory system; the nervous system.

I5. What sense organs did Triarthrus possess?

16. How did it breathe?

I7. By what means is the embryology of such a fossil form as Triarthrus known?

IS. What is the protaspis? Its characters?

I9. How did the trilobite increase in size from this early larval condition to the adult?

20. What reasons are there for believing that trilobites were bisexual?

2I. What reasons for placing the trilobites in the class Crustacea?

22. Why are trilobites made a separate sub-class, and that the most primitive?

\section{General Survey of Sub-class Trilobita}

The trilobites are extinct marine crustaceans with the body divided into a variable number of segments, and entirely incased in a protective chitinous skeleton; this is thickened and hardened with lime carbonate where no movement is required, but thin and flexible in the intermediate spaces. These thin places act as joints and it is here that after the molting or death of the animal a rather easy separation of the skeletal elements takes place.

Trilobites were undoubtedly marine, since they are always found associated with such forms as corals, crinoids, brachiopods and cephalopods, the living representatives of which are wholly marine. They lived during the entire Paleozoic, from the Cambrian to the Permian, inclusive. 
The skeleton (Fig. I 26) consists of a thick dorsal shield, a very thin ventral membrane, and the covering of the body appendages. The dorsal shield is divided into head (cephalon), thorax and pygidium. The head shield comprises three pieces, - a median one consisting of the glabella and fixed cheeks, and the two free cheeks, the three united by thin chitinous joints. The free cheeks may represent the pleuræ of one of the anterior head segments. The thoracic shield consists of many segments, - transverse divisions, varying from two in Agnostus to twentynine in Harpes, all united by thin chitinous joints ; each of these segments is made up of a central axial lobe and two pleural lobes firmly united into one piece so that movement takes place only between the segments. The pygidium consists of a single piece, due to the welding of a number of similar segments.

On the ventral surface of the head are five pairs of appendages, all of which, except the anterior pair, are similar in appearance and function, differing thus from those of Apus (p. 300) and the crayfish (p. 275).

Muscles. - The bodies of many trilobites, as Calymene, possessed the power of enrollment, like the pill-bug among the isopod crustaceans at present. This was brought about by the contraction of the ventral muscles (p. 278). By this means the soft under surface was protected and the animal exposed to attack only along the hard dorsal shield.

Sight. - The organs of sight vary greatly among trilobites; when present they are situated on the free cheeks (except in Harpes, where they are on the fixed cheeks). A few genera, as Agnostus, and the larvæ of many forms appear to have been totally blind; others, as Conocoryphe, have small simple eyes, granule-like, at the end of a raised line (eye-line, Fig. I26, F) running from the anterior end of the glabella outward to the free cheeks. The majority of trilobites, however, had compound eyes of varying size; these either have (I) the separate facets covered by a continuous smooth or granular, horn-like, protective layer 
- the cornea, as in Calymene; or (2) each facet with a separate cornea, as in Phacops (Fig. I3 I, C).

Preservation. - Since the thin ventral membrane and delicate limbs were usually quickly destroyed after the molting or the death of an animal, they are very seldom preserved in the fossil state; and as sediment would cling readily to the angular ventral surface of the dorsal shield, the hardened sediment splits most easily along the comparatively smooth dorsal surface. Hence trilobites are almost always found as mere exteriors of the dorsal shield, and even this shield occurs comparatively seldom as a complete whole, for its parts are easily separable from one another.

Development. - Judging by existing Crustacea, reproduction among the trilobites was sexual. Frequently the same species shows a broad and a narrow form ; the former may represent the female and the latter the male. The minute rounded bodies associated with many trilobite remains are regarded as possible trilobite eggs. The earliest stage in their development definitely known is the larval form, - named protaspis. This is believed to approach closely the proto-nauplius, the theoretical primitive larval form of all Crustacea, occurring as it does in the Lower Cambrian and possessed of such simple characters. The dorsal shield of this protaspis has been discovered in all the principal trilobite groups and its characters may be summed up as follows: minute, less than I $\mathrm{mm}$. long, circular or ovate in outline, with distinct and more or less strongly annulated axial lobe. It consists of a large cephalon and a very small pygidium. The glabella has at the beginning, or after a few molts, five transverse grooves; eyes when present are anteromarginal or submarginal; free cheeks when visible are narrow and marginal. The pygidium has an axial lobe of one to several annulations, its pleural portion smooth or grooved (Fig. $126 E, F)$.

The various stages in the growth of a trilobite have been studied by means of long series of specimens, separate molts of the same 
species but of differing sizes, just as the record of the growth of a crayfish may be read in the series of molts it discards. During growth, the body elongates through successive molts; the eyes when present move dorsally toward the glabella, and the free cheeks increase in size. Several molts take place before the introduction of the first thoracic segment, during which the glabella becomes more strongly annulated, the free cheeks appear on the dorsal surface and the introduction of new appendages and segments to the pygidium produces in that additional grooves in the axial and pleural portions. The pygidium, in some genera, is completed before the introduction of the first thoracic segment. From the anterior edge of the pygidium are developed all thoracic segments and by the forward movement of this growing area the enlargement of the pygidium is effected. Apparently never more than one segment is added at each molt, but there may be more than one molt to each segment. In Triarthrus the full number of body segments was attained when the animal was about $7 \mathrm{~mm}$. long; from then on it merely increased in size until adulthood, with a length of $25-40 \mathrm{~mm}$., was attained. The simplest protaspis is found in the Cambrian rocks; in later periods it acquires through acceleration in development adult characters such as dorsal movement of the eyes, free cheeks, etc.

Relationship. - That trilobites belong to the class Crustacea and are closely related to the sub-class Phyllopoda (e.g. Apus, p. 299), the most primitive of living Crustacea, is shown by the following characters common to both, - (I) variable number of thoracic and abdominal segments among species of each genus ; (2) slight distinction between thoracic and abdominal feet, each of which is more or less leaf-like and respiratory in character, is biramous and usually produced into a gnathobase; (3) five pairs of head appendages ; (4) an upper lip (hypostome) and lower lip (metastome); (5) a pair of slender, jointed antennules.

That they are more primitive than the Phyllopoda is indicated by the following facts, - (I) all are marine; (2) all seg- 
ments, except the anal, bear a pair of appendages ; (3) all appendages, except the antennules, are biramous and are produced into gnathobases which on the head are used as organs of mastication; (4) the digestive tube is a straight canal, apparently without an anterior expansion into a stomach; (5) typically, the head gives indication dorsally of the five segments of which it is composed; (6) the earliest larval form (protaspis) of a trilobite from the Cambrian is more primitive than the simplest larval form (nauplius) of existing Crustacea.

Derivation of name. - Trilobita < Latin tri, three, +lobus, a lobe, referring to the division of the dorsal shield into three longitudinal portions, - the axial lobe and two pleural lobes.

Paradoxides (Fig. I 27 ).

Middle Cambrian.

The portion of the animal found fossil is the strongly calcified dorsal shield, and very frequently also the upper lip (hypostome). The glabella of the dorsal shield enlarges anteriorly with its lobes well defined; the genal angles are usually produced into spines as are consequently likewise the tips of the pleuræ; the genal spines are borne by the free cheeks; the eye lobes are large and arched; the thorax has I7 to 20 segments; the pygidium is small, plate-like and segmented. The name was given by Brongniart in I 822 out of compliment to Linné's name for a trilobite, - Entomolithus paradoxus, the paradoxical insect.

It is very abundant in North America and Europe.

I. Sketch specimen, labeling cephalon, glabella, eye lobes, genal spines, fixed and free cheeks, facial suture, thorax, axis, segments of thorax, pygidium.

2. Make an ideal sketch showing the relationship of the hypostome to the rest of the animal.

3. Why is this genus placed under the trilobites?

4. Was the skeleton external or internal? How much of the entire animal is preserved in the specimen sketched?

5. What was the composition of the skeleton in the living state? What is its composition now?

6. Does this specimen necessarily represent the death of an animal? Why? 


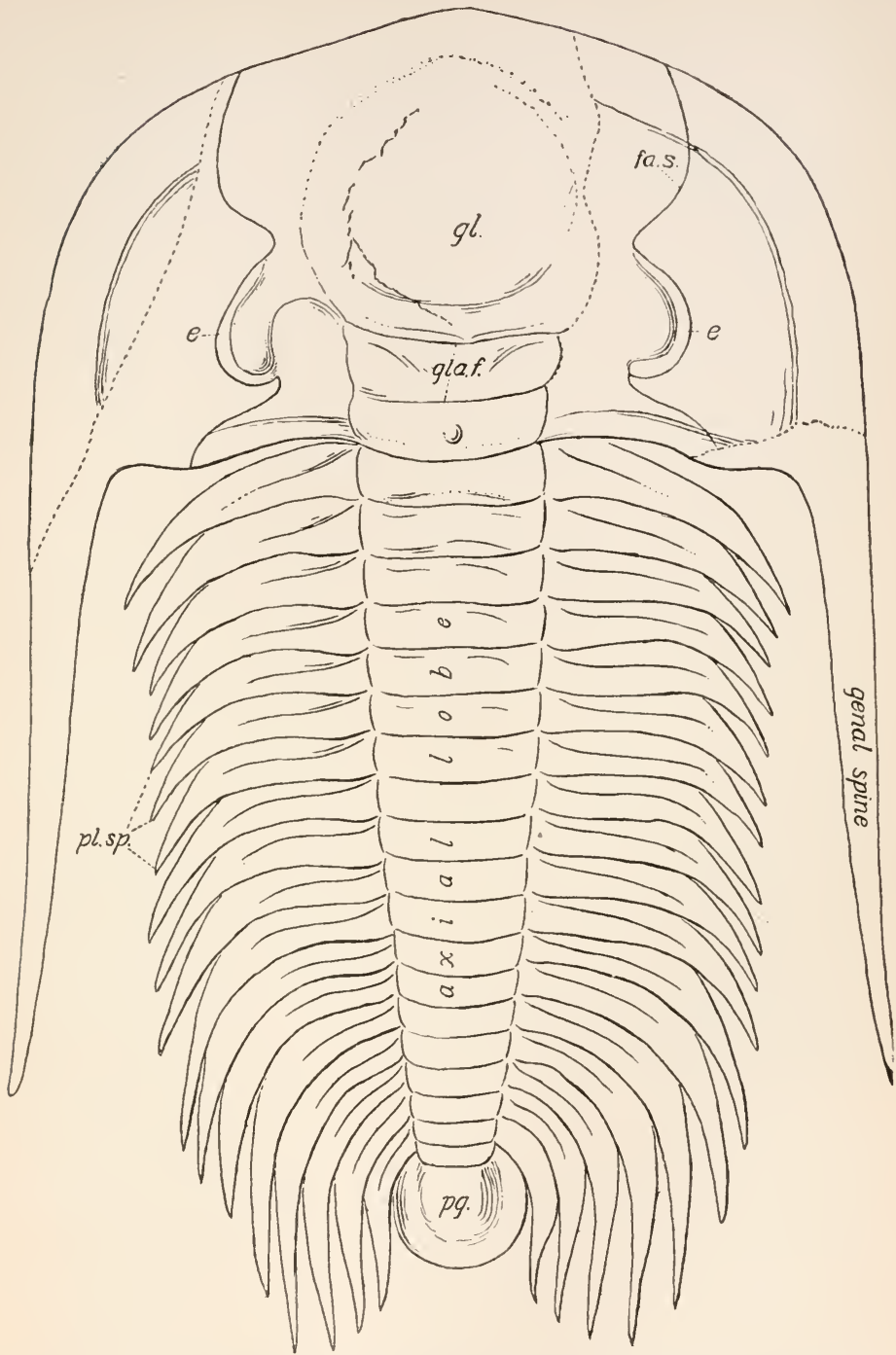

FIG. I 27. - The trilobite, Paradoxides harlani Green $\left(\times \frac{2}{3}\right)$, abundant in the marine Braintree slates (Middle Cambrian) of eastern Massachusetts. $e$., eye lobe; fa.s., facial suture; gl., glabella ; gla.f., glabellar furrows; pg., pygidium; pl.sp., pleural spines. (Redrawn from Walcott.) 
296 AN INTRODUCTION TO THE STUDY OF FOSSILS

Isotelus (Fig. I 28 ).

Ordovician.

Dorsal shield oval, its cephalon and pygidium large, subequal, with obsolete segmentation and wide flattened borders. The
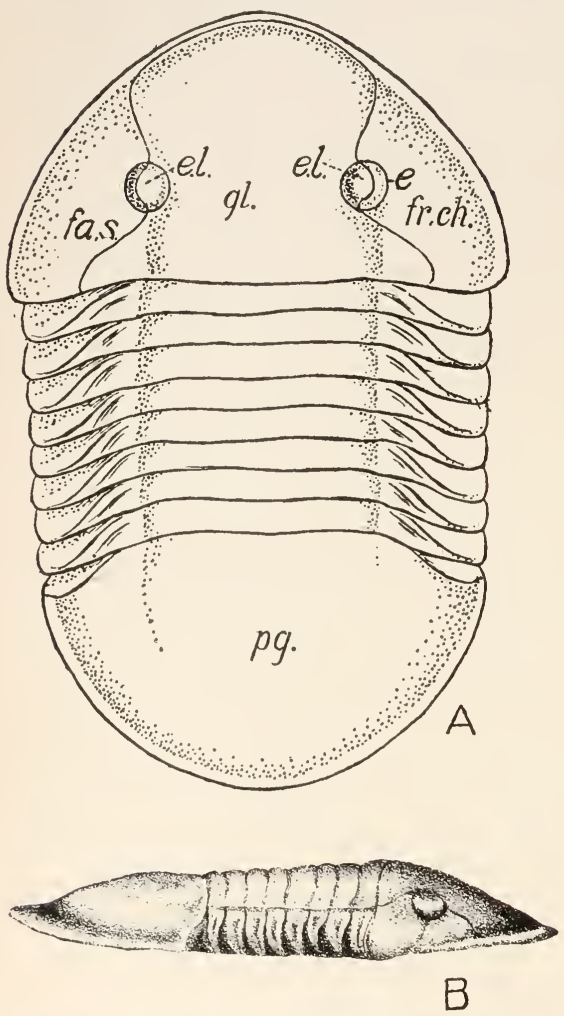

Fig. I28. - Isotelus gigas Dekay. Natural size. $A$, dorsal view of a broad form, possibly a female, of this species. $B$, a side view. e., eye; c.l., eye lobe; fa.s., facial suture; gl., glabella; pg., pygidium. ( $A$, after Logan; $B$, after Hall.) thorax has eight segments, with a broad and rather indistinct axial lobe. The name was given by Dekay, I 824 , in reference to the subequal cephalon and pygidium, from the Greek isos, equal, + telos, end.

Abundant in North America. I. gigas, a species abundant in the mid-Ordovician of North America, occurs very frequently with the dorsal shield entire.

I. Sketch specimen, noting glabella, eye lobes, thorax, pygidium.

2. How does this differ from Paradoxides in (a) glabella, (b) eye lobes, (c) axial lobe of thorax, (d) pygidium?

3. What is the significance of the name?

Trinucleus (Fig. I 29).

Ordovician.

The dorsal shield, the part of the animal usually found fossil, possesses the following characters: the cephalon is very broad 
in comparison to its length, with long genal spines (borne by the free cheeks) and a regularly pitted border, whence its common name, - lace-collar trilobite. The glabella is prominent, with a strongly convex area on each side, giving thus three prominent elevations to the cephalon (whence the name from Latin tres (tri-), three, + nucleus, little nut). Eyes are usually absent; the thorax has six segments; the axial lobe is narrow.

It is abundant in North America and Europe.

I. Sketch specimen, labeling the portions preserved.

2. What is the significance of the common name? The technical name? sent?

3. What part of the living animal do fossils of trilobites repre-

Calymene (Fig. I30).

Ordovician-Devonian.

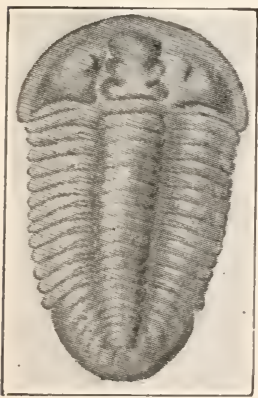

FIG. I30. - Calymene niagarensis Hall. A trilobite living in the seas of the Silurian period. Dorsal view. Natural size. (After Hall.)

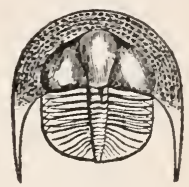

Fig. I 29. - Trinucleus concentricus Eaton. Natural size. The lace-collar trilobite, abundant in the Ordovician seas of North America and Europe. (After Logan.) 
Europe and Asia. C. niagarensis is very abundant in the mid-Silurian (Niagaran) rocks of central and eastern North America.

I. Sketch specimen, labeling the various parts.

2. Why are these found so often in an enrolled state?

3. Of what advantage was this to the animal? Name a living animal which enrolls.

4. Are the eyes simple or compound? How do you account for the smooth surface?

5. During what eras did trilobites live?

6. Why are the legs of trilobites found so very infrequently?

7. Why is this genus placed under the phylum Arthropoda?

Phacops (Fig. I3I).

Silurian-Upper Devonian.

The dorsal shield has the following characters, $-(a)$ the cephalon is convex; the glabella is very wide in front, narrowing

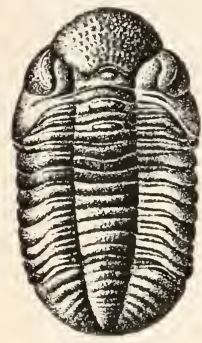

A
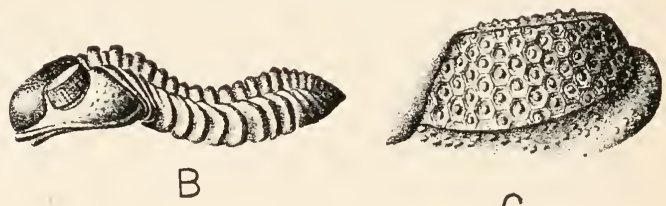

C

FIG. I31. - A trilobite. Phacops rana Green, from the Hamilton (Middle Devonian) formation of New York. $A$, dorsal view. Natural size. $B$, side view. $C$, an eye $\left(\times_{3}\right)$, showing the facets with their lenses preserved. (After Hall.)

behind, its anterior two pairs of lateral furrows indistinct; eyes very large, always with many distinct facets; the facial suture cuts the lateral margin of the cephalon anterior to the genal angle; $(b)$ the thorax has eleven segments; $(c)$ the pygidium is semi-circular. The surface of the entire dorsal shield, especially the glabella, is often pustulose. The name, from the Greek 
phakos, lentil (lens), +ops, eye, refers to the many lens-like facets of the compound eyes.

This genus is abundant throughout the world. P. rana was abundant in the sea covering eastern North America during the middle of the Devonian period.

I. Sketch $(a)$ specimen; $(b)$ entire eye. Note glabella, facial sutures, eyes, eye facets, pygidium, pustulose surface.

2. What part of the entire animal does this fossil represent?

3. What is the significance of the name?

4. What differences between the eyes of Phacops and those of Calymene?

5. How does the glabella of Phacops differ from that of Paradoxides? from that of Calymene?

6. How does the relation between fixed cheek, facial suture and genal angle differ in Phacops, Calymene and Paradoxides?

7. From analogy with a living crayfish describe how Phacops molted.

\section{Sub-class 2, Phyllopoda}

Small, with elongate body segmented and covered anteriorly with a carapace. The great majority inhabit fresh water; Artemia lives in salt lakes and brine pools. Many produce two kinds of eggs, the parthenogenetic thin-shelled and the sexually produced thick-shelled ones, which latter alone can survive cold and desiccation. Known in the fossil state from the Cambrian to the present.

Derivation of name. - Greek phyllon, leaf, + pous (pod), foot. So named from the broad, flat, leaf-like feet.

Apus (Fig. 132).

Triassic to present.

Apus is one of the most primitive of all living Crustacea; it is present, though not common, in the fresh waters of nearly every portion of the world and is found in the fossil state from the Triassic to the present.

In general appearance it differs from the crayfish in its broadly projecting oval carapace, in the pair of long processes at the end of the anal segment, in its small size (it is an inch or 
two long), in the variable number of body segments, and in the thinner and more flexible exoskeleton.

Apus is similar to the crayfish in the growth of the hard parts, in the presence of the upper and lower lips and in the five pairs of head appendages, but is more primitive in having the posterior pair of cephalic appendages biramous, and in the practical absence of distinction between the thoracic and abdominal

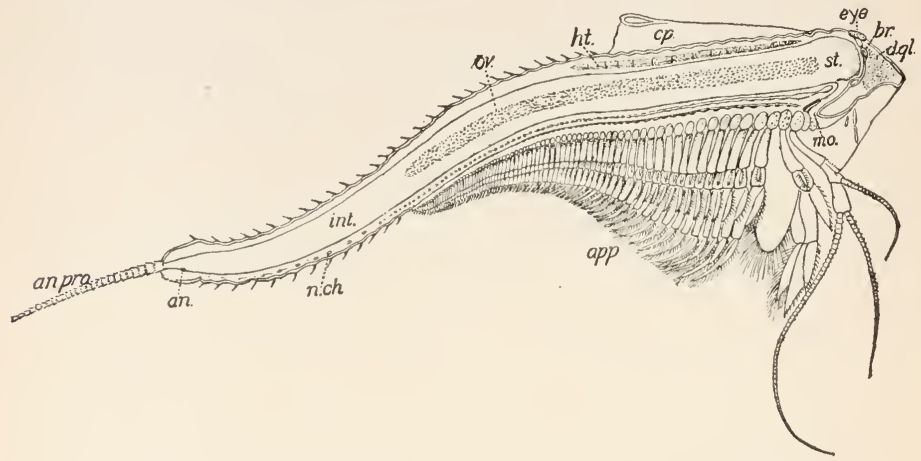

FIg. I32. - The primitive, fresh-water crustacean, Apus lucasanus Packard, from

Kansas. Section through the body, with intestine removed. Length of body, exclusive of anal processes, is twenty millimeters. an., anus; an.pro., anal process; $a p p$., appendages; br., brain; $c p$., carapace; $d . g l$., digestive gland; $h t$., heart; int., position of intestine; mo., mouth; n.ch., ventral nerve chain; ov., ovary; st., position of stomach. (Redrawn from Packard.)

appendages. All of these except a few at the apex are leaf-like with a spinose projection (gnathobase) from the basal portion ; these gnathobases, meeting the ones from the opposite side of the body, function as a conveyor of food to the mouth.

In the muscular system, its more primitive structure is shown by the arrangement of the muscles in a tube, as in the Annulata ; they do not fill up most of the abdomen as they do in the crayfish.

The kind of food, its intake, the digestive system, absorption of food and excretion are similar to the crayfish. There is, however, but one division to the stomach, neither gastric mill 
nor sieve being developed. The digestive fluid is poured into the stomach.

In the absence of large claws most of the food is moved forward to the mouth by the long line of paired gnathobases, to which it is brought by the rhythmical movements of the appendages in swimming.

The blood circulatory system is simple. The long, tubular heart, traversing the first eleven thoracic segments with a pair of valvular openings in each, forces the blood to the head and carapace, whence it travels, through the blood sinus surrounding the intestine, to the posterior end of the body, and thence to the limbs, a portion of each of which acts to a greater or less degree as a gill. The movements of the limbs insure a constant renewal of water with its free oxygen. The blood then returns to the sinus surrounding the heart.

The nervous system differs from that of the crayfish in having the ventral nerve cord entirely double and ladder-like. The sense organs are confined to organs of touch (the setæ, especially abundant as fringes to the limbs) and of sight. The latter consist of a pair of compound eyes similar to those of the crayfish, but sessile, and a simple, single, median one.

Males are few, and reproduction is as a rule parthenogenetic, that is, by unfertilized eggs.

I. What is the habitat of Apus? Its geologic range?

2. How does it differ in general appearance from Cambarus?

3. In what respects is it more primitive than Cambarus, nearer the trilobites? Note $(a)$ external appendages, $(b)$ muscular system, $(c)$ digestive canal, $(d)$ circulation of blood, $(e)$ nervous system.

Estheria (Figs. I33, I34).

Devonian to present.

Carapace developed into a horny shell of two thin, rounded, inequilateral valves, united by a straight dorsal margin. The surface of each valve is covered with concentric ridges, between which are interlacing striæ. The umbonal region sometimes bears a strong muscle node. 
The modern species of Estheria live in fresh water, especially in ponds and rain pools, very rarely in brackish water. The concentric ridges, coarsest near the umbo, are due to the fact
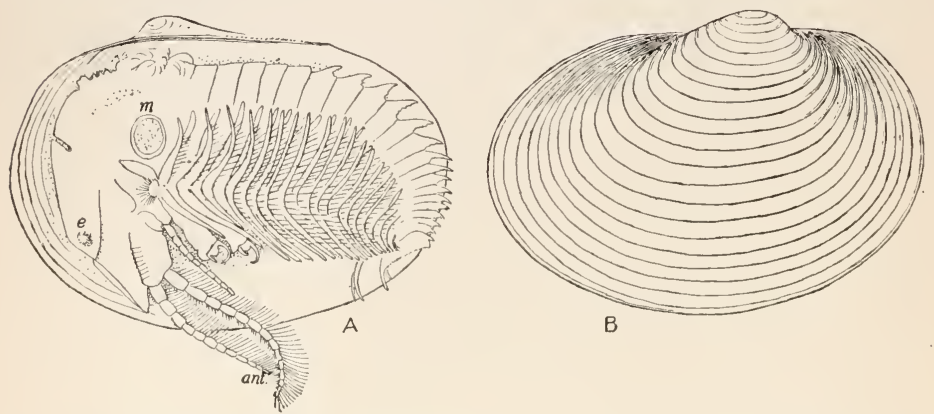

FIG. 133. - Estheria belfragei Packard, from Texas. $(\times 5) \quad$.$A , the body of the$ animal shown after the removal of one valve. ant., antenna; $e$., eye; $m$., adductor muscle. $B$, exterior of one valve. (Redrawn from Packard.)

that "the integument of the outer surface of the shell is not cast off in ecdysis [molting], but remains in position, giving rise to a series of lines of growth marking the increased size of the shell at each molt" (33). The spaces between the suc-

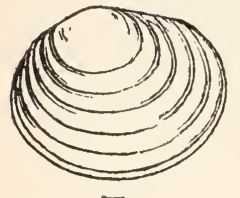

Fig. 134. - The minute phyllopod crustacean, Estheria ovata Lea, from the fresh-water Shinarump formation of southern Utah. $(X$ 12 ; line below indicates true size.) cessive ridges are marked with irregular, interlacing striæ, differing thus from any pelecypod shell which the bivalved carapace otherwise closely resembles.

E. ovata is abundant in the Triassic of North America, such as the Newark berds of the Atlantic coast and the Shinarump of Arizona.

I. Sketch the outside of one valve.

2. How much of the body of the animal did the shell cover?

3. How can you tell from the fossil alone that this is a crustacean and not a pelecypod?

4. What is the origin of the concentric ridges?

5. Name three characters which distinguish crustaceans. 
Other examples of the Phylloporla are Protocaris (Lower Cambrian, looking much like Apus), Branchipus (living).

\section{Sub-class 3, Ostracoda}

Minute, with body short, unsegmented or very indistinctly so, completely inclosed by the carapace which here becomes a lateral, two-valved chitinous or strongly calcareous shell, usually $.5-5 \mathrm{~mm}$. long; this opens by means of an elastic, dorsal ligament and is closed by a large, subcentral adductor muscle. When closed the edges of the usually unequal valves as a rule fit closely, the edge of the one valve within a groove at the margin of the other. There is a median eye and at times also compound eyes. When the shell is strongly calcified so as to become opaque, more transparent spots in the antero-dorsal part of the shell mark the position of the eyes. The position of the adductor muscle is likewise usualiy noticeable upon the exterior of the shell as a group of spots. There are seven pairs of appendages which can be protruded when the valves open. The first and second pair of antennæ are large and are used for swimming or creeping. The outer surfase of the valves is seldom smooth; usually it is covered with rigid hairs, or is pitted or sculptured. Sometimes the shell is notched anteriorly to allow the passage of the antennæ when the valves are closed. The posterior half of the shell is usually thicker than the anterior. The ostracod shell is distinguished from that of the pelecypod by its minute size, its usually unequal valves, its external sculpturing, the absence of concentric growth lines, and the presence of the eye spot on the exterior of the sheli.

Ostracods are abundant in marine, brackish and fresh waters, usually creeping among the plants or burrowing in the mud. They are abundant in all ages from the Ordovician to the present; usually only the bivalve shell is preserved in the fossil.

Derivation of name. - Greek ostrakon, a shell, + eidos (oid), form; the carapace takes the form of a two-valved shell. Cypris (living) is very abundant in stagnant pools. 
Leperditia (Fig. I35).

Cambrian-Devonian.

Shell thick, smooth, biconvex, $2 \mathrm{~mm} .-22 \mathrm{~mm}$. long. Hinge line straight, usually angular at the extremities. Anteriorly,

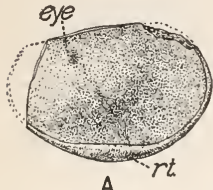

A

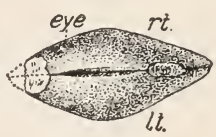

B

FIG. I35. - A fossil ostracod, Leperditia alta Conrad, from the uppermost Silurian of New York. The ends are imperfect. $A$, left valve (lt .) of the carapace, showing the incurving edges of the larger right valve $(r t$.$) , and the eye tubercle (eyc),$ beneath which the eye was located. $B$, view of hinge margin. (Both $\times 2$.) near the hinge, a small tubercle marks the position of the eye.

I. Sketch shell $(a)$ view of one valve; $(b)$ hinge view of combined valves. Label eye tubercle, ligament.

2. How much of the body of the animal did the shell cover?

3. Why is this bivalve shell placed under the Crustacea and not under the Pelecypoda? How can this be told from the fossil alone?

4. Compare the shell of Leperditia with that of Estheria (a phyllopod). How do they differ?

5. What opens the valves? What closes them?

\section{Sub-class 4, Copepoda}

Body elongate, segmented, covered with a carapace; thorax usually with four or five pairs of biramous feet; abdomen free from appendages. Copepods are mostly marine though many inhabit fresh water. Very many are parasitic, especially on fish; few fish are entirely free from them. Name from Greek cope, oar, + pous (pod), foot. So named because their feet are used mostly for swimming. Unknown in the fossil state.

Two kinds of copepods occur, - (a) parasitic, e.g. carp lice (Argulus) ; (b) free-swimming, e.g. water fleas (Cyclops). Under favorable conditions one cyclops might have five billion descendants in one year. In this form anal respiration is especially noticeable. This method of breathing, common among the lower Crustacea, consists of rhythmical contractions of the intestine, which admit and expel the water. 


\section{Sub-class 5, Cirripedia (Barnacles)}

Body imperfectly segmented; posterior part of trunk vestigial. The carapace of other Crustacea here forms a fleshy mantle, usually strengthened by calcareous plates.

These degenerate animals are marine, and fixed during adult life, or they are parasitic. The fixed forms have the body and limbs completely inclosed in a mantle strengthened by calcareous plates. They are attached by the anterior part of the head either by a flattened disk (as in the acorn barnacle, Balanus), or by an elongate, muscular stalk (as in the goose or ship barnacle, - Lepas).

Barnacles are a very interesting example of degeneracy, their life history passing from a free-moving youth to an attached maturity, accompanied by a degeneration of the body until the whole posterior portion becomes vestigial. The young larva is free-swimming, hatched as a free nauplius; after several molts this passes into the Cypris stage, with a bivalve shell like an ostracod but with limbs and internal anatomy unlike this sub-class. Later it attaches itself to some object by its antennules aided by a secretion poured out from a gland at their base; soon the parts of the new, changed shell appear beneath the old one, which is molted, and the adult form is thus attained.

The Cirripedia are known from the Ordovician to the present, but have been abundant only since the upper Tertiary.

Derivation of name. - Latin cirrus, a fringe, + pes, foot; referring to the fringe-like feet which the animal can protrude from its shell and by means of which it respires and gathers food.

Examples are Balanus (Eocene to present; attached to rocks between tide levels), Lepas (Pliocene to present; growing on the bottom of ships, etc.), Tubicinella (living deeply embedded in the skin of whales), Anelasma (living embedded in the skin of sharks and partially parasitic by means of roots), Sacculina (living entirely parasitic on crabs, its roots penetrating all parts of the body except heart and gills). Probably the best known of 
all of these is Balanus balanoides which grows in such immense numbers over the whole northern Atlantic coast that it covers the rocks in many places with a white incrustation.

I. Distinguish between the calcareous skeleton of the acorn barnacle and the skeleton of the goose barnacle. Give their geologic range.

2. Briefly trace the development of a barnacle.

3. Compared with its own larval state, is the adult advanced or degenerate? Why?

4. What is the habitat of living barnacles?

\section{Sub-class 6, Malacostraca}

Body usually divided into a thorax of eight and an abdomen of seven segments. A gastric mill for grinding the food is present. Excretory organs are glands in the antennæ. The nauplius stage is usually passed through in the egg. Known in the fossil state from the Cambrian to the present.

Derivation of name. - Greek malakos, soft, + ostrakon, shell; so named because the carapace or shell is softer than the shell of the mollusk.

This is subdivided into the following orders:

The old division Entomostraca, comprising the very diverse groups Phyllopoda, Ostracoda, Copepoda and Cirripedia, was characterized by only negative characters, while the old order Schizopoda comprised the three very distinct groups, - Anaspidacea, Mysidacea and Euphausiacea.

(a) Phyllocarida (Cambrian to present), a connecting link between the Phyllopoda and Copepoda on the one hand and orders $d-f$ on the other. Example, Ceratiocaris (Ordovician and Silurian). (b) Anaspidacea (Pennsylvanian to present). A well-known example is Paleocaris from the Pennsylvanian coal measures of North America and England. (c) Mysidacea (Mississippian to present). (d) Cumacea (not known fossil). (e) Isopoda (Devonian to present). A common living example is the pill-bug (Armadillidium); this is found in damp places 
under boards and stones and when disturbed rolls itself up into a ball. $(f)$ Amphipoda (Silurian to present), e.g. beachfleas. (g) Euphausiacea (not known fossil).

(h) Decapoda.

Triassic to present.

The posterior five pairs of thoracic legs are long and are used in walking, whence the name from Greek deka, ten, + pous $(p o d)$, foot. The abdomen may be long and straight as in the lobster and crayfish or permanently flexed beneath the long cephalothorax, as in the crab group (examples 4-6). The latter group include the most advanced of all Crustacea. No undoubted decapods have been found in the Paleozoic, but their ancestors are to be sought for in the generalized schizopods (orders $b, c$, and $g$ ) of that era, and were probably not differentiated from the latter until the Triassic.

Examples: (I) Cambarus (Fig. I23). Crayfish of the family Astacidæ, to which Cambarus belongs, have been found from the Cretaceous to the present day. The distinction of Cambarus from Astacus, the other genus of this family, lies in the character of the gills, features not preserved in the fossil forms known. The crayfish is descended from marine lobsterlike ancestors. (2) Homarus (Cretaceous to present). $H$. americamus (Fig. I25), the single Atlantic coast species of the American lobster, ranges from North Carolina to Labrador and from near shore to a depth of Ioo fathoms. It is omnivorous and is attracted to its food mostly by the sense of smell. A female seventeen inches long will lay at one time about 60,000 eggs. The young pass through a stage in which they resemble the Mysidacea. The lobster molts about eight times the first year, five the second, and three the third. (3) Eryon (Jurassic to Cretaceous). (4) The Japanese spider crab (Macrocheira kämpferi) is the largest living crustacean, with at times a spread of legs of 18 to 20 feet. (5) The blue or edible crab (Callinectes sapidus or hastatus) ranges from Florida to Cape Cod; it prefers muddy shores and like the lobster lives largely upon decomposing 
animal matter. It molts at least once during the summer, at which time it is sold in the markets as a "soft-shelled crab." When raised for commercial purposes it is usually kept floating in a box until molting occurs. (6) Lobocarcinus (Eocene). This has a broad carapace, arcuate and much lobed in front.

1. What is the geologic range of the members of this sub-class?

2. Give a common example of the order Isopoda. Its habitat.

3. In what orders and era are the ancestors of the decapods to be sought?

4. Name four living and one fossil example of the decapod crustaceans.

5. How many eggs does a lobster lay at one time?

6. What is a "soft-shelled" crab?

7. What part of a malocostracan is most apt to be preserved in the fossil state? Why?

\section{Sub-Class 7, Stomatopoda}

The thoracic legs bend forward towards the mouth, whence the name from Greek stoma, mouth, + pous (pod), foot. Known in the fossil state from the Pennsylvanian to the present. The mantis shrimp, Squilla (Jurassic to present), ranges from Cape Cod to Florida.

\section{CLASS B, ONYCHOPHORA}

This class includes the single genus Peripatus, mostly confined to the Southern Hemisphere. It looks much like a caterpillar and is a typical arthropod except in its excretory and nervous systems, in which it approaches the Annulata and flat-worms. Of this very primitive class no fossil representatives are yet definitely known, though a form from the Middle Cambrian Burgess shale of British Columbia resembles Peripatus rather closely.

Derivation of name. - Greek onyx, a claw, + pherein, to bear, in reference to the pair of horny claws terminating each foot. 


\section{CLASS C, MYRIOPODA}

Body worm-like, of many similar segments, each bearing one (in centipedes) or two (in millipedes) pairs of legs (whence the name from Greek myrioi, 10,000, + pous (pod), foot). Skin stiffened with chitin, legs jointed. Head distinct, bearing a pair of eyes. Respiration by tracheæ like those of insects. Found from the Devonian to the present day.

The Myriopoda include (a) the centipedes (e.g. Lithobius, of world-wide distribution, living on earth worms, insects, etc.); (b) the millipedes, (e.g. Julus, the thousand-legged or galleyworm, carnivorous like Lithobius; when at rest it coils its body).

\section{CLASS D, ARACHNIDA}

Body usually divided into cephalothorax and abdomen; six pairs of legs (except in order Limulava) about the mouth, four of which at least are used in walking, the first usually bearing claws. No antennæ present (except in Limulava); eyes sessile, usually simple; in orders I and 2 both simple and compound eyes occur, in order 3 compound eyes only. Respiration by tracheæ (see page 3I7), book-lungs, or book-gills.

In the book-lung each opening leads into an internal chamber, the lining membrane of which has been folded into very many delicate laminæ, lying parallel with one another like the leaves of a book. The air circulates between the leaves, thus giving oxygen to the blood which circulates through each leaf. Bookgills are similar to book-lungs, but are external, attached to the abdominal appendages.

Relationship. - The class Arachnida typically includes a water-breathing division, - the orders Xiphosura, Eurypterida and Limulava (often placed together in the sub-class Merostomata) and an air-breathing division - the remaining orders. That these two divisions are intimately related is best shown in comparing Limulus, a water-breather, with Scorpio, an airbreather. These agree in the possession of the following char- 
acters: six pairs of limbs about the mouth, the anterior pair chelate ; first pair of abdominal segments forming an operculum, with the genital aperture beneath it; the following five segments (except the first in Scorpio) respiratory in function; a ventral shield ; paired median and lateral eyes ; a vibratile spermatozoön (no crustacean except the Cirripedia have such). They agree also in the absence of antennæ. The book-gills of the former are replaced by the book-lungs of the latter (probably developed through invagination, this in turn giving rise to the trachea of the other Arachnida). Both have a post-anal spine and in both the anus opens on the segment anterior to this, but this is in Scorpio the twelfth abdominal segment and in Limulus the seventh, the other five being absent. The embryo of the latter, however, when hatched, i.e. during its three-lobed stage, shows the eighth pair well developed and an indication of the ninth. In Neolimulus of the Silurian period there are at least nine abdominal segments, while the Eurypterida (Cambrian to Permian) possess twelve abdominal segments besides the postanal spine, in this being the exact parallel of Scorpio.

The eurypterids, Limulus and the scorpions, are thus intimately related. The limulids and eurypterids had already diverged in pre-Cambrian times. The scorpions likewise developed very early. The Silurian scorpions, - Palæophonus, etc., represent apparently the persistence of a group intermediate between the typical modern scorpion and Limulus or Eurypterus; this is seen particularly in the appendages. The apparent absence of spiracles in these early scorpions indicates that they had not yet taken to a life out of water. This derivation from a life in the water is corroborated in the ontogeny of the living Scorpio, where the book-lungs of the adult are derived from gills borne upon abdominal appendages in the young. Of these three orders the Eurypterida is the most primitive; but the evidence now at hand apparently indicates that the three have descended from a common ancestor and not from one another. 
That trilobites may possibly be distantly related to these is suggested by the three-lobed structure of the dorsal shield of many of the Merostomata. This trilobation as well as the separation of the thorax into distinct segments is complete in Belinurus (Devonian-Pennsylvanian), Neolimulus (Silurian), and Aglaspis (Cambrian). This relationship is further corroborated by the Middle Cambrian Sidneyia of the order Limulava, in which to typical eurypterid affinities are added the trilobitelike antennæ and biramous appendages, and the higher crustacean caudal fin. On the other hand, there is nothing to suggest a crustacean nauplius form in the ontogeny of the Eurypterida, Limulus or the scorpions.

Derivation of name. - Greek arachne, a spider, referring to the typical example of this class.

The Arachnida are subdivided into sixteen orders.

\section{Order i, Xiphosura (including Synxiphosura)}

Body trilobed by longitudinal furrows. Cephalothorax covered by a large, semicircular carapace. Abdomen of seven to ten segments including the long, movable spine-like terminal segment, - the telson. In at least some genera there are simple eyes present in addition to the compound eyes. Respiration by lamelliform gills (book-gills) attached to the abdominal appendages. Marine and fresh water dwellers. Known from the Cambrian to the present.

This order, in some of its genera, resembles the trilobites but differs in the presence (at least in most of the genera) of both simple and compound eyes, in the absence of free cheeks and of an annulated pygidium, and especially in the character of its appendages, such as the presence of book-gills instead of limb fringes for respiration, and six pairs of legs about the mouth instead of a pair to each segment.

Derivation of name. - Greek xiphos, sword, + oura, tail; referring to the sword-shaped tail or telson. 
The best known example is the horseshoe crab, - Limulus polyphemus (Fig. I 24). In this the six pairs of appendages are all chelate except the sixth, which is surrounded with whorls of plates which aid in pushing the animal over or through the mud. Of the seven abdominal segments the six anterior ones consist of operculum and five pairs of book-gills; there are over one hundred pairs of gill leaves in all. This species lives in shallow water, grubbing in the mud for its food. It ranges from Yucatan to Maine. The eggs hatch in July and August. The young are tri-lobed like the trilobites; they swim much upon their backs. This is the last surviving genus of an order whose members were abundant both in number of genera and species throughout the world from early Cambrian times. (See relationship of the Arachnida, p. 309.) The only other living species (L. molluccamus) occurs off the east coast of Asia and in the Malay Archipelago. Limulus occurs from the Triassic to the present. The many other representatives of this order exist only as fossils, as Belinurus (Devonian to Pennsylvanian), Neolimulus (Silurian) and Aglaspis (Cambrian).

I. Sketch the horseshoe crab, side view, showing one half of the dorsal carapace. Label carapace, compound eye, telson, book-gills, operculum, legs.

2. Where does Limulus live? How?

3. Why is it placed under the Arachnida, and not under the Crustacea?

4. What is its geologic range?

5. Why do we expect an order with but a single living genus to have had a long ancestral history, with many fossil representatives? Mention examples of this among plants.

\section{Order 2, Eurypterida}

Body elongate with comparatively small cephalothorax and an abdomen of thirteen segments, including the post-anal telson. There are two large, lateral, faceted eyes, and a pair of median, simple ones. Six pairs of legs surround the mouth, 
the first pair probably always chelate, and the last pair, the broad, powerful paddle, used in swimming and in burying itself in the mud. The anterior six abdominal segments consist of the anterior genital operculum and the posterior five pairs of broad, leaf-like appendages, probably respiratory; these six are apparently comparable to the operculum and book-gills of Limulus (see relationship of the Arachnida, p. 309). The mode of life was varied; it included swimming, crawling and burrowing.

Though the order is entirely extinct, yet the growth stages of many of the Eurypterida are well known. In the Shawangunk grit (Middle Silurian) of southeastern New York excellent series have been obtained, some of the stages measuring less than two millimeters in length. The larval stages have a comparatively larger carapace, with compound eyes larger and nearer the margin, swimming legs usually larger, and a less number of segments to the body. The later larval stages of the mid-Paleozoic species show some characters present in the adult Cambrian and Ordovician forms.

The Eurypterida (Cambrian to Permian) were probably at first marine, later (Devonian to Pennsylvanian) they became adapted to brackish water, and finally (Permian) to a fresh water environment. The earlier species are usually found associated with the marine cephalopods and trilobites, while the later forms occur in strata along with land plants, insects, scorpions and fresh water Amphibia. (There are some students who believe that all eurypterids from the Cambrian to the Permian were fresh water inhabitants, because of the apparent evidence that the inclosing sediments were deposited upon land and not in the sea.) Some forms, as Pterygotus, attained at times a length of nine feet. Stylonurus is another large form from the Silurian and Devonian, distinguished by the possession of two pairs of enormously elongated appendages.

Derivation of name. - Greek eurys, broad, + pteron, wing, referring to the broad, wing-like pair of legs. 
3 I4 AN INTRODUCTION TO THE STUDY OF FOSSILS

Eurypterus (Fig. I36).

Ordovician to Permian.

Abdomen, including the telson, about five times as long as the subquadrate cephalothorax, which is bordered by a narrow furrow. Compound eyes reniform; the simple ones between these are close to the median line. First pair of head appendages very small; second to fourth pairs covered with spines; the sixth or last pair very large.

I. Sketch Eurypterus, dorsal view, noting both simple and compound eyes, cephalothorax, telson, appendages if present.

2. Describe its habitat and probable mode of life, giving reasons for your views.

3. How can the ontogeny of an extinct animal like Eurypterus be known?

4. In what respects do the larval stages of this genus differ from the adult?

5. What is the significance of the name Eurypterus?

\section{Order 3, Limulava}

An imperfectly known order from the Middle Cambrian. Attached to the short cephalothorax are a pair of long, simple, jointed antennæ similar to those of trilobites, and four pairs of other appendages, some of which are likewise trilobite-like in being biramous. The broad, tapering abdomen of twelve segments ends in a compound fin-like telson similar to that of the decapod crustaceans. Compound eyes only are present. This order may represent species transitional between the primitive arachnidan order Eurypterida and the primitive crustacean order Trilobita. The best-known genus is Sidneyia from the Stephen formation of British Columbia.

\section{ORDERS 4 TO I6}

(The air-breathing portion of the Arachnida)

4. Scorpionida (Silurian to present). The telson is modified to form a poison gland and sting. The scorpions have decreased since their maximum development in the Upper Paleozoic. For 


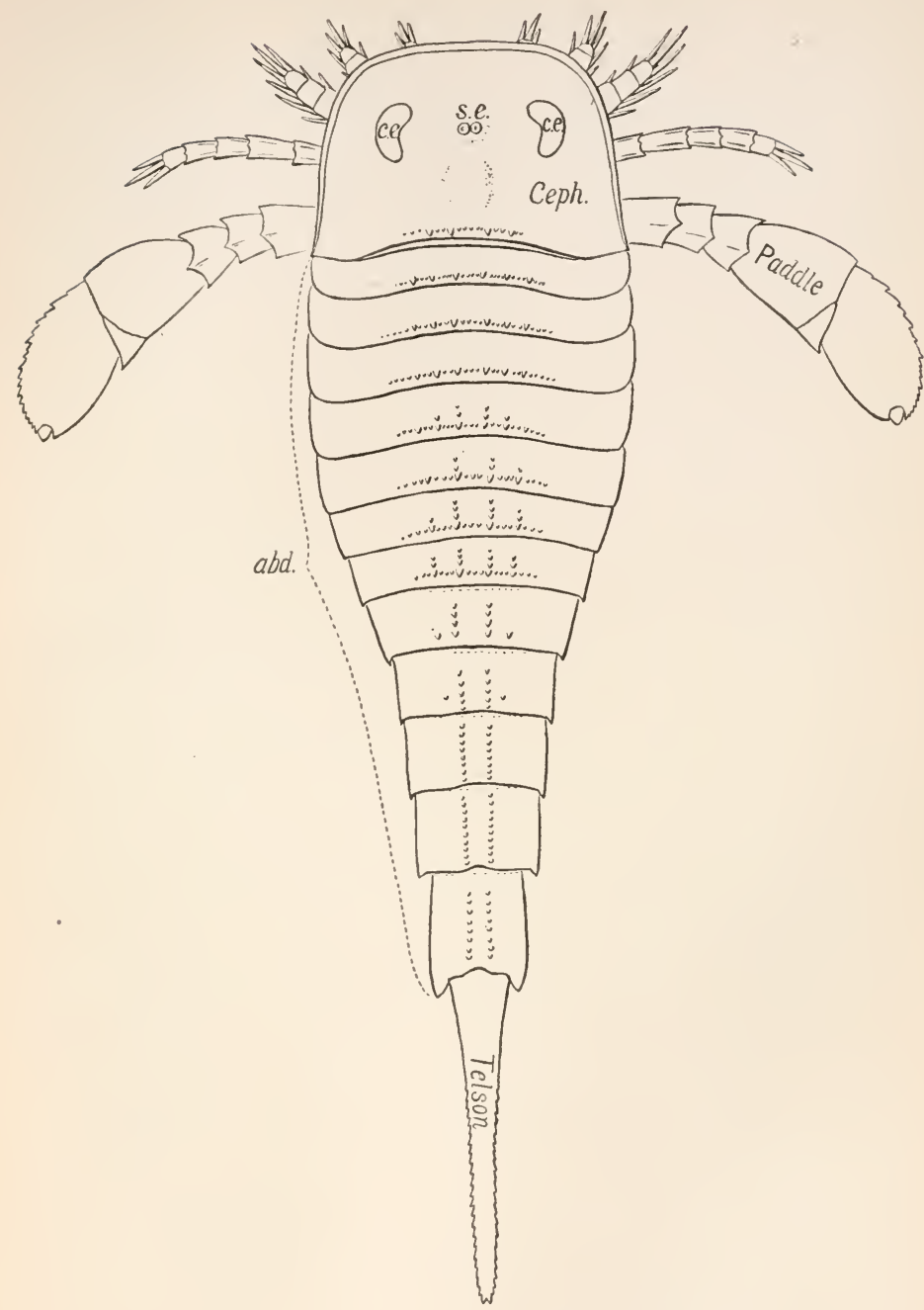

FIG. 136. - A representative of the class Arachnida, Eurypterus remipes Dekay, from the Bertie formation (mid-Silurian) of New York. Dorsal view $\left(\times \frac{1}{2}\right)$, showing the compound eyes (c.e.) and the simple ones (s.e.) upon the cephalothorax (ceph.), five of the six pairs of legs, and the abdomen (abd.). (Redrawn from Clarke and Ruedemann.) 
a consideration of relationships, see page 309. 5. Pedipalpida (Pennsylvanian to present). 6. Palpigrada (living). 7. Kustarachnida (Pennsylvanian). 8. Solpugida (Pennsylvanian to present). 9. Ricinulei (Pennsylvanian to present). Io. Pseudoscorpionida (Oligocene to present). II. Araneida (Pennsylvanian to present). Cephalothorax and abdomen are distinct but neither is segmented. At the posterior end of the abdomen are tubes (spinnerets), the tips of each perforated by very many openings from which comes a fluid which hardens upon contact with the air; the union of these hundreds of microscopic threads forms the ordinary thread just visible to the naked eye. This order includes the true spiders. I2. Anthracomarti (Pennsylvanian). Probably ancestral to the Pedipalpida and Phalangida. I3. Haptopoda (Pennsylvanian). I4. Phalangiotarbi (Pennsylvanian). I5. Phalangida (Pennsylvanian to present). A well-known example is daddy longlegs (Phalangium); this lives upon small insects. I6. Acarina (Oligocene to present). Degenerate arachnids. These include the mites and ticks.

I. Distinguish the Arachnida from the Insecta.

2. What difference between the water-breathing and airbreathing divisions of the Arachnida?

3. Distinguish between book-gills, book-lungs and tracheæ. Name animals of which these are characteristic.

4. Compare the branchiate Limulus with the tracheate Scorpio. In what respects do they $(a)$ agree, $(b)$ differ?

5. In what respects do fossil scorpions from the Silurian unite still more closely these branchiate and tracheate portions?

6. What fossil forms agree with Scorpio more closely in abdominal segments?

7. Why are the eurypterids and the limulids (Order Xiphosura) supposed to have already separated in pre-Cambrian time?

8. Are the trilobites related to the limulids, eurypterids or scorpions? Reasons.

9. How early in geologic time are the Scorpionida known? the Araneida?

Io. How is a spider's thread formed? 


\section{CLASS E, INSECTA}

These six-footed arthropods have a body consisting of head, thorax and abdomen, with the skin hardened by chitin. To this hardened skin, as in all other Arthropoda, the muscles are attached. The head bears normally a pair of feelers or antennæ, a pair of mandibles and two pairs of maxillæ, and usually a pair of compound, sessile eyes (the house fly has 4000 facets (i.e. individual eyes) to each eye; the dragon fly 28,000). The thorax has a pair of unbranched legs to each of its three segments and usually two pairs of wings. The abdomen of seven to eleven segments has no appendages. Since the wings are merely expansions of the chitinous skin stretched over chitinous tubes, - the veining, these are often preserved in the fossil state notwithstanding their extreme delicacy. These tubes consist of a tube within a tube, the inner carrying air, the outer blood.

Respiration is by trachece, - a system of air-tubes held open by elastic, spiral threads, penetrating all parts of the body and terminating upon the surface of the body in several buttonhole-like openings, the stigmata; by the expansion of the abdomen air is drawn in through the stigmata and forced throughout the body; the contraction of the abdomen forces the air out again. Thus air is taken directly to all parts of the body instead of indirectly as in the vertebrates, where the blood acts as carrier of oxygen from the lungs. There is accordingly no need for either arteries or veins, though there is an elongate tubular heart situated in the dorsal part of the abdomen, which aids the movements of the body in transferring the blood and with it the digested food particles to all parts of the body.

The sexes are separate. Development is usually accompanied by metamorphosis. For example, the house fly lays 100 to 200 eggs in decaying animal matter, such as a manure pile; these in warm weather hatch into larvæ ("maggots") which, living upon this putrid matter, become fully grown in about one week, when 
each surrounds itself with a brown case (pupa case), from which it bursts a week later as a full-grown fly.

The generalized structure of the early insects indicates that the various individuals were more similar to one another than at present. They combine in the same individual characters which are now found only in distinct families and even orders. Insects are known from the Pennsylvanian to the present.

The following are some of the localities where the delicate bodies of insects, arachnids and myriopods occur well preserved : Pennsylvanian of Commentry, central France; Saarbrücken, southwestern Rhenish Prussia; Mazon Creek, Illinois; Rhode Island Coal Measures; Jurassic of Solenhofen, Bavaria ; Oligocene of East Prussia and Baltic amber; Miocene of Oeningen, Baden, on Lake Constance, and that of Florissant, Colorado.

Derivation of name. - Latin in, into, + secare, to cut. Originally named from such forms as bees and wasps, which are almost completely cut into two or three parts.

\section{SumMARY OF THE ORders OF INSECTA}

I. Paleodictyoptera (Pennsylvanian). These are possibly the ancestors of all winged insects. 2. Mixotermitoidea (Pennsylvanian). 3. Reculoidea (Pennsylvanian). 4. Protorthoptera (Pennsylvanian and Permian). 5. Orthoptera (Jurassic to present) ; e.g. grasshoppers, crickets. 6. Phasmoidea (Jurassic to present). 7. Dermaptera (Eocene to present). 8. Diploglossata (living). 9. Thysanoptera (Eocene to present). ı. Protoblattoidea (Pennsylvanian and Permian). II. Blattoidea (Pennsylvanian to present). These, the cockroaches, were exceedingly abundant in the upper Paleozoic coal swamps. r2. Mantoidea (Permian to present). I3. Isoptera (Eocene to present); e.g. white ants. I4. Corrodentia (Oligocene to present); e.g. book lice. I5. Mallophaga (living); e.g. bird lice. r6. Siphunculata (living). r7. Coleoptera (Jurassic to present) (Fig. I37). Beetles. I8. Hymenoptera (Jurassic 
to present); e.g. bees, ants, wasps. I9. Hadentomoidea (Pennsylvanian). 20. Embioidea (Oligocene to present). 2I. Sypharopteroidea (Pennsylvanian). 22. Hapalopteroidea (Pennsylvanian). 23. Perlaria (Permian to present). 24. Protephemeroidea (Pennsylvanian). 25. Plectoptera (Permian to present); e.g. May-flies. 26. Protodonata (Pennsylvanian to Triassic). Some of these primitive dragon flies from the Pennsylvanian had a length of body of fourteen inches with a spread of wing of at least two feet (Fig. I50). 27. Odonata (Jurassic to present). Dragon flies. 28. Megaloptera (Triassic to present). 29. Raphidioidea (Oligocene to pres-

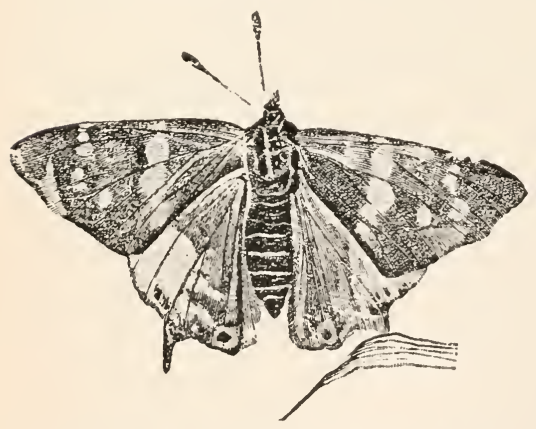

FIg. I38. - The butterfly, Prodryas persephone Scudder, from the Miocene shales of Florissant, Colorado. In this specimen are marvelously preserved not only the knobbed antennæ and entire form as though mounted in a cabinet, but the very scales upon the wings. (From Scudder.)

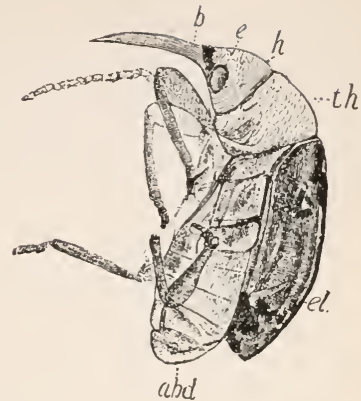

FIG. I37. - A beaked insect, Teretrum primulum Scudder, of the order Coleoptera, from the Miocene of Florissant, Colorado. Length $3 \mathrm{~mm}$. $b$., beaks, not well preserved (the point of the beak was most probably rounded) ; $e$., eye ; $e l$., elytra (the thick anterior pair of wings serving only as a protection of the posterior pair); $h$., head; th., thorax; abd., abdomen. (From Scudder.)

ent). 30. Neuroptera (Jurassic to present); e.g. lacewing flies. $3 \mathrm{I}$. Megasecoptera (Pennsylvanian). 32. Panorpatæ (Jurassic to present). 33. Trichoptera (Jurassic to present). 34. Lepidoptera (Jurassic to present). Butterflies (Fig. I38) and moths. 35. Diptera (Jurassic to present). Flies. 36. Suctoria (Oligocene to present). Fleas. 37. Protohemiptera (Permian). 
38. Paleohemiptera (Permian to Jurassic). 39. Hemiptera (Jurassic to present). Bugs. 40. Homoptera (Jurassic to present); e.g. plant lice, harvest-flies. 4I. Aptera (Oligocene to present). Spring-tails. This is often separated into four orders.

I. Why are insects classed within the phylum Arthropoda?

2. What characterizes an insect?

3. In what respects are the eyes of most insects like those of most trilobites?

4. Account for the fossil preservation of the delicate veining in the wings of insects.

5. How does an insect breathe? How does this differ from the respiration of a vertebrate?

6. What is meant by metamorphosis?

7. Outline the development of the house fly.

8. Name some localities famous for the preservation of such delicate bodies as those of the Insecta and Arachnida.

9. What is meant by the generalized structure of the early insects?

ıо. Name some orders of insects, giving under each the geologic range and a living example.

I. What characters distinguish the Arthropoda from other phyla?

2. Give some characters which place them at the top of all invertebrate animals.

3. How long geologically has this phylum been in existence?

4. How do you account for the earlier existence of waterdwelling than of open-air-dwelling arthropods ?

5. Define Arthropoda, illustrating your definition with examples.

6. How do the Arthropoda differ from the Annulata in the following characters: $(a)$ habitat, $(b)$ protecting and supporting skeleton, $(c)$ locomotion, $(d)$ food, $(e)$ its capture, $(f)$ its intake, $(g)$ digestion, $(h)$ blood circulation, $(i)$ excretion of waste, $(j)$ respiration, $(k)$ nervous system, $(l)$ sense organs, $(m)$ reproduction, $(n)$ geologic range.

7. How do the members of the larger divisions of this phylum avoid competition in food getting? 


\section{PHYLUM XII, CHORDATA}

In the phylum Chordata life has an instrument through which it not only can take cognizance of its environment through the special organs of touch, taste, smell, hearing and sight, but has a centrally controlled system of nerves and a complex muscular system to respond quickly and accurately to this environment. The members of this phylum, comprising the most highly evolved animals, possess in common throughout life or only in the young, (I) the notochord (primitive backbone), a cord of cells developed from the endoderm, extending along the middle line of the dorsal side of the body between the digestive canal and the extension of the central nervous system (spinal cord of higher forms); (2) branchial clefts, a series of clefts perforating the walls of the pharynx; and (3) the neurocœle, one or more cavities within the central (dorsal) nervous system.

The main advance of the typical Chordata (Vertebrata) upon the Invertebrata lies in the development of the second body cavity, which lodges the central nervous system, - the spinal cord and its anterior enlargement, the brain. This cavity is dorsal to the one containing the digestive canal, heart and lungs.

Derivation of name. - Chordata $>$ Latin chorda, a cord, referring to the universal presence of the notochord at some stage in development.

This phylum is divided into the following sub-phyla :-

I. Adelochorda

2. Urochorda

3. Vertebrata 


\section{SUB-PHYLUM I, ADELOCHORDA}

This comprises but nine genera and some thirty species, the best-known of which, Balanoglossus, burrows in the sand or mud of the sea-bottom. In this form the mouth is at one end of the body and the anal opening at the opposite end; immediately dorsal to the mouth is a small, cord-like body correlated with the notochord of the typical Chordata. This somewhat concealed relationship to the Chordata suggested the name from Greek adelos, not manifest, + chorde, a cord. These forms show relationship also to the annelids, to the Phoronida of the Molluscoidea and to the Echinodermata. Unknown in the fossil state.

\section{SUB-PHYLUM 2, UROCHORDA}

The tunicates are degenerate Chordata, with the notochord confined to the tail region (whence the name from Greek oura, a tail, + chorde, a cord). The adult body is inclosed in a tunic, suggesting the common name.

In all but one small order the tail with its included notochord disappears in the adult, which is free-swimming (e.g. Doliolum) or sessile (e.g. the majority of ascidians or sea-squirts). Many in both of these groups form colonies by budding, a process of growth characteristic of plants and of many of the lower classes of invertebrates, but absent in all higher invertebrates and in all the Chordata except these degenerate forms. Most of the ascidians also show degeneration in the development of cellulose within the skin. Cellulose is a protective and strengthening substance characteristic of plants. Unknown in the fossil state.

\section{SUB-PHYLUM 3, VERTEBRATA}

The notochord extends through the greater part of the elongated body and persists throughout life (in Acrania) or gives place (in Craniata) to a jointed vertebral column or backbone (whence the name from Latin vertebra, a joint of the backbone). 
The backbone in lower forms consists mainly of cartilage, in the higher forms this cartilage is replaced by bone. The central nervous system (spinal cord) is penetrated by a very small longitudinal canal. The pharynx is perforated throughout life or only in the embryo by paired branchial openings, the gill-slits. The mouth is ventral and anterior, the anus ventral and posterior. An important digestive gland, the liver, is developed as a hollow outpushing of the intestine; the blood from the intestine passes through this before entering the general body circulation.

The Vertebrata are subdivided into:-

Division a, Acrania. - True skull absent (whence the name from Greek $a$, negation, + kranion, the skull). Brain slightly developed; no heart present; blood colorless. Notochord persistent throughout life, extending from end to end of body.

This division includes only two genera, the most important of which, Amphioxus, is world-wide in its distribution. No fossil remains referable to this division are known.

Division b, Craniata. - True skull present (whence the name, from Greek kranion, a skull). Brain highly developed; a pair of very complex eyes present; heart of three or four chambers; blood with red corpuscles. Pharynx (with single exception of Bdellostoma) perforated by not more than seven pairs of gill-slits; notochord present only in the embryo, after which it becomes surrounded by a segmented ring of cartilage (only rods of cartilage in the Cyclostomata); this cartilage in higher forms changes to bone. Paired limbs usually present.

The Craniata are divided into the following classes :-
A. Cyclostomata
B. Ostracodermi .
C. Pisces
D. Amphibia
E. Reptilia
F. Aves
G. Mammalia 
Type of the Vertebrata, - Fclis domestica (Figs. 139-142).

The cat is a four-footed mammal with the protective skin largely covered with soft hair and with an internal supporting skeleton of bone. Its organs of offense and defense are sharp carnivorous teeth and curved claws.

The elastic skin, which is united to the underlying flesh by a connective tissue, is composed of a deeper layer, the dermis, or corium, and an outer layer, the epidermis. As the superficial cells of the latter are continually drying up and falling off, new cells form beneath. The claws and hair are special modifications of the epidermis. The oil-glands, the product of which keeps the surface of the skin and the hair soft, are developed in the dermis, and each usually opens into a hair follicle, - a sac-like sheath lodging the base of the hair. The sweat-glands, whose function is in some mammals to aid in the maintenance of a uniform body temperature, are in the deepest part of the dermis, or even in the tissue beneath, with openings at the surface. They are of comparatively slight importance in the Carnivora, the order to which the cat belongs.

Skeleton. - The cat's body is supported by an internal framework of bone and moved by muscles attached to their outer surfaces. There are about 230 separate bones; these are fewer in the old than in the young, owing to the union of some bones later in life. Bone is composed of about one-third organic matter (gelatine and blood-vessels) and two-thirds inorganic matter (lime-phosphate about fifty and lime-carbonate ten per cent). Each bone is covered completely, except on its articulating surfaces, with a membrane, the periosteum; this serves to renew the bone when injured.

The principal portion of the skeleton is the backbone; to it are attached either directly or indirectly all the other bones of the body (see Fig. I39). To it anteriorly is attached the skull, - the brain-inclosing box, to which the upper jaw (maxilla) is solidly joined in front and the lower jaw (mandible) attached by muscles and ligaments below, while posteriorly are 


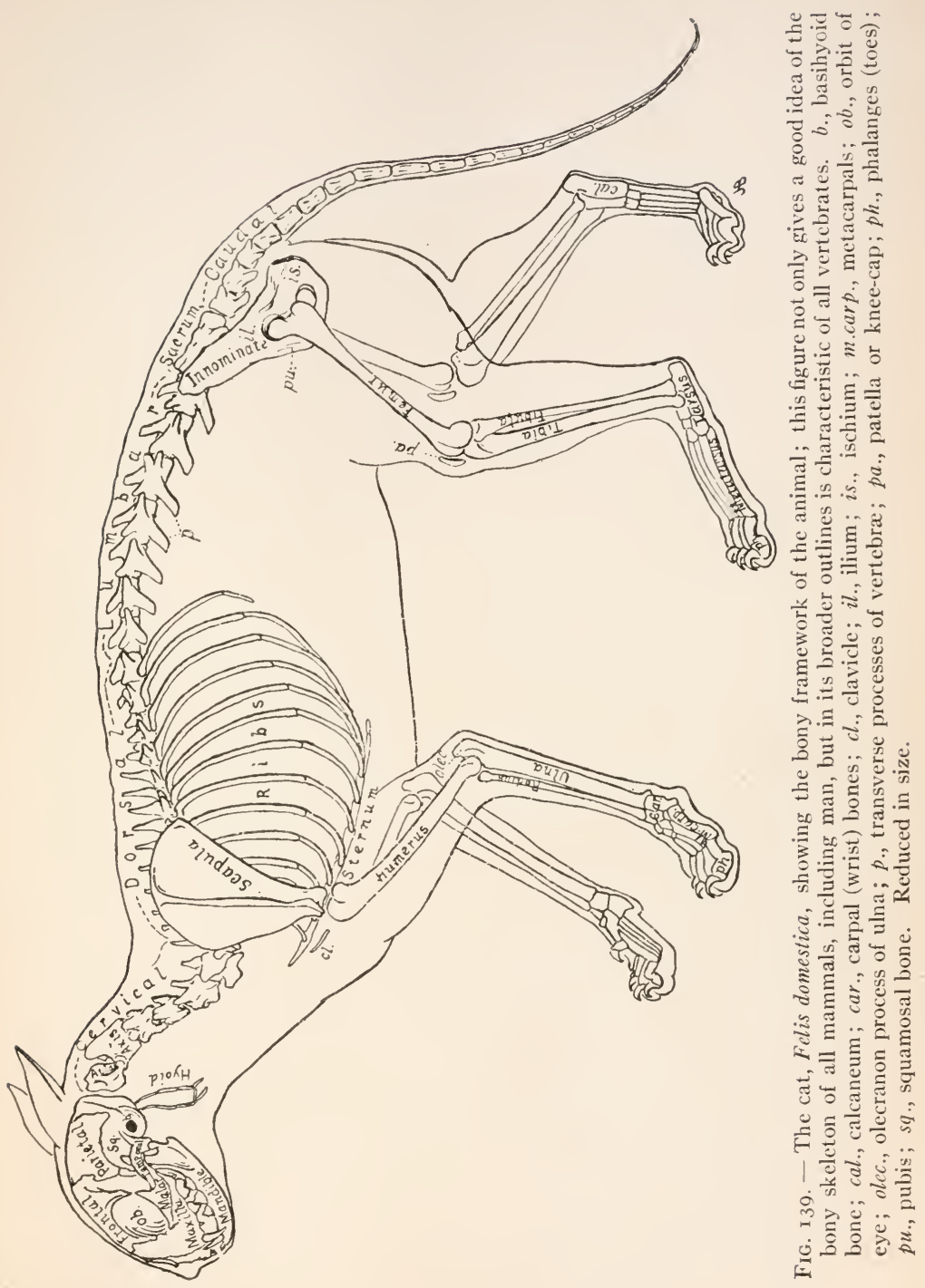


attached the hyoid bones, which support the larynx, or voice box. To the backbone ventrally are joined the ribs, which

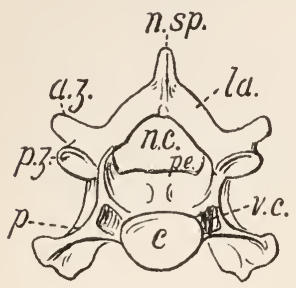

FIG. I40. - Posterior view of the fifth cervical vertebra of the cat; to illustrate nomenclature. a.z., anterior zygapophysis, - a flattened articulating surface upon the neural arch (pe. and $l a$. combined), looking downwards upon the posterior zygapoph$y$ sis of the vertebra ahead. This a.z. at times, especially in the lumbar region, looks inwards; $c$., centrum; la., lamina, - transverse portion of the neural arch. Its anterior and posterior faces, called zygapophyses, are flattened for articulation with neighboring vertebræ; n.c., neural canal, lodging the spinal cord; n.sp., neural spine; $p$., transverse process, sometimes divided into a superior and an inferior branch; pe., pedicle, - the vertical portion of the neural arch, notched upon the side for exit of nerves from the spinal cord; p.z., posterior zygapophysis; this looks downward (in the lumbar region often outward) ; v.c., vertebrarterial canal, piercing the base of the transverse process. In the caudal region, especially where the tail is well developed, paired bones, uniting at times to form an arch, arise upon the ventral side of the centrum; these are the cheoron bones. (Redrawn from Mivart.)

of the individual vertebræ. with the breastbone (sternum) protect the heart and lungs.

Primitively, as in most fish (Fig. 149) and snakes, a pair of ribs is attached to each vertebra from the base of the head into the tail region. But with upright land life they have become reduced to a small part of the trunk region. Even in the higher mammals, however, there occur in the embryo beginnings of the other ribs coalescing later with the vertebræ.

The backbone, or vertebral column, is a hollow rod lodging the spinal cord, and divided into some thirty to fifty sections, or vertebræ; i.e. seven neck (cervical, Fig. I40), thirteen chest (thoracic), with attachment for the thirteen pairs of ribs, seven back (lumbar), three hip (sacral) and four (in the manx cat) to twenty-six tail (caudal) vertebræ.

In most mammals the number of cervical vertebræ is seven; the long neck of the giraffe has thus been produced merely through the lengthening With the swan, among the birds, however, there has been an increase in their number to twentythree and with this a consequent increase in grace of movement. 
The fore limb, attached to the backbone by muscles only, is composed of a shoulder-blade (scapula), collar-bone (clav-

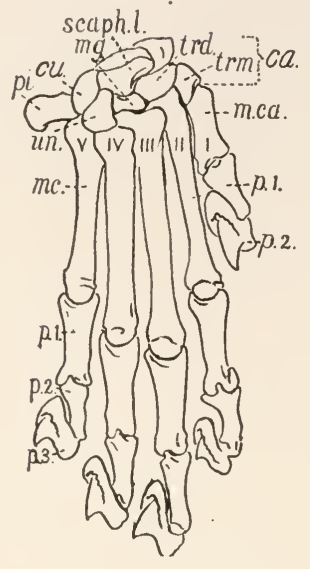

A

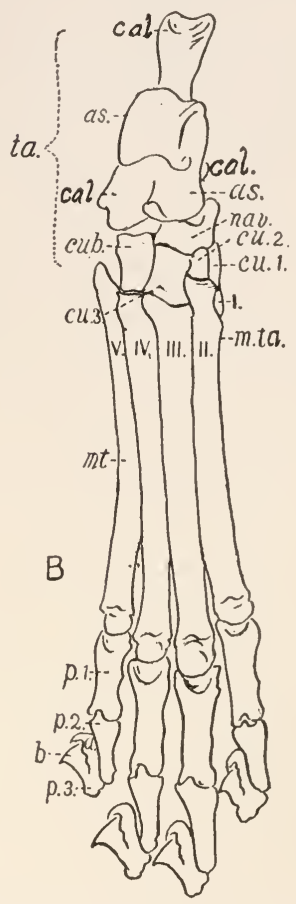

FIG. I4I. - A, bones of the right fore foot of the cat; dorsal view. ca., carpus (or wrist); cu., cuneiform; mg., magnum; mc. and m.ca., metacarpal (palm) bones ; p., phalanges (or bones of the toes); pi., pisiform; scaph.l., scapholunar; trd., trapezoid; trm., trapezium; un., unciform; $I, I I$, etc., digits, Ist (thumb), $2 \mathrm{~d}$, etc. $B$, bones of the right hind foot of the cat; dorsal view. $a$., hood to inclose root of claw; $a s$. , astragalus; $b$., process to sustain the claw; cal., calcaneum; $c u .{ }^{1}, c u{ }^{2}$, $c u{ }^{3}$, internal, middle and external cuneiform respectively; $c u b$., cuboides; $m t$. and m.ta., metatarsals; nav., navicular; p., phalanges; ta., tarsus (or ankle); $I, I I$, etc., digits, Ist (represented only by a degenerate metatarsal), $2 \mathrm{~d}$, etc. (Redrawn from Mivart.)

icle), arm-bone (humerus), bones of forearm (radius and ulna), seven wrist bones (carpals) arranged in two rows, five palm bones (metacarpals) and fourteen finger bones (phalanges) 
arranged in five toes (Fig. I4 I, $A$ ). The hind $\operatorname{limb}$ is composed of the hip bone or innominate, firmly attached to the sacral vertebræ, and made up of the ilium, ischium and os pubis, the thigh-bone (femur) with the knee-cap (patella) protecting its lower edge, the bones of the foreleg (tibia and fibula), the seven ankle bones (tarsals) arranged in two rows, five metatarsals and twelve phalanges (three to each of the four toes) (Fig. I4 I, $B$ ).

The clavicle is vestigial in the Carnivora and entirely wanting in many of the Ungulata. In those vertebrates, however, in which the fore limbs are capable of a great variety of motions and a freedom of movement, as in flying birds, bats and in primates, it is well developed.

Hind limbs are wanting among the Sirenia and Cetacea, though a small, degenerate, functionless hip bone is present. In Halitherium, a Miocene sirenian, a vestigial femur is present. In the snakes both fore and hind limbs are absent; but a few forms, as Python, have a vestigial hip bone.

The primitive number of digits to each foot is five, but a reduction occurs in many animals. In the birds there are usually but three upon the wing and four upon the foot; in many reptiles the number is reduced to three; among the mammals the pig has four digits, the rhinoceros three, the camel two and the horse but one.

The source of the footprints made by the pads and claws of the cat's feet in walking upon a yielding surface, such as dense mud, is rather easily recognizable; so, too, that of other living animals. By being covered with sediment these footprints may be preserved fossil. Many such vertebrate fossils occur from the Mississippian to the present. The Triassic sandstone of the Connecticut River valley contains especially notable examples. These footprints made upon an ancient mud-flat are mostly due to the reptiles of the time.

The bones of the fore limbs are attached to the thin triangular scapula, the head of the humerus fitting into a socket in the lower end of this bone, while the hind limbs are similarly attached to the innominate, the head of the femur fitting into a socket in this bone. Both are thus ball-and-socket joints, 
while the elbow and knee, at the junction of humerus and radius, femur and tibia respectively, are hinge joints.

Joints. - The articulating surfaces of bones at immovable joints, as between the bones of the skull, are separated by a fibrous membrane only, hence the contiguous bone surfaces are irregular and they are stronger thus than when smooth. At joints where there is very slight movement, as between contiguous vertebræ, each surface is faced with a layer of cartilage and the bone surface is but slightly rough. At joints where movement is very free, as the ball-and-socket and the hinge joints, the bordering surfaces are also covered with cartilage, but the two bones are likewise held apart by a fluid; the bone surfaces here are very smooth. Hence in fossil bones the place and extent of movement between bone surfaces is easily noted.

Muscles. - The complicated muscular apparatus, by which the various parts of the body are moved, is primarily derived from the vertical muscle segments (myomeres) lying on each side of the spinal column (as seen typically in Amphioxus and the fish). But in the cat, as in all forms above the fish, this arrangement is obscured, since the muscles are greatly modified both in form and position in adaptation to terrestrial life. The muscles, commonly called flesh, are made up of fibers (coarsest in fish), which are bound together into bundles. These bundles, or true muscles, are usually fastened by each end to a roughened surface of a bone by means of the tough membrane of the periosteum, the larger the muscle the larger being the roughened surface or projection for attachment. Since muscles make up the bulk of the cat's body, the muscular system largely determines the shape of its trunk and limbs (see page i 8 ).

More than four hundred of the muscles found in the cat's body occur also in man with the same general location, function and nerve supply.

All muscles are either voluntary, under control of the will, or involuntary, incapable of control by will. The vol- 


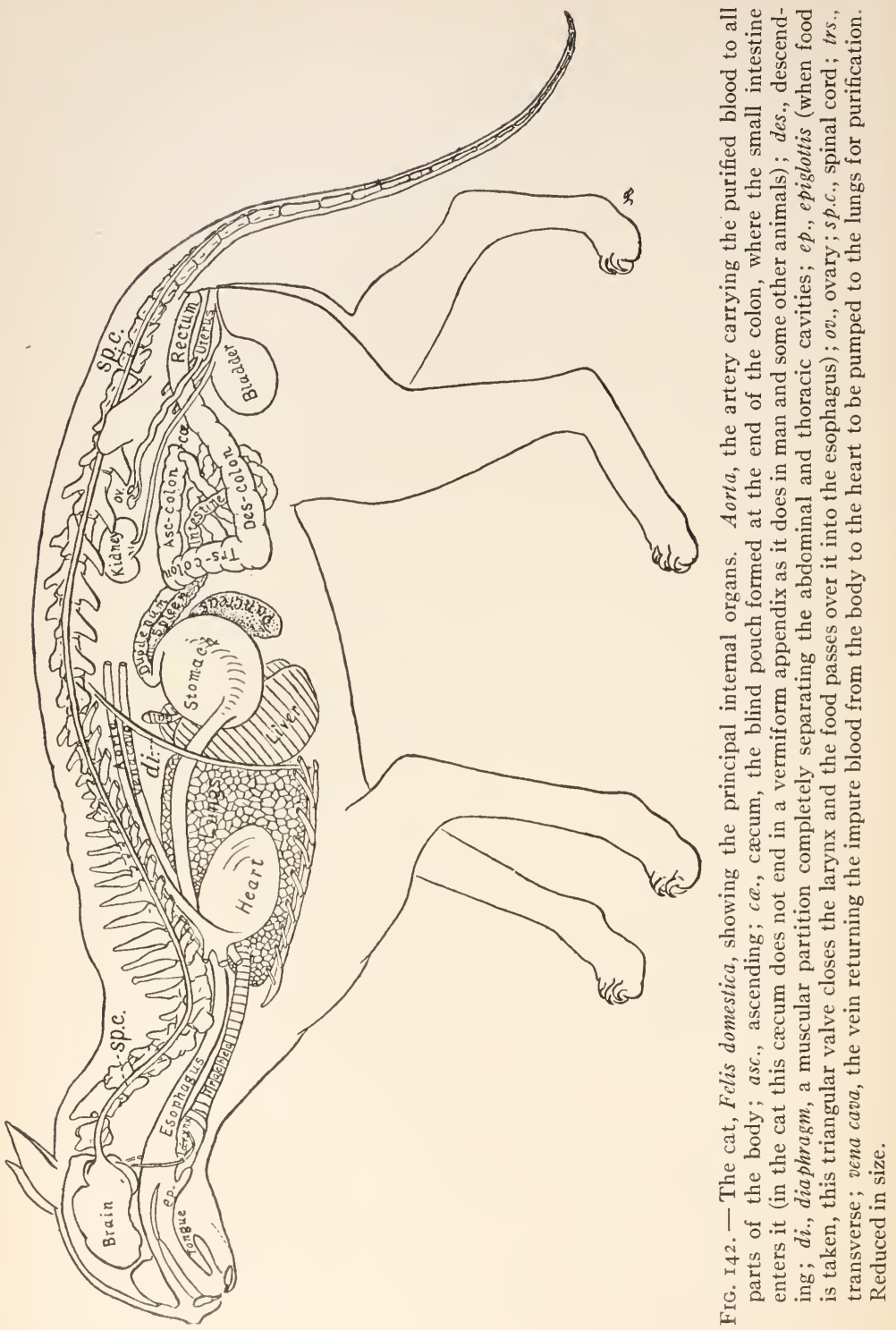


untary muscles, all muscles moving the bones, for example, are supplied with nerves from the brain or spinal cord. The involuntary muscles, those in the walls of the blood vessels and digestive canal, for example, are supplied with nerves from the sympathetic nervous system.

The interior of the trunk, called the body cavity, is divided into two parts by a flat partition-like muscle, the diaphragm, attached to the backbone and ribs (Fig. I42, di.). The anterior or thoracic cavity contains the heart and lungs; the posterior or abdominal cavity contains the stomach, intestine, liver and kidneys.

Digestion. - In a wild state the food of the cat consists principally of animals which it procures by means of its sharp claws and sharp teeth. This is then partially crushed by the teeth and at the same time preparatory to being swallowed is thoroughly moistened by the saliva. Passing down the esophagus the food enters the stomach, where the gastric juice dissolves the proteid constituents, thence to the small intestine, where bile, poured in from the liver, emulsifies the fats, and the pancreatic juice from the pancreas acts upon starches, proteids and fats. The digested food is absorbed by the many bloodvessels and lymphatics surrounding the digestive canal, especially the stomach and small intestine; the undigested remnant passes through the large intestine and out by the anus.

As in most of the higher animals, both Invertebrata and Vertebrata, the digestive canal is much coiled to give a greater area for digestion and absorption; in the cat it is five times the length of the body exclusive of the tail.

The cat has two sets of teeth; the thirty of the second or permanent set begin to displace the twenty-six of the first set or milk teeth at the end of the fourth month. In the adult cat there are in the upper jaw, upon each side, three small cutting teeth or incisors, one fang or canine, three premolars, and one molar. The back premolar, very large and especially adapted to cutting flesh, is called the sectorial tooth. In the lower jaw, 
each side has three incisors, one canine, two premolars and one molar, the molar being the sectorial tooth here. Sectorial teeth are characteristic of the Carnivora.

In the elephant the single pair of upper incisors develop into tusks. Mammals that chew the cud, like the sheep and cow, have no upper incisors in the adult state, though they are present in the embryo, and in their Tertiary precursors they were well developed.

Absorption and blood circulation. - As the food is absorbed from the digestive canal the (r) emulsified fats and most of the water are carried immediately to the heart and are thence forced to all parts of the body, where the former are stored in the fattissue, the (2) sugars, including what when eaten was starch, are taken to the liver, where they are stored until needed; the (3) proteids are taken directly to the liver, where their preparation for use in the body is continued. The energy and heat of the food is set free in the millions of body cells through oxidation, the oxygen being derived from respiration. The end products of (I) and (2) are carbon dioxid and water, in (3) there exist in addition mainly such waste products as urea and uric acid.

This nutrient food, added to the blood already existing, is pumped by the very muscular heart to all parts of the body through a system of contractile, non-collapsible tubes, - the arteries; these keep branching until every portion of the body is reached, and are so numerous that the point of a needle cannot penetrate the body without piercing one or more of them. As the terminal microscopic tubes, called capillaries, are exceedingly thin and delicate, the food material and oxygen pass through the walls, partially at least by osmosis, into the cells needing them, while back into the tubes pass the waste products of the cells, such as carbonic acid and nitrogenous compounds. The blood, now laden with waste material, passes backwards towards the heart through a system of collapsible tubes, the veins; some of the blood passes through the kidneys, there getting rid of the waste products from the breaking down 
of the proteids; the inorganic salts and much water are likewise brought to the kidneys. From the heart it is all pumped to the lungs, where much of the carbon dioxid is given up by the blood and oxygen is taken into it.

Body waste. - Thus the solid waste passes out of the body by way of the digestive canal; the liquid waste by means of the kidneys through the bladder, and also through the agency of the sweat glands; the gaseous, through the lungs.

Respiration is performed by the lungs, - a hollow, blind, spongy outpushing from a part of the throat (pharynx). Air is drawn into and forced out of these, through nasal passages, pharynx, larynx, and trachea, by the contraction and relaxation of the muscles of the chest. Since a network of blood capillaries lines each of the myriad of minute air-chambers, the interchange of carbon dioxid and oxygen is rapid. The oxygen carrier of the blood is the hæmoglobin of the red blood corpuscles, for which oxygen has a strong affinity.

Voice. - An outgrowth of this method of respiration is the development of voice. As the air passes to or from the lungs it must traverse the larynx (Fig. I42), upon the sides of which are developed folds, - the vocal cords; the rapid passage of the air over these produces an audible vibration. As muscles are attached to the ends of these, they can be expanded and contracted, thus giving rise to variations in the pitch of the voice.

Nervous systems. - The nervous elements form (I) the central nervous system, and (2) the peripheral nervous system. The former consists of the brain and spinal cord; the latter is made up of those nerves which establish a connection between the periphery of the body and this central system. The brain, situated in the posterior portion of the skull, gives off, especially to the muscles of the head and neck, twelve pairs of cranial nerves. The spinal cord, which is continuous with the brain and occupies a tube extending through the spinal column, gives off especially to the muscles of the legs and trunk, forty pairs of spinal nerves. The cranial and spinal nerves with the 
nerves of the sympathetic system and their associated ganglia constitute the peripheral nervous system. The sympathetic nervous system, a derivative of the spinal nerves, consists of a pair of nerve-cords extending from the base of the skull to the root of the tail, one upon each side of, and ventral to, the backbone. From these, branches are given off especially to the blood-vessels and digestive system. At intervals throughout the entire system are enlargements, or ganglia, from which additional nerves arise. The peripheral nerves, composed of fibers of various kinds, divide and subdivide until they reach every minute portion of the body. The spinal cord and the sympathetic system are in communication by means of nerves passing from the ganglia of the main sympathetic nerve-cords to the ventral branches of the spinal nerves.

Organs of special sense. - The vertebrate eye is the most highly developed eye in the animal kingdom. It consists of a more or less globular body protected by a tough, fibrous outer layer, the sclerotic coat. Through the anterior transparent portion of this, the cornea, the light passes; next it passes through a watery fluid, the aqueous humor, then through the central black spot, the pupil. The bi-convex tissue forming the lens next concentrates the rays in an image which is projected back through the jelly-like substance, the vitreous humor, upon the inner coat of the eyeball, the retina. In the retina are lodged the ends of the nerves of sight; these take the sensation, transmitting it to the brain, where the image is perceived. The middle coat of the eye is lined with black, which absorbs all deflected light rays, hence the colorless pupil appears to be black. The colored portion surrounding the pupil, the iris, contains numerous radial and circular muscle fibers, by the contraction of which alternately the pupil is enlarged and reduced in size, for times of less and greater amount of light respectively. The lens is inclosed in an elastic sac and by means of muscles fastened to the sides of the eyeball may be decreased or increased in convexity for seeing objects at a greater or less dis- 
tance respectively. The eyeball is kept distended by the large mass of vitreous humor and by the smaller aqueous humor.

In vertebrates below the mammals, and even in the Monotremata, the sclerotic coat is more or less cartilaginous, and within it many species have developed a ring of delicate, bony plates near the junction with the cornea; these sclerotic plates surrounding the orbit of the eye are especially conspicuous in the extinct Stegocephalia and Ichthyosauria, in lizards, chelonians, and modern birds (Fig. I59, scl.).

The organ of hearing is similarly a complicated apparatus. As in the invertebrates it acts likewise in the maintenance of equilibrium, though in the more highly organized vertebrate only a portion of the hearing mechanism, the semi-circular canals, performs this function. The sense of smell is lodged in the nasal cavity, that of taste chiefly in the tongue, while the surface of the entire body is an organ of touch.

Cats are of two sexes. The ova are fertilized within the female by the spermatozoa introduced by the male. Soon each developing embryo, the foetus, becomes attached to the walls of the uterus by a special structure, the placenta. Through this it is nourished for fifty-five or fifty-six days. The young are then produced, usually five or six at a birth, fully formed except that the eyelids are still closed and the hairy covering is incomplete. The young before birth are enveloped in several foetal membranes. The inner one, called the amnion, is similar in the reptiles and birds. Because of its presence in the three groups, the reptiles, birds, and mammals are sometimes classed together as the Amniota. After birth the young of the cat are nourished by milk, which is secreted by skin glands known as breasts or mammæ. Because of the possession of these glands the group of animals to which the cat belongs is called Mammalia.

I. Examine the mounted skeleton, identifying the various bones by means of the illustration and description.

2. How is the cat protected against changes in climate? from enemies? 
3. Compare in general the composition of a bone with that of a clam or oyster shell.

4. Give two causes of variation in the total number of bones in the cat.

5. Compare the arrangement of the ribs in the cat with that in fish and snakes.

6. What evidence does the cat show in its development that its ancestors possessed a larger number of ribs?

7. Compare the elongation of the neck of the giraffe with that of the swan.

8. How are the fore limbs attached to the trunk? The hind limbs?

9. In what groups of vertebrates is the clavicle well developed? In what vestigial or entirely wanting? Account for this difference.

Io. What does the condition of the clavicle in the cat indicate as to its past history?

I I. Of what significance are the vestigial hip bones in the Sirenia and Cetacea?

I 2. What is the primitive number of digits in a mammal? Note variations from this.

I3. What is the function of joints? How can you note their presence in fossils?

I4. Distinguish between voluntary and involuntary muscles. Give examples of each.

I5. Given the bones of an extinct vertebrate, how can you estimate its shape when living?

I6. Describe briefly the digestion and assimilation of the cat's food from its capture to its use by the millions of individual cells.

I7. Enumerate the cat's teeth with the special function of each group. What special tooth distinguishes the Carnivora, both recent and fossil?

I8. How many sets of teeth does a cat have?

I9. Give an example of change of function in teeth; of reduction in numbers.

20. Describe briefly the course of the blood through the circulatory system.

$2 \mathrm{I}$. What element is necessary to the freeing of the energy and heat stored up in the food?

22. Describe the procurement of oxygen by the living body.

23. How is voice produced? 
24. What is the source of the bodily waste and how is it excreted?

25. What coördinates the various parts of a muscle, or the different muscles or organs, so that they work together?

26. Describe briefly the central nervous system; the peripheral system.

27. What in general would be the path of a nerve impulse passing from the intestine to the brain?

28. Describe the passage of light from its entrance into the eye of a vertebrate to its perception by the brain.

29. What are sclerotic plates? Where developed and in what animals?

30. Besides sight, what other senses does a cat possess? Where is each located?

3I. What is meant by the Amniota?

32. How are cats nourished before birth? How after birth?

33. Why are cats called mammals?

\section{Class A, Cyclostomata}

Degenerate eel-like fishes, without functional jaws but with a round, sucker-like mouth (whence the name from Greek cuclos, a circle, + stoma, mouth). Paired fins absent.

It is doubtful if the Cyclostomata are known from the Paleozoic, though Palæospondylus of the Devonian of Scotland, about two inches long with an eel-shaped body, may be a cyclostome. Existing forms are the lamprey-eels and hag-fishes.

I. Which of the two sub-divisions of the Vertebrata have known fossil representatives?

2. Name the seven classes into which the Craniata are divided.

3. Give distinguishing characters of Class Cyclostomata, also a living and a possible fossil example.

\section{Class B, Ostracodermi}

Entirely fossil. No trace of backbone or of ordinary jaws present; mainly because of this absence they are by some removed from the Vertebrata and placed in the phylum Arthropoda. They are characterized by the wonderful development 
of an external (dermal) armor (whence the name from Greek ostrakon, shell, + derma, skin). There is always a large shield composed of several pieces, completely inclosing the head and usually also the thorax. The tail was flexible and usually protected by scales. A pair of dorsally or laterally placed eyes was present; between the orbits is a deep pit, at times only visible upon the inner surface of the shield, occupying the exact position of the pineal body of the vertebrate brain. These animals had probably the mud-grubbing habit like the contemporaneous eurypterids and the living horseshoe crab.

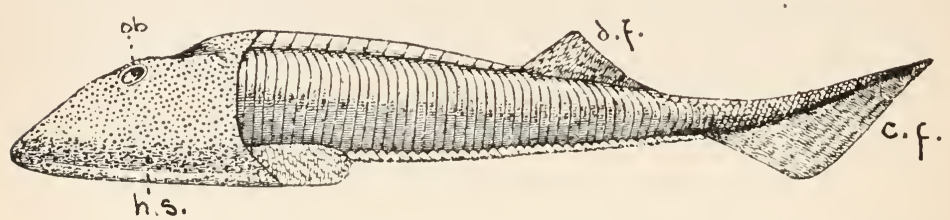

FIG. I43. - Restoration of the ostracoderm, Cephalaspis murchisoni, from the Upper Silurian of England. c.f., caudal fin (this is heterocercal); d.f., dorsal fin; h.s., head shield; $a b .$, orbit of eye. (From British Museum Catalog.)

The Ostracodermi are well known from the Ordovician through the Devonian of North America and Europe. They are divided into the two groups, Euostracophori and Placodermata. Under the former are included the most primitive forms (e.g. Cephalaspis of the Upper Silurian and Devonian), with a head shield only (Fig. I43). In the Placodermata are placed the more complicated forms (such as Pterichthys of the Devonian), with a shield, composed of several overlapping plates, surrounding head and trunk, and Dinichthys, a huge armored genus from the Devonian of North America and Europe, whose head shield at times measures over three feet across.

I. Define Class Ostracodermi.

2. To what phylum other than the Chordata may these fossils belong?

3. What is their age geologically?

4. What were their probable habits? 


\section{Class C, Pisces (Fishes)}

Cold-blooded, aquatic vertebrates, both marine and fresh water. The organs of locomotion are the paired fins and the flexible tail. Gills are the chief, usually the only, organs of respiration, and are attached to the gill arches throughout life. The notochord is more or less completely replaced by cartilaginous or bony vertebræ. The skull is well developed; in its embryonic growth each of the two bars of the first (mandibular) visceral arch divides into a dorsal and a ventral portion. The former, the palatoquadrate cartilage, is situated forward and, uniting in the median line with the corresponding portion of the opposite bar, forms the upper jaw. The latter, Meckels cartilage, similarly extends forward and, uniting with its fellow, forms the lower jaw. The second (hyoid) visceral arch likewise divides into a dorsal and a ventral portion. The latter amongst other uses serves to support the tongue. The former (hyomandibular) unites the jaws with the skull in most Elasmobranchii and Teleostomi ; hence most of these are called hyostylic fishes; in other fishes, e.g. the Holocephali and Dipneusti, the hyomandibular is atrophied and the jaws are fused with the skull by means of the quadrate bone, hence these are called autostylic fishes. Most fishes lay eggs, but in some forms (e.g. Mustelus of the Elasmobranchii and the blenny of the Teleostomi) the young are developed within the mother and brought forth alive; they usually develop lying frce within the uterus, but exceptionally are attached to its walls. The eggs, when produced, vary much in size; where they are minute, i.e. with little yolk, they are exceedingly numerous, and where large, few.

Development of fins. - Fishes, known from the Silurian to the present, are conceived to have originally possessed (I) a median fold of skin extending along the back from the base of the head around the tail almost to the anus, giving rise by division to the dorsal, caudal and anal fins, and (2) a horizontal fold 
extending from the gills to the tail, giving rise to the paired fins, - the pectorals and the ventrals or pelvic fins (Fig. I44). These fin folds, probably developed as balancing organs, were supported by rods of cartilage extending outward from the vertebral arches. Gradually the fins became shortened, the cartilaginous rods

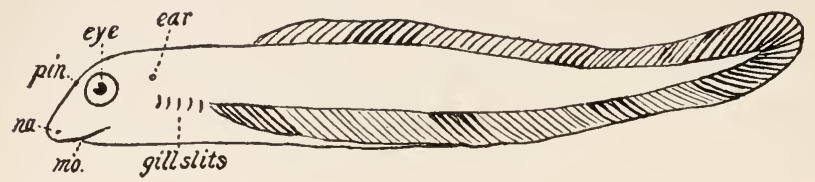

A

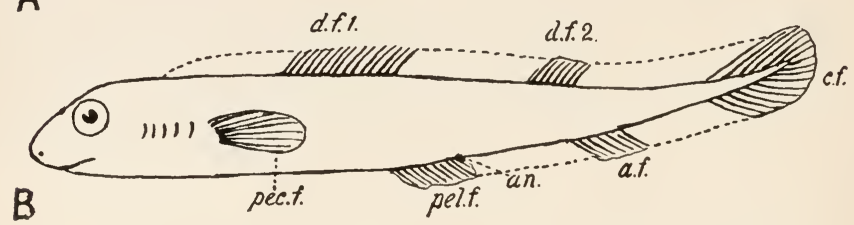

FIG. I44. - Ideal diagram representing the probable development of the fins. $A$, fish with a continuous fin-fold. $B$, fin-fold broken up into distinct fins. $a . f$., anal fin; $a n$., anus, in position midway between the two pelvic fins; $c . f$., caudal fin; d.f. $I$., anterior, and $d . f .2$, posterior dorsal fins; ear, location of the auditory organ, - the semicircular canals (functioning both in hearing and in the maintenance of equilibrium); mo., mouth; na., nasal opening; pec.f., pectoral fin ; pel.f., pelvic or ventral fin; pin., pineal eye; a.f., d.f. $I$, d.f. 2 , and $c . f$. are unpaired fins, while pec.f. and pel.f. are paired fins.

supporting them became crowded together though still parallel (as in the Pleuropterygii of the early Paleozoic); next followed either a fusion of the basal supports of each fin into one (as in the Ichthyotomi of the late Paleozoic, in the Paleozoic and Mesozoic Crossopterygii and in the living Dipneusti) or the cartilages became rudimentary (as in the Acanthodii of the Paleozoic and the Actinopterygii of Paleozoic time to the present).

Caudal fin. - When the tail fin is divided into two somewhat equal lobes and the vertebral column extends nearly to its end, it is most primitive and is called diphycercal (Fig. I47). When the vertebral column extends into the upper lobe, making it much longer than the lower one, the caudal fin is called hetero- 
cercal (Fig. 143). When, with nearly equal lobes, the column stops near the base of the fin, it has received the name homocercal (Fig. 149). In most Paleozoic fishes the caudal fin is diphycercal or heterocercal. From the Cretaceous onward adult bony fish have usually homocercal tail fins, but they are always diphycercal or heterocercal in the immature stage.

Derivation of name. - Pisces > Latin piscis, a fish.

The class Pisces is divided into the following sub-classes:

PAGE

I. Elasmobranchii . . . . . . . . . . 34I

2. Holocephali . . . . . . . . . . . . . 343

3. Dipneusti . . . . . . . . . . . . . 343

4. Teleostomi . . . . . . . . . . . . . . . 344

\section{Sub-class I, Elasmobranchii (Sharks, etc.)}

Internal skeleton composed essentially of cartilage. External (dermal) skeleton nearly always present; when present it is of a placoid type, that is, each scale consists of a basal plate of bony tissue bearing a pointed spine and composed of dentine covered with enamel. Such skin is called shagreen. Dermal fin-rays horny. Cloaca present, serving as the common outlet for the anal, urinary and genital products. Extending outward from each gill-arch and supporting the gills is a long, broad plate or septum (whence the name from Greek elasmos, a plate, + Latin branchia, gill). These fishes breathe by opening and closing the mouth instead of only sucking; in this they display a vast advance over the Cyclostomata. The sharks lay few eggs, but each contains much yolk, and hence the embryo is well developed when leaving the shell. The majority of the elasmobranchs are marine, a few genera only living in fresh water.

The Elasmobranchii (Silurian to present) are sub-divided into the orders: $a$. Pleuropterygii, - lateral fins very primitive as shown in the only well-known genus, Cladoselache, from the Upper Devonian (Cleveland shale) of Ohio ; $b$. Ichthy- 
otomi, likewise extinct, best known in the world-wide genus Pleuracanthus; $c$. Acanthodii, a large Paleozoic group, exemplified by Acanthodes, Lower Devonian to Permian; $d$. Selachii, upper Paleozoic to present. Examples of the selachians are: (I) Cestracion, found from the Jurassic to the present, most

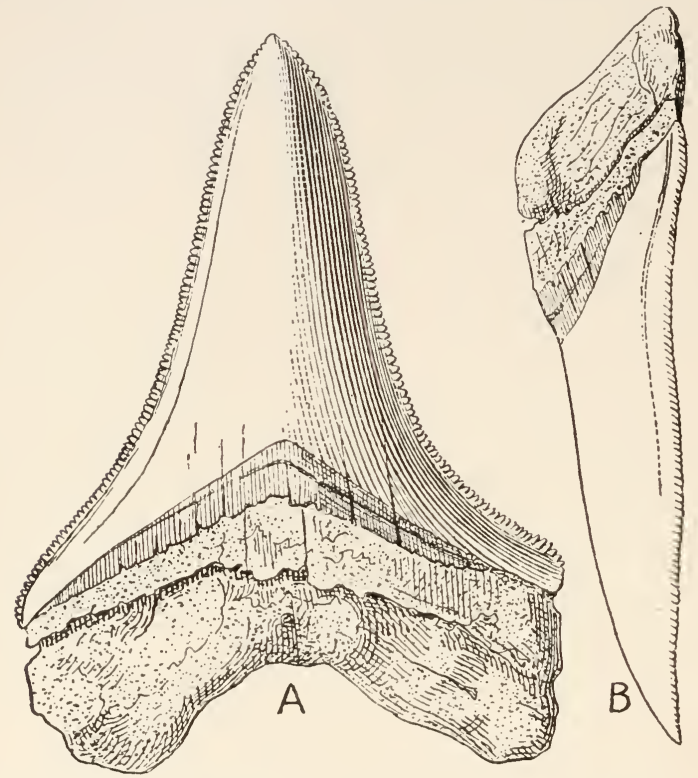

FIG. I45. - The extinct marine shark, Carcharodon megalodon Charlesworth, from the Miocene (Calvert) of Maryland. Natural size. It is much more abundant in the Eocene of South Carolina. $A$, anterior tooth, inner face. $B$, same in profile. (From Eastman.)

characteristic of the Mesozoic. This genus shows close relationship to some Pennsylvanian and Permian forms, and survives to-day in the two or three species of Port Jackson shark of Australia, Japan and California. (2) Lamna and (3) Carcharodon (Fig. I45) (both from Cretaceous to present) have teeth with a sharp, wedge-shaped crown fixed upon a somewhat bifurcate base which is much compressed antero-poste- 
riorly. The teeth of the former (Lamna) have small lateral denticles at the base of the crown. Here likewise are placed the other existing sharks, dog-fish and skates.

\section{Sub-class 2, Holocephali (Chimeras, etc.)}

The Holocephali (Devonian to present) differ from the preceding sub-class in the large compressed head, small mouth, single external gill opening (the true gill-slits are covered by a fold of skin), and in the separation of anal and urino-genital openings. Palatoquadrate bone immovably fused with the cranium (whence the name from Greek holos, whole, + cephale, head).

The only Paleozoic forms classed with the Holocephali are the ptyctodonts; these, however, may belong with Dinichthys in the class Ostracodermi. They are known by their two pairs of plate-like teeth, one pair in the upper jaw and one in the lower. The remainder of the Holocephali, dating back to the Triassic, have two pairs of dental plates in the upper jaw opposing the single pair below. An example of these latter is Chimæra, widespread in the present seas, called sea-cat in the United States.

\section{Sub-class 3, Dipneusti (Lung-fish)}

Respiration is by both gills and lungs (whence the name from Greek di, two, + pneo, to breathe; whence, too, the common name of lung-fish; also called mud-fish). In pure water they breathe by means of their gills, like an ordinary fish; but in stagnant or muddy water they come to the surface and draw air into their lungs. The gills are like those of other fishes; the lung is morphologically the air-bladder of the Teleostomi, but differs in being covered by a network of veins supplied by a special artery, hence acting like a true lung. Notochord persistent without a trace of separate vertebræ except in tail. Cloaca present. Paired fins lobate, - an archipterygium (see page 345 and Fig. I46). Bones mostly cartilaginous. 
The Dipneusti are known from the Devonian to the present. Dipterus and Scaumenacia are well-known Devonian genera

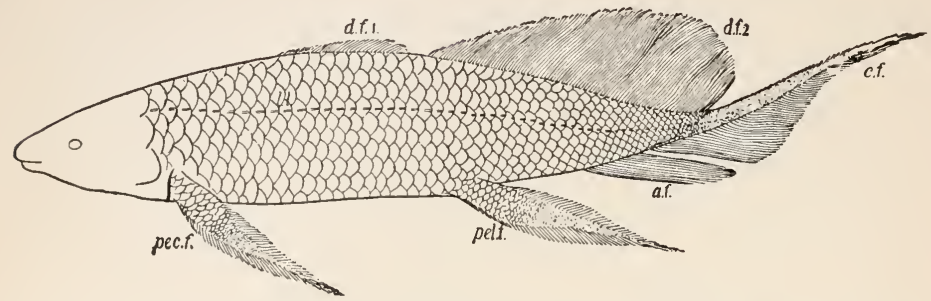

Fig. 146. - A restoration of a dipneustan fish, Scaumenacia curta Whiteaves, from the Upper Devonian of Scaumenac Bay, Quebec. a.f., anal fin; c.f., caudal fin (this is heterocercal) ; d.f. $I$ and $d . f .2$, anterior and posterior dorsal fins; l.l., lateral line (a groove lined with sensory hairs) ; pec.f., pectoral fin; pel.f., pelvic fin. In the last two, - the paired fins, - the flesh of the body extends far into the fin; these fins correspond to the fore and hind limbs of higher vertebrates. Reduced in size. (From Hussakof.)

(Fig. I46). Ceratodus, spread over the entire world during the Triassic and Jurassic, survives at present only in certain rivers of Queensland, Australia. The other living forms of Dipneusti are the Lepidosiren of central South America and Protopterus from tropical Africa.

\section{Sub-class 4, Teleostomi (Bony fishes)}

In the Teleostomi (Devonian to present) the skull and shoulder girdle have many dermal bones in addition to those of the internal skeleton; many of these dermal bones enter into the formation of the upper and lower jaws (whence the name from Greek teleos, complete, + stoma, mouth). The entire skeleton is usually more or less ossified. Fin-rays bony. Gills covered by an operculum. Anus distinct from urinary and genital openings. Tail homocercal except in such survivors of ancient types as the sturgeon and garpike, in which it is heterocercal. Swim bladder used merely for hydrostatic purposes, not respiratory. 
The Teleostomi are subdivided into the following orders, -

a. Crossopterygii

b. Chondrostei

c. Holostei

d. Teleostei

PAGE

Orders $a$ to $c$, inclusive, often classed as ganoids, include few living forms but were exceedingly numerous during Paleozoic and Mesozoic times; their scales are thick, usually rhombic plates composed of a bone-like dentine, ganoin, giving an iridescent appearance, and generally united to one another by peg and socket joint, hence strong and flexible. The last three orders, $b-d$, are sometimes classed together as actinopterygians.

Order a, Crossopterygii. - In living forms of the fringe-finned ganoids the pectoral fin is made up of a solid basal portion supported by internal bones and a fringe of rays (whence the name from Greek crossoi, a fringe, + pterygion, a small wing). Caudal fin diphycercal. In fossil forms the pectoral fin is a true archipterygium, that is, it is a leaf-shaped fin consisting of an elongate, segmented central axis bearing two opposite and more or less symmetrical rows of jointed rays; central axis and rays com. posed either of cartilage or bone.

This is an ancient order, beginning in the Devonian. It combines characters of the Elasmobranchii, Dipneusti and Teleostomi, and is represented at present by but two living species, Polypterus of the Nile valley and equatorial Africa and Calamoichthys from western Africa. Holoptychius is a Devonian form widely spread in North America and Europe. In this genus no ossification has been noted in the sheath of the notochord to form vertebræ. In Eusthenopteron such ossification has begun in the anterior portion (Fig. I47).

The three remaining orders of the Teleostomi have no basal fleshy lobe to the paired fins. 
Order b, Chondrostei. - Caudal fin heterocercal. This order includes Cheirolepis from the Devonian of North America and

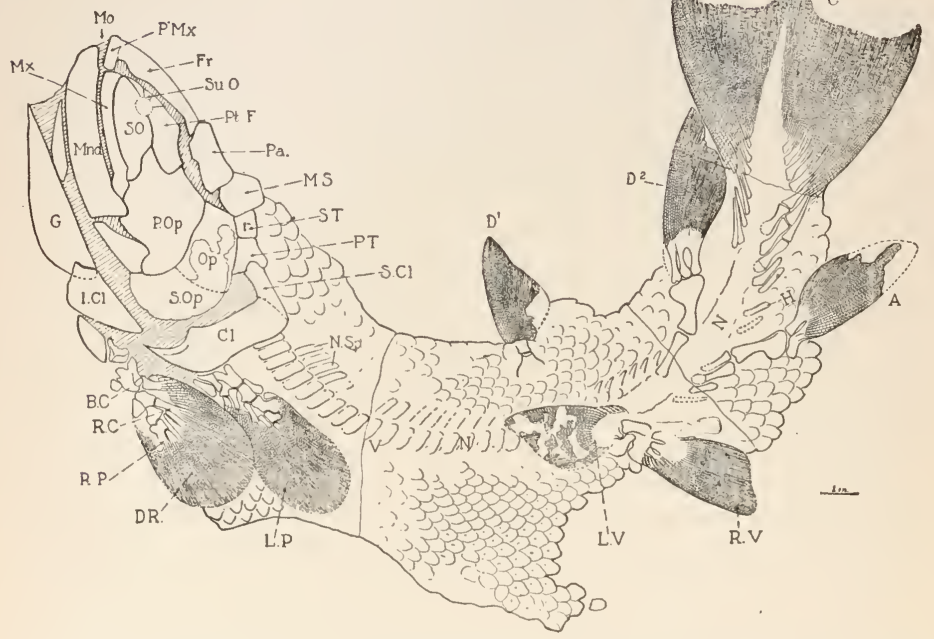

FIG. I47. - A well-preserved crossopterygian fish, Eusthenopteron foordi Whiteaves, nearly three feet long from the Upper Devonian of Scaumenac Bay, Quebec. The paired fins of both sides are shown. The vertebræ had ossified only in the anterior portion of the notochordal sheath, though neural and hæmal spines continue welldeveloped to the caudal fin. The internal cartilaginous supports of the fins are well preserved. A., anal fin; B.C., basal fin cartilages; $C$., caudal fin; this is diphycercal ; $C l$., clavicle ; $D^{1}, \mathrm{D}^{2}$, anterior and posterior dorsal fins ; D.R., dermal fin rays; $F r$., frontal; $G$., gular plate; $H$., hæmal spines; I.Cl., infraclavicle; L.P., left pectoral fin; $L . V^{\prime}$., left ventral or pelvic fin; Mo., mouth; Mnd., mandible; $M . S$., median supratemporal ; $M x$., maxilla; $N$., position of notochord; $N . S p$., neural spines; $O p$., operculum; $P a$., parietal ; $P . M x$., premaxilla ; $P . O P$., preoperculum; $P T$., post-temporal ; $P t . F$., post-frontal; R.C., radial fin cartilages; R.P., right pectoral fin; R.V., right ventral or pelvic fin; S.Cl., supraclavicle; SO., suborbitals; $S . O p$., suboperculum; $S T$., lateral supertemporal ; Su.O., supraorbitals; $V$., vertebral centra. (After Hussakof.)

Europe, Catopterus from the Triassic of North America, and the living sturgeons from seas of the Northern Hemisphere; the latter enter the various rivers of North America, Europe and Asia. 
Order c, Holostei. - Tail heterocercal or nearly homocercal. (I) Semionotus (Fig. I48), fusiform, with rhombic scales, the dorsal ones forming a crest. Triassic of North America, Europe and South Africa. Those from Massachusetts, Connecticut and New Jersey were formerly called Ischypterus.

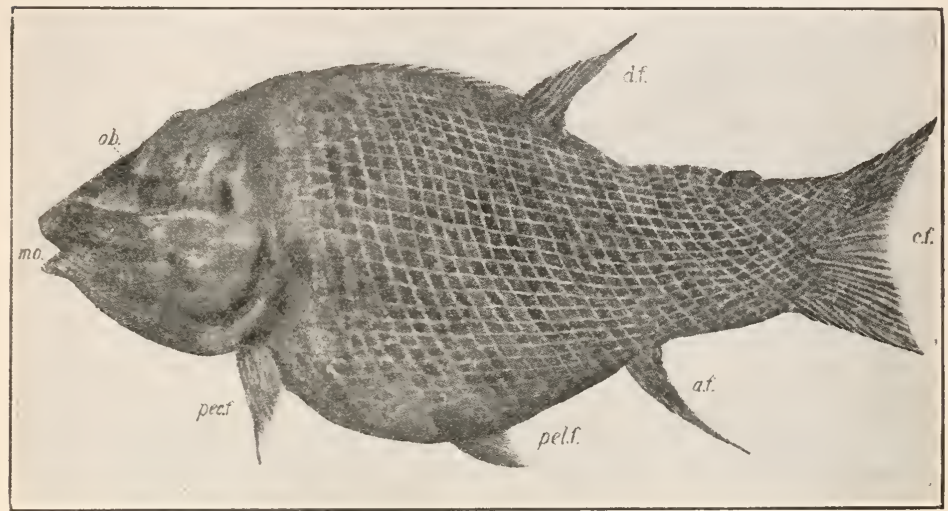

Fig. I48. - An actinopterygian fish, Semionotus (Ischypterus) lenticularis Newberry, from the fresh water Triassic shales of Boonton, New Jersey. a.f., anal fin; c.f., caudal fin; d.f., dorsal fin; mo., mouth; ob., orbit of eye ; pec.f., pectoral fin; pel.f., pelvic (or ventral) fin. (Newberry's figure.)

(2) The mud-fish (Amia), from the rivers of the United States, and (3) the garpike (Lepidosteus), from the fresh waters of the southern half of North America and Cuba, are living examples; both occur fossil from the Eocene to the present.

Order d, Teleostei. - The Teleostei (Jurassic to present) are merely improved ganoids. Scales overlapping, in oblique rows, usually thin, elastic, generally round with a smooth margin or with the posterior margin toothed. Backbone typically ossified. Tail homo- or diphycercal.

The herrings are known from the Comanchean to the present; species of Diplomystus (Cretaceous to present) are beautifully preserved in the fresh water Green River shales 
(Eocene) of Wyoming, and closely related genera are still living in the rivers of New South Wales and Chili. Of the salmons

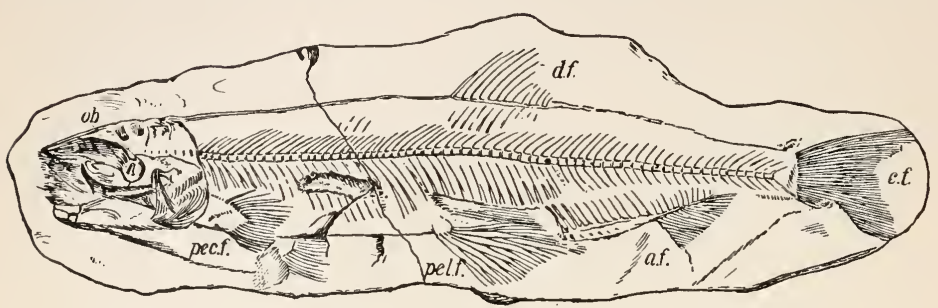

FIG. I49. - The caplin, Mallotus villosus Cuvier. $\left(\times \frac{1}{3}.\right)$ This member of the smelt family is an abundant fossil in the glacial (Pleistocene) clays of eastern Canada. a.f., anal fin; c.f., caudal fin (this is homocercal); d.f., dorsal fin; $o b$., orbit of eye; pec.f., pectoral fin; pel.f., pelvic fin. (Redrawn from Logan.)

(Upper Tertiary to present), fossil skeletons of the existing $\mathrm{Mal}$ lotus villosus are very common in concretions in the Pleistocene clays of Greenland and eastern Canada (Fig. 149). The perches, catfishes, mackerels, codfishes occur from the Eocene to the present, eels since the Cretaceous and pikes since the Miocene.

I. Give distinguishing characters of Class Pisces.

2. How do the majority of fish breathe? the lung-fish?

3. State briefly the probable origin of the fins; the three kinds of caudal fin.

4. What distinguishes the sub-class Elasmobranchii?

5. Give its geologic range.

6. Name some living examples of this sub-class. Name some fossil examples.

7. Sketch a tooth of Lamna or Carcharodon, both broad and narrow views.

8. Give geologic range of the sub-class Holocephali; a living example.

9. Define the sub-class Dipneusti, noting the significance of the name.

Iо. Give its geologic range; fossil and living representatives.

I I. Give geologic range of the sub-class Teleostomi.

I2. Into what four orders is this sub-class divided? Give fossil and living example of each. 
I3. Define archipterygium. What is the probable relation of this to the limbs of the higher vertebrates?

I4. Sketch Semionotus in outline, with a small portion of body in detail to show the rhombic scales. Label scale and the various fins. To what order does it belong?

I 5. Sketch Diplomystus or Mallotus, noting fin-rays, vertebræ. To what order does it belong?

\section{Class D, Amphibia}

These differ from fish mainly as follows: they have paired fivetoed limbs in place of paired fins; each limb consists, as in all the higher vertebrates, of one bone in its upper portion, two in the lower portion, also several wrist or ankle bones and jointed fingers or toes; when a median fin is present, as in the tadpole, it lacks fin-rays. Amphibians breathe by gills in the larval condition, but usually by lungs in the adult. A cloaca is present. Skin usually without scales; it is kept soft by the many mucus-secreting glands, hence the animals breathe also through the skin. The skeleton is ossified. The skull is flat and articulates with the spinal column by two condyles. The ribs are short, not encircling the thorax. Nearly all pass through a gill-breathing, tadpole stage before breathing by lungs. See page 353 .

The structure of amphibians is such that they could not adapt themselves to dry air but could live in swamps and damp places where fish could not live. In the order Stegocephalia they tried to adapt themselves to a life upon dry ground but were not very successful.

Derivation of name. - Amphibia > Greek amphi, both, + bios, life. They are water-dwellers during one portion of their lives, and land-dwellers during another portion.

The Amphibia are divided into the following orders :-

I. Stegocephalia

2. Urodela (Caudata) .

3. Anura (Ecaudata) .

4. Gymnophiona 


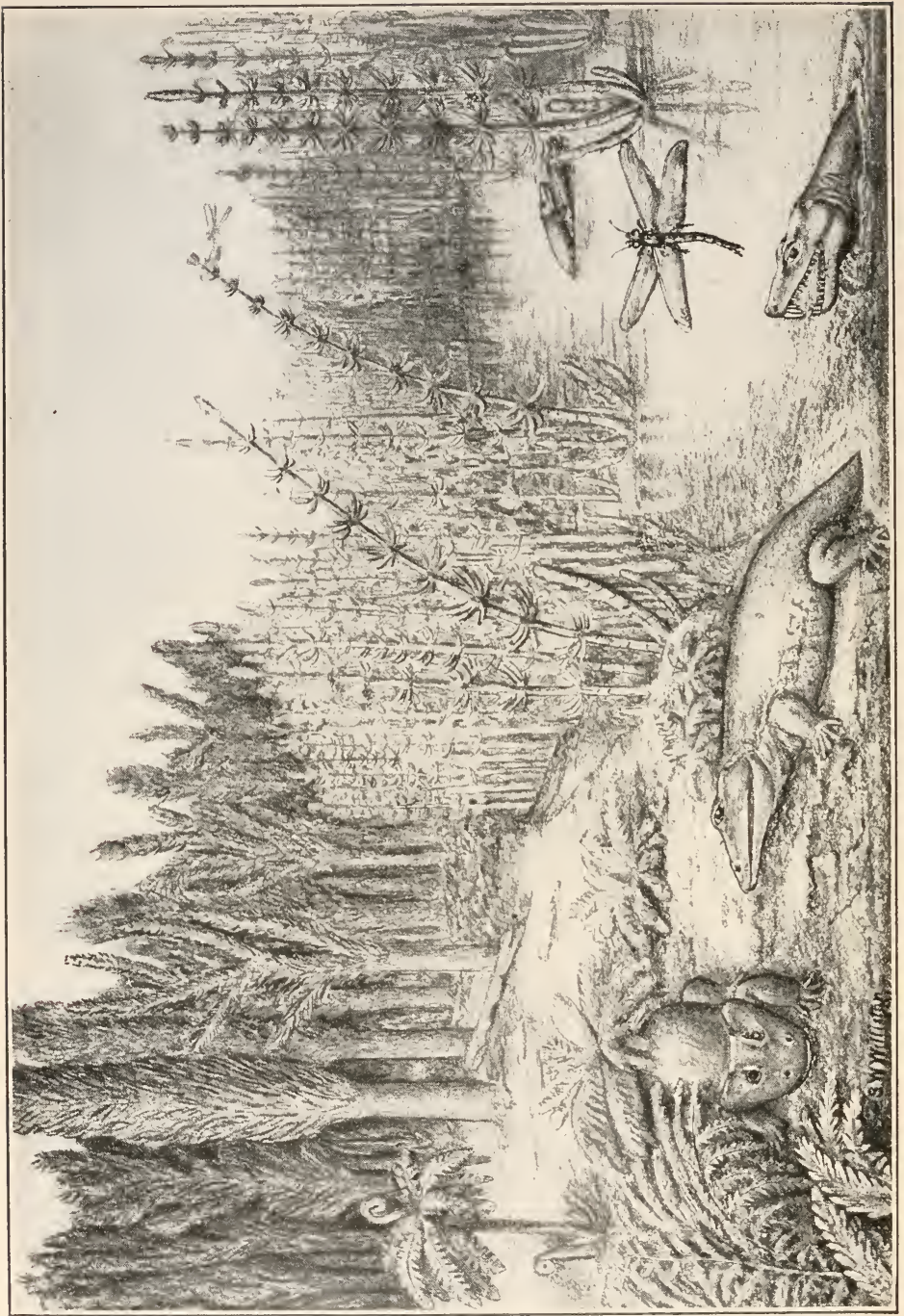


FIG. I 50. - Restoration of a landscape by the side of a sluggish creek in Texas and New Mexico during the Upper Pennsylvanian and Lower Permian times. Of the abundant fauna of this period, nearly fifty distinct genera of amphibians and reptiles have been so far recovered. This fauna is of especial interest since it is the oldest known reptilian fauna and the most comprehensive of the older amphibian. Only one example of each is here restored. Upon the land are two figures of Eryops, - a stegocephalian amphibian, about seven feet long, with a skull nearly two feet long, while other adult amphibia living with it have a skull no larger than a man's thumb nail. The lowlands must have swarmed with these animals and the contemporaneous reptiles. In the water is a theromorph reptile, Limnoscelis, about seven feet long, with a beak-like skull armed with strong conical teeth. Flying above this is one of the giant "dragon fies," Meganeura, some representatives of which had a two-foot spread of wings. The fern-like trees and bushy plants of the foreground are cycadofilicaleans. To the right are wide stretches of the huge scouring rush, Calamites; on slightly higher ground to the left are Lepidodendrons (branched) and Sigillarias (unbranched), these latter still being quite as prominent forest constituents as earlier in the coal period.

One must view this single river bank, creek, or shore of an inlet as a single one of many such landscapes, ever varying in detail. Cordaites, which in later Devonian time made the first great forest constituent of which there is record, is still present, though not shown. So, too, there are hidden in the recesses of the forest the forerunners of the modern coniferous types as well as other forms destined to give rise to the angiosperms. (From Williston, the landscape adapted from Neumayr.) 


\section{Order I, Stegocephalia}

Extinct, tailed Amphibia, often very large. There are, as a rule, two pairs of limbs present and usually a ventral external armor of plates over the thorax, and behind these overlapping scales; more rarely scales are present upon the back.

These are included with the Amphibia because (I) gill-arches are present in immature skeletons; (2) they breathed by lungs alone in adult, or by lungs and gills ; (3) the ribs do not encircle the thorax; $(4)$ the mucus-canal system was well developed as indicated by deep impressions, especially observed in the bones of the head. They show probable derivation from the crossopterygian fishes in that (I) the conical teeth are often complexly infolded (e.g. the labyrinthodonts) as in some Paleozoic fish (e.g. Holoptychius); (2) a ring of bony plates is present around the eye-sockets; (3) a pineal foramen is present; (4) the bones of the skull roof are similar in arrangement.

They lived in fresh water, though some may have been more or less completely terrestrial. In the Joggins coal mines (Pennsylvanian) of Nova Scotia such genera as Dendrerpeton and Hylonomus are common in decayed trunks of Sigillaria and Lepidodendron associated with the fresh-water gastropod Dendropupa vetusta. They were abundant in the TexasNew Mexico region during the Upper Pennsylvanian and Lower Permian times (Fig. I 50).

Stegocephalia have been recognized from the Mississippian to the Triassic. Branchiosaurus is a well-known genus from the Permian and the labyrinthodont genus Mastodonsaurus from the Triassic. The latter is the largest amphibian known, with a skull over four feet long and almost as wide.

\section{Order 2, Urodela (Salamanders)}

Tail present throughout life (whence the name from Greek oura, a tail, + delos, apparent). Two pairs of approximately 
equal limbs are usually present. In some (as Necturus and the eel-like Siren of North America) gills are present throughout life; in others (as the salamanders and the American Amblystoma) the adult breathes by means of lungs.

Fossil remains are rare. They have been found from the Jurassic to the present. A giant salamander from the Miocene of Oeningen, Baden, was mistaken by the early scientist Scheuchzer for the remains of a man and named by him. Homo diluvii testis (man as witness of the flood); this famous fossil, now named Andrias scheuchzeri, is preserved in the Teyler Museum in Haarlem.

\section{Order 3, Anura (Frogs, Toads)}

Tail absent in the adult (whence the name from Greek $a$, implying negation, + oura, a tail). Hind limbs much larger than fore. Gills never present in adult.

The eggs of frogs (in shapeless masses) and toads (in ropes) look like little black beads (the yolk) surrounded by transparent jelly (the white). Each bead attracts the sun's rays, which causes the germ or fertilized cell within to develop, through feeding upon the yolk and white, in to the embryo young. In about two weeks the embryo leaves what is left of the jelly. It then has external gills; but later internal gills develop from slit-like openings in the gullet walls, and the external gills, always a source of danger, are gradually resorbed. This tadpole is now in the fish stage, in which respiration takes place by the water passing in through the mouth and out through the openings in the gullet walls over the gills. Next the fore and hind limbs bud out and become jointed, lungs are formed, gills and tail entirely disappear and the developing animal becomes adult in appearance.

Fossils are rare, and are known only from the Comanchean to the present. These include remains of both frogs and toads. 


\section{Order 4, Gymnophiona}

Snake-like, without limbs or tail. Examples are the tropical, subterranean cocilians. Fossil remains are unknown. fish?

I. In what ways are the Amphibia an advance upon the

2. Name one way in which the embryo shows its fish ancestry.

3. What is the habitat of the Amphibia?

4. Give the significance of the name.

5. What is the geologic range?

6. Name the four orders into which Amphibia are divided, with a living example of each existing order.

7. Outline the development of a toad.

8. Give an example of the Stegocephalia. Why are these included with the Amphibia?

\section{Class E, Reptilia}

Cold-blooded vertebrates, usually with two pairs of five-toed limbs and a horny exoskeleton of scales (e.g. snake, lizard), or of horny (e.g. tortoise) or bony (e.g. Stegosaurus) plates. Thorax usually near head, hence the short neck. Living reptiles periodically cast off this horny exoskeleton either as a whole or in fragments. They breathe by lungs throughout life. The heart is incompletely four-chambered, the two ventricles being separated by a partial partition. There is no metamorphosis, the young leaving the egg in the adult form; hence the eggs are large. Reptiles are mostly oviparous. Unlike the Amphibia, the structure of reptiles is such that they could adapt themselves to dry air, and could hence spread more widely upon land.

Reptiles were very abundant and dominant during the entire Mesozoic time; they ruled not only the earth and sea but the air as well.

Derivation of name. - Reptilia > Latin reptilis, creeping; from the mode of progression of snakes, the best known of reptiles. 
Reptilia are subdivided into the following orders :-

I. Rhynchocephalia

2. Anomodontia

3. Sauropterygia

4. Ichthyopterygia .

5. Dinosauria

6. Pterosauria

7. Crocodilia .

8. Chelonia

9. Squamata .

\section{Order I, Rhynchocephalia}

Lizard-like, scaly reptiles with biconcave vertebræ and frequently with a beak at the end of the skull (whence the name from Greek rhynchos, a beak, + cephale, head).

The Rhynchocephalia are known from the Permian to the present, with maximum development in the Triassic. The sole survivor is the small Hatteria (or Sphenodon) now living on two or three small islands off the coast of New Zealand. This is similar to the fossil Paleohatteria from the Permian of Europe, which in its turn has many points of similarity with the amphibian order, Stegocephalia. The survival of the very primitive Hatteria is probably primarily due to its removal in the Australian region from competition with the higher mammals, and secondarily to its burrow life, which withdraws it still further from competition. The Rhynchocephalia unite pretty closely the orders Squamata, Crocodilia and Dinosauria; in other words, they are generalized types.

\section{Order 2, Anomodontia (Theromorpha)}

Extinct land reptiles with limbs adapted to the habitual support of the body. Pineal foramen always present. Teeth usually lodged in sockets and varying from an arrangement in 
a uniform series to one differentiated into incisors, canines and molars (whence the name from Greek anomos, without.law + odous (odont), tooth). They are intermediate in character of skeleton between the highest of the amphibian labyrinthodonts and the lowest mammals, the Monotremata. It is probable that a primitive anomodont reptile gave rise to the mammals. Because of the many resemblances in their skeleton to that of the latter group they were later called Theromorpha (from Greek ther, a wild beast, with a derived meaning of mammal, + morphe, form).

The anomodonts, which are Permian and Triassic in age, vary from the large massive Pariasaurus about ten feet long, with its triangular head, stout limbs and short tail, to the small, probably agile, Galesaurus. The majority, so far found, are from the Upper Pennsylvanian and Lower Permian of the TexasNew Mexico area (Fig. I 50) and from the lower part (Permian) of the Karroo formation in South Africa.

\section{Order 3, Sauropterygia (Plesiosaurs)}

Extinct, aquatic reptiles (commonly called plesiosaurs), with long neck, small head and two pairs of limbs; they are thus lizard-like (whence the name from Greek sauros, a lizard, + pterygia, fins). Teeth conical. A pineal foramen is present. They swam at the surface of the water but could doubtless make swift dives. Some attained a length of forty feet.

Sauropterygians are known from the entire Mesozoic, Triassic to Cretaceous. In Triassic forms (as Lariosauru.3) the limbs are long and rather slender with the normal number of phalanges to the digits, but in later genera (as Plesiosc urus of the Jurassic) the limbs are true paddles with the bones short and the number of phalanges very much increased (Fig. I 5I). Their ancestors were thus in all probability land animals. Some specimens of Plesiosaurus exhibit what were apparently embryos within the abdomen and hence must have produced their young alive. 
Stomach-stones (gastroliths) nearly always accompany complete skeletons of the plesiosaurs, at least those from the

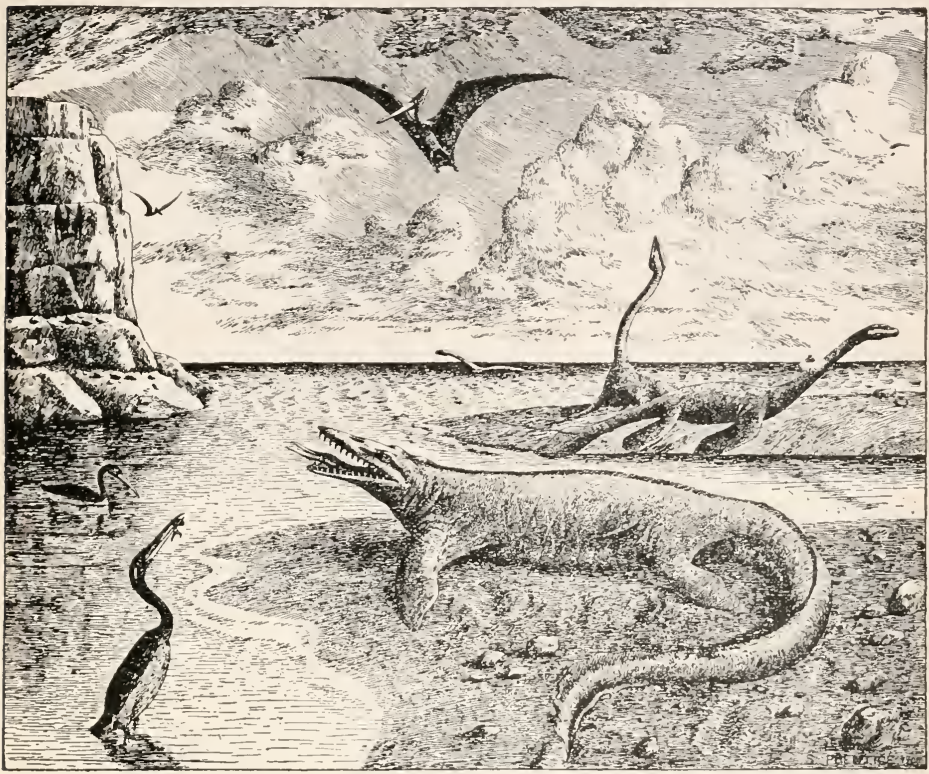

Fig. I51. - An imaginary view along the margins of the sea which covered a large portion of central and western North America during the Cretaceous time. In the background, flying, are the leathery winged pterodactyls; one is clinging to a cliff by the claws upon its wings; swimming or upon land are three plesiosaurs, with snake-like neck and head. In the foreground to the left are two examples of the three-foot high diving bird, - Hesperornis; to the right a mosasaur reptile, one of the Squamata. (From Williston.)

Cretaceous of western North America. Within one large specimen from this region were one half bushel of polished stones, ranging in size up to four inches in diameter. I : is known by the bones and shells found in the region of that portion of the body where the stomach must have been located that these plesiosaurs lived upon such invertebrates as Scaphites, and such vertebrates as fish and pterodactyls; they hence probably 
possessed a gizzard. Evidence is also accumulating to indicate that the stomachs of some dinosaurs, both carnivorous and herbivorous, had a gizzard-like compartment.

\section{Order 4, Ichthyopterygia (Ichthyosaurs)}

Extinct aquatic reptiles, with large head, no neck, and a long tail expanded in a vertical plane; they are thus fish-like (whence the name from Greek ichthys, a fish, + pterygia, fins). The two pairs of limbs are true paddles. They doubtless swam largely beneath the surface of the water, but were compelled to come to the surface for breathing. Within one individual were found the internal skeletons of two hundred belemnites; such records as well as the fish scales and bones in the many coprolites left by them indicate that they lived largely upon fish and cephalopods.

These ichthyosaurs, Triassic to Cretaceous in age, parallel the whales amongst the mammals but were smaller, with a

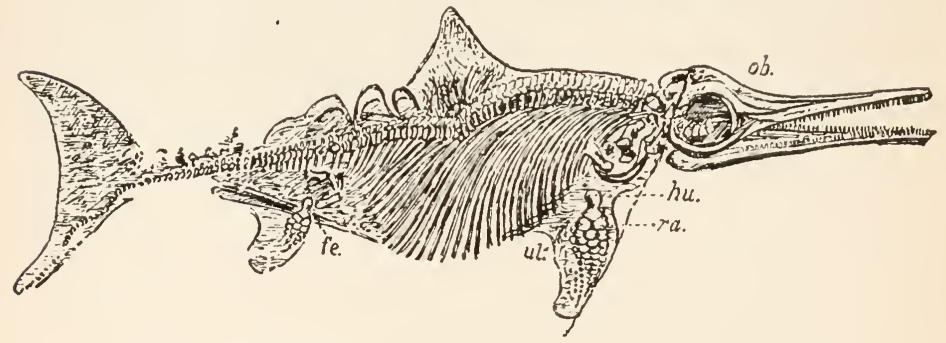

FIG. I52. - The ichthyopterygian reptile, Ichthyosaurus quadriscissus, from the Jurassic of Germany. This remarkably preserved form shows not only the outline of the dorsal and caudal fins, but also the integument surrounding the limbs. $f e$., femur; $h u$., humerus; $o b$. , orbit of eye; ra., radius; $u l$. , ulna. (After Fraas, from Woodward's "Vertebrate Paleontology.")

maximum length of twenty to thirty feet against sixty to seventy for the whales. Some at least bred their young alive, producing eight to ten at a birth. They indicate, as do the whales, a derivation from land forms; the bones of the forearm (radius 
and ulna) in the Triassic forms (e.g. Mixosaurus) are always longer and more slender and hence less paddle-shaped than in later forms (e.g. Ichthyosaurus; Jurassic to Cretaceous) (Fig. I 52).

\section{Order 5, Dinosauria}

Extinct land reptiles with elongate limbs adapted for the habitual support of the body on land, while the long massive tail suggests that they were also good swimmers. The surface of the body was in some forms covered with scales, in others with a bony armor, while in others it was probably naked. Well-preserved external molds of the skin of various dinosaurs (e.g. Trachodon) have been found in western North America (Fig. 5). Some had sharp carnivorous teeth, others bluntcrowned herbivorous ones. (Name $>$ Greek deinos, terrible, + sauros, a lizard.)

The dinosaurs are known from the Triassic to the Cretaceous inclusive; the earliest species, those from the Triassic, were

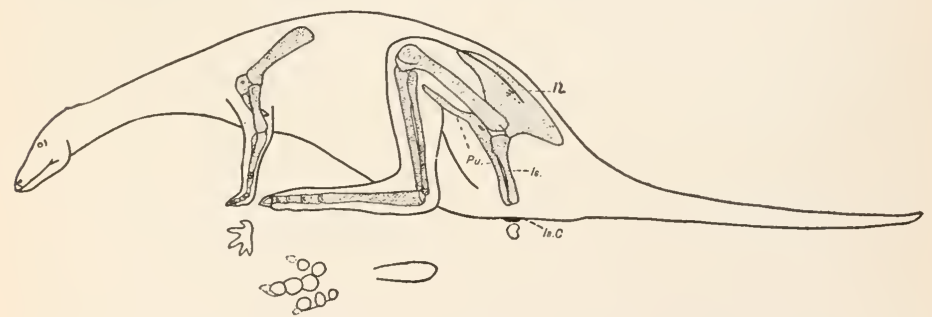

Fig. I 5.3. - A bipedal dinosaur, Fulicopus lyellianus Hitchcock, known only from its tracks preserved in the Triassic shaly sandstones of the Connecticut Valley. It is here restored as though in the act of drinking. The bones of the left fore and hind foot are shown in place, and in the foreground their tracks in the mud. Beneath the union of the pubis $(P u$.) and ischium (Is.) a callosity (Is.C.) is represented, which gave rise to the impression in the yielding mud beneath; $I l$., ilium. (After Lull.)

carnivorous, later many became herbivorous. The Dinosauria, probably derived from the Rhynchocephalia of the Permian, form an exceedingly variable order. One branch (Therop- 


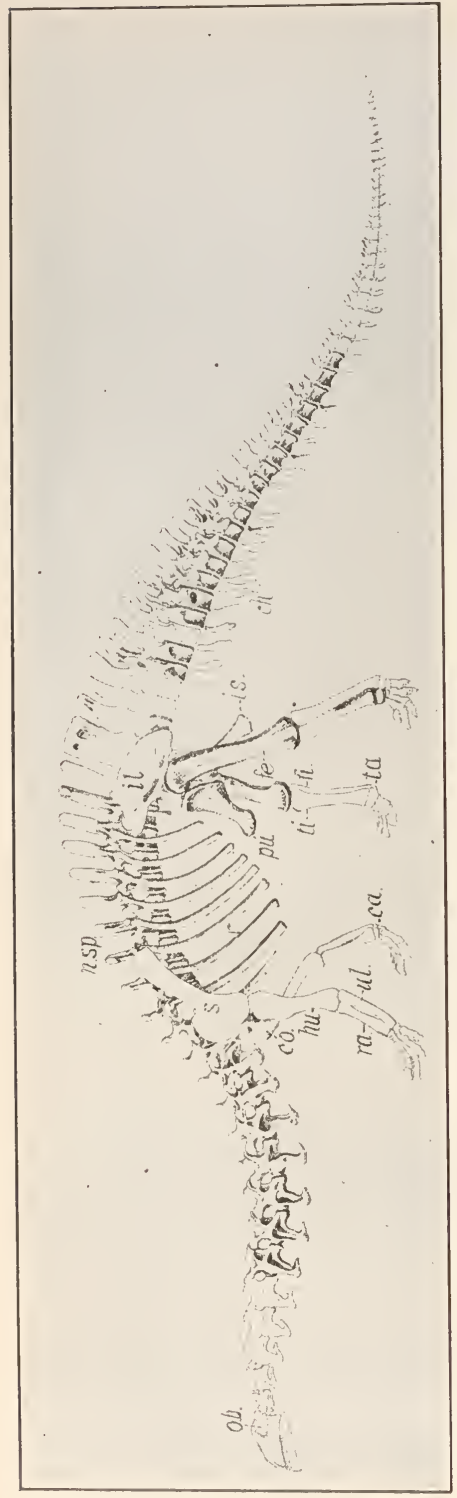

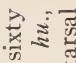

茫

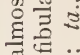

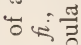

范䜦

过 हี

$\rightarrow$

ฮี่

$\ddot{z}$

:

.

है: $: \frac{\text { की }}{4}$

छें

\&o

$\Xi$ 웅

预

를

$=0$

ㄴำ oda) includes forms which were lightly built, walking bird-like upon their toes, with short fore legs and long hind ones, hollow limb bones, and sharp carnivorous teeth. The union of the ischia extended backwards and downwards, forming a kind of third foot when the animal rested upon his hind legs (Fig. I53). One of these, Anchisaurus, has been found only in the Triassic sandstones of the Connecticut Valley and is doubtless responsible for many of the three-toed tracks so numerous upon these old muddy sands. Another branch (Sauropoda) includes massively built herbivores, walking semiflatfooted, with fore and hind legs more nearly equal in length, and with limb bones apparently solid. Some of the Jurassic forms were, so far as 
known, the largest land animals that ever lived on this earth. Brontosaurus excelsus (Fig. I 54) from the Upper Jurassic of the Rocky Mountain region was about sixty feet long; while Atlantosaurus immanis from the same region was probably eighty feet long by twenty or twenty-five feet high, and Gigantosaurus, from East Africa, was still more immense.

The problem of food supply for such huge animals must at times have been very real. A full-grown Indian elephant weighing 8000 pounds eats 800 pounds of green fodder and I 8 pounds of grain per day. A Brontosaurus with a probable weight of twenty tons would consume at least 4000 pounds of leaves and twigs. If these animals, like the living reptiles, were coldblooded, they would eat somewhat less, but they may possibly have been warm-blooded. The difference between the daily rations of the warm-blooded lion and the cold-blooded crocodile of equal weights is very slight. A twelve-foot crocodile of 4I5

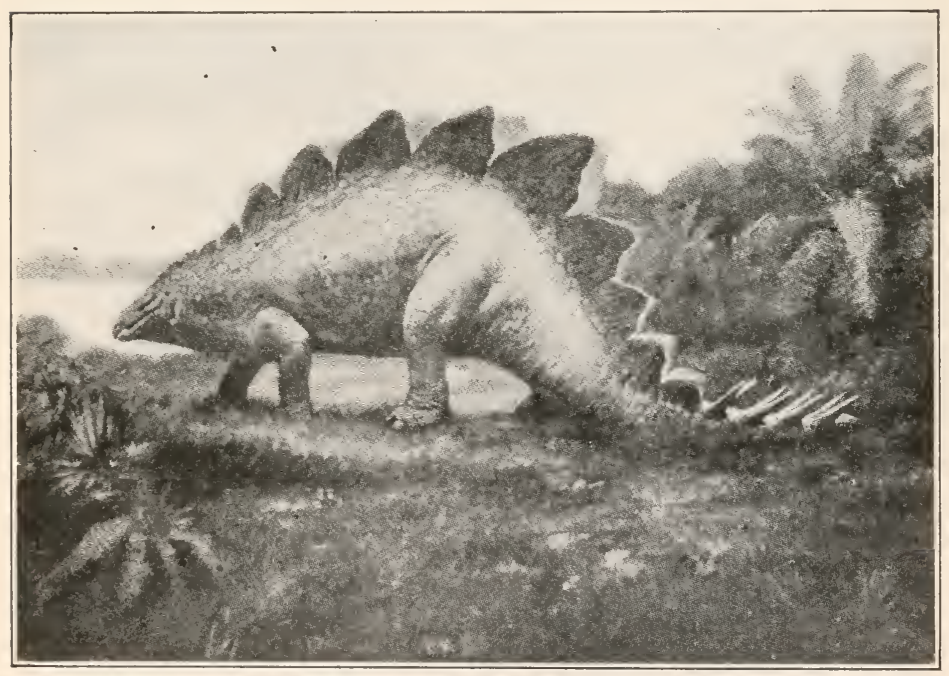

Fig. I55. - A restoration of the reptile, Stegosaurus ungulatus (Fig. I56), by C. R. Knight. (From Lucas, through the courtesy of McClure, Phillips \& Co.) 


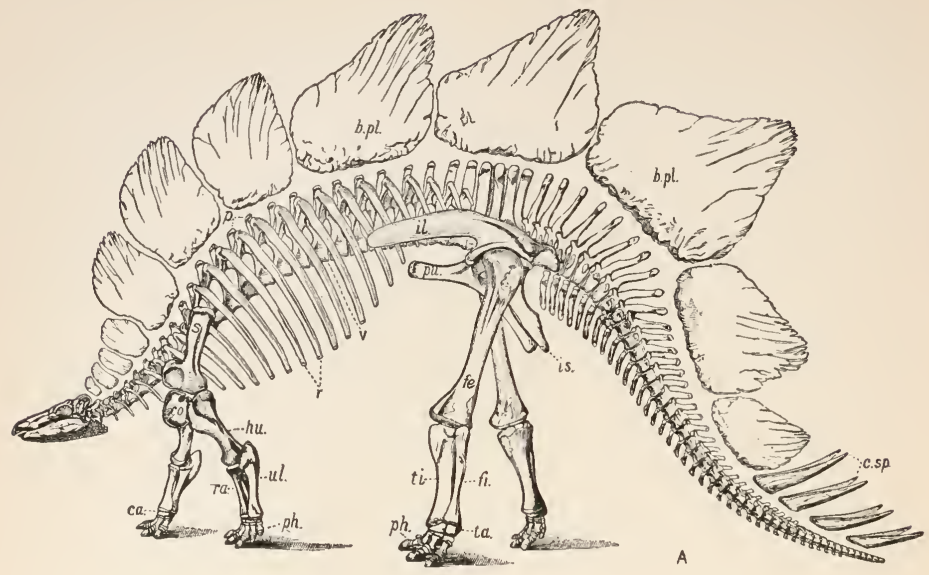

Fig. 156. - A thirty-foot-long dinosaur, Stegosaurus ungulatus Marsh, abundant during the Jurassic period upon the lands now occupied by the Rocky Mountains long before their upheaval into the present mountain system. $A$, entire skeleton. There should most probably be double the number of large bony plates represented here, arranged in alternating rows, as in Fig. I55. Note the broad attachment of the rib to the back bone for the support of the heavy bony plates. $B$, ideal section through the neck, and $C$, through the trunk of the animal. b.pl., bony plates, in life covered with horn; ca., carpal bones; co., coracoid, c.sp., caudal spines; $f e$. , femur; $f i$. , fibula; h., encasing-horn ; il., ilium; is., ischium; $p .$, transverse processes; $p h$. , phalanges; $p l$., bony plate; $p u$., pubis; $r_{\text {., }}$ rib; ra., radius; s., scapula; $t a$., tarsal bones; $t i$. , tibia; $u l$., ulna; $v$., vertebra. ( $A$, from Marsh; $B, C$, from Lull.)

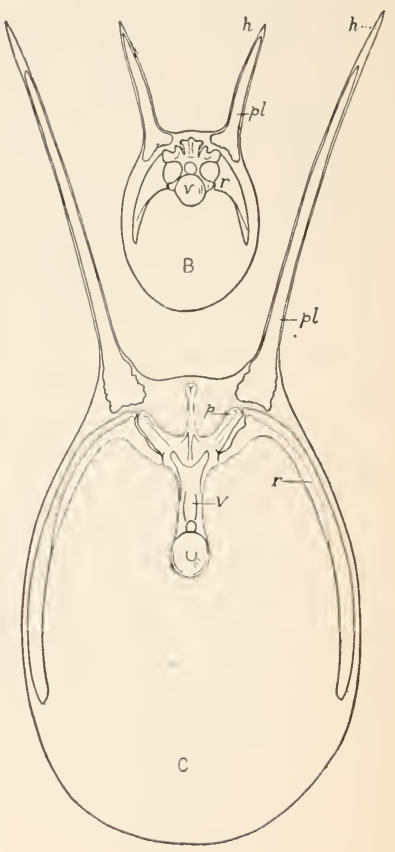


pounds weight eats 30 pounds of meat per day, while a full grown male lion weighing 500 pounds consumes in the active wild state 40 pounds of meat per day.

The third branch (Ornithopoda), also herbivorous, had bird-like or tortoise-like horny beaks. Some, as Trachodon from the Upper Cretaceous of the Rocky Mountains, walked upon two feet and were unarmored. Others, including the following, walked upon all four feet and were covered with a bony armor. Stegosaurus ungulatus (Figs. I55, I 56), from the Upper Jurassic of the Rocky Mountains, was about thirty feet long and weighed at least ten tons. It had probably the smallest brain (about ten pounds) in proportion to its size of any land vertebrate, but to control the huge tail and hind limbs there was a very large expansion of the spinal cord in the region of the hip bones, making a sort of second brain, twenty times larger than that in the head. The animal was protected by numerous small, bony plates embedded in the skin of the head and neck, and by huge, massive, triangular bony plates extending along the middle of the back from the head over two-thirds of the tail, the remaining one-third bearing two or four pairs of large spines. These plates and spines were in life covered by horny sheaths as is shown by their superficial vascular grooves. As the bones are solid the animals doubtless moved very slowly; this, added to their small head, small blunt teeth and huge size necessitated an abundance of succulent herbage near at hand; otherwise they would have died of starvation.

Immediately preceding the extinction of an order or family there is usually a development of bizarre forms, as spinous shells, and twisted cephalopods, representing apparently the remnant of developmental force in that family or order thrown out spasmodically just before. its extinction. Stegosaurus is an example of this among the dinosaurs; another excellent example is the Upper Cretaceous Triceratops prorsus, also one of the Ornithopoda (Fig. 157). This quadrupedal, herbivorous animal with solid bones had a sharp cutting beak, a 


\section{AN INTRODUCTION TO THE STUDY OF FOSSILS}

horn upon its nose and a very large pair of horns on the top of its head, while the posterior part of the skull developed into a

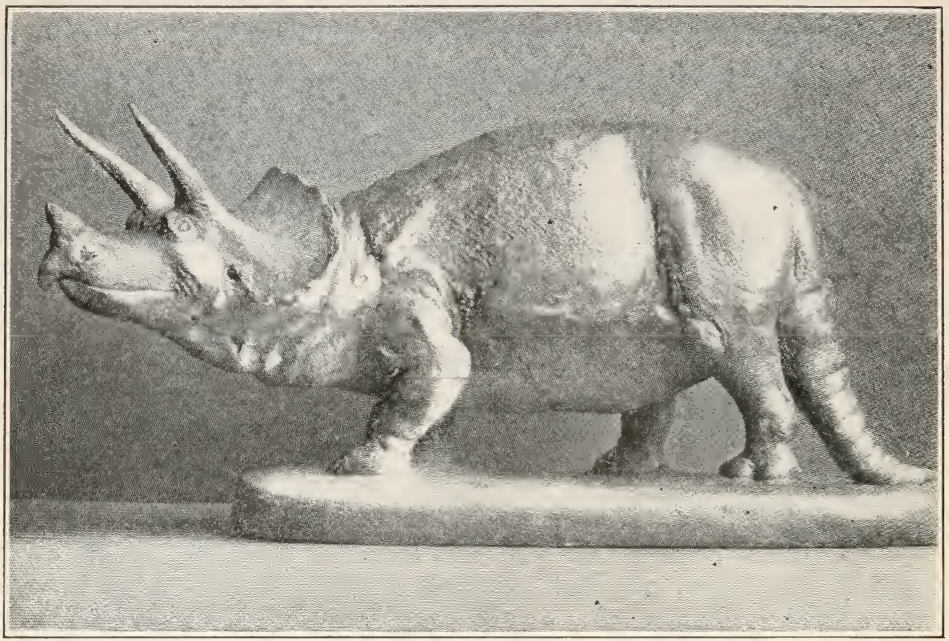

FIG. 157. - A restoration of the three-horned, neck-frilled dinosaur, Triceratops prorsus, living during the uppermost Cretaceous in the lowlands of what at present forms the Rocky Mount ain area of North America. This reptile was twenty-five feet long. Restoration by Charles R. Knight. (From Lucas, through the courtesy of McClure, Phillips \& Co.)

huge horn-covered frill margined with spines. This frill protected the top of the neck and gave to the skull its wedge-shaped appearance, the beak being pointed, bird-like.

\section{Order 6, Pterosauria (Flying reptiles)}

Extinct flying reptiles with a long neck and a general birdlike build. The anterior of the two pairs of limbs are large, bat-like, leathery wings, the smooth membrane of which was supported between the greatly elongated little finger and the sides of the body (whence the name from Greek pteron, a wing, + sauros, a lizard). The thumb is lacking; the other three fingers bear claws. Bones hollow and light. Breast- 
bone with a keel. The power of flight was probably bat-like, more feeble than that of birds (Fig. I51).

The Pterosauria begin suddenly, fully differentiated, in the Jurassic and become extinct in the Cretaceous. They vary in size from that of a sparrow to double that of an albatross. The earlier forms had sharp teeth. Rhamphorhynchus (Jurassic) had a long tail with an expanded membrane at its tip indicating very rapid turnings in its flight, which, with its long, sharp, slender teeth suggests that it was probably an insect feeder. Pterodactylus (Jurassic) had a very short tail. Some of the later forms were toothless, possibly fish-eating. Some huge ones (Pteranodon) from the Kansas Cretaceous had a skull over thirty inches long with a probable stretch of wings of twenty feet. The largest known living sea-bird, the albatross, has a stretch of wings of only twelve feet, with a weight of eighteen pounds.

\section{Order 7, Crocodilia}

Reptiles with the dorsal surface of body, or both dorsal and ventral surfaces, covered with rows of sculptured bony plates which are covered with horn. Scales also present. Known from the Triassic to the present.

The Crocodilia are a modern edition of some dinosaur characters. The genus Belodon (Triassic) may belong to a stock ancestral to the Crocodilia or may possibly be assigned to the early dinosaurs. Living examples are the crocodiles and alligators.

\section{Order 8, Chelonia (Turtles, etc.)}

Reptiles with body inclosed in bony plates, - the dorsal carapace and ventral plastron, composed largely of the expanded dorsal and ventral parts of the ribs. Between these plates the animal can for protection withdraw head, legs and tail. These plates and often other portions of the body are covered with horny expansions and scales. The jaws are with- 


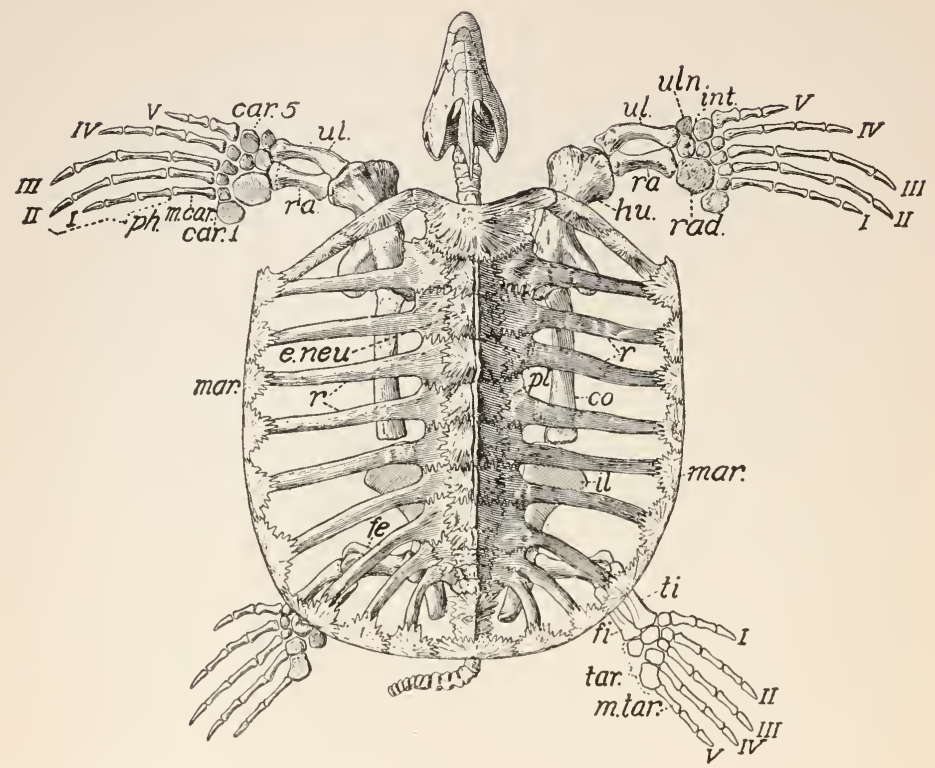

FIG. 158. - The marine turtle, Archelon ischyros Wieland, from the Pierre (Upper Cretaceous) of South Dakota. Dorsal view $\left(\times \frac{1}{40}\right)$. The animal was protected (I) dorsally by a carapace consisting of marginal plates, ribs, etc., united and covered by leather or horn; (2) ventrally by a plastron of dermal bones similarly covered. The jaws have no teeth, but were covered by horn. The distal portion of the right hind limb has been restored; this was bitten off when the animal was young, the end of the tibia and fibula, where the bite occurred, showing healed surfaces. car. I to 5, carpals I to 5, i.e. the distal row of carpal (wrist) bones; co., coracoid; e.neu., epineural plates of the carapace; these dermal plates are usually undeveloped in the Chelonia, only the neurals -- the expanded processes of the vertebræ - being developed; int., intermedium; il., ilium; mar., the dermal marginal plates of the carapace; m.car., metacarpals ; m.tar., metatarsals; $p h$., phalanges; $p l$. , the dermal pleural (costal) bones, covering only about onefifth of the length of each rib; $r$., ribs (the anterior one of the ten pairs not showing); ra., radius; rad., radiale; tar., tarsus; ti.,tibia; $u l$., ulna; uln., the ulnare bone of the carpus; $I, I I$, etc., are the digits, I (thumb or great toe), II, etc., of the hand and foot, which were distinct paddles. (From Wieland.)

out teeth but are covered with a bird-like horny sheath. (Name < Greek chelone, a tortoise.)

Here are included the living tortoises and turtles. Undoubted chelonians are known from the Triassic to the present (Fig. I58). 


\section{Order 9, Squamata}

Reptiles with an external protection of horny scales (whence the name, from Latin squamatus, scaly). The quadrate bone is movably articulated with the skull. Limbs present or absent.

This order, known from the Triassic to the present, includes the lizards (limbs usually present and adapted for walking), snakes (with the long, narrow body devoid of limbs) and pythonomorphs (with a long snakelike body and limbs modified into swimming paddles). The pythonomorphs, found all over the world during the Cretaceous, usurped the place left by the declining sauropterygians and ichthyopterygians; some of these, as Mosasaurus of North America and Europe, attained a length of fifty feet and more (Fig. I59). These aquatic forms developed probably from the semi-aquatic aigialosaurs of the Comanchean and these in turn from the terrestrial varanoids of the Upper Jurassic.

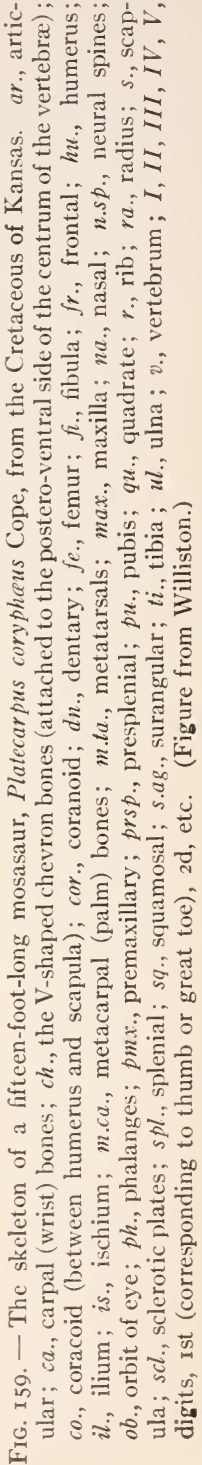


I. Briefly define Reptilia. What is the significance of the name?

2. Name some ways in which the Reptilia represent an advance upon the Amphibia.

3. What is their geologic range?

4. What were their past habitats? Their present habitats?

5. Name the living orders into which the class Reptilia is divided; the extinct orders; give under each $(a)$ their habitat, (b) a living and a fossil example where possible.

6. In what respects is the order Rhynchocephalia a generalized order? Why is a generalized form regarded as primitive?

7. How do we account for the survival of the very primitive Hatteria?

8. What is the significance of the name Anomodontia? Of Theromorpha?

9. How do you distinguish the Sauropterygia and the Ichthyopterygia? What indication of a gizzard-like compartment to the stomach of the former?

Io. What indications of evolution do you note among these?

I I. Briefly define the order Dinosauria. What do we know concerning their external ornamentation? How?

I2. Give the geologic range of the Dinosauria.

I3. Amongst fossil vertebrates what is the chief means of telling a carnivorous form from a vegetable feeder? Which is the earlier type?

I4. Describe an example of a carnivorous dinosaur; three examples of vegetable-feeding dinosaurs.

I 5. How did the probable amount of food eaten by a Brontosaurus compare with that required by an elephant?

I6. Given only the footprints of an animal, what would be your procedure in making a restoration of the animal which produced it?

I 7. How may such bizarre forms as Stegosaurus and Triceratops be accounted for?

I 8. Give the distinguishing characters of Pterosauria, and the significance of the name; their size and geologic range.

I9. How do Pterosauria resemble birds? How differ?

20. Define Crocodilia; Chelonia. Give a living example of each.

2I. Distinguish the three divisions of the Squamata. 


\section{Class F, Aves (Birds)}

Body a compact mass with five spindle-like extremities. Thorax shifted very far back, hence the long flexible neck, and hence, too, the small head. Bones hollow and light.

The external protective skeleton consists of feathers, covering most of the body, a horny beak, claws on feet and sometimes on hands, and reptilian-like scales upon the lower portions of the legs and feet. The feathers are developed from reptilianlike scales fringing at their edges. The fore limbs are modified to form wings, upon the tips of which are three reduced fingers, representing probably the first, second and third of the typical hand. There are four toes upon the hind limbs, the fifth toe of the typical foot being absent. In modern birds, one of the two rows of the ankle bones (tarsus) is fused with those of the foot, the other with the bones of the lower leg (tibia and fibula); the joint is thus between the two rows of tarsal bones and not as in mammals between the bones of the lower leg and tarsus (Fig. I6I). In all flying birds the breastbone has a well-developed keel for the attachment of the flying muscles.

Teeth are absent in all adult birds from the Tertiary to the present; Mesozoic birds had functional teeth. The esophagus is dilated to form a crop for the storage of the food which is usually eaten so rapidly. From here the food passes to the stomach, a division of which, the gizzard, has in grain-eating birds (e.g. pigeon) its wall so thickened with muscles and its inner lining so hardened and horny that, with the aid of the small stones the bird swallows, it forms an excellent grinding apparatus. In flesh-eating birds (e.g. gulls, owls) it is thin-walled with a non-horny lining. If the gull is fed upon grain, its gizzard will gradually become thick, with a horny lining; the opposite effect will occur if the diet of the pigeon is changed to meat.

The excellent respiratory apparatus produces a higher body temperature $\left(100^{\circ} \mathrm{F}\right.$.) than in any other animal; the air is pumped into the lungs and forced out by the elevation and de- 
pression of the breastbone, or back, or both. The lungs extend as prolongations all over the body and into many of the hollow bones. Birds thus agree with insects, the only other typically aërial class in having the fresh air carried throughout a large portion of the body and not only into the chest. The brain is large.
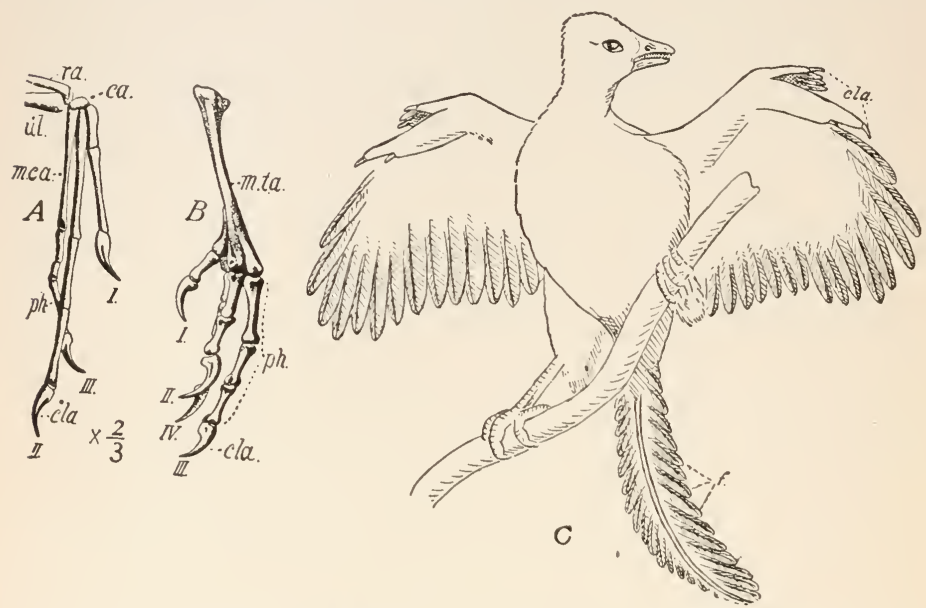

FIg. 160. - The earliest known bird, - Archeopteryx, of the size of a small crow, from the Upper Jurassic of Solenhofen, Bavaria. The jaws bear many sharp, conical teeth (there are 26 in the upper jaw). A, right hand (or wing bones). $B$, right foot. $C$, restoration. $c a$., carpus (not well known): cla., claws; $f$., distinct feathers, - each pair of these tail feathers is attached to a separate vertebra ; m.ca., metacarpal (palm) bones: m.la., tarso-metatarsals; the fusion of the metatarsals is not as complete as in modern birds; ph., phalanges; ra., radius; $u l$., ulna; $I, I I, I I I, I I^{\text {, }}$, digits, ist (corresponding to thumb and great toe), 2d, etc. ( $A$ from Osborn, after Dames; $B$ from Osborn, after Owen ; $C$ modified from Woodward's "Vertebrate Paleontology," after Pycraft.)

The heart is completely four-chambered. The sense of smell is poorly developed, but those of sight and hearing are usually remarkably acute. Birds are oviparous. As the ovum or yolk passes down the oviduct it receives first the coat of white, or albumen, next a parchment-like membrane and finally a calcareous coating, the shell, over all.

Migration may have been impressed upon the northern birds 
since the close of Tertiary times by the semi-arctic winters to the northward. Forced southward during winters into areas already crowded, they returned into the northern regions of less severe competition for the rearing of young.

Derivation of name. - Latin plural of avis, a bird.

Birds are exceedingly rare as fossils; their remains falling upon the surface of the land or water are quickly destroyed. The earliest known bird, Archeopteryx, is known only from two entire specimens and a single feather from the lithographic stone quarries (Upper Jurassic) of Solenhofen, Bavaria (Fig. I60). These indicate a reptile-like animal covered with feathers, and about the size of a small crow. It had sharp teeth, a short neck, claws upon each of the three fingers terminating the wings as well as the four toes of each foot, a small keel to the breastbone (hence it could fly), shoulder girdle exceedingly small (for a flying bird) and a long tail composed of about twenty separate vertebræ with a pair of feathers attached apparently to each vertebra. During the remainder of the Mesozoic birds became more modern in appearance through the shortening of the tail by means of the consolidation of some of its vertebræ, the nearly universal loss of the claws from wings and the lengthening of the neck.

Teeth did not disappear from the adult bird until the Tertiary. Avian remains from the Cretaceous include Hesperornis regalis, the three-foot high diving bird, and the small flying Ichthyornis, both from Kansas (Fig. I6I). One of the largest birds known is the but recently extinct Dinornis maximus from New Zealand, which stood twelve feet high.

In the late embryo of most modern birds, the tail consists of five to ten separate vertebræ which later coalesce. Teeth are present in the embryo of certain species of parrot. A similar repetition of ancestral characters is seen in the Hoactzin, a native of the Amazon Valley. Directly after birth it makes climbing expeditions by means of its beak, feet and the claws upon its wings. These claws disappear in the adult bird. In 

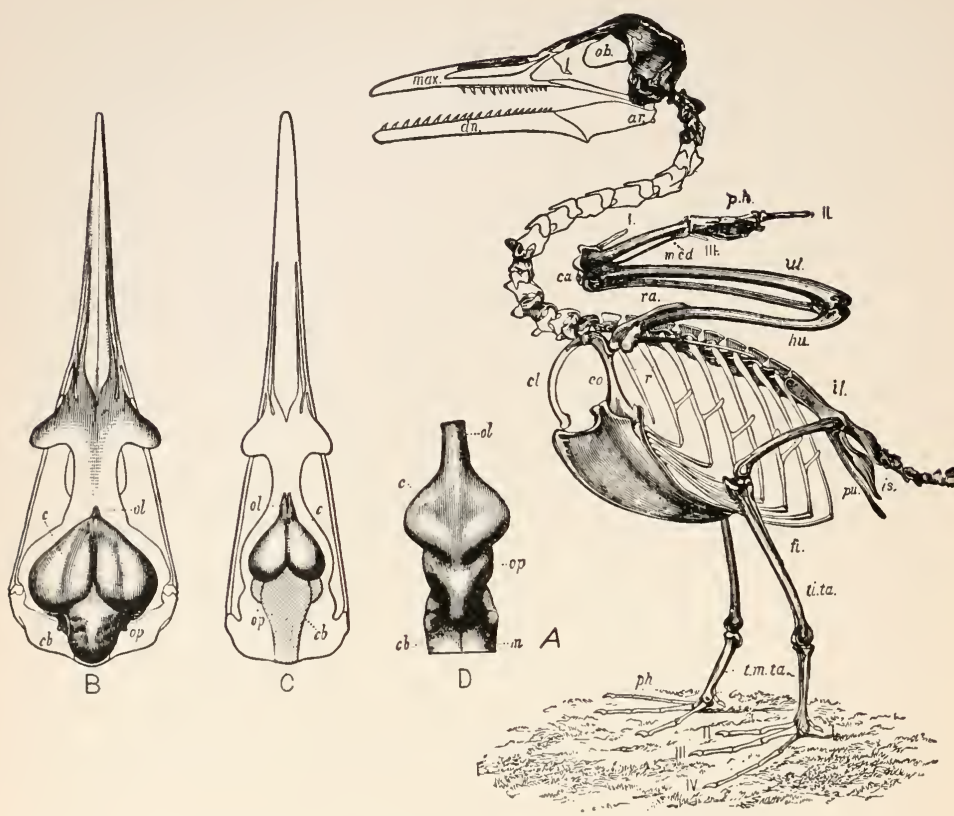

FIG. I6r. - Ichthyornis victor Marsh, from the marine Niobrara beds (mid-Cretaceous) of western Kansas. It was slightly larger than a common pigeon. The hollow bones, strongly keeled breastbone and large wings indicate this to have been an excellent flyer, while its association with such universally marine forms as ammonites shows that it must have lived at least upon the borders of the sea. Though similar in general appearance to living birds, yet it shows its ancestry in its small, elongate, reptile-like brain (compare figures $B, C, D$, all drawn to same scale) and in its sharp, pointed, recurved teeth which are lodged in distinct sockets. $A$, restoration of entire skeleton. $B$, outline of the skull and brain cavity of the modern tern, seen from above. $C$, same view of 1 chthyornis victor. $D$, cast of brain cavity of a young ailligator. ar., articular bone or mandible; $c$., cerebrum; $c b$., cerebellum; $c a$., carpal (wrist) bones; $c l$., clavicle (the "wish bone"); $c o$., coracoid ; $d n$., dentary bone of mandible; $f$., fibula, - very small as in all modern birds; hu., humerus; il., ilium, - the hip bone; is., ischium; m., medulla; max., maxilla; m.ca., metacarpals ; ot., orbit of eye ; ol., olfactory lobes of brain ; $o p .$, optic lobes of brain; ph., phalanges (digit II has two phalanges) ; $f u$., pubis; $r$., rib; ra., radius; ti.ta., tibio-tarsals, - the union of the tibia and proximal row of tarsals as is seen in the development of modern birds; t.m.ta., tarso-metatarsal bones, - union of the distal row of tarsals with the metatarsals as is shown in the young of modern birds; $u l$., ulna; $I, I I$, etc., digits, Ist (corresponding to the thumb and great toe), 2d, etc. (After Marsh.) 
the young Hoactzin, as in Archeopteryx, the hand is longer than the forearm, but before the resorption of the claws the hand ceases to grow while the forearm becomes much longer, so that their relative lengths become reversed.

Birds and dinosaurs may have descended from a common stem . derived from the Rhynchocephalia.

I. Give distinguishing characters of Class Aves.

2. Distinguish the ankle-joint of reptiles and birds from that of mammals.

3. What is the significance of a keel to the breastbone?

4. Why do grain-eating birds swallow small stones? What difference between the gizzard of these birds and that of flesheaters?

5. What is the principal difference between the breathing apparatus of birds and that of mammals? birds?

6. What is the possible origin of migration among northern

7. Give the geologic range of birds.

8. Why are birds rare as fossils?

9. Describe Archeopteryx, distinguishing the reptilian from the avian characters.

Io. Under what conditions were the lithographic slates of Solenhofen deposited?

I I. What is the probable origin of birds?

I2. In what ways do modern birds and especially the Hoactzin indicate their ancestry in their ontogeny?

\section{Class G, Mammalia (Mammals)}

Air-breathing, warm-blooded vertebrates usually with a protective exoskeleton of hair. The temperature of most mammals is about $98^{\circ} \mathrm{F}$. The skull is articulated with the backbone by two rounded prominences (condyles), instead of by one as in birds and in most reptiles, and the lower jaw is articulated with the skull directly without the aid of the separate quadrate bone present in those two classes. The teeth, typically forty-four in the placental mammals, are nearly always differentiated into three incisors on each side above and below, 
one fang (canine) and seven premolar and molar teeth. Molars are distinguished by having no milk teeth preceding them.

The ankle-joint is always between the bones of the lower leg (tibia and fibula) and the ankle bones (tarsus), never between the two rows of tarsal bones as in birds and reptiles. A muscular partition, - the diaphragm (Fig. I42, di.), divides the body cavity into an anterior portion, the thorax, containing the completely four-chambered heart and the lungs, and a posterior portion, the abdomen, containing the digestive canal and the excretory and reproductive organs. All mammals, except the most primitive, the Monotremata, are viviparous; that is, the egg develops into a form more or less like the adult before leaving the body of the mother. The young, before birth, is nourished by the blood of the mother (except in the Marsupialia) through the placenta, a spongy membranous mass attached to the walls of the uterus; after birth, by milk, - the secretion of the mammary glands.

Most mammals, as the horse and deer, live upon the surface of the ground; some, as the squirrel and monkey, are arboreal or tree dwellers; rarely do they fly, as the bat; a few, such as the mole, are fossorial (burrowing); some, as the muskrat and beaver, have taken to an aquatic life in fresh waters, others, such as the seal and whale, to a marine life.

For discussion of a typical mammal see the cat, p. 324 .

Derivation of name. - > Latin mamma, the breast. The young are nourished for a time after birth by milk secreted by the glands of the mother's breast.

Causes of extinction of mammals. - Animals with relatively larger brains being more alert, and adaptable to new conditions (Fig. I62), will survive in competition with smallerbrained forms; they will also get more food and take better care of the young. Other characters, besides defective brain, which gradually lead to the extinction of their possessors are inadaptive tooth and foot structure, excessive bulk, or extreme 
specialization in whatever direction, such as an exceptional development of organs of combat (e.g. horns). Growing aridity. with the consequent drying up of water courses, is another powerful factor in extinction. For example, the growing aridity of the Pliocene in the Rocky Mountain region and the Great Plains region to the east, seen also in the sandy nature of the stratigraphic deposits as well as in the peculiar fauna and flora, was most probably the cause of the extinction of the rhinoceroses as well as of some of the browsing types of horses and camels.

During early and midPleistocene time North America was covered with herds of mastodons, many varieties of elephants, large llamas, camels and enormous numbers of horses; of the last there were at least ten species. Prong-horn antelopes, white-tailed deer, peccaries, giant sloths and glyptodonts were also abundant. (The moose,
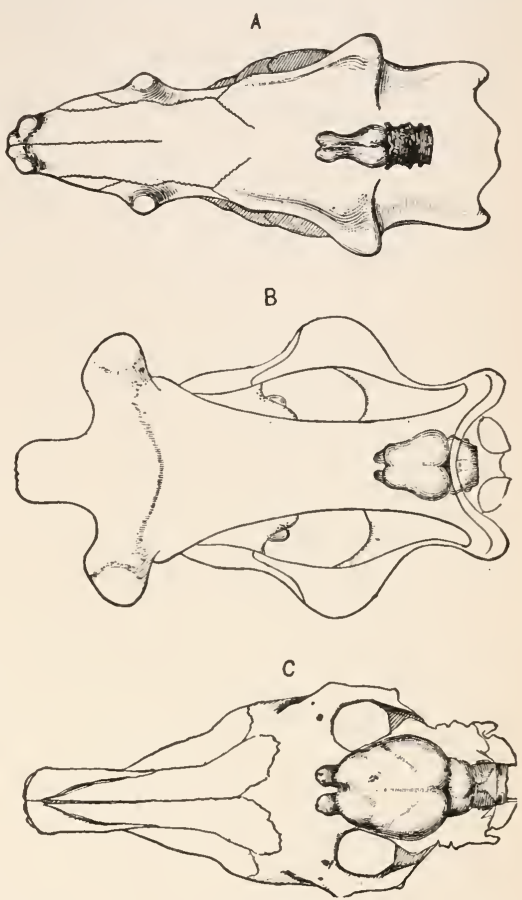

FIG. I62. - A comparison of relative size of brains of ungulate mammals from the Eocene to the present. A, outline of skull of the Eocene Uintatherium mirabile Marsh with cast of brain in position. $\left(\times \frac{1}{16}\right.$. $B$, same of Brontotherium ingens Marsh $\left(\times \frac{1}{20}\right)$ from the Hiocene; $C$, same of the modern horse, Equus caballus Linn. ( $\times \frac{1}{12}$.) (From Marsh.)

bison, mountain goat, musk-ox, red-deer, bear and reindeer did not arrive from Eurasia until near the close of the Pleistocene.) Preying upon these were the saber-tooth tigers as well as large, 
lion-like cats and giant dogs. The extinction of the majority of these Pleistocene mammals was probably mostly due, either directly or indirectly, to the accompanying glacial conditions. Exceptionally cold waves or unusually prolonged cold seasons even now lead to a temporary diminution in the number of animals in a herd. This may be due to the freezing of the young and other weak members, complete starvation from the deep covering of snow over their food, or merely partial starvation and a consequent inability of the individual females to protect their young from the Carnivora. This reduction of the herd may in turn lead to its complete destruction through the insufficiency in the number of bulls to protect the young; the reduction in the number of herds leads in turn to inbreeding and to its probable accompaniment of infertility. Infertility may likewise often be produced by an increasingly unfavorable climatic environment. The change from a forested condition, such as existed in the Northern Hemisphere north to the Arctic Ocean during the early Pleistocene, to an unforested one, and back again during times of increasing moisture, as happened at least once during the Pleistocene, would cause the diminution of both forest animals, such as the browsing camels, browsing horses, mastodons, elephants, tapirs and deer, and of grazing animals. The remains of the larger Pleistocene animals, now extinct, are nearly always associated with evidences of forests. It has been suggested that a corollary cause in the extinction of the horse from North America may have been some epidemic disease, or diseases, carried by some fly, tick or other parasitebearing insect; the multiplication and spread of such insects are increased by the presence of a moist climate. If southern North America accordingly was exceptionally moist during a portion of the Pleistocene, of which there is evidence, some such insect-spread epidemic may have led to the extinction of the horse by the close of the Pleistocene.

Mammals are divided into the following orders :- 
I. Monotremata . . . . . . . . . . 378

2. Marsupialia . . . . . . . . . . . 378

3. Insectivora . . . . . . . . . . . . . . 379

4. Chiroptera . . . . . . . . . . . . 379

5. Carnivora . . . . . . . . . . . . . . 379

6. Rodentia . . . . . . . . . . . . 38 I

7. Edentata . . . . . . . . . . . . 382

8. Ungulata . . . . . . . . . . . . . 382

9. Sirenia . . . . . . . . . . . . . 398

ıо. Cetacea . . . . . . . . . . . . . 398

I I. Primates .

The species of mammals represent an ascending series as follows, (I) The very primitive, reptile-like sub-class Prototheria (represented by Order I). These are egg-layers; the egg is (in Echidna) placed by the mother in a ventral pouch containing milk glands without nipples; here it is hatched and then nourished by the milk poured out around it. Ornithorhynchus lays its eggs in a nest in its burrow, brooding over them birdlike. The body temperature is variable (changing as much as $\mathrm{I} 5^{\circ}$ according to the temperature of the environment). A cloaca is present, in which terminate the ducts of the urinary, reproductive and digestive systems. (2) The more advanced subclass Metatheria (including Order 2). They produce the young alive, but in so rudimentary a condition that directly after birth they are placed by the mother in a ventral pouch which contains the false nipples and are there sheltered until able to take care of themselves; a placenta is absent or functional only for a short period. Cloaca absent. (3) The sub-class Eutheria (including Orders $3_{-1 \text { I }}$ ) are the most highly evolved. The young are nourished through a placenta until well advanced (whence the name placental mammals for this sub-class); after birth they are nourished by milk through true nipples. The young are never carried in a pouch. Cloaca absent. 


\section{Order I, Monotremata}

Principal characters given above under sub-class Prototheria. Name from Greek monos, one, + trema, opening, in allusion to the cloaca.

If we except the very small, primitive, and doubtfully mammalian Protodonta (e.g. Dromatherium) of the Upper Triassic of North America, no remains of this order have with certainty been found before the Pleistocene. The two living genera, duck bill (Ornithorhynchus) and the spiny anteater (Echidna) are confined to the Australian region.

\section{Order 2, Marsupialia}

Chief characters given above under sub-class (2), the Metatheria. Name from Latin marsupium, a pouch, in allusion to the ventral pouch for carrying the young.

If we include here the possibly marsupial carnivorous sub-order Triconodonta (Jurassic; including Triconodon and Phascolotherium) and the herbivorous, North American, European and South African sub-order Multituberculata (Upper Triassic to Eocene, including the Jurassic Plagiaulax and the Basal Eocene Polymastodon), this order is known from the Upper Triassic to the present. The opossums, now confined to North and South America, are known here probably since the Cretaceous and in Europe during the Lower Tertiary. Except for the American opossums and Cænolestes all marsupials are at present confined to the Australian region; they include the Tasmanian wolf and bandicoots of the polyprotodonts, or marsupials with many front teeth of equal size, and the kangaroos, wombats and flying phalangers of the herbivorous diprotodonts, or marsupials with two enlarged incisors. Representatives of both of these groups were living in South America during the Tertiary. 


\section{Order 3, Insectivora}

Small mammals, eating worms and insects, - (whence the name).

These have a low type of brain and occur from the Jurassic to the present, including the extinct sub-order of the Jurassic Pantotheria. The living families of the moles, shrews and hedgehogs have existed since the Eocene.

\section{Order 4, Chiroptera (Bats)}

Mammals with the fore limbs modified to form wings by the development of a broad web between the greatly elongated fingers (usually the second to fifth) and the sides of the body and the hind limbs (hence the name from Greek cheir, a hand, + pteron, a wing). Breastbone with a keel for attachment of flying muscles.

This order is known from the basal Eocene of Colorado to the present, and now includes the fruit-eating bats of the tropics of the Eastern Hemisphere and the insect-eating bats so abundant throughout the world.

\section{Order 5, Carnivora (Cats, Dogs, etc.)}

Fur-covered, flesh-eating mammals (whence the name from Latin carnis, flesh, + vorare, to devour); all teeth have cutting edges.

This order is known from the Eocene to the present. It includes: (I) the extinct primitive Creodonta (Basal Eocene to Lower Oligocene, mostly of North America, but also of Europe and Africa). These are such generalized types that they are only with difficulty distinguished from the Eocene Insectivora and Ungulata. As they do not possess well-developed sectorial teeth (see below under Fissipedia), they are not perfected as flesh eaters. Examples of these are Mesonyx and Patriofelis (Fig. I63, 2-4), both from the Middle Eocene (Bridger) of the 

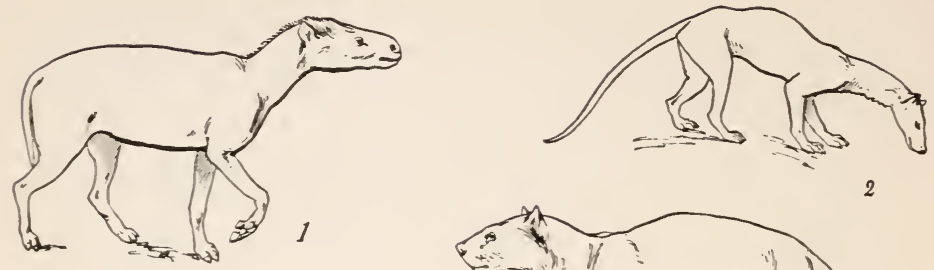

2
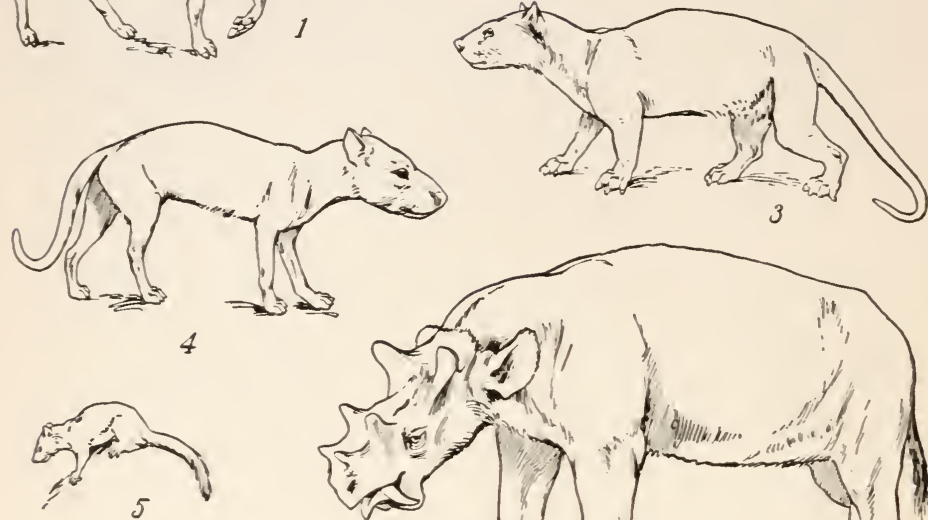

$\infty$

4

s
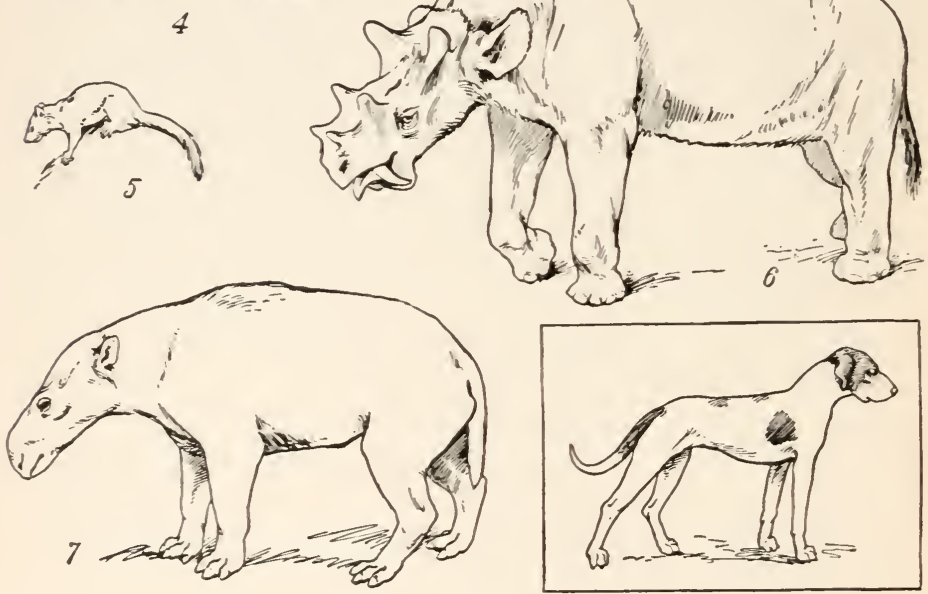

FIG. I63. - Outline restorations of some of the more characteristic mammals living in North America during Upper Eocene (Bridger) time. These are reduced to a uniform scale, with a pointer dog (in the frame) to show relative sizes. I. A primitive rhinoceros (Hyrachyus eximius). 2-4 arecreodonts, - primitive carnivora. 2. Tritemnodon agilis, a form with hyena-like teeth. 3. Patriofelis ferox. 4 . Dromocyon velox, a big-headed, wolf-like form, though with a very small brain cavity. 5. A primitive rodent (Paramys deticatior). 6. The huge ungulate, Uintatherium alticeps. This had an extremely small brain. 7. One of the smaller early titanotheres (titanic beasts), Mesatirhinus superior. (From Scott.) 
Rocky Mountains. (2) Fissipedia (Upper Eocene to present); last premolar above and first molar below, called sectorials, always specially modified for cutting and bruising; in front of these the teeth are always compressed and pointed; behind them they have broad, tuberculate surfaces. The dog tribe (Canidæ) made its appearance in the Eocene, passing through the greater part of its development in North America. The cat tribe (Felidæ) is first known from the Oligocene; of these the huge saber-tooth tigers Machairodus and Smilodon (Fig. I64, 7), living in Eurasia and in North and South America, survived from the Miocene to the Pleistocene. The raccoons (Miocene to present), a North American family, were probably derived from the dogs in the Oligocene. The bear tribe (Ursidæ) came in with the Miocene; it originated in Eurasia and did not reach North America until the Pleistocene; during the Pleistocene the great cave-bear (Ursus spelaus) of Europe was hunted for food by contemporaneous man. The different branches of the Fissipedia converge as they are traced back into the lower Tertiary, pointing to a common ancestor in the Eocene. The Pinnipedia (Miocene to present) have limbs adapted to aquatic life. They may have descended from forms allied to the creodont Patriofelis. They are represented at present by the seals and walruses.

\section{Order 6, Rodentia (Rodents)}

Small, fur-covered, vegetable-feeding mammals without canine teeth and usually with only two long, chisel-like, continuously growing incisors in each jaw. The typical incisor, seen in most modern rodents, such as rats, mice, squirrels and beavers, has the enamel confined to a band upon the anterior face; since the remainder of the tooth consists only of the softer dentine, a most efficient, continually sharpened chisel is the result (whence the name from Latin rodens, gnawing).

The extinct Tillodontia (Lower to Middle Eocene of North 
America and possibly of Europe) may belong to this order; they have a primitive type of brain and retain traces of canine teeth. True rabbits (Lepus) date from the Oligocene of North America, the squirrel (Sciurus) from the Oligocene of North America and Europe, the beaver (Castor) as well as the rats and mice (Mus) from the Pliocene of Europe (Figs. I63, 5 and I64, 5).

\section{Order 7, Edentata (Sloths, etc.)}

Dentition imperfect (i.e. incisors and canines usually absent, premolars and molars without roots or enamel) or teeth entirely absent (whence the name from Latin $e$, without, + dens, a tooth).

These degenerate mammals may possibly have evolved from the common ancestors of the rodents and ungulates through the extinct Tæniodonta (Ganodonta) from the Basal to Middle Eocene of North Africa. The earlier tæniodonts have welldeveloped, rooted and more or less completely enameled teeth; in the later forms the teeth lose their roots and most of the enamel. True edentates are known from the Eocene to the present and from all continents except Australia. No fossil remains of the modern sloths (Bradypodidæ) and anteaters (Myrmecophagidæ) are known; these two families are combined in the extinct ground sloths (Megatheriidæ) which have the head and teeth of a sloth and the tail of an anteater (Fig. I64, 2); a late American genus (Megatherium of the Pliocene and Pleistocene) of this family is the largest-known edentate, one species attaining a length of almost twenty feet. Armadillos are found as early as the Eocene; one of the largest genera known is Glyptodon from the Pliocene of North and South America with a rigid, usually ornate carapace; this animal attained at times a total length of fifteen feet.

\section{Order 8, Ungulata (Hoofed Mammals)}

Land-dwelling mammals with the weight of the body usually resting upon the ends of the toes which are nearly always invested 

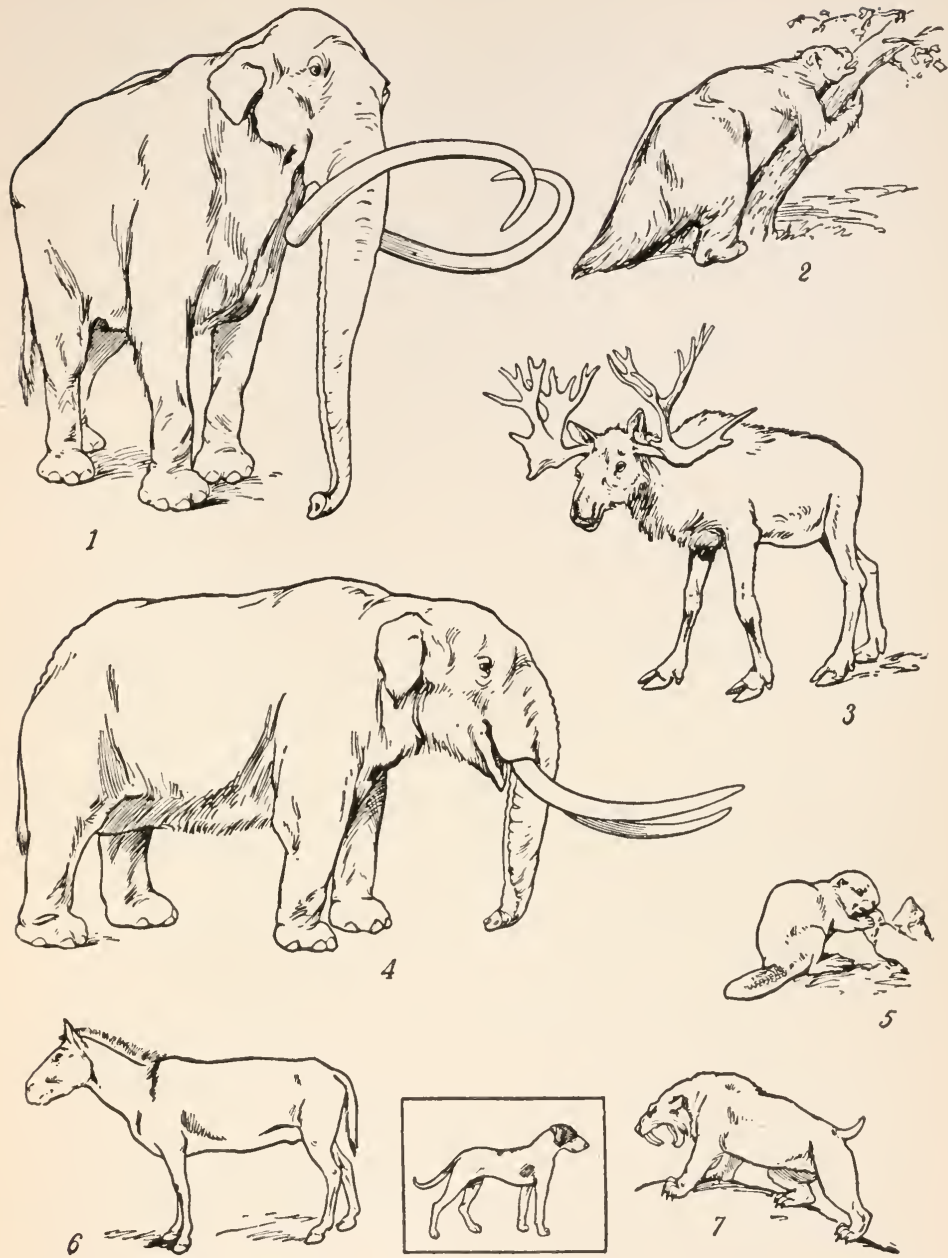

FIG. I64. - Outline restorations of some of the more characteristic mammals living in North America during the Ice age (Pleistocene). These are reduced to a uniform scale, with a pointer dog (in the frame) to show relative sizes. Note the difference in size between these and the Eocene mammals (Fig. I63). I. The Columbian elephant (Elephas columbi). 2. The giant ground-sloth (Megalonyx jeffersoni), an edentate. 3. Stag-moose (Cervalces scotti), one of the artiodactyl ungulates. 4. The American mastodon (Mammut americanum). 5. The giant beaver (Castoroides ohioensis), a rodent. 6. Texas horse (Equus scotti). 7. Sabertooth tiger (Smilodon californicus). (From Scott.) 


\section{AN INTRODUCTION TO THE STUDY OF FOSSILS}

by solid horny nails, the hoofs. (Hence the name from Latin ungula, a hoof.) Canine teeth absent or small ; premolars and molars large, their broad crowns beset with ridges or tubercles. _. In the lowest Eocene it is almost impossible to distinguish the ancestors of mammals with claws (the Unguiculata, including orders 3-7) from those with hoofs (the Ungulata). They are both flat-footed, five-toed animals with the toes terminating in nails intermediate between claws and hoofs, with freely movable fore limbs and tuberculate molar teeth, the tubercles in the former being slightly more pointed and cutting than in the latter. The primitive Ungulata were mostly small, inhabiting marshes or forests, with teeth adapted to succulent herbage. Many branches of these early Ungulata (which were probably not developed from any of the Condylarthra known at present) became modified during the course of the Tertiary into hardhoofed dwellers of the dry, upland plains with teeth capable of grinding the dry grasses. Grasses were probably establisł ed ar

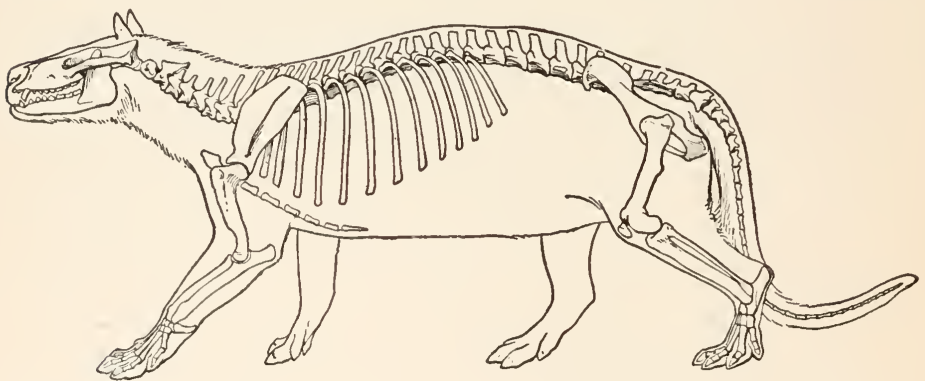

FIG. I65. - Restoration of skeleton of Phenacodus primavus, from the Lower

Eocene (Wasatch). This is one of the Condylarthra, - an exceedingly primitive group of ungulates which serve to connect quite intimately the hoofed and clawed mammals. (From Scott.)

a rather dominant factor in the earth's vegetation by the time of the Upper Eocene, though the siliceous grasses, now constituting the grasses of the plains, probably did not come into prominence until the Miocene. As the Tertiary is ascended, 
especially during the Oligocene, Miocene and Pliocene, there is a reduction in the number of browsing and ambulatory animals and an increase in the grazing and cursorial types. The

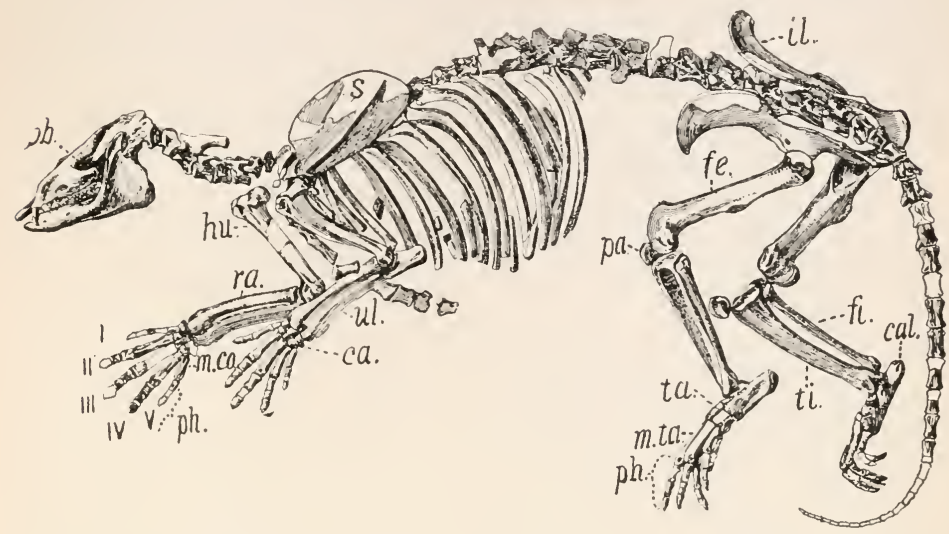

FIG. r66. - A primitive light-limbed, omnivorous, hoofed mammal. Phenacodus primaius Cope, one of the Condylarthra, from the Wasatch (Lower Eocene) of Wyoming. This animal, somewhat larger than a sheep, was in this case exceptionally well preserved. It is shown here, laterally crushed, just as it occurred in the rocks. ca., carpal (wrist) bones; cal., calcaneum; fe., femur; fi., fibula ; hu., humerus; il., ilium; m.ca., metacarpal (palm) bones; m.ta., metatarsals; $o b$, orbit of eye; pa., patella; ph., phalanges (toes); ra., radius; s., scapula; ta., tarsal bones; $t i$., tibia; $u l$., ulna ; $I, I I, I I I, I V, V$, digits, Ist (corresponding to thumb and great toe), 2d, etc. (After Cope.)

principal advance in the mammals lay, however, in the enlargement of the brain (Fig. I62).

The Ungulata include the following ten sub-orders:-

(I) The most primitive of the Ungulata are the extinct Condylarthra (Eocene), difficult of separation from the early Carnivora, - the Creodonta. They are light-limbed animals with a small brain and usually with forty-four short-crowned and tuberculate teeth. The best-known example is Phenacodus from the Lower Eocene (Figs. I65, I66).

(2) The Hyracoidea (Lower Oligocene to present) are probably but slightly modified descendants of the Condylarthra; these 
small rock- and tree-living hoofed animals include the coney (Hyrax) of Africa and southwestern Asia.

(3) The extinct Amblypoda (Eocene of North America) were huge, heavy-limbed, blunt-footed animals. They include the huge hippopotamus-like Coryphodon, and the giant Dinoceras, Uintatherium (Fig. I63, 6), Eobasileus, etc., with three pairs of bony, horn-like prominences upon the top of

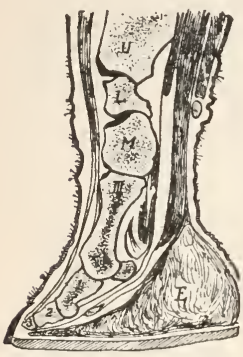

Fig. I67. - Vertical section through the fore foot of the Indian elephant. $U$, lower end of ulna; $L$, lunar bone of the carpus (wrist); $M$, magnum of carpus; $I I I$, third metacarpal (palm) bone; $I, 2$, 3 , phalanges of the third digit (middle finger); $E$, pad of elastic tissue. (From Scott, after M. Weber.) the skull.

(4) The Proboscidea, the elephant tribe (Upper Eocene to present), are primitive ungulates. Each of the massive limbs terminates in five toes which are separately incased in hoofs (Fig. I67). Canine teeth are absent; the molars are large and transversely ridged. These molars (Fig. I68) come in successively from behind and move obliquely forward to be finally, when worn down very low, pushed out from the front of the jaw. Owing to the great size of the teeth and the shortness of the jaw, only one tooth on each side, above and below, is in full use at one time. In existing forms there is only one pair of incisors present, the upper; these are free from enamel and are developed into continuously growing tusks. Many early forms had tusk-like incisors both above and below (e.g. Paleomastodon [Fig. 169] of the Upper Eocene of northern Africa). As is true of all animals, there is seen in the elephant a persistence of primitive, archaic characters alongside of highly adaptive, modern ones. The elephant retains the primitive mammalian form of body, the five toes and the carpal bones arranged in vertical rows, but these are associated with such highly specialized characters as reduction in number of teeth, remarkable growth of two incisors, wonderful increase in height of 
skull due to the development of air cavities and the acquirement of the muscular trunk.

According to present evidence the evolution of the elephant (Fig. I69) began in northern Africa with the mid-Eocene swampdweller, Mœritherium; this seems to have had a prehensile upper lip, since the nasal bones were beginning to recede. This recession of the nasal bones became more and more marked, indicating thus a longer and larger trunk, in the line ascending into the modern elephant (Elephas), i.e. Paleomastodon, Gomphotherium, Mammut, Stegodon, Elephas.
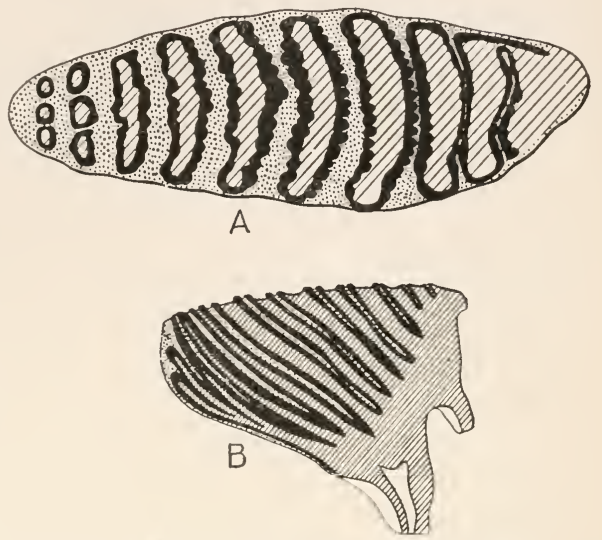

Fig. I68. - Molar tooth of an Indian elephant. $A$, crown view much reduced in size. $B$, longitudinal section. Black, portion enamel; dotted, cement; cross-lined, dentine or ivory. Shows the deep infolding of the enamel and its projection as grinding ridges. (After Lull.)

The first of these,

like its ancestor, Mœritherium, was confined to northern Africa, the rest had migrated more or less fully over the entire Northern Hemisphere.

In North America the most conspicuous and abundant species during the Pleistocene (Fig. I 70) were ( $a$ ) the American mastodon (Mammut americanum) ranging from Alaska and California to Prince Edward Island, Florida and Central America (Fig. I64, 4). The teeth were comparatively small so that two or three could be in use simultaneously upon each side in each jaw. (b) The mammoth (Elephas primigenius), with height usually less than 9 feet, and abundant throughout the Northern Hemisphere. It is of this species that complete carcasses have been 


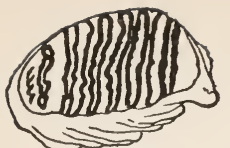

Elephas 1/8

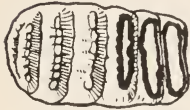

Stegodon $1 / 8$

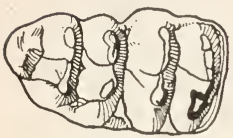

Mastodon 1/8

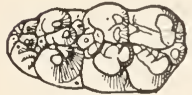

Tetrabelodon $\%$

?

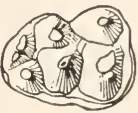

Paloeomastodon $1 / 4$

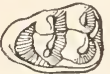

Moeritherium $1 / 4$ ?

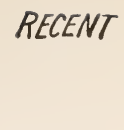

UPPERPLIOCENE)

Slegodon (short chin).

Mastodon
PLEISTOCENE

(shorl chiin).

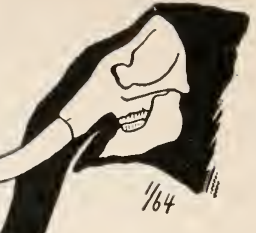

(short chin).

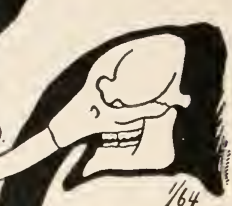

LOWER PLIOCENE Gomphotherium longirostris stage, UPPER MIOCENE $\begin{gathered}\text { (shortening } \\ \text { chin) }\end{gathered}$

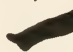

MIODLE MIOCENE

Migration into

North America

LOWER MIOCENE)

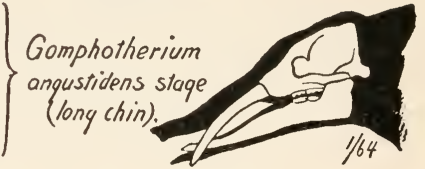

$?$

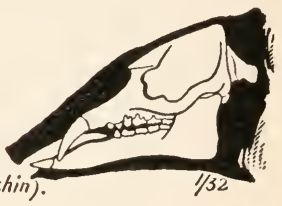

(lengthening chin).

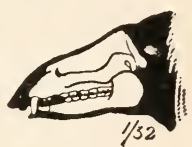

?

FrG. I69. - The evolution of the elephants: On the right the skulls, with the proboscis restored in black; on the left the last lower molar. The principal changes lie in the increased height of the skull and its decreased length with a consequent reduction in number of teeth, also in the development of a long snout or trunk and in the increased length of two or four incisors into tusks. (Tetrabelodon should read Gomphotherium.) (From Scott, after Lull, modified by Sinclair.) 
found frozen in the sands and gravels of northern Siberia along the Lena River. That it was adapted to a life in a cold climate is shown both by its dense, woolly short hair covered with long outer hair, and by the contents of the stomach, remnants of present-day Siberian vegetation. (c) The Imperial elephant (Elephas imperator), attaining a height of over thirteen feet and ranging at least from Ohio to Mexico City. (Among the existing African elephants the male often attains a height of over eleven feet.) The mastodon (Mammut) was more of a forest dweller than Elephas; its low-crowned teeth had each two to five high ridges for crushing the succulent herbage, especially the twigs of coniferous trees, while the true elephant (Elephas) with its highcrowned teeth, each with ten to sixteen very low ridges, can grind the harder grasses of more open regions.

(5) Embrithopoda (Upper Eocene and Oligocene of Africa). A well-known genus is Arsinoitherium, - large, rhinoceros-like animals, some almost six feet high at the shoulders, with a pair of huge, pointed, forwardly directed horns over the snout and a smaller pair above the eyes.

(6) Toxodontia (Eocene to Pleistocene of South America). The molars have flattened outer walls. Toxodon of the Pleistocene is a characteristic genus.

(7) Litopterna (Eocene to Pleistocene of South America). Some of these animals paralleled the horses in their development, but their more primitive character is shown in their smaller brain, less adaptive skeletons, and lower-crowned molars. The number of toes varies from five to one in different genera, but the third is always the longest. Examples are: Macrauchenia (Pleistocene), - three toes on both fore and hind feet; Thoatherium (Miocene), - a small animal with but one toe on fore and hind feet like the existing horse.

(8) Perissodactyla (Lower Eocene to present). In these, the odd-toed ungulates, the third toe on both fore and hind foot is the longest (whence the name from Greek perissos, odd, + dactylos, a finger). The plane of symmetry of the foot bisects the third 


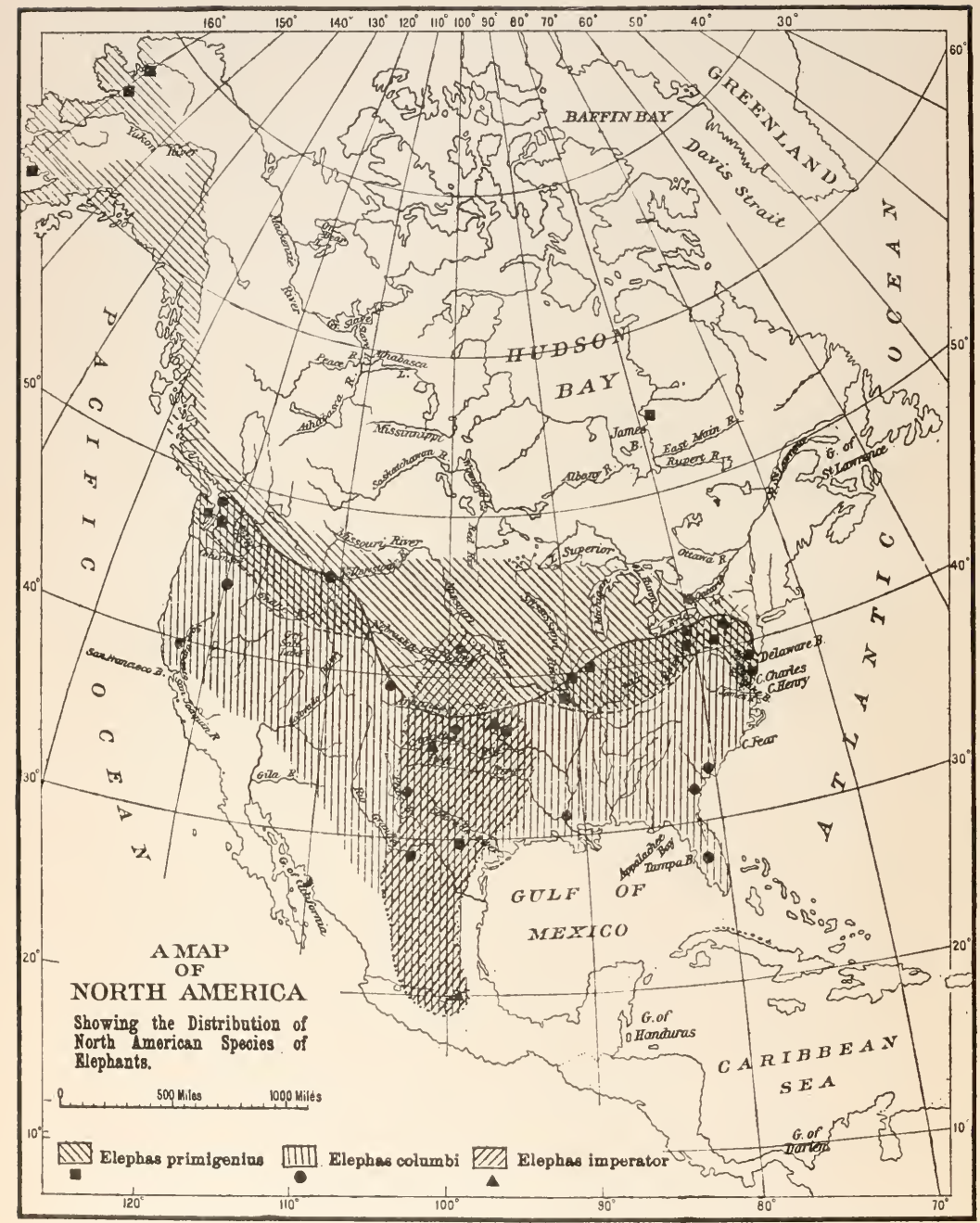

FIG. I70. - A map showing the widespread distribution of elephants in North America during the Pleistocene. (From Lull.) 

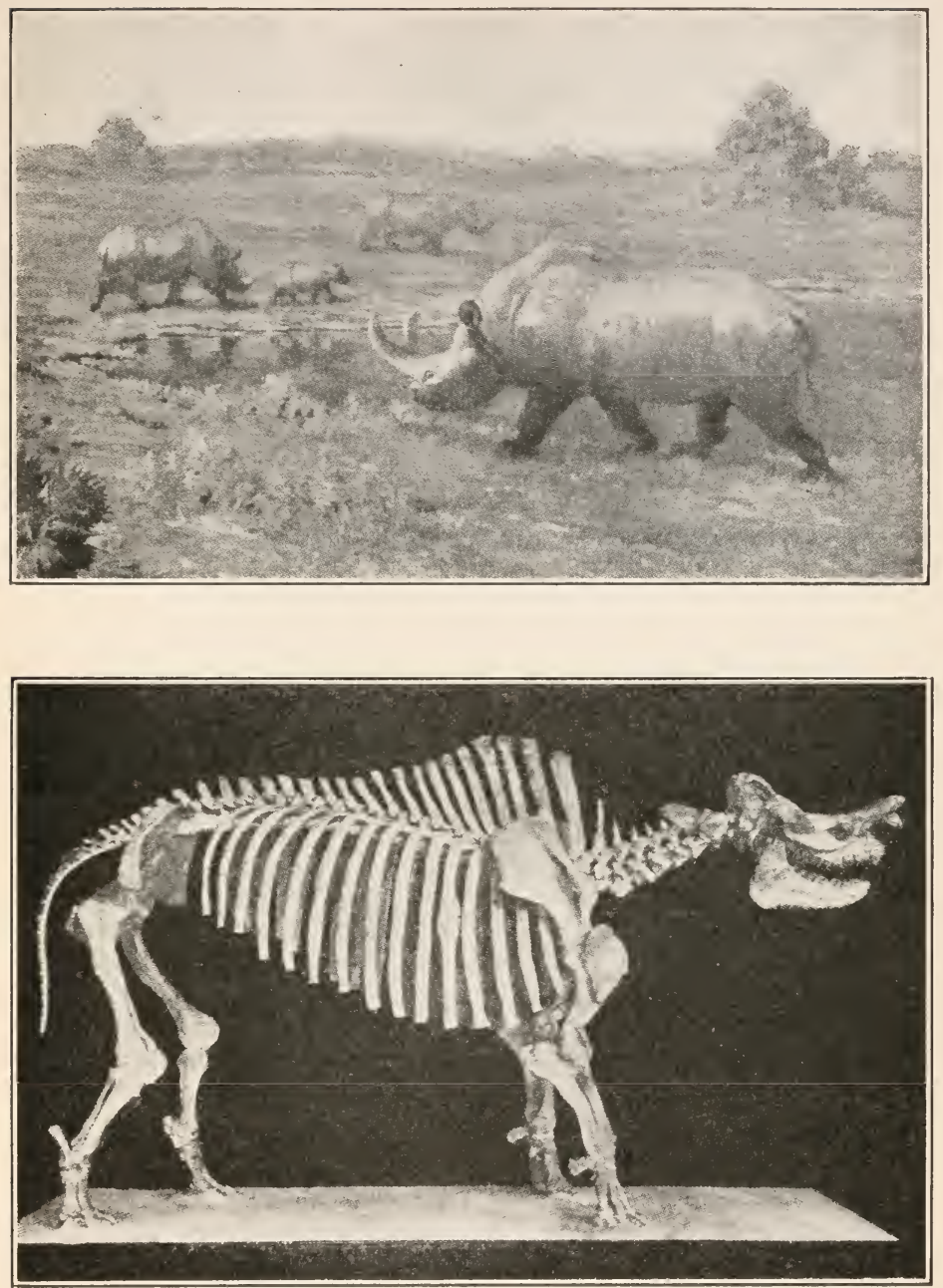

Fig. I7I. - Above: Typical scene in western North America during the Lower Oligocene time, showing a small herd of titanotheres of the genus Brontotherium. The individual in the foreground is a male. Below: A skeleton of a female Brontotherium gigas from South Dakota. Note the small nasal horns in comparison with their tremendous development in the male above. (From Osborn.) 
digit. Examples include: (a) tapirs and rhinoceroses, both of which families date from the Eocene, and were present during the Tertiary upon most of the continents. Both disappeared from North America during the Pliocene. The rhinoceroses very probably originated in North America (Fig. I63, I). (b) The huge titanotheres (Figs. I63, 7 and $17 \mathrm{I}$ ), some of the later members of which attained a height of eight feet and a length of fifteen feet, existed during the Eocene to Oligocene.

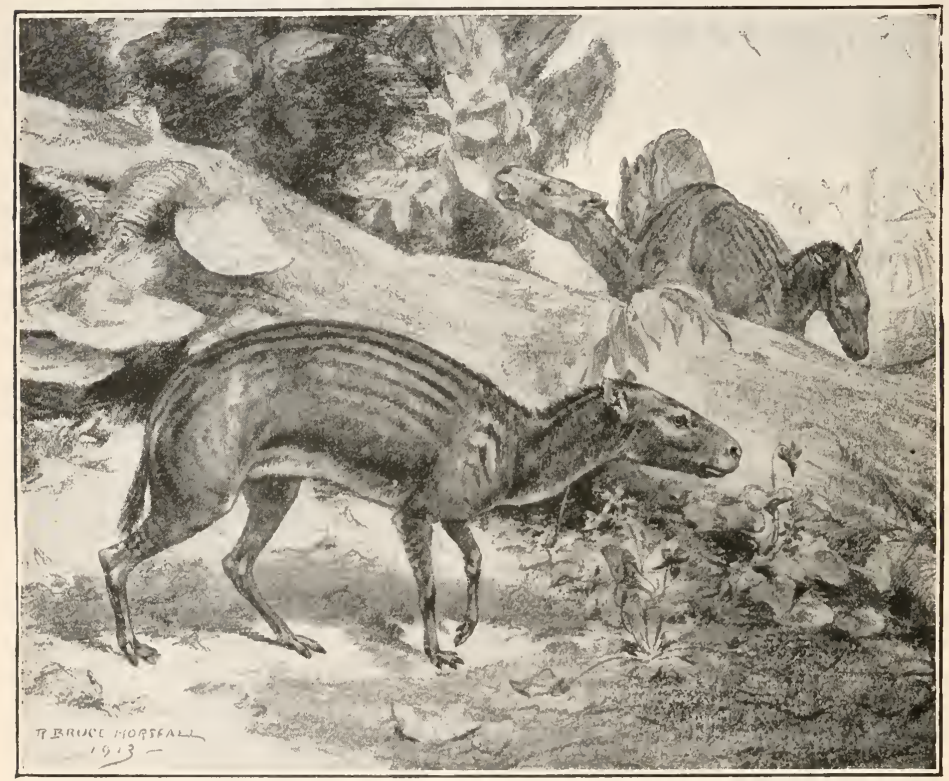

FIG. I72. - A restoration of the earliest known ancestor of the modern horse, Eohippus, - the Dawn Horse, from the Lower Eocene (Wasatch) of western North America. In size these varied from that of a cat to a small fox. Note the short face (distance from eye forwards), short neck, arched back, short limbs and similarly short feet, with several divergent toes upon each. (From Scott.)

(c) The horse family dates from the Lower Eocene in both North America and Eurasia. The family branched from a so far undiscovered five-toed primitive ungulate, which gave rise in 
time to the four-toed Lower Eocene Eohippus of Europe (Fig. I72). This tiny animal, less than a foot high, migrated across Asia into western North America, where the evolution (Figs. I72-I75) of the modern horse (Equus) was completed, giving an ascending series somewhat as follows: Eohippus (Lower Eocene), Protorohippus (mid-Eocene), Orohippus (Upper Eocene), Epihippus (topmost Eocene), all more or less fully four-toed but increasing in size. The line is continued in Mesohippus (Lower Oligocene), the two-foot-high Miohippus (Upper Oligocene), both three-toed with the side toes touching the ground, through the three-foot-high Merychippus (Miocene), three-toed but side toes not touching the ground and hence almost functionless, into the typical grazing horse, - the onetoed Equus (Pliocene to present), with the side toes reduced

Fore foot Hind foot Molar teeth

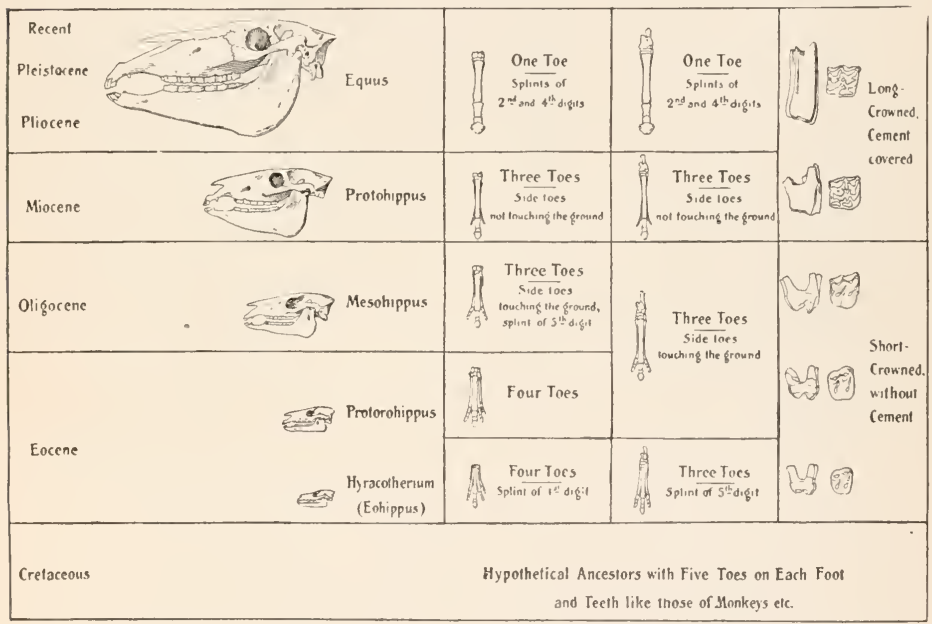

Fig. 173. - Evolution of the horse. I. (Drawn to same scale.) Note the increase in vertical diameter of the skull, the movement of eye backwards (hence increase in length of face), the increase in height of teeth accompanied by an infolding of cement between the enamel ridges of each tooth and the decrease in number of toes upon both fore and hind feet. (After Matthew.) 
Fore arm

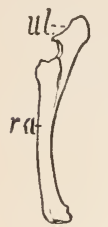

PROTOHIPPUS

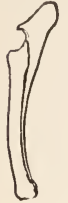

MESOHIPPUS

OROHIPPUS

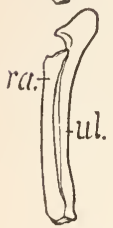

FIG. I74. - Evolution of the horse. II. (Not drawn to scale.) In the course of evolution from Orohippus (Upper Eocene) to Equus, the bones of the fore arm (radius and ulna) gradually became consolidated into one bone, resulting in the disappearance of the lower end of the ulna. In the fore leg (fibula and tibia) the fibula was gradually obliterated. These changes resulted in a more slender limb and hence greater speed. $f i$., fibula; $r a$., radius; $t i$., tibia; $u l$., ulna. (After Marsh.)
Fore leg to bony splints at the sides of the leg bone. The embryo of the modern horse passes through at least some of these stages in its development. For example, a horse embryo fourteen inches long has three toes with well-developed metacarpal and phalangeal structures, resembling Miohippus. Merychippus shows well its intermediate position between the browsing and grazing type of horse in its teeth; its milk teeth are shortcrowned and without a covering of cement like its ancestors; its permanent set are long-crowned with cement filling the spaces between the enamel ridges, as in its descendant Equus. This change from the little Eohippus, the " dawn horse," to the large modern horse took place through changes in all parts of the skeleton. Besides increase in size of most bones in the body, the succeeding descendants walked more and more upon the ends of the toes. Since the series began by having the middle digit the longest, this digit gradually assumed the weight of the body.

The arched back likewise became straight, and the molar teeth changed from a rooted, low-crowned, cement-free type adapted only to browsing, to one growing until an advanced age and hence 


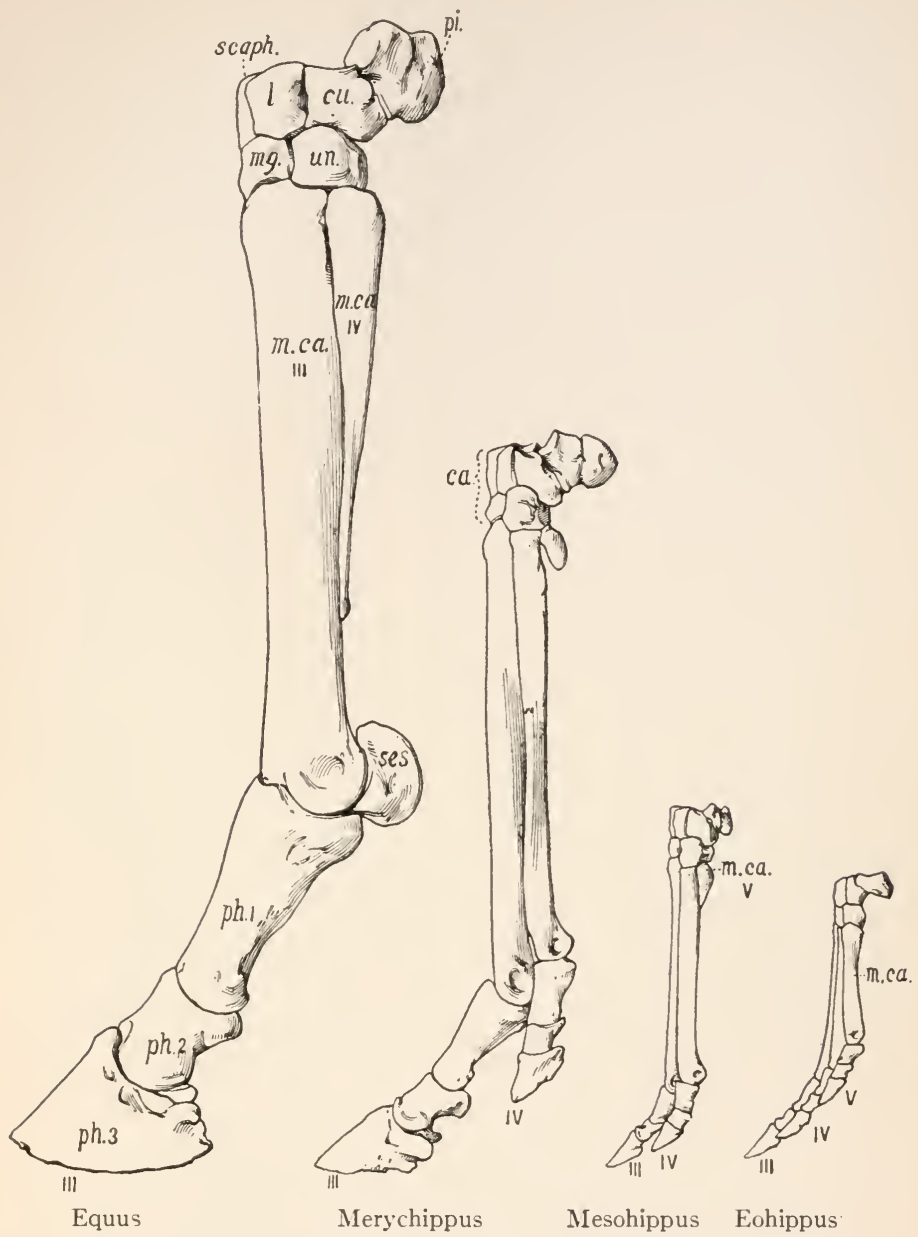

FIG. 175. - Evolution of the horse. III. The left fore foot (viewed from the left side) of the one-toed Lpper Pliocene, Pleistocene and modern horse, Equus, the three-toed Miocene horse Merychippus, the three-toed Oligocene horse, Mesohippus and the four-toed Eocene horse, Eohippus. All are drawn to same scale. According to Scott (see Fig. I 72) the toes should be almost horizontal. ca., carpal (wrist) bones; cu., cuneiform; l., lunar; $m . c a ., I I I, I V$ and $V$, metacarpal three, four and five; mg., magnum; $p h .1,2$ and 3 , proximal, middle and terminal (ungual) phalanges; pi., pisiform, - the ulnar sesamoid bone developed in the tendon of the flexor muscle; ses., the sesamoid bone developed in the tendon behind the junction of the metacarpal and phalanges; un., unciform; III, IV, $\mathrm{V}$, the digits. (After Matthew.) 
high-crowned, usually without roots, and cement-covered. This type of tooth is well fitted for grazing, for the soft cement and hard enamel are folded down into the dentine, which is intermediate in hardness, and consequently the grinding surface is always rough from the projecting enamel ridges (compare with Fig. 168). During the Pliocene and Pleistocene (Fig. I64, 6) Equus migrated from America into all other continents except Australia, over the land connections then existing. It had, however, become extinct in North and South America before the time of Columbus; all wild horses here are escaped descendants of those brought in by European explorers.

The evolution of the horse thus occurred upon the North American continent in the era immediately succeeding its elevation from the Cretaceous seas. At the beginning of this Cenozoic Era the warped land surface was necessarily occupied by many swamps, lakes and aggrading stream beds. Later, the filling up of these depressions, accompanied by the growing aridity produced by the increasing elevation of the land to mountain heights, led to the drying up of many water courses and to the necessity of greater speed in the inhabitants to reach food and water. The incoming of the more siliceous grasses about the middle of this era, which adapted themselves to this more arid climate, placed a premium also upon longer and better grinding teeth.

(9) Ancylopoda (Eocene to Pliocene), a primitive sub-order closely related to the Perissodactyla, and widely distributed over most of the world.

(ro) The Artiodactyla (Lower Eocene to present). In these, the even-toed ungulates, the third and fourth toes of both fore and hind feet are the longest and are of equal size (whence the name from Greek artios, even, +dactylos, a finger). The plane of symmetry of the foot passes between the third and fourth digits. In the earlier forms the grinding teeth are low-crowned and tuberculate; later (in cattle and antelopes) these tubercles unite to form continuous crescents, and the crown becomes almost as 
high as in the horses among the Perissodactyla. Pigs, dating from the Middle Eocene, are the least modified descendants of the early Artiodactyla; even the canine teeth are pretty well retained. True pigs (Sus), known from the Miocene to present, had, up to the time of Columbus, always been confined to Eurasia and Africa. Another very primitive family, that of the Hippopotami, now confined to Africa but formerly found throughout Eurasia and Africa, has thus far been traced back only to the Upper Miocene.

It is likely that all lower Tertiary Artiodactyla, like the primitive existing forms noted above, possessed a simple stomach and did not chew the cud; this power was probably accompanied by the development of the crescent-shaped ridges, so characteristic of modern ruminants. An example of primitive, possibly transitional, ruminants is seen in the extinct family of the oreodonts ranging in time from the Upper Eocene to the Lower Piiocene and confined to North America; these were very numerous, not larger than a sheep, with four functional toes upon each foot and a very long tail ; the genus Oreodon is confined to the Oligocene. The family of camels (camels, llamas, etc.) was evolved upon the continent of North America from primitive Upper Eocene forms; they were very abundant here during the Oligocene and Miocene. During the Pliocene they migrated into South America, Asia and Africa, where they exist to the present, but they disappeared from their native home during the Pleistocene.

In the following forms, - the true ruminants, the upper incisors are always absent, and likewise usually the upper canines. North America played a very insignificant rôle in the evolution of these forms. In the solid-horned ruminants (giraffes and deer) the usually branched horn, an outgrowth of the frontal bone, is shed each year; it usually increases in size and number of branches with each renewal. The giraffes (Pliocene to present), now confined to Africa, were formerly present also in Eurasia; they never had any representatives in the Western 
Hemisphere. The deer family has been present in the Northern Hemisphere since the Oligocene (Fig. I64, 3). In the hollowhorned ruminants (antelopes, sheep, oxen, etc.) the unbranched horn covers a solid bony outgrowth of the frontal bone; it is usually present in both sexes and is never shed, except in the pronghorn antelope of western North America, which species is similarly exceptional in having branched horns. The sheep and goat sub-family dates from the Upper Miocene of Europe; they had reached Asia and Africa by the Pliocene, but North America only in recent times. Domestic cattle (Bos) have been found in Asia from the Pliocene, in Europe since the Pleistocene, brought in by man, and in America since recent times only. The bison is known from the Pleistocene to the present in North America and Europe. The solid-horned and the hollow-horned ruminants diverged from a common stock in the Oligocene.

\section{Order 9, Sirenia (Sea Cows)}

Aquatic mammals, with a moderate-sized head, a fish-like body, front limbs paddle-like, hind ones absent and a horizontally expanded tail fin. Pelvic bones vestigial.

This order of sea cows, a highly modified offshoot of the ungulates, is probably of African origin. It is first recognized from the Eocene of Egypt and the West Indies; later it occurs also in Europe and America. During the Pliocene and Pleistocene it was abundant upon both the Atlantic and Pacific coasts of North America. At present it is represented by the dugong of the Indian Ocean and the manatee of the rivers of northeastern South America and western Africa. The sea cows and the elephants may possibly have a similar origin, both being derived from a form closely allied to the mid-Eocene Mœritherium (Fig. I69).

\section{Order io, Cetacea (Whales)}

Aquatic mammals, with a large head, fish-like body, front limbs paddle-like, hind ones absent and a horizontally expanded tail fin. Vestiges of pelvic bones present. 
These are probably descended from the unguiculates. They include :-

(I) Zeuglodontia, - primitive Eocene whales with certain characters which are transitional to primitive Carnivora. The typical genus Zeuglodon has been found in the Upper Eocene of North America, Europe, North Africa and in probably equivalent strata of New Zealand.

(2) Odontoceti, - toothed whales, including (a) squalodonts, confined to the Middle Tertiary; $(b)$ dolphins, porpoises, etc., not known in the fossil state; $(c)$ narwhals, not known in the fossil state; $(d)$ sperm and beaked whales, - Upper Eocene to the present.

(3) Mystacoceti - whale-bone whales, including the gray, fin, hump-backed and right whales and the rorquals - are known from the Miocene to the present.

\section{Order II, Primates}

Arboreal, or bipedal walking mammals, with thumb and often great toe opposable to the other digits. Digits usually five and provided with flat nails, very rarely with claws. Eye surrounded by a complete bony ring.

The primitive forms of the Primates are related to the Insectivora of the unguiculate section of mammals. Sub-order (I) Lemuroidea (Lower Eocene to present) includes the extinct families Notharctidæ and Anaptomorphidæ, both Lower to Upper Eocene of North America and Europe. The surviving family of Lemuridæ, the lemurs, has been found in the fossil state only since the beginning of the Pleistocene.

Sub-order (2) Anthropoidea (Lower Miocene to the present) includes (a) the "broad nostril" or New World monkeys of South America to Mexico; examples of these are the marmosets, not known in the fossil state, the capuchins, the howlers, spider and squirrel monkeys, some of which are known as fossils from the Pleistocene; (b) the "narrow nostril" or Old World 
monkeys, the anthropoid apes and man. The first, or the family Cercopithecidæ, includes the extinct Oreopithecus (Middle Miocene of Europe) and the living baboons, macaques and langurs. The anthropoid apes, or the family Simiidæ, include the extinct Pliopithecus (Lower Miocene to Lower Pliocene) and Dryopithecus (Middle to Upper Miocene) of Europe, and the four living anthropoid apes, the gibbon (Hylobates), the orang-utan (Simia), the gorilla (Gorilla) and the chimpanzee (Anthropopithecus). Finally the family Hominidæ, or man, includes the extinct Sussex man (Eoanthropus dawsoni), the Heidelberg man (Homo heidelbergensis) and the Neanderthal man (Homo primigenius), all from the Pleistocene, as well as modern man, Homo sapiens.

I. Define Mammalia. What is the significance of the name?

2. What are the placental mammals? Why so called?

3. In what ways do the mammals represent an advance upon the reptiles? Your reasons?

4. Into what various habitats have mammals diverged?

5. Since the beginning of the Tertiary thousands of species of mammals have become extinct and many others have disappeared from a former habitat. Give some probable causes of such extinction, especially during $(a)$ the Pliocene and $(b)$ the Pleistocene.

6. Show that the three sub-classes of the mammals represent an ascending series.

7. Enumerate the orders of mammals, giving a living and a fossil example of each where possible, and the significance of the names.

8. Give the geologic range of the Monotremata; the Marsupialia.

9. What marsupials exist outside the Australian region? Where?

ı. Define Cheiroptera, giving geologic range.

II. What are the Carnivora? Distinguish their three divisions, giving an example under each, stating likewise the geologic range of each.

I 2. How are rodents distinguished? Give the significance of the name; the geologic range.

I3. Under what order has Glyptodon been placed? Why? 
I4. Define the order Ungulata. Distinguish them from Unguiculata.

I5. In what part of the Tertiary were the hoofed and clawed mammals very similar in appearance?

I6. What were the primitive Ungulata like? The incoming of what food aided largely in their separation into browsing and grazing types?

I7. Enumerate the ten sub-orders of ungulates with an example and the geologic range of each.

I8. Give briefly the evolution of the elephant. Distinguish between archaic and modern characters.

I9. Describe the most conspicuous species of elephant in North America during the Upper Tertiary and Pleistocene.

20. How is the migration of animals brought about? How does the present distribution of a form give us knowledge of former geographic conditions?

2I. Distinguish between the tooth of a true elephant (Elephas) and that of the more primitive mastodon.

22. What sub-order of ungulates in South America paralleled the horses in their development? In what respects?

23. What is the significance of the name Perissodactyla? Why applied to this sub-order?

24. Briefly trace the evolution of the horse. Upon what continent did this probably occur?

25. Make sketch to show why the horse's tooth (also elephant's tooth) is so well adapted to grinding hard grasses.

26. What genus of Perissodactyla was one of the largest of ungulates?

27. What is the significance of the name Artiodactyla? Why applied to this sub-order?

28. What are the least modified descendants of the Artiodactyla? Why?

29. Why is it thought that the Lower Tertiary representatives of this sub-order did not chew the cud?

30. Distinguish between the molar teeth of the horse and those of a ruminant like the cow.

3I. What difference between solid-horned and hollow-horned ruminants? Examples of each. When were these groups probably united?

32. When and upon what continent did the evolution of the camels take place?

33. What are sea cows? Their probable origin? 
34. Name the three classes of whale with an example of each. From what forms may they possibly be descended?

35. Define the order Primates. Give the sub-orders into which they are divided with an example and geologic range of each.

36. Name some of the primitive characters of the genus Homo.

37. Name three generalized types and the lines of descent which diverged from them.

I. Distinguish the Chordata from Invertebrata.

2. Why is the name Chordata used for this phylum?

3. Which alone of the three sub-phyla has known fossil representatives?

4. What is the significance of the term Vertebrata for the members of this sub-phylum?

5. Name the phyla into which animals are divided, giving the bases of this classification. How does this increase in complexity of organization correspond to the order of their appearance in geologic time? 


\section{BIBLIOGRAPHY}

(Reference to these works in the text is made by number.)

\section{GENERAL}

i. Arnold, A. F., "The Sea Beach at Ebb Tide." The Century Co., I 903.

(A popular guide to the study of marine seaweeds and invertebrates.)

2. Davenport, C. B. and G. C., "Introduction to Zoölogy." I 900 .

(Excellent for forms common to Long Island Sound.)

3. Chamberlin and Salisbury, "Geology." 3 vols., Henry Holt \& Co., 1906.

(Excellent for giving a general survey of the faunas and floras of successive geologic periods.)

4. Grabau, A. W., "Principles of Stratigraphy." A. G. Seiler \& Co., N. Y., I9I3.

(Considers the relation of plants and animals to stratigraphic deposits.)

5. Grabau, A. W., and Shimer, H. W., "North American Index Fossils." 2 vols., A. G. Seiler \& Co., I909-19ro.

(A description of the more common fossil invertebrates of North America.)

6. Korschelt, E., and Heider, K., "Text Book of the Embryology of Invertebrates." 4 vols., I899.

7. Le Conte, J., "Outlines of the Comparative Physiology and Morphology of Animals." D. Appleton \& Co., I900.

(Includes both invertebrates and vertebrates.)

8. LuCAS, F. A., "Animals before Man in North America." D. Appleton \& Co., 1902.

(An excellent popular presentation of ancient animal life.)

9. Parker, T. J., and Haswell, W. A., "Text Book of Zoölogy." Vol. I, Macmillan \& Co., I897.

(A good reference zoölogy.) 
го. Scotr, W. B., "An Introduction to Geology." The Macmillan Co., 1908 .

(Gives a very good summary of historical geology.)

Ioa. U. S. Bureau of Fisheries, Washington, D. C., and various state organizations of sinilar names have many free publications full of information of the highest value.

I I. Woods, H., "Elementary Paleontology" (Invertebrate). Cambridge Univ. Press, I 896 .

I2. Zittel, K. A. von, "Text Book of Paleontology" (Invertebrata). Ed. by C. R. Eastman, ed. 2, 1913.

(A standard reference and textbook on invertebrate paleontology.)

\section{PROTOZOA}

I3. Calkins, Gary N., "Protozoölogy." N. Y., ig09.

14. Cushman, J. A., "A Monograph of the Foraminifera of the North Pacific Ocean.” U. S. Nat. Mus. Bull. 7 I, I9Io.

I 5. Jennings, H. S., "Behavior of the Lower Organisms." Columbia Univ. Press, I 906.

\section{SPONGES}

i6. Hall, J., and Clarke, J. M., "The Paleozoic Dictyospongidæ.” N. Y. State Museum, Mem. 2, I 898 .

I7. Minchin, E. A., The Porifera. "A Treatise on Zoölogy." El. by Lankester, pt. 2, A. \& C. Black, London, I9oo.

\section{COLENTERATA}

I8. Bourne, G. C., "The Anthozoa." Zoölogy, ed. by Lankester. pt. 2, I900.

I9. Fowler, G. H., "The Hydrozoa." Zoölogy, ed. by Lankester pt. 2, I900.

20. Ruedemann, R., "Graptolites of New York." N. Y. State Mus., Mem. 7, I904, and II, I908.

\section{ECHINODERMATA}

2i. Bather, F. A., Echinoderma. "A Treatise on Zoölogy." Ed. by Lankester, pt. 3, I 900.

22. Jackson, R. T., "Phylogeny of the Echini." Mem. Bos. Soc. Nat. Hist., vol. 7, I 9 I 2. 
23. Wachsmuth, C., and Springer, F., "The Crinoidea Camerata of North America." Mem. Mus. Com. Zoöl., vols. 20, 2 I, I897.

\section{MOLLUSCOIDEA}

24. Conklin, E. G., "The Embryology of a Brachiopod, Terebratulina septentrionalis, Couthouy." Proc. Am. Philos. Soc., vol. 4I, I902.

25. Hall, J., and Clarke, J. M., "An Introduction to the Study of Brachiopods." N. Y. State Geol. Ann. Rep. i I.

(Excellent discussion of Paleozoic brachiopods.)

26. Morse, E. S., "Observations on Living Brachiopoda." Mem. Bost. Soc. Nat. Hist. 5, I902.

27. Ulrich, E. D., and Bassler, R. S. "Revision of the Paleozoic Bryozoa." Smith. Misc. Coll., vols. 45-47, I904.

\section{MOLLUSCA}

28. Belding, D. L., "A Report upon the Quahog and Oyster Fisheries of Massachusetts." Mass. Fish and Game Comm., i 9 I 2.

(Includes anatomy, development and habits of Venus mercenaria.)

29. Griffin, L. E., "Anatomy of Nautilus pompilius." Mem. Nat. Acad. Sci., vol. 8, rgoo.

30. JAckson, R. F., "Phylogeny of the Pelecypoda." Mem. Bost. Soc. Nat. Hist., vol. 4 , I 890 .

3i. Pelseneer, G., Mollusca. "A Treatise on Zoölogy," ed. by Lankester, pt. 5, 1906.

(Detailed anatomy of mollusks in general.)

\section{ARTHROPODA}

32. Clarke, J. M., and Ruedemanx, R., "The Eurypterida of New York." N. Y. St. Mus., Mem. I 4.

33. Calman, W. T., "The Crustacea." Zoölogy, ed. by Lankester, pt. 7, I909.

34. PaCkARD, A. S., "The Anatomy, Histology, and Embryology of Limulus polyphemus." Mem. Bost. Soc. Nat. Hist., I880. 


\section{CHORDATA}

35. DeAn, B., "Fishes, Living and Fossil." Macmillan \& Co., I 895. 36. Osborn, H. F., "The Age of Mammals in Europe, Asia and North America." The Macmillan Co., I9ıo.

37. Parker, T. J., and Haswell, W. A., "Text Book of Zoölogy." Vol. 2, Macmillan \& Co., I897.

38. Reighard, J., and Jennings, H. S., "Anatomy of the Cat." Henry Holt \& Co.

39. Scotr, W. B., "History of Land Mammals in the Western Hemisphere." The Macmillan Co., I9I3.

40. Seeley, H. G., "Dragons of the Air." D. Appleton \& Co., I9or. (A popular account of extinct flying reptiles.)

4I. Wiedersheim, R., "Comparative Anatomy of Vertebrates." Macmillan \& Co., I907.

42. Woodward, A. S., "Vertebrate Paleontology:" Cambridge Univ. Press, I898.

43. Zittel, K. A. von, "Text Book of Paleontology" (Vertebrata).

Ed. by C. R. Eastman, Macmillan \& Co., I902.

(Includes fish, amphibians, reptiles and birds.)

\section{PLANTS}

44. Atkinson, G. F., "Elementary Botany." Henry Holt \& Co., I 898 .

(Excellent for laboratory work.)

45. Coulter, J. M., Barnes, C. R., and Cowles, H. C., "A Text Book of Botany." American Book Co., r9ıо.

46. Curtis, C. C., "Nature and Development of Plants." Henry Holt \& Co., I907.

47. "Funafuti, The Atoll of." Roy. Soc. London, I904.

(Observations on a typical coral reef.)

48. Scotт, D. H., "The Evolution of Plants." Henry Holt \& Co., I9I I.

49. Scotт, D. H., "Studies in Fossil Botany." A. and C. Black, I900. (Pteridophytes to Gymnosperms, inclusive.) 
AN INTRODUCTION TO THE STUDY OF FOSSILS 407.

GEOLOGIC TIME SCALE

ERA

Cenozoic

Mesozoic

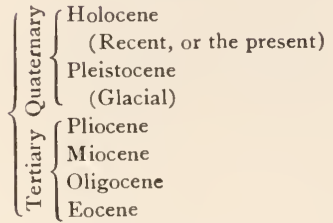

Paleozoic $\quad\left\{\begin{array}{l}\text { Permian } \\ \text { Pennsylvanian } \\ \quad \text { (Upper Carboniferous) } \\ \text { Mississippian } \\ \quad \text { (Lower Carboniferous) } \\ \text { Devonian } \\ \text { Silurian } \\ \text { Ordovician } \\ \text { Cambrian }\end{array}\right.$

Pre-Cambrian

(Many Geologists use the Period Names as Follows)

Holocenic

Pleistocenic

Pliocenic

Miocenic

Oligocenic

Eocenic

Cretacic

Comanchic

Jurassic

Triassic

Permic

Pennsylvanic

Mississippic

Devonic

Siluric

Ordovicic

Cambric

Pre-Cambric 


\section{TABULAR VIEIV OF THE PLANT KINGDOM}

\begin{tabular}{|c|c|c|c|c|c|}
\hline & Division & & $\begin{array}{l}\text { SUBDIVISION, } \\
\text { LASS OR ORDER }\end{array}$ & RANGE & $\begin{array}{l}\text { Common Name } \\
\text { OR EXAMple }\end{array}$ \\
\hline \multirow{2}{*}{ IV. } & \multirow{2}{*}{$\begin{array}{l}\text { Spermatophyta } \\
\text { (Seed-plants) }\end{array}$} & 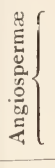 & $\begin{array}{l}\text { Dicotyledones } \\
\text { Monocotyledones }\end{array}$ & $\begin{array}{l}\text { Comanchean to present } \\
\text { Comanchean to present }\end{array}$ & $\begin{array}{l}\text { oaks } \\
\text { grasses }\end{array}$ \\
\hline & & 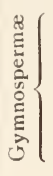 & $\begin{array}{l}\text { Gnetales } \\
\text { Coniferales } \\
\text { Ginkgoales } \\
\text { Cordaitales } \\
\text { Cycadales } \\
\text { Cycadofilicales }\end{array}$ & $\begin{array}{l}\text { (Fossil record scant) } \\
\text { Permian to present } \\
\text { Permian to present } \\
\text { Devonian to Permian } \\
\text { Permian to present } \\
\text { Devonian to Jurassic }\end{array}$ & $\begin{array}{l}\text { Ephedra } \\
\text { pines } \\
\text { Ginkgo } \\
\text { Cordaites } \\
\text { cycads } \\
\text { Neuropteris }\end{array}$ \\
\hline III. & $\begin{array}{l}\text { Pteridophyta } \\
\text { (Fern-plants) }\end{array}$ & & $\begin{array}{l}\text { Lycopodiales } \\
\text { Equisitales } \\
\text { Sphenophyllales } \\
\text { Filicales }\end{array}$ & $\begin{array}{l}\text { Devonian to present } \\
\text { Devonian to present } \\
\text { Devonian to Permian } \\
\text { Devonian to present }\end{array}$ & $\begin{array}{l}\text { club mosses } \\
\text { horsetails } \\
\text { Sphenophyllum } \\
\text { ferns }\end{array}$ \\
\hline II. & $\begin{array}{l}\text { Bryophyta } \\
\text { (Moss-plants) }\end{array}$ & & $\begin{array}{l}\text { Musci } \\
\text { Hepaticæ }\end{array}$ & $\begin{array}{l}\text { Tertiary to present } \\
\text { Tertiary to present }\end{array}$ & $\begin{array}{l}\text { mosses } \\
\text { liverworts }\end{array}$ \\
\hline & $\begin{array}{l}\text { Thallophyta } \\
\text { (Thallus-plants) }\end{array}$ & & $\begin{array}{l}\text { Fungi } \\
\text { Algæ } \\
\text { Diatomeæ } \\
\text { Schizophyta } \\
\text { Myxomycetæ }\end{array}$ & $\begin{array}{l}\text { Silurian to present } \\
\text { Pre-Cambrian to present } \\
\text { Jurassic to present } \\
\text { Pennsylvanian to present } \\
\text { (Fossil record lacking) }\end{array}$ & $\begin{array}{l}\text { fungi } \\
\text { seaweeds } \\
\text { diatoms } \\
\text { bacteria } \\
\text { slime-molds }\end{array}$ \\
\hline
\end{tabular}




\section{TABULAR VIEW OF THE ANIMAL KINGDOM}

\begin{tabular}{|c|c|c|c|c|}
\hline \multicolumn{2}{|l|}{ Phylum } & Class & \multirow{2}{*}{\begin{tabular}{l}
\multicolumn{1}{c}{ RAxGE } \\
Triassic to present \\
Jurassic to present \\
Pennsylvanian to present \\
Devonian to present \\
Silurian to present \\
Ordovician through Dev'n \\
Devonian ? to present \\
(Fossil record lacking) \\
(Fossil record lacking) \\
(Fossil record lacking)
\end{tabular}} & \multirow{2}{*}{$\begin{array}{l}\text { COMMON NAME } \\
\text { OR EXAMPLE } \\
\text { mammals } \\
\text { birds } \\
\text { reptiles } \\
\text { amphibians } \\
\text { fish } \\
\text { shield-fish } \\
\text { lamprey-eels } \\
\text { Amphioxus } \\
\text { Balanoglossus } \\
\text { ascidians }\end{array}$} \\
\hline XII. Chordata & 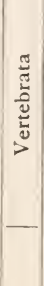 & $\begin{array}{l}\text { Mammalia } \\
\text { Aves } \\
\text { Reptilia } \\
\text { Amphibia } \\
\text { Pisces } \\
\text { Ostracodermi } \\
\text { Cyclostomata } \\
\text { Acrania } \\
\text { Urochorda } \\
\text { Adelochorda }\end{array}$ & & \\
\hline XI. Arthropoda & & $\begin{array}{l}\text { Insecta } \\
\text { Arachnida } \\
\text { Myriopoda } \\
\text { Onychophora } \\
\text { Crustacea }\end{array}$ & $\begin{array}{l}\text { Pennsylvanian to present } \\
\text { Cambrian to present } \\
\text { Devonian to present } \\
\text { Cambrian ? to present } \\
\text { Cambrian to present }\end{array}$ & $\begin{array}{l}\text { insects } \\
\text { spiders } \\
\text { centipedes } \\
\text { Peripatus } \\
\text { lobster }\end{array}$ \\
\hline X. Mollusca & & $\begin{array}{l}\text { Cephalopoda } \\
\text { Scaphopoda } \\
\text { Gastropoda } \\
\text { Pelecy poda } \\
\text { Amphineura }\end{array}$ & $\begin{array}{l}\text { Cambrian to present } \\
\text { Ordovician to present } \\
\text { Cambrian to present } \\
\text { Cambrian to present } \\
\text { Ordovician to present }\end{array}$ & $\begin{array}{l}\text { Nautilus } \\
\text { tooth shells } \\
\text { snails } \\
\text { clams } \\
\text { chitons }\end{array}$ \\
\hline IX. Molluscoidea & & $\begin{array}{l}\text { Brachiopoda } \\
\text { Phoronida } \\
\text { Bryozoa }\end{array}$ & $\begin{array}{l}\text { Cambrian to present } \\
\text { (Fossil record lacking) } \\
\text { Ordovician to present }\end{array}$ & $\begin{array}{l}\text { brachiopods } \\
\text { Phoronis } \\
\text { bryozoans }\end{array}$ \\
\hline VIII. Echinodermata & 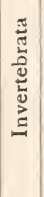 & $\begin{array}{l}\text { Holothurioidea } \\
\text { Echinoidea } \\
\text { Ophiuroidea } \\
\text { Asteroidea } \\
\text { Crinoidea } \\
\text { Blastoidea } \\
\text { Cystoidea }\end{array}$ & $\begin{array}{l}\text { Cambrian to present } \\
\text { Ordovician to present } \\
\text { Ordovician to present } \\
\text { Cambrian to present } \\
\text { Ordovician to present } \\
\text { Ordovician to Permian } \\
\text { Cambrian to Permian }\end{array}$ & $\begin{array}{l}\text { sea cucumbers } \\
\text { sea urchins } \\
\text { brittle-stars } \\
\text { starfish } \\
\text { sea lilies } \\
\text { sea buds } \\
\text { cystoids }\end{array}$ \\
\hline $\begin{array}{l}\text { VII. Annulata } \\
\text { VI. Trochelminthes } \\
\text { V. Nemathelminthes } \\
\text { IV. Platyhelminthes }\end{array}$ & & $\begin{array}{l}\text { Classes } \\
\text { are } \\
\text { omitted }\end{array}$ & $\begin{array}{l}\text { Cambrian to present } \\
\text { (Fossil record lacking) } \\
\text { Cambrian ? to present } \\
\text { Pennsylvanian to present }\end{array}$ & $\begin{array}{l}\text { segmented worms } \\
\text { wheel worms } \\
\text { thread worms } \\
\text { flat worms }\end{array}$ \\
\hline III. Cœlenterata & & $\begin{array}{l}\text { Ctenophora } \\
\text { Anthozoa } \\
\text { Scyphozoa } \\
\text { Hydrozoa }\end{array}$ & $\begin{array}{l}\text { (Fossil record lacking) } \\
\text { Cambrian to present } \\
\text { Cambrian to present } \\
\text { Cambrian to present }\end{array}$ & $\begin{array}{l}\text { comb-jellies } \\
\text { corals } \\
\text { jelly-fish } \\
\text { hydrozoöns }\end{array}$ \\
\hline II. Porifera & & Spongiæ & Pre-Cambrian to present & sponges \\
\hline I. Protozoa & & $\begin{array}{l}\text { Infusoria } \\
\text { Sporozoa } \\
\text { Mastigophora } \\
\text { Sarcodina }\end{array}$ & $\begin{array}{l}\text { (Fossil record lacking) } \\
\text { (Fossil record lacking) } \\
\text { Cretaceous ? to present } \\
\text { Pre-Cambrian to present }\end{array}$ & $\begin{array}{l}\text { infusorians } \\
\text { Gregarina } \\
\text { Euglena } \\
\text { Amœba }\end{array}$ \\
\hline
\end{tabular}





\section{INDEX - GLOSSARY}

Every reference is to the page; words in italics are names of genera and species. Figures in italics indicate illustrations; in heavy type, principal descriptions.

Abdomen, of the crayfish, 275, 276; of the horseshoe crab, 277 ; of trilobites, 286,287 .

Abdominal ganglia, in gastropods, 237 .

Abietæ, 7 I.

Absorption, of old skeleton in Crustacea, 278.

Abyssal, depths greater than roo fathoms; seas, beginning of, I9I.

Acanthodes, 342 .

Acanthodii, 342 ; fins in, 340.

Acarina, 3 I 6.

Accidents to ancient life preserved in fossils (in the turtle), 366 .

Acorn barnacle, 305 .

Acrania, 322, 323; geologic range of, 409 ; notochord in, 323 .

Actinophrys, 93.

Actinopoda, 93.

Actinopterygians, 345 ; see Actinopterygii.

Actinopterygii, 345 ; fins in, 340.

Adductor muscle, effect of loss of one upon pelecypod shell, 222 ; of brachiopods, $182, \mathbf{I} 83$; of pelecypods, 209, $2 I O, 2 I I, 214,22 I$; of phyllopods, 302.

Adelochorda, 321, 322; geologic range of, 409 ; related to annelids, Molluscoidea and Echinodermata, 322 .

Age, method of determining age of pelecypods, 215 ; of pelecypods, 2 I 8 .

Agelacrinus, I56-157; A. cincinnatiensis, I56; ambulacra of, ${ }_{5} 6$; calyx of, I 57 .

Aglaspis, 3 I I, $3 \mathbf{2} 2$.

Agnostus, $29 \mathrm{I}$.

Aigialosaurs, 367 .

Air-breathing snails, 242.

Albatross, compared to pterosaurs, 365 .

Alcyonaria, I 29, I3I, I35-138.

Alcyonium, I28.
Algæ, 35-40, I69; as rock builders, 38 ; blue-green, 33 ; brown, 36 ; doubtful, 40; geologic range of, 408 ; in sponges, 96 ; green, 27,35 ; lime carbonate in, 27; lime secretion in, 38-40; red, 27,37 ; thermal, 39 .

Alligator, 365 ; brain of young, 372; compared to fossil birds, 372 ; compared to Ichthyornis, 372 .

Alluvial fan of Newark beds, 6 .

Alternation of generation, in bryophytes, 42 ; in Hydrozoa, I I I.

Alveolus, of Belemnites, 27I, 272.

Amber, 4, 10 .

Amblypoda, 386 .

A mblystoma, 353 .

Ambulacra, of Agelacrinus, 156 ; of Asterias, I49; of Caryocrimus, I55; of cystoids, I 55, 156 ; of echinoderms, 148; of echinoids, 167,170 ; of Pentremites, I58; of starfish, I49.

Ambulacral grooves, of Asterias, I49; of Pentremites, I58, 158 ; of starfish, I 49 .

Ambulacrum, plural ambulacra.

Amia, 347.

Ammonites, 263, 272 ; see also Ammonoidea; associated with Ichthyormis, 372 . Ammonitic type of suture, 264, 266, 267,268 .

Ammonoidea, 26I, 263-268; as index fossils, 263; geologic range of, 263 .

Amnion, 335.

Amniota, 335

Amaba proteus, $84-87,85 ; A$. verrucosa, 85 ; assimilation of, 86 ; contractile vacuole of, 84 ; digestion of, 85 ; excretion of, 86 ; movement of, 85 ; nervous system of, 87 ; nucleus of, 84 ; reproduction of, 87 ; respiration of, 86 . 
Amœbea, 88.

Imphibia, 349-354; differ from fish, 349 ; geologic range of, 409 ; habitat of, 349 ; mucus-secreting glands of, 349 ; respiration of, 349 ; subdivision of, 349 .

Amphibians, see Amphibia.

Amphineura, 207-208, 208; geologic range of, 409; skeleton, etc., see chitons.

Amphioxus, 323.

Amphipoda, 307 .

Ampulla, I 50, I 5 I.

Anal fin, 376 .

Anal respiration, 304 .

Anal siphon, the exhalent or excurrent siphon.

Anaptomorphidæ, 399 .

Anaspidacea, 306.

Anatinacea, 22 I.

Ancestral characters, repetition of, see recapitulation.

Ancestry, see evolution and recapitulation.

Anchisaurus, 360.

Ancient geography, interpretation of, 23.

Ancylopoda, 396.

Ancyrocrinus, I 59.

Andrias scheuchzeri, 353.

Anelasma, 305.

Angiospermæ, 75-82 ; flower, etc., see angiosperms.

Angiosperms, 62, 75-82, 351 ; asexual stage in, 77; earliest appearance of, 77 ; fertilization in, 76, 43; flower of, 76; fossil, 77; gametophyte stage in, 77; geologic range of, 408; rapid rise of, 77 ; sexual stage in, 77 ; sporophyte stage in, 77 .

Animals, 83-402; distinguished from plants, 2, 29; evolution of, 83 ; migration of, 23,24 .

Ankle bones, see tarsal bones.

Annelids, the annulate worms, in evolution, 274 .

Annual rings in wood, 71 .

Annularia, 50; A. longifolia, 50.

Annulata, I40, I4I-I47; compared to Peripatus, 308; digestion, etc., see

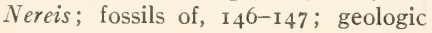
range of, 409 .
Anodonta, sex in, $22 \mathrm{I}$.

Anomodontia, 355-356; geologic range of, 356 ; intermediate position of, 356 ; teeth of, 355 .

Anomodonts, see Anomodontia.

Anteater, 382 ; spiny, 378 .

Antelopes, 398; pronghorn, 398; in North America, 375; teeth of, 396.

Antenna (plu. antennæ), of crustaceans, 276, 279, 286; of Estheria, 302; of the lobster, 279; of phyllopods, 302 ; of trilobites, 286.

Antennules, the anterior of the two pairs of feelers upon the head; of trilobites, 286, 288, 289 .

Anterior adductor muscle, 209 ; retractor muscle, 209, 2IO, 2II, 214.

Anthers, 56 .

Anthozoa, I22-138; compared with Hydrozoa, I28; digestion, etc., see Astrangia; fossils of, I3I-138; geologic range of, 409; survey of, I28I3I.

Anthracomarti, 316.

Anthropoid apes, 400; chimpanzee, 400 ; gibbon, 400; gorilla, 400; orang-utan, 400 .

Anthropoidea, 399.

Anthropoids, 399.

Ants, 3 I9; white, 3 I8.

Anura, 349, 353; development of, 353; eggs of, 353; fossil, 353 .

Aorta, in the cat, 330 ; in pelecypods, 2 I 2 .

Apes, anthropoid, 400.

Aplacophora, 208.

Appalachian Revolution, $\mathbf{1 9}$.

Appendages, of crayfish, 275-276, 276; of trilobites, 286.

Appendix, vermiform, 330 .

Aptera, 320.

A pus, 299-301; A. lucasanus, 300; appendages of, 300,300 ; blood circulation of, 301 ; compared to the crayfish, 299-300; compared to Triarthrus, 285; digestive system of, 300 ; eyes of, 300, 301 ; food of, 300; gills of, 301 ; gnathobases of, 300; habitat of, 299; heart of, 30n, 301 ; more primitive than the crayfish, 300 ; muscular system of, 300; nervous system of, 30I; relationship to trilo- 
bites, 29I, 293; reproduction of, 301 ; size of, 299; ventral nerve cord of, 300,301 .

Aquatic mammals, 374 .

Aqueous humor of eye, 334 .

Arachnida, 275, 309-316; respiration, etc., see arachnids.

Arachnids, 309-316; air-breathing, 309; evolution of, 274,310 ; evolution of respiratory organs of, 310 ; famous localities for fossil, 318; geologic range of, 409 ; relationship of, 3093 II ; respiration of, 309 ; waterbreathing, 309 .

Aragonite in animils, 25; distinguished from calcite, 26 .

Araneida, 3 I 6 .

Araucariæ, 71 ; distribution of, present and past, $7 \mathbf{I}$.

Arbacia, $\mathbf{6} 66$.

Arboreal mammals, 374 .

Arbor vitæ, 74.

Arca pexata, 220; A. transversa, 14.

Archaic characters, persistence of, with modern ones, 386 .

Archelon ischyros, 366.

Archeopteryx, 7, 370, $37 \mathrm{I}$.

Archi-annelida, 142.

Archipterygium, 345; of crossopterygii, 345, $34^{6}$; of lung-fish, $343,344$.

Argonanta, 268, 273.

Argulus, 304 .

Aridity, its bearing upon the extinction of life, 375 .

Aristotle's lantern, I68; use of, I69. A rmadillidium, 306.

Armadillos, 382 .

Arm-bone, see humerus.

Arrowhead, 272.

Arsinoitherium, 389 .

Artemia, 285, 299.

Arteries, in the arthropods, $28 \mathrm{I}$; in the mollusks, $212,237,257$; in the vertebrates, 332 .

Arthrophycus harlani, 40.

Arthropod skeleton compared with that of vertebrates, 274 .

Arthropoda, 274-320; skeleton of, etc , see arthropors.

Arthropods, 274-320; classification of, 275; descent of, 274; evolution of, 274 ; geologic range of, 400 ; in evolu- tion, 83 ; molting of, 274 ; skeleton of, 274 .

Articular bone, of birds, 37 ?; of reptiles, 367 .

Articulata (brachiopods), I89, I90, I9I, I02, 195-204

Artiodactyla, 396-398; see also artiodactyls.

Artiodactyls, 396-398; evolution of teeth of, 396; geologic range of, 396; stomach of primitive, 397 .

Ascaris lumbricoides, $\mathrm{I} 4 \mathrm{I}$.

Ascidians, 322.

Aseptata, I3I.

Asexual stage, of plants, 42 ; of pteridophytes, 45 ; of seed-plants, 56 ; of spermatophytes, 56 .

Assimilation, see also under the various classes; in Amøba, 86; in Protozoa, 86.

Astacidæ, 307 .

Astacus, 275; distinguished from Cambarus, 307 .

Asterias forbesi, I 49-154, I50, I63; A. vulgaris, $\mathrm{I} 63$; blood circulation of, I52: digestion of, I 52 ; eye of, I53; food of, I 51 ; growth of, I 53; locomotion of, I5I; method of eating, I5I ; nervous system of, 152 ; regeneration of, I53 ; reproduction of, I53 ; respiration of, 152 ; sense organs of, 153 ; skeleton, I5I; water vascular system of, 150 .

Asteroidea, I63-I65; digestion, etc. see Asterias; fossils of, I $63-\mathrm{I} 65$; geologic range of, $163,409$.

Astragalus bone, in the cat, 327 .

Astrangia dance, 122-127, 123; "blood" of, I 24 ; circulation of "blood," I 24; digestion of, I24; food of, I24; growth of colony of, 127 ; muscles of, I 24 ; nerves of, I25; polyp of, I 23 ; respiration of, I 24 ; sense organs of, I25; sexes in, I25; waste excretion of, 124 .

Astroides calicularis, $I 26$.

Astromma, 94.

Astylospongia, 97, 105; A. promorsa, Io6.

Athyris, I9o.

Atlantosaurus immanis, 36I.

Atlas bone, of the cat, 325 . 
Atremata, a subdivision of the inarticulate brachiopods characterized by absence of pedicle opening. Lingula is an example.

Atrypa, 189, 190, 202; A. reticularis, 22, I $92,202,203$.

A ulopora, 136; A. repens, 136 .

Aves, 369-373; teeth, etc., see birds.

Avicularium, I 73, 17.4 .

Aviculopecten, 231 .

Axial lobe in trilobites, 286, 287, 295.

Axis, bone of the cat, 325 .

Axonolipa, I I6, I 18.

Axonophora, I 16, I 18.

Baboons, 400 .

Back, see lumbar.

Backbone, of birds, 372; of cat, 324 . 325,326 ; of fish, 346,348 ; of reptiles, $358,360,362,367$.

Bacteria, 6, 33; absence of chlorophyl in, 3 ; food getting in, 29.

Bactrites, 263-264; B. gracilior, 264; transitional characters of, $26 \mathrm{I}$.

Baculites, 267; B. compressus, 267, 268.

Balancing organs, see otocysts and semicircular canals.

Balanoglossus, 322, 409.

Balanus, 305; B. balanoides, 306.

Bald cypress, 73, 74; distribution of, present and past, 73 .

Ball-and-socket joints, of echinoids, I 68 ; of vertebrates, 328 .

Banana, 78 .

Bandicoots, 378 .

Barbados earth, 94.

Barnacles, I 5I, 305-306; acorn, 305; degeneracy of, 305; fossils of, 305 ; geologic age of, 305; goose, 305; habitat of, 305 ; ship, 305 ; skeleton of, 305; young compared to adult ostracod, 305 .

Basal plates, of blastoids, 158 ; of corals, I 25, 126.

Basihyoid, bone of the cat, 325 .

Batocrinus, 149 .

Bats, 379; fruit-eating, 379; geologic range of, 379 ; habitat of, 374 ; insecteating, 309 .

Bdellostoma, 323 .

Beak, of brachiopod shells, I83, I88; of pelecypod shells, 2 I 6 .
Bear, arrival in North America, 375.

Bear tribe, $38 \mathrm{I}$.

Beavers, 381, 382, 383 ; habitat of, 374 .

Beech, 77.

Beekmantown formation, fossils from, 37 ; geologic age of, 37 .

Bees, 78, 319 .

Beetles, 318, 319 .

Belemnites, 269, 271-272, 27I; $B$. densus, 27I; as an index fossil, 272 ; compared to the squid, 27I; food of ichthyosaurs, 358; funnel of, $27 I$; guard of, 27I, 27I; phragmocone of, 271,272 ; proöstracum of, 27I, 272; protoconch of, 271 ; restoration of, 271 ; siphuncle of, 271,272 ; skeleton of, $27 \mathrm{I}-272,271$; sutures of, 271 .

Belemnoids, including forms like $\mathrm{Bel}$ emnites, restoration of, I8; siphuncle of, $26 \mathrm{r}$.

Belinurus, 3 I I, $3 \mathbf{2} 2$.

Bellerophon, 244, 245.

Belodon, 365.

Bennettites, 65 .

Bertie formation, fossils from, 315 ; geologic age of, 3 I 5 .

Big trees, 73.

Bilateral symmetry, with the individual parts arranged symmetrically along the two sides of an elongate axis as in the earthworm, cat, etc.

Biogenetic law, see recapitulation.

Birch, 77.

Bird lice, 3 I 8 .

Birds, 369-373 ; ankle-joint of, 374 ; bones hollow, 369 ; cervical vertebræ in, 326; comparison of respiration to that of insects, 370; development of egg, 370; development of feathers, 369 ; evolution in, 37I ; evolution of, 372 ; exoskeleton of, 369 ; fossil, 37 I- $^{-}$ $373,370,372$; geologic range of, 409; gizzard of, 369 ; lungs of, 370 ; migration of, 370 ; number of digits in, 328 ; respiration of, 369 ; sclerotic plates in, 335 ; teeth of, 369,372 .

Bison, 398; arrival in North America, 375.

Bizarre forms, in evolution, 363 .

Bladder, of pelecypods, $2 \mathrm{I}_{3}$; of vertebrates, 330 .

Blastoidea, I57-r59; see blastoids and Pentremites. 
Blastoids, I57-I59; calyx, etc., see Pentremites; geologic range of, 409.

Blastopore, I I I ; of Hydrozoa, I I I.

Blastula, in brachiopods, 186 ; in corals, I25; in crustaceans, 283 ; in hydrozoöns, III; in pelecypods, 216 ; in sponges, I0I.

Blattoidea, $3 \mathbf{1} 8$.

Blenny, 339 .

Blind crayfish, 27.5 .

Blind trilobites, 291.

Blood, of crustaceans, $28 \mathrm{I}$; of gastropods, 242; of vertebrates, 332, 333 .

Blood circulation, see under the separate classes.

Blood sinuses, 28r .

Blue crab, 307.

Blue-green algæ, 33 .

Bone, composition of, 324; compared to slag, Io; formation of, I ; phosphoric acid in, 26.

Bony fishes, 344-348.

Bony plates, of Stegosaurus, 362 .

Book-gills, 309 ; evolution of, 3 ro.

Book lice, 3 I 8 .

Book-lungs, 309 ; evolution of, 3 Io.

Bos, 398.

Brachia, I82, I82, I84, I92, 193.

Brachial valve, $182, I 82, I 88$; distinguished from pedicle valve, 189 ; secretion of, I89.

Brachidium (plu. brachidia), I8I, 182 , I84, 20.4.

Brachiopoda, I 8I-204; fossils of, etc., see brachiopods.

Brachiopods, I 8I-204; classification of, I 92 ; composition of shell of, 25, 26, I87, I93; development of, I86; distribution of, in space, 190 ; food of, etc., see Terebratulina; fossils of, I 92-204; geologic range of, I92, 409; habitat of, I9I ; living, I9I ; longlived, I92; movement of, I0.3; persistence in time, 192 ; retrogression in, I90; short-lived, I92; size of, I9I; survey of, $187-192$; use of, in ancient geography, I9I; young stages in growth of, 197.

Brachiopod shells, composition of, 187 , I93; distinguished from pelecypod shells, 190; fungi in, 40.

Bradypodidæ, 382 .
Brain, function of, in preservation of species, 374, 375; of alligator, 372 ; of Annulata, I45; of Brontotherium, 375 ; of cat, 330,333 ; of Chordata, 321 ; of crustaceans, 282, 279; of Equus, 375; of horse, 375; of Ichthyornis, 372; increase in size of during the Tertiary, 375; of lobster, 279 ; of mammals, 330,333 ; of tern, 372 ; of Uintatherium, 375 ; of ungulates, comparison, 375 .

Brain-coral, 130.

Braintree slates, fossils from, 295; geologic age of, 295 .

Branchiæ, 274.

Branchial, pertaining to the branchiæ, or gills.

Branchial chamber, in pelecypods, 2 Io.

Branchial clefts, gill-slits, 32 I.

Branchial siphon, incurrent siphon.

Branchiata, 274.

Branchionus, I4I.

Branchiosaurus, 352 .

Branchipus, $285,303$.

Breast bone, see sternum.

Bridger formation, fossils from, 379,380 ; geologic age of, 379,380 .

Brine shrimp, 285 .

Brittle stars, 165 .

Brontosaurus, 360, 361 ; B. excelsus, 361 ; food supply of, 361 .

Brontotherium gigas, 39I; B. ingens, 375; skull and brain of, 375; herd of, 391 .

Brooksella alternata, 122 .

Bryophyta, f., 45; see bryophytes.

Bryophytes, 42, 43, 44, 45; classification of, 44; geologic range of, 408 .

Bryozoa, classification of, 177 ; digestion, etc., see Bugula; fossil, I77-180; geologic range of, 177,409 ; survey of, I 76 .

Buccal cavity of Busycon, 236.

Budding, in ascidians, 322 ; in Chordata, 322 ; in corals, 127 ; in hydrozoöns, I 10; in sponges, 96 .

Bugs, 320.

Bugula avicularia, $\mathbf{1 7 3 - 1 7 6 , ~ I 7 4 ; ~} B$. turrita, I73; chitin in, I74; digestive system of, I74; embryo of, I76; excretion of waste of, 175 ; introvert of, I74, I77; lophophore of, I75, 174; 
nervous system of, I75; protection of, I74; reproduction of, I76; respiration of, I75; tentacles of, 174, I 75 .

Bulk, excessive, in the extinction of species, 374.

Burgess formation, fossils in, 285,308 ; geologic age of, 285 .

Burlington formation, fossils from, 180 ; geologic age of, 180 .

Burrows, 16.

Busycon, 234-241 ; B. canaliculatus, 234-24 I, 235, 238, 239 ; blood circulation of, 237 ; columella of, 238,239 ; development of, 239 ; digestion of, 237 ; digestive system of, 236 ; egg capsule of, 239, 239; embryos of, 239; excretion of, 237 ; eyes of, 238 ; food of, 237 ; foot of, 238 ; habitat of, 234 ; heart of, 237 ; introvert of, 236 ; muscles of, 238 ; nervous system of, 237 ; operculum of, 235,239 ; osphradium of, 238 ; otocysts of, 238 ; protoconch of, 239,240 ; respiration of, 235 ; sexes of, 239; shell of, 235, 238,238 ; siphon of, 235,235 ; survival of young of, 240 ; type of Streptoneura, 244.

Butterflies, 78, 319, 319 .

Byssus, 217.

Cæcum (plu. cæca), a cavity open at one end, 184, I88; of cat, 330 ; of cephalopods, 256; of crustaceans, 279; of lobster, 279; use of, 184 .

Canolestes, 378 .

Calamites, 2I, 48, 49-50, 350; C. suckowi, 49.

Calamoichthys, 345 .

Calcaneum, of cat, 325,327 ; of mammals, 325,385 .

Calcarea, 98, 102.

Calcareous algæ, 37-40.

Calcite, distinguished from aragonite, 26 ; in animals, 25 .

Calcium carbonate, in corals, $\mathbf{I} 25$.

Calicoblasts, I 25 .

Callinectes hastatus, 307; C. sapidus, 307.

Callixylon oweni, 68.

Callosity, a hardening and thickening of the skin or bark due to friction.

Callus, in gastropods, 243.
Calvert formation, fossils from, $34,34^{2}$; geologic age of, 34,342 .

Calymene, 297-298; C. niagarensis, 297, 298 ; enrollment of, 291 ; eyes of, 292.

Calyx (plu. calices), according to derivation a husk or covering; of Caryocrinus, I55; of corals, I26, 132 ; of crinoids, 163 ; of cystoids, 154,155 ; of plants, 76 .

Cambarus, 275-284, 307; C. bartoni, 276; absorption in, 28I ; appendages of, 275,276 ; blood circulation of, $28 \mathrm{I}$; blood of, 28I ; body of, 275; carapace of, 277 ; development of, 283 ; digestive system of, 280; distinguished from Astacus, 307; eggs of, 283; excretion of, 282 ; extent of chitinous skeleton, 277; eyes of, 282 ; food of, 280 ; habitat of, 275 ; molting of, 277-278; muscles of, 278 (compare 279) ; nervous system of, $282-283$; reproduction of, 283 ; respiration of, 281 ; sense organs of, $282-283$; skeleton of, 276-277; smell in, 283 ; stomach of, 280; touch, sense of, 282 .

Cambrian, 407.

Cambrian fossils figured, 37, 122, 295.

Camels, 397; causes of extinction of, 375; evolution of, in North America, 397 ; in North America, 375 ; number of digits in, 328 .

Camptopteris, 47.

Canidæ, $38 \mathbf{r}$.

Canine teeth, of the cat, $33 \mathbf{r}$.

Capillaries, 332 ; of crustaceans, $28 \mathbf{r}$.

Capuchins, 399 .

Carapace, of the crayfish, 275, 276, 277; of turtles, 365,366 .

Carbon dioxid, in $A m a b a, 86$; in cat, 333 ; in plants, 29 ; in Protozoa, 86.

Carboniferous, 407.

Carboniferous fossils figured, 49, 50, $52,54,55,57,58,91,158,170,180$, I88, 199, 265, 350 .

Carbonization, I3; process of, 13 .

Carcharodon, 342 ; C. megalodon, 342.

Cardiidæ, 221.

Cardinal, pertaining to the hinge.

Cardinal area, $\mathbf{I} 88$.

Cardinal extremities of brachiopod shell, $I 88$. 
Cardinal margin in pelecypod shells, $210,216$.

Cardinal process, $182, \mathbf{1 8 3}, 198$.

Cardinal teeth, 209, 216, 229.

Carinæ, $\mathbf{1 3 2 .}$

Carnivora, 324, 379-38I ; geologic range of, 379 ; sectorial tooth of, $38 \mathrm{r}$; subdivision of, $379,38 \mathrm{r}$.

Carnivorous gastropods, 242; distinguished from herbivorous, 242 .

Carpal bones; of birds, 370,372 ; of cat, $325,327,327$; of mammals, 325, $327,327,385,395$; of reptiles, 360 , 362.

Carp lice, 304.

Carpolithes macrophyllus, 76 .

Carpus, the wrist; see also carpal bones; of mammals, 327,386 ; of the cat, 327.

Caryocrinus, 155-156; C. ornatus, 155; calyx of, 155 ; compared to a starfish, I56; pore-rhombs of, 156 .

Castor, 382 .

Castoroides ohioensis, 383.

Casts, $14,15$.

Cat, 324-337, cat tribe, 379, 381 ; absorption in, 332; backbone of, 324 , 325, 326; blood circulation of, 332; body waste of, 333 ; bones of, 324 , 325; claws of, 324; development of, 335 ; digestion of, 33I ; eye of, 334; fore limb of, 327; hair of, 324; hearing in, 335 ; hind limb of, 328 ; joints of, 329; lion-like cats in North America, 376; muscles of, 329 ; nervous systems of, 333-334; oil-glands of, $324 ;$ organs of special sense in, 234; respiration of, 333 ; sexes of, 335 ; skeleton of, 324 ; smell in, 335 ; taste in, 335 ; teeth of, $33 \mathrm{I}$; touch in, 335 ; voice of, 333 .

Catfishes, 348 .

Catopterus, 346.

Cattle, domestic, 398; teeth of, 396.

Caudal fin, the tail fin; diphycercal, 340, 346; heterocercal, 338, 340, 344; homocercal, 34I, 348; recapitulation in, $34 \mathrm{I}$.

Caudal spines, in Stegosaurus, 362.

Caudal vertebræ, of the cat, 325,326 .

Caudata, 349 .

Cedars, 73 .
Cell, of $A m c e b a, 87,85$; of Protozoa, 87.

Cellular cryptogams, 45 .

Cellulose, a carbohydrate that forms the woody tissue of most plants; cotton is a pure example, I2 ; composition of, 26; formation of, 1,2 ; in ascidians, 322; in Chordata, 322 ; in Protozoa, 94 ; presence in animals, 3,26 ; presence in plants, 26 .

Cement, in molar teeth of elephant, 387 ; in molar teeth of the horse, 394, 396.

Cenosphara porosissima, 93.

Cenozoic, 407.

Centipedes, 309.

Central nervous system, in mammals, 333.

Centrum of a vertebra, 326 .

Cephalaspis, $338 ;$ C. murchisoni, 338 .

Cephalon of trilobites, $28 \% ; 287$.

Cephalopoda, 207, 25I-273; fossils of, etc., see cephalopods.

Cephalopods, 25I-273; compared to gastropods, 260; competitors of vertebrates, 26I ; digestion, etc., see Nautilus and Ommastrephes; evolution in, 26r ; food of fossil, 26r ; food of ichthyosaurs, 358 ; fossils of, $262-$ 268, 27I-273; geologic range of, 409 ; habitat of, 260; recapitulation in, 26 I sexes of, 260 ; shell of, 260 ; siphuncles compared, 26I ; subdivisions of, 260 ; survey of, $259^{-260}$; twisted, in evolution, 363; ventral and dorsal in, 253, 254, 261, 263.

Cephalothorax, of crayfish, 275, 276; of Eurypterus, 315; of horseshoe crab, 277; of trilobites, 286.

Ceratin, $\mathbf{1 9 3}$.

Ceratiocaris, 306 .

Ceratodus, 344.

Ceratospongida, 97, 98, 106.

Cercopithecidæ, 400.

Cerebellum, of alligator, 372; of Ichthyornis, 372 ; of tern, 372.

Cerebral ganglia, in gastropods, 237; in pelecypods, 221.

Cerebrum, of alligator, 372; of Ichthyornis, 372; of tern, 372 .

Cervalces scotti, 383 .

Cervical vertebræ, in cat, 326,326 ; in giraffe, 326 ; in swan, 326 .

Cestracion, 342. 
Cestus, 139.

Cetacea, 398-399; see also whales; hind limbs of, 328 .

Chetopleura apiculata, 208.

Chætopoda, I 42-1 47 .

Chain-coral, $137,13^{8}$.

Chalina, 97.

Chalk, 89 .

Chara, 27, 35; food of the crayfish, 280 . Cheeks, of trilobites, fixed, 286, 287, 29I, 296; free, 286, 287, 291, 296.

Cheirolepis, 346.

Cheirostrobus, 55 .

Chelonia, 365-366; bones of, 366; geologic range of, 366 ; protection of, 365 .

Chelonians, sclerotic plates in, 335 .

Chert, due to Radiolaria, 94; due to sponge spicules, 98 .

Chevron bones, 326; in reptiles, $360,367$.

Chimera, 343.

Chiroptera, 379; see also bats.

Chitin, composition of, 26 ; extent of, in the crayfish, 277; in animals, 26; in Annulata, I44; in fossilization, I I4 ; in graptolites, II4, I I5; in Hydrozoa, Io9; in Protozoa, 84, 94; in Sertularia, Iog.

Chitons, 207-208, 208; geologic range of, 208 ; mantle of, 208 ; skeleton of, 208; spicules in, 208.

Chlorophyl, 29; absence of, 2, 3; in algæ, 35 ; use of, 2.

Choanoflagellata, זоo.

Chondrostei, 346.

Chordata, 32 I-402; branchial clefts of, $32 \mathrm{I}$; classification of, 32I; geologic range of, 409 ; in evolution, 83 ; notochord of, $32 \mathrm{I}$.

Chordates, the Chordata.

Christmas fern, 46 ; development of, 45 . Chyle, in starfish, 152.

Cilium (plu. cilia), 95; in brachiopods, $182,184,185$; in Protozoa (Infusoria), 95 ; in sponges, 99.

Circulation, see under the various classes of animals.

Cirripedia, 305-306; skeleton of, etc., see barnacles; spermatozoön vibritile, 3 Io.

Cladoselache, $34 \mathrm{I}$.

Clams, I5I, I53; little-neck, 208.

Clathrospongia, 105 .
Clavicle, of bats, 328 ; of carnivora, 328 ; of cat, 325,327 ; of fishes, 346 ; of flying birds, 328,372 ; of mammals, 325,327 ; of primates, 328 ; of Ungulata, 328 .

Claws, of birds, 370,372 ; of cat, 327 ; of flying reptiles, 357 .

Cleveland formation, fossils from, 34I ; geologic age of, $34 \mathrm{I}$.

Climacograptus, I19; C. typicalis, I19, I2O.

Climate, as indicated by plants, 30 .

Clinton formation, fossils from, $41, I 20$; geologic age of, $4 \mathrm{I}, \mathrm{I} 2 \mathrm{O}$.

Clio, 244, 247-248; C. acicula, 248; a pteropod, 248 ; type of Euthyneura, 244.

Cliona, 96, 97, 106; C. sulphurea, 226.

Cloaca, the common chamber into which are discharged the waste prodducts of the intestine and kidneys as well as the generative products. This is present in many fishes, in amphibia, reptiles, birds and the lowest mammals.

Cloacal, pertaining to a cloaca.

Cloacal chamber in pelecypods, 2 r 0.

Club-mosses, 5I-54; in evolution, 55 .

Coal balls, 53, 54, 60 .

Coal mines, carbonized plants in, I3.

Coccinella septem-punctata, 24 .

Cockroaches, 318 .

Codfishes, 348 .

Codonotheca, 57 .

Coecileans, 354 .

Coelenterata, I08-139; see colenterates. Coelenterates, ro8-139; classification of, 108; compared with Echinodermata, ${ }_{4} 8$; compared with sponges, 102; geologic range of, 409.

Colenteron, 108 .

Coelome, 174 ; in brachiopods, 185,186 ; in Bryozoa, $174,174,175$; in pelecypods, 2 I 2.

Coenenchyme, 1 29, I34.

Coenosarc, 109, I09; in corals, 127, 130; in Hydrozoa, 109, 109 .

Cold-blooded animals, including practically all invertebrates and vertebrates except birds and mammals, have no uniform body temperature; this varies with the temperature of the environment. 
Coleoptera, 318, 319 .

Collar-hone, see clavicle.

Collecting fossils, 22 .

Colloidal, jellylike in appearance.

Colon, ascending, 330 ; descending, 330 ; transverse, 330 .

Colonies, in Hydrozoa, 11 r ; in sponges, 96.

Color, of fossils, 20.

Columella, of corals, $\mathbf{1 2 8}$; of gastropods, $238,239,243$.

Columellar muscle, 238.

Columnaria, 132 ; C. alveata, I33.

Comanchean, 407.

Comanchean fossils figured, $61,227$.

Comb-jellies, I 39.

Combretanthites eocenica, 76 .

Comparison of mammalian brains, 375 .

Concentric growth lines, 2IO, 215-216, 215.

Concentric lines, see concentric growth lines.

Conch, a name given to various marine gastropods.

Conchiolin, in pelecypods, 215.

Condylarthra, $384, \quad 384, \quad 385, \quad 385$; closely related to the early Carnivora (Creodonta), 385; generalized type, 384,385 ; geologic range of, 385 .

Condyle, a rounded articulating surface at the end of a bone.

Cones, of Calamites, 50; of club-mosses, $5 \mathrm{I}$; of conifers, 70; of cycads, 66; of Lepidodendron, 53; of Sigillaria, 54; of spermatophytes, 56 .

Coney, 386.

Coniferales, 70-75; derivation of, 70 ; geologic range of, 408 .

Coniferous types, $35 \mathrm{I}$.

Conifers, classification of, $70-74$; derivation of, 70; relationship to Cordaites, 68 .

Conocoryphe, 29I.

Conodonts, I46, 146.

Contractile vacuole, in $A m \ltimes b a, 84,85$, 86; in Protozoa, 84.

Conularia, 249.

Conularid, one of the Conularida, 249 .

Conularida, 249, 240 .

Convergence, in the Fissipedia, 38I.

Copepoda, 304, 306; see also copepods.

Copepods, 304; food of Globigerina, 90; free-swimming, 304; habitat of, 304 ; parasitic, 304 .

Coprolites, 9, I 7; of ichthyosaurs, 358 .

Coracoid bone, of birds, 372; of reptiles, 360, 362, 366, 367 .

Corallina, $37 ;$ C. officinalis, 27.

Corallines, 37 .

Corallites, in Bryozoa, 178 ; in corals, I $22, \mathbf{1} 28, I 36, I 37$.

Corallium, 128 .

Corallum, $\mathbf{1} 28$.

Coral-reefs, algæ in formation of, 38 ; corals in, 130 ; corals in formation of, 38 ; Foraminifera in formation of, 38.

Corals, I22-138; asexual reproduction in, I29, I30; digestion, etc., see Astrangia ; distribution of, 130 ; fossil, I3I-I38; geologic range of, 409 ; imperforate, 130; in coral-reefs, 38; nematocysts in, I29; nettle-cells in, I 29; perforate, I29; reef-building, I30; reproduction of, I 25, I 29; secretion of lime in, I25; sexual reproduction in, I 29 ; skeleton in, I28; tabulate, II 3, I $36-$ I 38 .

Coranoid, in reptiles, 367 .

Cordaitales, 67-69; relationship to other gymnosperms, 68 .

Cordaites, 2 I, 67, 68, 69, 351 ; C. oweni, 68; casts of pith cavity of, 67 ; fruit of, 67 .

Corium, see dermis.

Cornea of eye, 334.

Corolla, 76 .

Corpuscle, - an animal cell formed largely of protoplasm.

Corrodentia, 3 I 8 .

Coryphodon, 386.

Coscinodiscus lineatus, 34.

Costæ, the vertical ridges upon the outer side of a coral. True costæ are the outer edges of the septa.

Costal bones, in turtles, 366 .

Cotyledon, 77.

Crab, blue, 307; edible, 307; horseshoe, 277, 312; Japanese spider, 307 ; soft-shelled, 308.

Crabs, parasites in, 305 .

Crania, I88, 192, 195; C. bordeni, 195.

Cranial nerves, 333 .

Craniata, 322, 323-402; classification of, 323 ; gill-slits in, 323 ; notochord in, 323 . 
Cranids, 192

Cranium, that part of the skull which immediately incloses the brain; the brain case.

Crawling legs, in trilobites, 288 .

Crayfish, 275, 276, 307; see also Cambarus; ancestry of, 307 .

Creodonta, 379, 380 ; closely related to Eocene insectivores and ungulates, 379; geologic range of, 379 .

Creodonts, the Creodonta.

Cretaceous, 407.

Cretaceous fossils figured, 19, 47, 79, $202,224,266,267,268,357,364$, $366,367,372$.

Crickets, 3 I 8 .

Crinoidal limestone, I59.

Crinoidea, $\mathbf{5} 59^{-} \mathbf{6} 63$; see also crinoids and Pentacrinus.

Crinoids, $\mathbf{I} 59-\mathbf{I} \mathbf{6}_{3}$; fossils of, $\mathbf{I} 60-\mathbf{I} 63$; geologic range of, $\mathrm{r}_{59}, 409$.

Crocodiles, 365 ; food per day, 36I ; geologic range of, 365 .

Crocodilia, 365 ; see also crocodiles.

Crop, in birds, 360 .

Crossopterygii, 345 ; fins in, 340 ; generalized order, 345 ; geologic range of, 345 ; probable relationship to the Stegocephalia, $35^{2}$.

Crura, I 85, 185 .

Crustacea, 275-308; antennæ of, 276, 279,286 ; brain of, 279, 282; cæcum of, 279 ; chitin of, $284^{-285}$; circulation of, 285 ; digestion, etc., see Cambarus, Apus; digestive gland of, 279 ; dorsal muscles of, $\mathbf{2 7 8}$; evolution of, 274 ; extensor muscles of, 278, 279; eye of, 276, 279, 286; flexor muscles of, 278,279; food of cephalopods, $25^{6}$; food of squids, 270 ; foot jaws of, 279 ; fossils of, 285-307; gastric mill of, 279; geologic range of, 409; heart of, 279; intestine of, 279 ; pericardium of, 279 ; respiration of, 285 ; secretive and absorptive division of digestive canal of, 285 ; skeleton, external, 276, 279; skeleton, internal, 279 ; survey of, $28+-285$; telson of, 276,276,279; ventral muscles of, $\mathbf{2 7 8}$; ventral nerve cord, 279; walking legs of, 276,279 .

Crustaceans, see Crustacea.
Cryptogams, cellular, 45 ; vascular, 45 .

Cryptozoön, 37, 38; C. bassleri, 37; C. proliferum, 37 .

Ctenidia, in mollusks, 206.

Ctenophora, I 39 ; geologic range of, 409

Cuboides bone in the cat, 327 .

Cud, development of chewing the, 397 .

Cumacea, 306.

Cuneiform bone, of cat, 327 ; of mammals, 395 .

Cupresseæ, 74.

Cuttle bone, 272 .

Cycadales, 60-67; geologic range of, 408 . Cycadeæ, 66.

Cycadeoidea, 65; C. colossalis, 65; C. dacotensis, 63, 64; C. jenneyana, 62; C. marylandica, $6 I$.

Cycadeoideæ, 6o-66; in evolution, 63 .

Cycadeoids, the Cycadeoidex.

Cycadofilicaleans, see Cycadofilicales.

Cycadofilicales, 57-60, 350; geologic range of, 408.

Cycads, 66; age of, 66; fertilization of, 66 ; male cells motile, 66 .

Cycas, reproduction in, 66 .

Cyclops, 304.

Cyclostomata, 337 ; see cyclostomes.

Cyclostomes, 337; fossil, 337; geologic range of, 409 ; respiration in, 341 .

Cypraa, 243; anal siphon of, 246; mantle in, 243 .

Cypris, 303.

Cypris stage, 305.

Cyrenidæ, 221.

Cystoidea, I54-157; calyx, etc., see cystoids.

Cystoids, I 54-I 57; ambulacra of, I 54; calyx plates of, I54; geologic range of, 409 ; in evolution, I 54 .

Daddy longlegs, 3 I 6 ; trilobite, 288.

Dead men's fingers, 128 .

Decapoda, 307-308; abdomen, etc., see decapods.

Decapods, 307-308; abdomen of, 307 ; examples of, 307-308; food of cephalopods, 256; geologic range of, 307 .

Decay, of plants and animals, 5 .

Deer, 397, 398; extinction of, 376; habitat of, 374; red, arrival in North America, 375; white-tailed, in North America, 375. 
Degeneration, in barnacles, 305; in Urochorda, 322 .

Del Rio formation, fossils from, 227; geologic age of, 227.

Delta, of Ganges and Indus rivers, 5; of Greenbrier formation, 5 ; of Mauch Chunk formation, 5 .

Delthyrium, I8I, $I 88$.

Deltidial plates, I83, I89.

Deltidium, I89, 196 .

Dendrerpeton, 352.

Dendrite, $2 I, 22$.

Dendroidea, i 16 , I 17.

Dendropupa vetusta, 352.

Dentalium, 25I ; D. attenuatum, $25 I$.

Dentary bone, of birds, 372 ; of reptiles, 367 .

Dentine, of elephant's molar, 387 ; of horse's molar, 396 ; of rodent's incisor, $38 \mathrm{I}$.

Dermal, pertaining to the skin of animals.

Dermal branchiæ, I52.

Dermal fin rays, 346 .

Dermaptera, $3 \mathbf{1} 8$.

Dermis, the deep layer of the skin beneath the epidermis, or scarfskin; of the crayfish, 278 ; of vertebrates, 324.

Descent, see evolution.

Desmospongiæ, 98 .

Developmert; see also reproduction; of pelecypods, 216-218; of Unio, 228 .

Devil-fisi:, in evolution, 83 .

Devil's apron, 36,43 .

Devonian, 407.

Devonian fossils figured, $12,68,104$, $I_{31}, I_{32}, I_{36}, I_{76}, I_{64}, I_{95}, I_{98}, 203$, 204, 263, 26, 298, 347, 346 .

Dextral, 24 I.

Dextral shell in gastropods, $24 \mathrm{I}$.

Diaphragm, 330, 33 I.

Diatomaceous ooze, 34 .

Diatomeæ, 34 ; see also diatoms.

Diatoms, 34, 34; deposits of, I2 ; food of brachiopods, 184 ; food of crinoids, I6I ; food of Globigerina, 90; food of pelecypods, 2I2; geologic range of, 408; silica in, 26 .

Dibranchiata, 268-273; absence of ocular tentacles in, 258; geologic range of, 269 ; in evolution, 83 ; ink sac of, 268; skeleton, etc., see Ommastrephes.

Dicotyledones, 79-8I ; see also dicotyledons.

Dicotyledons, 79-8I ; early flora of, 77 ; fossil, 80-8I, $8 I$; geologic range of, 408; more primitive than monocotyledons, 80 .

Dictyonema, II7; D. Alabelliforme, II7, II 8 .

Dictyopteris, 47.

Dictyospongidæ, 105.

Diductor muscles, $I 82,183, I 85$.

Digestion, see also under the various classes; of A maba, 85; of Hydrozoa, I Iо; of Protozoa, 85.

Digestive canal, in cat, 330, 331; in Invertebrata, 331 ; in Vertebrata, 330, 331 .

Digits, toes; of birds, 370,372 ; of cat, 327; of horses, 393, 395; of mammals, 385 .

Digits, number of, in birds, 328 ; in camel, 328 ; in mammals, 328 ; in pig, 328 ; in reptiles, 328 ; in rhinoceros, 328 ; primitive, 328 .

Dileptus, 84 .

Diminution in number of mammals, causes of, $374-376$.

Dinoceras, 386.

Dinoflagellata, 84 .

Dinophilea, I4 I.

Dinornis maximus, $37 \mathrm{I}$.

Dinosaur, neck-frilled, 364 .

Dinosauria, 359-364, 359, 360, 361, 362, 36. ; food supply, etc., see dinosaurs.

Dinosaurs, 359-364, 359, 360, 361, 362, 367 ; bones of, I I ; derivation of, 359 ; evolution of, 373 ; food of, 359 ; problem of food supply of, 36I ; skin ornamentation preserved, I9, 359 ; subdivision of, $359,360,363$; the largest land animals, 36r.

Diploglossata, 3 I 8.

Diplograptus, II3, Iп6; D. foliaceus, I I3-II5, II 4, II9.

Diplomystus, 347.

Dipneusti, 343-344; autostylic, 339; examples of, 344,344 ; fins in, 340 ; geologic range of, 344 ; lung of, compared to air-bladder of Teleostomi, 343 ; respiration of, $3+3$. 
Dipnoi; see Dipneusti. (The name Dipnoi cannot be used for the lungfishes as it was used earlier for a group of the Amphibia.)

Diprotodonts, 378 .

Diptera, 3 r9.

Dipterus, 344 .

Discinids, I92.

Disk, of starfish, r 49.

Dismal Swamp, sphagnum in, 44 .

Dissepiments, in corals, oblique calcareous partitions stretching from septum to septum, I 29.

Dissoconch, 23 I, 231 .

Distal, remote from point of attachment.

Distomum hepaticum, I40.

Distortion of fossils, 2 I.

Ditypic, containing two representatives.

Divergence, of ruminants, 398 .

Dog-fish, 343.

Dogs, 379, 381 ; giant, in North America, 376.

Dog-tribe, 381 .

Doliolum, 322.

Dolphins, 399.

Dorsal fin, 338 ; in pelecypods, $210,216$.

Dorsal muscle, in crayfish, 278; in crustaceans, $\mathbf{2 7 8}$; in trilobites, 288 .

Dorsal shield of trilobites, 287, 29 I.

Dorsal vertebræ of the cat, 325, 326

Doublure, 286, 287.

Dragon flies, eye of, 317 ; modern, 319 ; primitive, $31 \mathbf{9}, 350$.

Dried specimens, preparation of, 2 I 9.

Dromatherium, 378 .

Dromocyon velox, 380 .

Dryopithecus, 400.

Duck-bill, 378.

Dugong, 398.

Duodenum, 330.

Earshell, see Haliotis.

Ecaudata; 349.

Echidna, 378; development of young, 377 .

Echinarachnius, 166.

Echinodermata, 148-172; see Asterias and echinoderms.

Echinoderms, I48-r73 ; ambulacra compared, I48; ancestry of, I49; classes of, compared, I48; compared with cœlenterates, I48; digestion, etc., see Asterias; geologic range of, 409.

Echinoidea, 165-I7I; see echinoids and Strongylocentrotus.

Echinoids, I 65-I 7I; geologic range of, I66, 409; habitat of, I66; respiration, etc., see Strongylocentrotus; skeleton (test) of, I65.

Ectoderm, in Cœlenterata, 108; in corals, 126 ; in crustaceans, $28 \mathrm{I}$; in sponges, 99.

Ectoprocta, I 77-r 80 .

Edentata, 382 ; evolution of, 382 ; geologic range of, 382 .

Edible crab, 307.

Edrioasteroidea, I49, I 57.

Eel-grass, 75, 217.

Eels, 248.

Egg, of bryophytes, 42 ; of crustaceans, 283; of Hydrozoa, III ; of plants, 30; of pteridophytes, 45.

Egg of birds, shell of, 370 ; white of, 370 ; yolk of, 370.

Egg capsule of gastropods, 239, 239.

Elasmobranchii, 34I-343; advance over Cyclostomata, 34I; born alive, 339; eggs of, 34I ; geologic range of, 34I ; habitat of, 34I ; hyostylic, 339; respiration of, $34 \mathrm{I}$.

Elasmobranchs, the Elasmobranchii.

Elephants, see also Proboscidea; African, 389; Columbian, 383; evolution of, 387,388 ; extinction of, 376 ; food per day, 361 ; Imperial, 389; Indian, molar tooth of, 387 ; Indian, vertical section through fore foot of, 386; in North America, 375; map showing distribution in North America, 390; migration of, 23; primitive characters of, 386; specialized characters of, 386 .

Elephant tribe, 386 .

Elephas, 387, 388, 389; E. columbi, 383; E. imperator, 389; E. primigenius, 387.

Elm, American, 43.

Elytra, 3 I9, 319.

Embioidea, $3 \mathbf{1 9}$.

Embrithopoda, 389.

Embryo, in angiosperms, 77 ; in brachiopods, 186; in fossil seeds, 62; in seed-plants, 56 ; in sponges, ror. 
Embryo-sheath, I 13.

Embryonic graptolites, I 16.

Embryonic life, freedom of movement in, 2.

Emulsify, to reduce fats to a milky fluid.

Enamel, of elephant's molar, 387 ; of horse's molar, 396; of rodent's incisor, $38 \mathrm{I}$; of teeth of Edentata, 382 .

Endoderm, in Cœelenterata, I08; in corals, 126 ; in crustaceans, 281 ; in sponges, 99.

Endopodite, 276; of the crayfish, 276 ; of the lobster, 279; of trilobites, 286 , 288.

Endoprocta, I 77, I8I.

Energy, derivation of, in body, 332 .

Engelhardtia, 80; E. mississippiensis, $8 I$; distribution, present and past, $8 I$.

Enrollment, in trilobites, 288, 291.

Entomolithus paradoxus, 294.

Entomostraca, 306.

Eoanthropus dawsoni, 400.

Eobasileus, 386.

Eocene, 407.

Eocene fossils figured, $76,81,92,177,246$, $375,380,384,385,388,392,393,394$, 395.

Eohippus, 302, 393 ; characteristics of, 392, 393, 394, 395 .

Eotomaria supracingulata, 24.

Ephedra, 75, 408.

Epidermis, the superficial non-sensitive layer of the skin, the scarfskin; of crustaceans, 28I ; of pelecypods, 228 ; of Unio, 228 ; of vertebrates, 324 .

Epiglottis, 330.

Epihippus, 393.

Epineural plates, 366 .

Epistome, in Bryozoa, I8o.

Epitheca, 126, I 28.

Epithelial, pertaining to the epithelium. Epithelium (plu. epithelia), the superficial layer of cells lining such surfaces as the digestive canal.

Equilibrium, maintenance of, in crustaceans, 283 ; in mammals, 335 .

Equisetales, 48-50; see equisetes.

Equisetes, 48-50; fossil, 48-50; geologic range of, 408; in evolution, 55 .

Equisetites, 48.

Equisetum, 48, 49.

Equus, 393, 393, 394, 395 ; E. caballus,
375; skull and brains of, 375; $E$. scotti, 383 ; evolution of, 392-396; recapitulation in, 394 .

Era, 407.

Eryon, 307.

Eryops, 350.

Esophagus (spelled also œsophagus), of cat, 330, 33I ; of corals, I23; of mammals, 330 , 33I.

Estheria, 301, 302; E. belfragei, 302; $E$. ovata, 302, 302; compared with Fordilla, 222; habitat of, 302 .

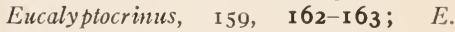
crassus, 163.

Euglena, chlorophyl in, 3; food getting in, 29.

Euphausiacea, 306, 307.

Euplectella, 96, го5; E. aspergillum, 103, 104; E. crassistellata, 103.

Eurypterida, 309, 3I2-3I4; compared to Scorpio, 310 ; environment of, 313 ; evolution of, 310 ; growth stages of, 313; habitat of, 3I3; larval stages of, 313; probable change in habitat of, $3 \mathrm{I} 3$; recapitulation in, $3 \mathrm{I} 3$; relationship to Limulus and scorpions, 310; relationship to trilobites, 3 II.

Eurypterids, the Eurypterida.

Eurypterus, 314; E. remipes, 315.

Euspongia, 96, 106.

Eusthenopteron, 345; E. foordi, 346. Eutheria, 377 ; production of young, 377. Euthyneura, 244.

Even-toed ungulates, 396-398.

Evolution, Bactrites in, 261; gastrula in, I1 2 ; in birds, 371 ; in brachiopods, 200 ; in caudal (tail) fins, $34 \mathrm{I}$; in eurypterids, 310 ; in Fissipedia, 381 ; in gastropods, 240,247 ; in ichthyosaurs, 358-359; in incisor teeth of mammals, 332; in Limulus, 310; in Merychippus, 394; in mollusks, 231 ; in plants, 31,43 ; in plesiosaurs, 356 ; in scorpions, 310 ; in Squamata, 367; in trilobites, $3 \mathrm{II}$; in Vermicularia, 247; Insectivora in, 399; Maritherium in, 398 ; of animals, 83 ; of birds, 372, 373; of book-gills, 310; of book-lungs, 310; of camels, 397; of Chordata, 83 ; of crayfish, 307 ; of crustaceans, 274; of cycadeoids, 63 ; of dinosaurs, 373 ; of echino- 
derms, I49; of edentates, $3 \delta 2$; of elephant, 387,388 ; of fore arm of horse, 394; of fore foot of horse, 393, 394 ; of fore leg of horse, 394; of hind foot of horse, 393, 394; of horse, 393-396; of Hyracoidea, 385; of mammals, 83 ; of molar teeth of the horse, $393,394,396$; of monocotyledons, 80; of Pecten, 231-232; of Pentacrinus, 162; of Pinnipedia, 381 ; of plants, 3I ; of Platystrophia, 200; of Primates, 399; of pythonomorphs, 367 ; of raccoons, $3 \mathrm{~S}_{1}$; of ruminants, 398 ; of sea cows, 397,398 ; of skull of horse, 302, 303; of spine-bearing cephalopods, 363 ; of spinous shells, 363 ; of teeth of artiodactyls, 396 ; of trachea, 310; of twisted cephalopods, 363 ; of whales, 399 ; Unguiculata in, 399 .

Excretion, in Ameba, 86; in cephalopods, 257; in gastropods, 237; in Protozoa, 86.

Excurrent canals, 99, roo.

Excurrent siphon, in pelecypods, 209, 209, $2 I I, 2$ I 2.

Exhalent siphon, excurrent or anal siphon.

Exogyra, 227-228; E. arietina, 227, 228 ; compared to the oyster, 227.

Exopodite, 276; of the crayfish, 276 ; of the lobster, 279; of the trilobite, $286,288$.

Exoskeleton, the protection surrounding the soft body, as the shell of brachiopods and pelecypods, and the hair of mammals.

Extensor muscle, 278, 279.

Extinction, of Pleistocene mammals from North America, 376; of species, causes of, $374-376$.

Eye-line in trilobites, 286, 291.

Eye lobe, 289, 296.

Eyes, of Apus, 300, 301 ; of cat, 334; of cephalopods, 252, 253, 257-258, 270; of crustaceans, $276,279, \mathbf{2 8 2}$, 286, 300, 301; of Estheria, 302; of Eurypterus, 315; of gastropods, 238; of insects, 319 ; of mammals, 334; of Nereis, I 45; of pelecypods, 213 , 221 ; of phyllopods, 302; of squids, $270-271$; of starfish, 150 ; of trilo- bites, 286, 289, 291, 295, 296, 298; of vertebrates, 334 ; squid and nautilus compared, 270; squid and vertebrate compared, 270 .

Face, 392.

Facets, in eye of dragon fly, 317; in eye of house fly, 317; in eyes of trilobites, 29I-292, 298.

Facial sutures in trilobites, 286, 287, $295,206$.

Fæces, of brachiopods, 193.

Fangs, 38r.

Fats, in vertebrate digestion, 332 .

Favosites, 1 36 ; F. favosus, I37.

Feathers, development of, 369 .

Felidæ, 381 .

Felis domestica, 324-337, 325, 326, 327, 330.

Femur, of cat, 325, 328; of mammals, 385 ; of reptiles, $358,360,362,366$, 367.

Fenestella, I79; F. filistriata, I8o; protœecium of, I80; zoœcia of, I79, I80.

Ferns, Christmas, 45, 46; fossil, 46-48; geologic range of, 408 ; royal, 46 ; sensitive, $43,46,47,48$.

Fertilization, in angiosperms, 43, 76; in brachiopods, 186 .

Fever, yellow, 84 .

Fibula, of birds, 372 ; of cat, 325,328 ; of mammals, $325,328,385,394$; of reptiles, $360,366,367$.

Fig, 77 .

Filicales, ${ }_{4}^{6-48}$; see ferns.

Finger bones, see phalanges.

Finger stone, 272.

Fins, anal, 3.0; caudal, 340; compared to limbs of higher vertebrates, 344 ; dorsal, 340 ; paired, 340, 340 ; pectoral, 340, 370; pelvic, 340, 340; probable development of, 339, 370; tail, caudal; 370; unpaired, 370 ; ventral, 340,340 .

Fishes, 339-349; born alive, 339; caudal fin of, 340 ; development of fins of, $339-340,370$; development of skull of, 339; diagram showing development of fins, 370 ; differ from amphibians, 349; eggs of, 339; food of cephalopods, 256 ; food of ichthyosaurs, 358 ; food of plesiosaurs, 
357; food of squids, 270; geologic range of, 339, 409; gills of, 339; organs of locomotion of, 339 ; ribs in, 326 ; tail fin of, 340 ; trails of fins of, I6.

Fission-plants, 33 .

Fissipedia, 38I; evolution in, $38 \mathrm{I}$; geologic range of, 381 .

Fissurella, 244, 245-246.

Fissuridea alticosta, 245.

Fixed cheeks of trilobites, 286, 287, 291, 206.

Flagella, 94; in Mastigophora, 94; in Protozoa, 94; in sponges, 100.

Flagellate canals, 99, 100.

Flat-worms, I40; compared to Peripatus, 308; fossils of, 140.

Fleas, 319 ; water, 304 .

Flesh, the muscles of a vertebrate body.

Flies, as disease carriers, 376; dragon, 317; house, etc., 317, 319; lacewing, 319.

Flint, 98.

Flood plain, of Bridger formation, 6; of Ganges and Indus rivers, 5; of Mauch Chunk shales, 5, 6; of Wasatch formation, 6 .

Florissant, 4; preservation of insects at, 4 .

Florissant formation, 4, 6; fossils from, 319; geologic age of, 319 .

Flower, 56; buds, fossil, 6I, 63, 64, 65.

Flowering plants, $\mathbf{7 5 - 8 2}$; see also angiosperms.

Flowers, 56 ; fossil, 76 ; most primitive fossil, $62,63,63,64,65$.

Flying birds, 369.

Flying mammals, 374, 379.

Flying phalangers, 378 .

Flying reptiles, 357, 364 .

Fœtus, 335.

Fold, median, 188 .

Follicle, hair, 324.

Food, see also under the various classes of animals ; of plants, 29.

Food groove, in brachiopods, $182, \mathbf{1} 84$.

Foot, of gastropods, 238; of mollusks, 206; of pelecypods, 208, 2IO, $21 I$

Foot muscles, in pelecypods, 209, 210 , $2 I I, 2 I_{4}$.
Footprints, 328; perservation of, 328 . Foot structure, inadaptive, in the extinction of the species, 374 .

Foramen, a small opening, as the pedicle opening of brachiopods, 202.

Foraminifera, 84,88 ; food of scaphopods, 250 ; in formation of chalk, 89 ; reproduction in, $8 \mathbf{9}$; skeleton of, 88 .

Foraminiferal ooze, 89 .

Fordilla, 222.

Forearm, bones of, see radius and ulna ; of Equus, 394; of Miesohippus, 394; of Orohippus, 394; of Protohippus, 394.

Fore foot, of Eohippus, 393, 395; of Equus, 393, 395; of Hyracotherium, 393; of Merychippus, 395; of Mesohippus, 393, 395; of Protohippus, 393; of Protorohippus, 393.

Fore leg, bones of, see tibia and fibula; of Equus, 394; of Mesohippus, 394; of Orohippus, 394; of Protohippus, 394.

Fore limb, of the cat, 325, 327 .

Fossil butterflies, 310 .

Fossil flower buds, $61,63,64,65$.

Fossil flowers, 76 .

Fossil forests, II, 72 .

Fossil fruit, 57.

Fossil insects, 319.

Fossil leaf-buds, 62.

Fossil, living, 70.

Fossils, altered (petrifactions), I I ; chance of preservation, 5, 6; classification of, 8, 9; collecting, 22 ; color of, 20 ; conditions of their preservation, $3-8$; definition of, 8 ; derivation of name, 8; distortion of, 21 ; due to former presence of organisms, I4; index, 22; interpretation of, 23; naming of, 24 ; of animals without hard parts, . 7; preservation in peat bogs, 4 ; preservation of soft parts, 9 ; preservation through carbonization, I3; preservation through freezing, 4, 7; preservation through incrustation, 3 ; preservation through molecular replacement, II, I2; preservation through pyritization, I2; preservation through silicification, II, I 2 ; pseudo, 2 I ; restoration of, I 7 ; soft portions of animals preserved as, 7 ; unaltered (original), 9; unaltered from Sankaty beds, Io. 
Fossorial, 374 .

Fossorial mammals, 374 .

Fossula, I 28, I 31 .

Free cheeks of trilobites, 286, 287, 291, 206.

Fringe-finned ganoids, 345 .

Frogs, 353 ; see Anura.

Frond, stem and leaf united into one body, 46 .

Frontal bone, growth of horns from, 398; in cat, 325 ; in fishes, 346 ; in reptiles, 367.

Fruit, fossil, 57 .

Fucus, 36, ro9.

Fulicopus lyellianus, 350.

Funafuti atoll, 38.

Fungi, 40; food-getting in, 29 ; geologic range of, 408 .

Funnel, in Belemnites, 271 ; in cephalopods, 252, 255.

Furrow, glabellar in trilobites, 286, 287, 295.

Fusulina, 89, 9I ; F. secalica,

Galesaurus, 356.

Gametophyte stage, 43, 44; in ferns, 45 ; in seed-plants, 56 ; in spermatophytes, 56.

Ganges, flood plain of, 5 .

Ganglion (plu. ganglia), a knot of nervous matter; in annulate worms, I 45; in gastropods, 237 ; in mammals, 334 ; in pelecypods, 213.

Ganodonta, 382 .

Ganoids, 345 ; fringe-finned, 345:

Ganoin, 345.

Garpike, 347 ; tail fin of, 344 .

Gastral canals, ıoo.

Gastric mill, 279, 280.

Gastric vacuole in $A$ maba, 85 .

Gastroliths, see stomach-stones.

Gastropods, 234-250; absence of shell in, 243; air breathing in, 242, 243, 250 ; asymmetry in body, 24I ; asymmetry in shells, 24I; blood in, 242; callus of, 243; carnivorous, 242; columella of, 243; compared to cephalopods, 260; determination of fossil, 243; dextral shell, 24I ; digestion, etc., see Busycon; fossils of, $244^{-}$ 250; geologic range of, 244, 409; heart of, 242 ; heart beat in, 242 ; herbivorous, 242; inclosure of shell within soft body, 243; nerve connectives crossed, 237, 242; operculum, of, 244 ; respiration in, 242 ; sight in, 243; sinistral shell, 24I; smell in, 242 ; subdivisions of, 244 ; survey of, 24I ; terrestrial, 250 ; touch in, 242; umbilicus of, 243 ; vegetable feeders, 242.

Gastrotricha, I41.

Gastrula, - that stage in the development of an animal from the egg to maturity, which is composed of two layers of cells, the outer layer or ectoderm and the inner or endoderm; this latter lines the future digestive cavity. In its primitive state the gastrula arises somewhat as if the hollow, rubber balllike blastula were pushed in at one side so as to bring the two walls into contact, producing thus a two-walled bag, Ior ; in brachiopods, I86; in crustaceans, 28I, 283; in evolution, I 12 ; in Hydrozoa, I I I ; in pelecypods, $2 \mathrm{I} 6$; in sponges, ror.

Genal spine, 295.

Generalized types, see also evolution; among insects, 3 I 8 ; anomodonts, 356 ; Bactrites, 261 ; Condylarthra, 384, 385 ; Creodonta, 379; Crossopterygii, 345; in the Cycadofilicales, 6o; Lyginodendron, 60; Megatheriidæ, 382; Rhynchocephalia, 355 .

Generation, alternation of ; see alternation of generation.

Genesee formation, fossils from, I46; geologic age of, 146 .

Genesis; see evolution.

Genital plate, $167, \mathbf{r} 6 \mathbf{9}$.

Geologic Time Scale, 407.

Gephyrea, I41, I42.

Gibbon, 400.

Gigantosaurus, 36г.

Gill-covers in the crayfish, 276, 277.

Gill-slits, branchial clefts, 323 .

Gills, of crayfish, 285; of crustaceans,

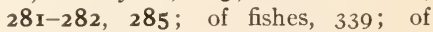
gastropods, 235; of mollusks, 206; of pelecypods, 209, 2 I 0-2I I, $2 I O, 2 I I$. Ginkgo biloba, 69; ancient distribution of, 70; motility of male cells, 69; present isolation as to species, 69; 
primitive in fertilization, 66 ; relationship to Cordaites, 68, 69.

Ginkgoales, 69-70; geologic range of, 408.

Giraffes, 397 ; cervical vertebræ of, 326 .

Gizzard, effect of change of diet upon, 369 ; of birds, 369 ; of dinosaurs, 358 ; of plesiosaurs, 357 .

Glabella, 286, 287, 295, 296.

Glabellar furrows, 286, 287, 295.

Glacial period, 407; influence of, upon extinction of mammals, 376 .

Glass sponge, 104 .

Globigerina, 89, 90 ; G. aquilateralis, 90 ; composition of test, 25 ; food of, 90 ; ooze, $89,90$.

Glottidia pyramidata, 193, 194.

Glypiodon, $\mathbf{3 8 2}$.

Glyptodonts, in North America, 375 .

Gnathobases, of Crustacea, 280, 286; of trilobites, 286, 286, 288.

Gnetales, 75; geologic range of, 408 .

Goat, mountain, arrival in North America, 375.

Goats, 398.

Gomphotherium, 387, 388 .

Gonangia, I 3 .

Goniatites, 264, 265 .

Goniatitic type of suture, 265 .

Gonotheca, 109, I 10.

Goose barnacle, 305.

Gordius, I4I.

Gorgonia, 135.

Gorilla, 400 .

Grains, 78 .

Grantia, 102; G. ciliata, 99-102, 99; body wall of, 99 ; circulation of, 100; digestion of, roo; food of, roo; muscles of, IOI; nerves of, IOI; reproduction of, IOI ; waste of, IOI.

Graptolites, II 3-I2I ; carbonized remains of, I3; digestion of, II5; embryonic, II6; habitat of, II6 ; reproduction of, II 5 ; subdivision of, II 7 ; survey of, II $5^{-1} 7$.

Graptolithida, II3-I2I ; see also graptolites.

Graptoloidea, II6, I I8.

Grasses, first prominent upon earth, 384 ; in evolution of the ungulates, 384,385 ; siliceous, prominent, 384 ; true, first appearance of, 78 .
Great toe, see under phalanges and digits, 385 .

Green algæ, 35.

Green gland, 282.

Gregarina, 95, 409.

Growth lines, in brachiopod shells, $\mathbf{1 8 2}$, 188 ; in pelecypod shells, $210,21 \mathbf{5}^{-2} \mathbf{1} 6$, 215.

Growth of shell, in pelecypods, $21 \mathrm{O}, 2 \mathrm{I}_{4}$ 216,215 .

Growth of the organic vs. the inorganic, 2. Guano, 17.

Guard, of Belemnites, 27I, 27I ; of Sepia, 272.

Gular plate, 346 .

Gulls, gizzard of, 369 .

Gymnolæmata, I 77-180; geologic range of, 177.

Gymnophiona, 349, 354.

Gymnospermæ, 56-75; see gymnosperms.

Gymnosperms, 56-75; classification of, 56-57; geologic range of, 408 .

Habitat; as controlling fossilization, $3-7,5$.

Hadentomoidea, $3 \mathbf{1 9}$.

Hæmal spines, 376 .

Hæmocyanin, 242 ; in crustaceans, $28 \mathrm{I}$; in gastropods, 242; in mollusks, 206; in pelecypods, $22 \mathrm{I}$.

Hæmoglobin, in cat, 333 ; in gastropods, 242 ; in mammals, 333 ; in mollusks, 206 ; in pelecypods, 220 .

Hag-fishes, 337.

Hair-cap moss, 42, 43, 44.

Hair follicle, 324 .

Hair worm, I4I.

Halimeda, 27, 35, 38 .

Haliotis, anal siphon of, 246 ; heart in, 242.

Halitherium, hind limbs of, 328 .

Halysites, $137 ; H$. catenularia, 138.

Hamilton formation; fossils from, $I 3 I$, 132, 198, 203, 207; geologic age of, I3I. Hapalopteroidea, $3 \mathbf{I 9}$.

Haptopoda, 3 I 6.

Hard parts, composition of, in animals, 25,26 ; in plants, $26,27$.

Harpes, 291.

Harvest-flies, 320.

Hatteria, 355. 
Head shield, of ostracoderms, 338; of trilobites, $29 \mathrm{I}$.

Hearing, of cephalopods, 258 ; of crustaceans, 283 ; of mammals, 335 ; of squids, $27 \mathrm{I}$.

Heart, in gastropods, 242 ; see also under the various classes.

Heat, derivation of, in body, 332 .

Hedgehogs, 379 .

Heidelberg man, 400.

Heliodiscus, 94.

Heliophyllum, I32; H. halli, I2, I32.

Heliozoa, 93.

Helix, 244, 250.

Hemiptera, 320.

Hemlocks, 73.

Hepaticæ, 44; geologic range of, 408 .

Herbivorous gastropods, 242 ; distinguished from carnivorous by means of the shell, 242 .

Hermaphrodite, an animal or plant having both sexes united in one individual.

Hermaphroditic, partaking of the characters of an hermaphrodite.

Herrings, 347.

Hesperornis, 357; H. regalis, $37 \mathrm{I}$.

Heterocercal tail fin, $338,340,344$.

Hexacoralla, I33-135.

Hexactinellida, 97, 98, I 02.

Hexalonche microphera, 93.

Hibernation, in gastropods, 242 .

Hind foot, of Eohippus, 393; of Equus, 393; of Hyracotherium, 393; of Mesohippus, 393; of Protohippus, 393; of Protorohippus, 393.

Hind limbs, of Cetacea, 328; of Malitherium, 328; of Python, 328; of Sirenia, 328 ; of snakes, 328 .

Hinge, in pelecypod shells, 210, 2 I 6 .

Hinge line, of brachiopod shells, I 88 .

Hinge plate, 2 I6.

Hinge teeth, cause of, 220.

Hip, see sacral, sacrum.

Hip bone, see innominate.

Hipparionyx, 192.

Hippopotami, 397.

Hirudines, I 42.

Hirudo, I 42 .

Hoactzin, 37I-373; recapitulation in, $371,373$.

Holly, 77 .

\section{Holocene, 407.}

Holocephali, 343; autostylic, 339; geologic age of, 343 .

\section{Holoptychius, 345, 352 .}

Holostei, 347; examples of, 347, 347.

Holothurians, I 7I-I 72 ; food of 172 ; fossils of, I72; geologic range of, 172 , 409 ; habitat of, I 72 ; spicules of, I72; tentacles of, I 72 ; tube feet of, I 72 .

Holothurioidea, I 7 I-I72; see holothurians.

Homarus, 307; H. americanus, 279, 307; habitat of, 307; molting of, 307; number of eggs laid, 307 ; recapitulation in, 307 .

Hominidæ, 400.

Homo, 400; H. diluvii testis, 353; H. heidelbergensis, 400; H. primigenius, 400 ; H. sapiens, 400.

Homoptera, 320.

Honey-comb coral, 136, 137 .

Hood, in cephalopods, 252, 253, 255.

Hoofed mammals, 382-398.

Horns, exceptional development of, in the extinction of the species, 375 ; hollow, 398; how former presence of is recognized in fossils, 363 ; solid, 397.

Horse family; see horses.

Horsehair worm, I $4 \mathrm{I}$.

Horses, causes of extinction of browsing, 375; changes during evolution, 393; environment of, during evolution, 396; evolution of, 392-396; extinction from North America, 376 ; geologic range of, 392; habitat of, 374 ; in North America, 375; modern, skull and brain of, 375 ; recapitulation in, 394 ; Texas, 383 .

Horseshoe crab, 277, 312.

Horsetails, 48-50; fossil, 48-50; in evolution, 55 ; silica in, 26 .

House fly, development of, 317-318; eye of, 3 I 7 .

Howlers, 399.

Humerus, of birds, 372 ; of cat, 325,327 ; of mammals, 325,385 ; of reptiles, 358 , $360,362,366,367$.

Hydnoceras, 105 .

Hydrocorallinæ, I 2 I.

Hydroids, I 08, I I I.

Hydrorhiza, I 09, I I I, I I 7 .

Hydrospire, I48, I 57, I 58, I58. 
Hydrotheca, I09, II3, II0, I20.

Hydrozoa, I08-I2I; digestion, etc., see Sertularia; fossil, II3-I2I ; geologic range of, 409 ; ocelli in, I I ; otocysts in, III; sense organs in, III; subdivisions of, I I3; survey of, I I 2 .

Hylobates, 400.

Hylonomus, 352.

Hymenoptera, $78,3 \mathbf{I} 8$.

Hyoid bone, of the cat, 325, 326 .

Hyolithes, 249.

Hyomandibular, 339.

Hyponome, in Ammonoidea, 263; in cephalopods, 255.

Hyponomic sinus, 255; in Ammonoidea, 263.

Hypostome, in crustaceans, 280, 286, 287.

Hyrachyus eximius, 380 .

Hyracoidea, 385-386; evolved from, 385 ; geologic range of, 385 .

Hyracotherium, 393.

Hyrax, 386.

Ichthyopterygia, 358,358 ; decline of, 367 ; habitat, etc., see ichthyosaurs.

Ichthyopterygians; see Ichthyopterygia.

Ichthyornis, $37 \mathrm{I} ; I$. victor, 372 ; associated with ammonites, 372 ; brain and skull of, 372; compared to tern and alligator, 372 .

Ichthyosauria, the ichthyosaurs.

Ichthyosaurs, 358,358 ; compared to whales, 358 ; decline of, 367 ; derivation of, 358; evolution in, 359; geologic range of, 358 ; habitat of, 358 ; production of young, $35^{8}$; sclerotic plates in, 335 .

Ichthyosaurus, $359 ;$ I. quadriscissus, 358 .

Ichthyotomi, 34I; fins in, 340.

Ilium, of birds, 372; of cat, 325, 328; of mammals, $325,328,385$; of reptiles, $360,366,367$.

Impunctate, lacking minute scattered pits.

Inadaptation, in the extinction of the species, 374 .

Inarticulata, I89, I90, I9I, I92, I95 ; vitality of, I9I.

Incisor teeth, 33I ; evolution in, 332 ; of cat, 33I; of cow, 332; of cud-chewing mammals, 332 ; of elephant, 332; of rodents, $38 \mathrm{I}$; of sheep, 332 ; recapitulation in, 332 .

Incurrent canals, 99, $\mathbf{1} 00$.

Incurrent siphon, in pelecypods, 209. 209, 211,2 I 2.

Index fossils, 22, 23; ammonites as, 263 ; Belemnites as, 272 .

Infertility, some causes of, in mammals, 376.

Infraclavicle, in fishes, $3+6$.

Infusoria, 95, I84; food of Tercdo, 233; geologic range of, 400 .

Infusorians, the Infusoria.

Injury of soft parts of body reflected in the shell, $I 8, \mathbf{1} 84$.

Ink sac of cephalopods, 268, 270; fossil, 269.

Innominate bone, 325; of cat, 325, 328 .

Inoceramus, 223-224, 267; I. barabini, 224 ; internal ligament of, $22 \mathrm{I}$.

Inorganic fossil objects, 20 .

Inorganic matter, growth of, 2 ; vs. organic matter, I.

Insect, paradoxical, 294.

Insecta, 275, 317-320; see insects.

Insectivora, 379; Eocene, closely related to Creodonta, 379; geologic range of, 379; in evolution, 399.

Insects, 3I7-320; ancient forms generalized, 318; comparison of respiration to that of birds, 370; development of, 317; evolution of, 274; famous localities for fossil, 3 I 8 ; flowerloving, 78 ; fossilization of wings of, 317; geologic range of, 318,409 ; in amber, Iо; in evolution, 83 ; metamorphosis in, 317 ; probable ancestors of winged, 3I8; respiration of, $3 \mathbf{I} 7$; compared to that of the vertebrates, 317 ; sexes of, 317; summary of orders of, 318-320; tracheæ of, 317.

Integument, a natural covering, as the skin; preservation of form of, in reptiles, 19,358 .

Interambulacrum (plu. interambulacra), of echinoids, $167, I 70$.

Intermedium bone, in turtles, 366 .

Internal mold, I4, 276.

Interradial plates, ${ }_{5} 8$.

Introduction, $\mathbf{I}-27$.

Introvert, of gastropods, 235, 236.

Invertebrate animals, restoration of, I7. 
Involuntary muscles, 329, 331 .

Iron, in petrifaction, $I 2$.

Iron fossils, preservation of, I 5 .

Ischium, of birds, 372 ; of cat, 325,328 ; of mammals, 325,328 ; of reptiles, 360 , 367.

Ischypterus, $347 ;$ I. lenticularis, 347.

Isoetes, 52 .

Isopoda, 291, 306.

Isopods, 29I, 306 .

Isoptera, $3 \mathbf{1 8 .}$.

Isotelus, 288, 296; I. gigas, 296, 296.

Ivory, of elephant's molar, 387 .

Ivy, 77 .

Japanese spider crab, 307 .

Jaw, of the cat, lower, 324, 325; upper, $324,325$.

Jelly-fish, IIO, I2I ; fossil, I22 ; impressions of, I8; trails of, I 6.

Jennings formation, fossils from, 136 ; geologic age of, 136 .

Jet, 7 I .

Joint, ball-and-socket, in echinoids, 168 .

Joints in vertebrates, ball-and-socket, 328; hinge, 329; immovable, 329; intertarsal, 369; in the cat, 328,329 ; recognition of in fossils, 329; separation of, 329 .

Julus, 309.

Juniper, 74 .

Jurassic, 407.

Jurassic fossils figured, $63,64,160,271$, $358,360,361,362,370$.

Kangaroos, 378 .

Kaskaskia formation, fossils from, 158 ; geologic age of, ${ }_{5}$ s.

Keel, in birds, 369,372 .

Keyhole limpet, $2+5$.

Kidneys, in cat, 330,332 ; in pelecypods, 213 ; work of, 332.

Kinderhook formation; fossils in, 265 ; geologic age of, 265 .

Knee-cap, see patella.

Kustarachnida, 3 I 6 .

Labial palps, 2 I 2.

Labrum, in crustaceans, see hypostome.

Labyrinthodonts, a division of the Stegocephalia, 352 ; relation to the anomodonts, 356 .
Lace-collar trilobite, 297.

Lacewing flies, 3 I9.

Lacuna, a vacant space in the tissues of plants and lower animals serving in the place of vessels for the circulation of the body fluid, or blood.

Lake.deposit of Florissant, 6.

Lamina of a vertebra, 326 .

Laminaria, 36 ; L. saccharina, 43 .

Lamna, 342.

Lamprey-eels, 337 .

Langurs, 400.

Lariosaurus, 356 .

Larva (plu. larvæ), of echinoids, I69; of mollusks, 207; of starfish, 153.

Larval shell, in pelecypods, 218 .

Larval stage, in pelecypods, 217 .

Larynx, 326, 330, 333 .

Lateral line in fish, 344, 314.

Lateral teeth, 209, 216.

Laurel, 77 .

Leaf-bases, in the cycadeoids, $6 I$; in cycads, 66.

Leaf-bud, fossil, 62.

Leaf-cushion, 51, 52; in Sigillaria, 54.

Legs, movement of, in crustaceans, 278 .

Lemuridix, 399.

Lemuroidea, 399.

Lemurs, 399.

Lens of eye of cat, 334 .

Lepas, 305, 382 .

Leperditia, 304 ; L. alta, 304.

Lepidodendron, 5I-54, 350; L. modulatum, 52 ; amphibians, in, 352 .

Lepidoptera 78, 319, 319.

Lepidosiren, 344 .

Lepidosteus, 347.

Lepidostrobus, 54

Leptena, 197; L. rhomboidalis, 192, 197; young shell of, 197.

Leptolinæ, I I I, II 3, I 20.

Leucocytes, I75, $28 \mathrm{I}$.

Lice, bird, 318; book, 318 ; plant, 320.

Lichens, $4 \mathrm{I}$.

Ligament, 214; C-spring, 2IO, 217 ; in pelecypods, 209, 2IO, 2II, 214, 22I ; origin of, $22 \mathrm{I}$; pit, $22 \mathrm{I}$.

Lily, 77,78 .

Lime carbonate, in animals, 25, 26; in plants, 27.

Lime phosphate, 26.

Lime secretion, in algæ, 38 ; in corals, $\mathbf{1 2 5}$ 
Limestone, crinoidal, 159 ; formation of, 38; formed by Fusulina, 89, 91; formed by Globigerina, 89, 90; formed by Nummulites, 92 ; formed by Orbitoides, 93; formed by Protozoa, $89-93$; of fresh water origin, 35,36 ; see also coral-reef.

Limnoscelis, 350.

Limpet, keyhole, 275 .

Limulava, 309, 311, 314 ; possibly a missing link, 3I4; relationship to trilobites, 3II; transitional between the trilobites and eurypterids, 3I 4.

Limulus molluccanus, 312; L. polyphemus, 277, 312; comparison of, with Scorpio, 309-3II; evolution of, 310; habitat of, 312 ; relationship to eurypterids and scorpions, 310 ; relationship to trilobites, 311 .

Line, lateral, in fish, $37 ., 344$.

Lines of growth, in pelecypods, 210,2 I 5 $216,215$.

Lingula, 190, 192, 193-194; L. anatina, 194; L. lepidula, 193.

Lingulids, I92; characteristic attitudes of, 193 .

Linnæus, 24.

Lion, color of young, 20; food per day, 363.

Liriodendron, 80; L. chinensis, 80; L. Iulipifera, 80; distribution, present and past, 80 .

Lithobius, 309.

Lithodomus, burrow of, I 7 .

Lithographic limestone of Bavaria, belemnoids of, 18 ; birds of, 7 .

Lithothamnion, 27, 37, 37; in formation of reefs, 38,39 .

Litopterna, 389; geologic range of, 389 ; parallelism in development of, 389 .

Littoral, inhabiting the shallow parts of the ocean from high water to the edge of the continental shelf, the one hundred fathom line.

Littorina littorea, migration of, 23.

Liver, in cat, 330,332 ; in gastropods, 235; in pelecypods, 211 .

Liver-fluke, 140.

Liverworts, 43, 44; fossil, 44 .

Living chamber, 251, 252.

Living organisms figured, $14,18,37,43$,

$47,85,90,99,107,109,114,123,126,1$ Maggots, 317.
$134,143,147,150,160,167,168,170$, $177,182,185,193,203,208,209,210$, $211,215,225,229,230,231,233,235$, $238,239,248,250,252,253,269,276$, $277,279,300,302,325,326,327,330$, $370,372,386,387,388,393,394,395$.

Lizards, 352, 367; see also Urodela; sclerotic plates in, 335 .

Lizzia, I I I.

Llamas, 397 ; in North America, 375.

Lobes, axial, in trilobites, 286, 287, 295; of cephalopod shells, 253, 265; pleural, in trilubites, $286,287$.

Lobocarcinus, 308.

Lobster, 84; American, 307.

Locomotion, of gastropods, 238 ; of starfish, 157.

Loess, 4.

Loligo, 273.

Lophophore, in brachiopods, 182, 184 , 187.

Lorraine formation, fossils of, 200 ; geologic age of, 200 .

Lower lip, in crustaceans, $280,286,287$.

Lumbar vertebræ, 325, 326.

Lunar bone, of mammals, 386, 395.

Lung-fish, 343-344; see also Dipneusti.

Lungs, of cat, 330, 333; of gastropods, 242 ; of lung-fish, 343 .

Lunule, $215,216$.

Lycopodiales, 5I-54; geologic range of, 408.

Lycopodium, 5 1.

Lyginodendron, 59; a synthetic type, 60. Lymphatics, vessels which collect lymph (an alkaline colorless fluid) from the digestive canal and other organs and tissues of the body, discharging it into the veins.

Lyssacina, 97.

Macaques, 400.

Machairodus, $38 \mathrm{I}$.

Mackerels, 348 .

Macrauchenia, 389 .

Macrocheira kämpferi, 307.

Mactra, $22 \mathrm{I}$.

Madrepora, I 29, I 34 .

Madreporite, of Asterias, I50; of echinoids, 167 ; of starfish, 150, 150, 167. 
Magnum bone of mammals, 386, 395.

Malacostraca, 306-308; fossil, 306307; geologic range of, 306 .

Malar bone in the cat, 325 .

Malaria, 95.

Mallophaga, 3 I 8.

Mallotus villosus, $34^{8}, 348$.

Mammæ, 335 .

Mammalia, 335, 373-402 ; see mammals and cat.

Mammals, 335, 373-402; an ascending series of, 377 ; ankle joint of, 374 ; causes of extinction of, $374-376$; digestion, etc., see cat ; exoskeleton of, 373; extinction of, from North America, 375; geologic range of, 409; habitats of, 374; hoofed, 382-398; in evolution, 83 ; migration of, 23 ; number of digits in, 328 ; of the Pleistocene in North America, 375; placental, 377; principal advance of in enlargement of brain, 375,385 ; recapitulation in, 326 ; ribs in, 326 ; subdivisions of, 377 ; teeth of, 373 .

Mammoth, 9, 387; see also Elephas primigenius preserved in Siberia, 19.

Mammut, 387, 388, 389; see also mastodon; M. americanum, 383, 387; compared to Elephas, 389; teeth of, 389 .

Man, 400; Heidelberg, 400; modern, 400; Neanderthal, 400; Piltdown, Eoanthropus dawsoni, 400; Sussex, 400; food of early, 38I; muscles of, compared to those of the cat, 329 ; parasites in, I40, I4I.

Manatee, 398.

Mandibles, of cat, 324,325 ; of crustaceans, 280 ; of fishes, 376 .

Mantis shrimp, 308.

Mantle, I84, 208-209; of brachiopods, I84, I93; of cephalopods, 255; of gastropods, 234, 235; of mollusks, 206; of pelecypods, 208, 209, 209, 210, $2 I I$.

Mantle muscles, in pelecypods, 209, 2 I 3 Mantoidea, 318.

Maquoketa formation, fossils from, 262 ; geologic age of, 262 .

Marattiaceæ, 46, 63.

Marchantia polymorpha, 43.

Marginal plates in turtles, 366 .
Maıine mammals, 374 .

Marl, 35 .

Marmosets, 399.

Marseniidæ, 243.

Marsupialia, 374, 378; geologic range of, 378 ; subdivision of, 378 .

Marsupials, the Marsupialia.

Mastigophora, 94, 100; geologic range of, 409.

Mastodon, see also Mammut; American, 383,387 ; compared with the elephant, 389 ; extinction of, 376 ; in North America, 375.

Mastodonsaurus, 352 .

Matter, inorganic, I; organic, I.

Mauch Chunk formation, a flood plain deposit, 5 ; amphibians in, 16 .

Maxilla, of birds, 372 ; of cat, 324, 325 ; of fishes, 346 ; of reptiles, 367 .

May-flies, 319.

Mazon Creek, concretions from, 59; fossils from, $57,58,59$.

Meandrina, I30.

Meckel's cartilage, $\mathbf{3 3 9}$.

Median, middle, fold, 188 .

Median sinus, 200, 201.

Medulla, of the alligator, 372 .

Medullary rays, 49.

Medusæ, I08, I II, I2I ; ocelli in, III ; otocysts in, III ; sense organs in, III.

Meekella, 188.

Megalonyx jeffersoni, 383.

Megaloptera, 3 I 9.

Megasecoptera, 3 I 9.

Megatheriidæ, 382, 383; generalized type, 382 .

Megatherium, 382.

Meleagrina, 225; M. margaritifera, 225.

Melonechinus multiporus, I70, I7I ; ambulacra of, $I 70$; genital plates of, 170 ; interambulacra of, $I 70$; ocular plates of, 170 ; spines of, I 7 I.

Melonites, I 7 I.

Membrane, ventral, 286, 287.

Membranipora, I78; $M$. pilosa, I77; $M$. rimulata, 177 ; zoœcia of, I 78 .

Menhaden, I 53.

Merostomata, 309.

Merychippus, 393, 395; intermediate between grazing and browsing horses, 394.

Mesatirhinus superior, 380 . 
Mesentery (plu. mesenteries), I23, I 24, I26.

Mesoderm, the layer of cells between the endoderm and ectoderm in the embryo of all animals above the coelenterates. It is composed of cells, as are the other two layers, and is probably developed from both of these.

Mesoglcea, the middle of the three body layers in the sponges and cœelenterates. It may be gelatinous (without cells) or cellular; but always differs from mesoderm (the middle layer of higher animals) in being derived from the endoderm or ectoderm comparatively late in life and not developed from a third embryonic layer (the mesoblast); of cœlenterates, IO8; of corals, I26; of Hydrozoa, I II ; of sponges, 99, 99, гог.

Mesohippus, 393, 393, 394, 395.

Mesonyx, 397.

Mesozoic, 407.

Metacarpal bones, of birds, 370,372 ; of cat, $325,327,327$; of mammals, $325,327,327,385,326,395$; of reptiles, 366,367 .

Metacarpus, the palm (327); see metacarpal bones.

Metamorphosis, example of among insects, 317; in the house fly, 317.

Metastome, in crustaceans, 280, 286 , 287.

Metatarsal bones, of cat, 327, 328 ; of mammals, 385 ; of reptiles, 366,367 .

Metatheria, 378 ; production of young, 377.

Metazoa, includes practically all animals above the Protozoa.

Metridium marginatum, I34.

Mice, 381 , 382 .

Microcyclas, I3I; M. discus, I $3 I$.

Migration, cause of, in birds, 370; of animals, 23, 24; of elephant, 23; of Littorina littorea, 23, 24; of mammals, 23; of Trinucleus, 23.

Mildews, 40.

Milk, of mammals, 374; secretion of, 335 .

Milk teeth, 33I.

Millepora, I2 I.
Millipedes, 309.

Miocene, 407.

Miocene fossils figured, $34,76,93,223$, $245,251,319,342,388,393,394,395$.

Miohippus, 393, 394.

Missing links, examples of, in arachnid evolution, $310,3 \mathrm{I} 4$; in the scorpions, 3 ro.

Mississippian, 407.

Mississippian fossils figured, 158,170 , I $80,188,265$.

Mites, 3 I6.

Mixosaurus, 359.

Mixotermitoidea, 3 I8.

Modern man, 400 .

II aritherium, 387, 388; in evolution, 398.

Molar tooth, cement of, 387 ; enamel of, 387; how distinguished, 374; ivory (dentine) of, 387; of cat, 33I; of Eohippus, 393; of Equus, 393; of Hyracotherium, 393; of Mesohippus, 393; of Protohippus, 393; of Protorohippus, 393.

Molds, I4, I4 ; external, giving former shape of organism, I6; external, of shells, I4; external, of skin, 19 ; internal, of shells, $I 7$, I 5, 246; internal, of sponge, 104 .

Molds (plants), 40.

Molecular replacement in fossils, II, I2.

Moles, 379; habitat of, 374.

Mollusca, see mollusks, 206-273.

Molluscoidea, I73-205; see under Bryozoa and Brachiopoda; geologic range of, 409 .

Mollusks, 206-273 ; circulatory system, 206; classification of, 207; development of, 207; digestive system, 206; excretory system, 207; food of squids, 270; fossils, see under the classes of ; geologic range of, 409 ; in evolution, 83 ; nervous system, 207; respiration in, 206; sexes of, 207; shell gland in, 207.

Molting, 277, 278; cause of, 277; in the crayfish, 277 ; in the horseshoe crab, 277; times of, 277 .

Monactinellida, 97, 98, 106.

Monkeys, broad nostril, 399 ; capuchins, 399; habitat of, 374; howling, 399; narrow nostril, 399; new world, 399; 
old world, 399; spider, 399; squirrel, 399 .

Monocotyledones, 78-79; see monocotyledons.

Monocotyledons, 78-79; early flora of, 77 ; fossil, 78, 79; geologic range of, 408 ; less primitive than dicotyledons, 80 .

Monograptus, I20; M. clintonensis, I2O.

Monotremata, 378; egg-laying, 374; geologic range of, 378 ; relation to the anomodonts, 356 .

Monotremes, the Monotremata.

Monotypic, containing but one representative.

Monticules, I 79.

Monticulipora, I78-179; M. arborea, $I 78$; corallites of, $I 78$; diaphragms of, I78, I 79 ; tabulæ of, 178 .

Moose, arrival in North America, 375 ; stag, 383 .

Mosasaurs, pythonomorphs somewhat like Mosasaurus, 357,367 .

Mosasaurus, 367 .

Moss, hair-cap, 42, 43 .

Mosses, 44; fossil, 44 ; geologic range of, 408.

Moths, 78, 319.

Mountain goat, arrival in North America, 375.

Movement, of $A m a b a, 85$; of Protozoa, 85.

Mucus-secreting glands of Amphibia, 349 .

Mud-fish, 343, 347 .

Mud-flows, fossil, 2 I.

Muensteroceras, 264; M. oweni, 265.

Multituberculata, 378 .

Mural pores, I33, I37.

Murex, 243.

Mus, 382 .

Musci, 44; see mosses.

Muscles, adductor, of Estheria, 302; adductor, of pelecypods, 209, 2IO, $2 I I$, 214; adductor of phyllopods, 302 ; annular, 252, 254; annulus, 254; aponeurotic bands, 254; circular, of eye, 334 ; columellar, 238 ; derivation in the cat, 329 ; derivation in mammals, 329; determination of size in fossils, 329; diaphragm, 330, 33I ; dorsal, in crustaceans, 278 ; extensor, in crustaceans, 278, 279; fibers of, 329; flexor, in crustaceans, 278, 279; foot, of pelecypods, 209, 2II, 2I4; in Hydrozoa, I Io; involuntary, 329, 33I ; mantle, in pelecypods, 209, $2 \mathbf{I} 3$; of cat, compared to those of man, 329 ; protractor, 214; radial, of eye, 334 ; retractor, anterior, 209, $2 I O, 2 I I, 214$; retractor, posterior, 209, 2II, 214 ; siphonal, in pelecypods, 209, 214 ; ventral, in crustaceans, 278 ; voluntary, 329, 331.

Mushrooms, 40.

Musk-ox, arrival in North America, 375.

Muskrat, habitat of, 374 .

Mussels, I5I ; river, 228.

Mustelus, 339.

Mycelium, 40, $4 \mathrm{I}$.

Myomeres, 329.

Myriopoda, 275, 309; see myriopods.

Myriopods, 275, 309; evolution of, 274; famous localities for fossil, 318 ; geologic range of, 309, 409 .

Myrmecophagidæ, 382 .

Mysidacea, 306, 307.

Mysis, 285.

Mytilus edulis, 25.

Myxomycetæ, 33; geologic range of, 408.

Myxospongida, 97, 98, 107.

Naming of organisms, 24.

Naples formation, fossils from, 264 ; geologic age of, 264 .

Narwhals, 399.

Nasal bone, in reptiles, 367 .

Nassa, smell in, 242 .

Natica, 240; $N$. heros, smell in, 242.

Nauplius, the larval form in which many crustaceans hatch from the egg; its body is small, oval, unsegmented, with three pairs of limbs corresponding to antennules, antennæ, and mandibles of the adult, but now all are used for swimming. A more or less definite carapace is present. Eye is simple and median. Nauplius larvæ, similar in all essentials, are present in the Phyllopoda, Copepoda, Cirripedia, and some Malacostraca.

Nauplius stage, 283,285, 294, 305, 306; absence of in merostomes and scorpions, 3 II . 
Nautiloidea, 252, 26I-262; see also Nautilus; geologic range of, 26r .

Nautilus, 89, 206, 25I-259, 262, 263 , $270 ; N$. macromphalus, 253; N. pompilius, 252, 254; N. umbilicatus, 254; body of, 254 ; creeping, 252-253, 253 ; development of, 258 ; digestion of, $256-257$; distribution of, 262 : eggs of, $25^{8}$; excretion of, 257 ; eyes of, $252,253,257^{-258}$; food of, 256 ; funnel of, 252, 255; geologic range of, 260 ; gills of, 255,256 ; habitat of, $25 \mathrm{I}$; hearing of, 258 ; heart of, 257 ; hyponome of, 252, 255; jaws of, 256 ; kidneys of, 257 ; lobes of, 253 ; mantle of, 255; muscles of, 254; nervous system of, 257 ; osphradia of, 255,258 ; otocysts of, 258 ; radula of, 257 ; respiration of, 256 ; saddles of, 253 ; sense organs of, 257 ; septa of, 251, 252; sexes of, 258 ; shell of, 253 ; siphon of, 25I-252, 252, 254, 255; smell of, 258 ; sutures of, 253 ; tentacles of, 255 ; umbilicus of, $\mathbf{2 5 4}$.

Navicular bone, in the cat, 327.

Neanderthal man, 400 .

Neck, see cervical.

Neck-frilled dinosaur, 364.

Necturus, 353.

Nemathelminthes, I40-I4I ; fossils of, I 4O, I4I; geologic range of, 409 .

Nematocysts, I 24; see nettle-cells.

Nematophycus, 36 .

Neolenus serratus, 285.

Neolimulus, 3 I0, 3 I I, $3 \mathbf{2} 2$.

Nephridia, in Annulata, I44; in brachiopods, I86; in cephalopods, 257 ; in pelecypods, 213.

Nereis, I46; $N$. virens, I42-145, I43; blood of, I44; body of, 142 ; digestion of, I44; excretion of, I44; food of, I 43 ; fossils of, I45; muscles of, I 43 ; nervous system of, I45; sense organs of, I 45 ; sexes of, I 45 .

Nerves, in plants, the principal fibrovascular bundles or ribs in a leaf; in animals, the whitish fibers which transmit nervous impulses throughout the body; cranial, 333; in Hydrozoa, I 10; in plants, 50, 59; spinal, 333334 ; ventral nerve cord in crustaceans, 279.
Nervous system, central, 333; connection of, in mammals, 334; of $A$ maba, 87 ; of cat, 333 ; of mammals, 333 ; of Protozoa, 87 ; peripheral, 333-334; sympathetic, 334 .

Netted-veined leaves, with ribs or veins branching, the minute branches uniting, thus giving a netlike appearance to the leaf, 79 .

Nettle-cells, the poison of some of these cells is believed to be formic acid; in Coelenterata, I08, I10; in corals, I23, I 24; in Hydrozoa, 110; in Sertularia, I IO.

Neural arch, 326 .

Neural canal in vertebræ, 326 .

Neural spines in vertebræ, 326, 346, 360,367 .

Neurals, in turtles, 366.

Neurocole, 32 I.

Neuroptera, $3 \mathbf{I} \mathbf{9}$.

Neuropteris, 45, 59; N. hirsuta, 58; N. smithsii, 58 .

Newark beds, 6; fish from, I4; fossils from, I4. 350 .

Niagara formation, fossils from, 137,138 , I55; geologic age of, 137 .

Niobrara formation, fossils from, 372; geologic age of, 372 .

Nodes, in Calamites stem, 49, 50.

Non-calcarea, 98, ro2.

Notharctidæ, 399 .

Notochord, 321 ; in fishes, 346.

Nucleus, in Amceba, 84, 85; in Protozoa, 84.

Nucula, 223, 23I ; N. proxima, 223.

Nudibranchs, 243; absence of shell in, 243.

Nullipores, 37, 38.

Nummulites, 88, 91, 92 .

Oak, 77 .

Ocelli, in Hydrozoa, II ; in medusæ, I I I.

Octocoralla, I 35-136.

Octopus, 269, 273.

Octoseptata, I3I.

Ocular plate, 167, I 69.

Ocular tentacles, 252, 253, 258.

Odd-toed ungulates, $389-396$; see perissodactyls.

Odonata, $3 \mathbf{1 9}$. 
Odontoceti, 399.

Odontophore, in gastropods, 236 .

Esophagus, see esophagus.

Oil-glands, 324 .

Old age characters in shells, $I 8$.

Oldhamia, 40.

Olecranon process of ulna, in the cat, 325.

Olfactory lobe of brain, of alligator, 372; of Ichthyornis, 372; of tern, 372.

Oligocene, 407.

Oligocene fossils figured, 93, 388, 391, $393,39.4,39.5$.

Ommastrephes, 269-27I, 273; O. illecebrosa, 260; distribution of, 269; eyes of, 270; food of, 270; funnel of, $269,270,27 I$; hearing of, 27I ; ink sac of, 270 ; jaws of, 260 ; locomotion of, 270 ; otocysts of, $27 \mathrm{I}$; sexes of, $27 \mathrm{I}$; skeleton of, 269,270 ; suckers of arms, 270 ; tentacles of, 260 .

Ommatideum, of crayfish, $\mathbf{2 8 2}$; of crustaceans, $28 \mathbf{2}$.

Onoclea $43,46,47,48 ;$ O. inquirenda, 47 ; O. sensibilis, 47,48 .

Onondaga formation, fossils from, 263; geologic range of, $26_{3}$.

Ontogeny, the life history of an individual organism from the egg to adulthood.

Onychophora, 275, 308; fossil, 308; geologic range of, 409 .

Ö̈lites, 33, 34 .

Ooze, diatomaceous, 34; foraminiferal,

- 89; globigerina, 89 , 90; radiolarian, 94.

Operculum, of fishes, 344,346 ; of gastropods, 235, 239, 244 .

Ophioglossales, 46.

Ophiopholis aculeata, ${ }_{1} 65$.

Ophiuroidea, I65; geologic range of, 165 , 409.

Opisthobranchia, 243, 244, 248.

Opossums, 378.

Optic lobe of brain, of the alligator, 273; of Ichthyornis, 372; of the tern, 372.

Orang-utan, 400.

Orbit of eye, of birds, 372; of cat, 325, 335 ; of mammals, 325, 335, 385; of ostracoderms, 338 ; of reptiles, 360 , 367.

Orbitoides, 88, 92, 93.
Ordovician, 407.

Ordovician fossils figured, $36,37,114$, $I 18,119,120,133,156,178,196,197$, 200, 201, 244, 262, 286, 296, 297.

Oreodon, 397.

Oreodonts, 397.

Oreomunnea mississipiensis, $8 I$.

Oreopithecus, 400.

Organic matter, growth of, 2 ; vs. inorganic matter, $\mathrm{I}$.

Organisms, naming of, 24.

Organ-pipe coral, I 28, 135 .

Ornithopoda, $363-364$.

Ornithorhynchus, 378 ; hatching of eggs of, 377 .

Orohippus, 393, 394.

Orthis lenticularis, 200.

Orthoceras, $262 ;$ O. sociale, 262.

Orthoptera, 3 I 8 .

Osculum, of sponges, 96, 99, 104, 106 .

Osmosis, the tendency of liquids or gases of differing densities to mix through a porous structure.

Osmunda, 46.

Osmundaceæ, 46.

Osmundites, 46.

Osphradium (plu. osphradia), of cephalopods, 255,258 ; of gastropods, 238 ; of pelecypods, 2 I $3,22 \mathrm{I}$.

Os pubis, see pubis.

Ostracoda, 303-304, 306; see also ostracods.

Ostracodermi, 337-338; geologic range of, 338,409 ; habits of, 338 ; place in classification, 337 .

Ostracods, 303-304, 306; compared to young barnacles, 305; eyes of, 303, 304; fossil, 304; geologic range of, 303 ; habitat of, 303 ; shell of, distinguished from pelecypod shell, 303 ; skeleton of, 303, 307 .

Ostrea, 225-226; O. virginica, 225; attachment of shell, 226 ; blood of, 221 ; bored by Cliona, 226; composition of shell, 25; effect of loss of one muscle upon shell, 222; fossils of, 226 ; resilium (internal ligament) in, $22 \mathrm{I}$; sex in, $22 \mathrm{r}$.

Otocyst, method of functioning, 283 ; molting of, 283 ; of cephalopods, 258 ; of crustaceans, 283; of crustaceans compared to the semicircular canals of 
man, 283 ; of gastropods, 238; of Hydrozoa, I I ; of medusæ, III; of pelecypods, 213,22I; of squids, 271.

Otoliths, of cephalopods, 258; of pelecypods, 2 I 3.

Ovary, of cat, 330 ; of plants, 76 .

Oviparous, referring to animals whose eggs are first laid and then hatched. Opposed to viviparous.

Ovule, 73, 56, 67, 77 .

Ovum (plu. ova), egg, of Annulata, I45 ; of brachiopods, I 86 ; of Bryozoa, I 76 ; of corals, I 25 ; of echinoids, I 69 ; of Hydrozoa, IIo; of mammals, 335; of pelecypods, 2 I 6 ; of seed-plants, 56 ; of sponges, ror ; of starfish, I 53.

Owls, gizzard of, 369 .

Oxen, 398.

Oxidation, 2 .

Oxygen; this enters into a loose chemical union with hæmoglobin and hæmocyanin of the blood; in Amaba, 86; in Protozoa, 86.

Oxyuris vermicularis, $\mathrm{I} 4 \mathrm{I}$.

Oyster, see Ostrea.

Oyster drill, 2I 8.

Oysters, I5I.

Pad, of elephant's foot, 386 .

Palatoquadrate cartilage, 339.

Paleaster, I63-I65; $P$. eucharis, I64.

Paleobotany, the study of fossil plants, 32.

Paleocaris, 306.

Paleodictyoptera, 3 I 8.

Paleogeography, the study of the geography of past geologic periods of the earth's history; interpretation of, 23 ; use of brachiopods in, r9.

Paleohatteria, 355 .

Paleohemiptera, 320.

Paleomastodon, $386,387,388$.

Paleontology, the study of the past life of the earth.

Paleophonus, 3 Iо.

Paleospondylus, 337.

Paleozoic, 407.

Palets, of Teredo, 233, 233.

Pallial, pertaining to the pallium, or mantle, of mollusks and brachiopods.

Pallial cavity, in gastropods, 234.

Pallial line, 209, 2 I4; simple, 220.
Pallial sinus, in pelecypods, 209, 2 I4, 220.

Pallial sinuses, in brachiopods, 185,189 , 203.

Palm bones, see metacarpals.

Palmoxylon anchorus, 79 .

Palms, 77, 78, 79; sago, 66.

Palpebral lobe, 289, 296.

Palpigrada, 316.

Palps, labial, $2 \mathbf{2}$.

Pancreas, 330.

Panorpatæ, $3 \mathbf{1 9 .}$

Pantotheria, 379 .

Paradoxides, 294; P. harlani, 205.

Paragastric cavity, 96, 99, I04.

Parallelism in development, example of, in the Litopterna and horses, 389 .

Paramacium, 95.

Paramys delicatior, 380 .

Parapodium (plu. parapodia), I42, 143.

Parasite, an organism which lives at the expense of another organism.

Parasitic plants, 29.

Parenchyme, I 76.

Pariasaurus, 356.

Parichnos, 52.

Parietal bone, of cat, 325; of fishes, 346.

Parrot, teeth in, $37 \mathrm{I}$.

Parthenogentic, 301 .

Patapsco formation, flora of, 77 ; geologic age of, 77 .

Patella, of cat, 325, 328; of mammals, $325,328,385$.

Patriofelis, 379, 38I ; P. ferox, 380 .

Pearls, secretion of, 220.

Pearly layer of the shell, in pelecypods, 215.

Pearly Nautilus, 25 I.

Peat bogs, 4 .

Peccaries, in North America, 375.

Pecopteris, 59 ; P. plunckneti, 59.

Pecten, 230-232; $P$. gibbus borealis, 18 , 230, 23I, 232; $P$. gibbus irradians, 232 ; P. magellanicus, 232 ; blood of, 22I ; composition of shell of, 25 ; development of, 23I ; dissoconch stage of, 23I, 23I; evolution of, 23I-232; eyes of, 220,230 ; method of swimming, 231, 230; plicated stage of, 23I, 231 ; prodissoconch of, 23I, 23I ; recapitulation in, $23 I-232$; sex in, 22 . 
Pedal, pertaining to the foot.

Pedal ganglia, in gastropods, 237 ; ganglia, in pelecypods, $22 \mathrm{I}$.

Pedicellaria (plu. pedicellariæ), in echinoids, 168 .

Pedicle, 187 ; attachment of, 203; in a vertebra, 326; of brachiopods, I $8 \mathrm{I}$, 182 ; opening, $\mathrm{I} 8 \mathrm{I}, I 82$; valve, $\mathrm{I} 8 \mathrm{I}$, I $82, I 88$.

Pedicle valve, I8I, I82, I88; distinguished from brachial valve, I 89 ; secretion of, $\mathrm{r} 89$.

Pedipalpida, 3 I 6 .

Pelecypod, ideal section through, 210 ; shells distinguished from brachiopod shells, I90, 222 .

Pelecypoda, 206, 208-234; see pelecypods and Venus.

Pelecypods, 206, 208-234; anterior end of shell distinguished from posterior end, 222; blood of, 220 ; digestive system of, 220; food of, etc., see Venus; fossils of, 223-234; function of teeth of shell of, $22 \mathrm{I}$; geologic range of, 222, 400; muscles of, $22 \mathrm{I}$; nervous system of, 221 ; right valve distinguished from left valve, $22 \mathrm{I}$; sexes of, $22 \mathrm{I}$; survey of, $2 \mathrm{I} 9^{-222}$; valves of, 22 I.

Pelmatozoa, I 54.

Pennsylvanian, 407.

Pennsylvanian fossils figured, 49, 50, $52,54,55,57,58,91,199,350$.

Pentacrinus, I 59, I60-I62; P. asteriscus, I60, I62; P. caput-medusa, I6o; ambulacral grooves of, I6I ; ambulacral system of, I6I ; calyx of, I6I ; cirri of, 160 ; evolution in, 162 ; food of, I6I ; nervous system of, I6I ; pinnules of, I6I ; plates of, I6I ; recapitulation in, 162 ; sexes of, 162 ; skeleton of, I6I; stalk of, I62.

Pentremites, I57-I59; $P$. pyriformis, 158 ; ambulacral grooves, 158 ; calyx of, I 57 ; marginal pores of, I 58, 158 ; nerves of, I58; plates of, I 50 .

Perches, 348.

Perianth, 76 .

Pericardial sinus, in crustaceans, 279, 28I.

Pericardium, of crustaceans, 270; of gastropods, 237; of pelecypods, 2 I 2.
Period, 407.

Periosteum, 324; a use of, 329; function of, 324 .

Peripatus, 308; fossil, 308.

Peripheral nervous system, in mammals, 333.

Periproct, in echinoids, $167, \mathbf{1 6 7}$.

Perissodactyla, $389-396$; see perissodactyls.

Perissodactyls, $389-396$; geologic range of, 380 .

Periwinkle, the small marine gastropod, Littorina; often also applied to Busycon.

Perlaria, 3 I 9.

Permian, 407.

Permian fossils figured, 350 .

Petrifaction, 8, I I, I 5 .

Phacops, 298-299; P. rana, 298, 299; eyes of, 292.

Phalangers, flying, 378.

Phalanges, middle, 395 ; of birds, 370 , 372; of fore limb, 325, 327, 327; of hind limb, 325, 327, 327; of mammals, 385,386 ; of reptiles, 362,366 , 367; proximal, 395; terminal, 395; ungual, 395.

Phalangida, 3 I 6.

Phalangiotarbi, 3 I 6.

Phalangium, $3 \mathbf{1} 6$.

Phanerogams, 45.

Pharynx, the part of the digestive canal between the mouth and the esophagus.

Phascolotherium, 378 .

Phasmoidea, 3 I 8.

Phenacodus, $\bullet 85$; P. primcevus, 384,385 ; restoration of, 384 .

Phloem, 79 .

Phoronida, I 8I ; geologic range of, 409 .

Phoronis, I $8 \mathbf{I}$.

Phragmocone, compared to the tetrabranch shell, 272; of Belemnites, 27I, 272.

Phycomycete, 4I, $4 I$.

Phylactolæmata, I 75, I 77, I 80.

Phyllocarida, 306.

Phyllograptus, II8; $P$. angustifolius, IIO; P. ilicifolius, IIO.

Phyllopoda, see phyllopods.

Phyllopods, 285, 299-303, 306; relationship to trilobites, 293.

Physalia, I 2 I. 
Pierre formation, fossils from, 266, 267, 366; geologic age of, 266, 366.

Pigeon, compared to Ichthyornis, 372 ; gizzard of, 369 .

Pigs, 397; number of digits in, 328; parasites in, 140,141 .

Pikes, 348.

Pill-bug, 306; enrollment of, 291.

Piltdown man, Eoanthropus dawsoni.

Pinaceæ, $7 \mathrm{I}$.

Pincer, of crustaceans, 276, 270.

Pineal opening, in ostracoderms, 338; in plesiosaurs, 356 ; in Stegocephalia, 352 ; in theromorph reptiles, 355.

Pines, 73.

Pinna (plu. pinnæ), 46.

Pinnate, furnished with pinnules or leaflets, 58, 59 .

Pinnipedia, 38I ; evolution of, $38 \mathrm{I}$; geologic range of, $38 \mathrm{r}$.

Pinnules, of blastoids, I57 ; of crinoids, I6I; of Pentremites, I58; of plants, 58,64 .

Pin-worm, I4 I.

Pisces, 339-349; see fishes.

Pisiform, of cat, 327 ; of mammals, 395 , 395 .

Pistil, 76.

Placenta, 335, 374, 377 .

Placental mammals, $373,374,377$.

Placenticeras, 264; P. intercalare, 266.

Placoid, 34I.

Plagiaulax, 378 .

Planaria, I40.

Planktonic, drifting aimlessly, without power to direct a course, 89 .

Planorbis, blood in, 242.

Plantain, 78.

Plant lice, 320.

Plants, 29-82; as indicators of climate, 30; classification of, 32 ; distinguished from animals, 2, 29; evolution of, $3 \mathrm{I}$; food of, 29; preservation of, 3I ; reproduction of, 30 ; respiration of, 30.

Planula, I 25.

Plasmodium, 95.

Plaster of Paris, use in restoring shape of organisms, I 6.

Plastron, of turtles, 365,366 .

Platecarpus corypheus, 367.

Platyhelminthes, I40; fossils of, 140 ; geologic range of, 409 .
Platystrophia, 199; P. lynx, 200, 200; evolution of, 200; recapitulation in, 200.

Plectoptera, 3 19.

Pleistocene, 407.

Pleistocene fossils figured, 348,383 , $388,393,394,395$.

Pleistocene mammals, extinction of, from North America, 376 .

Pleopods, in crustaceans, $\mathbf{2 7 6}, 270$.

Plesiosaurs, $356-358,357$; evolution in, 356 ; food of, 357 ; geologic range of, 356 ; habitat of, 356 ; production of young, 356 ; stomach-stones of, 356 .

Plesiosaurus, 356.

Pleura (plu. pluræ), 286.

Pleuracanthus, 342 .

Pleural, pertaining to the pleuræ or sides of the thorax.

Pleural bones, in turtles, 366 .

Pleural ganglia, in gastropods, 237; in pelecypods, $22 \mathrm{I}$.

Pleural lobes, in trilobites, 286, 287.

Pleural spines, 295.

Pleuropterygii, 34 I ; fins in, 340.

Pleurotomaria, 244.

Pleurotomariidæ, 244, 246.

Plicated stage in Pecten, 23 I, 231 .

Plications, I88, $20 \mathrm{I}$.

Pliocene, 407.

Pliocene fossils figured, $388,393,394$, 395.

Pliopithecus, 400.

Plumatellites, 180 .

Pneumatocyst, I I 3; in graptolites, II4, II 5 .

Podozamites, 66.

Pollen, 56; germination of, 43 .

Polygyra albolabris, 250; blood in, 242; sense of smell in, 242; sight in, 243.

Polymastodon, 378.

Polyplacophora, 208

Polyprotodonts, 378 .

Polyps, $>$ French poulpe or polypus, the common name for the Octopus in France, applied to the colenterate individual because of a superficial resemblance; feeding, Iog, III ; in corals, I 23, 123; in Hydrozoa, I08, 100 ; in Sertularia, 108, I00; reproductive, I09, I IO, III.

Polypterus, 345 . 
Polystichum, 46.

Polytrichum commune, 42, .13, 44 .

Pondweed, 77, 78 .

Poplar, 77, 8I ; fossil record of, 8I.

Populus, the poplar, $8 \mathrm{I}$.

Pore-rhombs, I48; of Caryocrinus, I 56.

Pores, in corals, 137 ; in sponges, 100.

Porifera, 96-107; see sponges.

Porospora gigantea, 84 .

Porpoises, 399.

Port Jackson shark, 342 .

Portuguese man-of-war, I2I.

Posterior adductor muscle, 209; retractor muscle, 200, $2 I I, 2$ I 4 .

Post-frontal bone, in fishes, 376 .

Post-temporal bone, in fishes, 346 .

Potomac formation, fossils from, $6 I$; geologic age of, 6I.

Pre-Cambrian, 407.

Precious red coral, $\mathrm{I} 2 \mathrm{~S}$.

Premaxilla bone, in fishes, 346 .

Premaxillary bone, in reptiles, 367 .

Premolar teeth, of the cat, 33 I.

Preparation of dried specimens, 2 I 9.

Preservation, of fossils, $3-8$; of plants, 3 I .

Presplenial bone, in reptiles, 367 .

Primates, 399-400; evolution of, 399.

Primicorallina trentonensis, 36, 37 .

Primitive characters, persistence of with modern ones, example of, the elephant, 386.

Prioniodus, 146, I46.

Prismatic shell structure, 2 I5.

Prismodictya, 97, 103-105; P. prismatica, 104 .

Proangiosperms, age of, 66 .

Proboscidea, 386-389; geologic range of, 386; hoofs of, 386,386 ; incisor teeth of, 386,388 ; molar teeth of, 386 , 387,388 .

Proboscis, in Nereis, I43, I 44.

Prodissoconch, 218, 23 I, 231 .

Prodryas persephone, 319 .

Productus, I88, I98; $P$. giganteus, I9I ; $P$. semireticulatus, 23, 192, 198, I99.

Proloculum, 89.

Pronghorn antelope, 398.

Proöstracum compared to squid skeleton, 272; function of, 272 ; of Belemnites, 271, 272; of Sepia, 272.

Protaspis, 286, 292-293.

Protegulum, I87, 185 .
Proteid, 2.

Proteids, in vertebrate digestion, 332.

Protephemeroidea, $3 \mathbf{I}$ 9.

Prothallus, 43,45 .

Protoblat toidea, 3 I 8 .

Protocaris, 303.

Protoconch, of Belemnites, 271 ; of gastropods, 238, 239, 240; of nautiloids and ammonoids compared, 26r.

Protodonata, 319, 350 .

Protodonta, 378 .

Protocium, in Bugula, $\mathbf{1 7 6}$; in Fenestella, $\mathbf{1 8 0 .}$

Protohemiptera, 3 I9.

Protohippus, 393, 394.

Proto-nauplius, 292.

Protonema, 42.

Protoplasm, I ; in Protozoa, 83, 84.

Protopodite, 276; of the crayfish, 276; of the lobster, 279; of the trilobite, $286,288$.

Protopterus, 344.

Protorohippus, 393, 393.

Protorthoptera, 318.

Prototheria, 377,378 .

Protozoa, 83-95, 212; classification of, 84 ; compared with sponges, Io०; digestion, etc., see Amœba; geologic range of, 409 ; secretion of hard parts in, 84 ; size of, 84 .

Protozoöns, the Protozoa, 2 I 2.

Protractor muscle in pelecypods, 2 I 4.

Protremata, I 89 .

Proximal, near the point of attachment; opposed to distal.

Pseudo-columella, I23, I 26.

Pseudo-fossils, 2 I.

Pseudomorphs, I 3.

Pseudopodia, in Amaba, 85; in Foraminifera, 88; in Globigerina, 90; in Protozoa, 85; in Rhizopoda, 88.

Pseudoscorpionida, $3 \mathbf{I} 6$.

Pteranodon, 365.

Pteria, 224-225, 23I.

Pteridophyta, 43, 44-55; classification of, 46 ; geologic range of, 408 .

Pteridophytes, the Pteridophyta.

Pteris, 30.

Pterodactyls, the pterosaurs, 357; food of plesiosaurs, 357 .

Pterodactylus, 365 .

Pteropoda, 248, 248; see also pteropods. 
Pteropods, 243, 248, 248; absence of shell in some, 243 .

Pterosauria, 357, 364-365; bones hollow, 364 ; geologic range of, 365 ; size of, 365 ; wings of, 364 .

Pterosaurs, see Pterosauria.

Pterygotus, $3 \mathrm{I} 3$.

Ptyctodonts, 343.

Pubis, of birds, 372 ; of cat, 325,328 ; of reptiles, 360,367 .

Pulmonata, the pulmonate gastropods.

Pulmonate gastropods, 242, 243, 2.44.

Pulmonates, the pulmonate gastropods.

Punctate, covered with minute pits; appearance, cause of, 189 .

Pupa case, 318.

Pupil of the vertebrate eye, 334 .

Pustule, a minute blister-like elevation.

Pustulose, covered with pustules or small blisters, see glabella of Phacops, 298 .

Pygidium, the portion of the dorsal shield in trilobites covering the abdomen, 286, 287, 29 I, 295, 296.

Pyritization, 12 .

Python, hind limbs in, 328; hip bone in, 328.

Pythonomorphs, 367 ; evolution of, 367 ; habitat of, 367 .

Quadrate bone, 339, 367 .

Quahog, 208.

Quaternary, 407.

Rabbits, 382 .

Raccoons, 38I ; evolution of, $38 \mathrm{r}$.

Radial plates, in blastoids, 158 .

Radial symmetry, with the individual parts arranged symmetrically around a central axis, as in the starfish, 150 ; in Coelenterata, $108,109,123 ;$ in Echinodermata, 150, 167, 167,170 .

Radiale bone, in turtles, 366 .

Rarliolaria, 84, 93-94, 93.

Radiolarian ooze, 94.

Radius, of birds, 370,372 ; of cat, 325 , 327 ; of mammals, 385,394 ; in reptiles, $358,360,362,366,367$.

Radula, 236 ; in carnivorous gastropods, 243 ; in gastropods, 236 ; in herbivorous gastropods, 243.

Rafinesquina, 188, 189, 195-196, 197; R. alternata, 196, 196.
Rain-drop impressions, fossil, 2 I.

Raphidioidea, 3 I9.

Rats, 381, 382.

Recapitulation, in birds, 371, 373; in brachiopods, 200 ; in caudal (tail) fins, $34 \mathrm{I}$; in eurypterids, $3 \mathrm{I} 3$; in gastropods, 240, 247; in higher mammals, 326; in Hoactzin, 371, 373; in Homarus, 307; in horse, 394; in incisor teeth of mammals, 332; in leg bones of modern birds, 372 ; in lobster, 307; in Merychippus, 394; in mollusks, 23I; in number of ribs, 326; in Pecten, 23I-232; in Pentacrinus, I62; in Platystrophia, 200; in Scorpio, 310 ; in toad and frog, 353 ; in Vermicularia, 247; use of, in restoration of animals, I9.

Rectum, 330.

Reculoidea, 3 I 8.

Red-deer, arrival in North America, 375.

Redwood, 73.

Reef-building corals, I 30 .

Reindeer, arrival in North America, 375.

Relationship between the soft body and hard shell, 18,195 .

Renieria, 97 .

Rensselceria, 190, 192, 202.

Repetition of ancestral characters, see recapitulation.

Reproduction, in Algæ, 30; in $A m \propto b a$, 87 ; in bacteria, 30 ; in Cycas, 66; in Foraminifera, 89 ; in graptolites, I I 5 ; in Hydrozoa, I10; in plants, 30 ; in Protozoa, 87, 88, 89; see also the various classes.

Reproductive stage, in plants, 43 ; in pteridophytes, 45 ; in seed plants, 56 ; in spermatophytes, 56 .

Reptiles, 354-369; see also snakes; dominance of, 354; exoskeleton of, 354 ; flying, 357,364 ; geologic range of, 409 ; habitat of, 354 ; number of digits in, 328 ; respiration of, 354 ; subdivision of, 355 ; swimming, 355 , $356,357,358,365,367$.

Reptilia, 354-369; see reptiles and snakes.

Resilifer, 22 I.

Resilium, 190, 22 I, 225.

Resorption, the act of absorbing again; see absorption. 
Respiration, anal, 304; of Amoba, 86; of brachiopods, I86; of cat, 86 ; of crustaceans, 285 ; of fishes, 339 ; of gastropods, 235; of Hydrozoa, I Io; of mammals, 333; of plants, 30 ; of Protozoa, 86.

Restoration, of a trilobite, I7; of $\mathrm{Bcl}$ emnites, 27I; of belemnoids, i 8 ; of fossils, I 7-20; of invertebrate animals, I 7 ; of muscular system of fossil vertebrates, 329 ; of shape of organism from external molds, I6; of Triarthrus, I 7 ; of vertebrate animals, I $8-20$; use of recapitulation in, $\mathbf{1} 9$.

Resupinate, inverted in position; a resupinate brachiopod, 196, 197 .

Retina of cat's eye, 334.

Retractor muscles, in pelecypods, 209, $210,211,214$.

Rhabdosome, I I5.

Rhamphorhynchus, 365

Rhinoceroses, $3 \delta 0,392$; causes of extinction of, 375 ; number of digits in, 328 .

Rhombopteria, 231, 231 .

Rhynchocephalia, 355; generalized types, 355 ; geologic range of, 355 ; in evolution, 373 ; relationship to dinosaurs, 359 ; sole survivor of, 355 .

Rhynchonclla, г go.

Rhynchonellids, 192.

Rhychotrema, 201 ; $R$. capax, 192, 201.

Ribs, of birds, 372; of cat, 325, 326; of fish, 326 ; of higher mammals, 326 ; of reptiles, $360,362,366,367$; of snakes, 326; recapitulation in, 326 ; upon shells, cause of, 220.

Richmond formation, fossils of, 192 ; geologic age of, 192.

Richthofenia, I88.

Ricinulei, 3 I6.

Ringworms, I40, I4I-I47.

Ripple marks, fossil, 2 I.

River mussels, 228 .

Rockweed, Iog.

Rodentia, 381-382; see rodents.

Rodents, $3 \delta_{0}, \mathbf{3} 8 \mathbf{I}-\mathbf{3} 8 \mathbf{2}, 3 \delta_{3}$; geologic age of, 381,382 ; incisors of, $38_{1}$.

Rorquals, 399.

Rostrum; a beak ; of Ammonoidea, 263 ; of Crustacea, 278.

Rotalia, 91.

Rotifer, I4I.
Rotifera, I4I, 212; size of, 141.

Round-worm, 141 .

Royal fern, 46 .

Ruminants, divergence of, 398 ; evolution of, 397; hollow-horned, 398; primitive, 397; solid-horned, 397; true, 397 .

Ryticeras, $262 ; R$. trivolie, 263.

Saber-tooth tigers, $3 \delta_{1}, 3 \delta_{3}$; in North America, 375.

Sacculina, 305 .

Sacral vertebræ, of the cat, 326 .

Sacrum, 325 ; see also sacral.

Saddles, of cephalopod shells, 253.

Sagartia lucia, $\mathbf{1} 34$.

Sagitta, IfI.

Sago palms, 66.

St. Louis formation, fossils from, 170 ; geologic age of, 170.

Salamanders, 353 .

Salmons, 348 .

Sand dollar, I 66.

Saprophyte, a plant which grows on decayed animal or vegetable matter; seed-plant saprophytes are colorless; 40.

Surcodina, 84, 88; geologic range of, 409. Sargassum, 36 .

Sassafras, 8o; S. officinalis, So; distribution, present and past, So.

Sauropoda, $360-363$.

Sauropterygia, $35^{6}-35^{8}, 357$; decline of, 367 ; stomach-stones, etc., see plesiosaurs.

Sauropterygians, see Sauropterygia.

Sauropus primavus, I6.

Scalariide, 242.

Scallop, see Pecten.

Scaphites, 265-267; food of plesiosaurs, 357 ; S. nodosus brevis, $\mathbf{2 6 5}, 267$.

Scapholunar bone, of the cat, 327 .

Scaphopoda, 250-25I, 25I; food of, 250; shells of, 250; geologic range of, 25I, 409.

Scapula, of cat, 325, 327; of mammals, 385 ; of reptiles, $360,362,367$.

Scaumenacia, 344; S. curta, 374.

Sceptroneis caduceus, $3+$.

Schizophyta, 33; geologic range of, 408 .

Schizopoda, 306, 307.

Schizopods, the Schizopoda. 
Scriuus, 382 .

Sclerotic coat of eyeball, 334 ; see also sclerotic plates; in the cat, 334 ; in the Monotremata, 335 ; in the Stegocephalia, 335 .

Sclerotic plates of eyeball, 335; in chelonians, 335; in Ichthyosauria, 335 ; in lizards, 335 ; in modern birds, 3.35 ; in mosasaurs, 367 ; in Stegocephalia, 3.35 .

Scolilhus, 17.

Scorpio, 314; see also scorpions; comparison with Limulus, 309-311; evolution of, 310 ; recapitulation in, 310 ; relationship to eurypterids and Limulus, 310 ; relation to trilobites, 3II.

Scorpionida, 314; see also Scorpio and scorpions; geologic range of, 3 I 4 .

Scorpions, evolution from water to land life, 310; Silurian, 310.

Scyphozoa, I 21-I22; fossils of, I 2 I, I22; geologic range of, 400 .

Sea anemone, I28, I33, I34.

Sea-buds, I57-159; the Blastoidea.

Sea-cat, 343.

Sea cows, 398; evolution of, 398; geologic range of, 398 .

Sea cucumbers, I 71-I 72; fossil, I72; impressions of, 18 .

Sea-hares, 243.

Sea-lilies, I 59-163.

Sea-squirts, 322 .

Sea urchins, I65-I $7 \mathbf{1}$; see also echinoids; respiration, etc., see Strongylocentrolus; trails of, 16 .

Seals, 381; habitat of, 374 .

Seaweeds, 147, 159, 160.

Secretion of lime, in algæ, 38 ; in corals, 125.

Sectorial teeth, 381; characteristic of Carnivora, 332; of the cat, 331 .

Sedentary, stationary, not moving from place to place.

Sedge, 77,78 .

Seed, food for embryo in, 77 ; in angiosperms, 76,77 ; in the spermatophytes, 56 ; plants, $51,55-82$.

Seed plants, 51, 55-82; see Spermatophyta.

Segments, of the crayfish body, 275; of the trilobite skeleton, 29 I

Selachii, 342 .
Selaginella, 51, 52.

Semi-circular canals, 335 ; of man compared to the otocyst of crustaceans, 283.

Semionolus, 347; S.lenticularis, 347.

Sense organs, see also under the various classes ; in Hydrozoa, 111 ; in medusæ, I I I.

Sensitive fern, $43,46,47,4^{8}$.

Sepia, 272; coloring matter from, 272; guard of, 272 ; proöstracum (pen) of, $272 ;$ S. offucinalis, 272.

Sepioids, including cephalopors like Sepia; siphuncle of, 26r.

Septum (plu. septa), of Belemniles, 271 , 272; of cephalopods, 251, 252; of corals, I23, I26, I 26 , I 28.

Sequoia, 73, 74; S.giganlea, 73; S.langsdorfii, 74; S. magnifica, 71, 72, 74; S. sempervirens, 73 ; age of, 73 ; distribution of, present and past, 73, 74 .

Serpula, 146.

Serlularia, S. pumila, I08-I I 2, I09, II4; compared with a graptolite, II3-II5; digestive cavity of, 109 ; food of, 109 ; gonotheca of, IO9; hydrotheca of, 109 ; muscles of, I10; nerves of, 100 ; polyp of, 100 ; reproduction of, 110 ; respiration of, 110 .

Sesamoid bones, bones developed in tendons where there is much movement; of mammals, 395; pisiform, 395; ulnar, 305.

Sessile, attached by a broad base, not by a stalk.

Setà (plu. setæ), 189, 193.

Sexes, see under the various classes.

Sexual stage, in bryophytes, 45; in plants, 44; in pteridophytes, 45; in seed-plants, 56 ; in spermatophytes, 56.

Shagreen, 34I.

Sharks, 341, 343; Port Jackson, 342 ; Carcharodon, 342 ; parasites in, 305 .

Shawangunk formation, fossils from, 313 ; geologic age of, 3I 3 .

Sheep, 398; parasites in, 140

Shell-building glands, in pelecypods, $2: 4$; in mollusks, 207.

Shell gland, in mollusks, 207.

Shells, formation of, $\mathrm{I}$; growth of, in pelecypods, 210, 214-216, 215; section 
of, in pelecypods, $210,2 \mathbf{2 5}$; spinous, in evolution, 363 .

Shinarump formation, fossils from, 302 ; geologic age of, 302 .

Ship barnacle, 305 .

Shoulder-blade, see scapula.

Shrews, 379 .

Shrimp, brine, 285 ; mantis, 308 .

Sicula, II3, II , II5, II9, 120.

Sidneyia, 3I I, 3 I 4.

Sight, sense of, see eyes.

Sigillaria, 53, 54, 350; S. polita, 54; amphibians in, 352 ; fungus on, 40.

Sigillariostrobus, 54 .

Silica, 26 ; in animals, 26 ; in plants, 26 ; in plants (diatoms), 34; in Radiolaria, 93, 94; solubility of, I 2 .

Silicification, I I .

Silicispongiæ, 98 .

Silurian, 407.

Silurian fossils figured, $41,106,120$, $137,138,155,163,249,297,304,315$, 338.

Simia, 400 .

Simiidæ, 400 .

Sinistral shell, in gastropods, $24 \mathbf{I}$.

Sinus (plu. sinuses), a cavity or depression; blood, 2I 2, 28I ; hyponomic, 255; in cephalopods, 257; median, 200, 201 .

Siphon, of cephalopods, 251-252, 252, 254,255 ; of gastropods, 235, 235; of pelecypods, 208, 209, 209, $2 I I$.

Siphonal collar, 254 .

Siphonal muscle, in pelecypods, 209, 2 I 4. Siphonophora, I 14 , 121.

Siphuncle, of Belemnites, 271, 272; of cephalopods, 252, 254, 262, 264; of cephalopods compared, 26 I ; of nautiloids, ammonoids, belemnoids, and sepioids compared, 26I.

Siphunculata, 3 I 8.

Siren, 353.

Sirenia, 398; see also sea cows; hind limbs of, 328 .

Skates, 343.

Skeleton, see under the various classes; modification of during fossilization, 97 .

Skin, preservation of surface characters of, 19 .

Skull, bones of, in the cat, 324, 325; in the fish, 346 ; in the reptile, 367.
Slickensides, resemblance to fossils, 21 . Slime-molds, 33 .

Slit band, in gastropods, 244, 244.

Sloths, extinct ground, 382 ; giant, in North America, 375; modern, 382 .

Slugs, 243.

Smell, sense of, in crustaceans, $28_{3}$; in gastropods, 237, 242; in mammals, 335 .

Smelt, 348 .

Smilodon, 381; S. californicus, 383 .

Snails, see gastropods.

Snakes, 367 ; see also reptiles; fore limbs of, 328 ; hind limbs of, 328 ; ribs in, 326 .

Social crowding, the massing of many individuals during growth, as is the habit of the sea mussel, Mytilus.

Sockets, in brachiopod shells, $182, \mathbf{1} 8 \mathbf{3}$, I 89, 203; in pelecypod shells, 209, 216 , 223,229 .

Soft-shelled crab, 308 .

Solenhofen lithographic stone, fossils from, 370, 371; geologic age of, 370.

Solenia (Greek solenion, a little pipe), applied by Bourne to the canals lined by endoderm, which branch out as offshoots from the digestive cavities of the polyps comprising a colony, as of corals. These comprise the whole of the cxnosarc or are merely tubes running through it. From these solenia arise, by budding, new polyps; I 29.

Solenopora compacta, 39 .

Solpugida, 3 I 6.

Sori, $\mathbf{4 5}, 46$.

Sparrow, compared to pterosaurs, 365 .

Spatangoids, 165 .

Specialization, extreme, in the extinction of the species, 375 .

Spermatophyta, $43, \mathbf{5 5 - 8 2}$; classification of, 56 ; geologic range of, 408 .

Spermatophytes, the Spermatophyta.

Sphagnum, 44.

Sphenodon, 355 .

Sphenophyllales, 55; geologic range of, 408.

Sphenophyllum, 55; S. schlotheimii, 55 .

Spicules, in corals, I 28 ; in echinoderms, I 48 ; in holothurians, 172 ; in sponges, 97, 100. 
Spider crab, Japanese, 307.

Spiders, 3 I 6.

Spider's threads, 316.

Spinal cord, 321, 326, 330, 333.

Spinal nerves, exit of, from backbone, 326.

Spines, caudal, in Stegosaurus, 362; hæmal, in fish, 376 ; neural, in fish, 376 ; neural, in reptiles, 360,367 ; of echinoids, $166,167,168$; of starfish, I50; upon shell, cause of, 220 .

Spinous shells, in evolution, $36_{3}$.

Spiny anteater, 378 .

Spiracle, I 57, I 58 .

Spiracles, presence of, in ancient scorpions, 3 Io.

Spirals, brachidia as, 20., 204.

Spirifer, 203-204; S. cameratus, 204; S. disjunctus, 204; S. increbescens, I88; S. mucronatus, $207,204$.

Spirogyra, 35 .

Spirorbis, I46, 147; S.borealis, I47.

Spleen, 330.

Splenial bone, in reptiles, 367 .

Splints, of the horse's legs, $393,395$.

Sponges, 96-107; canals in, 96; classification of, 98 ; colonies of, 96 ; commercial, I o6; compared with Colenterata, IO2; compared with Protozoa, Ioo; digestion, etc., see Grantia; fossil, I03-IO5; geologic range of, 409; glass, 104; individual, 96; not colonies of Protozoa, 97; paragastric cavity of, 96; skeleton of, 97 ; spicules of, 97.

Spongilla, 96, 100, 106.

Spongin, the horny or fibrous substance of many sponges, as of the common bath sponge. It is an organic substance allied to silk, apparently of variable composition, formed as a cuticular secretion of certain cells called sponginblasts.

Sporangia, in the seed plants, 56 .

Spore-formation, in Protozoa, 88.

Spores, 57 ; in ferns, 45 ; in plants, 30 ; in Protozoa (Sporozoa), 95; in the seed plants, 56 ; in the spermatophytes, 56 .

Sporophyte stage, 43 ; in the ferns, 45 ; in the mosses, 42 ; in the seed plants, 56 ; in the spermatophytes, 56 .
Sporozoa, 95; geologic range of, 409.

Spring-tails, 320 .

Spring wood, $7 I$.

Squalodonts, 399 .

Squamasal bone, in mammals, 325 ; in reptiles, 367 .

Squamata, 367 ; evolution in, 367 ; geologic range of, 367 .

Squids, 18, 255, 269, 269, 273; American, 273 ; in evolution, 83 .

Squilla, 308.

Squirrels, 381 , 382 ; habitat of, 374 .

Stag-moose, 383 .

Stamens, in angiosperms, 76 .

Starfish, I 49-1 54, I 50, I 63 .

Statocyst, 283.

Stegocephalia, 349, 352, 355; geologic range of, $35^{2}$; habitat of, $349,35^{2}$; pineal opening present, $35^{2}$; probable derivation from crossopterygian fishes, $35^{2}$; reason for inclusion with $\mathrm{Am}$ phibia, $35^{2}$; sclerotic plates in, 335 .

Stegodon, 387, 388 .

Stegosaurus ungulatus, $361,362,363$; brain of, 363 ; in evolution, 363 .

Stentor, 95.

Stephanosaurus marginatus, 19 .

Stephen formation, fossils from, 314; geologic age of, 3I4.

Sternbergia, 67.

Sternum, of the cat, 325, 326.

Stigma, 43, 76 .

Stigmaria, 53.

Stigmata, 3 I 7.

Stipule, 58 .

Stomach, see also under the various classes; in $A$ maba, 85 ; in the cat, 330 .

Stomach-stones, of dinosaurs, 358 ; of plesiosaurs, 357 .

Stomatopoda, 308; geologic range of, 308.

Stone canal, I50.

Stones River formation, fossil in, 247; geologic age of, 244 .

Stonewort, 35 ; food of the craytish, 280.

Straparollina remota, 240.

Streptelasma, I32.

Streptoneura, 243, 244.

Striæ, fine lines upon the surface of shells.

Stromatopora, I2I.

Strongylocentrotus, I66-I7I; S. drö- 
bachiensis, 167,168 ; ambulacra of, I66, I67; ambulacral areas, I66; Aristotle's lantern, I68; blood of, I69; blood vascular system of, I69; digestive system of, I69; eye spot of, I67, I69; food of, I69; genital plate of, 167 , I69; growth of, I68; interambulacra of, 167,168 ; madreporite of, 167 ; nervous system of, 169 ; ocular plate of, $167, \quad 169$; periproct of, 167 ; reproduction of, 169 ; respiration of, I69; spines of, I68; teeth of, I 69 ; tube-feet of, $167, \mathbf{1 6 8 , I 6 8 , ~} 169$; water vascular system, I68.

Stropheodonta, I90, 198; S. concava, 198 ; S. demissa, 188 .

Strophomena, 190, 196; S. planumbona, I97.

Strophomenids, 192.

Sturgeons, 346; tail fin of, 344 .

Stylonurus, 313.

Suborbital bones, in fishes, 346 .

Suckers, of cephalopods, 270 ; of echinoids, $I 68$; of squids, 270.

Suctoria, 3 I9.

Sugars, in vertebrate digestion, 332 .

Summer wood, $7 I$.

Sun-animalcules, 93.

Supraclavicle bone, in fishes, 346 .

Supraorbital bone, in fishes, 346 .

Supratemporal bone, in fishes, 346 .

Surangular bone, in reptiles, 367 .

Sus, 397.

Sussex man, 400 .

Sutures, facial, in trilobites, 286, 287, 205, 296; of Belemenites, 27I; of cephalopod shells, 262, 263, 264, 266, 267,268 .

Swan, cervical vertebræ in, 326 .

Sweat-glands, $\mathbf{3 2 4}$.

Swimming legs, in trilobites, 288 .

Swine, color of young, 20.

Sycon, 102.

Sycotypus, see Busycon.

Symbiosis, 4 I.

Sympathetic nervous system in mammals, 334 .

Synangia, a type of pollen sacs, 67 .

Synthetic types, see generalized types.

Synxiphosura, 3 I I.

Sypharopteroidea, 319 .

Syringopora, I 29.
Tabula (plu. tabulæ), in Bryozoa, 178 ; in corals, $129, I 33, I 37, I 38$.

Tabulata, 136-138.

Tabulate corals, I I3.

Tania solium, I40.

Tæniodonta, 382 ; teeth of, 382 .

Tæniodonts, the Tæniodonta.

Tail, see also caudal.

Tail fin, of crustaceans, 276, 276, 279.

Taonurus cauda-galli, 40.

Tape-worm, I 40.

Tapirs, 392; color of the young, 20; extinction of, 376 .

Tarsal bones, of birds, 369 ; of cat, 325 , 328 ; of mammals, $325,328,385$; of reptiles, $360,362,366,367$.

Tarsals, see tarsal bones.

Tarso-metatarsals, of birds, 370, 372 .

Tarsus, the ankle, 327 ; see tarsal bones.

Tasmanian wolf, 378 .

Taste, see sense organs under the various classes.

Taxaceæ, 70.

Taxodium, 74; T. distichum miocenicum, 74; distribution of, present and past, 73 .

Taxodont dentition, $\mathbf{2 2 3}, 223$.

Tectibranchs, 248.

Teeth, canine, 33I ; hinge, cause of, 220 ; incisor, 33I ; milk, 33I ; molar, 33I ; of brachiopod shells, $182, \mathbf{1} 8 \mathbf{3}, \mathbf{1} 89$, I96, 203; of cat, 33I; of pelecypod shells, 209, 216, 223, 229; of radula of gastropods, 236; permanent, 33I ; premolar, 33I ; sectorial, 33I ; two sets of, in cat, $33 \mathrm{I}$.

Teleostei, 347-348; examples of, $347^{-}$ $348,3.8$; geologic range of, 347 .

Teleostomi, 344-348; air-bladder compared to lung of the lung-fish, 343 ; born alive, 339 ; geologic range of, 344 ; hyostylic, 339; subdivision of, 345 ; tail fin of, 344 .

Tellina, 220.

Telotremata, I 89 .

Telson, of crayfish, 275, 276; of Eurypterus, 315 ; of the horseshoe crab, 277; of the lobster, 279.

Temperature, body, of birds, 369; of mammals (except the monotremes), 373 ; of reptiles, 354 ; of the Monotremata, 377 ; of the Prototheria, 377. 
Temporal bone, in the cat, 325 .

Tentacles, ocular, 252, 253, 258; of brachiopods, $182, \mathbf{I} 84$; of cephalopods, $252,253,255$; of gastropods, 237; of holothurians, 172; of Hydrozoa, I08, 109, I 10.

Tentaculites, 244, 248-249; T. gyracanthus, 279.

Terebratella plicata, 189, 202.

Terebrutula, 202; T. harlani, 202, 202; forms like, 202.

Terebratulids, 192 .

Terebratulina coreanica, 203; T. septentrionalis, $18 \mathbf{8}-\mathbf{1} 87,182,185,202$; blood of, 185 ; cardinal process of, 182 , I83; circulation of blood, I 85 ; digestion of, I 85 ; embryo of, I86; excretion of waste, I85, I86; fertilization of, I 86 ; food of, I 84 ; geographic range of, I $8 \mathrm{I}$; mantles of, $\mathrm{I} 84$; muscles of, $182,183,185$; nervous system of, I86; protection of, I8I ; protegulum of, 187 ; respiration of, I86; sexes in, I86; skeleton of, I 81 ; soft body of, $182,184,185$; valves of, I81, 182 .

Teredo, 222, 233-234; T. navalis, 233 , 233; burrow of, 17 ; siphons of, 233, 233.

Teretrum primulum, 319 .

Tern, compared to Ichthyornis, 372 ; skull and brain of, 372 .

Tertiary, 407.

Tertiary fossils figured, $7 I, 7+$; see also Eocene, Oligocene, Miocene, and Pliocene.

Test, the name applied to the skeleton, where, as in sea urchins and protozoöns, it is internal or is secreted by the whole surface of the body. The skeleton is called a shell when it is secreted by a mantle, as in brachiopods.

Tetrabranchiata, 260-268; food of fossil, 26I ; protoconch of, 26r ; recapitulation in, 26I ; subdivision of, $26 \mathrm{I}$.

Tetracoralla, I 3 I-I 33 .

Tetractinellida, 97, 98, I 05 .

Tetraseptata, I3I.

Textularia, 90.

Thallophyta, 32-42, 43; classification of, 32 ; geologic range of, 408 .

Thallophytes, the Thallophyta.
Theca, $\mathbf{2} 28$.

Thermal algæ, 39 .

Theromorpha, 355-356; see Anomodontia.

Theromorphs, see Theromorpha.

Theropoda, 359-360.

Thoatherium, 389.

Thoracic, see dorsal.

Thoracic shield in trilobites, $29 \mathrm{I}$.

Thorax of trilobites, $286,287$.

Thread-worms, I40-I4I; fossil, I \&O, I4I.

Thumb, see under phalanges and digits. of the cat, 327.

Thunderbolt, 272 .

Thunder stones, 272.

Thysanodictyon, 105 .

Thysanoptera, 3 I 8.

Tibia, of cat, 325,328 ; of mammals, 385 . 397; of reptiles, $360,362,366,367$

Tibio-tarsals, of birds, 372 .

Ticks, 316 ; as disease carriers, 376 .

Tiger, saber-tooth, 381,383 ; in North America, 375 .

Tillodontia, 381-382.

Time scale, geologic, 407 .

Titanotheres, $380,391,392$.

Toads, 353 ; see Anura.

Toadstools, 40.

Toes, see phalanges.

Tongue, 330 .

Tooth structure, in the extinction of the species, 374 .

Tortoises, 366; see Chelonia.

Touch, sense of (see also sense organs under the various classes), in Apus, 301 ; in crustaceans, 282, 301; in gastropods, 242; in mammals, 335 ; in trilobites, 289 .

Toxodon, 389 .

Toxodontia, 389.

Trachea, respiratory tubes, evolution of, 310 ; in mammals, $330,333$.

Tracheata, 275.

Trachodon, 359,363 .

Trachylinæ, I 2 I.

Tracks, $\mathbf{I} 6$.

Trails, $\mathbf{I} 6$.

Transverse processes of vertebræ of the cat, $325,326$.

Trapezium of the cat, 327 .

Trapezoid of the cat, 327 . 
Trenton formation, fossils from, 36; geologic age of. 36 .

Triarthrus, 285-290; T. becki, 286; abdomen of, 287 ; antennules of, 289 ; appendages of, 288 ; blood circulation of, 289 ; cephalon of, 286,287 ; compared to a phyllopod, 285 ; digestive canal of, 286; dorsal shield of, 287 ; excretion of, 289 ; eyes of, $2 \mathrm{~S}_{9}$; food of, 288; growth of, 293 ; habitat of, 286,287 ; muscles of, 288 ; nervous system of, 289 ; pygidium of, 286,287 ; respiration of, 286,289 ; restoration of, I 7 ; skeleton of, 287 ; thorax of, 286 , 287.

Triassic, 407 .

Triassic fossils figured, $302,3+7,350$.

Triceratops prorsus, 363,367 ; in evolution, 363 .

Trichina spiralis, $\mathbf{1}+1$.

Trichoptera, 3 I9.

Triconodon, 378 .

Triconodonta, 378 .

Trilobita, 285-299; see trilobites and Triarthrus.

Trilobites, 285-299; appendages of, 291; blind, 29I; cause of joints in, 290; daddy longlegs, 288; development of, 292; eggs of, 292; enrollment of, 291 ; eye-line in, 286, 291; growth of, 292-293; habitat of, 290; lace collar, 297; more primitive than phyllopods, 293; muscles of, 29I ; preservation of, 292; protaspis of, 292; related to phyllopods, 293; relationship of, 293; relationship to Limulus, eurypterids, scorpions, 3II ; relationship to phyllopods, 293 ; reproduction of, 292; restoration of, I7; sight of, 29I ; skeleton of, 291; survey of, 290-294.

Trinucleus, 288, 296; T. concentricus, 297 ; migration of, 23.

Tritemnodon agilis, 380 .

Trochelminthes, I40, I4I.

Trochospere stage, in Annulata, I45; in pelecypods, $2 \mathbf{2} 7$.

Tube feet, movement of, I5I; of Asterias, I49; of echinoids, 168; of starfish, I 49.

Tubicinella, 305

Tubipora, I28, 129, I 35 .
Tubularia, I I.

Tubules, 184, I 88.

Turritella, 244, 246-247; T. mortoni, 246,247 ; evolution in, 247.

Turtles, 365, 366; see Chelonia.

Uintatherium, 386; $U$. alticeps, 380 ; $U$. mirabile, skull and brain of, 375 .

Ulmus americanus, 13.

Ulna, of birds, 370,372 ; of cat, 325,327 ; of mammals, $385,386,394$; of reptiles, $358,360,362,366,367$.

Ulnare bone, of turtles, 366 .

Umbilicus, in cephalopods, 254, 265, 266,267 ; in gastropods, 243 .

Umbo, in brachiopods, 188 ; in pelecypods, 2 I 6, 220.

Unciform bone, of cat, 327 ; of mammals, 395.

Ungual phalanges, 395 .

Unguiculates, see Unguiculata.

Unguiculata, 384; compared with Ungulata from early Eocene, $38_{4}$; in evolution, 399.

Ungulata, see ungulates, 382-398.

Ungulates, 382-398; ambulatory, reduction in, 385 ; browsing, reduction in, 385 ; compared with the unguiculates from the early Eocene, 384 ; cursorial increase in, 385; Eocene, closely related to Creodonta, 379 ; even-toed, 396-398; evolution of, 384 ; function of grasses in evolution of, 384,385 ; grazing, increase in, 385 ; odd-toed, 389-396; primitive, 384 ; principal advance of, in enlargement of brain, 375,385 ; subdivisions of, 385,386 , $389,396$.

Unio, 228-229; U. luteolus, 220; age of individual, 228; arching of female shell, 288; composition of shell, 25 ; corrosion of shell of, 229 ; development of young of, 228; epidermis of, 228 ; external protection of, 228 ; habitat of, 228 ; sexes of, 228 ; siphons of, $228,229$.

Upper lip, in crustaceans, $280,286,287$.

Urea, see also excretion and waste under the various classes; in $A m \propto b a, 86$; in mammals, 332 ; in Protozoa, 86.

Uric acid, in Annulata, I44; in Mammalia, 332 . 
Urnatella, I8I.

Urochorda, 321, 322; degeneration in, 322 ; geologic range of, 409 .

Urodela, 349, 352-353; fossil, 353 .

Ursidæ, 38r.

Ursus speleus, 38r.

Uterus, 330 .

Utica formation, fossils from, I3, II f, I I 5, I2O, 286; geologic age of, II 4, 286.

Valves, movement of, 22I ; of brachiopods, I $81, I 82, I 88,189$; of crustaceans, 301, 302, 303, 304; of pelecypods, 208, 209, 210, $22 \mathrm{I}$.

Varanoids, 367 .

Varix (plu. varices), each such elevation usually indicates the position occupied for some time by the mantle edge; in pelecypods, 210,2 I5-2I6, 215.

Vascular bundles, 20; in Calamites, 19 ; in dicotyledons, 8o; in Lepidodendron, 52 ; in monocotyledons, 78.

Vascular cryptogams, 45.

Vegetable-feeding gastropods, 242 .

Vegetative stage, in bryophytes, 45 ; in plants, 43 ; in pteridophytes, 45 ; in the seed plants, 56 ; in the spermatophytes, 56 .

Veined, netted, see netted-veined; parallel, see parallel-veined.

Veins, in animals one of the tubes which carries blood to the heart; in plants one of the smaller branches of the framework of a leaf; in mammals, 332.

Veliger, in mollusks, 207 ; in pelecypods, 2 I 7.

Velum, in mollusks, 207; in pelecypods, 2 I 7.

Vena cava, 330 .

Veneridæ, $22 \mathrm{I}$.

Venter, ventral side of shell in cephalopods.

Ventral blood sinus, in crustaceans, 28I.

Ventral groove, in Belemnites, the shallow furrow extending the length of one side of the guard.

Ventral membrane in trilobites, 286, 287.

Ventral muscle, in crayfish, 278; in crustaceans, 278 ; in trilobites, 288.
Ventral nerve cord, of Annulata, I 45; of $A$ pus, 300,301 ; of crustaceans, 279, 300, 301 .

Venus mercenaria, 208-219, 200, 210, 2II, 2I5, 236; blood of, 2I 2, 22I ; body of, 208; circulatory system of, 212 ; development of, $2 \mathrm{I} 6$; excretory organs of, 2I3; food of, 2I 2 ; foot of, 208, 209, 210, 2II ; gills of, 209, 2IO, 2I0-2II, 2II; habitat of, 208; heart of, 2I 2 ; ligament of, 22I ; mantle of, 208. 200, 2IO, 2II; muscles of, 213 ; nervous system of, $2 \mathrm{I} 3$; position for feeding, 200, 2II; rate of growth of, 218 ; respiration of, 209 ; section through shell, 2I5; sense organs of, 213 ; sexes of, 216; shell-building glands of, 2I4; siphons, 208, 209, 209 ; valves of, 208, 200 .

Venus' flower basket, I03, I04, 105.

Venus' girdle, 139 .

Vermes, I 40.

Vermetus, see Veimicularia.

Vermicularia, 247; evolution in, 247; recapitulation in, 247 .

Vermiform appendix, 330.

Vertebra (plu. vertebræ), back, 326 ; caudal, 325, 326; cervical, 325, 326, 326 ; dorsal, 325, 326; hip, 326; lumbar, 325, 326; neck, 326, 326; of cat, 326,326 ; of fish, 376 ; of mammals, 326,326 ; of reptiles, 362,367 ; processes of, in reptiles, 362 ; sacral, 325, 326; tail, 326; thoracic, 326; transverse process of, 325,326 .

Vertebral column, see backbone.

Vertebrarterial canal, 326.

Vertebrata, 321, 322-402; see vertebrates.

Vertebrate animals, restoration of, 17 .

Vertebrates, 32I, 322-402; backbone of, 323; digestion of, etc., see cat; gill-slits of, 323 ; in evolution, 83 ; respiration compared to that of insects, 317 ; restoration of, $18-20$; subdivision of, 323 .

Vertebrate skeleton compared with that of arthropods, 274 .

Vestigial, pertaining to a remnant; used in reference to an organ which is in course of disappearance.

Virgula, I I 8, I 20. 
Visceral, pertaining to the viscera, the organs of the abdomen, such as stomach and intestines.

Visceral arch, first, 339; hyoid, 339; mandibular, 339; second, 339.

Visceral ganglia, in gastropods, 237; in pelecypods, $22 \mathrm{I}$.

Visceral spiral, in gastropods, 234, 235.

Viscero-pedal mass, 2 I 0.

Vitreous humor of eye, 334 .

Viviparous, 374.

Viviparous elasmobranchs, 339; ichthyosaurs, 358 ; mammals, 374 ; plesiosaurs, 356 ; teleostomes, 339 .

Vocal cords, 333 .

Voice, development of, 333.

Voice box, 326, 330, 333 .

Voltzia, 73 .

Voluntary muscles, 329, 33 I.

Vorticella, 95 .

Walnut, 77 ; relative of, $8 \mathrm{I}$.

Walruses, $38 \mathrm{I}$.

Wasatch formation, fossils from, 384 , 385 , 395; geologic age of, 384,385 , 395 .

Washita formation, fossils from, 227; geologic age of, 227.

Wasps, 78, 3 I9.

Water fleas, 304.

Water vascular system, of Asterias, I 50 ; of echinoderms, I48; of starfish, I 50 .

Wave-marks, fossil, 2 I.

Whales, 398-399 ; beaked, 399; compared to ichthyosaurs, 358 ; derivation of, 358; evolution of, 399 ; fin, 399 ; food of, 247; geologic range of, 399; gray, 399 ; habitat of, 374 ; humpbacked, 399; parasites in, 305; right, 399 ; sperm, 399 ; subdivision of, 399 ; toothed, 399; whale-bone, 390.

Wheel-worms, I 4 I.

White ants, 318.

Whorl, a single circle of leaves or a turn of a shell ; in leaves, 50, 55; in Protozoa, 9I.

Wielandiella, 65.

Williamsonia, 65 .

Willow, 77 .

IVings, of birds, 369; of flying reptiles, 364 .

Wish bone, see clavicle of birds.

Wolf, Tasmanian, 378 .

Wombats, 378 .

Wood, fossil, 68, 7I, 79; petrifaction of, II $-\mathrm{I} 2$.

Worms, 140-147; burrows of, I6; impressions of, 18 .

Wrist, the carpus, 327.

Wrist bones, see carpal bones.

Xenophyophora, 88.

Xiphosura, 309, 3 II-3 I 2 ; geologic range of, 3 II; resemblance to trilobites, 3 I I.

Xylem, 79 .

Yeast, 40.

Yellow fever, 84 .

Yew, 70.

Yolk, variation in fish eggs, 339 .

Zamites, 66.

Zeuglodon, 399.

Zeuglodontia, 399.

Zoantharia, I29, I30, I3I, I 3 I-I34.

Zoarium, I 73 .

Zoøe, the larval stage in which the young of crabs are hatched. (The nauplius stage is passed through in the egg.) It consists of an enormous cephalothorax produced into spines, large stalked eyes and a long slender abdomen, 285 .

Zoøecium (plu. zoøcia), I73, I74, I 76.

Zostera, 75 .

Zygapophysis, 326; anterior, 326; posterior, 326 . 

















